\title{
An Archaeological Inventory of Camp Swift, Bastrop County, Texas
}

David G. Robinson

Timothy M. Meade

Leeann Haslouer Kay

Linn Gassaway

Dustin Kay

Follow this and additional works at: https://scholarworks.sfasu.edu/ita

Part of the American Material Culture Commons, Archaeological Anthropology Commons, Environmental Studies Commons, Other American Studies Commons, Other Arts and Humanities Commons, Other History of Art, Architecture, and Archaeology Commons, and the United States History Commons

Tell us how this article helped you.

This Article is brought to you for free and open access by the Center for Regional Heritage Research at SFA ScholarWorks. It has been accepted for inclusion in Index of Texas Archaeology: Open Access Gray Literature from the Lone Star State by an authorized editor of SFA ScholarWorks. For more information, please contact cdsscholarworks@sfasu.edu. 


\section{An Archaeological Inventory of Camp Swift, Bastrop County, Texas}

\section{Licensing Statement}

This is a work produced for the Texas Department of Transportation (TxDOT) by the report producer. TxDOT and the report producer jointly own all rights, title, and interest in and to all intellectual property developed under TXDOT's contract with the report producer. The report may be cited and brief passages from this publication may be reproduced without permission provided that credit is given to both TxDOT and the report producer. Permission to reprint an entire chapter, section, figures or tables must be obtained in advance from either the Supervisor of the Archeological Studies Branch, Environmental Affairs Division, Texas Department of Transportation, 125 East 11th Street, Austin, Texas, 78701 or from the report producer. 
An Archaeological Inventory of Camp SwifT,
Bastrop County, Texas

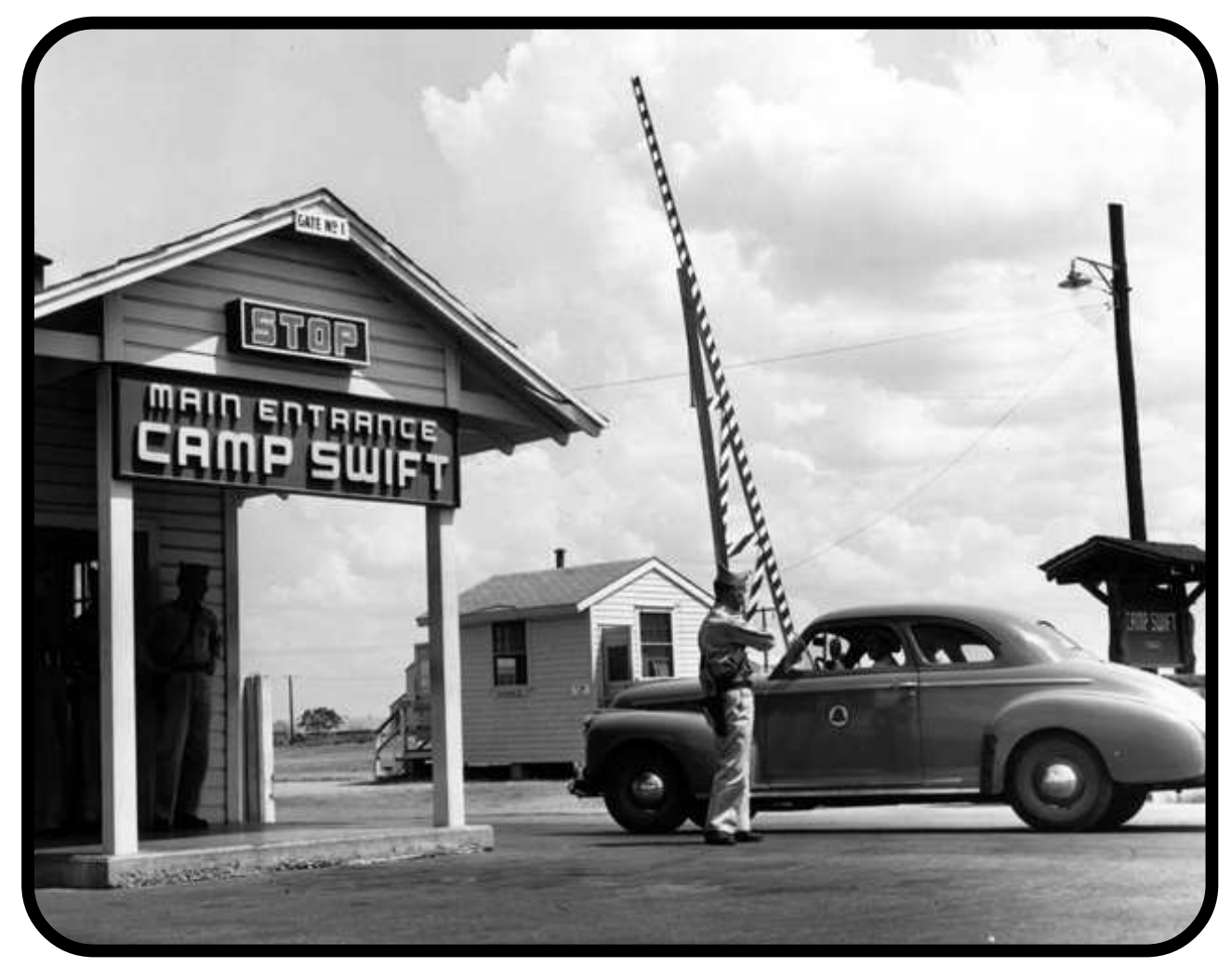

David G. Robinson, Timothy M. Meade, Leeann $\mathbb{H}$ aslouer $\mathbb{K}$ ay, Liinn Grassaway, and Dustin $\mathbb{K}$ ay

\section{Edited by}

Barbara A. Meissner

\section{With contributions by}

John J. Leffler, Shane Prochnow, Raymond P. Maruldin, and Steve A. Tomka

Archaeological Survey Report Number 316

Center for Archaeological Research

The University of Texas at San Antonio 


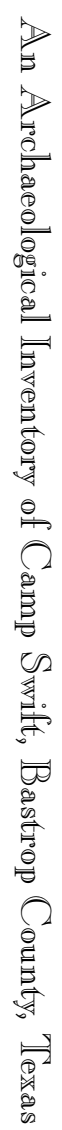

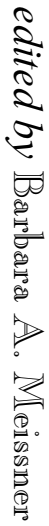

$\frac{d}{d}$

I

$\stackrel{\text { ev }}{\ominus}$

些

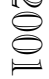




\title{
An Archaeological Inventory of Camp Swift, Bastrop County, Texas
}

\author{
David G. Robinson, Timothy M. Meadle, \\ Leeann $\mathbb{H}$ aslouer $\mathbb{K}$ ay, Linn Grassaway, and Dustin $\mathbb{K}_{\text {ay }}$
}

\author{
Edited by \\ Barbara A. Meissner \\ With contributions by \\ John Jo Leffler, Shane Prochnow, Raymond P. Maulldin, \\ and Steve A. Tomka
}

\section{Steve A. Tomka Principal Investigator}

Texas Antiquities Permit No. n/a

Prepared for:

Adjutant General's Department of Texas Directorate of Facilities and Engineering

Environmental Branch Austin, Texas
Prepared by:

Center for Archaeological Research The University of Texas at San Antonio Archaeological Survey Report, No. 316 San Antonio, Texas 
The following information is provided in accordance with the General Rules of Practice and Procedure, Chapter 41.11 (Investigative Reports), Texas Antiquities Committee:

1. Type of investigation: Supplemental cultural resource inventory, revised survey report and historic research

2. Project name: Camp Swift

3. County: Bastrop County, Texas

4. Principal investigator: Steve A. Tomka

5. Name and location of sponsoring agency: Adjutant General's Department of Texas, Austin, Texas, 787635218

6. Texas Antiquities Permit No.: n/a

7. Published by the Center for Archaeological Research, The University of Texas at San Antonio, 6900 N. Loop 1604 W., San Antonio, Texas 78249-0658, 2001

A list of publications offered by the Center for Archaeological Research is available. Call (210) 458-4378; write to the Center for Archaeological Research, The University of Texas at San Antonio, 6900 N. Loop 1604 W., San Antonio, Texas 78249-0658; e-mail to car@lonestar.utsa.edu; or visit CAR's web site at http://car.utsa.edu. 


\section{Abstract}

Beginning in November 1996 and continuing until July of 1997, the Adjutant General's Department of Texas conducted a self-sponsored Phase I cultural resources survey of Camp Swift in Bastrop County, Texas. The project surveyed approximately 5,000 acres of the camp, approximately 1,000 of which had been previously surveyed. A total of 58 new archaeological sites were recorded, of which 26 were prehistoric, 24 were historic, and 8 had both prehistoric and historic components. In addition to these sites, 42 previously identified sites were revisited.

In September 2000, the Center for Archaeological Research of the University of Texas at San Antonio completed shovel tests on two sites and acquired GPS data on 28 sites. At this time, a geomorphologist excavated a series of 12 backhoe trenches and - subsequently - a report on the geoarchaeology of Camp Swift was added to this report.

An assessment of the 169 sites now known on Camp Swift found one site (41BP138, the Wine Cellar Site) eligible for inclusion in the National Register of Historic Places. A total of 106 sites are considered not eligible for inclusion in the National Register of Historic Places. Fifty-nine sites are considered potentially eligible, and should be tested to determine their eligibility. Three marked cemeteries are protected by state law. 


\section{Contents}

Abstract

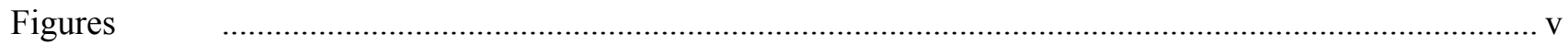

Tables

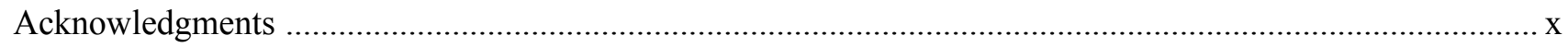

Chapter 1: Introduction

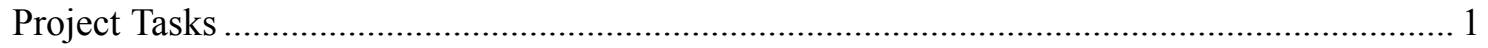

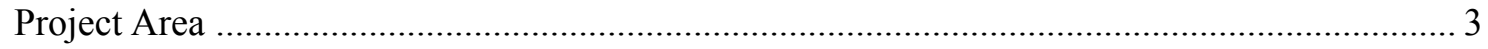

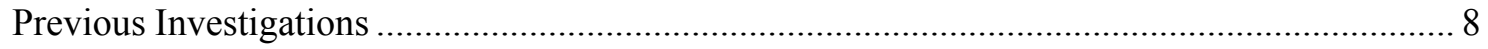

Chapter 2: Historic Background

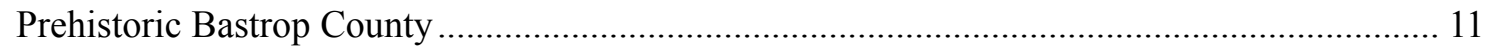

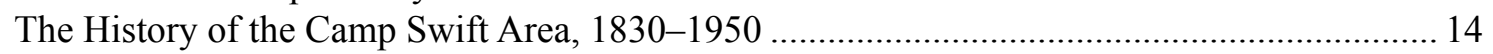

Chapter 3: Geoarchaeological Assessment

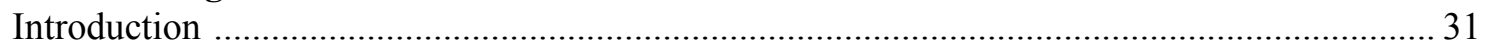

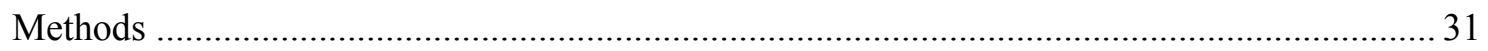

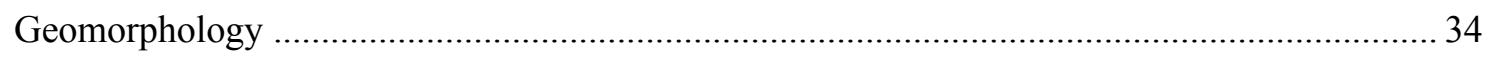

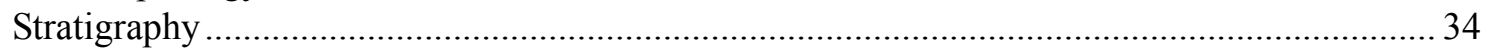

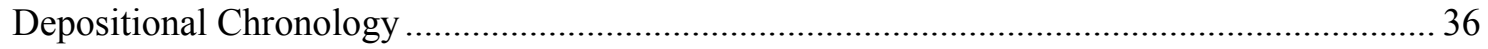

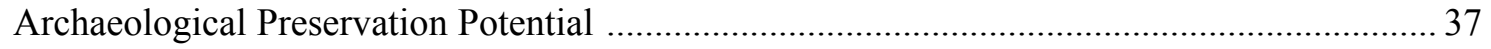

\section{Chapter 4: Methods}

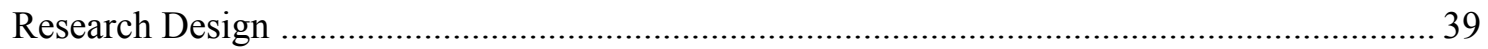

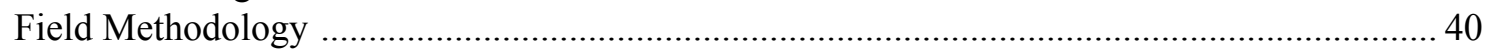

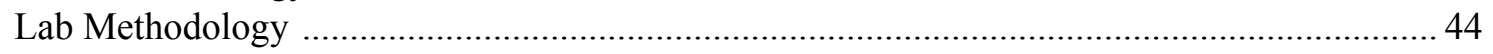

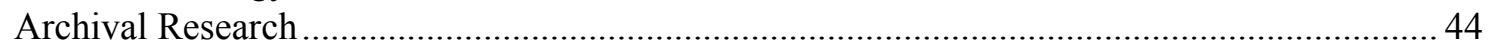

Chapter 5a: Results - Prehistoric

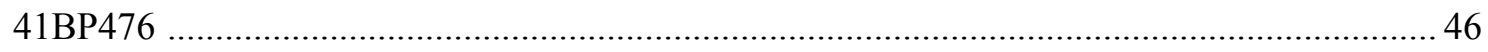

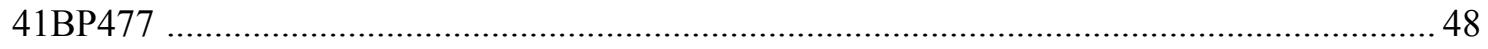

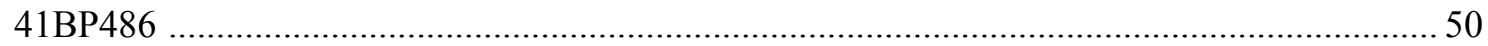

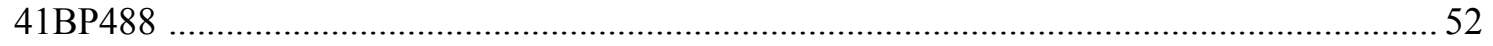

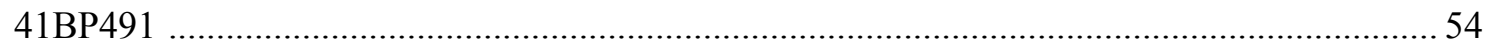

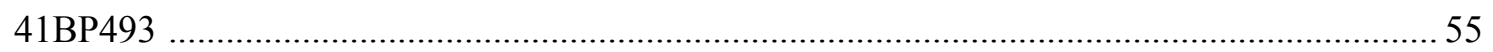

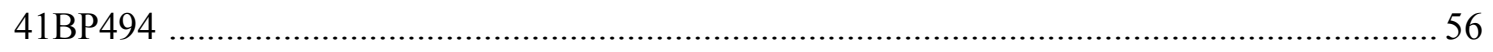

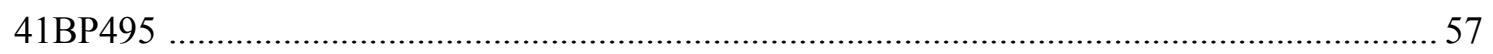

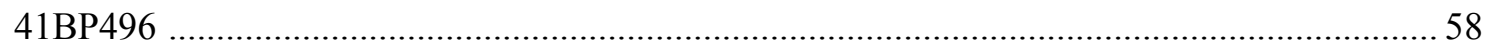

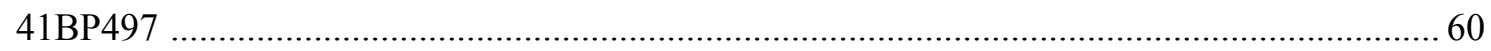

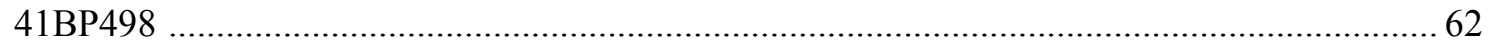

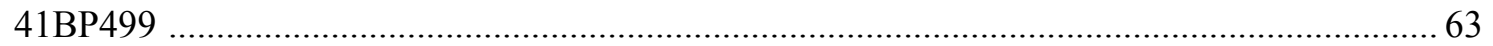

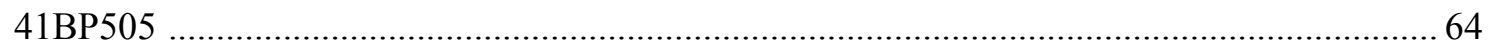

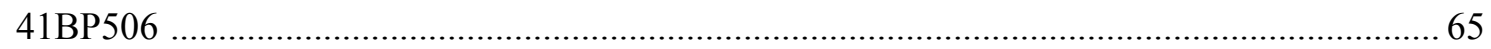

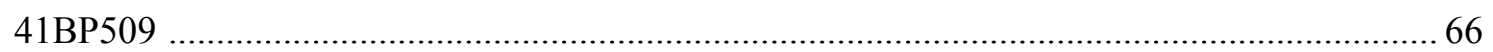

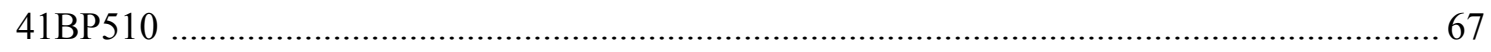

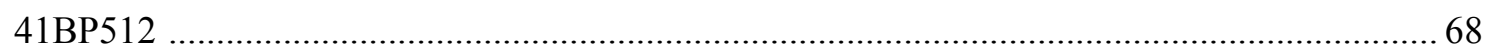

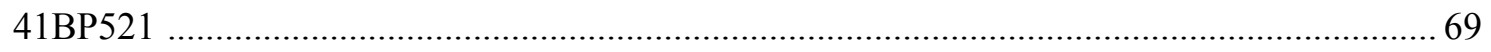

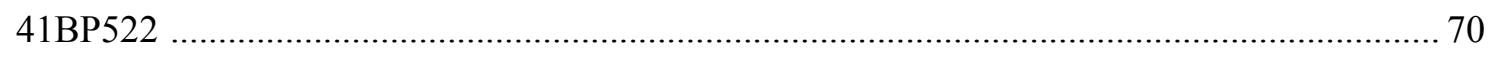

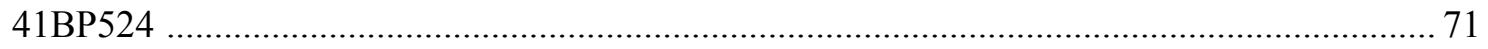


41BP526 418 527

\section{Chapter 5b: Results - Historic}

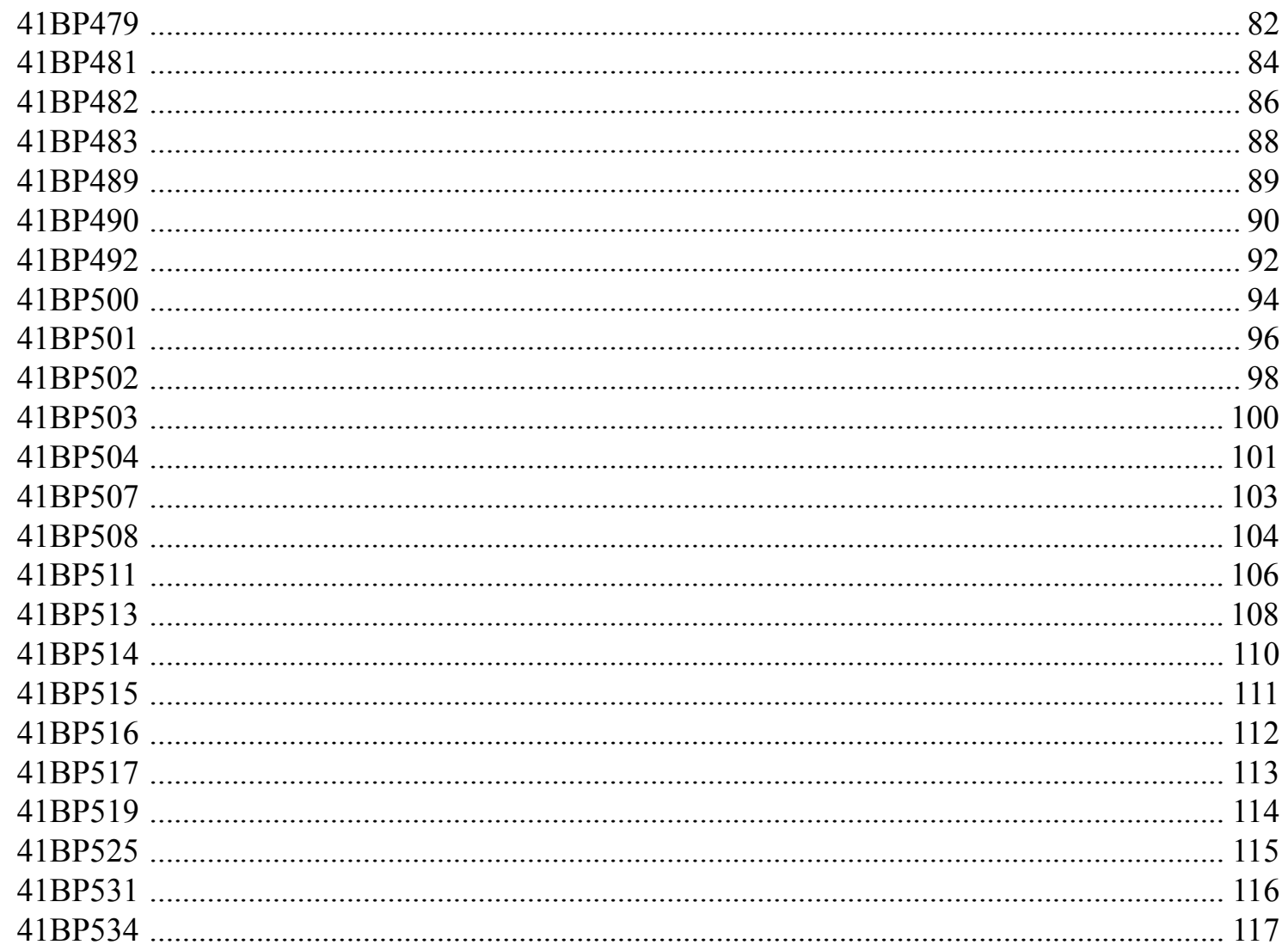

\section{Chapter 5c: Results - Multi-Component}

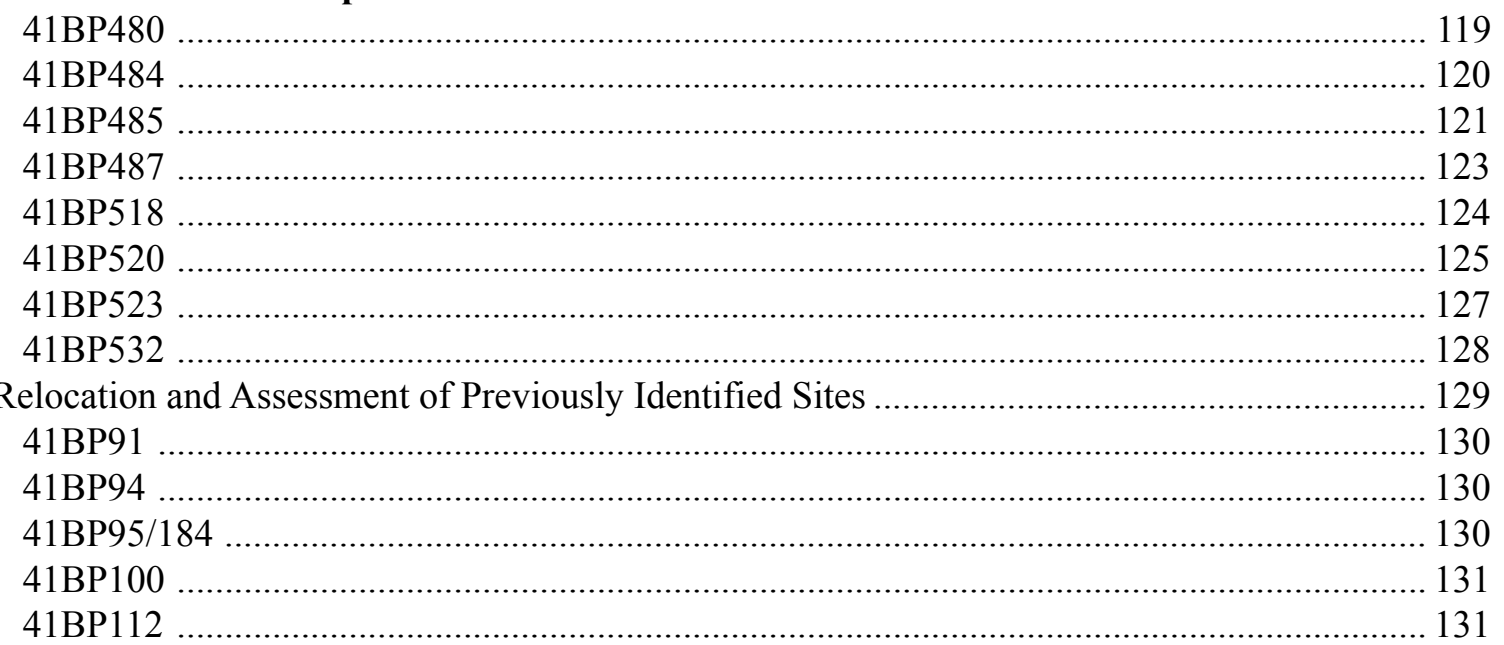




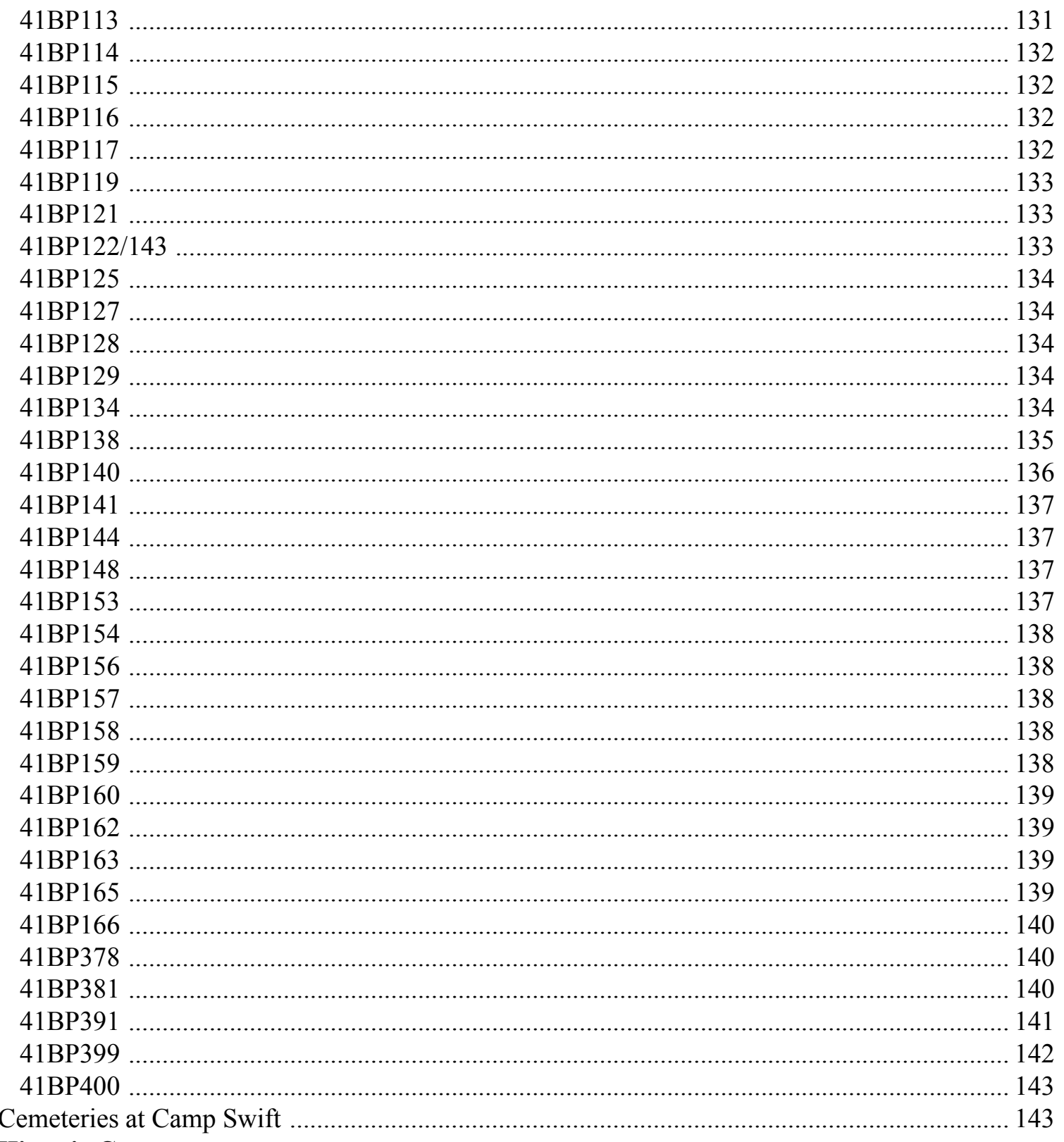

\section{Chapter 6: Historic Contexts}

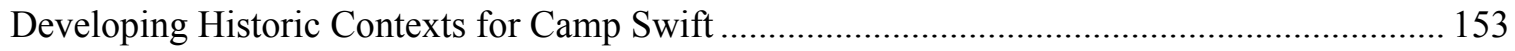

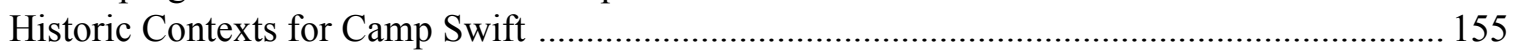

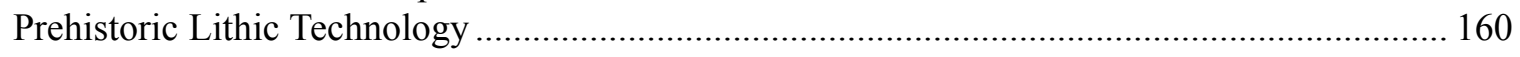

Chapter 7: Assessments and Recommendations

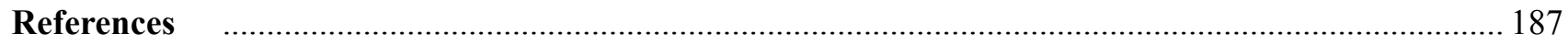

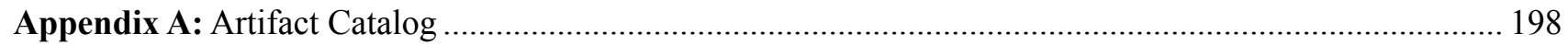

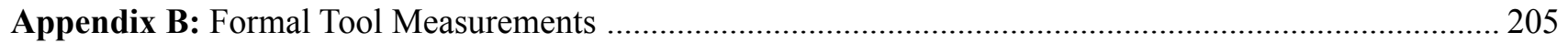

Appendix C: Backhoe Trench Profile Descriptions ........................................................................... 207

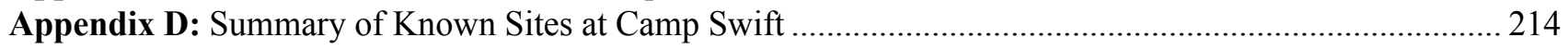


Figuries

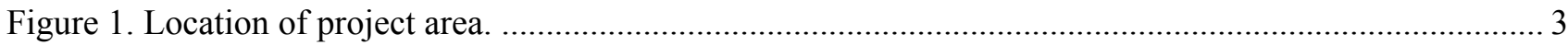

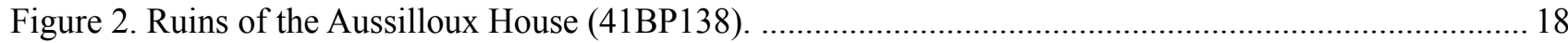

Figure 3. Railroad ties for the spur being built from the Sayers Mine to the MKT line, ca. 1914. ................. 19

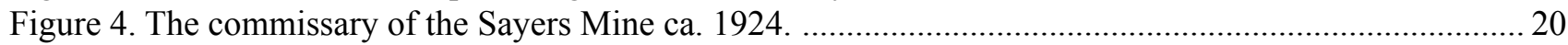

Figure 5. Tipple at the Sayers Mine, 1913 to 1924 .................................................................................... 20

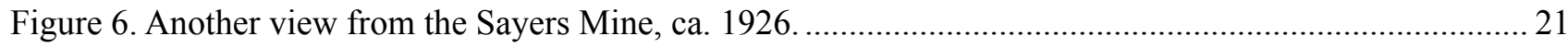

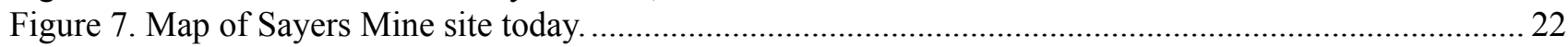

Figure 8. Map based on 1936 map of Bastrop County, showing roads and structures. ................................ 24

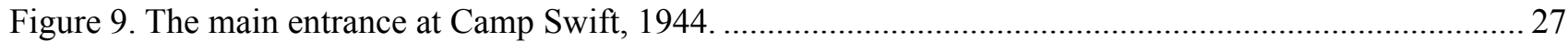

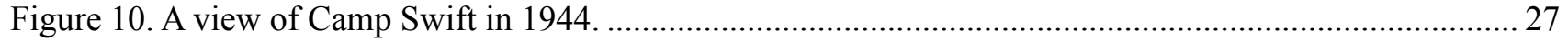

Figure 11. Geomorphic map of Camp Swift showing the location of backhoe trenching. ............................ 32

Figure 12. Idealized cross section of alluvial valleys within Camp Swift. .................................................... 33

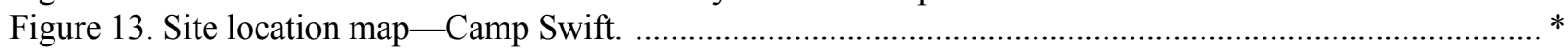

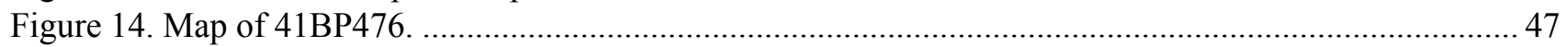

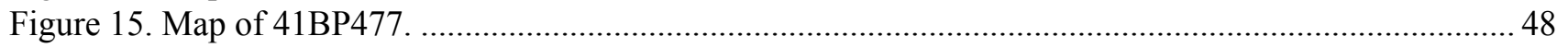

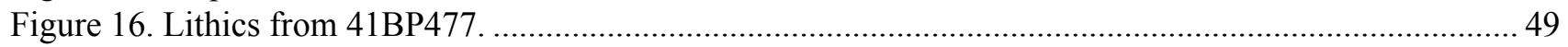

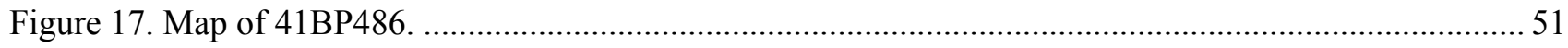

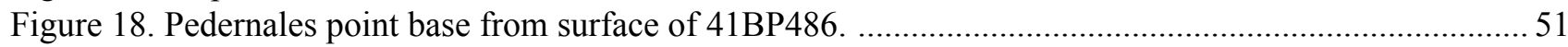

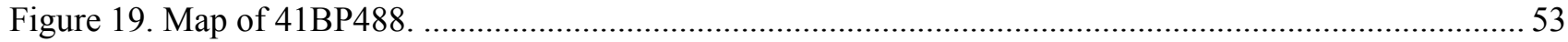

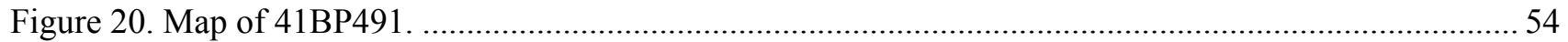

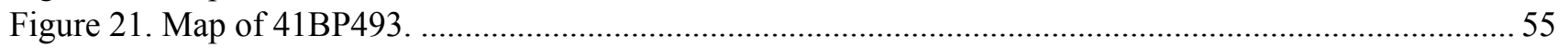

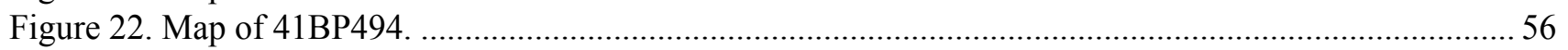

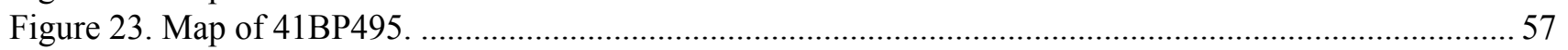

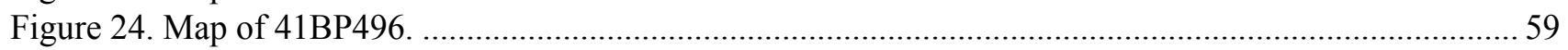

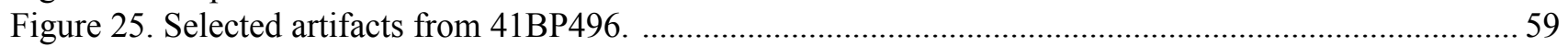

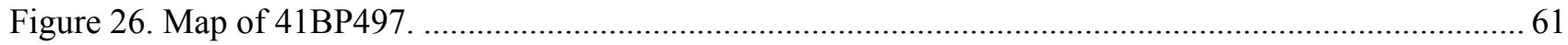

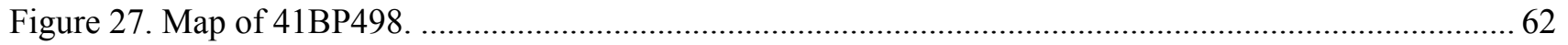

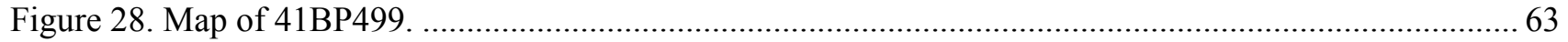

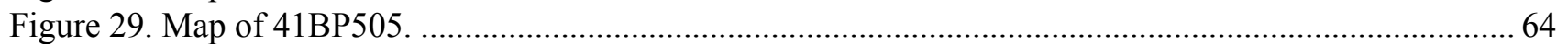

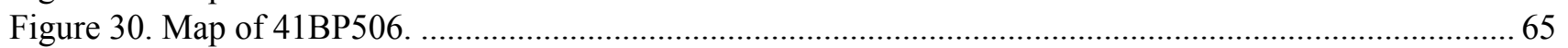

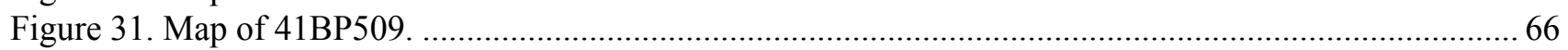

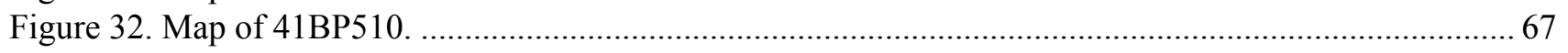

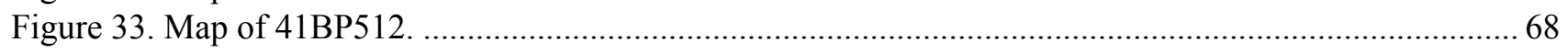

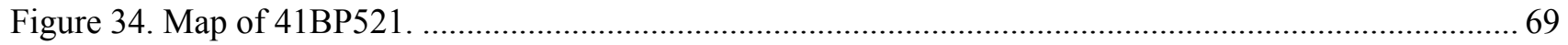

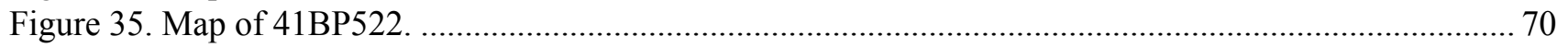

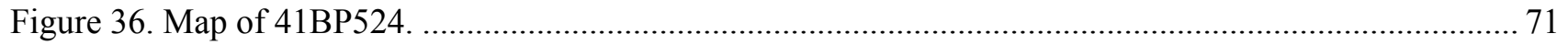

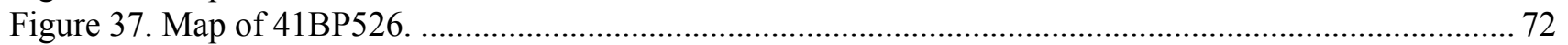

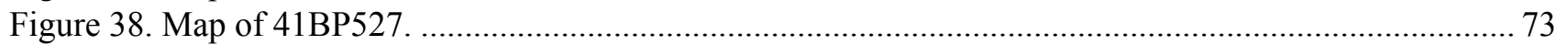

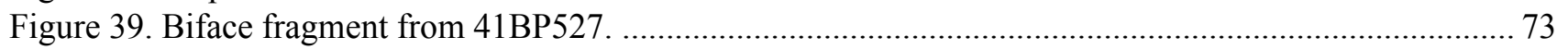

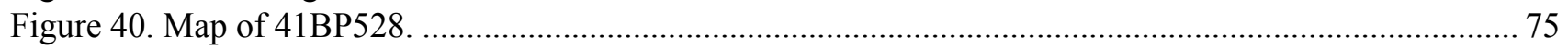

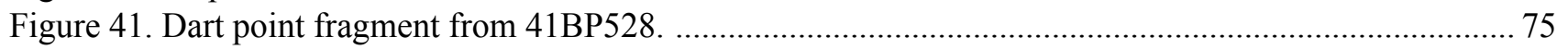

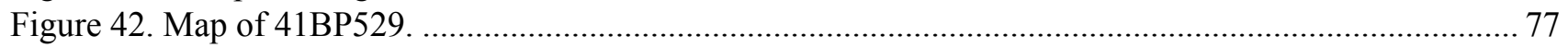

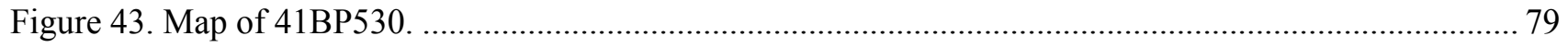




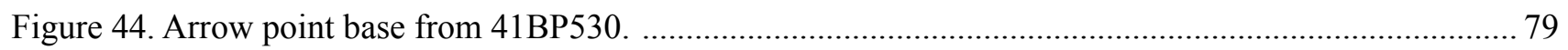

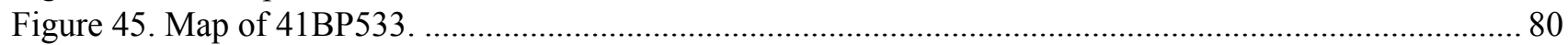

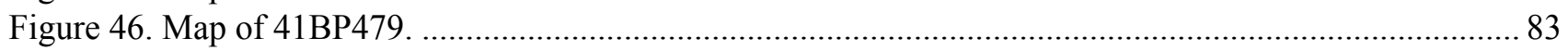

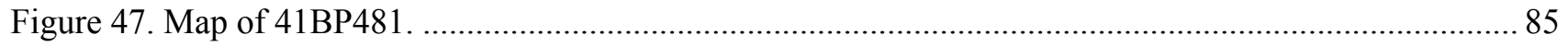

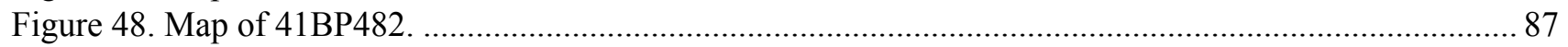

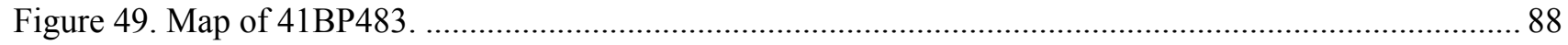

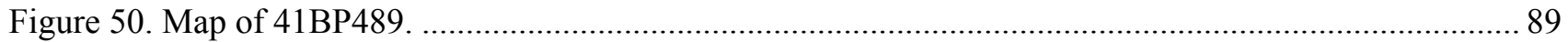

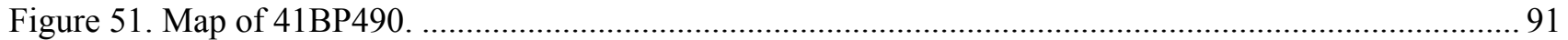

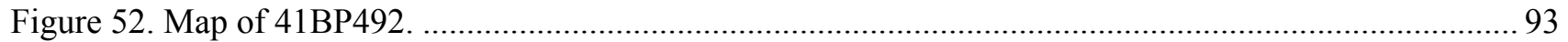

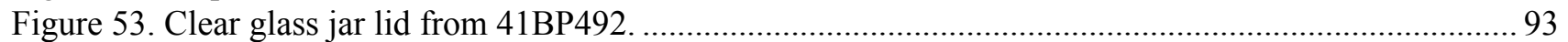

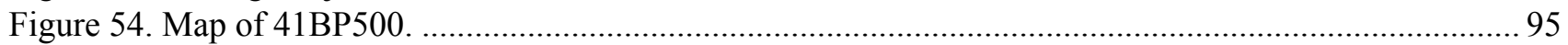

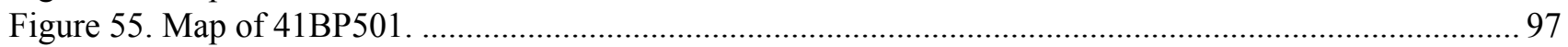

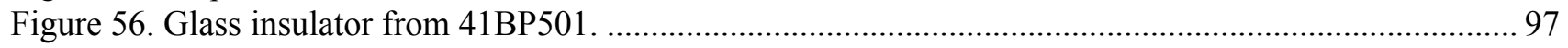

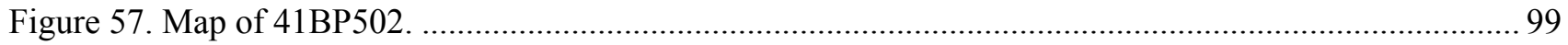

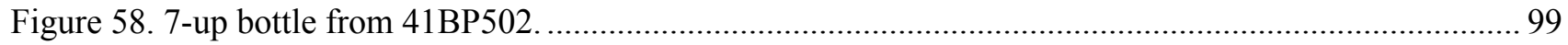

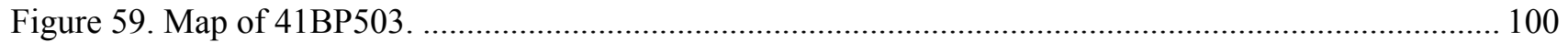

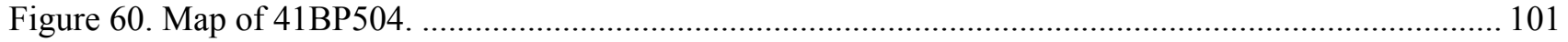

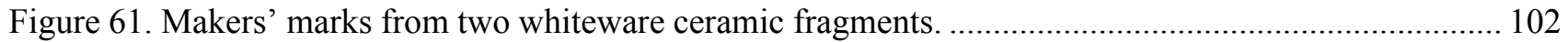

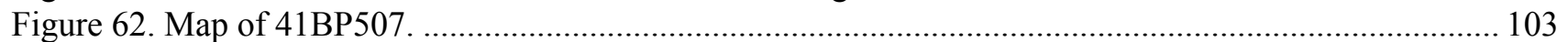

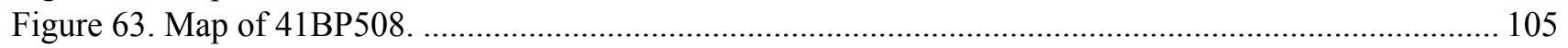

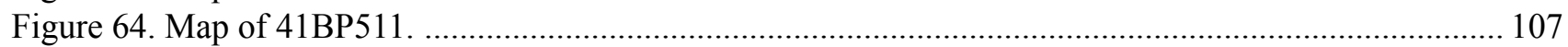

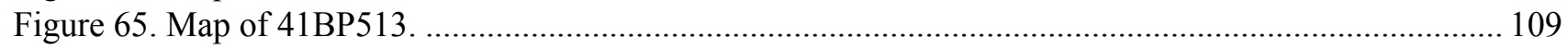

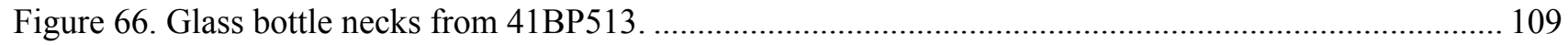

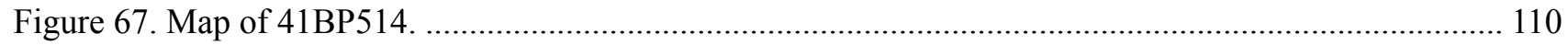

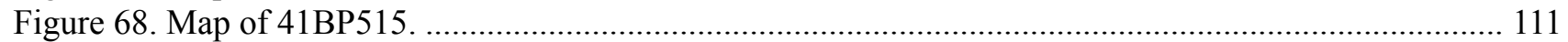

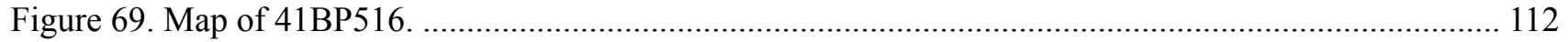

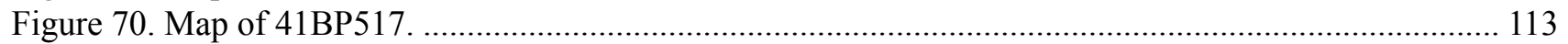

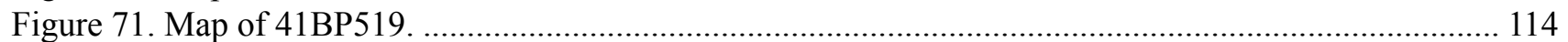

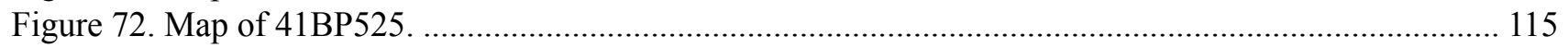

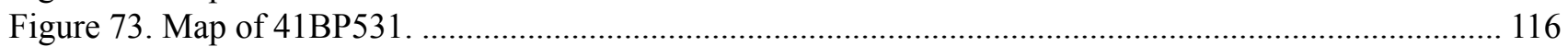

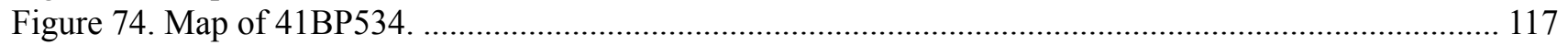

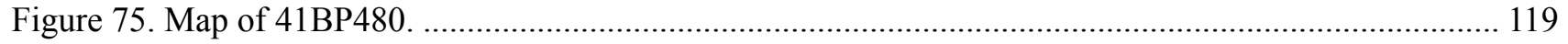

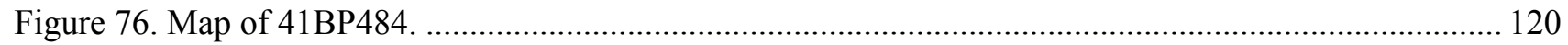

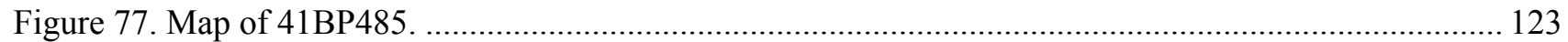

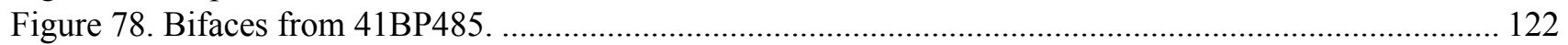

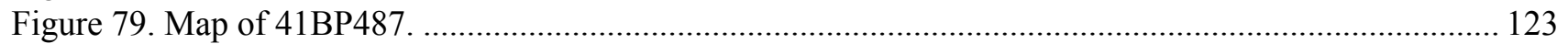

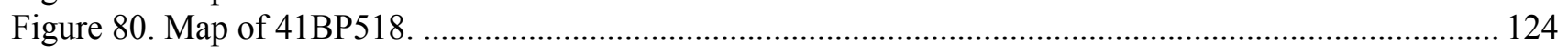

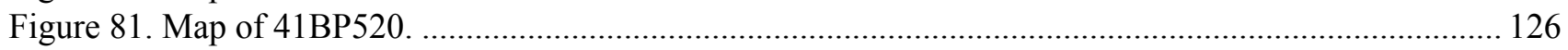

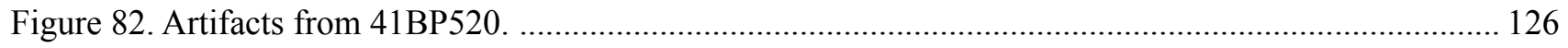

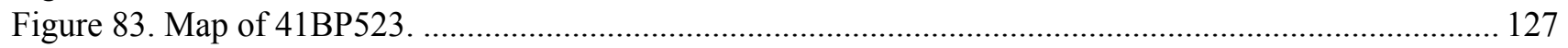

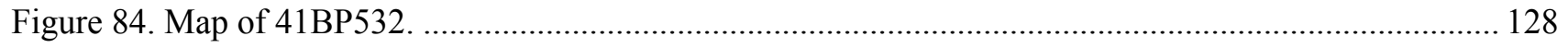

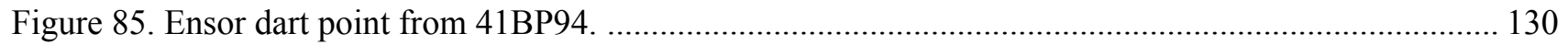

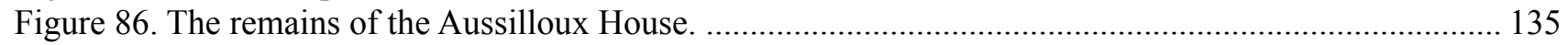

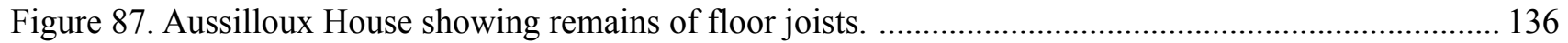

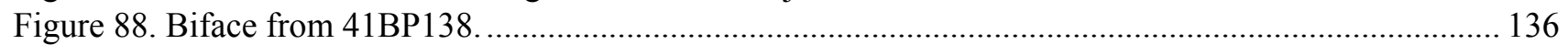

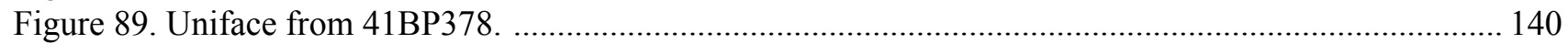


Figure 90. Artifacts from 41BP381.

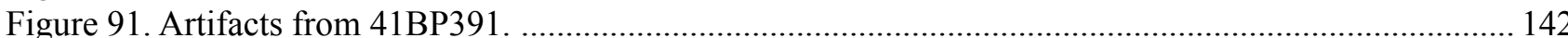

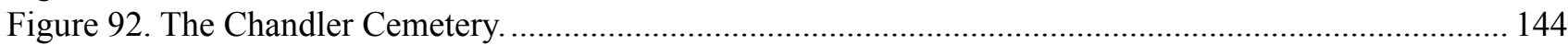

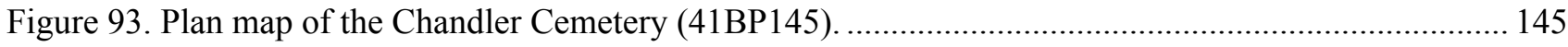

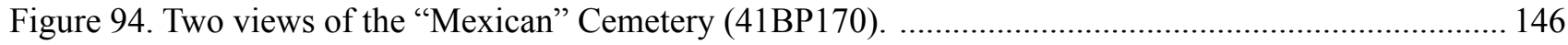

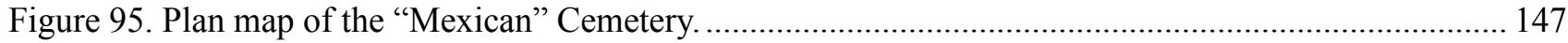

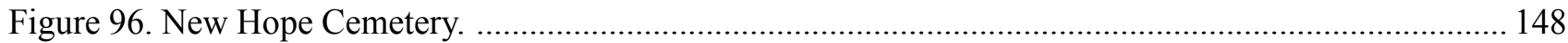

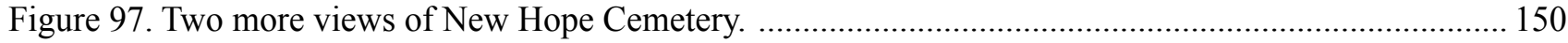

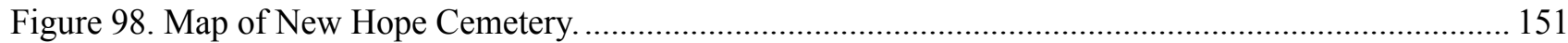

Figure 99. Depth of lithic material by site and physiographic zone.......................................................... 161

Figure 100. Debitage density distribution by site and physiographic zone. .............................................. 162

Figure 101. Distribution of average flake thickness/length ratios by site and physiographic zone. .............. 163

Figure 102. Distribution of ranges in flake thickness/length ratios by site and physiographic zone............. 163

Figure 103. Density of unaltered, burnt, and heat-treated flakes and shatter by physiographic zone............. 165

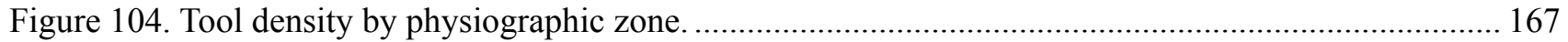

* Site location map-Camp Swift.

We have elected not to include the overall site location map in this report because of sensitivity issues involved with archaeological sites. For those readers who are interested this map may be requested by calling (512) 782-6194, or writing to:

AGTX-EV, Cultural Resources, P.O. Box 5218, Austin, TX 78763-5218 


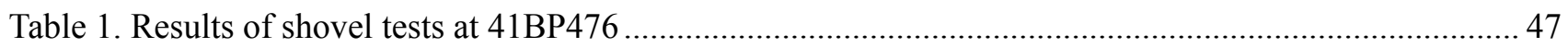

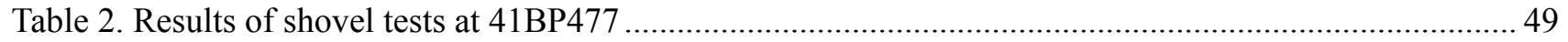

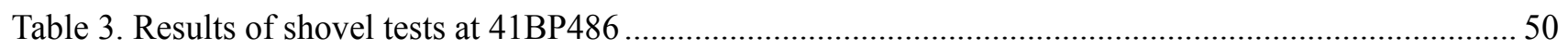

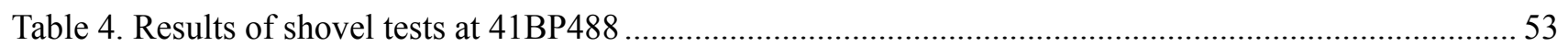

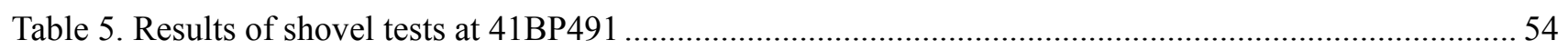

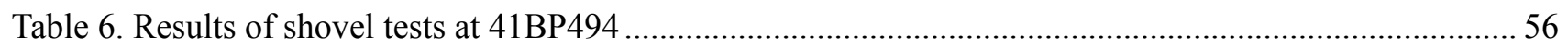

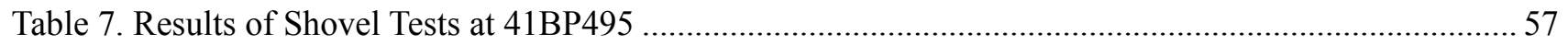

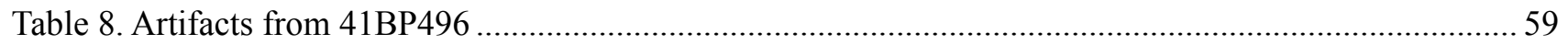

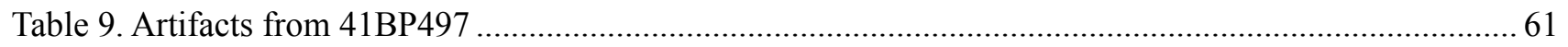

Table 10. Results of shovel tests at 41BP505

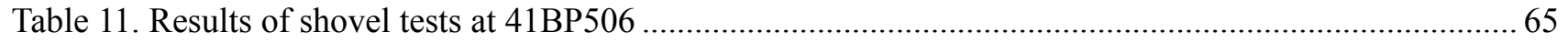

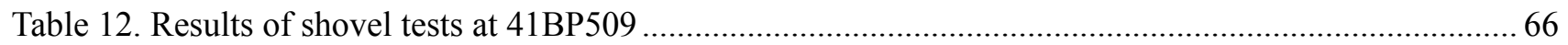

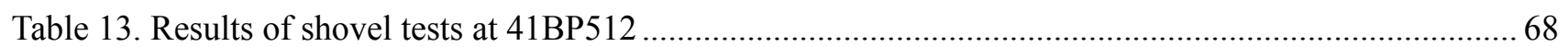

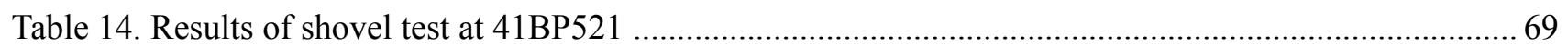

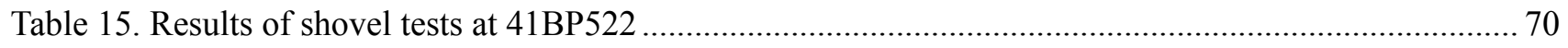

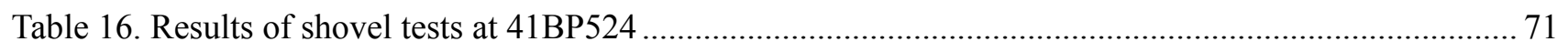

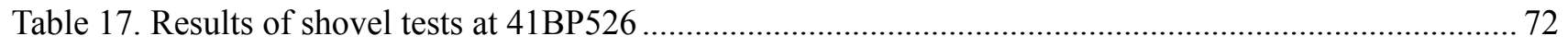

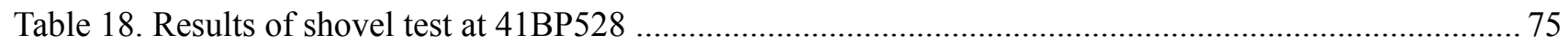

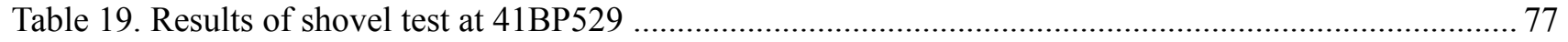

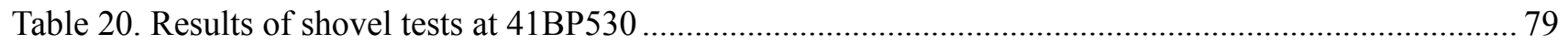

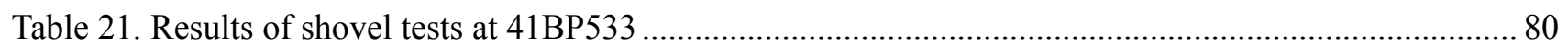

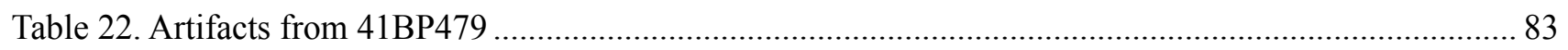

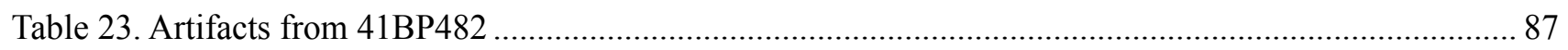

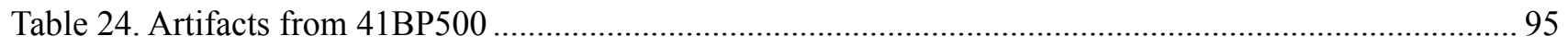

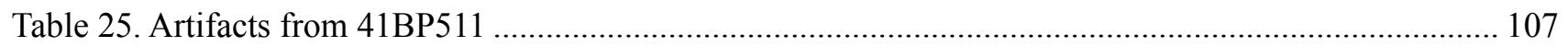

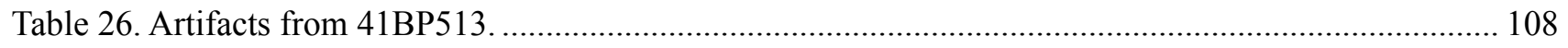

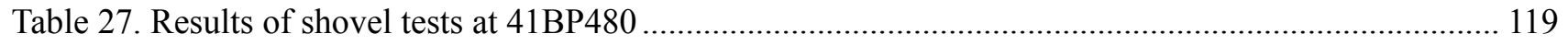

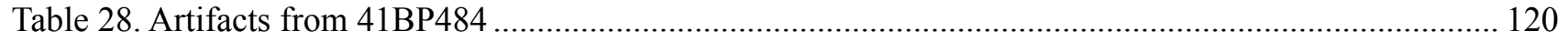

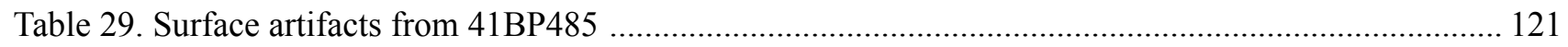

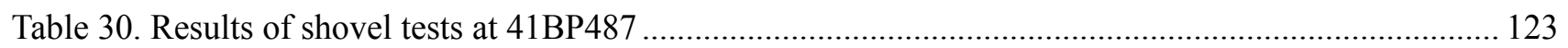

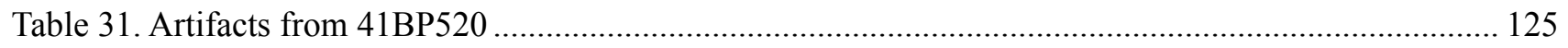

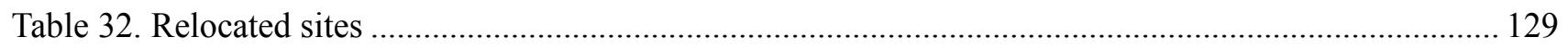

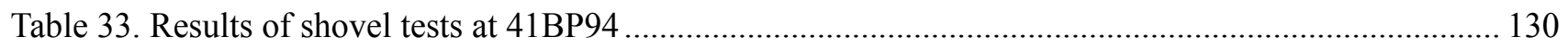

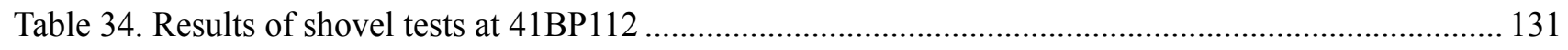

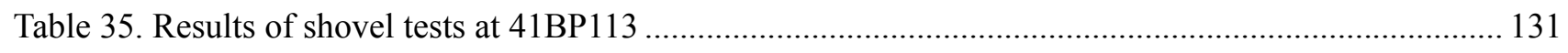

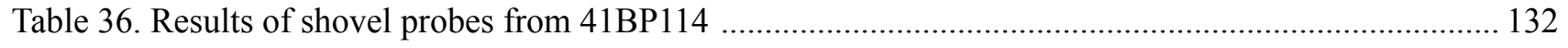

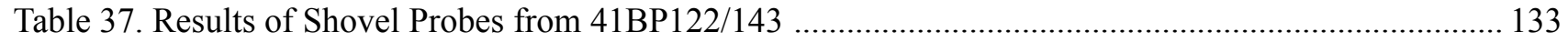

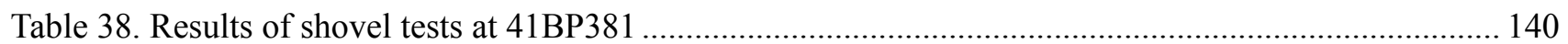

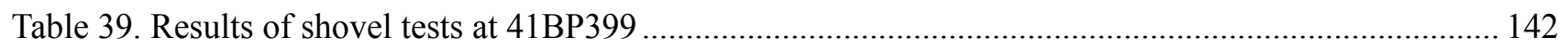

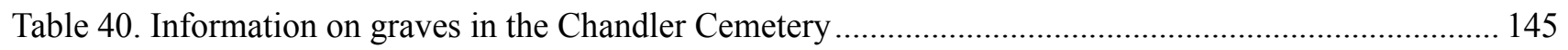

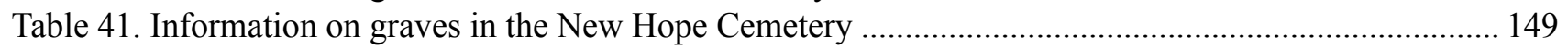

Table 42. Summary of prehistoric components represented among the surveyed sites .............................. 157

Table 43. Comparison of sites by physiographic zone ......................................................................... 158 
Table 44. Types of sites found in the 1996-1997 survey compared with the 1979 survey......

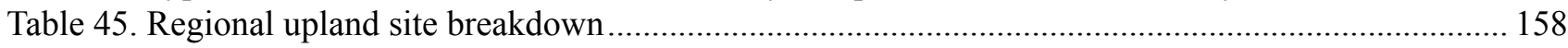

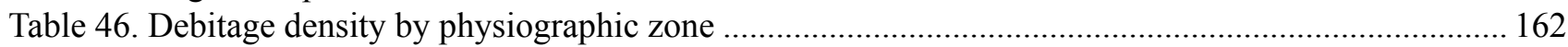

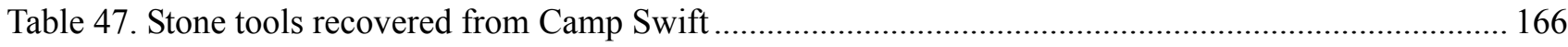

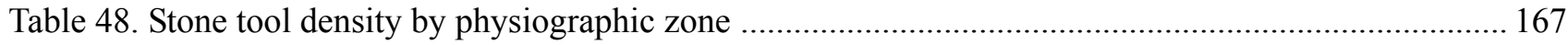

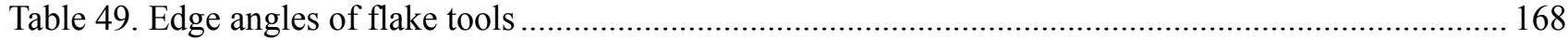

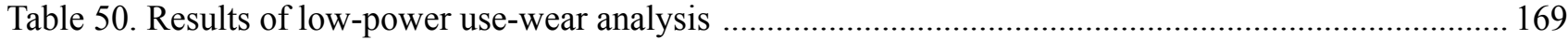

Table 51. Eligibility assessments for known sites at Camp Swift ............................................................ 177 


\section{Acknowledgments}

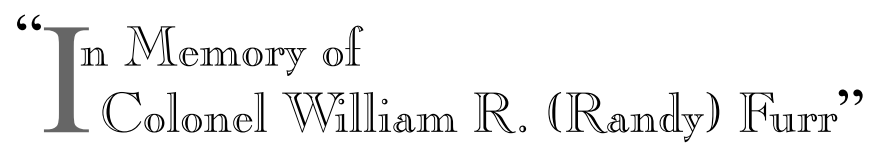

A large group of people brought this project to completion. The Camp Swift Phase I field survey was conducted by Dr. David G. Robinson, Timothy Meade, Leeann Haslouer Kay, Dustin Kay, and Linn Gassaway. Michael Jordan was a student intern who contributed substantially to the field and laboratory efforts. The supplemental survey for the Phase I survey was conducted by the Center for Archaeological Research (CAR), The University of Texas at San Antonio (UTSA). Fieldwork for the supplemental survey was conducted by David Nickels, Rick Robinson, and Ruth Mathews, and the report composition was compiled and conducted by Raymond P. Mauldin, and Barbara A. Meissner. Thanks are also in order for the CAR editorial staff, Maryanne King, Johanna Hunziker and Jennifer Logan.

Many military leaders within the Texas National Guard gave our program their full support. These include: Major General Daniel James III, the Adjutant General of Texas, Colonel William R. Furr, who was head of the Directorate of Facilities and Engineering of the Adjutant General's Department when the 1997 survey began; Colonel Dennis Haire, who succeeded Colonel Furr at the end of his tenure; and Colonel John A. Wells, who succeeded Colonel Haire. Within the directorate our appreciation is extended to Valerie Stein, Environmental Program Manager, and Dr. Paul Powell, Natural Resources Manager. In-house cultural resources staff -Stephen Stringer and Shellie Prewitt provided administrative assistance. The Cultural Resources Manager at the time of the Phase I survey was Alan J. Wormser, who handled project management of the Phase I survey. Mr. Wormser was then succeeded by Shellie Prewitt, who managed the supplemental survey contract with CAR-UTSA. Outside the Adjutant General's Department, Debra Beene of the Texas Historical Commission represented the interests of the Texas State Historic Preservation Officer and reviewed the report for eligibility assessment issues. Her advice and guidance were highly appreciated. Captain Michael Diltz of the Texas Army National Guard was facility manager of Camp Swift and an enthusiastic facilitator of all phases of the work conducted there. Captain Diltz was then succeeded by Master Sergeant Robert West, who also offered his assistance whenever it was needed.

The Bastrop County Historical Society - a local group — provided useful background information. Furthermore, many local residents of Bastrop County were source informants on the historical background of the camp and the historic contexts. They include Barbara Brinkmeyer, Louise Goerlitz, Ken Kesselus, Jonell Majors, Clyde Reynolds, Abner C. Scott, and all of the staff of the Bastrop County Clerk's office. No single person, however, was more generous with their time, resources, and homegrown tomatoes than Fay Pannell of Sayersville, descendant of early Bastrop settlers and witness to the development of Camp Swift from its beginnings until now. 


\section{Chapter 1: Introduction}

\section{David G. Robinson}

This report documents a cultural resources inventory of Camp Swift, a U.S. Army National Guard training facility in northern Bastrop County, Texas, conducted by the Adjutant General's Department of Texas (AGTX). The project included a pedestrian survey of 4000 acres of previously unsurveyed property, a resurvey of approximately 1000 acres of previously surveyed property, and an assessment of prehistoric and historic sites identified in previous surveys. The inventory of cultural resources produced will be used to develop a cultural resources management plan for this federally owned land, supporting land management practices established under Section 110 of the National Historic Preservation Act (NHPA, 16 U.S.C. 470h-2). Section 110 encourages federal agencies to inventory their holdings for historic properties that could be affected by their undertakings. In addition, Presidential Executive Order EO11593 requires such inventories. Under Section 106 of NHPA (16 U.S.C. 470f), specific undertakings are reviewed for their potential impact on historic properties. By having inventories available beforehand, the Section 106 process is expedited.

Army Regulations AR200-4 require inventories in support of cultural resource management plans. In addition to NHPA concerns, AR200-4 also addresses a broad array of other laws and regulations. For example, the Native American Graves Protection and Repatriation Act (NAGPRA, 25 U.S.C. 3001 et seq.) requires federal agencies to report to recognized Native American tribal groups and Native Hawaiian organizations on native burial grounds, interments, and burial objects.

The Camp Swift inventory will help the AGTX to comply with federal laws and implement good land management practices. At the same time, the present study will add to our knowledge of the archeology and history of central Texas.

\section{Project Tasks}

The inventory project consisted of four tasks:

1. A pedestrian survey of approximately 4000 acres of Camp Swift not previously surveyed.

2. A resurvey of approximately 1000 acres that had been surveyed in 1979 by the Lower Colorado River Authority (Skelton and Freeman 1979).

3. Revisit selected sites documented in the 1979 survey (Skelton and Freeman 1979) and others (Davis 1994a, 1994b, 1995; Leshley 1994, 1996; Nightengale and Moncure 1996; Schmidt and Cruse 1995) in an attempt to assess their current condition.

4. Summarize historic contexts within which the significance of the cultural resources can be assessed.

Reconnaissance visits took place in November 1996, and the full survey began in December 1996. The fieldwork was largely completed by June 30, 1997. The field crew was comprised of David G. Robinson (project manager), Timothy Meade, Leeann Haslouer Kay, Dustin Kay, and Linn Gassaway. AGTX archeologist Stephen Stringer and intern Michael Jordan also provided assistance during the fieldwork.

Subsequently, the Center for Archaeological Research (CAR) of The University of Texas at San Antonio (UTSA) contracted with AGTX to conduct shovel testing of sites 41BP485 and 41BP487 and acquire GPS locations of 28 sites. This fieldwork was performed in September 2000. Project director for the field phase 
was David L. Nickels, who worked with crew members Ricky Robinson and Ruth Mathews. In addition, a geomorphologist, Shane Prochnow, visited the site and excavated 12 backhoe trenches to collect data for his report (see Chapter 3). John J. Leffler wrote a history of the Camp Swift area, making use of, among other resources, some of the preliminary draft reports written by Linn Gassaway, Leeann Haslouer Kay, and David G. Robinson. Steve A. Tomka edited the lithic analysis by Leeann Haslour Kay, correcting several figures and reevaluating some of the conclusions. Raymond P. Mauldin rewrote the summary of the project, including National Register of Historic Places (NRHP) evaluations of all known archaeological sites on Camp Swift. Barbara A. Meissner then put together the final report, reorganizing the original draft while incorporating the additional material.

\section{Structure of The Report}

The remainder of this chapter will present a brief description of the project area, and a discussion of previous archaeological research at Camp Swift and the immediate area. Chapter 2 provides a prehistoric background to the remainder of the report and the John Leffler report on the history of the Camp Swift area. Chapter 3 is a report on the geoarchaeological work completed by Shane Prochnow. Chapter 4 details the field and laboratory procedures used during the project. Results of the survey and reassessment of previously discovered sites are presented in Chapter 5. Chapter 6 provides a set of historic contexts within which the significance of the sites at Camp Swift was assessed. Chapter 7 summarizes the reports and the eligibility assessments for all known sites at Camp Swift and provides recommendations for cultural resource management of the Camp. Appendix A is a list of collected artifacts. Appendix B is a table of measurements of formal lithic tools. Appendix $\mathrm{C}$ is the backhoe trench descriptions by Shane Prochnow. Appendix $\mathrm{D}$ is a table summarizing information on all the known sites of Camp Swift. 


\section{Project Area}

\section{David R. Robinson and Timothy M. Meade}

Camp Swift is located in northern Bastrop County, Texas and covers about 11,500 acres. It is about halfway between the towns of Elgin and Bastrop on State Highway 95 (Figure 1).

The camp is a remnant of the 52,982-acre Army training facility created in 1942 during the mobilization for World War II. After the war, the camp was subdivided to serve a variety of purposes. The northern portion was transferred to the Texas National Guard, and other parcels are now owned by the University of Texas at Austin, Texas Parks and Wildlife Department (TPWD), or have reverted to private ownership.

\section{Topographic Setting}

The region around Camp Swift consists of moderately dissected, rolling uplands with flat bottomlands (Skelton and Freeman 1979). The camp itself is in one of the dissected upland areas. Small streams, many of which flow seasonally, cut across the camp. Within the camp, the slope relief tends to be gentle to moderate (3\% to $8 \%$ slopes) and elevation varies from 400 to 500 feet above mean sea level (AMSL).

\section{Geology}

Chapter 3 contains a detailed discussion of the geology of Camp Swift. The following is a brief, generalized overview.

\section{Wilcox Group, Calvert Bluff Formation}

Bastrop County is on Eocene age outcrops within the western portion of the Gulf Coastal Plain (Avakian and Wermund 1993). The Wilcox Group underlies the region and includes fine to coarse-grained sands, clay, sandstone, and silty shale with lenses of limestone and lignite.

Three formations occur within the Wilcox Group: Hooper, Simsboro, and Calvert Bluff. Of these, only the Calvert Bluff formation outcrops at Camp Swift.

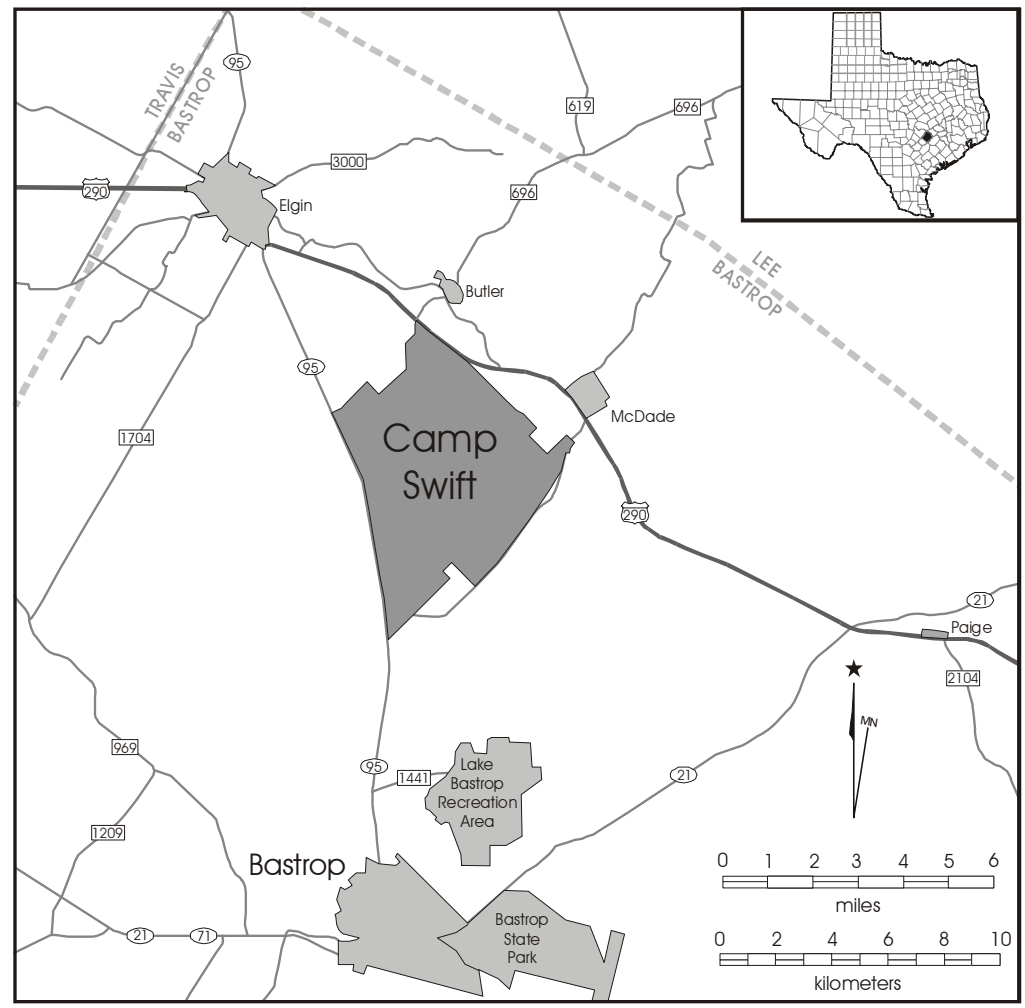

Figure 1. Location of project area. 
Across southern Texas, the formation trends roughly parallel to the Gulf coastline. It is mostly mudstonesome of which is glauconitic ("green sand") — and can occur in locally thick beds (Proctor et al. 1974). Also occurring in this formation are varying amounts of sandstone, lignite, and hematite.

\section{Uvalde Gravels}

Uvalde gravels overlie the Wilcox deposits, and consist of a thin veneer of lag deposits dating to the formation of the Colorado River drainage between the Miocene and Pliocene epochs (Byrd 1971). Deposits of Uvalde gravels consist of pebbles and cobbles of chert, quartzite, jasper, limestone, and silicified wood. Fragments of granite, rhyolite, and other igneous rock occur infrequently.

The Uvalde gravels occur below the 450-foot elevation contour and are most abundant in the northern portions of Camp Swift. The deposits are especially prevalent along the lower reaches of the Big Sandy Creek drainage, and are associated with ridges and sandy hilltops within the camp. Small concentrations of Uvalde gravels have also been noted in the main channels of the Big Sandy Creek drainage, usually near headwater confluences (Skelton and Freeman 1979). The gravels offered a readily available source of chert to the Native American population.

\section{Hydrology and Physiography}

\section{Drainages}

The area's major drainage, the Colorado River, flows southeasterly and is several miles south of the camp. Within the Camp Swift boundaries, the main watershed is Big Sandy Creek, which is a tributary of the Colorado River.

Four other streams also extend through Camp Swift. McLaughlin Creek is in the north-central portion of the camp, Dogwood Creek is in the northwest portion, Dogwood Branch is in the south-central portion, and Harris Creek flows through the extreme southeast portion of the camp. These flow most of the year.

Camp Swift is over the Wilcox-Carrizo aquifer, which trends southeast to the Colorado River. The aquifer is of significance to the development of historical settlements and the local farming economy.

Camp Swift is in the uplands north of the Colorado River. Skelton and Freeman (1979) noted that four physiographic zones have been identified within the camp:

1. Active floodplains;

2. Upper terraces;

3. Valley margins; and

4. Upland divides.

\section{Active floodplains}

Active floodplains border modern drainage channels and are flat to gently sloping landforms composed of sediments recently deposited by the associated stream. They are frequently subject to alternating periods of scouring and deposition. Active floodplains are sometimes covered with water during periods of flooding. Vegetation on the active floodplains consists of a riparian plant community (Skelton and Freeman 1979).

\section{Upper Terraces}

Upper terraces within Camp Swift are relatively flat landforms bordered on one side by low vertical escarpments, which are generally less than 10 meters in height. Landforms associated with upper terraces include slopes, rises, and terrace knolls. Terrace knolls are uncommon, but have been identified by previous investigators as having a high probability of containing prehistoric sites (Skelton and Freeman 1979). Soils usually associated with upper terraces are alluvial or colluvial sandy loams. Some may include reworked eolian material. Depth of the soil ranges from a few centimeters to more than three meters. Underlying the sandy horizons are clayey sediments, some of which predate the Pleistocene. Vegetation on the upper terraces can include riparian, post oak, and cedar plant communities.

\section{Valley Margins}

Valley margins include the areas between the lower terraces and the higher upland drainage divides. Numerous headwater streams dissect the flat to moderately sloping valley margins. The most prominent features associated with valley margins are small knolls, which appear as secondary terraces. These 
knolls usually occur near down-slope gradients, especially near stream confluences. Soils on the valley margins are sandy and vary from a few centimeters to more than one meter in depth. In areas subject to slope wash and modern disturbance, erosion has exposed the clayey subsoil. Valley margins also contain deposits of Uvalde gravels, which were used by Native Americans as raw material for stone tools. The vegetation of the valley margins has been greatly impacted by historic farming and ranching activities. In lower areas, the plant community reflects an earlier use of the land for agriculture and pasture, while in higher elevations Mesquite-Brushland plant communities are the most common (Skelton and Freeman 1979).

\section{Upland Divides}

Upland divides are the interfluvial summits that separate the major tributaries of a common drainage system. This physiographic zone is characterized by rolling terrain with round and linear hills with gentle to moderate slopes. The soil of the upland divides has both sandy and clayey deposits and is often covered with a thin veneer of pebble- to cobble-sized Uvalde gravels. Vegetation on the upland divides most often consists of dense woodland (Skelton and Freeman 1979).

\section{Soils}

Two soil associations occur at Camp Swift and comprise 14 soil series (Baker 1979). The Patilo-DemonaSilstid association occurs along Big Sandy Creek in the northern portion of the camp, and in small, isolated patches along the southeastern boundary of the camp. It is characterized by gently to strongly sloping, upland soils with a sandy surface layer. They have moderately slow to moderate permeability.

The other soil association, Axtell-Tabor, occurs over the remainder of Camp Swift. Soils in this association tend to have shallow A-horizons (40 cm or less), and vary from nearly-level to strongly-sloping terrain. This association tends to have soils with loamy surfaces over very slowly permeable clayey lower layers. Axtell-Tabor soils are typically on stream terraces and uplands.

\section{Potential for Buried Sites on Specific Soil Units}

The potential for intact buried sites at Camp Swift is dependent on the soils on which the sites may be situated. Sullo and Wormser (1996) identified the archaeological potential for eight soil series located within a proposed Bradley Fighting Vehicle (BFV) training area at Camp Swift. The soils were categorized as having low, moderate, and high potential to contain buried sites. This section will utilize their criteria to evaluate the potential of all soil series mapped at Camp Swift.

\section{Soils with Low Potential}

Soils with low potential for containing intact buried archeological sites are characterized as having shallow sandy or loamy A-horizons, which overlie deep clayey B-horizons or have an A-C pedon. Common characteristics of the $\mathrm{B}$ - and $\mathrm{C}$-horizons of these soils include mottling, calcium carbonate $\left(\mathrm{CaCO}_{3}\right)$ development, and iron magnesium (Fe- $\mathrm{Mg}$ ) concentrations. In most instances the Holocene-age deposits have been truncated by erosion or, as in the case of Uhland soils, have been scoured by fast-moving water during frequent flood events. For the most part, these soils form on ancient (Pleistocene or older) deposits. Examples at Camp Swift include Axtell fine sandy loam, Crockett soils, Ferris clay, Mabank loam, Rosanky fine sandy loam, Tabor fine sandy loam, Uhland soils, and Wilson clay loam.

\section{Soils with Moderate Potential}

Soils with moderate potential for containing intact buried archeological deposits are characterized as upland soils with deep A-horizons. At Camp Swift these soils are sandy soils developed mainly from alluvial and colluvial depositions that have been reworked by eolian processes. Soils with moderate archeological potential mapped at Camp Swift include Demona loamy fine sand, Patilo complex; Sayers fine sandy loam, and Silstid loamy fine sand.

\section{Soils with High Potential}

Ideally, soils with a high potential for containing intact buried archeological deposits would have cumulic horizons dating to the Holocene. In addition, highpotential soils would have paleosols caused by rapid soil aggradation punctuated by periods of stability. 
This rapidity of sediment deposition increases the probability that the site's cultural components remain intact, while the punctuated nature of the deposition helps insure that the components are vertically separated. Unfortunately, no soils within the limits of Camp Swift meet these requirements. Areas at Camp Swift which might have experienced rapid sediment deposition may have also been subject to massive scouring at approximately 600 B.P. (see Chapter 3). Any artifacts in these locations dating to the Late Archaic or before are probably in secondary contexts.

\section{Paleoclimate}

Evidence for climatic change from the Pleistocene to the present is most often obtained through pollen and faunal studies (Bryant and Holloway 1985; Collins 1995; Toomey 1993). A sequence of climatic change for east/central Texas from the Wisconsin Full-Glacial period $(22,500-14,000$ B.P.) through the Late Glacial period $(14,000-10,000$ B.P.) to the Post Glacial period (10,000 B.P. to Present) has been presented by Bryant and Holloway (1985).

Evidence from the Wisconsin Full-Glacial period in east-central Texas suggests that the climate was considerably cooler and more humid than present. Pollen data indicate that the region was more heavily forested in deciduous woodlands than is found in later periods (Bryant and Holloway 1985).

The Late Glacial period in east-central Texas was a transitional period characterized by slow climatic deterioration and a slow warming and/or drying trend (Collins 1995). In east-central Texas the deciduous woodlands began to disappear and were replaced by grasslands and oak savannas (Bryant and Holloway 1985).

The Post Glacial period was characterized by more subtle changes than those which marked the previous period. In general, the environment of east-central Texas appears to have been fairly stable. The deciduous forests and woodlands of the preceding glacial periods were gone, having been replaced by prairies and post oak savannas. A drying and warming trend begun in the Late Glacial period continued into the
mid-Holocene, at which point there appears to have been a brief amelioration to more mesic conditions lasting roughly from 6,000 to 5,000 B.P.

Initial studies by Bryant (1977) indicated that the modern Post Oak Savanna environmental conditions were established by 3000 years ago. However, more recent studies (Bryant and Holloway 1985) have refined the model and indicate that present conditions date to about 1500 years ago.

\section{Modern Climate}

Bastrop County is within the south-central climatic division (Carr 1967). The modern climate is characterized as dry and sub-humid with long hot summers and short mild winters. Precipitation is greatest during May and September. Annual rainfall is $93.5 \mathrm{~cm}$ ( 36.8 inches) and the average growing season is 270 days.

\section{Resources-Flora}

Camp Swift is within a secondary forest and woodland region termed the Post Oak Savannah vegetational area. Pre-settlement climax vegetation within the Post Oak Savannah consisted of post oak (Quercus stellata), blackjack oak (Quercus marylandica), southern red oak (Quercus falcata), elm (Ulmus spp.), hickory (Hickory spp.), loblolly pine (Pinus taeda), flowering dogwood (Cornus florida), red maple (Acer rubrum), and various tall grasses including little bluestem (Schizachyrium scoparium), Indian grass (Sorghastrum nutans), and switch grass (Panicum virgatum). Prior to settlement in the Post Oak Savannah vegetational area, it is likely that trees were spaced widely in clumps. Following historic settlement, the proportion of trees to grassland appears to have increased. This increase in forested areas has been linked to a decline in prairie fires.

Dramatic changes in the native vegetation region have occurred during the post-settlement period (Skelton and Freeman 1979). These changes have occurred primarily as a result of land disturbance associated with military, agricultural, and ranching activities. 
Indications of land-disturbing activities can be seen in the plant communities in the form of invader species which are currently found on Camp Swift. These invader species include eastern red cedar (Juniperus virginiana), mesquite (Prosopis glandulosa), yaupon holly (Ilex vomitoria), eastern prickly pear (Opuntia compressa), and green briar (Smilax spp.).

Skelton and Freeman (1979) have identified four plant communities within Camp Swift:

1. Post Oak-Red Cedar Woodlands;

2. Mesquite Brushland;

3. Old Field; and

4. Riparian.

The Post Oak-Red Cedar Woodlands community is found on sandy soils in upper sections of valley margins and upland divides. The predominant vegetation in this plant community is post oak and red cedar. The Mesquite Brushland plant community is commonly found along disturbed areas on valley slopes and knolls. The predominant vegetation of this plant community includes mesquite, red cedar, netleaf hackberry, and winged elm. The Old Field plant community consists of the remnants of former agricultural fields; it is found primarily on floodplains and lower sections of valley margins on thick sandy deposits. The predominant vegetation of this plant community is various grasses and weeds. The Riparian plant community is restricted to active floodplains with alluvial deposits. The predominant vegetation of this plant community includes red cedar, black willow, elm, cottonwood, black hickory, pecan, post oak, and hackberry.

\section{Resources-Fauna}

Camp Swift is in the southwestern portion of the Texan Biotic Province (Blair 1950). The fauna from this region are represented by a mixture of species from the Austroriparian, Tamaulipan, Chihuahuan, Kansan, Balconian, and Texan biotic provinces (Schmidt and Cruse 1995). Common mammalian species include white-tailed deer (Odocoileus virginianus), opossum (Didelphis virginiana), eastern cottontail rabbit (Sylvilagus floridanus), raccoon (Procyon lotor), striped skunk (Mephitis mephitis), hispid cotton rat
(Sigmodon hispidus), white-footed mouse (Peromyscus spp.), nine-banded armadillo (Dasypus novemcinctus), and fox squirrel (Sciurus niger). During the fieldwork, evidence of the presence of beavers (Castor canadensis) was found along Big Sandy Creek in the form of tree gnawing, two dams, and the remnants of a lodge. Common bird species include northern bobwhite (Colinus virginianus), eastern meadowlark (Sturnella magna), mourning dove (Zenaida macroura), killdeer (Charadrius vociferous), field sparrow (Spizella pusilla), red-tailed hawk (Buteo jamaicensis), turkey vulture (Cathartes aura), belted kingfisher (Ceryle alcyon), and mockingbird (Mimus polyglottos). Reptile and amphibian species common to this biotic zone include six-lined racerunner (Cnemidophorus sexlineatus), rat snake (Elaphe spp.), eastern hognose snake (Heterodon platirhinos), Gulf Coast toad (Bufo valliceps), Texas spiny lizard (Sceloporus olivaceus), rough green snake (Opheodrys aestivus), copperhead (Agkistrodon contortix), western diamondback rattlesnake (Crotalus atrox), green treefrog (Hyla cinerea), Blanchard's cricket frog (Acris crepitans blanchardii), diamondback water snake (Nerodia rhombifera), Houston toad (Bufo houstonensis), and green anole (Anolis carolinensis). The Houston toad is a listed endangered species at Camp Swift. 


\section{Previous Investigations in Bastrop County}

\section{David R. Robinson}

The earliest collected information on prehistoric sites is Wilson's (1930) unsystematic survey of Bastrop and Fayette counties. His work amply demonstrated the prehistoric significance of the county, but descriptions were so sketchy that many sites could not be positioned accurately on the state site file maps at the Texas Archeological Research Laboratory of the University of Texas at Austin (TARL) (UT-Austin). Later, A. T. Jackson entered agreements with landowners to investigate 41BP40, the Maney Gravel Pit, but excavations remain unreported, if they actually took place. The Goodwin Site (41BP1) yielded two Late Prehistoric burials during a 1953 excavation program sponsored by the Department of Anthropology, UT-Austin.

In the mid-1960s, the University of Texas Anthropological Society (UTAS) conducted archeological research in the area. In addition to survey, the society recorded Late Prehistoric burial remains at the McCormick Site (41BP43) near McDade. A possible Paleoindian site, the Pease Site (41BP51) was recorded, and a Late Prehistoric campsite, 41BP55, received test excavations in 1966. Sites 41BP62, 41BP63, and 41BP64 were tested by UTAS in 1968 and all yielded evidence of occupations from the Archaic period through the Late Prehistoric. Also in the 1960s, the Travis County Archeological Society investigated (41BP70) the Oliver Balsh Site, (TARL site files).

Legally mandated contract archeology began in Bastrop County in the mid-1970s, initially by the Texas Archeological Survey, UT-Austin. Contract projects began with an intensive 160-acre survey of federal property near Camp Swift. The survey identified one lithic scatter, 41BP68 (Fawcett 1975). Dibble (1976) surveyed another small area in Camp Swift before the major intensive survey and testing program was conducted by Skelton and Freeman (1979). As a result, 42 prehistoric and 41 historic sites were recorded. A large Lower Colorado River Authority (LCRA) project, the Powell Bend Lignite Mine, provided cultural resource studies from the northern uplands near Camp Swift. The Powell Bend findings (Bement 1984;
Kenmotsu 1982; Robinson 1983a) combined with the Camp Swift research provided a representative picture of prehistoric upland settlement patterns.

The Texas Department of Transportation (TxDOT) reported sites sporadically through the 1970s and 1980s, most significantly 41BP19, the Kennedy Bluffs Site (Bement 1989) and the nearby Bull Pen Site, 41BP280 (Ensor and Mueller-Wille 1988). Duke (1978) published a report on the Lake Thunderbird Site (41BP78). Kelly and Roemer (1981) identified four prehistoric and four historic sites on a lignite prospect survey north of Butler for the City of San Antonio. Additional transmission corridor surveys were conducted by Laurens et al. (1979), Nightengale (1980), and Brown (1984); and small grazing area surveys near Lake Bastrop were carried out by Prewitt and Associates, Inc. The Bastrop County Historical Commission's sesquicentennial project survey concentrated on the riverine environment in an effort to gain a representative sample of that zone (Robinson 1987). Survey and testing efforts in Lake Bastrop State Park were sponsored by TPWD (Medlar 1995). The two permitted efforts in that project recorded six sites and accomplished test excavations on 41BP377. TPWD also sponsored another historical and archeological study of Lake Bastrop State Park (Tomka and Crouch 1996). In that study, clearance surveys located 18 cultural properties. Here, intensive shovel testing contributed to impact assessments of threatened sites.

Espey, Huston and Associates, under the sponsorship of the LCRA, conducted a cultural resources survey of a 28-mile-long power line corridor in Bastrop and Travis counties (Schmidt and Cruse 1995). The corridor passes through the western edge of Camp Swift in a roughly north-south direction paralleling State Highway 95 . The survey recorded 18 newly discovered sites, seven of which (41BP383, 384, 385, 389, 390, 391, and 392) were located on Camp Swift. Five of these were deemed potentially eligible for the National Register of Historic Places (see Appendix D).

Significant research has focused on the historical period of the county. Historical archeological studies have been conducted on the George Washington Jones House, 41BP86 (Robinson 1989), and the Bastrop County Courthouse and Old Jail (Robinson and Utley 1990). Kesselus $(1986,1987)$ synthesized 
documentary evidence to create a compendium of sources on nineteenth-century Bastrop County in addition to a well-knit historical narrative of the period from 1827 to 1865 . The aforementioned study of Lake Bastrop State Park (Tomka and Crouch 1996) focused on the establishment of Camp Swift and the World War II period. Nightengale and Moncure (1996) applied their study to the cantonment and the prisoner of war camp; their work adds to the history of the developed parts of the camp. Finally, a local history group, the Sayersville Historical Association, published an occasional series, the Sayersville Historical Association Bulletin, on a variety of historical and archeological topics.

Since 1993, staff of the cultural resources branch of the Directorate of Facilities and Engineering, headquartered at Camp Mabry in Austin, have conducted small-scale surveys in advance of ground-disturbing training exercises and facilities construction projects. Additionally, Espey, Huston, and Associates (Schmidt and Cruse 1995) conducted a large clearance survey, adhering to standards and a scope of work written by the Adjutant General's Department of Texas. The findings of each of these projects have made a collective contribution to research at Camp Swift and the cultural resources management plan under development. The projects are summarized to offer a baseline context to the larger-scale research reported herein.

Survey in advance of field training exercises on the northwest side of Scott Hill located no new cultural sites, although shovel testing was employed (Wormser 1993a). Preexisting site 41BP98 was reassessed and recommended for avoidance. Wormser (1993b) also reported on the survey of a proposed septic field facility near the Blackwell drop zone at the southeastern edge of the camp. The survey was supplemented by shovel testing and screening of exposed fill for cultural materials. No cultural sites were found, and the proposed development was cleared to proceed.

Survey of a proposed firing range road extension yielded two sites, 41BP379 and 41BP380 (Davis 1994a). Both sites were in areas of heavy disturbance and lacked integrity. The sites are multicomponent prehistoric and historic debris scatters. 41BP380 had a basal fragment of a Middle Archaic projectile point; 41BP379 contained nondiagnostic chert flakes. The defining historic debris on each of the sites dates to the late nineteenth and early twentieth centuries.

Survey of six acres on the site of a proposed mock village for urban terrain training on the eastern side of the camp had negative results (Davis 1994b). A shovel test pattern was employed during the fieldwork.

Further survey was conducted near the mock village in anticipation of the construction of ammunition storage facilities (Leshley 1994). The survey covered approximately 30 acres, ten of which were defined as the area of potential effect (APE). One site, 41BP378, was discovered about 300 meters south of the APE. The site was an open campsite containing burned rock, lithic debitage, and a bifacial core chopper.

Wormser (1994) reported on a survey performed prior to a stream rechannelization project. The stream channel was intruding on the M-60 machine-gun firing range. One site, 41BP381, was found north of the APE. The site is a thin lithic scatter with a mano and a chert core. The southern portions of the site may have been disturbed by the machine-gun range.

Espey, Huston, and Associates conducted a cultural resources survey of a seismic exploration tract of approximately 10 square kilometers in the northeast quarter of the camp (Schmidt and Cruse 1995). The Adjutant General's Department provided a scope of work and stipulations for the exploration. The survey was carried out as a narrow corridor survey along the routes of clearing for the proposed seismic test lines. Field observations were supplemented with shovel tests at regular intervals. Seven previously unrecorded sites were discovered (41BP430-41BP436), and five of these sites (41BP430, 431, 432, 435, and 436) were thought to warrant further work to determine their eligibility.

Davis (1995) reported on the survey of an approximately 40 -acre area slated for fire-fighting training. The APE was in the extreme northeastern corner of the camp adjacent to the FM2336 right-of-way (ROW). Augmented by shovel testing, the survey discovered one site, 41BP400, a historic trash scatter dating to the 1940s. The site was deemed ineligible for the National Register of Historic Places, and the proposed project was cleared to proceed. 
Wormser and Leshley (1995) reported on the survey and assessment of dispersed areas slated for squad and platoon maneuvers. By employing a shovel testing field methodology, three previously undiscovered sites were found. One, 41BP397, is a multicomponent prehistoric and historic site. Sites 41BP398 and 41BP399 are prehistoric artifact scatters; 41BP398 yielded a basal fragment of a bifacial tool. Eligibility assessments were not made on these sites, but avoidance was recommended for all the located cultural resources.

Leshley's (1996) survey of an Army aviation support facility, employing shovel testing to enhance site discovery, nevertheless failed to locate any cultural resources. The proposed APE covered 40 acres and was in the extreme northern end of the camp adjacent to the U.S. Highway 290 right-of-way (ROW). Clearance was granted for the development to proceed.

Stringer and Wormser (1996) reported on a five-acre survey for pond improvements. The preexisting artificial pond had been built across a tributary of McLaughlin Creek in the northeastern portion of the camp. It had been slated for widening and deepening and use as a fire-fighting reservoir. The survey, although employing a shovel testing field methodology, yielded negative results.

Sullo and Wormser (1996) discussed findings of a survey of three dispersed training areas (collectively, Area A) in the northern zone of the camp. The training areas were for tracked vehicle maneuvers (Bradley Fighting Vehicles) and subject to surface and subsurface disturbance. Four sites were discovered within the training areas, and three previously known sites were relocated. One newly recorded site, 41BP471, was recommended for avoidance and testing to determine its eligibility for the National Register of Historic Places. Previously recorded sites 41BP108 and 41BP397 were also recommended for avoidance and eligibility testing. The remaining sites, 41BP398, 41BP470, 41BP472, and 41BP473 were deemed ineligible for the National Register of Historic Places. The potentially eligible site, 41BP471, yielded 19 lithic flakes from six shovel tests.
Wormser and Sullo (1996) surveyed a second training zone (Area B) in the northern end of the camp and discovered 41BP474, a shallow lithic scatter. The survey employed a patterned shovel test methodology over a 90-acre survey plot. Site 41BP474 was deemed potentially eligible for the National Register of Historic Places. 


\section{Chapter 2: Historic Backgroumd}

\section{Prehistoric Bastrop County}

\section{David G. Robinson}

This chapter presents a brief summary of what is known of the prehistory of the Camp Swift area. A brief discussion on the history of the area, including the building of Camp Swift, and the impact that this massive undertaking had on this rural county is also included.

In discussions of the prehistory of Texas, Bastrop County has often been treated as a cultural transition zone (Goode 1989:163-166). The regions to which it has been deemed transitional are Central Texas, East Texas, and Upper Coastal Texas. This section summarizes the cultural sequences of these regions as a way of framing the prehistoric cultural background of Bastrop County.

\section{Central Texas Sequences}

Suhm et al. (1954:99-117) offered the first major modern synthesis of the region, which included Bastrop County in the Central Texas area. Their work dominated Texas archeology until the 1970s, when new data and methods compelled new formulations. The first modern revision in this era was Weir's (1976), a major reordering despite its restriction to the Archaic stage. Weir defined five broad phases within the overall Archaic stage:

1. San Geronimo;

2. Clear Fork;

3. Round Rock;

4. San Marcos; and

5. Twin Sisters.

The most recent reformulation of Central Texas chronology is Prewitt's $(1981,1985)$ extension of Weir's sequence. Significantly, Prewitt established the town of Bastrop as the southeastern boundary of his study region, the Central Texas Archaeological Region. As with Suhm et al. (1954) before him, Prewitt (1981:71) made no phase subdivisions of the Paleoindian stage.
He added more phases to the Archaic stage, ordered by radiocarbon dating. They are, from early to late:

Circleville, San Geronimo, Jarrell, Oakalla, Clear Fork, Marshall Ford, Round Rock, San Marcos, Uvalde, Twin Sisters and Driftwood.

The Archaic stage ended about 1250 B.P. (Prewitt 1981:71-74). Prewitt's Neoarchaic stage corresponds roughly to the Neo-American stage of Suhm et al. (1954), and it is subdivided into two phases, Austin and Toyah. The Neoarchaic lasted from 1250 B.P. to 200 B.P. Prewitt does not discuss potential connections between archeological cultural units and later, ethnohistorically known, cultures (Prewitt 1985:74, 82-84). Except for the later beginning date of A.D. 1750, Prewitt's Historic stage conforms in all particulars to the Historic stage of Suhm et al. (1954). This conformity includes the lack of subordinate cultural units. Prewitt's phase chronology has undergone recent refinements (Prewitt 1985:215) and suffered much criticism.

Johnson (1986) has voiced general concern over the application of the stage-phase concept in Texas and has critiqued the sequences proposed by Weir and Prewitt. To Johnson (1986:7-8), Weir classed broad categories of material culture and features, forming them into phases of duration too long to represent socio-cultural units. Weir's phases are better applied as broad cultural patterns, within which phases and subphases may eventually be defined. Johnson asserts (1986:8-17) that Prewitt validly defined phases at the latter end of his sequence (i.e., Round Rock, Twin Sisters, Driftwood, Austin, and Toyah). For the earlier time periods, Prewitt neglected to make the 
associations among artifacts, site contexts, and radiocarbon assays that are critical to identifying components that might be said to belong to a unitary society. Johnson (1986:11) suggests that Prewitt in reality has isolated historical time periods rather than socio-cultural units.

In summary, fter a generation of research that proposed viable sequences and subjected them to critique, the Central Texas cultural sequence consists of defined phases from the Late Archaic to Historic times and a picture of broad historical time periods and cultural patterns from the Paleoindian through the Middle Archaic. Cultural sequences elsewhere in Texas are more tentative and have less reliable phase definition than Central Texas. Connections to the Upper Coast and East Texas, apparent in Bastrop County artifact assemblages, make it advisable to consider the cultural sequences of those areas in addition to that of Central Texas.

\section{Upper Coastal Regional Sequences}

Aten (1983) divided the Upper Coastal region generally into Preceramic and Ceramic periods, with the Ceramic Period subdivided into a series of phases based on pottery types. The Ceramic Period succeeded the Preceramic Period at about 1900 B.P. with the Clear Lake Phase. This phase was followed in order by the Mayes Island Phase (1550 B.P.), Turtle Bay Phase (1350 B.P.), Round Lake Phase (1050 B.P.) and Old River Phase (650 B.P.). The Orcoquisac Phase was essentially the Historic aboriginal phase, dating to about 300 B.P.

Patterson (1995) summarized much of his own and others' long-term research in updating the regional chronology. Unlike Aten, he addressed the entire known prehistoric period, but he did not define cultural phases. His temporal scheme identifies long time-periods marked by appearance, continuity, and change in artifact styles, with culture and populations only implicit. His temporal periods, from earliest to latest, are:

$\begin{array}{lr}\text { Early Paleoindian } & 12,000-10,000 \text { B.P. } \\ \text { Late Paleoindian } & 10,000-7000 \text { B.P. } \\ \text { Early Archaic } & 7000-5000 \text { B.P. } \\ \text { Middle Archaic } & 5000-3500 \text { B.P. } \\ \text { Late Archaic } & 3500-1900 \text { B.P. } \\ \text { Early Ceramic } & 1900-1400 \text { B.P. } \\ \text { Late Prehistoric } & 1400-500 \text { B.P. } \\ \text { Protohistoric } & 500-300 \text { B.P. } \\ \text { Historic Indian } & 300-200 \text { B.P. }\end{array}$

(Patterson 1995:242-243).

\section{East Texas Cultural Sequences}

Story (1981) laid forth a monumental East Texas chronology and lamented the general lack of chronology building in this important region. The undifferentiated Paleoindian period extended from about 12,000 B.P. to about 8000 B.P. Components of this period yield Scottsbluff, Meserve, San Patrice and probably Dalton projectile points. The extremely long and poorly differentiated Archaic period lasted from 8000 B.P. to 2200 B.P. Gary and Kent points are indicative of its more recent millennia. The Early Ceramic Period, 2200 B.P. to 1250 B.P., is indicated by Bear Creek Plain pottery in the south, Williams Plain pottery in the northeast, and the beginning of mound-building in both regions. The Late Prehistoric Period is distinguished by the Caddoan mound-building development in the northeast, until the Historic period, about 250 B.P. (Story 1981).

Perttula (1995) summarized East Texas and established a sequence of time periods distinguished by similarities and differences in artifact styles and sites. Perttula's periods are Paleoindian (11,000-8000 B.P.), Archaic (8000-2200 B.P.), Early Ceramic (2200-1200 B.P.), Formative Caddoan (1200-1000 B.P.), Early Caddoan (1000-800 B.P.), Middle Caddoan (800-600 B.P.), and the Late Caddoan (600-320 B.P.). The Late Caddoan period is subdivided into two cultural phases, the Whelan phase (650-450 B.P.) and the Titus phase (450-380 B.P.). The Formative, Early, and Middle Caddoan periods may also be considered viable cultural phases as well. 


\section{Prehistoric Chronology at Camp Swift}

These composite regional sequences have value as background for the prehistory of Bastrop County, especially in studies of shifting cultural boundaries. The cultural content of the major stages-Paleoindian, Archaic, Late Prehistoric, and Historic - is summarized in the following sections, synthesized from the above and other sources.

\section{Paleoindian: Pre-8500 B.P.}

The Paleoindian Stage is, at present, considered the initial occupation of North America. Paleoindian people practiced the specialized hunting of Pleistocene megafauna such as mammoth, mastodon, and bison, and, after the widespread extinctions at the end of the Pleistocene, generalized hunting and gathering strategies. Major temporally diagnostic Paleoindian artifacts are stone tools, notably Clovis, Folsom, Plainview, and San Patrice projectile point types. Artifact assemblages in the eastern half of Texas, below the Llano Estacado and Edwards Plateau, indicate diversified hunting and gathering of a wide spectrum of subsistence resources. The Paleoindian presence in Bastrop County is manifested primarily by surface finds of diagnostic artifacts in upland areas. A probable campsite in nearby western Fayette County, the Little Pin Oak Creek site, has received some investigation (Shafer 1977; Wilson 1979).

\section{Archaic: 8500-1250 в.P.}

This long stage is characterized by hunting and gathering economies. Weir (1976:119-121) divided the Central Texas Archaic into phases on the basis of shifting economic emphases, tool kits, and stylistic changes. Aside from its distinctive dart point sequence, the Archaic stage is noted for the formation of burned rock middens, beginning in the Middle Archaic. Classic Edwards Plateau burned rock middens have not yet been recorded in Bastrop County, no more than thirty miles east of the Balcones Escarpment. This contrast bespeaks the sharp regionalization and economic specialization characteristic of the Archaic stage. The majority of datable sites in Bastrop County belong to the Archaic.
Late Prehistoric: 1250-350 в.P.

Technological innovations applied to continuing Archaic subsistence strategies define the Late Prehistoric stage. Principally, these innovations were the adoption of the bow and arrow and the use of pottery. The stage is indicated by diagnostic arrow points of the Granbury, Scallorn, Edwards, Perdiz, and Cliffton types, and by pottery. Aboriginal pottery in Bastrop County is primarily the highly varied and ill-defined Leon Plain ware usually found in Central Texas. Sandy-paste pottery from Upper Coastal Texas has been found as near as Fayette County. As previously discussed, the Late Prehistoric is divided into two cultural phases, the earlier Austin phase and the later Toyah phase. The Toyah phase, beginning about 800 B.P., is marked by the migration of bison into large areas of Texas and the adoption of specialized hunting of them as a primary economic pursuit. In East Texas, however, the Late Prehistoric is associated with the cultural climax of the Caddoan mound builders. Sites of the Late Prehistoric stage comprise a significant proportion of Bastrop County sites (Perttula 1995; Prewitt 1981, 1985; Skelton 1977; Story 1981).

\section{Beginning the Historic Period}

The Spanish claimed what is now known as Texas in 1519, when Álvarez de Pineda explored the northern shores of the Gulf of Mexico, but the historic period in Texas actually began in 1528 with Cabeza de Vaca's shipwreck on the Gulf Coast and his subsequent recording of his travels. Cabeza de Vaca did not approach the Colorado River basin or the Bastrop region, and the exploration of the region waited until 1691 and the expedition of Terán de los Ríos. 


\section{The History of the Camp Swift Area, 1830-1950}

\author{
John J. Leffler
}

\section{Early Settlement in the Camp Swift Area}

Spanish expeditions began to pass through what is now Bastrop County in the late seventeenth century. In 1691 Domingo Terán de los Ríos led an expedition along the route that became known as the Camino Real, which connected San Antonio and Nacogdoches. Terán and his men forded the Colorado River near presentday Bastrop and then camped on the river near their crossing-point for about a month before moving on. Subsequent Spanish expeditions, including columns led by Pedro de Aguirre in 1709, and Louis Juchereau St. Denis in 1714, also crossed the Colorado at or near the ford used by Terán. Over the next century the crossing, became one of the most familiar and important fords along the Camino Real. Possibly because the Indians near the crossing sometimes proved hostile, however, the Spanish did not attempt to establish any settlements in the vicinity until the early nineteenth century (Skelton and Freeman 1979:85-86).

Partly to protect New Spain's northern frontier against possible encroachments by France and the United States, and partly to fend off threats to their trade along the Camino Real, the Spanish established a series of forts at key points on the highway. One of these, Puesta de Colorado, was built at the Colorado crossing in 1804. The existence of the post was noted by Zebulon Pike, the American explorer and adventurer, who traveled up the Camino Real in 1807 while returning to the United States from Chihuahua that year (Cutrer 1996a:201). Puesta de Colorado was a relatively small outpost - no more than 30 soldiers were ever stationed there at one time - and it had been abandoned by 1821, when Stephen F. Austin used the old Colorado crossing during his preliminary travels through the area (Skelton and Freeman 1979:87-89).

In 1827, empresario Austin received a grant from the government of the Republic of Mexico for his "Little Colony," which according to the contract extended fifteen leagues north from Terán's old crossing on the
Colorado River to a ridge separating the watersheds of the Brazos and Colorado rivers. By 1828, a number of settlers had moved into Austin's "Little Colony," and by 1830 , several - including Jess Barker, James Burleson, Ruben Hornsby and Josiah Wilbargerwere living in the vicinity of the Colorado crossing. The town of Bastrop was officially platted in 1832; it was named after Austin's friend the Baron de Bastrop, who himself had earlier attempted to plant a colony in the area. By 1835, about 1,100 people were living in or around Bastrop, but apparently few, if any, settlers had yet ventured into the area of present-day Camp Swift. Hostile Indians seem to have restricted settlement to sections along the Colorado until after 1836, when Texas won its independence from Mexico (Skelton and Freeman 1979:88-89; Marks 1996a: 410-411, 1996b:412).

The new Republic of Texas offered generous land grants to new settlers, Revolutionary veterans, and others. Thousands of immigrants moved to Texas in the aftermath of the Texas Revolution, and many Texans from older, more established settlements began to look west for new lands. As the demand for land intensified, the frontier moved westward. Texas Rangers attacked Indian tribes in central Texas and elsewhere to push them out of the paths of pioneers and to ensure the safety of existing settlements. In the late 1830 s, as new areas all across central Texas were opened to settlement, a number of people laid claim to properties in present-day Camp Swift. These included David Holderman, William McLaughlin, Robert Owen, Dennis Dykes, Jesse Barker, Lenian Barker, James Rians, Samuel Wolfenberger, Augustin Martinez, Peter Wade, and John Anderson. While some of these men settled on their grants, several of the grantees seem to have been more interested in land accumulation and speculation than settlement. Many of them had been living in Bastrop or the surrounding area for several years before they applied for their grants in what is now Camp Swift.

David Holderman moved to Texas and settled in Bastrop County in 1832. As a married man who had settled in Texas before the Revolution, Holderman was entitled to a first-class grant (4,428.4 acres). In March 1838 , he surveyed his league ( 888.5 acres of temporal land and 3,320 acres of pasture), which extended into 
the northeastern corner of present-day Camp Swift (Land Grant File Bas-1-66, Texas General Land Office [TGLO], Austin). It is not clear when Holderman moved onto the property, but though he sold off much of his land he seems to have prospered there; in 1840, Holderman was taxed on 545 acres (appraised at \$2,180), 12 slaves, and 30 cattle (Gassaway 1997). Holderman's tax assessment "strongly suggests that he was attempting to practice a plantation way of life" (Skelton and Freeman 1979:90) in the Camp Swift area even at that early date.

William McLaughlin, a married man who had arrived in Bastrop in 1822, surveyed his first-class land grant for 4,605 acres in the northwestern corner of presentday Camp Swift, just west of Holderman's property, in March 1838. It is not known whether he ever settled on the property, but he patented the land in December 1841 , and also paid taxes on it that year; the survey was divided among members of the McLaughlin family in the 1860s. Court documents created in 1874 mention an "Old Fort" on the north bank of McLaughlin Creek in the McLaughlin survey (on LCRA acquisition tract D-146). The "Fort" may have been built before McLaughlin received his grant; it is also possible that he or another settler built it in or after 1838. The precise location of the structure is unknown (Land Grant File Bas-1-70, TGLO; Gassaway 1997; Skelton and Freeman 1979:89).

Robert Owen, a single man, surveyed his grant for one-third of a league $(1,476.1$ acres: four labors temporal and one labor pastoral) in February 1838. Most of his grant is in the south-central sections of presentday Camp Swift. He patented the property in March 1845 , but it is not clear whether or when he actually lived there (Land Grant File Bas 1-249, TGLO; Gassaway 1997).

Part of the land grant received by Dennis Dykes extends into the southwestern corner of what is now Camp Swift. Dykes surveyed his property in May 1838, but he never seems to have lived on it; rights to the property passed through several hands by January 1841, when James Wallace paid the taxes on it (Land Grant File Bas 1-99, TGLO; Gassaway 1997).

Peter Wade immigrated to Texas in 1836 and served in a Texas military unit from December 1836 to
December 1837. In May 1838, he surveyed a land grant (eight and a third labors), part of which is now in the southeastern sections of Camp Swift. It appears that Wade never lived on the property, as he sold the rights to the grant shortly after the survey, and in 1841 , one M. Hemphier paid taxes on much of the land (Land Grant File Bas 1-101, TGLO; Gassaway 1997).

In November 1837, John Anderson received a bounty warrant for 480 acres from the Republic of Texas as a reward for his military service between November 1836 and November 1837. It is not known whether he ever lived on the property (now in the south-central sections of Camp Swift). But at some point he sold half of it to Thomas J. Gazley, who patented the grant in 1846 (Gassaway 1997).

Another bounty grant, for 640 acres located just west of the Anderson survey, was awarded to Samuel Wolfenberger for his participation in the "Storming of Bexar" in December 1835. Wolfenberger, born in Virginia in 1804, had moved to the Bastrop area from Missouri with his wife and eight children in 1831 . He became active in the town's affairs, and in 1834 was appointed alcalde (mayor) of the municipality. In November 1835, at the beginning of the Texas Revolution, Texas' provisional government appointed him as a commissioner responsible for organizing the militia from the area surrounding Bastrop. An active participant in the Revolution, in 1836 he received a league and labor on Walnut Creek, south of Bastrop, established a ranch there, and for many years continued to play a prominent role in the area's civic life. It appears that Wolfenberger never lived on his Camp Swift property and it was sold in the 1850s (Land Grant File Bas 1-2234, TGLO; Gassaway 1997; Vest 1996:1034).

The circumstances surrounding the Augustin Martinez grant (part of which extends into the northeastern sections of Camp Swift) also suggest that it was patented primarily for speculative purposes. Martinez sold his first-class grant for a league and labor to Leander C. Cunningham - five days before Martinez received his grant certificate in February 1838. The land was surveyed for Cunningham in March of that year, and eventually patented in 1845. Cunningham, born in Tennessee in 1810, had immigrated to Bastrop with his two brothers in 1833; he was the first lawyer to move into the area. By 1838, when Cunningham 
surveyed the Martinez grant, he was one of Bastrop's most prominent citizens. He almost certainly never lived on the Camp Swift property himself. By the early 20th century the grant had been divided into at least nine separate tracts, four of which were acquired by the U.S. government in 1942 when Camp Swift was created (Land Grant File Bas 1-73, TGLO; Cutrer 1996b:449; Gassaway 1997).

Lenian Barker was another longtime resident of the Bastrop area, having moved there in 1827. In 1838, he received a grant for a league and a labor which extended into the southern sections of present-day Camp Swift. There is no available evidence that either he or his son, Jesse Barker (who bought the title to the one labor of his father's grant in the Camp Swift area), ever lived on this land. The property changed hands at least twice before 1841, when W. L. Wallace (who owned other nearby properties not within the present camp boundaries) paid the taxes on it (Land Grant File Bas 1-428, TGLO; Gassaway 1997).

James Rains (or Raines), a single man, received his grant for one-third of a league (which extended into the east-central sections of the present camp) in 1838 from Sabine County based on his claim that he had entered Texas in 1829. The legitimacy of his grant was later successfully challenged in court. The legal history of the property is too complex to be discussed here, but in all likelihood Rains never even saw this land (Gassaway 1997).

By the end of 1838 , virtually all of the property in what is now Camp Swift had been surveyed for or granted to various men, many of whom had been living in the vicinity of Bastrop for several years before Texas became an independent republic. It seems that only a few of the original grantees (like David Holderman) actually settled on these properties themselves.

Bastrop County experienced steady population growth in the $1840 \mathrm{~s}$ and $1850 \mathrm{~s}$. By 1860 , there were more than 7,000 people (including 2,248 slaves) living in the county (Marks 1996b:412). During this period, many of the old grants in the Camp Swift area were divided among heirs or cut up to be sold to speculators or new settlers. A few of the new landholders in the area at this time were Isaac Harris, who purchased four tracts out of the Robert Owen survey between 1839 and 1845; Henry Crockeron, who bought a third of a league from Dennis Dykes out of Dykes' survey in 1840; Larkin Sullivan, who bought part of the Peter Wade survey in 1843; William Cannon, who bought 100 acres of the John Anderson survey in 1848; Archibald W. Moore, who purchased the David Holderman survey at a sheriff's sale in 1854; Lyman Coulson, who bought 200 acres of the Holderman survey from Moore in 1856; Henry Pollard, who bought 120 acres in the McLaughlin survey from James Yeoman in 1855; and Margaret Hemphill, who bought 1,148 acres from P. F. Wade out of the Wade survey in 1856 (Gassaway 1997).

It is not clear how many of these new landholders actually settled in the Camp Swift area, although there is evidence that at least some of them did. The Coulson family, for example, came to own a number of properties in the vicinity. One of the few documented settlers in the Camp Swift area during this period was S. B. Chandler. Chandler, born in South Carolina in 1812, had served as a judge in New Hope, Arkansas before moving to Texas; he settled in the Camp Swift area about 1845. In August 1854, he bought 400 acres out of the David Holderman survey from David and Tabitha Reynolds for $\$ 250$. By the late 1850 s, Chandler owned a number of slaves and was operating a plantation in the area.

Martha Scott, another relatively early setter, was born in Virginia about 1800. In the early 1830s she moved to Fort Bend County, Texas with her husband Henry, who died a few years later. Martha traveled to Bastrop County about 1850 with her sons, Abner and David, and bought some land on Sandy Creek. In 1857, the Scotts moved into the Camp Swift area, buying 370 improved acres on the Peter Wade survey from Larkin P. Sullivan. It is not clear when Martha died or what happened to her property, but in the years after the Civil War her son Abner remained in the Camp Swift area and became one of the largest landholders there (Skelton and Freeman 1979:93-95).

While David Holderman, the Scotts, and S. B. Chandler are the only settlers definitively known to have moved into the Camp Swift area before the Civil 
War, indirect evidence (for instance, repeated sales of relatively small acreages, the sale of improved land to early settlers like the Scotts) suggests that there were more people there by 1860 than previous studies have indicated (c.f. Nightengale and Moncure 1996:13-14 and Skelton and Freeman 1979:92). In any case, many people settled in the Camp Swift vicinity in the decades after 1865 , as the frontier moved west and railroads moved in.

\section{Farmers and Industry in the Camp Swift Area, 1860-1940}

Hundreds of thousands of immigrants moved into Texas during the late nineteenth century. Many of them, from states in the Old South such as Tennessee, Kentucky, Missouri, Louisiana, and Alabama, were attempting to escape the social, political, and economic disruptions of the Civil War and Reconstruction. Thousands of others came from Germany, Czechoslovakia, and other European nations for various reasons.

Railroads began to enter Bastrop County in 1871, when the Texas Central Railway, building between Austin and Brenham, laid tracks across the northern sections of the county. In the 1880 s the Taylor, Bastrop, and Houston Railway (later part of the Missouri, Kansas \& Topeka line) also built through the area. The railroads gave local farmers new markets for their corn and cotton crops, encouraged immigration, and made it possible for new businesses to form. In the northern part of the county, the arrival of the railroads also quickly led to the creation of new towns like Sayersville, McDade and Elgin in the immediate vicinity of what is now Camp Swift. Bastrop County's population grew from about 7,000 in 1860 to over 11,000 in 1870; by 1900 almost 27,000 people were living in the county (Buder 1996:907; Marks 1996b:412, 1996c:389-390).

Many new farms were established in the Camp Swift area during the late nineteenth and early twentieth centuries, and the local economy began to diversify. Antoine Aussilloux set up a successful winery in the Camp Swift area in the late 1870s. Not long after that, lignite mines began to appear in northern Bastrop County. The opening of the Sayers lignite mine, which operated in what is now Camp Swift between 1913 and 1928, led to the creation of a small village on-site to house and care for the workers.

Skelton and Freeman (1979) have traced the landholdings of several families who lived in the Camp Swift area during the late nineteenth century. Between about 1870 and 1900, the Flemings, the Evanses, the Floyds, and the Scotts and the Springers (who were interrelated) established homesteads and came to control thousands of acres between McLaughlin and Sandy Creeks. In the northeastern sections of what is now Camp Swift lived the Westbrook and Joiner families, who built homes along the Sayersville and McDade road. On a lot between their houses the Wayside School (site 41BP154) was established, which - after 1902was attended by many of the Camp Swift area children. Meanwhile, a number of farming and ranching families (including the Becks, the Scruggs, and the Eschbergers) settled in the southern portion of what is now Camp Swift and lived along Dogwood Creek in the Wolfenberger survey during this period. By 1900 , perhaps as many as 60 homesites had been established in the Camp Swift area, and other families, such as the Sowells, moved there in the early twentieth century.

One notable settler in the Camp Swift area in the late nineteenth century was Antoine Aussilloux. Born in France in 1850, Aussilloux emigrated to the United States with A. Cologne, his half-brother, after the Civil War. Aussilloux settled first in Galveston, but by the 1870s he was living in Bastrop County and working as a stonemason. In 1875, he filed an application to become a naturalized citizen of the United States. The next year, in 1876, Aussilloux and his partner, Frank Gorton, bought 60 acres on the north bank of Big Sandy Creek in the McLaughlin survey and set up a wine-making business. A number of wineries had already been established in and around the county by that time (Frazee 1991:11).

Soon after purchasing their land, Aussilloux and Gorton built an "ingenious" two-story stone residence with a deep limestone basement that would serve as their wine cellar. Frazee's (1991) detailed description of the structure is worth repeating here, since only ruins remain at the site (41BP138) on Camp Swift today (Figure 2): 


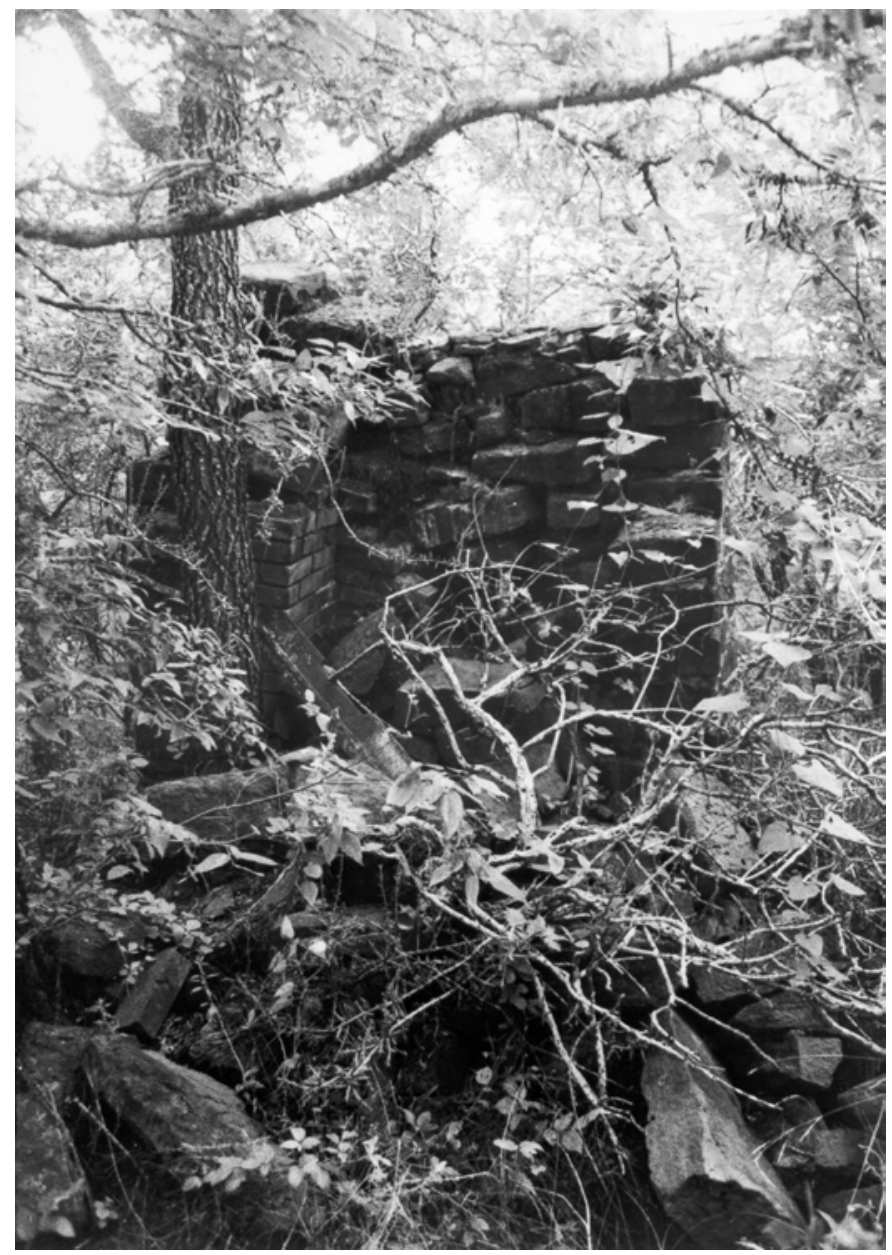

Figure 2. Ruins of the Aussilloux House (41BP138).
Above the cellar sat a main floor facing southeast. The entrance door had an impressive stone lintel, and was flanked with two windows with shutters. Above this main floor was a bedroom reached by an internal stair. The roof was of cedar shakes... The basement was entered from the rear by a dozen descending stone steps. Inside, the walls had ducts to carry the cool air [from the basement] to the first floor. The subfloor was of half-finished boards, and over this was smooth flooring. The main floor measured about twelve by sixteen feet. In the southwest wall a fireplace was built. In front of the fireplace, one-inch metal bars projected into the wall to support a hearthstone. As in the cellar, the walls of the main floor had ducts to carry cool air to the top floor (Frazee 1991:11).
Frazee (1991) did not clearly indicate this source for this description, though he implied it came from local informants familiar with the structure.

To house their cows, pigs, and a mule, and to store hay and wine, Aussilloux and Gorton also built a 20 x 30-foot red ironstone barn about 50 yards from their house. A mule-driven winepress was set up next to the barn. The barn, or what was left of it, was taken apart in 1942; the stone was used to build the entrance gate for Camp Swift. Their original vineyards ran southeast from the house down to the north bank of Big Sandy Creek. In 1885, the partners bought another 40 acres on Spring Branch and two small other tracts nearby. These purchases enabled them to build a dam across the creek; with some excavation, they created a pond behind the dam that they used to irrigate the 40 -acre tract (Frazee 1991:12).

Aussilloux and Gorton's winery apparently prospered from the early 1880 s until the early 1890 s, when a series of drought years seems to have undermined production and profits. After Gorton "disappeared from the area" in 1892, Aussilloux continued to operate the winery, with good profits in some years, until 1919, when the passage of the Prohibition amendment finally forced him to shut down (Frazee 1991:12; Kay 1997).

Aussilloux as a person seems to have steadily deteriorated after his winery closed. His health declined, and he became something of a hermit; in 1924 a neighbor found him dead in the front yard of his old stone home. According to county probate records examined by L. H. Kay (1997), Aussilloux's home and everything in it was in "a very dilapidated condition" when he died. His personal possessions and household goods were judged worthless, and because of "unsanitary conditions in the home" authorities burned "practically everything." The house itself may have been burned at this time. In any case, the site seems to have remained abandoned for many years thereafter. In 1942, when Camp Swift was created and the U.S. government acquired the property, Aussilloux's estate was still unclaimed. The very low price the government paid for the property ( $\$ 477$ dollars for a 100 acres) would seem to indicate that the house was already a ruin by that time. Long after Aussilloux's death, 
however, his winery left a lasting legacy: the pond behind the dam he built was for many years a favorite swimming hole for local children (Frazee 1991:13).

In 1914, while Aussilloux was still operating his vineyard, Frank L. Dennison was preparing to establish a lignite mine a few miles to the south. Settlers in Bastrop County had been digging and burning lignite, a soft brownish coal-like mineral, since the early $1800 \mathrm{~s}$. The first commercial mine in the area opened in 1868 , when a shaft was sunk about three miles west of Bastrop. Though this mine closed in the $1870 \mathrm{~s}$, the arrival of the railroads at about that same time soon encouraged others to exploit lignite deposits in the northern part of the county. By 1910 several mines were operating there (Bastrop Advisor 1978).

In September 1914, Frank Dennison signed a lease with Mrs. Mary C. Young on a number of acres in the Robert Owen survey east of the tracks of the Missouri, Kansas \& Topeka (MKT) Railroad. By the end of the year, Dennison had already begun to construct facilities for his lignite operation, which came to be known as the Sayer's Mine after the nearby town of Sayersville. A 2.5-mile rail spur was run southwest to the MKT tracks (Figure 3), the first timbers of a slope mine were put into place, and a large wooden tipple (to load the lignite into railroad cars) was constructed. The mine's facilities also included a small village to house and feed the Mexican miners Dennison employed to work the lignite out of the ground. Eventually, a small cemetery, known as the "Mexican Cemetery" (41BP170), had to be laid out to bury workers or members of their families who died there (see Chapter 6). The village included a commissary (Figure 4), where workers could buy food and other necessities with the tokens they earned (Bastrop Advisor 1978; Robinson 2001:7-8).

Dennison's 1914 lease with Mary Young provides some indication of the scope of the Sayers Mine's operations. Dennison pledged that the mine would be large enough to produce eighty tons of screened, market-ready lignite per day, and promised to pay Mrs. Young five cents for every railroad car of lignite extracted. That would amount to a little over $\$ 100$ per month for Mrs. Young at this minimum production level. Dennison seems to have met this quota during the years the mine was operated, and perhaps even surpassing it (Robinson 2001:7-8).

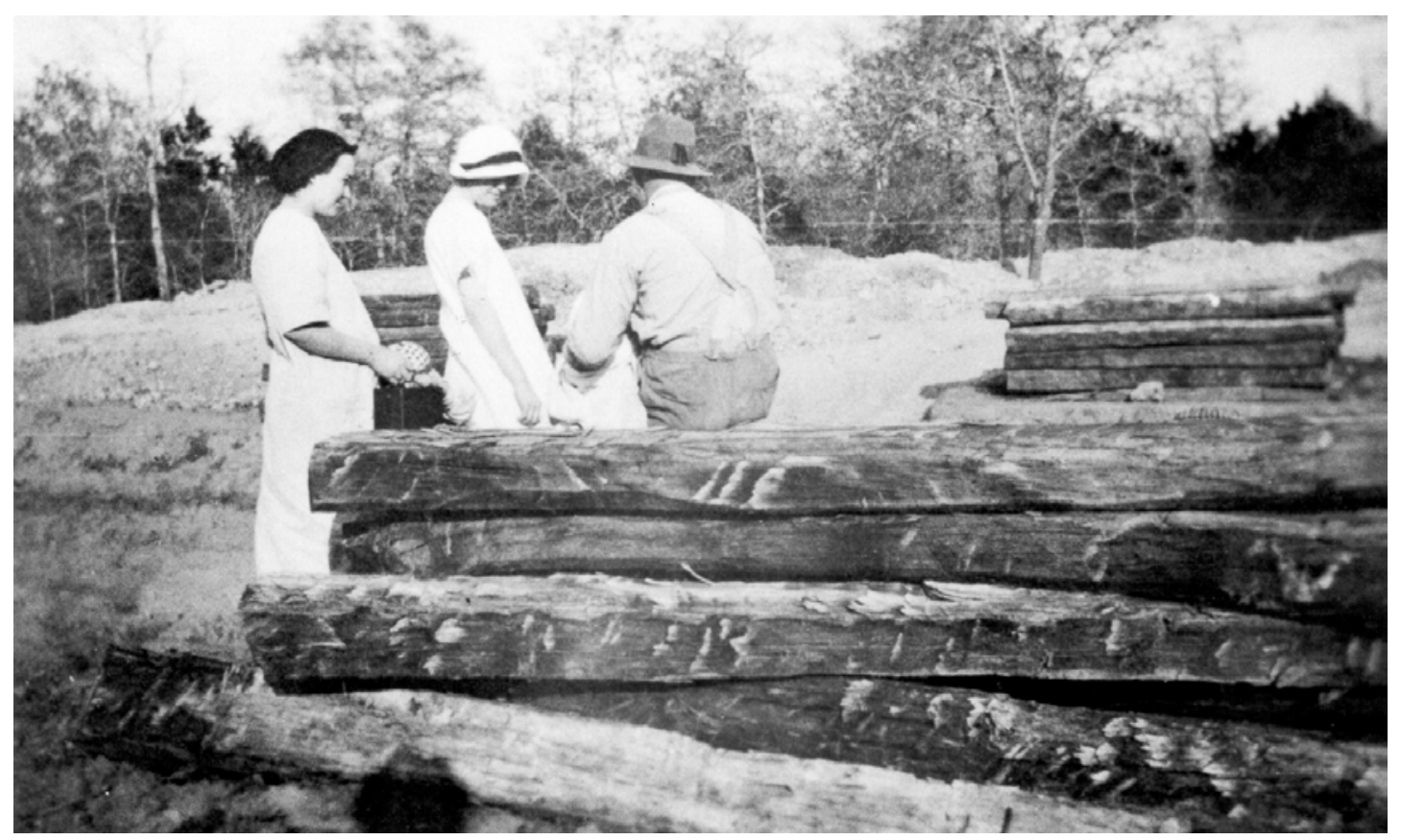

Figure 3. Railroad ties for the spur being built from the Sayers Mine to the MKT line, ca. 1914. From left to right: Sue Smith, Mrs. J. D. Owens, and J. D. Owens, the supervisor of the mine. (Photograph in the Camp Swift historical files, AGTX-EV, Camp Mabry.) 


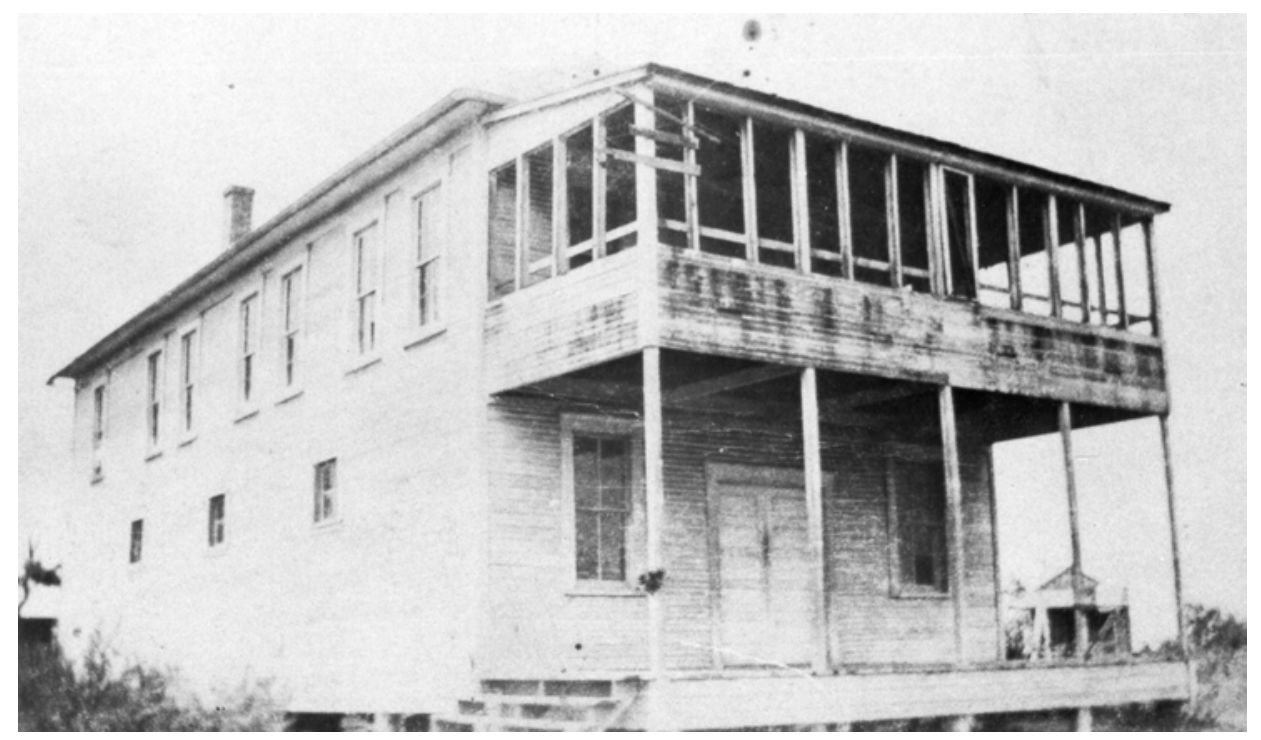

Figure 4. The commissary of the Sayers Mine, ca. 1924.

(Photograph in the Camp Swift historical files, AGTX-EV, Camp Mabry.)

Sources differ about when the Sayers Mine began to extract lignite (1913 to 1916), but Dennison's lease stipulated that the mine would be operational by September 1915, and it was certainly producing by the next year (Bastrop Advisor 1978; Buder 1996:907;
Robinson 2001:7). The mine grew to become a considerable enterprise but never operated on a truly large scale. Photos of the mine and interviews with people familiar with it suggest that Dennison probably employed about 12 miners per shift (Figures 5 and 6).

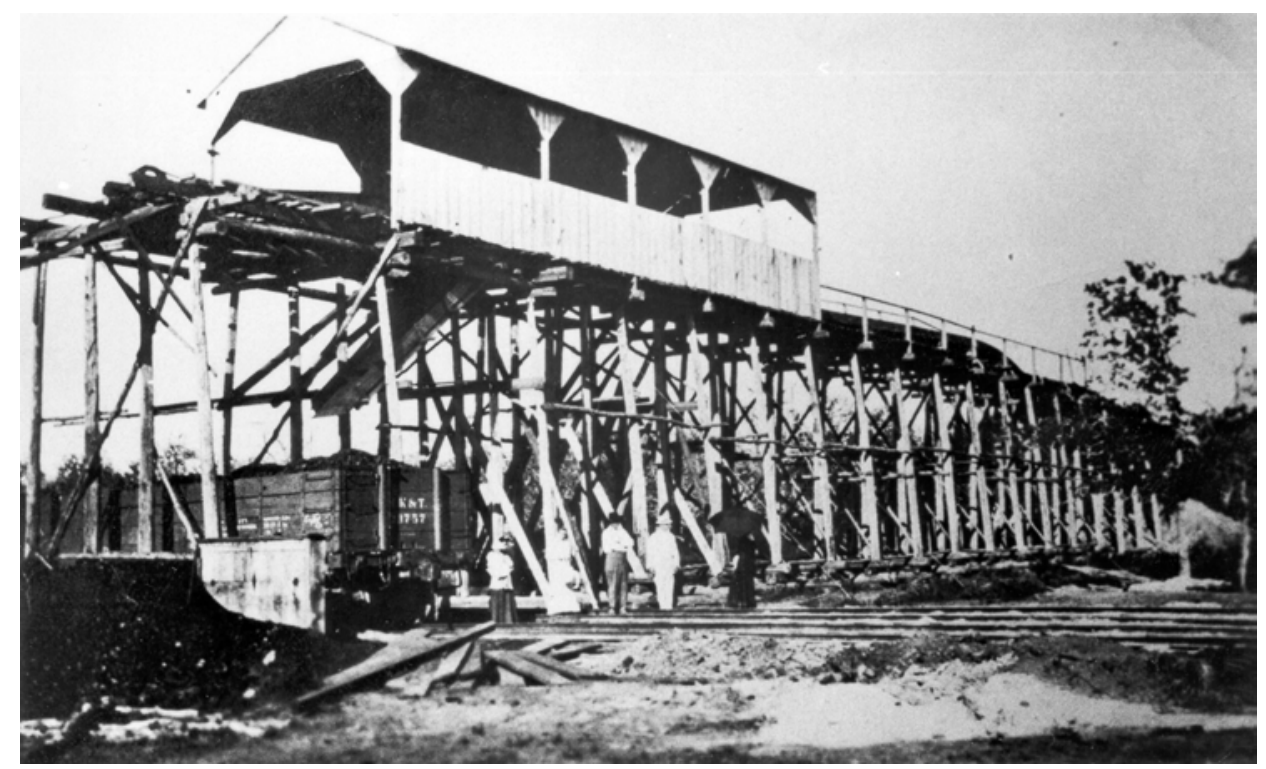

Figure 5. Tipple at the Sayers Mine, 1913 to 1924.

(Photograph in the Camp Swift historical files, AGTX-EV, Camp Mabry.) 


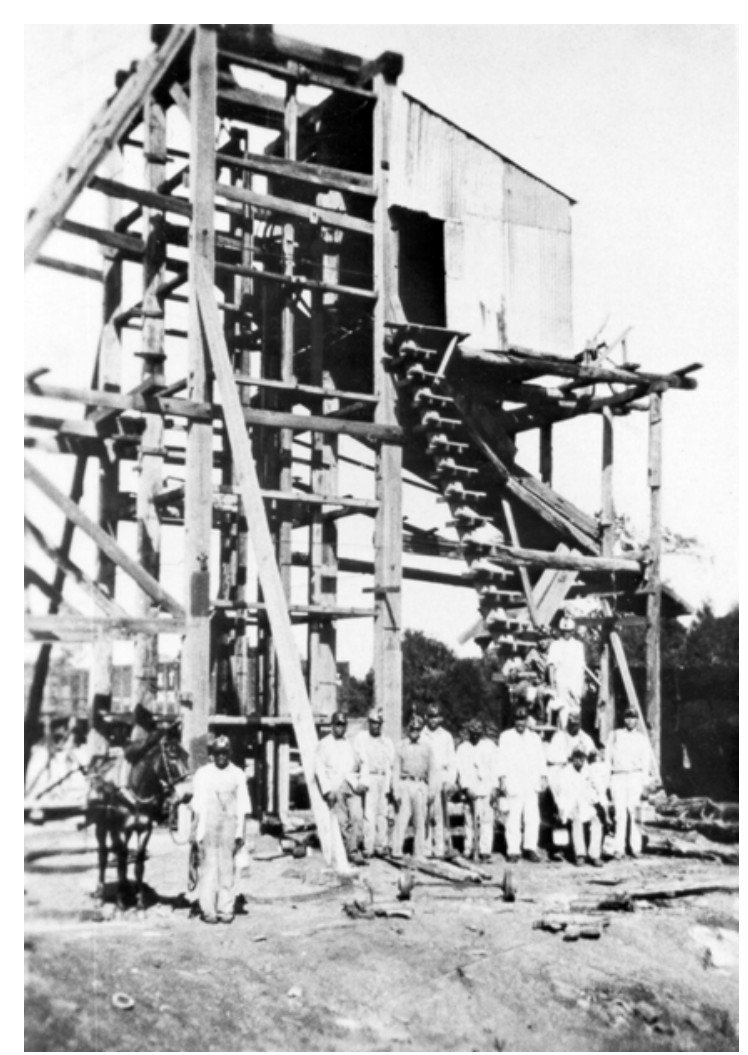

Figure 6. Another view from the Sayers Mine, ca. 1926, showing what was probably a typical shift at the mine. Notice the MKT railroad cars in the background.

(Photograph in the Camp Swift historical files, AGTX-EV, Camp Mabry.)

At the Sayers Mine, virtually all of the workers who actually did the dirty and dangerous work of digging the mineral out of the ground had been recruited from Mexico. The workers at the Sayers Mine, like other Mexican mine workers in the county, stayed to themselves for the most part and had only limited connections to other people living in the area. Farmers around the Sayers Mine profited from the miners, however, by selling them milk, vegetables, and other products the miners could not buy at the mine's commissary (Bastrop Advisor 1978; Robinson 2001:8-9).

After the original Sayers slope mine was destroyed in a fire in 1924, Dennison converted his mine to a "shaft and gallery" scheme. The new mine's main shaft penetrated 80 feet down; a steam engine pulled lignite up the shaft and helped load it onto the tipple (Figure 5). But in spite of Dennison's best efforts, the mine's profits declined, and when it experienced another fire in
1928, Dennison decided to close down the operation. His 1914 contract with Mrs. Young required him to remove any and all improvements from the property. Much of the equipment from the Sayers Mine, and at least some of the buildings, were subsequently moved a few miles south to Dennison's Glenham mine (Robinson 2001:10-11).

Virtually nothing of the Sayers Mine can be seen today. Only a few residual artifacts remained on the site of the old mine in 1979, when it was visited by Martha Doty Freeman, who designated it as historical site 41BP148 (Freeman 1979). In 2001, a group of people from the Sayersville Historical Association revisited the site and found a number of slump ponds that probably correspond to old mining shafts (Robinson 2001:10; F. Pannell, personal communication 2001). David G. Robinson, one of the Sayersville group, drew a map of the site showing the locations of spoil piles, slump ponds and other features (Figure 7). 


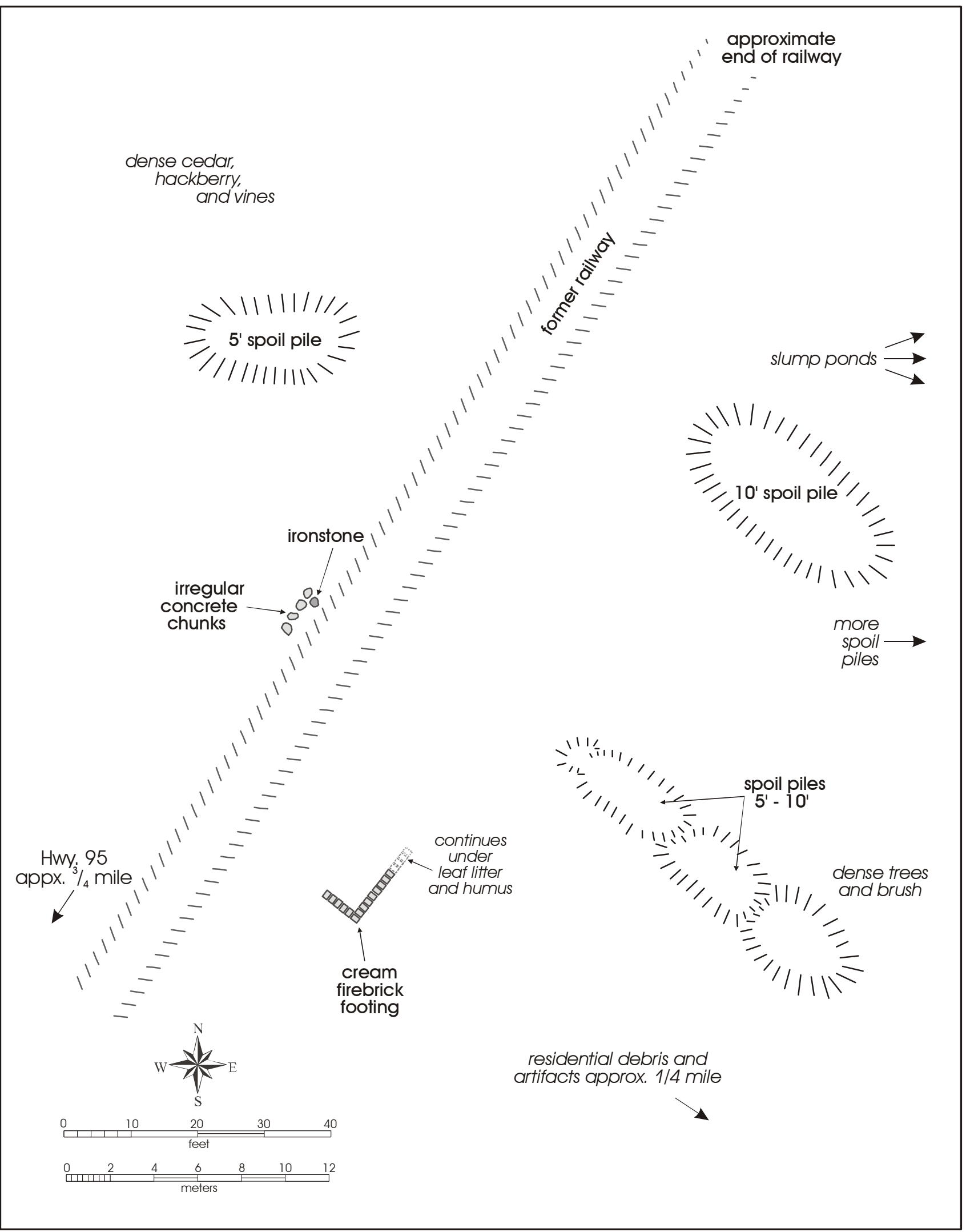

Figure 7. Map of Sayers Mine site today.

(Based on drawing by David G. Robinson made during visit to the mine site in 2001 [Robinson 2001:10].) 
During the late nineteenth and early twentieth centuries, many families had settled in the Camp Swift area, and two notable businesses-Aussilloux's winery and the Sayers Mine - had been established there. Both the winery and the mine had closed by the end of the 1920 s, however, and by that time farmers in the county were already experiencing financial difficulties exacerbated by the onset of the Great Depression in 1929. The county lost almost one-third of its farms during the 1930s, and farmers in the area that later became Camp Swift area did not fare much better. While a county highway map dated 1936 shows many houses in the vicinity (Figure 8), the area was relatively lightly populated at that time (Marks 1996b:412). In 1940, the county was still suffering from the effects of the Depression and when local officials began searching for land for an army training camp in that same year (which, they hoped, would help the local economy), it is not surprising that they looked closely at the area between Bastrop and Elgin.

\section{The Creation of Camp Swift}

After May 1940, when Holland, Belgium, and France were overrun by the Nazis, Americans were beginning to prepare for the possibility that the United States would eventually have to join the conflict; new legislation for mandatory military training and a draft meant that millions of dollars would be invested in new training camps. In early June of that year, after France had fallen, Oscar Parke Houston was driving from Austin to Midland with Nat Perrine, the director of the Texas Safety Association, who also happened to be a colonel in the Texas National Guard. The conversation turned to events in Europe. "We cannot dodge this war," Perrine said, and he and Houston began to discuss the possibility of locating an army training camp in Austin. Both agreed that Austin's experience with hosting a camp during the First World War had been in some ways unpleasant, and that "Austin people would perhaps not want a large military camp near the city." But both apparently also believed the economic advantages of locating a camp in Central Texas, perhaps near Bastrop, were too good to ignore (Houston 1958:1).
Over the next few days, Houston enlisted support for the idea from A. B. Spires, president of the Austin Chamber of Commerce; he also called Paul Page, a Texas senator who was a banker and "leading businessman" in Bastrop. After Page indicated his "sincere interest" in the idea, members of the Austin Chamber of Commerce's Military Affairs Committee traveled to Bastrop to meet with businessmen there. After the group toured several thousand acres of land around the city, the Bastrop businessmen assured the Austin committee that at least 50,000 acres in the area could be acquired "at a reasonable cost," perhaps three to five dollars per acre. "The city of Bastrop had recently been through hard times," Houston later wrote. "A section of business property had recently been sold for nonpayment of taxes. The more the plan for a camp was considered, the more enthusiastically it was received." At subsequent meetings, the Austin committee found that businessmen in Smithville and Elgin were equally excited about the idea (Houston 1958:1-2).

The plan was presented to General Hubert Brees, commander of the Army's Eighth Corps Area. A delegation mainly composed of Austin businessmen, led by Spires, met with the general at his headquarters at Fort Sam Houston in San Antonio. Brees' initial reaction was not at all sympathetic: "Gentlemen, you are the seventeenth damn committee which has been here asking for a camp for [their] city the last two months." Only after Spires explained that the camp would be located in Bastrop County, not Austin, did Brees begin to warm up. "That's damned unusual," he said, and eventually took interest (Houston 1958:3-4).

Through the last five months of 1940 , members of the Austin Chamber of Commerce, working closely with Austin's mayor Tom Miller and the chambers of commerce in Bastrop, Elgin, and Smithville, labored "day and night" to work out a detailed proposal to submit to the Army. They also held many meetings to promote the camp to local businesses and citizens. Detailed reports on the area's land, transportation facilities, available housing, and other factors were prepared and passed on to the Army (Houston 1958:4-5). 


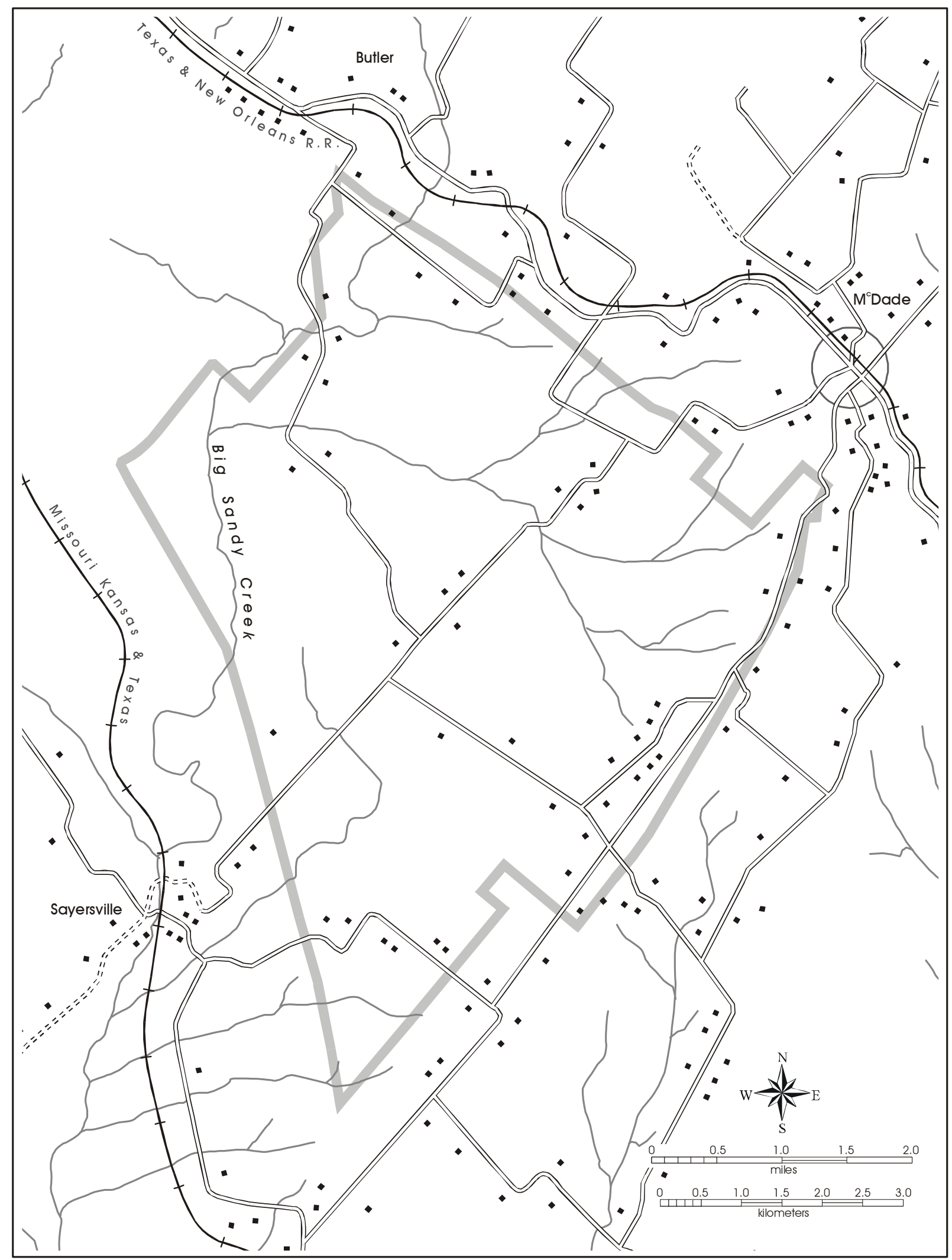

Figure 8. Map based on 1936 map of Bastrop County, showing roads and structures in the area. Outline of modern Camp Swift is shown in gray. 
The site eventually chosen for the camp (and later adopted by the federal government) was a huge triangle extending north and east of Bastrop (see Figures 1 and 8). The area had several advantages that the organizers believed would be particularly attractive to the Army. The triangle was bounded on all three sides by existing highways, and on two sides by railroads; a 75,000-volt power line and a United Gas Company pipeline already ran through it; and an abundance of good well water was available only 600 feet down. Moreover, as Houston later noted, because the land was "not rich" it would not cost much to acquire: "[T]here were only a few small farms scattered over a great area," he wrote, "and the buildings on these farms were not expensive because of the limited productivity of the soil" (Houston 1958:5-8).

After the Army sent an inspection team to the site in October 1940, the four chambers of commerce organized a group to acquire options to purchase or rent the properties that had been inspected. In January 1941, the Army informed the Austin Chamber that it wanted to build a camp on the site; in July, a Fort Worth firm was contracted to conduct an engineering survey of the proposed camp area. Meanwhile, spurred by the Army, the local camp organizers continued to plan for every possible contingency: two Austin Chamber of Commerce staffers, for example, spent many days trying to ensure that enough milk would be available for the tens of thousands of soldiers expected to be stationed at the camp. By December 1941, when the United States entered World War II, engineers had almost completed a plan for the general layout of the future camp's buildings, streets, and utilities. By January 1942, bids were being accepted on various contracts to construct the camp, which at that time was planned to hold 30,000 to 40,000 soldiers. The War Department began to take possession of properties in the future camp in early January. Land was being cleared by February, and construction began the next month (Houston 1958:7-10; Leonard 1981).

In his account of the origins of the camp, Houston (1958) clearly implies that the land for the camp was acquired through the options campaign organized in 1941. "As had been anticipated," he writes, "these options were not exceptionally difficult to secure. The land itself was not rich and consequently not high priced" (Houston 1958:7). In fact, however, most of the properties - totaling 52,162 acres of the 55,906 acres the government acquired to build the campwere taken in condemnation proceedings conducted between March and May of 1942. By May 5, when the first deeds transferring these properties were filed, construction of the camp was already almost half completed, and most or all of the original landowners had vacated their properties (Houston 1958:7-10; Leonard 1981).

The land acquisition process was painful for many families who lost their lands. A number of the properties had been in family hands for generations, and their owners left reluctantly and, sometimes, bitterly. Even tracts that were not actually condemned were bought by the Lower Colorado River Authority, the government's agent for the sales, at low prices $(\$ 6.00$ to $\$ 10.00$ per acre) that approached what one writer has called "ill-disguised condemnation." The purchase prices did not allow for any improvements on the properties, and those forced to leave were given thirty days to move their houses, barns or anything else in the way of the camp, bearing the costs of removal themselves. While many structures were moved or torn down for construction materials, others were abandoned by their former owners (Robinson 1998:3-4). Some of these, like the old Ransom house (built about 1852), were later used as bombing targets during training exercises at Camp Swift (Pannell 1998:5).

According to one account, the whereabouts of about 350 families of property owners and tenants displaced by the camp and forced to move was not known. Some families settled on other properties in the area, and some who lost land were lucky that their actual homesteads did not lie within the projected borders of the camp. Others, though, were not so fortunate. The arrival of thousands of construction workers to build the new camp had already created a housing shortage in Bastrop County, and some of the displaced had nowhere to go. One family was forced to live under a tree for a while. Sharecroppers in the area were hit particularly hard, since the government paid no relocation expenses. Though most of the displaced knew their sacrifices contributed to the war effort, many felt that they had been treated harshly, and would remain "bitter to their dying day" (Leonard 1981; F. Pannell, personal communication 2001; Robinson 1998:6). 
The construction of the camp was a mammoth undertaking. The four major contractors on the project were given 108 working days to build a city that could house, feed, and care for at least 35,000 people. Hundreds of miles of sewer lines, water pipes, roads and electrical lines had to be laid, and 2,750 buildings of all sorts erected. Almost 18,000 workers scrambled to complete the project on time. Though thousands of men and women moved into Bastrop County in search of jobs, the demand for local labor was intense. According to Cecil Long, who owned a mercantile store in Bastrop at the time, "every person who could bought a hammer, saw and other tools to become an instant carpenter at the camp" (Houston 1958:11; Leonard 1981).

Almost overnight, Bastrop County was pulled out of the Great Depression. By March, the town was "full of newcomers, men and their families who are housed in private homes, apartments, trailer camps and tents in town and for miles around in every direction in the rural communities of Smithville, Bastrop, McDade, Paige, Taylor, Kimbro and Austin" (Murphy 1995). Business boomed in Bastrop, where several new downtown stores opened and old businesses rang up big sales. Land on Depot Street sold for $\$ 100$ a frontal foot; the assets of the city's First National Bank almost doubled during the construction months. By July, Bastrop also had a new bowling alley, a swimming pool, and two new movie theaters (Greenwood 1947; Leonard 1981; Murphy 1995).

On May 3, 1942, when the camp was still under construction, Lt. Colonel Laurence A. Kurtz assumed his duties as the post's first commander and the camp was formally commissioned. It was named after General Eben Swift, a native Texan who had distinguished himself during his service in the Spanish-American War, the Pershing Expedition, and World War I (Figure 9). In July, as initial construction neared completion, the first trainees began to arrive; they were assigned to the 95th Infantry Division, which only recently had been reactivated at the new Camp Swift (Henderson 1956; Houston 1958:12; Tyler 1996 Vol. 6:177).

\section{Soldiers and Civilians, 1942-1945}

By 1943, Camp Swift had become perhaps the largest World War II Army training camp in Texas (Figure 10). Its huge cantonment area, which spread "as far as the eye could see" across five miles of Bastrop County sand, included more than 2,750 buildings linked together by 40 miles of streets. In addition to its headquarters buildings, the camp had barracks to house almost 45,000 soldiers, maintenance facilities and gas stations to service thousands of vehicles, a number of large warehouses, its own train station, landing strip, telephone exchange, post office, bank, fire department and film library, and a number of movie theaters, beauty parlors, chapels, swimming pools, post exchanges, mess halls, and clubs. The camp's six water wells produced 600 gallons of water per minute to fill its million-gallon concrete reservoir and two 500,000gallon elevated tanks. Its sewage treatment plant was large enough for a city of 50,000 people; its bakery could produce for 90,000 . The hospital complex alone encompassed 157 buildings (including 77 wards, seven mess halls, and ten nurses' quarters) spread over 350 acres of land. Swift also had its own newspaper, the Camp Swift Baron, a well-illustrated eight-page weekly that ran sports news, pin-up photos, and reports of the war effort (Henderson 1956; Houston 1958:13-14, 44; Tomka and Crouch 1986:13, 16-17; Austin American 1947a, 1951a).

Camp Swift's extensive training facilities occupied most of its acreage. They included rifle and machine gun ranges, each with hundreds of targets; maneuver areas for troops and tank destroyers; a "fortified area" and a "Japanese Village" (most likely used to train troops in assault techniques); artillery ranges; and a "booby trap" area (Leffler 2001).

By 1943, Camp Swift also had three auxiliary components: a tank-destroyer training center known as "Wake Island," which housed and trained two tank destroyer groups (about 2,000 men at a time); a nurse's combat training center; and a prisoner-of-war internment camp. The POW camp was built to house 3,000 prisoners, but by the end of the war it was responsible for the supervision of about 4,500 internees. Of these, about 1,500 were detached to satellite camps or outside work details at any given time (Houston 1958: 16, 39; Tomka and Crouch 1986:20) 


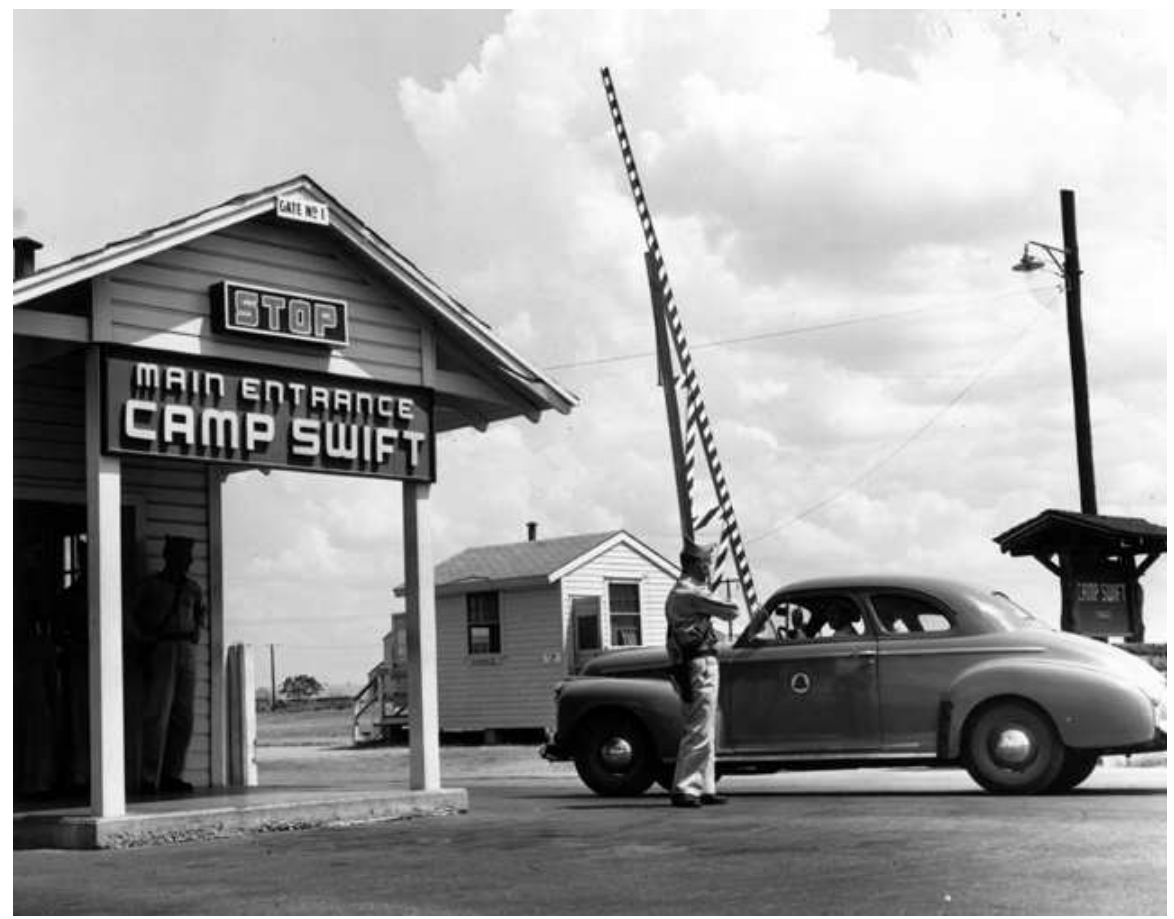

Figure 9. The main entrance at Camp Swift, 1944.

(Photo courtesy of the Denver Public Library, available at:

http://gowest.coalliance.org/cgi-bin/imager?00200393.)

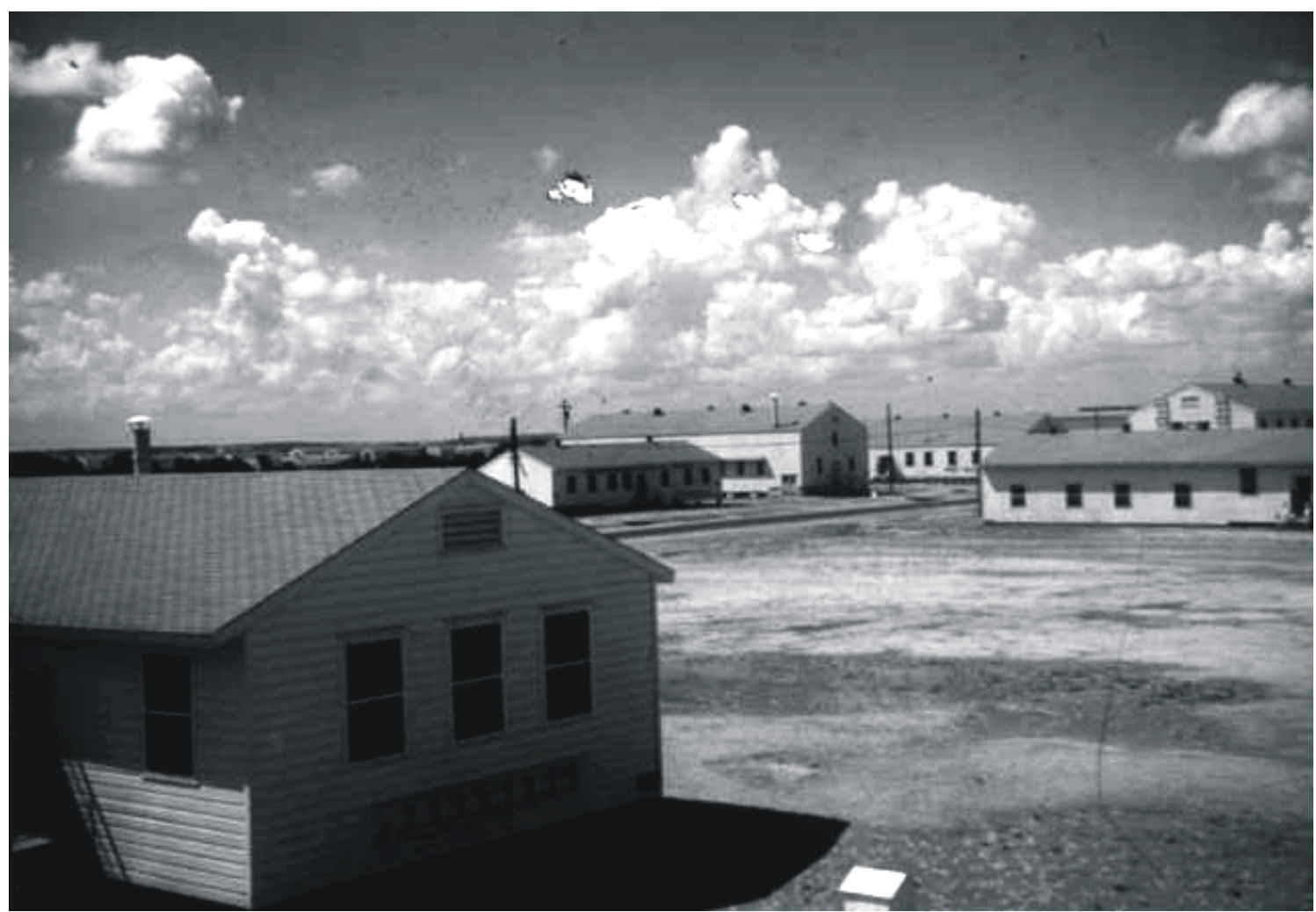

Figure 10. A view of Camp Swift in 1944.

(Photo courtesy of the Denver Public Library, available at: http://gowest.coalliance.org/cgi-bin/imager?00200802.) 
Yet another related facility, Swiftex Village, was completed in 1943. Located just off the Camp Swift reservation, directly across the highway from the main gate, Swiftex Village was a federal housing development with about 200 apartments that housed "key civilians" associated with the camp. Operated by the Public Works Housing Authority, Swiftex Village was technically not part of Camp Swift but was certainly associated with it. About 500 people, including almost 100 children, lived there in 1944. In all, almost 50,000 men and women were living at Camp Swift and its related facilities by the end of the war (Austin American 1944, 1951b; Tomka and Crouch 1986:17).

During the years it existed, Camp Swift had a dramatic impact on the areas surrounding it. As noted earlier, the establishment of the camp helped to pull Bastrop County out of the Depression. Thousands of local residents had made money building the camp, and after its completion about 2,000 people in the area continued to work there in various capacities. The purchasing power of the tens of thousands of soldiers stationed at Swift encouraged the creation of many new local businesses - cafes, restaurants and beer joints, men's stores, hardware stores, theaters, trailer parks and tourist camps - and gave new life to old businesses that had been hovering on the verge of collapse in 1941. Even before the camp was completed, the streets of Bastrop and Elgin were crowded with cars and people seven days a week until late into the night. The camp had created one of the greatest economic booms the county had ever experienced (Greenwood 1947; Leonard 1981).

Aside from the soldiers themselves, thousands of civilian "newcomers" had moved into the area during the camp's construction. Many of them remained in the area over the next several years, and they were soon joined by others, including many wives of men in the camp. While locals enjoyed their new prosperity, the camp created problems. First and foremost was a severe housing shortage. In 1940, before the camp arrived, about 2,000 people lived in the city of Bastrop; in May 1942, almost 7,000 sugar rations (the best available indicator of the city's population then) were issued there. Even in the best of times, the number of people moving into the area would have created problems, but given strict wartime restrictions on building materials, the housing shortage was particularly acute. By early 1942, some landlords in Bastrop were already cutting out old tenants so that they could charge "exorbitant prices" to newcomers (Greenwood 1947; Leonard 1981).

Though some new developments such as Swiftex Village and the Ridgetop Addition were built in the Bastrop area during the early 1940s, there was not nearly enough room for everyone who wanted to live near the camp. As one local resident later noted, "Almost any building that could provide shelter was used." Anything that had "a floor, a door, and a cot," he said, could be rented to someone. One enterprising farmer turned his hog shed into an apartment, and rented out part of his property for a "tent city," complete with showers and toilets. Others cut their houses into apartments or rented out rooms; one couple had twelve people living in their house with them (Greenwood 1947; Leonard 1981).

The Bastrop city council passed new ordinances to limit the size and location of tent towns, "trailer cities" and "tourist courts," and set new sanitation standards for developments. To help Bastrop cope with the camp's impact, the Works Progress Administration gave the city $\$ 370,000$ to construct a new sewer system. Still, in many ways, the city was simply overwhelmed by this "drastic revolution," as a later writer termed it; and local residents dealt with it as best they could. A large new USO building was constructed downtown to entertain at least some of the servicemen that were crowding into the town every night (Greenwood; 1947).

Austin, 35 miles from the cantonment area, was a favorite destination for soldiers looking for diversion. The Army contracted with the Kerrville Bus Company to provide direct service back and forth to Austin, but even though 65 buses were assigned to the route, it was a logistical nightmare. On most Saturdays about 20,000 men stood in lines a quarter-mile long waiting for a their rides. To make matters worse, because of wartime tire rationing, buses were often delayed because of flat tires. To control the soldiers once they got to Austin and to avoid trouble, a detail of military police from Camp Swift was permanently stationed in the city (Houston 1958:42-43, 50). 
Though by most accounts most soldiers generally conducted themselves well while enjoying their passes in the towns surrounding the camp, conflicts and even violence occasionally erupted. In July 1942, a military policeman shot and killed a black soldier in a Bastrop "dance and drink spot," when the MP was subsequently exonerated after a court martial, more trouble ensued (Houston 1958:20).

The commanders at Camp Swift worked hard to cooperate with local authorities and various civic organizations to create a connection between the camp and its neighbors, to help boost public wartime morale, and to sell war bonds. Local groups such as women's clubs, Boy Scout troops, ROTC units, teachers, schoolchildren and others were often taken on tours of the camp's facilities, and were sometimes invited to watch firing drills and maneuvers. Camp authorities also worked with recruitment officers and the Women's Victory Committee in Austin to coordinate activities intended to encourage local women to work at Camp Swift as WACs (Brown and Smedley 1944; Center for American History 1943; Houston 1958:44).

Every May, on the anniversary of its founding, the camp was opened to the public for tours and dramatic firing demonstrations. Thousands of local citizens attended, along with state and local officials, including the governor of Texas and the mayors of Austin, Bastrop, Elgin, Taylor, and Smithville. In November 1943, the camp furnished the personnel and material for what was called "the Southwest's largest display of army equipment" in Austin. The week long program was an "astounding" success. About 46,000 people crowded in to see a wide variety of exhibits showing the incredible complexity of the war effort: there were displays about weaponry and chemical warfare, the Signal Corps, the WACs, the Medical Corps, the Dental Corps, dehydrated foods, and even the Tire Repair Section (Brooks 1945; Houston 1958:46-47)

Between July 1942 and August 1945, dozens of military units were trained or stationed at Camp Swift, including four combat infantry divisions, tank destroyer battalions, and a variety of engineering, medical, police and quartermaster units (Tomka and Crouch 1986:151-164). The four largest and best known of these were the 95th Infantry Division (which trained between July 1942 and February 1943), the 97th Infantry Division (February through November, 1943), the 102nd Infantry Division (November, 1943 to June, 1944), and the 10th Mountain Division (June, 1944 to December, 1944). All four of these divisions were sent to Europe and together suffered tens of thousands of casualties in battles there (Murphy 1995:14-23).

In late July and early August 1945, the Army's 2nd Infantry ("Indian Head") Division, which had fought at Normandy and the Battle of the Bulge, moved into Camp Swift to begin training for battle against Japan. The war ended even before the division was fully assembled. In September 1945, Camp Swift was designated a separation point for servicemen returning to civilian life, and over the next few months the soldiers, POWs, and civilian employees there dwindled away. The last elements of the 2nd Infantry Division left Camp Swift on April 6, 1946, on their way to civilian life (Henderson 1956; Houston 1958:40).

Despite intensive efforts by local citizens and even formidable politicians like Lyndon B. Johnson, who hoped to keep the installation alive, Camp Swift was declared "surplus" in January 1947. Piece by piece, most of its land, buildings and other assets were sold off by the War Assets Administration (WAA) over the next few years. Some buildings, like the camp's chapels, were given away to schools and congregations in Smithville, Austin, McDade, and other surrounding communities. Under the system of sales priorities established by the WAA, the Texas National Guard and the Texas Game, Fish and Oyster Commission (now the Texas Parks and Wildlife Department) and other government entities were given acquisition rights above and beyond those of people who owned the land before the war. Although some of the former landholders were able to repurchase their old properties, many others could not (Austin American 1945, 1947b, 1951b; Austin Statesman 1946; Carpenter 1947; Center for American History 1946a, 1946b, 1946c, 1947). 
By the mid-1950s, there was very little left of the military city that had once trained almost 300,000 men and women for combat during World War II. Grass covered old roads, and thousands of concrete posts that once supported hundreds of barracks stood out from green bramble-like rows of tombstones in a cemetery. Nevertheless, Camp Swift had left a lasting impression on Bastrop County. Although the economic boom created by the camp disappeared soon after it was deactivated, in 1950 the city of Bastrop's population was still almost two and a half times what it had been back in 1940, and its downtown district had a number of new, modern buildings that would never have been built without Swift. In 1947, the city's USO building was converted into a public auditorium, and many houses and other buildings in the area were constructed of materials taken from the old camp. Elgin's population had almost doubled. Bastrop County had become more developed and sophisticated than ever before, and local business leaders had learned important lessons that they would later use to draw new businesses into the area (Greenwood 1947; Henderson 1956).

In October, 1996, about 500 people, including many veterans, gathered at Camp Swift for a ceremony to dedicate a historical marker commemorating the old camp and the men and women who had once trained there. Daniel James III, the Adjutant General of Texas, gave a moving speech to remind his listeners of the sacrifices made by so many during World War II:

$$
\begin{aligned}
& \text { "Let us look into the eyes of our soldiers } \\
& \text { and let us say we are a grateful nation." }
\end{aligned}
$$

One veteran who had traveled hundreds of miles to attend the event had one particularly fond memory of the old camp,

"This was the first and only area I was ever in, where [because of the sandy soil] it was easy to dig foxholes"

(Todd 1996). 


\section{Chapter 3: Geoarchaeological Assessment}

\section{Introduction}

\section{Shane Prochnow}

The geoarchaeological investigation was intended to assess the potential for uncovering buried archaeological sites in late Quaternary sediments at the Camp Swift Army National Guard project area. Camp Swift is located in Bastrop County about 12.9 kilometers north of the city of Bastrop on State Highway 95. The project area is limited to the current boundaries of the installation (Figure 11).

Camp Swift is situated on the Eocene Calvert Bluff Formation of the Wilcox Group (Sellards et al. 1932). The Calvert Bluff consists of mudstone and sandstone beds (Barnes 1974). The mudstone beds are massive to thin bedded, with very fine sand and silt laminae (Barnes 1974). The sandstone beds are fine to medium grained, moderately well sorted, cross-bedded, and lenticular (Barnes 1974). Ironstone concretions are also common in the Calvert Bluff (Barnes 1974). Colors range from light gray to yellowish brown (Barnes 1974).

The erosion and weathering of Wilcox Group sediments has produced a highly dissected upland with sandy soils (Sellards et al. 1932). The indurated and erosion resistant sandstones generally cap low hills, while areas underlain by mudstone tend to form valleys and slopes. Wilcox Group sandstone affects streams by confining the valley width, and increasing channel slope and incision. Associated mudstone tends to decrease channel slope and increase valley width.

Mature upland soils in Bastrop County are classified as alfisols, while alluvial soils are entisols or mollisols (Baker 1979). Mature, upland soils of significant occurrence within Camp Swift include the Axtell series (fine, montmorillonitic, thermic, udertic paleustalfs), Demona (clayey, mixed, thermic, aquic arenic paleustalfs), Patilo (loamy, siliceous, thermic, grossarenic paleustalfs), Silstid (loamy, siliceous, thermic arenic paleustalfs) and Tabor (fine, montmorillonic, thermic aquic paleustalfs) (Soil Conservation Service 1979). Alluvial soils are dominated by the Gowen (Fineloamy, mixed, thermic, cumulic hapludolls), and
Sayers (sandy, mixed, thermic, typic ustifluvents) series (Soil Conservation Service 1979).

Big Sandy Creek, Dogwood Branch, Dogwood Creek, and McLaughlin Creek drain Camp Swift (Figure 11). Big Sandy Creek is the dominant stream in the project area, which feeds into the Colorado River about $13 \mathrm{~km}$ to the southwest. Big Sandy Creek is a third order tributary of the Colorado River. The Big Sandy Creek alluvial valley widens considerably as it dissects the relatively soft Calvert Formation mudstone at Camp Swift, allowing for greater channel sinuosity than upstream reaches that dissect sandstone beds. The Big Sandy Creek alluvial valley is about 396 meters wide as it enters Camp Swift from the northeast, and about 853 meters wide near its exit to the southwest. Dogwood Branch, Dogwood Creek, and McLaughlin Creek are relatively entrenched second order tributaries of Big Sandy Creek, with narrower alluvial valleys and lesser channel sinuosities.

\section{Methods}

The geomorphic map was constructed from 7.5' and 15 ' topographic maps, the Austin sheet of the Geologic Atlas of Texas (Barnes 1974), and the Bastrop County soil survey maps (Soil Conservation Service 1979). Twelve backhoe trenches were excavated to depths of 1.5 to 2.5 meters to describe soils and subsurface stratigraphy (Appendix C). An additional 3 backhoe trenches from a previous geoarchaeological survey were also incorporated in the analysis (Lim et al. 2000). Soils were described based on the guidelines of the Soil Survey Division Staff (1993). Stratigraphy was described under the guidelines of the North American Stratigraphic Code (North American Commission on Stratigraphic Nomenclature 1983). The stratigraphy was described as landform-sediment assemblages and allostratigraphic units for the purposes of this investigation. Six backhoe trenches (BHTs-2, -3, -7, -9, -10, and -12) were used to construct an idealized cross section of alluvial valleys within Camp Swift (Figure 12). 


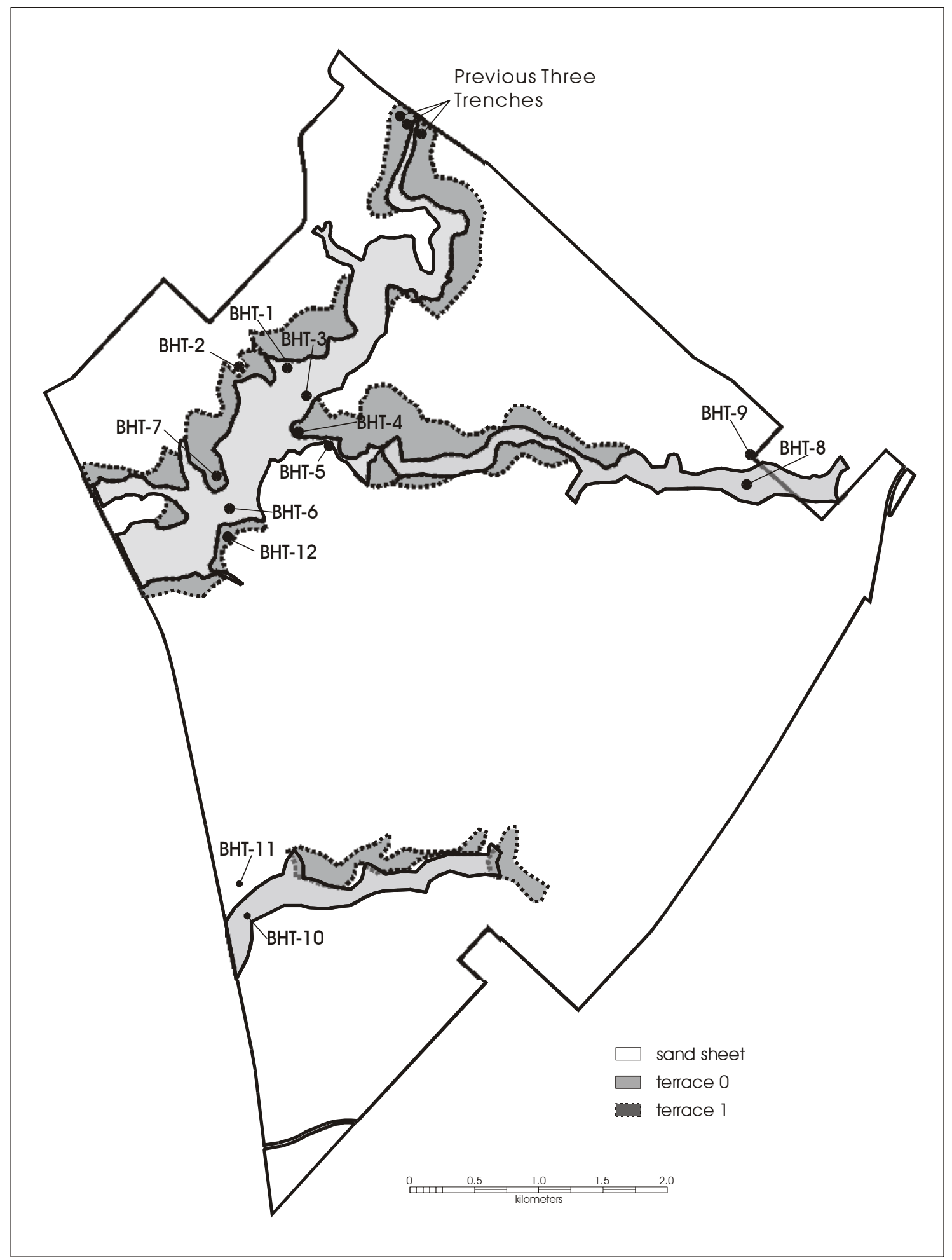

Figure 11. Geomorphic map of Camp Swift showing the location of backhoe trenching. Solid lines mark the outer limit of the T0. Broken lines mark the outer boundary of the T1. Sand sheets can occur outside these areas. 


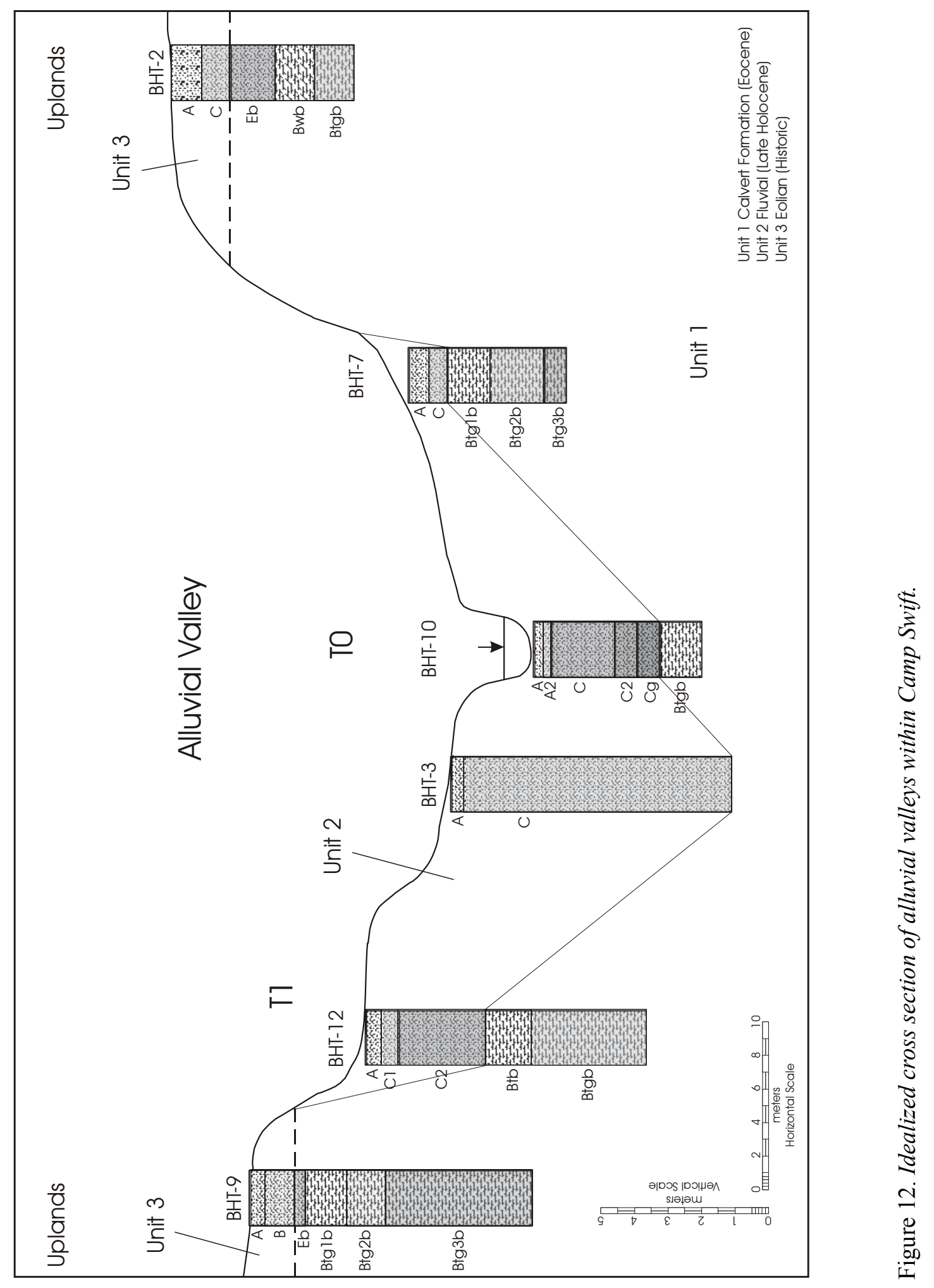




\section{Geomorphology}

The geomorphic map features three landforms:

1. Flood terrace (T1);

2. Floodplain (T0); and

3. Localized sand sheets.

The flood terrace is an abandoned floodplain, and occasionally floods during large-scale events. The floodplain (T0) is a modern landform and floods frequently. The localized sand sheets are aeolian features capping Eocene sediment in the upland adjacent to the alluvial valleys. It is assumed that the upland is not subject to flooding or alluvial deposition.

The $\mathrm{T} 1$ flood terraces are about four meters above the channel thalweg of the drainages. The T1 landform is wider along Big Sandy Creek, McLaughlin Creek, and Dogwood Branch. The T1 landform occurs only as isolated remnants along Dogwood Creek and other lower-order drainages. The floodplains (T0) widen with increasing drainage area in the project area. Big Sandy Creek has the largest floodplain width, followed by McLaughlin, and then other subordinate drainages. Floodplain widths in the project area of first order streams and the upper regions of the larger streams decrease to only to the width of the channel. The uplands are situated at a minimum of 12 meters above the channel thalweg of Big Sandy Creek, and less in the smaller drainages. Many of the first order streams are entrenched directly into upland bedrock.

\section{Stratigraphy}

Three depositional units and geomorphic landforms were encountered in the geoarchaeological investigation. Unit 1 is the Eocene Calvert Bluff formation. Unit 2 is a fluvial unit associated with two alluvial landforms were identified, the flood terraces (T1) and floodplains (T0). Unit 3 is an aeolian unit found at least adjacent to the alluvial valleys on the uplands.

\section{Flood Terrace (T1)}

BHT-2, BHT-4, BHT-7, and BTH-12 were opened in the T1 sediment assemblage of Camp Swift (see Figure 11, Appendix C). In addition, geoarchaeological investigation by Lim et al. (2000) opened a trench (BHT-1) in the T1 sediment assemblage. The T1 landform is a strath terrace. BHT-12 exemplifies the sediments encountered in these areas. Here, $77 \mathrm{~cm}$ of alluvial sand is weathered to a weakly developed entisol that buries a truncated Bt horizon from a paleo-alfisol.

The truncated Bt horizon in BHT-12 is weathered into the Calvert Bluff Formation. It is designated Unit 1. This remnant paleosol profile consists of thick Btb (77 to $97 \mathrm{~cm}$ ) and Btgb (97 to $201 \mathrm{~cm}$ ) horizons. The Bt paleo-subsoil is a mixture of oxidized sandy clay (red) and more recently reduced light gray mottles from fluctuating groundwater. Unlike the massive alluvial sands, the paleosol has well-developed structure. The buried subsoil horizons desegregate into strong, angular, medium-sizes prismatic peds.

The overlying alluvial sands of T1 are light brownish gray and very pale brown, single-grained, and noncalcareous. The alluvial material was deposited in at least two major flood events. The two sand packages have abrupt boundaries and are separated by a thin laminae of brown clay. The alluvial sands are designated Unit 2.

Fluvial sediments with similar soil development as the sands encountered in BHT-12 have been aged on the lower Colorado River to $<600$ years B.P. by Blum and Valastro (1994), and to $<500$ years B.P. on the middle Brazos River by Waters and Nordt (1995). Alfisols with less developed Bt horizons than in the BHT-12 paleosol have been aged between 20,000 and 15,000 years B.P. in the Fort Hood region of central Texas. (Nordt and Hallmark, 1998). It can be assumed that the truncated Bt encountered in BHT-12 has been weathering into the Eocene Calvert Bluff formation since the Pleistocene or earlier. 


\section{Floodplain (T0)}

BHT-1, BHT-3, BHT-6, BHT-8, and BHT-10 were opened in the active floodplain deposits (see Figure 11, Appendix C). Lim et al. (2000) also described two trenches on the T0 landform. BHT-3 was opened in the Big Sandy Creek floodplain near Scott Falls Road (see Figure 11). BHT-3 consisted entirely $(250 \mathrm{~cm})$ of massive channel margin sands with numerous wavy laminae of sandy clay (depositional) separating individual beds (see Figure 12, Appendix C). The sand/ sandy clay couplets are thicker towards the bottom of the profiles and become thinner higher in the exposure. The presence of the clay laminae as part of a couplet suggests a fluvial origin for the sands, as opposed to eolian. A weakly developed entisol is weathered into the upper part of the sediment package. This sediment is similar to that found on the upper portions of the $\mathrm{T} 1$ exposures, which likely dates to within the last 600 years.

BHT-10 was opened on the channel bottom of Dogwood Branch near its exit from the study area (Figure 11, Appendix C). BHT-10 exhibited an unconformity similar to that identified in the flood terrace (T1) deposits. Here, two fine sandy loam A horizons (0-10 $\mathrm{cm}$ and $10-16 \mathrm{~cm}$ respectively) are weathered into the upper part of the sediment package. The sediment beds $(\mathrm{C} 1, \mathrm{C} 2, \mathrm{C} 3$, and $\mathrm{Cg})$ represent deposition from separate flood events and are bounded abruptly. These sandy sediments are similar to those found in BHT-3 and in the upper portions of the T1 sediment assemblage. Thus, they correlate to Unit 2 and may be similar in age.

The fluvial sediments in BHT-10 also bury a truncated paleosol. The paleosol consists of a truncated Bt subsoil that is heavily mottled. The buried subsoil is a sandy clay with well-developed prismatic structure, and has a distinctive reddish yellow color and $40 \%$ gray mottles by volume. The truncated paleosol is the remnant of a mature alfisol that probably developed some time between the Eocene and the late Pleistocene on the Calvert Bluff Formation (Unit 1) like those observed below the surface of sands on the T1 landform. The unconformity at depth in the T0 landform represents the base of the alluvial valley.

\section{Uplands and Localized Sand Sheets}

BHT-2, BHT-5, and BHT-9 were opened on areas designated as upland/sand sheet. This landform was tested only on its margin with the alluvial valleys, and may vary further away. BHT-2 best exhibits the upland/sand sheet deposit. BHT-2 has two possible interpretations:

1. BHT-2 consists of $37 \mathrm{~cm}$ of sandy sediments unconformably burying a truncated paleo-alfisol;

2. BHT-2 is an alfisol with a complete A-E-Bt profile with all the horizons the same age. The $\mathrm{Bt}$ in either case is weathered on bedrock (Unit 1).

The upper $37 \mathrm{~cm}$ of sediment consists of a very pale brown, noncalcareous fine sand. The material has a loose, single-grained structure. There is a $25 \mathrm{~cm}$ thick yellowish brown A horizon. The lower $12 \mathrm{~cm}$ of sandy material may be interpreted as either a $\mathrm{C}$ horizon (depositional), or as the upper of two E horizons (pedogenic). The author prefers the idea that the sand encountered is depositional and not pedogenic because of the very abrupt boundary between the sand and the clay horizons (Hypothesis 1).

If assuming the first interpretation, the sandy sediments are deposited too high to be associated with recent fluvial activity. These sediments are also unlike other ancient high terraces documented on the middle Brazos or the Lower Colorado Rivers (Blum and Valastro 1994; Waters and Nordt 1995). The sands near the alluvial valleys are deposited in planar sheets and as topographic dunes upwind from obstacles such as vegetation. Deflationary surfaces expose a veneer of ironstone and quartzite pebbles in between sand sheets on the uplands near the alluvial valleys. The deflationary pebbles may have originated from Pleistocene high terrace material from the Colorado River. These pebbles appear to reside on the upland truncated $\mathrm{Bt}$ surface. Thus, the upper sediments are likely eolian, and are designated Unit 3.

The E-Bw-Btg horizon sequence is a buried paleosol in BHT-2. Truncation has removed the paleosol surface horizon and a portion of the Eb horizon. The Eb horizon is a very pale brown to white, single-grained 
fine sand. Nearly all of the clay minerals other than silica have been translocated from this horizon. The Eb has a clear, smooth boundary to the horizon below. Two other buried horizons were identified in BHT-2: a Bwb (80 to $114 \mathrm{~cm}$ ) and a Btgb (114-150 $\mathrm{cm})$. The Bwb consists of a pale brown, loamy sand with weakly developed, coarse, subangular blocky ped structure. The Bwb abruptly grades into the Btgb. The Bt horizon consists of a heavily mottled (pale brown mottles) reddish yellow sandy clay. Ped structure is moderate, coarse prismatic. Ironstone concretions are present in the Bwb and the Btgb, suggesting this paleosol developed on the Calvert Formation (Unit 1).

There is the possibility for a second interpretation given the meager data set. The above profile description for BHT-2 may represent a complete alfisol (Hypothesis 2). The surface sands may be the result of the removal of clays by translocation, with minimal eolian influence. In this case, there would be no widespread topsoil truncation during the landscape history, and eolian deposits would be much less significant. Instead, the uplands would be strictly underlain by bedrock with soils that developed on a geomorphic surface that is at least Pleistocene age. Without the luxury of laboratory analysis, this question can not be ascertained due to the difficulty in distinguishing such features in the field.

\section{Depositional Chronology}

The oldest sediment encountered in Camp Swift is designated Unit 1, and is probably part of the Eocene age Calvert Bluff formation. A paleo-alfisol developed in conjunction with a geomorphic surface on bedrock that is pedostratigraphically traceable throughout the study area as a buried Bt horizon (see Figure 11). The paleo-alfisol has been forming in Eocene sediments since at least the Pleistocene. The truncated surface of the paleosols is a past geomorphic surface.

The geomorphic surface that developed on Unit 1 was probably truncated sometime during the Holocene in response to one of the periods of channel incision identified on the lower Colorado River (Blum and Valastro
1994). Holocene truncation of Unit 1 is evident by the removal of surface horizons and an undetermined portion of subsoil horizons of the paleo-alfisol in the study area.

Unit 2 buries Unit 1 sediments on the floodplains (T0) and on the flood terraces (T1) (see Figure 12). Unit 2 is dominantly fluvial, but may have some eolian input. Unit 2 was deposited during a recent episode of valley filling. Unit 2 has been correlatively aged on the basis of similar pedogenic development to other modern fluvial deposits on the Lower Brazos and the Lower Colorado Rivers to the last 600 years (Blum and Valastro 1994; Waters and Nordt 1995).

The presence of an eolian depositional unit (Unit 3) is valid only if the first interpretation given above of the sediments encountered in the uplands is correct. Eolian Unit 3 buries Unit 1 sediments on the uplands. Unit 3 may not be regionally extensive, but does occur adjacent to the alluvial valleys investigated. Unit 3 began deposition sometime after the erosional Holocene event that truncated Unit 1 , evident in all landform-sediment assemblages in the study area. Exposures of Unit 3 (BHT-2 and BHT-9; Figure 12) exhibit weak pedogenic alteration on the surface, indicating a hiatus in deposition at least locally. However, exposures without surface pedogenic alteration were noticed, indicating current deposition. Moreover, eolian deposition was observed during the fieldwork firsthand during windy days. Eolian sedimentation in the study area may be the result of historic landscape degradation due to intensive agriculture. Thus, eolian deposition in the study area associated with Unit 3 is possibly historic and still geologically active.

The depositional vacuity between the truncated paleogeomorphic surface and the deposition of the more recent Unit 2 and Unit 3 sediments probably indicates the removal of late Quaternary deposits sometime during the late Holocene. The erosion of these materials may be related to an unconformity resulting in floodplain abandonment and soil formation that occurred around 1,000 years B.P. on the Lower Colorado River (Blum and Valastro 1994). In this case, a reduction in base level of the Colorado River may have caused its smaller tributaries to scour their alluvial valleys in association with knick point migration. 


\section{Archaeological Preservation Potential}

The potential for preservation of buried archaeological material in primary context within the project area appears to be low. This is due to the presumed absence of early to middle Holocene sediments and living surfaces, and the presence of extensive high-energy sandy deposits. Furthermore, no buried cultural materials were encountered during backhoe trenching. The conclusions of this study are similar to those by Lim et al. (2000).

Archaeological sites may be situated on either of two living surfaces present in the project area (see Figure 11). Sites may be found:

1. On the deeply truncated $\mathrm{Bt}$ paleosol (Unit 1) on the floodplains (T0) or flood terraces (T1) buried by modern fluvial sediments, or on the uplands either shallowly buried by eolian sand (Unit 3) or on the landscape surface; and

2. On the modern surface of Unit 2 and Unit 3 on the flood terraces (T1), floodplains (T0), and localized upland eolian blanket (Unit 3 only).

A major unconformity, resulting in the scour of deposits that predate 600 years B.P., may have removed buried archaeological material in the alluvial valleys (see Figure 12). The surface created by this scour on Unit 1 appears to have remained stable for too short of a period for pedogenesis to have redeveloped a soil horizon. Thus, it is unlikely that humans significantly utilized this geomorphic surface. The recent valley fill appears to be dominated by high-energy deposits, indicating low probability for primary archaeological material even in these deposits. Further, buried features would be subjected to intense bioturbation.

The localized upland eolian sand may also bury archaeological material. The surface of the sand sheets would be modern and contain historic archaeological sites. However, buried archaeological sites may reside on the truncated Bt such as in the alluvial valleys. The Bt would have been exposed for only a short interval because of the lack of renewed pedogenesis. In areas where the topsoil of the uplands was not truncated, the surface could potentially have been utilized for greater than 10,000 years before burial by recent eolian activity.
Late Holocene erosion may have removed much of the buried archaeological deposits in Camp Swift. Uneroded upland areas might contain mixed surface sites. Recent filling of eroded surfaces in the alluvial valleys (T1 and T0) by high-energy eolian and fluvial deposits results in a low potential for archaeological sites in primary context. 



\section{Chapter A: Methods}

\section{Research Design}

\section{David G. Robinson}

Research designs are guides to achieving the goals of any project, in this case the Phase I inventory of Camp Swift. As the Secretary of the Interior's Guidelines state; "the research design provides a vehicle for integrating the various activities performed during the identification process and for linking those activities directly to the goals and the historic context(s) for which those goals were defined (III-68)." As such, a research design bridges theory and methodology and shows how fieldwork and analysis will accomplish the necessary eligibility assessments, and from those the determination of historic properties. These components complete the groundwork needed for future management. The three parts of a research design are:

1. Objectives;

2. Methods; and

3. Expected results.

The Camp Swift Phase I inventory research design states the objectives of the survey and describes the field and laboratory methods implemented.

\section{Objectives}

The objectives of the Phase I cultural resources inventory of Camp Swift are to discover and identify the prehistoric and historic sites and other cultural resources on the camp and determine their eligibility for the National Register. A secondary objective is to resurvey a portion of previously investigated territory in order to assess the comparability of earlier efforts with the present intensive survey. The ultimate objective of the Phase I inventory is to provide the information necessary for cultural resource management of the camp in perpetuity.

\section{Methods}

The primary method of the Phase I inventory is archeological field survey to discover previously unrecorded sites, employing pedestrian transect survey with subsurface probes and tests. Details of the field methods and record keeping are given in Chapter 5. Limited archival research will be conducted to gain insights on historical resources, although the archival research will rely heavily upon the exhaustive work of Freeman (Skelton and Freeman 1979) on the historical period of Camp Swift and northern Bastrop County. Laboratory analysis will be conducted largely to relate the sites to the historic contexts of settlement patterns, lithic technology, and artifact seriation. Examination of diagnostic artifacts (projectile points, vessel forms, makers' marks) will be made to assist in the chronological placement of sites and, to a limited degree, infer their functions. Site forms, photographs, maps, all other records, and artifacts will be prepared carefully for curation at the Texas Archeological Research Laboratory, where they will be available for future reference.

\section{Expected Results}

The majority of prehistoric sites are expected to be debitage and artifact scatters. These may have subsurface depth on the west side of the camp where there are deep sandy soils. Some sites there may have buried features, mostly burned rock hearths (Bement 1984, Skelton and Freeman 1979). Artifact scatters on the eastern half of the camp, where the prevailing clayey loam soils are shallow, are not expected to have much subsurface depth or buried, intact features. Sites at the confluences of intermittent streams and creeks may be larger than sites at higher elevations. Altogether, the prehistoric sites at Camp Swift are expected to show functional differences among themselves and fit into the upland component of regional settlement patterns. Intactness of features is an accepted archeological measure of integrity, and intact sites are likely to rank high in their eligibility assessments. 
Historic period sites are expected to be middens or habitation sites of the historic settlement period, probably no earlier than 1850 . The Aussilloux winery site (41BP138) is a known property on the camp; it will be assessed in terms of the early Texas wine industry historic context. Twentieth-century military sites older than the 50-year cutoff for historic properties are not expected, however, younger sites deemed exceptional will receive eligibility assessments.

\section{Field Methodology}

\section{Goals and Strategies}

The Camp Swift survey fieldwork was finished on July 2,1997 . The work proceeded in two stages. The first stage was to examine portions of the camp that had not been surveyed previously. The second stage was to resurvey 1000 acres of the Skelton and Freeman (1979) survey area.

The goal of the first stage was to complete the inventory of cultural resources at the camp. If time permitted, all acreage outside the earlier LCRA study zone would be investigated by the stratified transect method.

The second stage actually proceeded in two parts. The first part was to resurvey 1000 acres by the stratified transect method to see if any sites were found that may have been overlooked by Skelton and Freeman (1979). This resurvey was stratified environmentally to gain a sub-sample of the physiographic zones covered by those researchers. These zones included active floodplains, upper terraces, valley margins, and upland divides. Upland divides provided the most resurvey area ( 575 acres), followed by valley margins (362 acres), upper terraces (67 acres), and active floodplains (22 acres).

The second part of the phase was a field effort to relocate and reassess a selected sample of previously recorded and known sites, not restricted to the LCRA study zone. The sites were relocated using their mapped locations and UTM coordinate data. Once found, site information was upgraded for the purposes of eligibility assessment and to reassess site condition and impacts that may have taken place between its original recording and the present.

Altogether, 4,694 acres of previously unsurveyed land at Camp Swift were investigated. Nine hundred seventy-seven acres of the LCRA zone were resurveyed, for a total of 5,671 acres. Within this area, 58 cultural sites were discovered (only one new site, 41BP532, was discovered within the LCRA survey zone). Of the newly recorded sites, 27 are prehistoric sites, 26 are historical sites, and eight are multicomponent sites having both prehistoric and historic components. Of the 80 earlier known sites, 42 were relocated and reassessed, and 38 could not be relocated even after repeated efforts to find them. More detailed site information and eligibility assessments are presented in Chapters 5 and 7.

Additional work was accomplished apart from the location of substantial cultural sites. A total of six wells and cisterns not previously mapped by the Bureau of Economic Geology were identified by the survey, and their locations and descriptions made available to that agency and the public. One such well located near the northwestern boundary of the camp had a steel pipe casing protruding about six inches above the ground surface and was otherwise unmarked; this well may have been an abandoned oil or gas well. The other wells found were brick lined water wells. Collection of the well data is for use in a statewide program for filling abandoned, hazardous wells.

An additional effort of the survey was the recording of cultural isolates. The ground surface of the camp is littered with cultural material everywhere, most of it debris from National Guard training, mostly shell casings and ration containers but also equipment and personal gear such as canteens, keys, and watches. A very small fraction of this material may have belonged to the historic or prehistoric periods. These latter items were the first step in discovering sites, but if no other cultural objects were found within ten meters of the first, a site could not be defined, and the first object was recorded as a cultural isolate (these items are described in Appendix A). 


\section{Survey Methodology}

\section{Transect Survey}

The Camp Swift survey was conducted in transects. The width of the intervals between transects varied with landforms and field conditions, but was never greater than 30 meters. Transects were numbered and recorded on 7.5 minute topographic maps. The number, angle, and topographic location of each transect was recorded in the daily journals of each crew member.

\section{Survey Techniques}

Three survey techniques - ground surface inspection, shovel probes, and shovel tests - were employed during transect survey. Surface inspection included examination of the ground surface and inspection of cut banks and other exposed ground surfaces. Artifacts diagnostic of a specific time period or tools diagnostic of site activities were collected at the discretion of the site investigator.

Shovel probes consisted of units at least 30 centimeters in diameter excavated to a depth of at least 20 centimeters, or until sterile subsoil was encountered. Screening of shovel probes was based on field conditions and at the discretion of the individual excavator. Detailed notes of individual shovel probes generally were not taken, unless cultural material was encountered.

Shovel tests consisted of units 30 to 50 centimeters in diameter excavated in 20 centimeter levels to a depth of at least 40 centimeters or until sterile subsoil was encountered. Shovel tests were screened through 1/4inch wire mesh screen. Information pertaining to soils, depth of excavation, artifacts encountered, and other relevant shovel test findings were recorded on standardized shovel test forms prepared by each crew member.

Artifacts recovered in shovel tests and shovel probes were retained in compliance with the Secretary of Interior's guidelines for archeological surveys, the Texas Historical Commission's (THC) recording standards, and provisions of the Archeological Resource Protection Act (ARPA). Artifacts were separated by shovel test and level, transported to Camp Mabry, and processed. The artifacts are to be curated at the Texas Archeological Research Laboratory (TARL).

Shovel probes were placed every thirty meters along a given pathway in areas where ground surface visibility was less than 25 percent. Shovel tests accompanied the shovel probes at 150-meter intervals, unless there was good ground surface visibility (greater than 25 percent) or cut banks were nearby. Shovel tests and shovel probes were placed more frequently in areas believed to have a higher probability of containing intact, buried archeological sites. The determination of whether shovel tests or probes were excavated was based on field conditions and left to the discretion of the individual surveyor.

\section{Site Identification and Assessment}

Once a site was identified, shovel tests were usually dug to help finalize the determination of eligibility of the site and to assist in estimates of site boundaries. The minimum number of shovel tests (see above) needed to assess and record a site were dug in order to reduce subsurface disturbance to the site and conserve the resource. Methods for the determinations made on site boundaries are explained in "Site Boundary Determinations.”

Sites recorded during the Camp Swift survey included historic, prehistoric, and multicomponent sites. The procedures used for recording these site types included both consistent methods used at all sites and site-typespecific procedures. Methods used at all of the sites included filling out a State of Texas Archeological Site Data Form (TexSite computerized form), a detailed site sketch map drawn to scale, and notes in each participating crew member's field journal. The majority of sites were photographed.

Prehistoric sites were investigated using both ground surface observation and subsurface testing (both shovel probes and shovel tests). Surface and subsurface testing was conducted at most prehistoric sites to define the sites both horizontally and vertically. The number of shovel tests excavated at any one site was generally limited to four or fewer tests. Historic sites were generally identified by surface artifacts and/or features and were seldom subsurface tested. 


\section{Operational Definitions Surface Artifact Density}

Assessing the surface densities of artifacts was complicated by limited ground surface visibility. The scale of site surface densities, accordingly, was Low -0 to 20 artifacts (all classes of cultural material combined), Medium-21 to 50 items, and High - 51 items and up. Statements of low, medium, or high surface densities in the site descriptions refer to this scale.

\section{Site Types}

The prehistoric site typology is functional; the use of this typology is explained further in Chapter 6, "Prehistoric Settlement Patterns." Defined briefly, open camps are sites with any class of cultural material and burnt rock (FCR). Limited activity sites may have lithic debris and formal artifacts, but no FCR. Lithic scatters have lithic debitage but no other class of cultural material and no FCR. The historic site typology is conventional usage, as such it is also functional. Historic site types on Camp Swift include habitation sites, trash scatters/dumps, installations (agricultural pens, etc.), bridge sites (41BP481 and 41BP482), and well sites. These site types correspond only partially to the types on the TexSite State of Texas Site Form site type menu. This discrepancy is accepted here and justified on the grounds that the Camp Swift site classification is based on the outcome of generations of regional research, whereas the TexSite site type menu is broader, designed and intended to encompass sites statewide. The regional background giving rise to the prehistoric functional site classification used here is presented in Chapter 2, and the settlement pattern section (see Chapter 6). The inconsistency between the site descriptions and the site forms is accepted for the sake of more accurate assessments.

\section{Site Depth}

Archeological deposits identified at the prehistoric sites were defined as deep if they were $60 \mathrm{~cm}$ in depth or greater, moderately deep if they were from 30 to $60 \mathrm{~cm}$ in depth, and surficial if they were confined to the surface. Thirteen of the sites are deeply buried, eight moderately buried, while seven appear to be limited to the present ground surface. Two of the sites noted as being deeply buried contain possible intact buried fire-cracked rock features. Historic sites generally were not subsurface tested, visual inspection of rills, gopher spoil, and other ground disturbances usually being adequate to determine if natural processes had advanced enough to start burying historical material.

\section{Site Boundary Determinations A Critique of the Traditional Approach}

In determining site boundaries, Texas archeologists frequently apply two factors to the exclusion of others - surface artifact distributions and the distributions of positive shovel tests, or site boundary determination by subsurface data. However, at Camp Swift these techniques were not adequate by themselves to define site boundaries.

Surface distributions could not be used exclusively because of the generally dense ground vegetation coverage, even in winter. This meant that ground surface visibility was intermittent, at best. Areas at Camp Swift where vegetation is less dense are on zones of disturbance; consequently, exposed artifacts are displaced. The use of distributions in these zones is often unreliable.

Secondly, the distribution of positive shovel tests (boundary determination by subsurface materials) also proved to be unreliable because of the sparse nature of artifacts at many of the sites in the Camp Swift survey area, especially in upland locales. For example, in attempting to define site limits using a radial pattern of shovel tests, there might be three negative tests for every positive one and the negative ones may well occur within the site boundaries. The site sketch maps of the Phase I sites show numerous examples of negative tests near the centers of sites whose peripheries were identified by fortunate surface artifact exposures or landform relationships (e.g., stream banks). Reliance on this technique at Camp Swift would result in underestimating site size and defining artificially convoluted site boundaries.

\section{Tailoring Criteria to Regional Parameters}

To be consistent, site boundary criteria must be defined explicitly and applied broadly. At the same time, the criteria must also be as holistic as possible and flexible enough to account for unanticipated situations. To define site boundaries for this project, the primary criteria included the following factors: 
1. Surface artifact distributions-a principal tool for determinations, but such distributions are conditioned by ground surface visibility.

2. Subsurface artifact distributions (based on distributions of positive shovel tests)-provide important clues also, but it should be remembered that subsurface distributions are variable due to cultural and natural factors.

3. Nature of the soils and soil dynamics-erosion, depth, and horizon-building processes have varying effects on the stability, dispersal, and exposure of cultural contexts.

4. Relationship of soil horizons and parent material-broadly, the solum of soils at Camp Swift is the Holocene deposit in which most cultural deposits are contained.

5. Landforms-these (especially slope) affect stability and transportability of cultural deposits.

6. Apparent orientation of sites in relation to landforms-this is the cultural component of landform evidence, involving anticipation of cultural choices of desirable or functional site locations, e.g. campsites on sheltered pecan bottom terraces.

7. Location of water sources-similar to the above, this factor involves anticipation of site locations and areal extent relative to this critical resource.

8. Features and artifact assemblages (inferred site function)-historically, minor lithic scatters have been found to be restricted in area unless they are co-extensive with Uvalde gravel outcrops. Open camps near watercourses may be linearly extended along terrace and stream banks, to the extent that in some regions they are called strip sites.

With this expanded list of relevant factors, site sizes and boundaries are estimated more accurately than if only the first two criteria are applied. The pertinence of landforms, especially in delimiting sites is often down-played or overlooked. Additionally, functional information about the sites, the last factor, plays a valuable part in site delimitation. The most obvious example of the use of this application is provided collectively by historic trash dumps in gullies. When these were unaccompanied by nearby agricultural installations, evidence of historic buildings, or remnant field patterns, it was assumed that the gully locale was the extent of the historic midden, the deliberate choice of a desirable point at which to dump refuse. The site was therefore defined as the gully segment at the locus of primary dumping and down-gully areas to the extent of erosion of cultural items from the primary dump. The site function - trash dump-is key to delimiting the site. In summary, the more factors that could be considered heightened our ability to adjust to the needs of each site on a case-by-case basis. But at the same time, we were able to apply the same criteria broadly and flexibly. The end result has been improved knowledge of each site and therefore better overall resource protection.

\section{Site Revisits}

The revisitation of previously recorded sites involved relocating the sites, verifying their topographic locations, and documenting these sites especially with regard to changes in their condition since they were originally recorded. Site relocation was undertaken with compass bearing and pacing in to the mapped site location. A systematic search of the mapped site area was then undertaken by using one or more of the following techniques: pedestrian surveys, shovel probes, and shovel tests. The majority of historic sites were sought using pedestrian survey because they were noted to consist of recorded surface features and/or artifacts. Prehistoric sites were sought using both surface and subsurface techniques.

Sites relocated during the revisitation phase of the Camp Swift survey were photographed, a State of Texas Additional Archeological Site Investigation Form (TexSite computerized form) was filled out, a detailed sketch map was drawn to scale, and detailed field notes were taken. Sites found to be in locations other than those originally mapped were replotted on topographic maps. No revisit form was filled out for sites not relocated during revisit attempts. However, notes were made regarding what was found at the mapped site location. In instances of discrepancies in site locations, the mapped site location, reported UTM point, and written site description were taken into account. 


\section{Lab Methodology}

All materials collected in the field were brought back to Camp Mabry where they were washed and inventoried. Artifact inventory sheets were filled out for each provenience and the data was input into a Microsoft Excel file. An attempt was made to date all historic artifacts with makers' marks and gain a typological assessment of prehistoric diagnostic artifacts. The cultural materials were made available to the research reported in the historic contexts in Chapter 6.

At the time that CAR began the editing of this report, the artifacts were re-assessed, and additional information, especially categorization of some lithics and dating of historic artifacts, was included in artifact descriptions for each site.

\section{Archival Research}

Archival research, vital to the development of the background and current research on Camp Swift, was conducted at various locations. The Barker Center for American History contained various items of special interest. These included newspapers, books, and personal files. The Bastrop Abstract provided access to a map showing property ownership prior to the existence of Camp Swift. The Bastrop Historical Society Museum provided access to its files on various topics relevant to the Phase I survey. The Bastrop Public Library provided census records. The Bastrop County Courthouse was a center for the archival work, housing three important archives: the District Clerk's office, the County Clerk's office, and the Tax Assessor's office. The District Clerk's office provided immigration and naturalization records and civil minutes. The County Clerk's office holds deeds, probate records, death records, maps, and judgment records. The Tax Assessor's office provided access to all historic tax records. The Texas State Archives was utilized for historic tax records. The Texas Archeological Research Laboratory in Austin was an important source for background on prehistoric research, and the Perry-Castaneda Library at the University of Texas at Austin was a valuable resource on historic and prehistoric topics. 


\title{
Chapter 5a: Resullits - Prehistoric
}

\section{Sites Recorded during 1997 Survey}

\author{
Leeann Haslouer Kay
}

This chapter includes details of the sites located in areas surveyed for this project, and discusses the results of the revisits of previously identified sites, including the historic cemeteries on Camp Swift that are considered separately at the end of this chapter. Assessment of each site's eligibility for placement on the National Register of Historic Places is discussed in Chapter 7. The known locations of historic and prehistoric sites within the current boundaries of Camp Swift are shown in Figure 13 (available as a supplement only).

\section{Prehistoric Sites}

Twenty-six prehistoric sites were recorded during this survey. They are: 41BP476, 41BP477, 41BP486, 41BP488, 41BP491, 41BP493, 41BP494, 41BP495, 41BP496, 41BP497, 41BP498, 41BP499, 41BP505, 41BP506, 41BP509, 41BP510, 41BP512, 41BP521, 41BP522, 41BP524, 41BP526, 41BP527, 41BP528, 41BP529, 41BP530, and 41BP533. The site descriptions for each follow. 


\section{BP476}

\section{Site Type:}

Prehistoric lithic scatter

Site Size:

$600 \mathrm{~m}^{2}$, determined by shovel tests and examining the surface and gully cutbanks (Figure 14)

Topographic Setting:

Upper terrace slope between two upland streams

\section{Description:}

41BP476 is a prehistoric lithic scatter on gully-dissected slopes near the northwest boundary of the camp on the upper slopes between two unnamed tributaries of Big Sandy Creek. Oak, cedar, pine, woody shrubs, and some grasses are the dominant ground cover, and ground surface visibility is $10-15 \%$. The soil at the site belongs to the Patilo complex. The deep incision of gullies through the center of the site has destroyed any integrity the Holocene deposits may once have had. We estimate that this gully has destroyed over $70 \%$ of the site.

Investigation:

Eight shovel tests were excavated on this site, seven of which were sterile. The crew also examined the surface of the site thoroughly. This was sufficient to determine that the site consisted of a very light scatter of lithic debris scattered over an area of $30 \mathrm{~m}$ north/south by $20 \mathrm{~m}$ east/west, or $600 \mathrm{~m}^{2}$. Inspection of gully cutbanks revealed no evidence of features.

\section{Results:}

Only three flakes were found. Two of these were on the surface in an eroded gully and the third was found in Shovel Test 7 at about $20 \mathrm{~cm}$ depth (Table 1). The Holocene deposits at the site are shallow, with a clayey C-horizon less than 30-40 cm below the surface. 


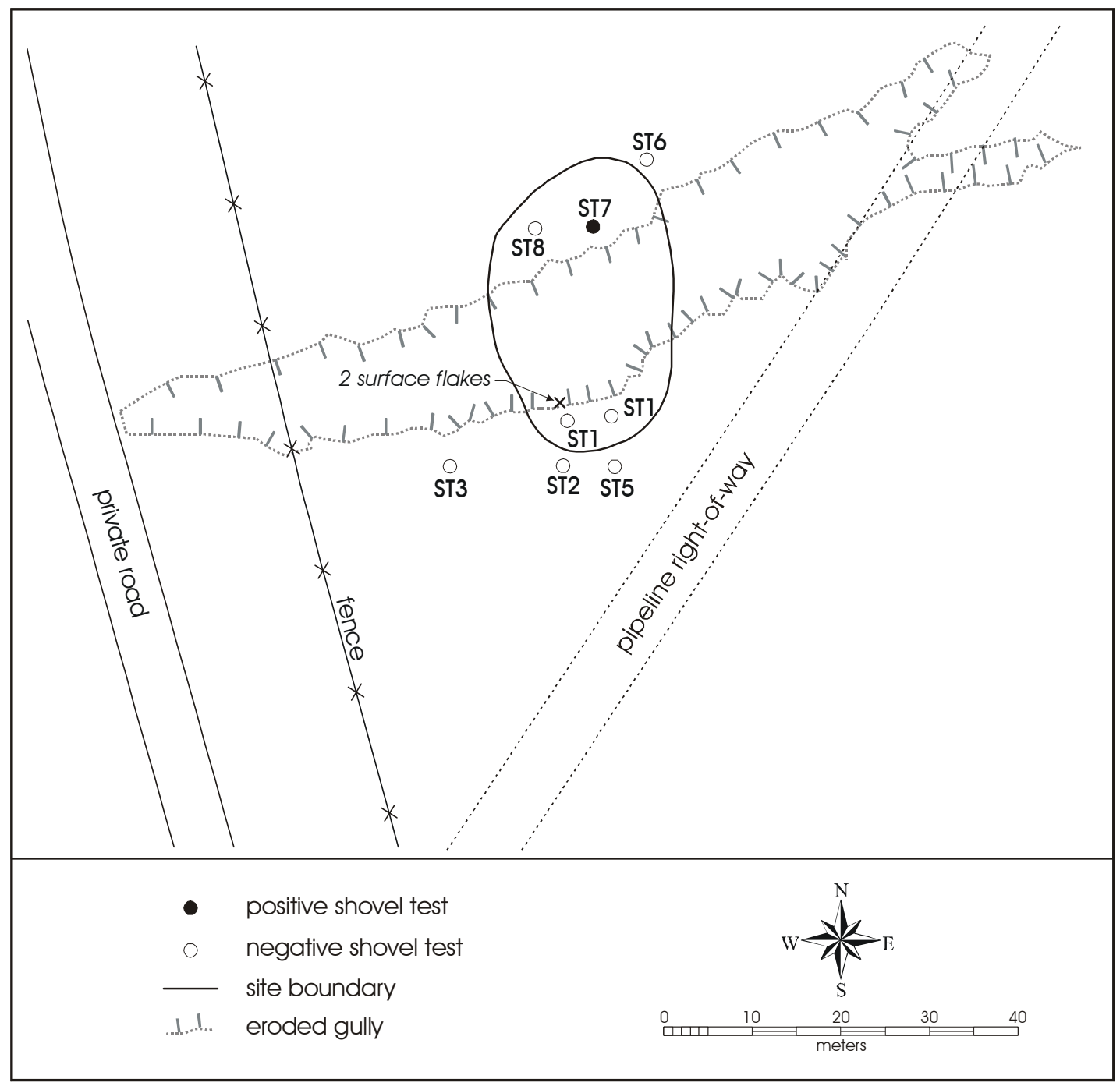

Figure 14. Map of $41 B P 476$.

Table 1. Results of shovel tests at 41BP476

\begin{tabular}{|lrl|}
\hline \multicolumn{1}{|c|}{ Unit } & \multicolumn{1}{c|}{ Depth $(\mathbf{c m})$} & \multicolumn{1}{c|}{ Artifacts Collected } \\
\hline Eroded gully & -- & 2 flakes \\
\hline ST-1 & $0-25$ & -- \\
\hline ST-2 & $0-35$ & -- \\
\hline ST-3 & $0-45$ & -- \\
\hline ST-4 & $0-35$ & -- \\
\hline ST-5 & $0-40$ & -- \\
\hline ST-6 & $0-30$ & -- \\
\hline ST-7 & $0-20$ & 1 flake \\
& $20-30$ & -- \\
\hline ST-8 & $0-40$ & -- \\
\hline
\end{tabular}




\section{BP477}

Site Type:

Prehistoric open camp

Site Size:

4,104 $\mathrm{m}^{2}$, determined by shovel tests, examination of the surface, and landforms (Figure 15)

\section{Topographic Setting:}

Upper slopes between two unnamed streams

\section{Description:}

Site 41BP477 is a prehistoric open camp on a nose slope above the confluence of two unnamed tributaries of Big Sandy Creek. Oaks, cedar, woody understory, and domesticated grasses are the dominant ground cover, and the site has $5-10 \%$ surface visibility. The soil at the site is part of the Patilo complex.

\section{Investigation:}

Fourteen shovel tests were excavated, three did not contain cultural material. The site is on a finger ridge landform that defines the east, west, and south boundaries. The field crew also inspected the surface of the site. This was sufficient to determine the site's horizontal and vertical extent of $108 \mathrm{~m}$ northwest/southeast by $38 \mathrm{~m}$

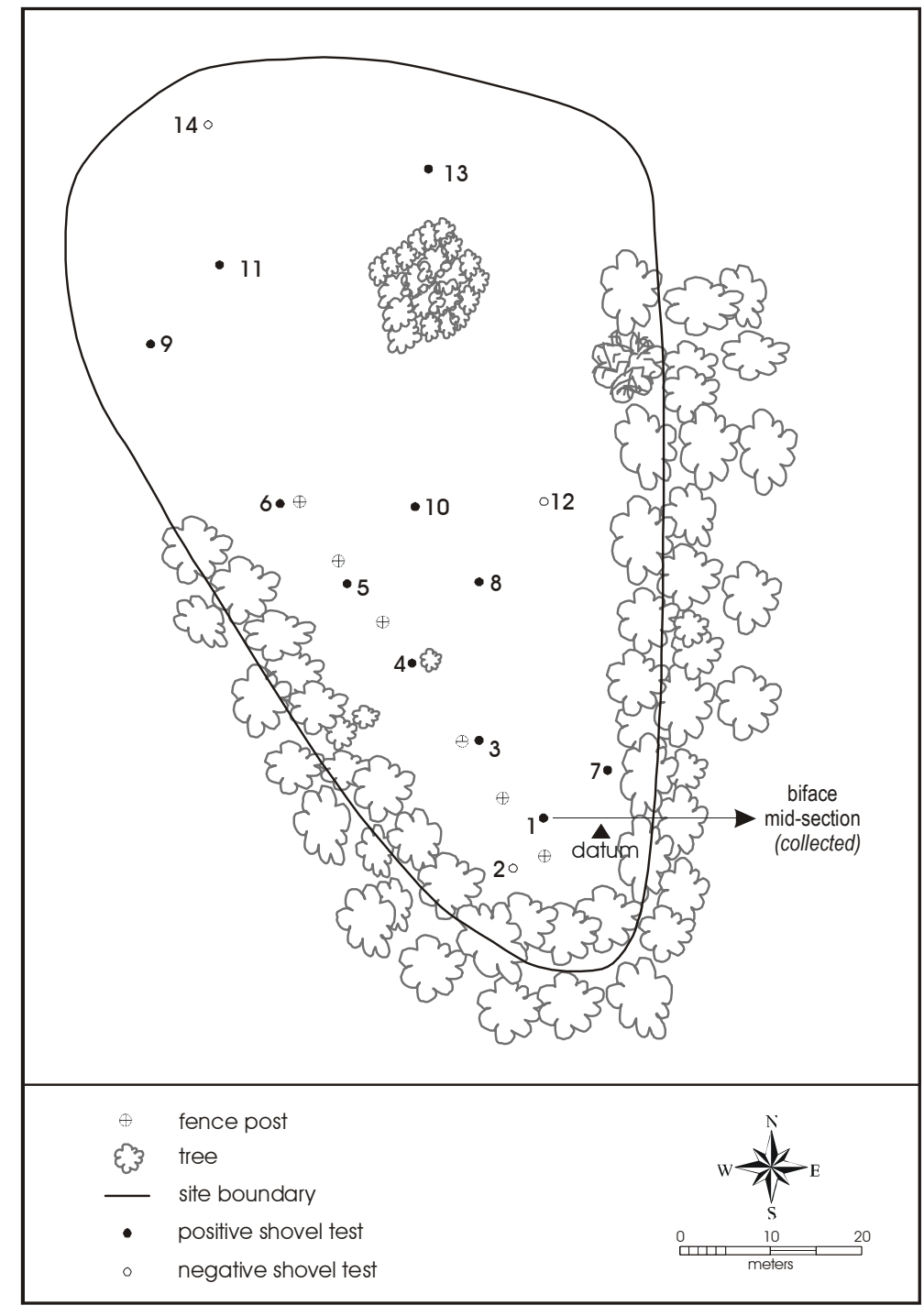

Figure 15. Map of $41 B P 477$. east/west, or $4,104 \mathrm{~m}^{2}$ in area.

\section{Results:}

A total of 87 artifacts were found (Table 2). One chert biface was found on the site's surface. Twenty-nine chert flakes, 55 pieces of burned rock, one possible bison tooth, and one Scallorn arrow point were found. Artifacts were recovered to a depth of $120 \mathrm{~cm}$ in 3 of the shovel tests. One shovel test was sterile. Although no defined features were identified at the site, the larger quantities of burned rock in Shovel Tests 3, 5, 10, and 11 may be the remnants of burned rock hearths, or indicate that such features are nearby.

\section{Artifacts:}

While most of the artifacts found consist of burned rock fragments and lithic debris, several selected items are described in more detail below (see also Appendix B for measurements).

- $\quad$ Specimen 477-4 is a thin biface midsection of dark brown translucent chert found on the surface (Figure 16a). The artifact was probably in the last stages of manufacture when it was broken and discarded. Two sections of the edges have steep edge chipping, which may be the result of postbreakage scraping or gouging utilization. Apart from the steep edge chipping, the blade edges were unfinished.

- Specimen 477-33 is a Scallorn arrow point base and was found in Shovel Test 10 at $20-40 \mathrm{~cm}$ below the surface (Figure 16b). 
Table 2. Results of shovel tests at 41BP477

\begin{tabular}{|c|c|c|c|c|c|}
\hline \multirow{6}{*}{$\begin{array}{l}\text { Shovel Test } \\
\text { ST-1 }\end{array}$} & Depth (cm) & Artifacts Collected & \multirow{6}{*}{$\begin{array}{l}\text { Shovel Test } \\
\text { ST-7 }\end{array}$} & \multirow{2}{*}{$\begin{array}{r}\text { Depth }(\mathbf{c m}) \\
0-20\end{array}$} & \multirow{2}{*}{$\begin{array}{l}\text { Artifacts Collected } \\
--\end{array}$} \\
\hline & Surface & 1 biface midsection & & & \\
\hline & $0-60$ & -- & & $20-40$ & 1 burned rock \\
\hline & $60-80$ & charcoal fragments & & $40-60$ & -- \\
\hline & $80-100$ & -- & & $60-80$ & 3 burned rock \\
\hline & $100-120$ & -- & & $80-120$ & -- \\
\hline ST-2 & $0-78$ & -- & \multirow[t]{4}{*}{ ST-8 } & $0-20$ & -- \\
\hline \multirow[t]{6}{*}{$\begin{array}{l}\text { ST-3 } \\
\end{array}$} & $0-20$ & -- & & $20-40$ & 2 flakes, 1 burned rock \\
\hline & $20-40$ & 2 burned rocks & & $40-60$ & 2 burned rock, 1 bovid tooth \\
\hline & $40-60$ & 1 heat spall & & $60-70$ & -- \\
\hline & $60-80$ & 6 burned rocks & \multirow[t]{3}{*}{$\overline{\text { ST-9 }}$} & $0-40$ & -- \\
\hline & $80-100$ & 3 burned rocks & & $40-60$ & 1 flake, 7 burned rocks \\
\hline & $100-120$ & 1 flake, 1 burned rock & & $60-100$ & -- \\
\hline \multirow[t]{5}{*}{$\begin{array}{l}\text { ST-4 } \\
\end{array}$} & $0-20$ & 3 burned rocks & \multirow[t]{6}{*}{ ST-10 } & $0-20$ & -- \\
\hline & $20-40$ & 1 flake, 4 burned rock & & $20-40$ & 1 Scallorn pt., 3 burned rocks \\
\hline & $40-60$ & -- & & $40-60$ & 2 flakes, 1 burned rock \\
\hline & $60-75$ & 1 flake & & $60-80$ & 1 flake, 2 burned rocks \\
\hline & $80-100$ & -- & & $80-100$ & 1 primary flake \\
\hline \multirow[t]{5}{*}{$\begin{array}{l}\text { ST-5 } \\
\end{array}$} & $0-20$ & 2 flakes, 1 shatter & & $100-110$ & -- \\
\hline & $20-40$ & 2 burned rocks & \multirow[t]{5}{*}{ ST-11 } & $0-40$ & -- \\
\hline & $40-80$ & -- & & $40-60$ & 1 flake, 1 burned rock \\
\hline & $80-100$ & 1 flake & & $60-80$ & 5 flakes, 1 burned rock \\
\hline & $100-110$ & -- & & $80-100$ & 6 flakes, 6 burned rocks \\
\hline \multirow[t]{6}{*}{$\begin{array}{l}\text { ST-6 } \\
\text { S }\end{array}$} & $0-20$ & -- & & $100-120$ & 2 burned rocks, charcoal \\
\hline & $20-40$ & 1 flake & ST-12 & $0-50$ & -- \\
\hline & $40-60$ & -- & \multirow[t]{3}{*}{ ST-13 } & $0-20$ & -- \\
\hline & $60-80$ & 1 flake, 1 burned rock & & $20-40$ & 1 tested cobble/core \\
\hline & $80-100$ & 1 flake & & $40-119$ & -- \\
\hline & $100-120$ & 1 burned rock & $\overline{\text { ST-14 }}$ & $0-40$ & -- \\
\hline
\end{tabular}

Originally, the point was probably elongate and triangular, but its length was truncated with a lateral snap fracture at mid-blade. The remaining specimen has deeply serrated edges. The edges within the notches show crushing, probably from the flaking of the notches. Otherwise, the edges are fresh. The artifact has a lenticular cross-section. The Scallorn type is a Late Prehistoric diagnostic projectile point (Turner and Hester 1993:230).

- Specimen 477-47 is a tested cobble of opaque chert, and was found in Shovel Test 13 at 20 to $40 \mathrm{~cm}$ below the surface. It has been burned and exhibits heat spalls. It also has six flake scars, of which four are the results of burning (crazing) and the other two appear to be purposeful flaking.
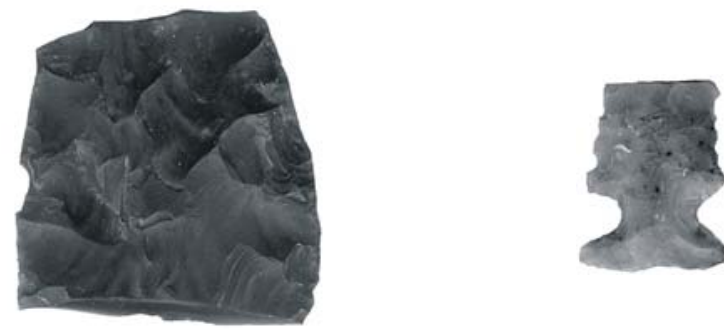

b

a

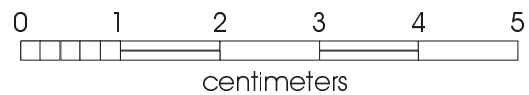

Figure 16. Lithics from 41BP477: a) Utilized biface mid-section; b) Scallorn point. 


\section{$41 \mathrm{BP486}$}

Site Type:

Prehistoric open camp

Site Size:

$18,812.5 \mathrm{~m}^{2}$, determined by a shovel test, surface inspection, and natural landforms (Figure 17)

Topographic Setting:

Upland stream terrace slope

Description:

Site 41BP486 is a prehistoric open campsite in an open field overlooking Big Sandy Creek. It is on an upland stream terrace slope, on the T1 terrace. Domesticated and native grasses are the dominant ground cover with 20$75 \%$ surface visibility. The soil type on the site is part of the Patilo complex.

\section{Investigation:}

The crew excavated one shovel test, which was positive. The crew also inspected the surface of the site. This was sufficient to determine that the site consists of a very light scatter of lithic debris and contains a burned rock feature at $50 \mathrm{~cm}$ deep. The boundary determined by the positive shovel test, surface inspection, and landform is $215 \mathrm{~m}$ northeast/southwest by 45 to $130 \mathrm{~m}$ northwest/southeast, or $18,812.5 \mathrm{~m}^{2}$.

\section{Results:}

Eight artifacts were found (Table 3). One Pedernales point base was found on the surface. Five flakes and two burned rocks were found in the shovel test. The shovel test was terminated at $50 \mathrm{~cm}$ deep because a potentially intact hearth feature was observed. None of the burned rock from this feature was collected.

\section{Artifacts:}

Specimen 486-66 is a fragmentary Pedernales dart point (Turner and Hester 1993: 171-173), consisting only of the stem and distinctive bi-pointed base (Figure 18). The material is translucent brown chert. The stem edges curve slightly inward to the basal points. The basal width, point-to-point, is $12.7 \mathrm{~mm}$; the basal concavity is $6.5 \mathrm{~mm}$ deep. The artifact lacks grinding anywhere on the stem, points, or basal concavity. The artifact is thin and well finished but has no patterned flake scars. A remnant fluting flake scar is visible on one face, extending upward from the basal concavity. This feature is said to be a trait of the Pedernales reduction process (Ensor and Mueller-Wille 1988: 168-170, Fig. 61). The Pedernales dart point type is a key regional diagnostic artifact, dating to the Late Middle or Early Late Archaic (Johnson and Goode 1994).

Table 3. Results of shovel tests from 41BP486

\begin{tabular}{|c|c|c|}
\hline Unit & Depth (cm) & Artifacts Collected \\
\hline Surface & -- & $\begin{array}{l}1 \text { Pedernales point } \\
\text { base }\end{array}$ \\
\hline \multirow[t]{3}{*}{ ST-1 } & $0-20$ & $\begin{array}{l}1 \text { flake } \\
2 \text { flakes, } 1 \text { burned } \\
\text { rock }\end{array}$ \\
\hline & $20-40$ & $\begin{array}{l}2 \text { flakes, } 1 \text { burned } \\
\text { rock }\end{array}$ \\
\hline & $40-50$ & $\begin{array}{l}\text { (numerous burned } \\
\text { rock, not collected) }\end{array}$ \\
\hline
\end{tabular}




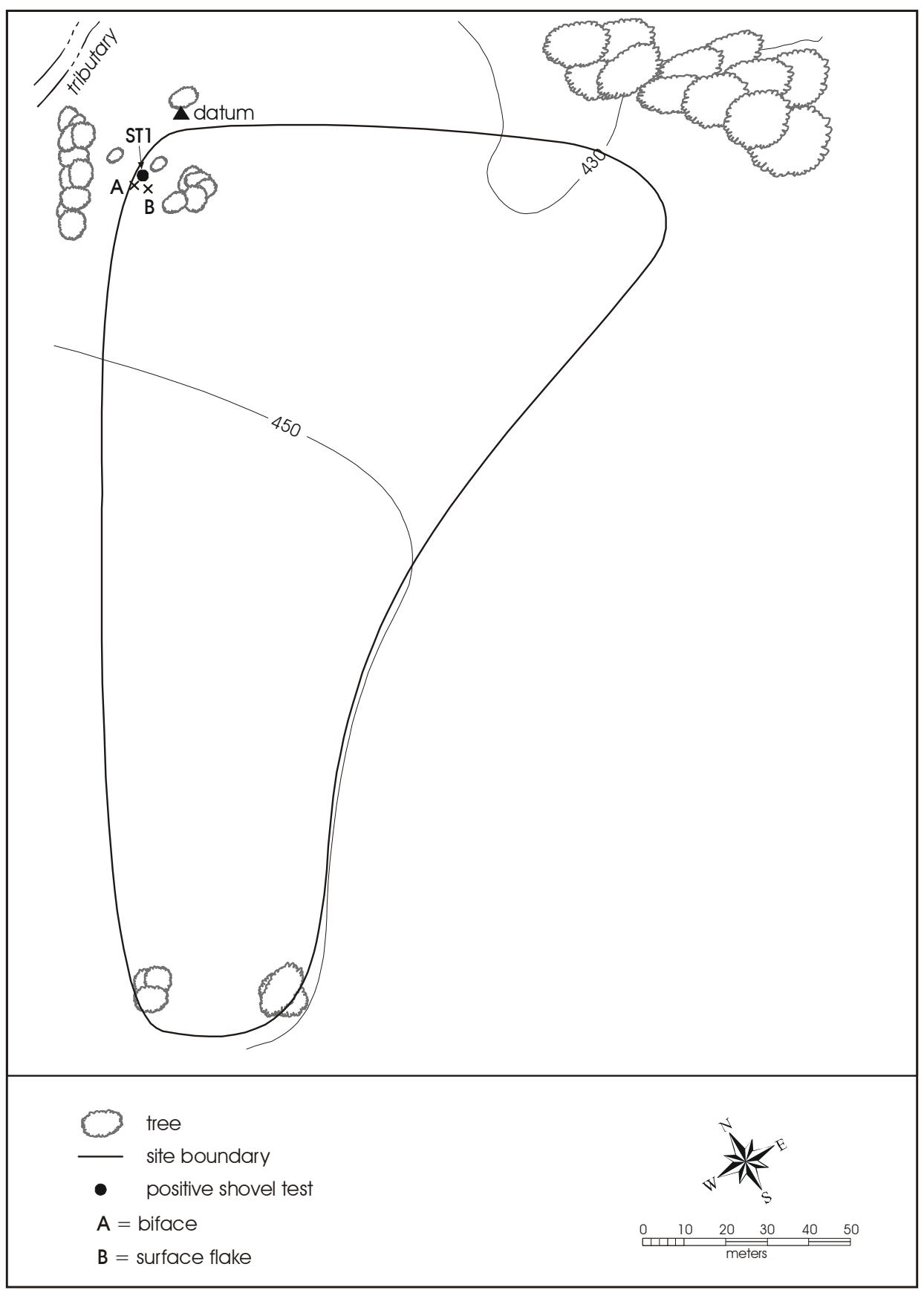

Figure 17. Map of $41 B P 486$.

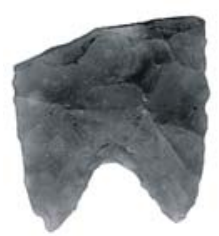

\begin{tabular}{|c|c|c|c|}
\hline $\begin{array}{ll}0 & 1\end{array}$ & 2 & 3 & 4 \\
\hline 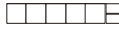 & $\Rightarrow$ & F & -1 \\
\hline
\end{tabular}

Figure 18. Pedernales point base from surface of $41 B P 486$. 


\section{$41 \mathrm{BP488}$}

Site Type:

Prehistoric open camp

Site Size:

2,275 $\mathrm{m}^{2}$, determined by shovel tests and surface inspection (Figure 19)

Topographic Setting:

Lower slopes above an upland creek

Description:

Site 41BP488 is a prehistoric open camp located on a nose slope overlooking Big Sandy Creek, on the T0 terrace. Domesticated grasses and riparian woodlands are the dominant ground cover with $45 \%$ surface visibility. The soils at the site are part of the Patilo complex.

\section{Investigation:}

The crew excavated two shovel tests, which were both positive. The field crew also inspected the site surface. This was sufficient to determine that the site consisted of lithic debitage and burned rocks to a depth of at least $100 \mathrm{~cm}$, suggesting that intact contexts may still exist. The site is $65 \mathrm{~m}$ northwest/southeast by $35 \mathrm{~m}$ northeast/ southwest, or $2,275 \mathrm{~m}^{2}$.

\section{Results:}

Approximately 50 artifacts were found (Table 4). On the surface, a moderate scatter of artifacts was observed, including approximately 20 chert flakes, approximately 10 pieces of burned rock, and one fractured cobble (of which three flakes were collected). Ten pieces of chert debitage and eight pieces of burned rock were recovered from the two shovel tests to a depth of $100 \mathrm{~cm}$. The cluster of burned rock between 40 and $60 \mathrm{~cm}$ in Shovel Test 2 may be the remnants of a feature and may represent intact subsurface deposits. 


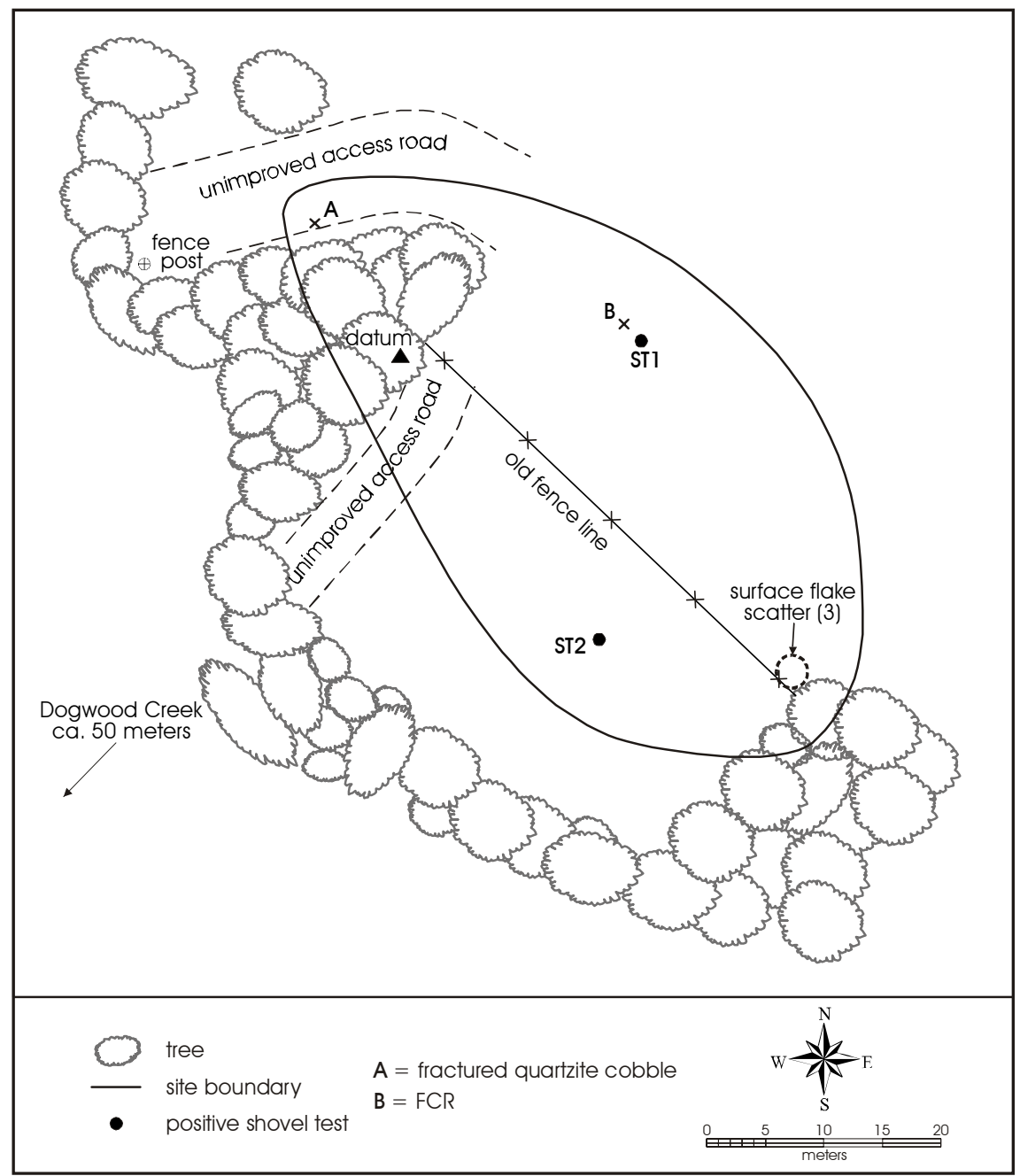

Figure 19. Map of $41 B P 488$.

Table 4. Results of shovel tests at 41BP488

\begin{tabular}{|lrl|}
\hline \multicolumn{1}{|c|}{ Unit } & Depth (cm) & \multicolumn{1}{c|}{ Artifacts Collected } \\
\hline Surface & -- & 3 flakes \\
\hline ST-1 & $0-20$ & 1 flake \\
& $20-40$ & 4 flakes \\
& $40-60$ & -- \\
& $60-80$ & 1 flake, 1 burned rock \\
& $80-100$ & -- \\
\hline ST-2 & $0-40$ & -- \\
& $40-60$ & 2 flakes, 6 burned rocks \\
& $60-80$ & -- \\
& $80-100$ & 2 flakes \\
& 1 burned rock \\
\end{tabular}




\section{BP491}

\section{Site Type:}

Prehistoric open camp

Site Size:

$600 \mathrm{~m}^{2}$, determined by shovel test and surface inspection (Figure 20)

\section{Topographic Setting:}

Upper drainage-divided slopes above Big Sandy Creek

Description:

Site 41BP491 is a prehistoric open camp located on gentle wooded slopes ca. $150 \mathrm{~m}$ from the northwest edge of the camp and located on upper drainage-divided slopes above Big Sandy Creek. Oak and cedar are the dominant ground cover with $5-10 \%$ surface visibility. The soil at the site is Silstid loamy fine sand.

\section{Investigation:}

The crew inspected the site surface and excavated three shovel tests, one of which was sterile. This was sufficient to determine that the site consists of a low density of lithic debitage and burned rocks in an area $40 \mathrm{~m}$ northeast-southwest by $15 \mathrm{~m}$ northwest-southeast, or $600 \mathrm{~m}^{2}$.

\section{Results:}

Eight artifacts were found (Table 5), including five pieces of burned rock and three flakes, in shovel tests to a depth of $100 \mathrm{~cm}$. No surface artifacts were found. Although no features were identified at the site, the presence of debitage and burned rock as deep as $80-100 \mathrm{~cm}$ indicates the potential for intact subsurface deposits.

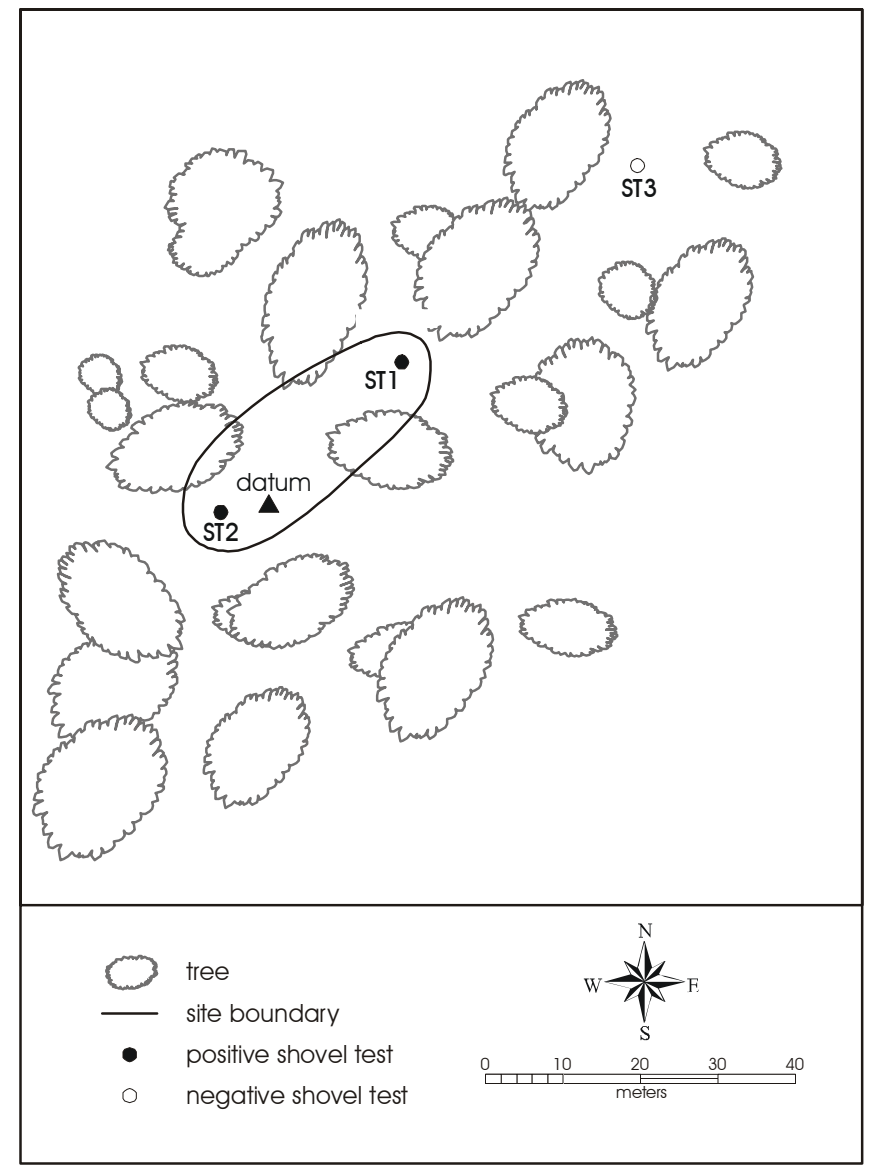

Table 5. Results of shovel tests at 41BP491

\begin{tabular}{|lll|}
\hline Unit & Depth (cm) & Artifacts Collected \\
\hline ST-1 & $0-20$ & 2 burned rock \\
& $20-60$ & -- \\
& $60-80$ & 3 burned rock \\
& $80-95$ & -- \\
\hline ST-2 & $0-40$ & -- \\
& $40-60$ & 1 flake \\
& $60-80$ & -- \\
& $80-100$ & 2 flakes \\
\hline ST-3 & $0-50$ & -- \\
\hline
\end{tabular}

Figure 20. Map of $41 B P 491$. 


\section{$41 B P 493$}

\section{Site Type:}

Prehistoric limited activity area

Site Size:

$25 \mathrm{~m}^{2}$ determined by shovel tests, a probe, and surface inspection (Figure 21)

\section{Topographic Setting:}

Upper stream-divided slopes between two unnamed tributaries of Big Sandy Creek

Description:

Site 41BP493 is a prehistoric limited activity site located on gentle wooded slopes ca. $50 \mathrm{~m}$ east of the northwest boundary fence of the camp. It is on the upper stream-divided slopes between two unnamed tributaries of Big Sandy Creek. Oak and cedar are the dominant ground cover, with 10-20\% surface visibility. Soils are Axtell fine sandy loam. There is observable mixing of surface materials.

\section{Investigation:}

The field crew excavated two shovel tests, both of which were negative, and one shovel probe, which was positive. The crew also inspected the site surface. This was sufficient to determine that the site consists of an extremely light surface scatter of artifacts in an area $5 \times 5 \mathrm{~m}$, or $25 \mathrm{~m}^{2}$.

\section{Results:}

Two artifacts were found on the surface at the location of the shovel probe: one flake and one mussel shell fragment. No subsurface artifacts or features were observed.

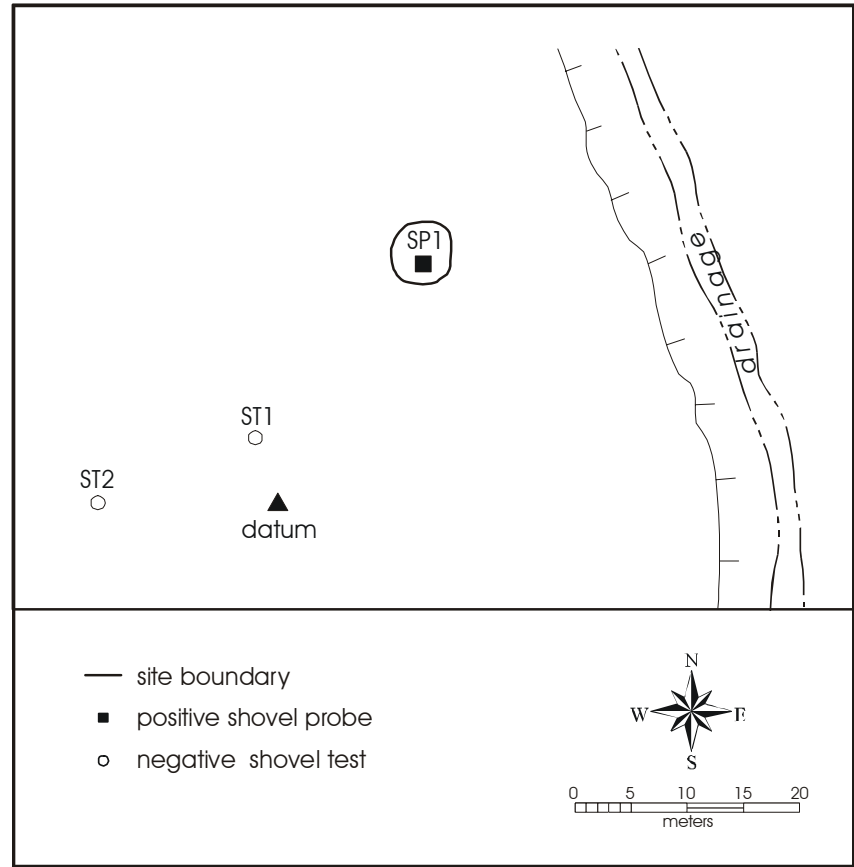

Figure 21. Map of $41 \mathrm{BP} 493$. 


\section{$41 B P 494$}

\section{Site Type:}

Prehistoric lithic scatter

Site Size:

$400 \mathrm{~m}^{2}$, determined by shovel tests, a shovel probe, and surface inspection (Figure 22)

\section{Topographic Setting:}

Upper stream slopes between two unnamed tributaries of Big Sandy Creek

Description:

Site 41BP494 is a prehistoric low density lithic scatter located on a gentle wooded slope approximately $200 \mathrm{~m}$ southeast of the northwest boundary fence of the camp, between two unnamed tributaries of Big Sandy Creek. The dominant vegetation is oak-cedar woodland, with 5-10\% surface visibility. The site's soils are part of the Patilo complex sandy loam.

\section{Investigation:}

The crew excavated three shovel tests, one of which was negative. The crew also excavated one shovel probe, which was sterile, and inspected the ground surface. This was sufficient to determine that the site consists of low-density lithic debitage scattered over an area $20 \mathrm{~m}$ north/south by $20 \mathrm{~m}$ east/west, or $400 \mathrm{~m}^{2}$.

\section{Results:}

Three flakes were recovered, one of which was found on the surface, the other two from depths ranging between the surface and $40 \mathrm{~cm}$ below surface (Table 6). No features were observed.

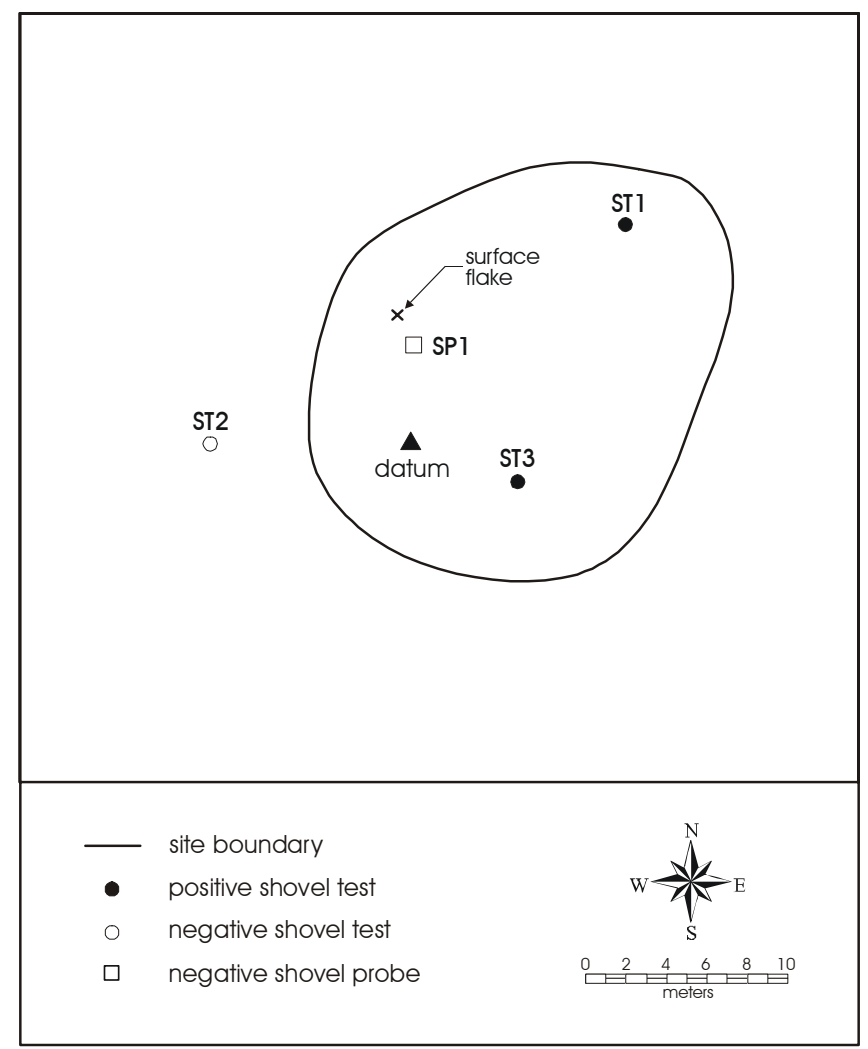

Table 6. Results of shovel tests at 41BP494

\begin{tabular}{|lrl|}
\hline Unit & Depth $(\mathbf{c m})$ & \multicolumn{1}{c|}{ Artifacts Collected } \\
\hline ST-2 & $0-20$ & 1 flake \\
& $20-80$ & -- \\
\hline ST-3 & $0-20$ & -- \\
& $20-40$ & 1 flake \\
& $40-80$ & -- \\
\hline
\end{tabular}

Figure 22. Map of $41 B P 494$. 


\section{BP495}

Site Type:

Prehistoric open camp

Site Size:

$700 \mathrm{~m}^{2}$, determined by shovel tests and surface inspection (Figure 23)

\section{Topographic Setting:}

Upper stream drainage slopes

\section{Description:}

Site 41BP495 is a prehistoric open camp on a wooded upper stream drainage slope overlooking an unnamed tributary of Big Sandy Creek. Oak and cedar are the dominant ground cover, with 30-50\% surface visibility. The site soils are part of the Patilo complex sandy loams. Shovel tests indicate that intact deposits may exist.

\section{Investigation:}

The field crew excavated two shovel tests, which were both positive. The crew also inspected the site surface. Off-site areas were identified by gopher spoil, rills, and the ravine cutbank northeast of the site. This established the site as a probable open camp $35 \mathrm{~m}$ northeast/southwest by $20 \mathrm{~m}$ northwest/southeast, or $700 \mathrm{~m}^{2}$ in area.

\section{Results:}

One flake and one burned rock were observed on the site surface. Nine artifacts were recovered from shovel tests (Table 7). Artifacts, including seven flakes and two burned rocks, were found to a depth of $40 \mathrm{~cm}$. Although no features were observed, there is a potential for intact hearth features based on the presence of burned rock and the lack of disturbance.

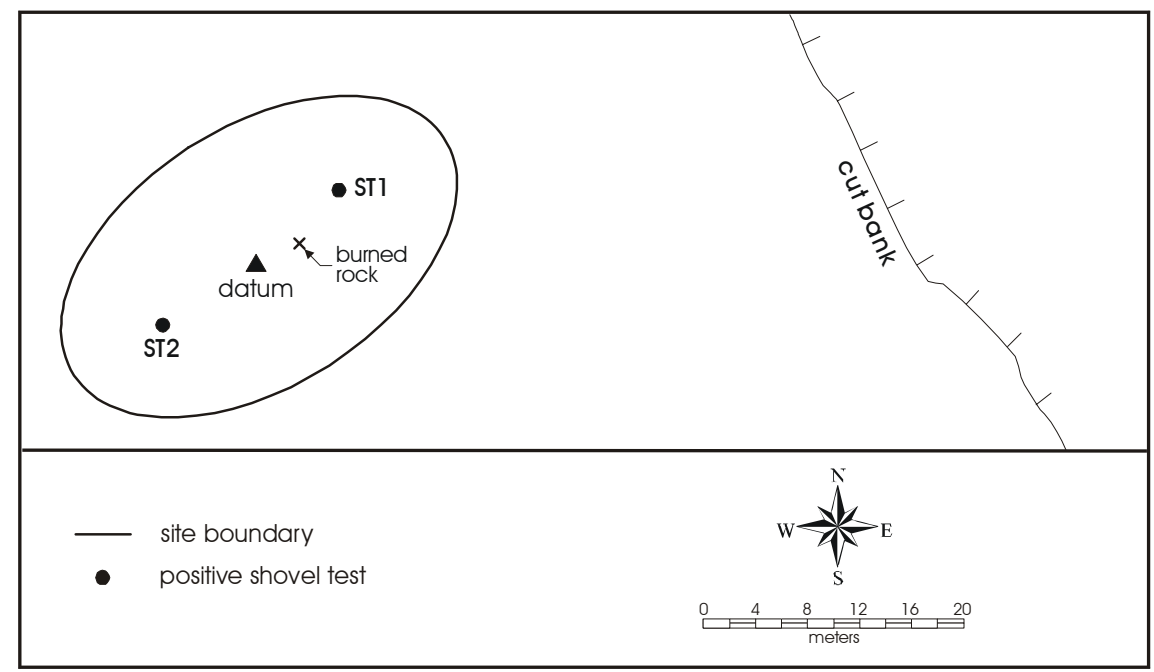

Figure 23. Map of $41 B P 495$.

Table 7. Results of Shovel Tests at 41BP495

\begin{tabular}{|l|r|l|}
\hline Unit & \multicolumn{1}{c}{ Depth (cm) } & \multicolumn{1}{c|}{ Artifacts Collected } \\
\hline ST-1 & $0-20$ & 1 flake, 1 burned rock \\
& $20-80$ & -- \\
\hline ST-2 & $0-20$ & 3 flakes, 1 burned rock \\
& $20-40$ & 3 flakes \\
& $40-60$ & -- \\
\hline
\end{tabular}




\section{$41 B P 496$}

\section{Site Type:}

Prehistoric open camp

\section{Site Size:}

$1,400 \mathrm{~m}^{2}$, determined by shovel tests and surface inspection (Figure 24)

\section{Topographic Setting:}

Stream-divided upland

\section{Description:}

Site 41BP496 is a prehistoric open camp in a former agricultural field immediately south of the pipeline road. Oak-cedar woodland, with domesticated grasses and invader species of herbaceous shrubs, are the dominant groundcover, with $70 \%$ surface visibility. The soils are part of the Patilo complex. Military training activities and pre-Camp Swift agricultural activities have destroyed any integrity the site may once have had.

\section{Investigation:}

The site surface was inspected and two shovel tests, both positive, were excavated. This was sufficient to characterize the site because there was high surface visibility. The site boundaries were determined largely by the reliable surface observations. The site is $35 \mathrm{~m}$ north/south by $40 \mathrm{~m}$ east/west, or 1,400 $\mathrm{m}^{2}$.

\section{Results:}

Eight artifacts were found on the site (Table 8). Four flakes, two biface fragments, and one burned rock were found on the surface, while one tertiary flake was found between $0-20 \mathrm{~cm}$. No features or intact deposits were observed.

\section{Artifacts:}

Two biface fragments were recovered from the site surface, and are described in more detail below (see Appendix B for measurements).

- Specimen 496-93 is a medial section of a biface (Figure 25a). The artifact is brownish-gray translucent chert, which has crazed fracture lines from burning. The burning probably occurred after discard of the biface and was not a result of deliberate heat treatment.

- Specimen 496-94 is a thin biface fragment of opaque tan chert (Figure 25b). It is probably an unfinished arrow point blank, based on the thickness. This break is a manufacturing failure. 


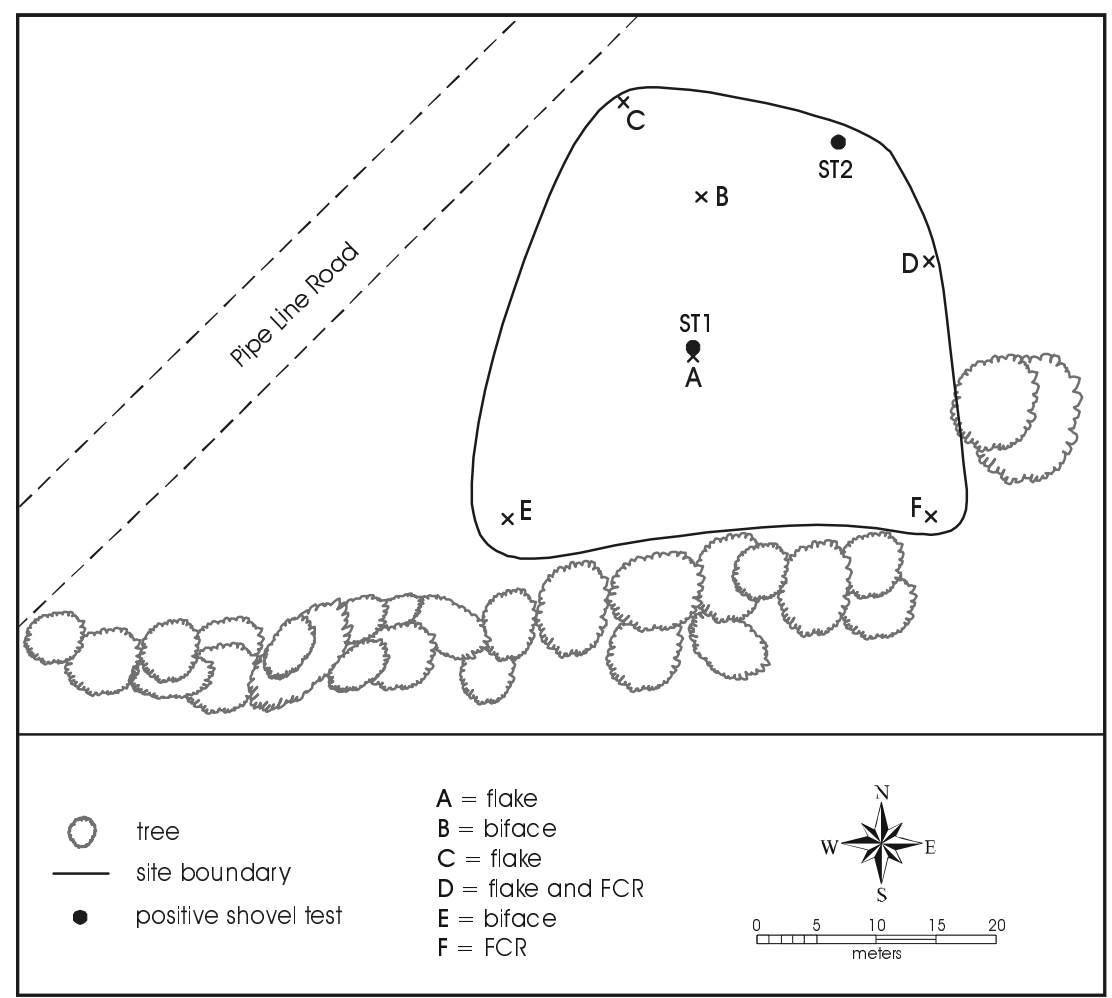

Figure 24. Map of 41 BP 496.

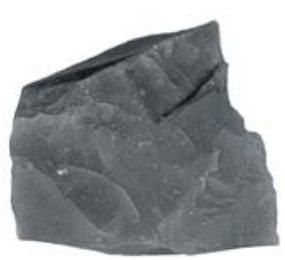

a

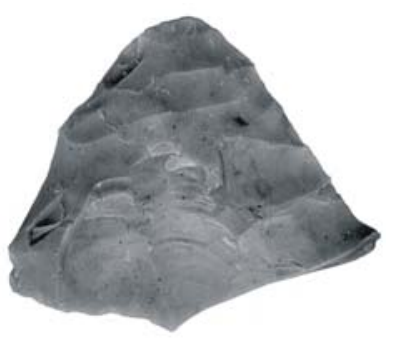

b

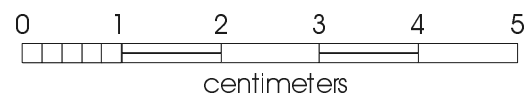

Figure 25. Selected artifacts from 41BP496: $a$-b) Biface fragments.

Table 8. Artifacts from 41BP496

\begin{tabular}{|ccl|}
\hline Unit & Depth $\mathbf{( c m})$ & \multicolumn{1}{c|}{ Artifacts Collected } \\
\hline Surface & & 2 biface fragments, \\
& & 4 flakes, \\
& & 1 burned rock \\
\hline ST-1 & $0-20$ & 1 flake \\
& $20-60$ & -- \\
\hline ST-2 & $0-60$ & -- \\
\hline
\end{tabular}




\section{BP497}

\section{Site Type:}

Prehistoric open camp

Site Size:

$24 \mathrm{~m}^{2}$, determined by shovel tests, probes, and surface inspection (Figure 26)

Topographic Setting:

Stream-divided uplands

Description:

Site 41BP497 is a prehistoric open camp located in a pasture just north of the pipeline road. Buffalo grass and cedar are the dominant ground cover. The soil at the site is Demona loamy fine sand.

\section{Investigation:}

The field crew excavated three shovel tests, one of which was negative. The crew also excavated shovel probes, all of which were negative, and inspected the site surface. This was sufficient to determine that the site consists of a very sparse deposit of debitage and burned rock over an area $3 \mathrm{~m}$ north-south by $8 \mathrm{~m}$ east-west, or $24 \mathrm{~m}^{2}$.

Results:

Four pieces of burned rock and two pieces of chert lithic debitage were retrieved from the two positive shovel tests, from as deep as $60 \mathrm{~cm}$ (Table 9). No cultural items were observed on the surface. No features were observed. 


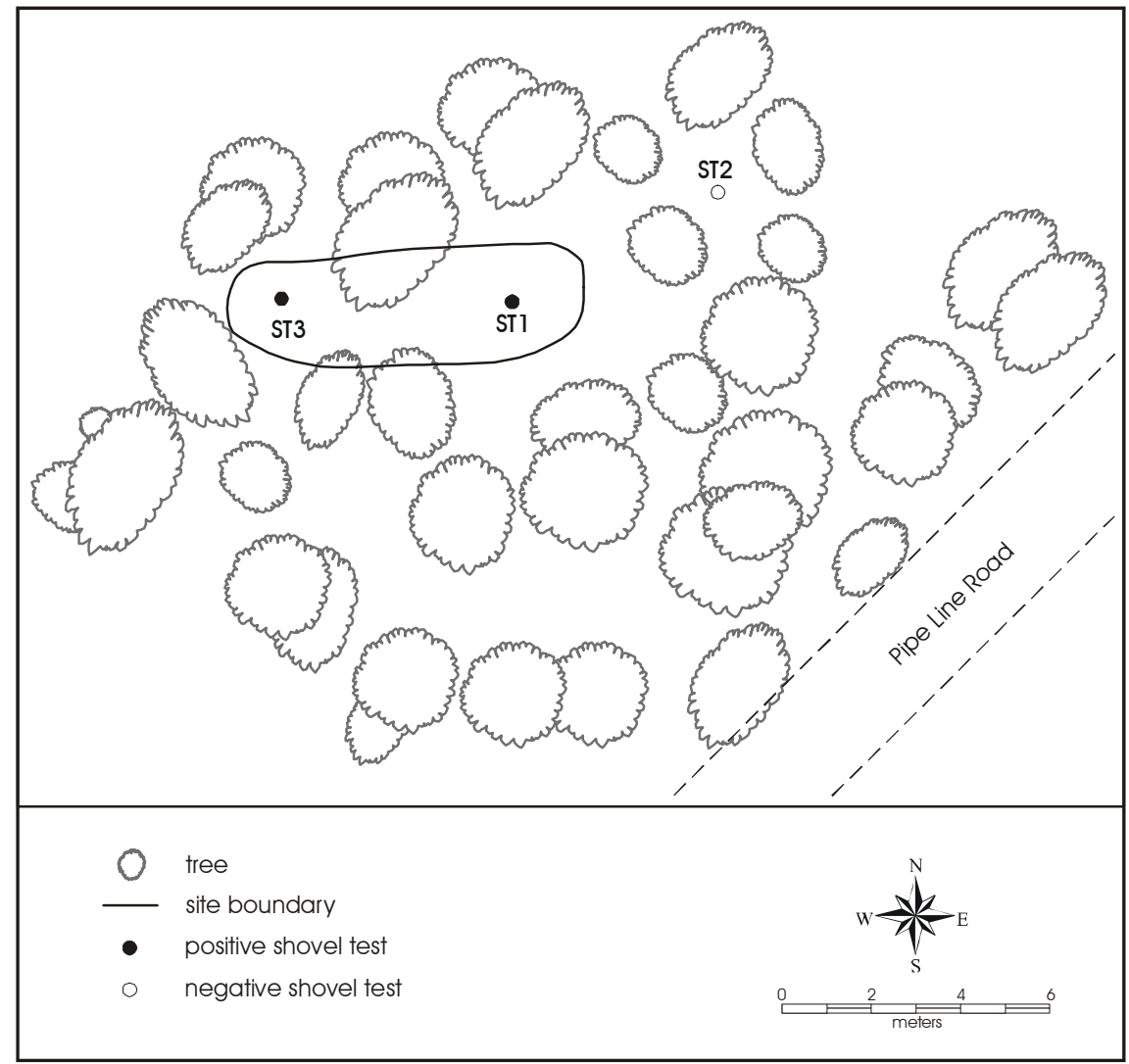

Figure 26. Map of 41 BP497.

Table 9. Artifacts from 41BP497

\begin{tabular}{|crl|}
\hline Unit & Depth (cm) & Artifacts Collected \\
\hline ST-1 & $0-20$ & 1 flake \\
& $20-40$ & -- \\
& $40-60$ & 1 flake \\
& & 3 burned rocks \\
& $60-80$ & --- \\
\hline ST-2 & $0-60$ & -- \\
\hline ST-3 & $0-20$ & -- \\
& $20-40$ & 1 burned rock \\
& $40-65$ & -- \\
\hline
\end{tabular}




\section{$41 B P 498$}

\section{Site Type:}

Prehistoric lithic scatter

Site Size:

$6,780 \mathrm{~m}^{2}$, determined by shovel probe and surface inspection (Figure 27)

Topographic Setting:

Lower stream slopes

Description:

Site 41BP498 is a prehistoric lithic scatter located in a dense, mixed woodland on the lower stream slopes. Oak and cedar are the dominants of the plant community, with a surface visibility of 50-60\%. The site is on Silstid loamy fine sand. Military training, erosion, and bioturbation have disturbed the site.

Investigation:

The field crew excavated one shovel probe, which was negative. The crew inspected soils exposed in minor rills and the site surface. This was sufficient to determine that the site consists of lithic debitage scattered over an area $113 \mathrm{~m}$ north/south by $60 \mathrm{~m}$ east/west, or $6,780 \mathrm{~m}^{2}$.

Results:

Approximately ten flakes and one core were observed on the surface. No subsurface artifacts were found in probing. No features were observed.

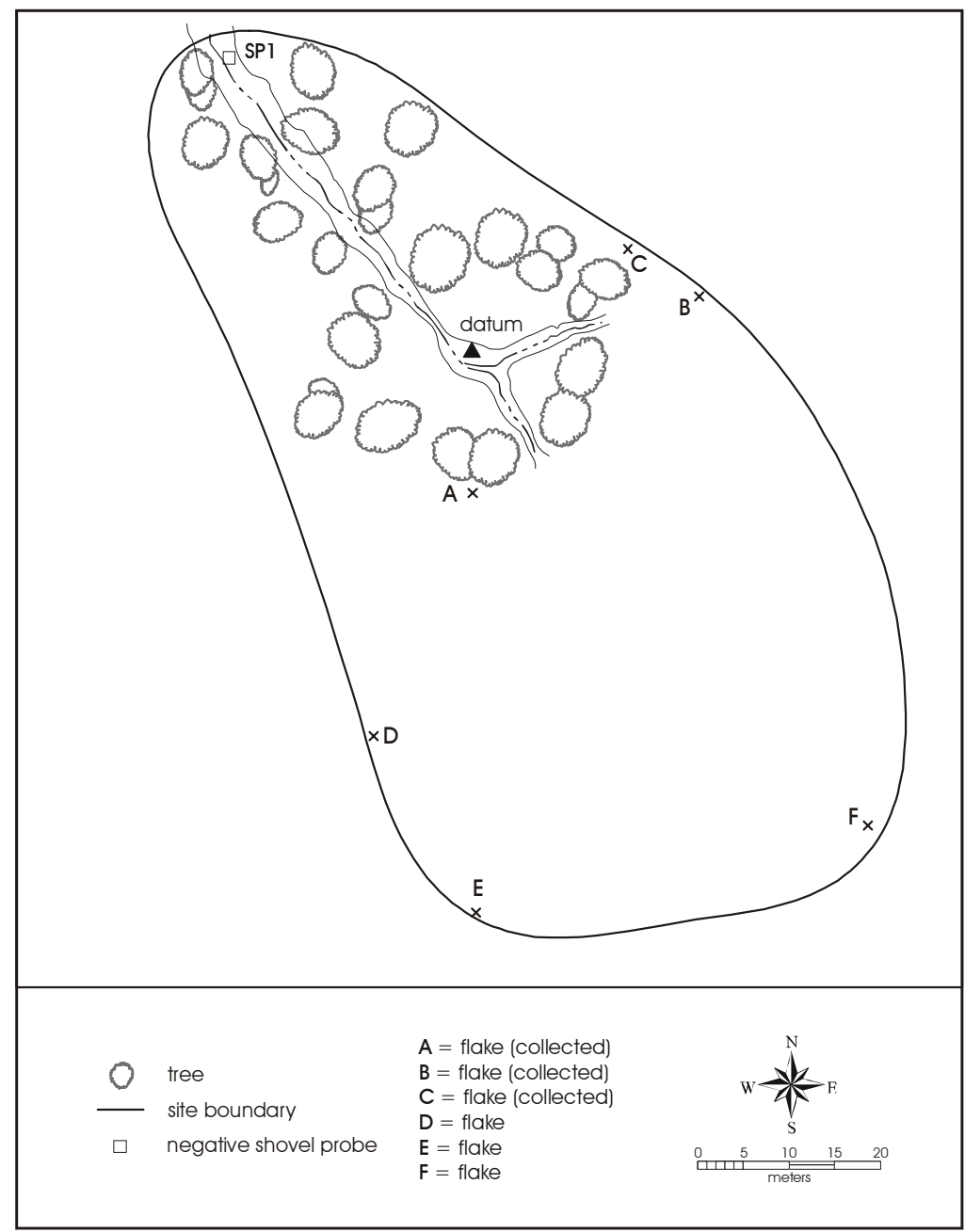

Figure 27. Map of $41 B P 498$. 


\section{$41 B P 499$}

\section{Site Type:}

Prehistoric lithic scatter

Site Size:

$16 \mathrm{~m}^{2}$, determined by shovel tests and surface inspection (Figure 28)

\section{Topographic Setting:}

Lower stream slopes

\section{Description:}

Site 41BP499 is an ephemeral, prehistoric lithic scatter located on wooded, lower stream slopes about $100 \mathrm{~m}$ north of Big Sandy Creek, on the T0 terrace. Oak and cedar are the dominant ground cover, with a surface visibility of $10-20 \%$. The site is on Demona loamy fine sand. The site has been disturbed by military training activity and bioturbation.

\section{Investigation:}

The field crew excavated three shovel tests, only one of which was positive. The site surface was also inspected. This was sufficient to determine that the site consists of a single positive shovel test. The site boundary is a circular buffer zone around the positive shovel test and is four $\mathrm{m}$ in diameter, or $16 \mathrm{~m}^{2}$.

\section{Results:}

One chert flake was found at the surface level of one shovel test. No cultural material was found subsurface. No features were observed.

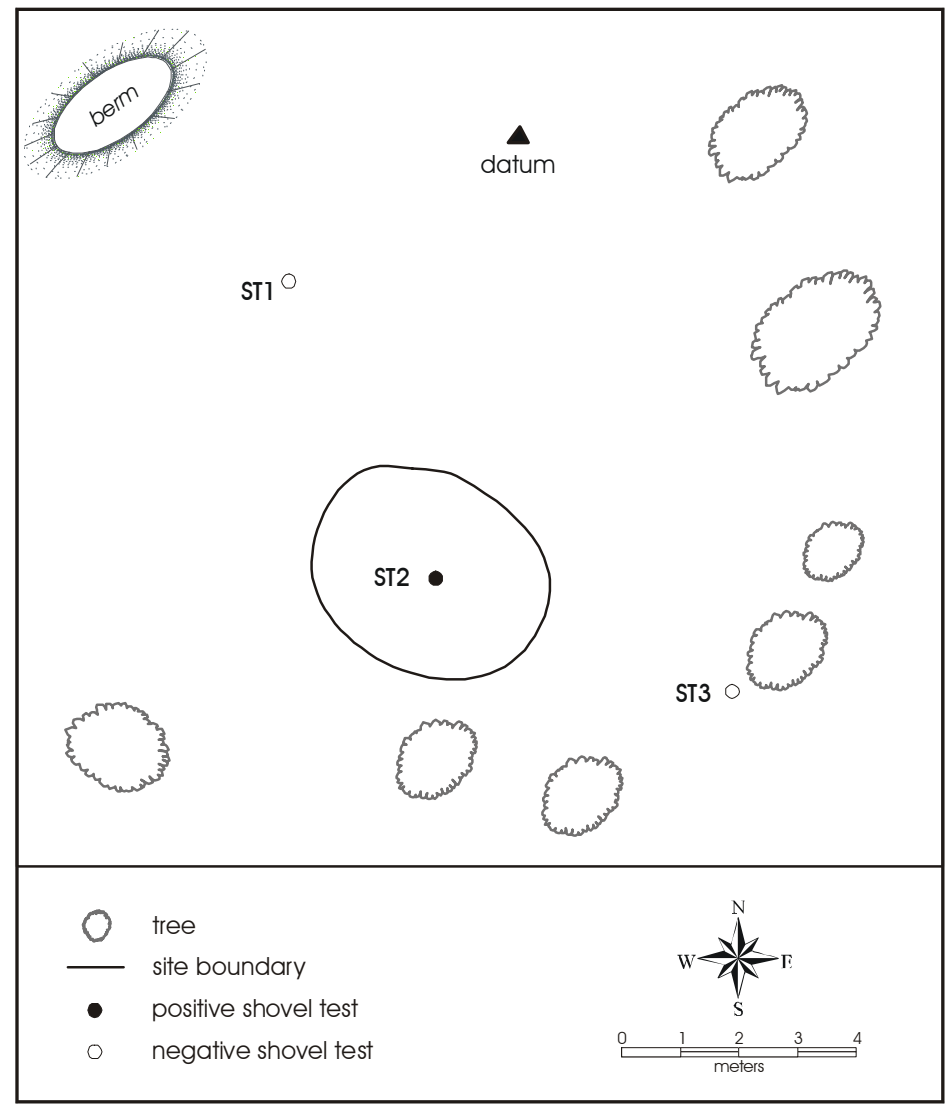

Figure 28. Map of $41 B P 499$. 


\section{BP505}

Site Type:

Prehistoric open camp

Site Size:

$120 \mathrm{~m}^{2}$, determined by shovel tests and surface inspection (Figure 29)

Topographic Setting:

Wooded stream-divided uplands

Description:

Site 41BP505 is a prehistoric open camp located in a wooded, stream-divided upland approximately $400 \mathrm{~m}$ west of Dogwood Creek. Oak and cedar are the dominant flora, with 10\% surface visibility. The site was on Patilo complex soils. There is some evidence of disturbance from military activities.

\section{Investigation:}

The crew inspected the site's surface and excavated three shovel tests, one of which was sterile. This was sufficient to determine that the site consists of a low-density subsurface deposit in an area $15 \mathrm{~m}$ by $8 \mathrm{~m}$, or $120 \mathrm{~m}^{2}$.

\section{Results:}

Seven artifacts were found, including four flakes and three burned rocks from a depth of 20-60 cm (Table 10). No surface artifacts were observed. Although the site shows some disturbance from military training activity and bioturbation, there is a potential for buried intact deposits.

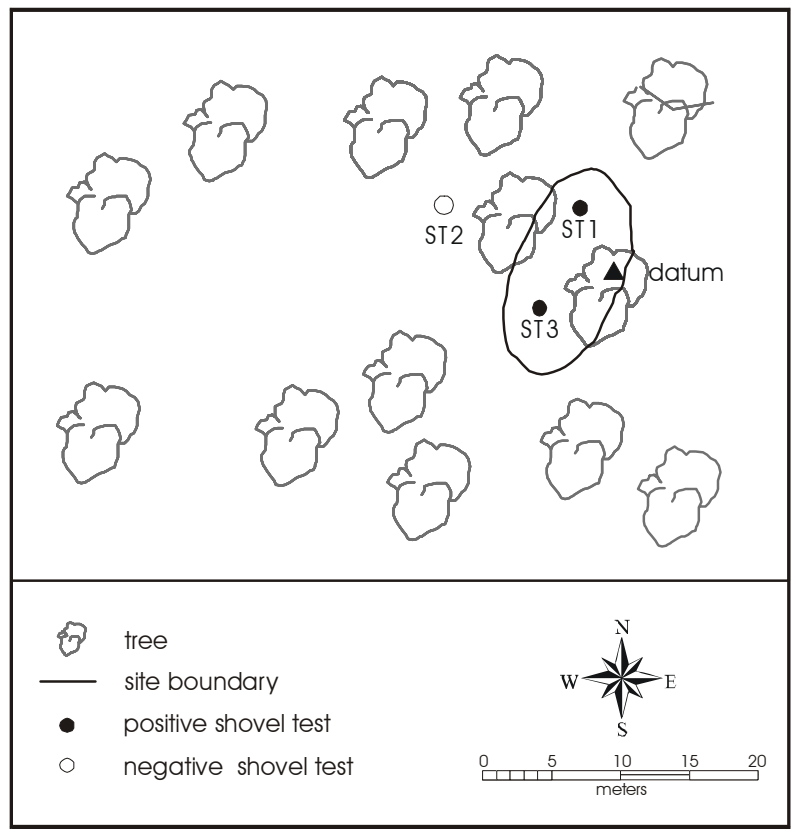

Figure 29. Map of 41 BP505.
Table 10. Results of shovel tests at 41BP505

\begin{tabular}{|crl|}
\hline Unit & Depth (cm) & Artifacts Collected \\
\hline ST-1 & $0-20$ & -- \\
& $20-40$ & 1 flake \\
& $40-60$ & 1 flake, 3 burned rock \\
& $60-100$ & -- \\
\hline ST-2 & $0-85$ & -- \\
\hline ST-3 & $0-20$ & -- \\
& $20-40$ & 2 flakes \\
& $40-80$ & -- \\
\hline
\end{tabular}




\section{BP506}

Site Type:

Prehistoric open camp

Site Size:

$6,150 \mathrm{~m}^{2}$, determined by shovel tests, shovel probes, surface inspection, and natural landforms (Figure 30 )

Topographic Setting:

Lower stream slopes

Description:

Site 41BP506 is a prehistoric open camp located in wooded lower stream slopes, at the confluence of Big Sandy Creek and an unnamed tributary, on the T0 terrace. Oak, cedar, and native grasses are the dominant ground cover, with $20-25 \%$ surface visibility. The soil type at the site is Demona loamy fine sand.

Investigation:

The field crew inspected the site surface, then excavated five shovel tests. Two tests were negative, as were the shovel probes. The site boundary was determined based on the results of the shovel tests and probes and the distribution of surface artifacts. An unnamed tributary forms a natural boundary of the southwest portion of the site. The site dimensions are $205 \mathrm{~m}$ northwest/southeast by $30 \mathrm{~m}$ northeast/southwest, or $6,150 \mathrm{~m}^{2}$.

Results:

A total of 22 artifacts was found at the site (Table 11). One secondary flake was observed on the site surface and 21 artifacts, including debitage and burned rock, were retrieved from subsurface deposits to a depth of $100 \mathrm{~cm}$. Shovel Test 3 had burned rock from 40-100 cm deep. The site is on the T0 terrace, which geomorphologic research indicates was probably deposited since 600 B.P. (see Chapter 3). The large number of burned rocks in ST-3, however, suggests the possibility of an intact burned rock feature.

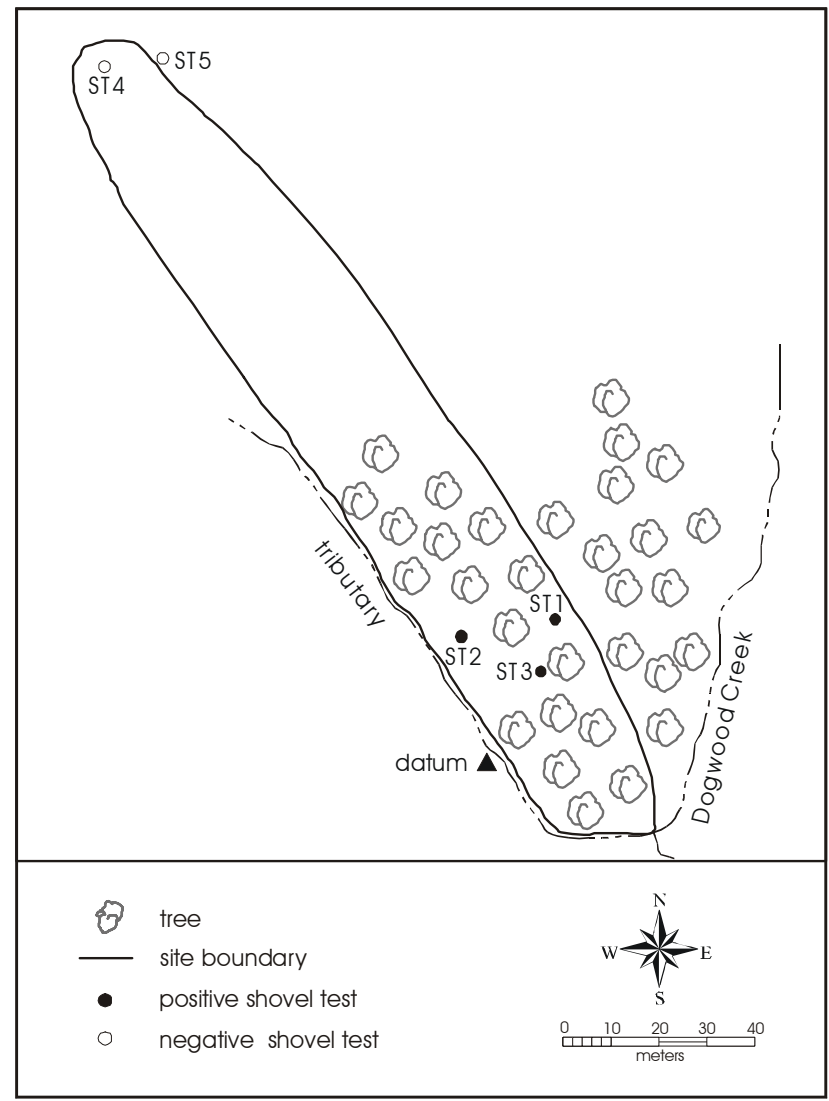

Figure 30. Map of 41BP506.
Table 11. Results of shovel tests at 41BP506

\begin{tabular}{|c|c|c|}
\hline Unit & Depth (cm) & Artifacts Collected \\
\hline Surface & -- & 1 flake \\
\hline \multirow[t]{2}{*}{ ST-1 } & $0-20$ & 2 flakes, 1 burned rock \\
\hline & $20-100$ & -- \\
\hline \multirow[t]{5}{*}{ ST-2 } & $0-20$ & -- \\
\hline & $20-40$ & -- \\
\hline & $40-60$ & 1 burned rock \\
\hline & $60-80$ & 1 flake \\
\hline & $80-100$ & -- \\
\hline \multirow[t]{5}{*}{ ST-3 } & $0-20$ & \\
\hline & $20-40$ & 2 flake, 1 burned rock \\
\hline & $40-60$ & 2 flake, 3 burned rocks \\
\hline & $60-80$ & 2 flakes \\
\hline & $80-100$ & 6 burned rocks \\
\hline ST-4 & $0-63$ & -- \\
\hline ST-5 & $0-60$ & -- \\
\hline
\end{tabular}




\section{BP509}

Site Type:

Prehistoric lithic scatter

Site Size:

$420 \mathrm{~m}^{2}$ (Figure 31).

Topographic Setting:

Wooded upper drainage-divided slopes

Description:

Site 41BP509 is a prehistoric lithic scatter located on wooded upper slopes about $40 \mathrm{~m}$ east of Highway 95 . The setting is wooded upper drainage-divided slopes, with oak and cedar comprising the dominant vegetation. The soil at the site is part of the Patilo complex. The site has been heavily disturbed by military training activity and bioturbation.

\section{Investigation:}

The characterization of the site was based on excavation of five shovel tests and ground surface inspection. The site was defined by three positive shovel tests about $20 \mathrm{~m}$ apart. By adding a slight buffer zone, the site dimensions were estimated to be no larger than $40 \mathrm{~m}$ northwest/southeast by $15 \mathrm{~m}$ northeast/southwest, an area of $600 \mathrm{~m}^{2}$.

\section{Results:}

No artifacts were observed on the surface but six chert flakes were retrieved from the subsurface, at depths ranging from 20 to $60 \mathrm{~cm}$ below surface (Table 12). No features were observed.

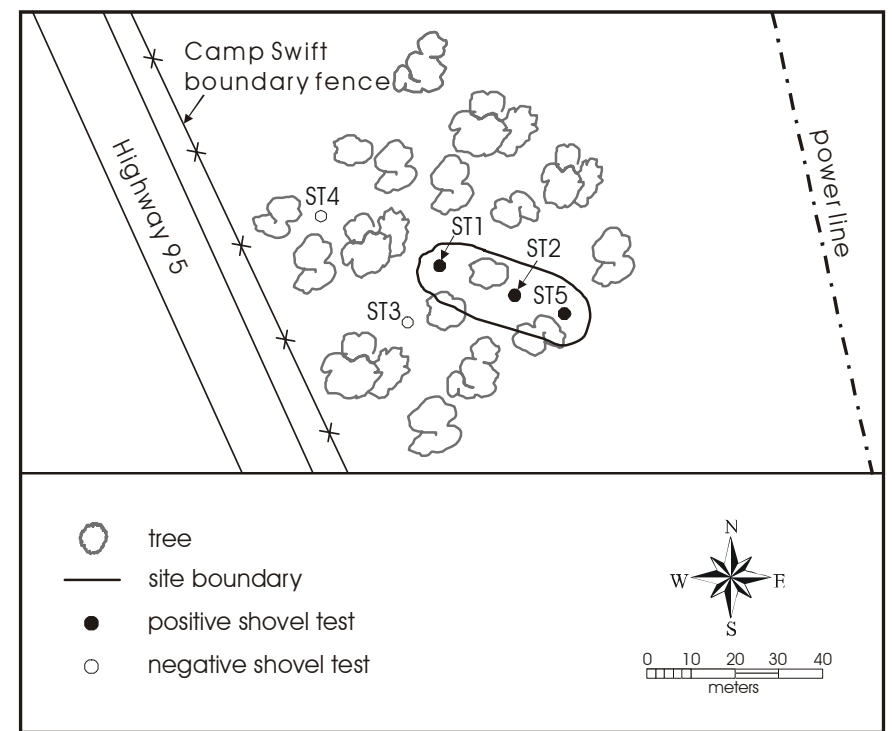

Figure 31. Map of $41 B P 509$.
Table 12. Results of shovel tests at 41BP509

\begin{tabular}{|lrl|}
\hline Unit & Depth (cm) & Artifacts Collected \\
\hline ST-1 & $0-20$ & -- \\
& $20-40$ & 3 flakes \\
& $40-60$ & 1 flake \\
& $60-80$ & -- \\
\hline ST-2 & $0-40$ & -- \\
& $40-60$ & 1 flake \\
& $60-80$ & -- \\
\hline ST-3 & $0-80$ & -- \\
\hline ST-4 & $0-80$ & -- \\
\hline ST-5 & $0-20$ & -- \\
& $20-40$ & 1 flake \\
& $40-80$ & -- \\
\hline
\end{tabular}




\section{BP510}

\section{Site Type:}

Prehistoric open camp

Site Size:

$1200 \mathrm{~m}^{2}$ (Figure 32).

\section{Topographic Setting:}

Wooded upper drainage-divided slopes

Description:

Site 41BP510 is a prehistoric open camp located on wooded upland slopes along a power line road. The setting is a wooded upper drainage-divided slope, with oak and cedar as the dominant ground cover. Ground surface visibility was $75-95 \%$ at the time of survey. The soil type at the site is Demona loamy fine sand.

\section{Investigation:}

The site surface was inspected and two shovel tests were excavated. The site boundary, determined by distribution of surface artifacts, was $80 \mathrm{~m}$ north/south by $15 \mathrm{~m}$ east/west. The site area is $1200 \mathrm{~m}^{2}$.

\section{Results:}

Within the site, burned rock, debitage, and one utilized flake were observed on the site surface; no artifacts were observed subsurface. There was a low density of surface artifacts based on observations and counts. The two shovel tests were negative, suggesting no remaining subsurface deposits. Artifacts observed included several flakes (one utilized) and pieces of burned rock. The site also had no visible features.

\section{Artifacts:}

Specimen 510-158 is a utilized flake of yellowish-brown opaque chert. The object is a secondary flake, with cortex running longitudinally along the dorsal face. The striking platform is non-cortical and single-faceted and bears three percussion rings as the results of failed blows. The flake is $36.2 \mathrm{~mm}$ wide, $57.4 \mathrm{~mm}$ long, and $14.0 \mathrm{~mm}$ thick. Due to the longitudinal cortex pattern covering approximately $40 \%$ of the dorsal face, one edge is cortex-covered and the other is of exposed chert. The latter shows evidence of use or wear from the striking platform to the distal end. A $14.3 \mathrm{~mm}$ length of the edge near the striking platform has regular microflaking and minor stepping. This has formed serration of the edge and may be deliberate preparation. The remaining 41.2 millimeters of the edge show irregular microflaking and step-fracturing, some of it on the ventral face. These wear features suggest opportunistic use of this portion of the edge.

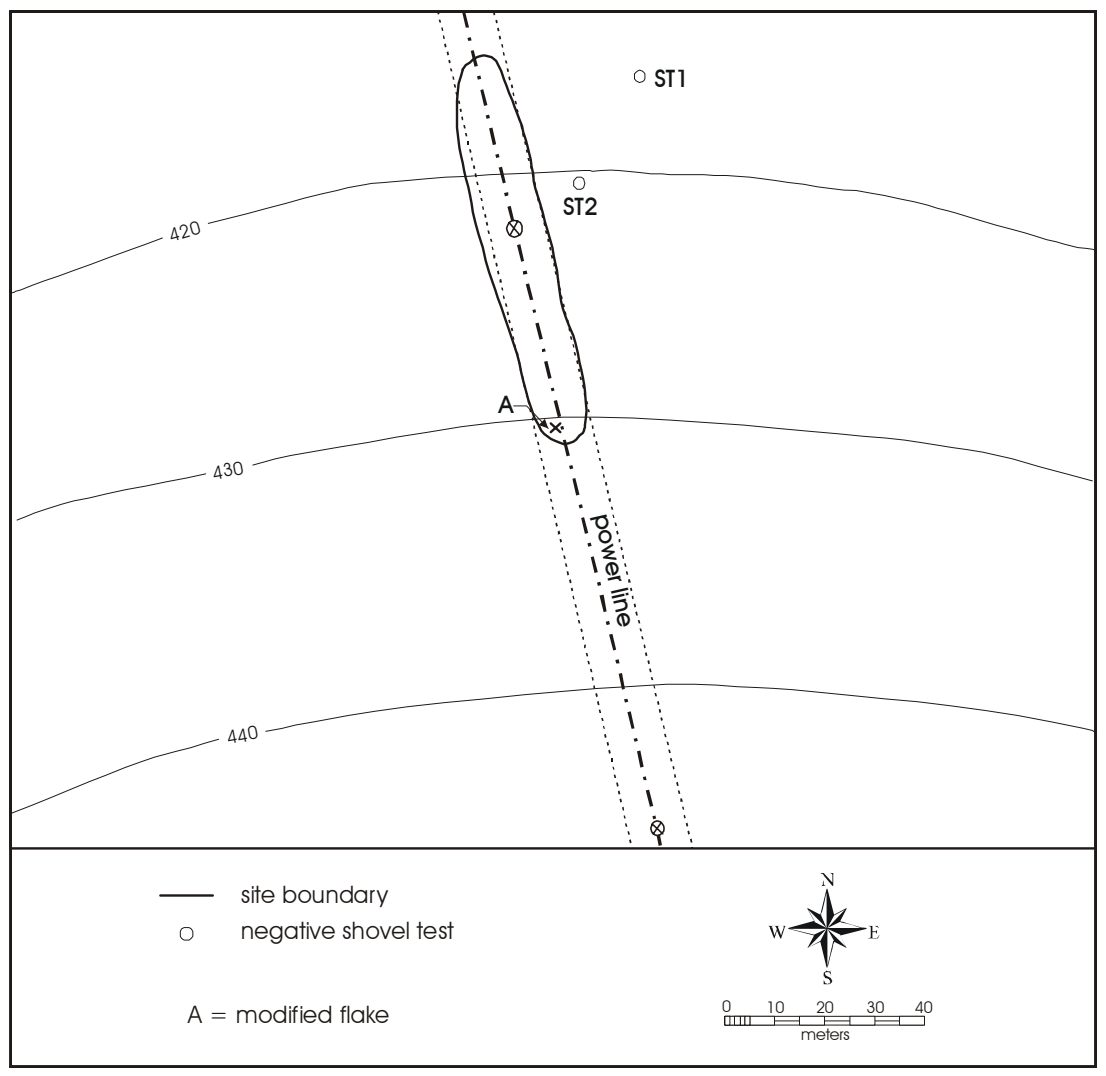

Figure 32. Map of 41 BP510. 


\section{$41 B P 512$}

Site Type:

Prehistoric open camp

Site Size:

2,400 $\mathrm{m}^{2}$ (Figure 33)

Topographic Setting:

Lower stream slopes

Description:

Site 41BP512 is a prehistoric open camp located on mixed wooded and cleared upland slopes overlooking Big Sandy Creek, with native grasses forming the dominant ground cover. Surface visibility at the time of survey was about $10 \%$. The site was on Patilo complex soils.

\section{Investigation:}

The field crew excavated four shovel tests and carefully inspected the site surface. The site boundary was $60 \mathrm{~m}$ northeast/southwest by $40 \mathrm{~m}$ northwest/southeast and was determined using the natural landform and by creating a buffer zone around the positive shovel tests. The site area is $2,400 \mathrm{~m}^{2}$.

\section{Results:}

No artifacts were observed on the site surface, but one flake and one piece of fire-cracked rock were retrieved from the subsurface (Table 13). No features were observed. The site has been disturbed by military training activity and bioturbation.

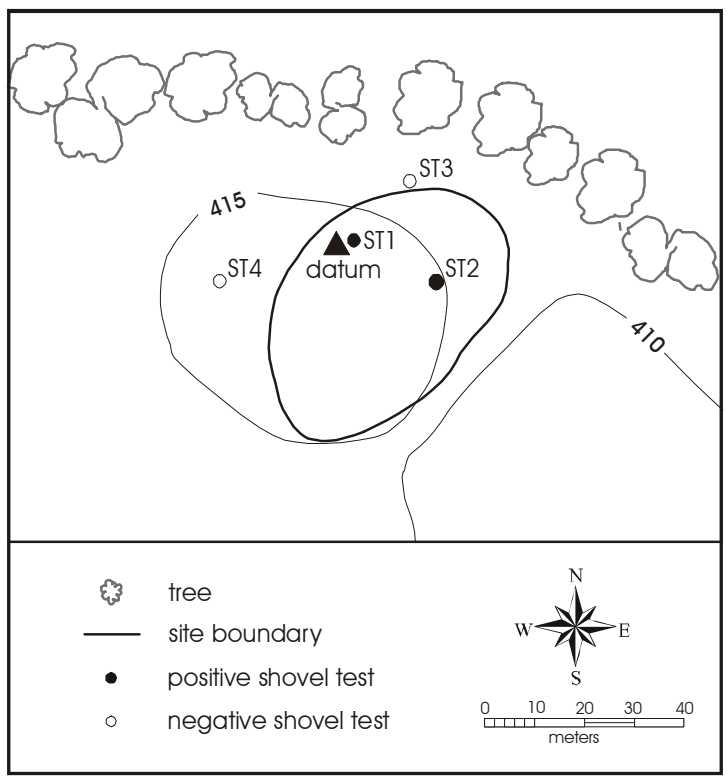

Figure 33. Map of $41 B P 512$.

Table 13. Results of shovel tests at 41BP512

\begin{tabular}{|c|c|c|}
\hline Unit & Depth (cm) & Artifacts Collected \\
\hline \multirow[t]{2}{*}{ ST-1 } & $0-80$ & -- \\
\hline & $80-100$ & 1 flake \\
\hline \multirow[t]{3}{*}{ ST-2 } & $0-40$ & -- \\
\hline & $40-60$ & 1 burned rock \\
\hline & $60-100$ & -- \\
\hline ST-3 & $0-100$ & -- \\
\hline ST-4 & $0-100$ & -- \\
\hline
\end{tabular}




\section{BP521}

Site Type:

Prehistoric open camp

Site Size:

$1,344 \mathrm{~m}^{2}$, determined by shovel test and surface inspection (Figure 34)

Topographic Setting:

Lower stream slopes above Big Sandy Creek

Description:

Site 41BP521 is a prehistoric open camp near Wine Cellar Road and above Big Sandy Creek, on the T0 terrace. Domesticated and native grasses are the dominant ground cover, with $30-50 \%$ surface visibility. The site was on Patilo complex soils. There is extensive disturbance from military activities on the site.

\section{Investigation:}

The field crew inspected the site surface and excavated one shovel test, which had cultural material to a depth of $60 \mathrm{~cm}$ below surface. This was sufficient to determine that the site consists of a scatter of prehistoric artifacts in an area $48 \mathrm{~m}$ north/south by $28 \mathrm{~m}$ east/west, or $1,344 \mathrm{~m}^{2}$.

\section{Results:}

A total of 11 flakes, six burned rocks, and one biface fragment were found. From the shovel test, three flakes, five burned rocks, and one biface fragment were recovered (Table 14). Eight flakes (not collected) and one burned rock were from the surface. No features were observed.

\section{Artifacts:}

Specimen 521-184 is a very small biface fragment of white chert (see Appendix B for measurements). Little can be said about the fragment other than that the unfractured edges have microflaking. It cannot be determined if this flaking is from preparation or use or a combination of the two.

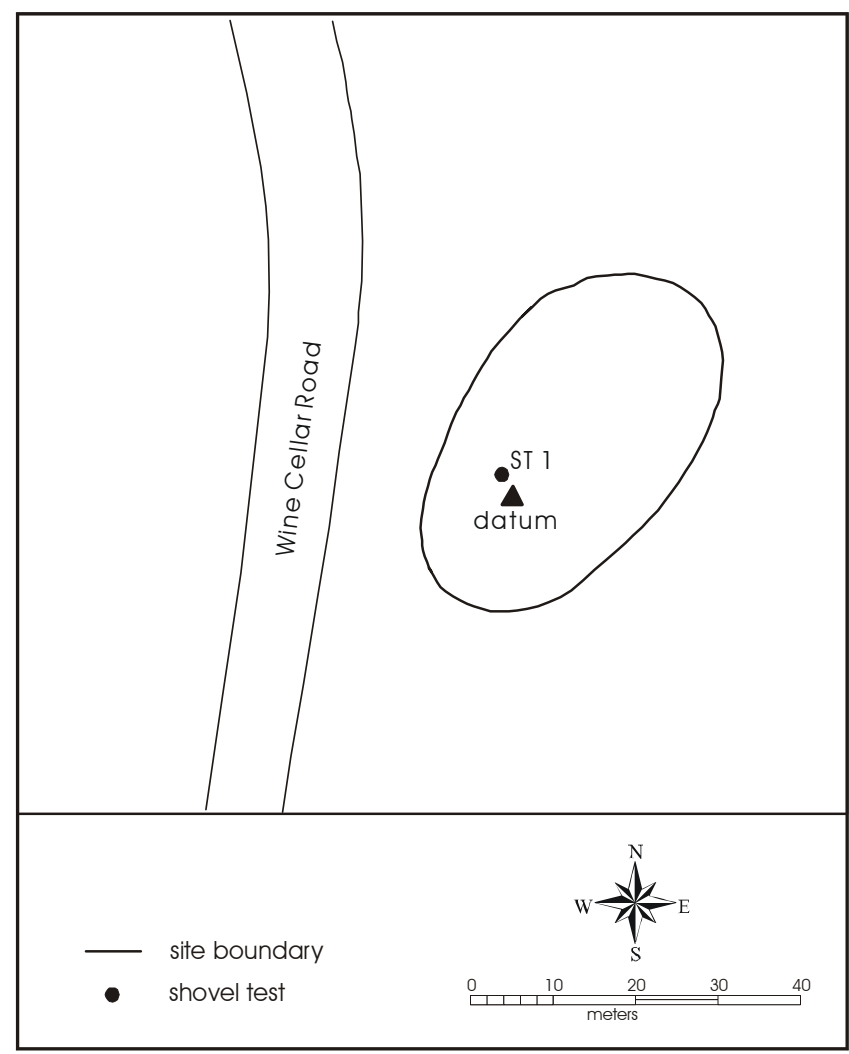

Figure 34. Map of 41 BP521.
Table 14. Results of shovel test at 41BP521

\begin{tabular}{|crl|}
\hline Unit & Depth (cm) & \multicolumn{1}{c|}{ Artifacts Collected } \\
\hline Surface & & 1 burned rock \\
\hline ST-1 & $0-20$ & 1 biface fragment \\
& $20-40$ & 1 burned rock (quartzite) \\
& & 1 flake \\
& $40-60$ & 2 flakes, 4 burned rocks \\
& $60-100$ & -- \\
\hline
\end{tabular}




\section{BP522}

Site Type:

Prehistoric open camp

Site Size:

$1,650 \mathrm{~m}^{2}$, determined by shovel tests, shovel probes, and surface inspection (Figure 35)

Topographic Setting:

Upper stream slopes

Description:

Site 41BP522 is a prehistoric open camp in an open field approximately $400 \mathrm{~m}$ south of East Loop Road, above an unnamed tributary of McLaughlin Creek. Buffalo grass and herbaceous annuals are the dominant ground cover, with 5\% surface visibility. The site was on Axtell fine sandy loam.

\section{Investigation:}

The field crew excavated three shovel tests, which contained cultural material as deep as $100 \mathrm{~cm}$. The crew also excavated two shovel probes, which were sterile, and inspected the site surface. This was sufficient to determine that the site consists of a scatter of prehistoric artifacts in an area $55 \mathrm{~m}$ northeast/southwest by $30 \mathrm{~m}$ northwest/ southeast, or $1,650 \mathrm{~m}^{2}$.

\section{Results:}

Seven pieces of debitage and eight burned rocks were retrieved from the shovel tests (Table 15). No artifacts were observed on the site surface. Subsurface deposits were present; lithic debitage was found as deep as a meter below surface, though the greatest amount of material was between 40 and $80 \mathrm{~cm}$ below surface. The site appears to be at least 25 to $50 \%$ disturbed by military training and bioturbation.

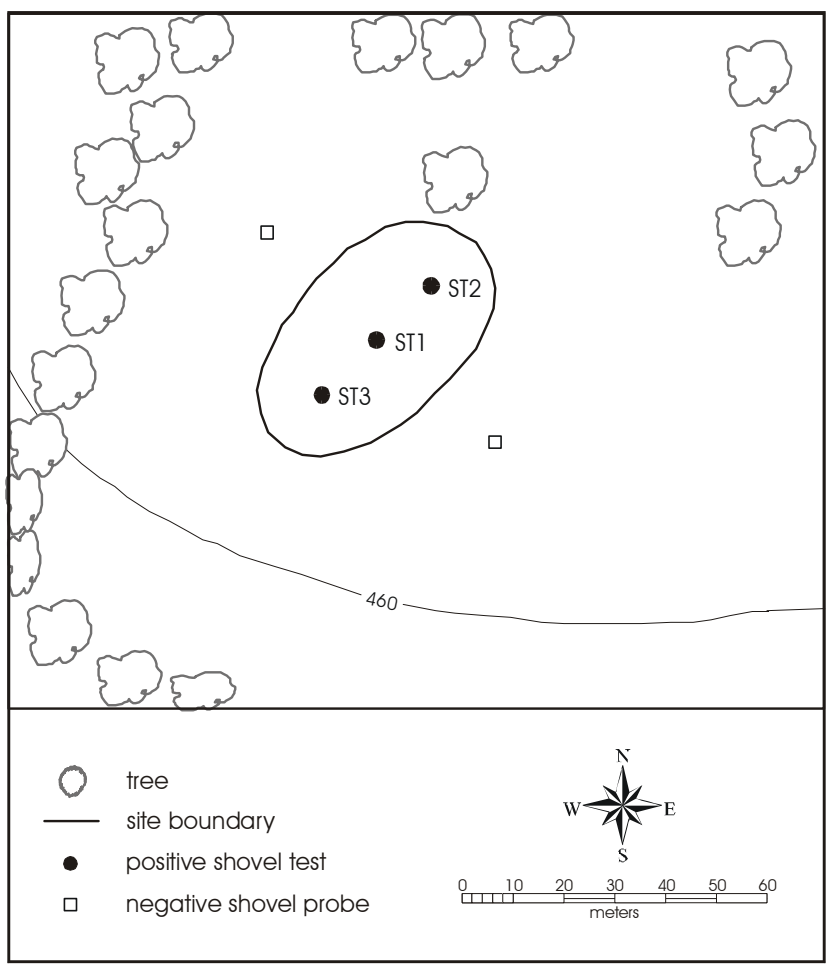

Figure 35. Map of 41BP522.
Table 15. Results of shovel tests at 41BP522

\begin{tabular}{|ccl|}
\hline Unit & Depth $\mathbf{( c m )}$ & \multicolumn{1}{c|}{ Artifacts Collected } \\
\hline ST-1 & $0-20$ & -- \\
& $20-40$ & 3 flakes \\
& & 2 burned rocks \\
& $40-60$ & 2 burned rocks \\
& $60-80$ & 1 flake, 1 burned rock \\
& $80-100$ & 1 flake \\
\hline ST-2 & $0-20$ & -- \\
& $20-40$ & 1 flake \\
& $40-60$ & -- \\
\hline ST-3 & $0-20$ & 1 flake \\
& $20-40$ & -- \\
& $40-60$ & 3 burned rocks \\
\hline
\end{tabular}




\section{BP524}

Site Type:

Prehistoric open camp

Site Size:

$770 \mathrm{~m}^{2}$, determined by shovel test, shovel probes, and surface inspection (Figure 36)

Topographic Setting:

Upper stream slopes

Description:

Site 41BP524 is a prehistoric open camp located on a gently sloping grassy field east of an unnamed tributary of McLaughlin Creek. Domesticated and native grasses are the dominant ground cover, with 20-30\% surface visibility at the time of survey. The site is on Patilo complex soils.

\section{Investigation:}

The field crew inspected the site surface and excavated two shovel tests and two shovel probes which were sterile. This was sufficient to determine that the site consists of scattered prehistoric material in an area $22 \mathrm{~m}$ north/south by $35 \mathrm{~m}$ east/west, or $770 \mathrm{~m}^{2}$.

\section{Results:}

A total of 23 artifacts were found at the site. From an approximately $3 \mathrm{~m}$ diameter area near the northern boundary of the site, seven lithic flakes and two pieces of burned rock were observed on the surface. One piece of debitage and 13 burned rocks were retrieved from the subsurface (Table 16). Subsurface material was recovered to depths of a meter below surface. No features were observed. Military training and bioturbation have seriously disturbed the site. The large amount of surface cultural material suggests that the subsurface disturbance is churning material to the surface and has likely penetrated the full depth of the site, at least $100 \mathrm{~cm}$. It is probable that any subsurface contexts have been totally disrupted.

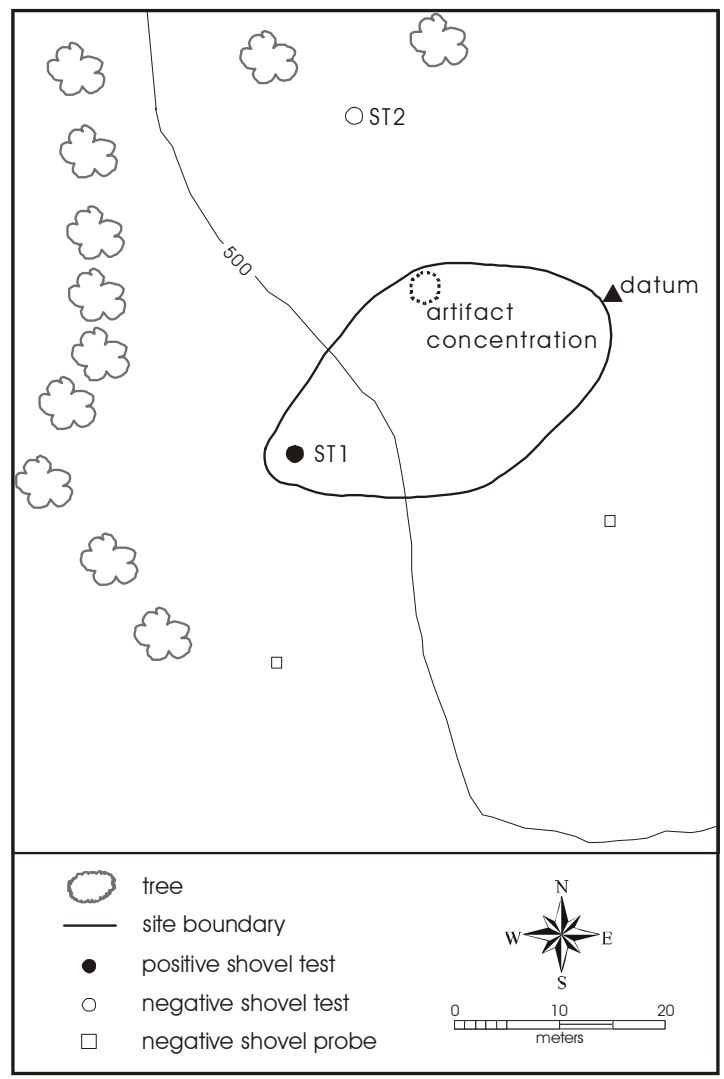

Table 16. Results of shovel tests at 41BP524

\begin{tabular}{|crl|}
\hline Unit & Depth (cm) & \multicolumn{1}{c|}{ Artifacts Collected } \\
\hline Surface & & 7 flakes, 2 burned rocks \\
\hline ST-1 & $0-20$ & 1 flake, 1 burned rock \\
& $20-40$ & 2 burned rocks \\
& $40-60$ & 1 burned rock \\
& $60-80$ & 3 burned rocks \\
& $80-100$ & 6 burned rocks \\
& $0-60$ & -- \\
\hline ST-2 & & \\
\hline
\end{tabular}

Figure 36. Map of 41 BP524. 


\section{$41 B P 526$}

Site Type:

Prehistoric open camp

Site Size:

$5,200 \mathrm{~m}^{2}$, determined by shovel tests, shovel probes, and surface inspection (Figure 37)

Topographic Setting:

Lower stream slopes

Description:

Site 41BP526 is a prehistoric open camp in densely wooded lower stream slopes. Deciduous hardwoods dominate the plant community, with 10-20\% surface visibility. The site was on Demona loamy fine sand.

\section{Investigation:}

The field crew inspected the site surface and excavated three shovel tests, all of which were positive, and ten shovel probes, one of which was positive. This was sufficient to determine that the site consists of a scatter of prehistoric artifacts in an area $130 \mathrm{~m}$ northwest/southeast by $40 \mathrm{~m}$ northeast/southwest, or 5,200 $\mathrm{m}^{2}$.

\section{Results:}

Table 17 enumerates the subsurface recovery of cultural material from the site. Subsurface material was from as deep as a meter below the surface. No artifacts were observed on the site surface. No features were observed on the surface, nor were any encountered in the subsurface tests.

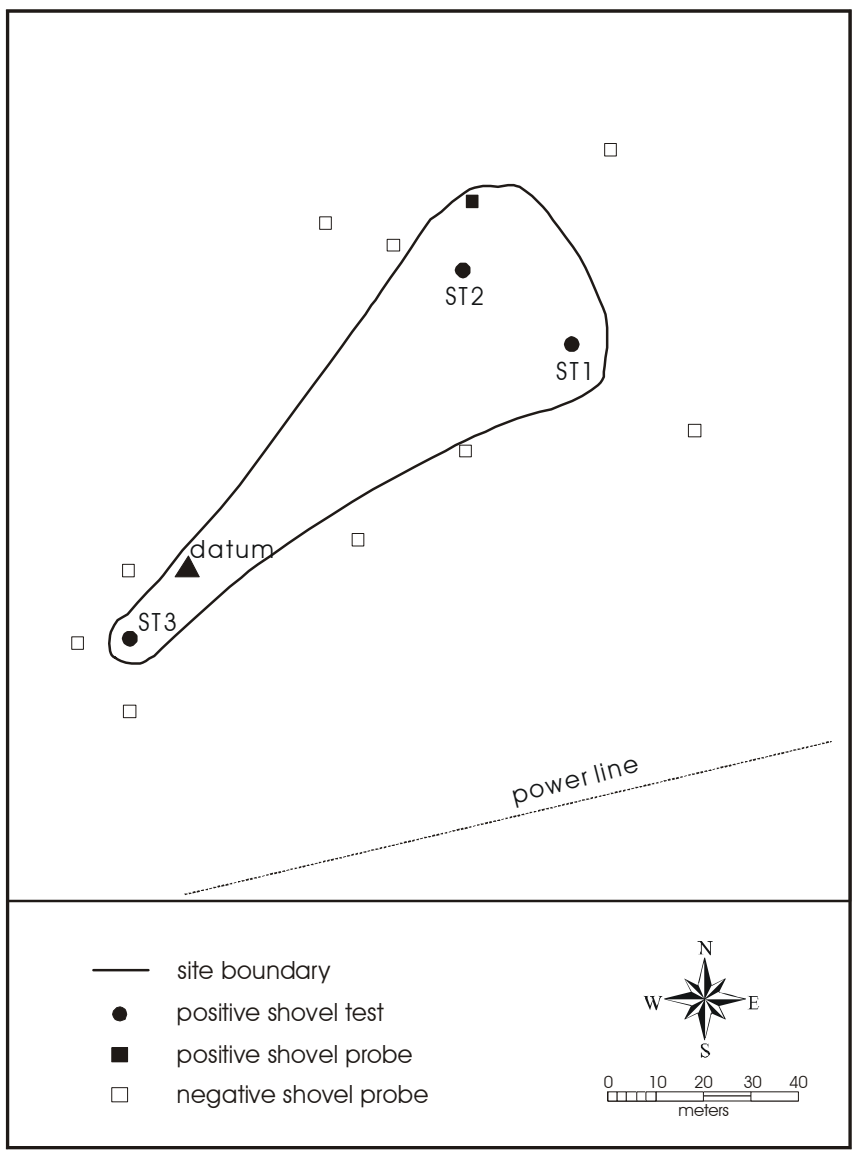

Table 17. Results of shovel tests at 41BP526

\begin{tabular}{|rrl|}
\hline Unit & Depth (cm) & \multicolumn{1}{c|}{ Artifacts Collected } \\
\hline ST-1 & $0-20$ & -- \\
& $20-40$ & 2 flakes \\
& $40-60$ & 3 flakes, 1 burned rock \\
& $60-80$ & 8 flakes, 1 burned rock \\
& $80-100$ & 2 burned rocks \\
\hline ST-2 & $0-20$ & 1 flake \\
& $20-40$ & -- \\
& $40-60$ & 4 flakes \\
& $60-80$ & -- \\
\hline ST-3 & $0-20$ & 1 flake \\
& $20-40$ & 1 flake \\
& $40-60$ & -- \\
\hline
\end{tabular}

Figure 37. Map of 41 BP526. 


\section{BP527}

\section{Site Type:}

Prehistoric limited activity area

Site Size:

$540 \mathrm{~m}^{2}$, determined by surface inspection (Figure 38)

\section{Topographic Setting:}

Upper drainage divide

Description:

Site 41BP527 is a prehistoric limited activity site in open woodland. Oak and cedar are the floral dominants, with $50-60 \%$ surface visibility. The soil type on the site is Axtell fine silty loam. Severe erosion has destroyed the entire site surface.

\section{Investigation:}

The field crew inspected the site surface, which was severely eroded. This was sufficient to determine that the site consists of a very low-density surface scatter of artifacts in an area $18 \mathrm{~m}$ north/south by $30 \mathrm{~m}$ east/west, or $540 \mathrm{~m}^{2}$.

\section{Results:}

On the surface, flakes and a chert biface fragment were observed. Military training, erosion, and bioturbation have disturbed the site. The site has no observed features and the surface is severely eroded.

\section{Artifacts:}

Specimen 527-226 is a small, lateral segment of a medial fragment of a biface (Figure 39). The material is greengray translucent chert (see Appendix B for measurements). The original artifact was finished, as shown by parallel thinning flake scars and bifacial secondary retouch on the edge. It was probably a dart point.

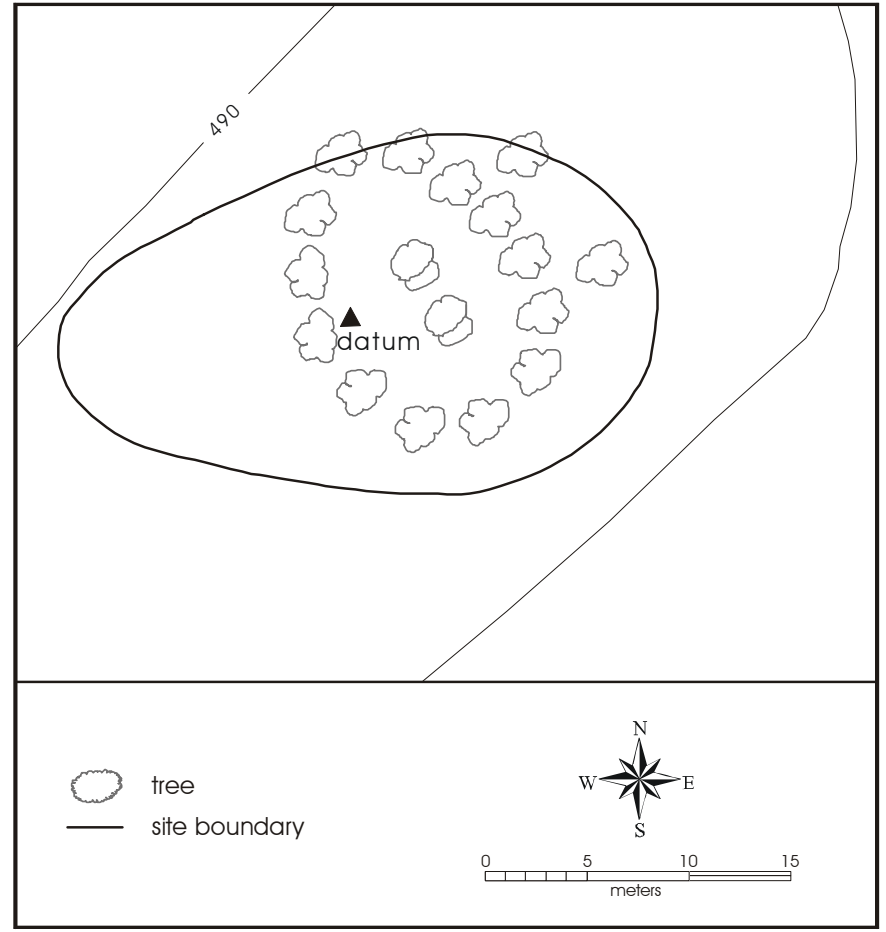

Figure 38. Map of $41 B P 527$.

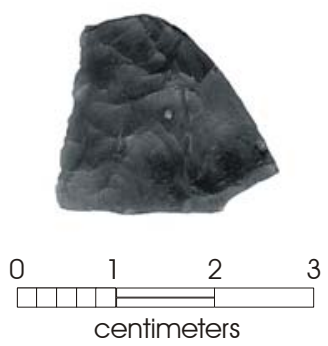

Figure 39. Biface fragment from $41 B P 527$. 


\section{$41 B P 528$}

Site Type:

Prehistoric open camp

Site Size:

$225 \mathrm{~m}^{2}$, determined by shovel test and surface inspection (Figure 40)

Topographic Setting:

Lower stream slopes

Description:

Site 41BP528 is a prehistoric open camp on the lower stream slopes in a mixed woodland. Oak and cedar are the local dominants, with 5-10\% surface visibility. The site was on Silstid loamy fine sand. The site potentially dates to the Early Archaic.

\section{Investigation:}

The field crew excavated one positive shovel test, and seven negative shovel probes. The crew also inspected the site surface. This was sufficient to determine that the site consists of a scatter of artifacts in an area $15 \mathrm{~m}$ north/ south by $15 \mathrm{~m}$ east/west, or $225 \mathrm{~m}^{2}$.

\section{Results:}

Several flakes, an untypeable dart point fragment, and a burned rock were retrieved from the subsurface (Table 18). No artifacts were observed on the site surface. The site has no observed features. The site appears to be relatively undisturbed, with slight evidence of military training and possible erosion from a nearby drainage. The site may have intact buried deposits.

\section{Artifacts:}

Specimen 528-230 is a dart point fragment of opaque chert (Figure 41). The artifact has been heavily burned and is dark pinkish red with lavender patches (see Appendix B for measurements). A remnant barb and base fragment are suggestive of the Bulverde type, but this attribution cannot be confirmed. 


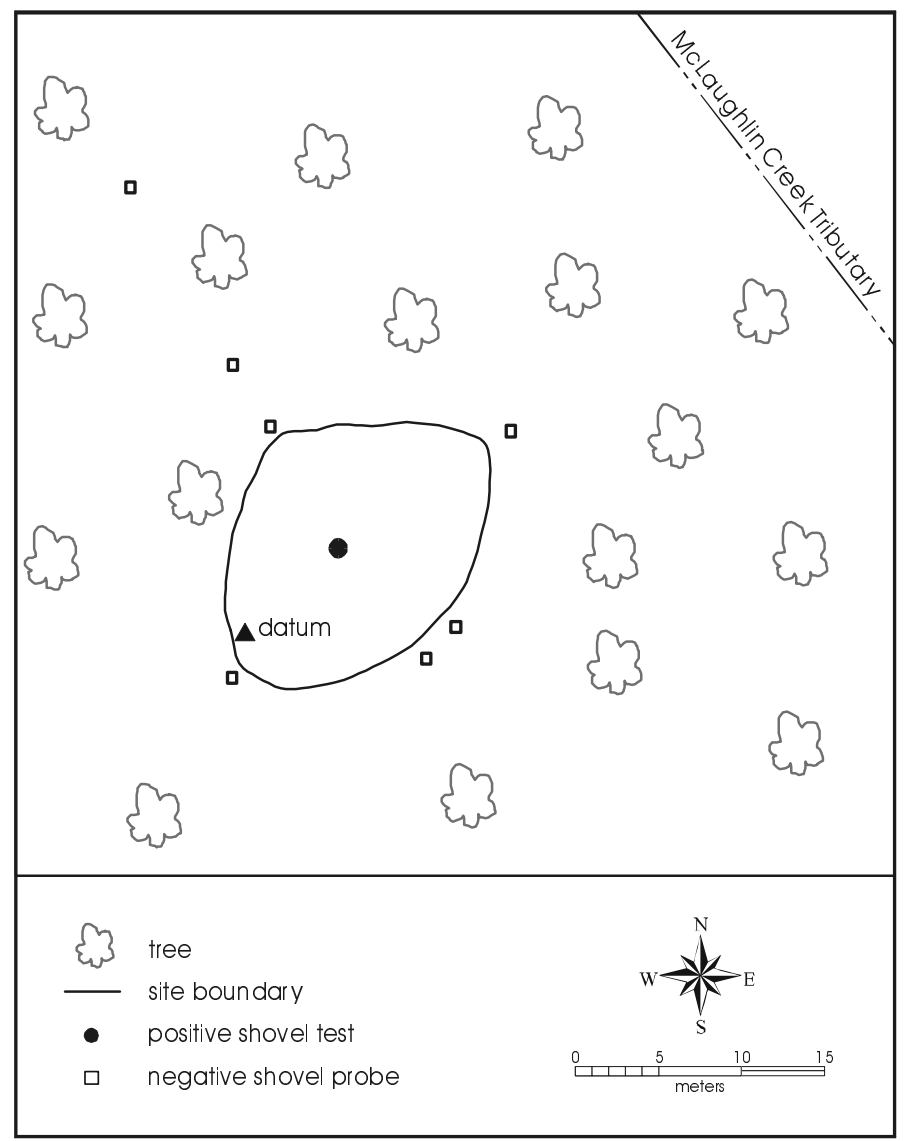

Figure 40. Map of 41BP528.

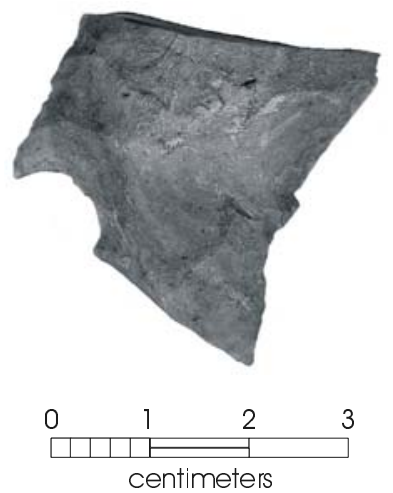

Figure 41. Dart point fragment from 41 BP528.

Table 18. Results of shovel test at 41BP528

\begin{tabular}{|lll|}
\hline Unit & Depth $(\mathbf{c m})$ & \multicolumn{1}{c|}{ Artifacts Collected } \\
\hline ST-1 & $0-20$ & 1 flake \\
& & 1 burned rock \\
& $20-40$ & -- \\
& $40-60$ & 5 flakes (broken from point \\
& & during excavation) \\
& & 1 dart pt. \\
& & 1 burned rock \\
& $60-70$ & -- \\
\hline
\end{tabular}




\section{BP529}

Site Type:

Prehistoric open camp

Site Size:

$400 \mathrm{~m}^{2}$, determined by shovel tests, shovel probes, and surface inspection (Figure 42)

Topographic Setting:

Upper stream slopes

Description:

Site 41BP529 is a prehistoric open camp on the slopes of a mixed woodland. Oak, cedar, and cactus are the dominants of the plant community, with $50-75 \%$ surface visibility. The site was on Patilo complex soils.

\section{Investigation:}

The field crew inspected the site surface then excavated one positive shovel test and four sterile shovel probes. This was sufficient to determine that the site consists of a low density of prehistoric artifacts in an area $20 \mathrm{~m}$ north/south by $20 \mathrm{~m}$ east/west, or $400 \mathrm{~m}^{2}$.

\section{Results:}

Three flakes and four burned rocks were found in the shovel test (Table 19). The shovel test was terminated at $60 \mathrm{~cm}$ because a heavy rock lens, possibly indicating a feature, was found. No artifacts were observed on the site surface. Cultural material extends at least $60 \mathrm{~cm}$ below the surface where a rock concentration prevented further excavation. There is a potential that intact buried deposits may exist. The site appears to be relatively undisturbed, albeit with some evidence of military training and bioturbation on the surface. 


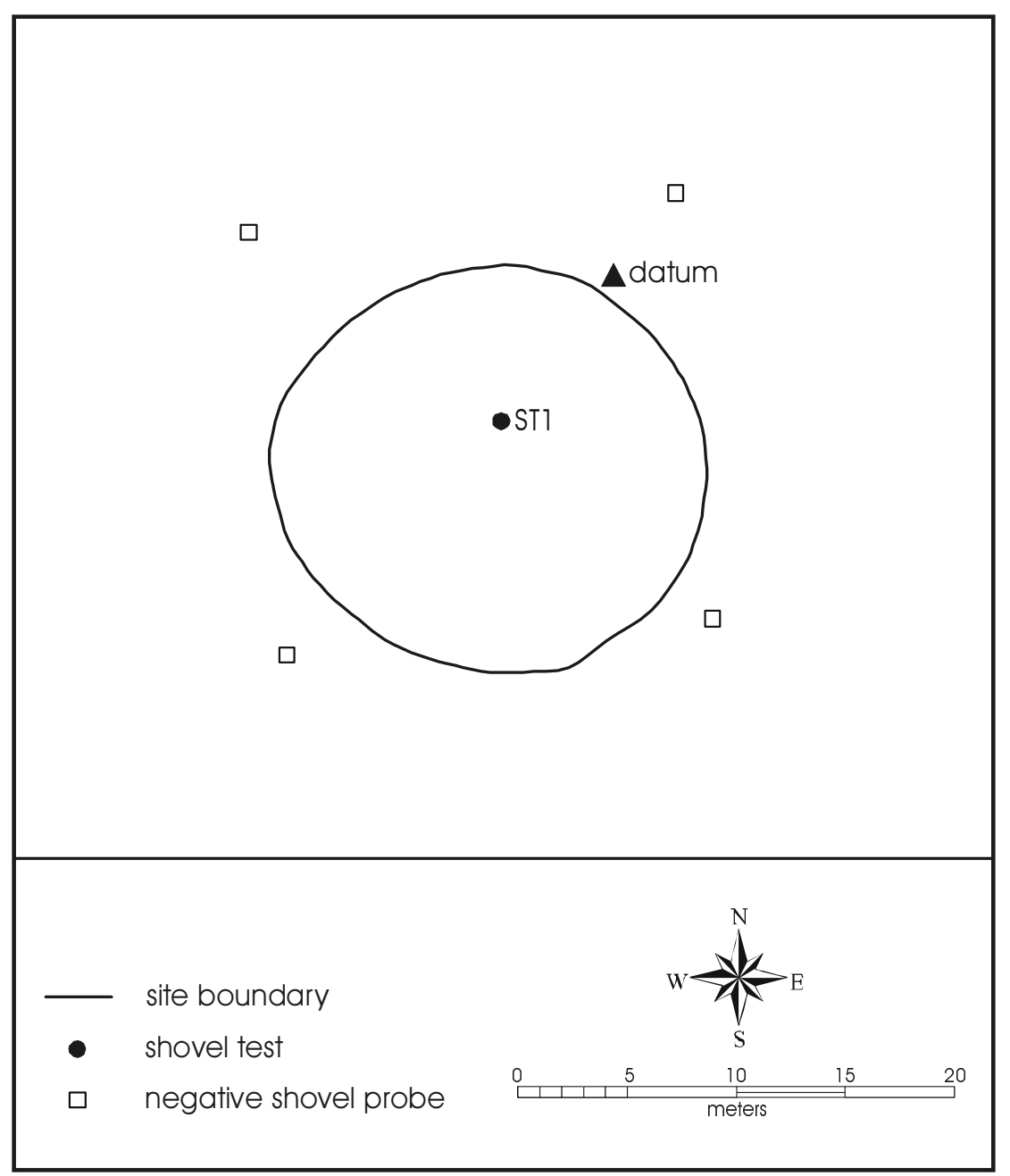

Figure 42. Map of 41 BP529.

Table 19. Results of shovel test at 41BP529

\begin{tabular}{|lcl|}
\hline Unit & Depth $(\mathbf{c m})$ & Artifacts Collected \\
\hline ST-1 & $0-20$ & 1 flake \\
& $20-40$ & -- \\
& $40-60$ & 2 flakes \\
& & 4 burned rocks \\
\hline
\end{tabular}




\section{BP530}

\section{Site Type:}

Prehistoric/Protohistoric open camp

Site Size:

2,100 $\mathrm{m}^{2}$, determined by shovel tests, shovel probes, and surface inspection (Figure 43)

\section{Topographic Setting:}

Upper drainage divide.

Description:

Site 41BP530 is a prehistoric/protohistoric open site in an upper drainage divide within a mixed woodland. Oak and cedar are the floral dominants, with $0-5 \%$ surface visibility. The soil at the site is an Axtell fine sandy loam.

Investigation:

The field crew excavated two positive shovel tests and four sterile shovel probes. The crew also inspected the site surface. This was sufficient to determine that the site consists of a scatter of prehistoric artifacts in an area $60 \mathrm{~m}$ north/south by $35 \mathrm{~m}$ east/west, or $2,100 \mathrm{~m}^{2}$.

\section{Results:}

Burned rock and one Turney arrow point base were retrieved from the subsurface (Table 20). No artifacts were observed on the site surface. Cultural material was retrieved from as deep as $40 \mathrm{~cm}$ below surface. The site has no known features and appears to be disturbed by military training, erosion, and bioturbation.

\section{Artifacts:}

Specimen 530-237 is a fragmentary arrow point strongly resembling the Turney type (Figure 44), although the specimen was somewhat south of the known distribution of the type (Turner and Hester 1993: 235). The material is a pinkish-gray translucent chert with vitreous luster (see Appendix B for measurements). The specimen is missing approximately the last $20 \%$ of the distal section of the blade, terminating at a transverse impact fracture. The original artifact was elongate-triangular, unstemmed, the blade edges descending directly to well-chipped basal ears. The lower portions of the blade curve slightly outward. The concave base is beveled on one face. Both faces of the blade have fine, long, collateral finishing flake scars. The cross section is lenticular. The Turney type dates to the historic period (Turner and Hester 1993:235). 


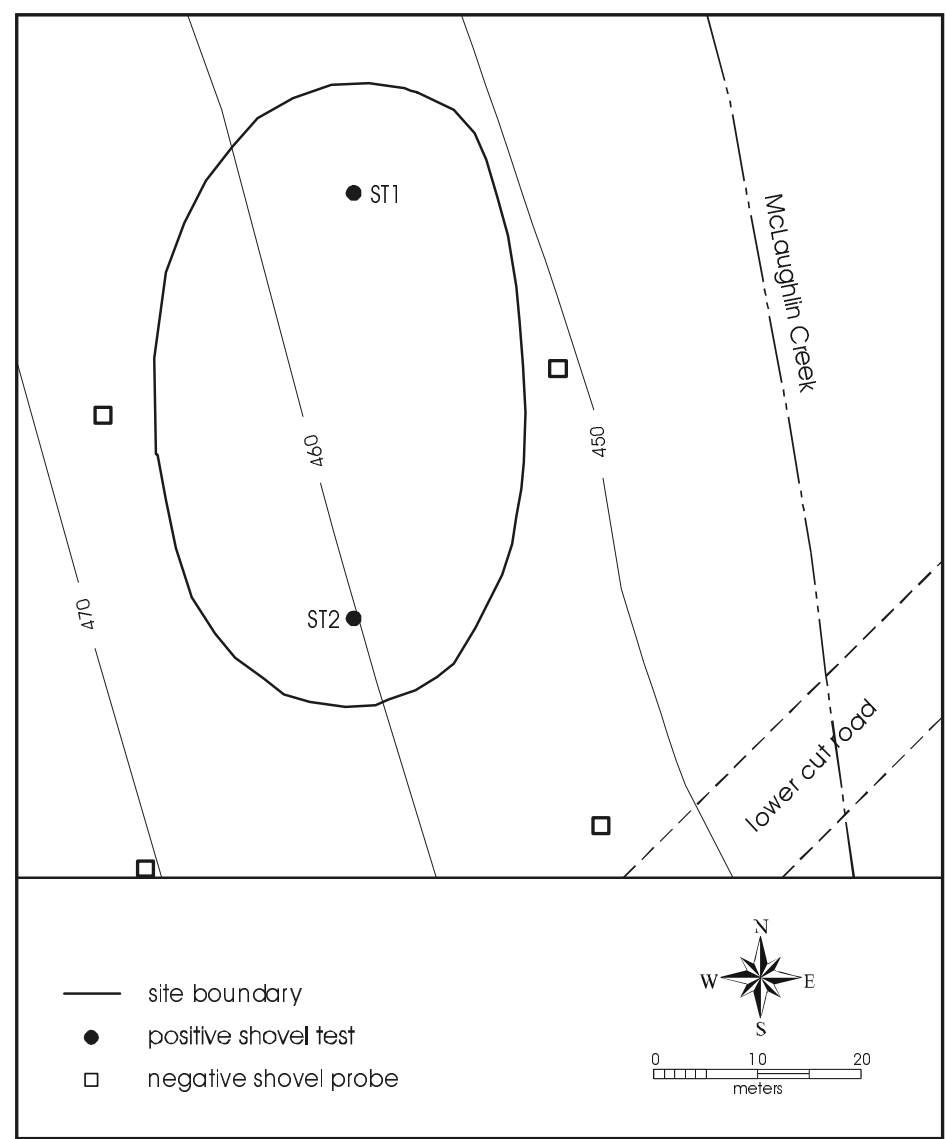

Figure 43. Map of 41BP530.

Table 20. Results of shovel tests at 41BP530

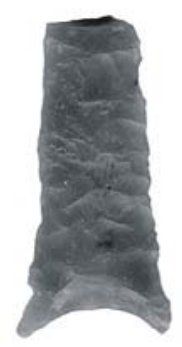

\begin{tabular}{|lll|}
\hline Unit & Depth $(\mathbf{c m})$ & Artifacts Collected \\
\hline ST-1 & $0-20$ & -- \\
& $20-40$ & Turney arrow pt. base \\
& $40-60$ & -- \\
\hline ST-2 & $0-20$ & 1 burned rock \\
& $20-60$ & -- \\
\hline
\end{tabular}

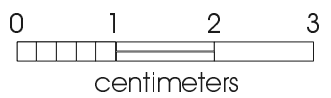

Figure 44. Arrow point base

from $41 B P 530$. 


\section{$41 B P 533$}

\section{Site Type:}

Prehistoric limited activity area

Site Size:

4,900 $\mathrm{m}^{2}$, determined by shovel test, shovel probes, and surface inspection (Figure 45)

\section{Topographic Setting:}

Upper stream slopes

\section{Description:}

Site 41BP533 is a prehistoric limited activity site within a mixed grass field with scattered trees. Mixed oak and pine and grasses are the dominants of the plant community. Ground visibility at the time of survey was 5\%. The soil type at the site is Demona loamy fine sand.

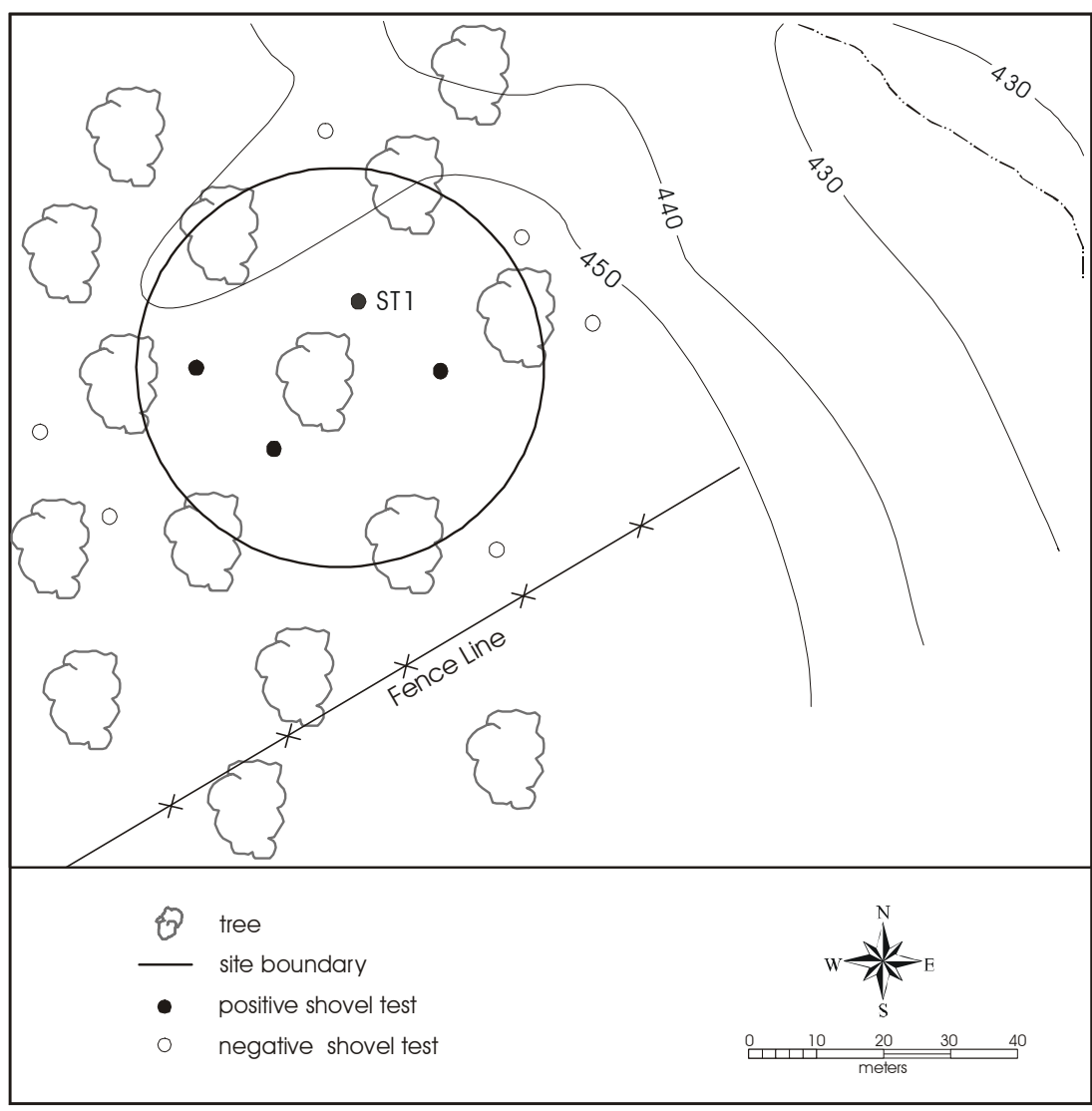

\section{Investigation:}

The field crew excavated one positive shovel test, and nine shovel probes, three of which were positive. This was sufficient to determine that the site consists of a scatter of prehistoric artifacts in an area $70 \mathrm{~m}$ north/ south by $70 \mathrm{~m}$ east/west, or $4,900 \mathrm{~m}^{2}$.

\section{Results:}

A total of five flakes were retrieved from the subsurface (Table 21). No artifacts were observed on the site surface. No features were observed. Military training and bioturbation have disturbed the site. Given the shallowness of the cultural material, the disturbance processes have likely disrupted all the cultural contexts of the site.

Figure 45. Map of 41BP533.

Table 21. Results of shovel tests at 41BP533

\begin{tabular}{|rrl|}
\hline Unit & Depth $(\mathbf{c m})$ & Artifacts Collected \\
\hline ST-1 & $0-20$ & -- \\
& $20-40$ & -- \\
& $40-60$ & 2 flakes \\
& $60-80$ & -- \\
\hline SP-1 & $0-20$ & -- \\
& $20-40$ & 1 flake \\
\hline SP-2 & $0-20$ & -- \\
& $20-40$ & 1 flake \\
\hline SP-3 & $0-20$ & -- \\
& $20-40$ & 1 flake \\
\hline
\end{tabular}


Chapter 5b: Results - Historic

\section{Historic Sites}

Twenty-four historic sites were recorded during this survey. They are: 41BP479, 41BP481, 41BP482, 41BP483, 41BP489, 41BP490, 41BP492, 41BP500, 41BP501, 41BP502, 41BP503, 41BP504, 41BP507, 41BP508, 41BP511, 41BP513, 41BP514, 41BP515, 41BP516, 41BP517, 41BP519, 41BP525, 41BP531, and 41BP534. Site descriptions for each follow. 


\section{$41 B P 479$}

\section{Site Type:}

Historic habitation

Site Size:

$9,912 \mathrm{~m}^{2}$, determined by shovel tests and surface inspection (Figure 46)

\section{Topographic Setting:}

Upland interfluve

\section{Description:}

Site 41BP479 is a historic habitation located on a nearly flat upland slope in the northwest end of the camp. Native and domesticated grasses and vines are the dominant floral assemblage, with less than $5 \%$ surface visibility. The soil at the site is Axtell-Tabor complex soil.

\section{Investigation:}

Four shovel tests were excavated, two of which were sterile. The crew also inspected the site surface. This was sufficient to determine that the site consists of a scatter of historic debris and house remains, with a basement, over an area $118 \mathrm{~m}$ east/west by $84 \mathrm{~m}$ north/south, or $9,912 \mathrm{~m}^{2}$.

\section{Results:}

The crew identified a basement depression, chimney fragments, a cistern, livestock pens, a trash midden, field outlines, and a dry pond. Surface artifacts found include metal siding, tires, buckets, bricks, sandstone slabs, metal sheets and wire, and an early 1950s model Chevrolet sedan with a 1966 license plate. Glass, wire, a wire nail, whiteware, and man-made fiber were found in shovel tests to a depth of $40 \mathrm{~cm}$ (Table 22). However, the shovel tests showed little or no integrity of subsurface deposits. Perry and Sarah Floyd were the last private owners of the site before it was sold to Camp Swift. Features identified at the site include a house depression with a collapsed brick chimney and scattered sandstone footing stones. This feature is not intact and, therefore, lacks integrity.

\section{Artifacts:}

Artifacts collected that are temporally diagnostic or of particular interest are listed below:

- Specimen 479-50-3 is a fragment of a Coca-Cola bottle. The fragment is aqua glass, molded in the classic Coca-Cola bottle style, which was adopted in 1915 (Munsey 1970:106).

- Specimen 479-50-4 is a fragment of the top of a kerosene lamp chimney. 


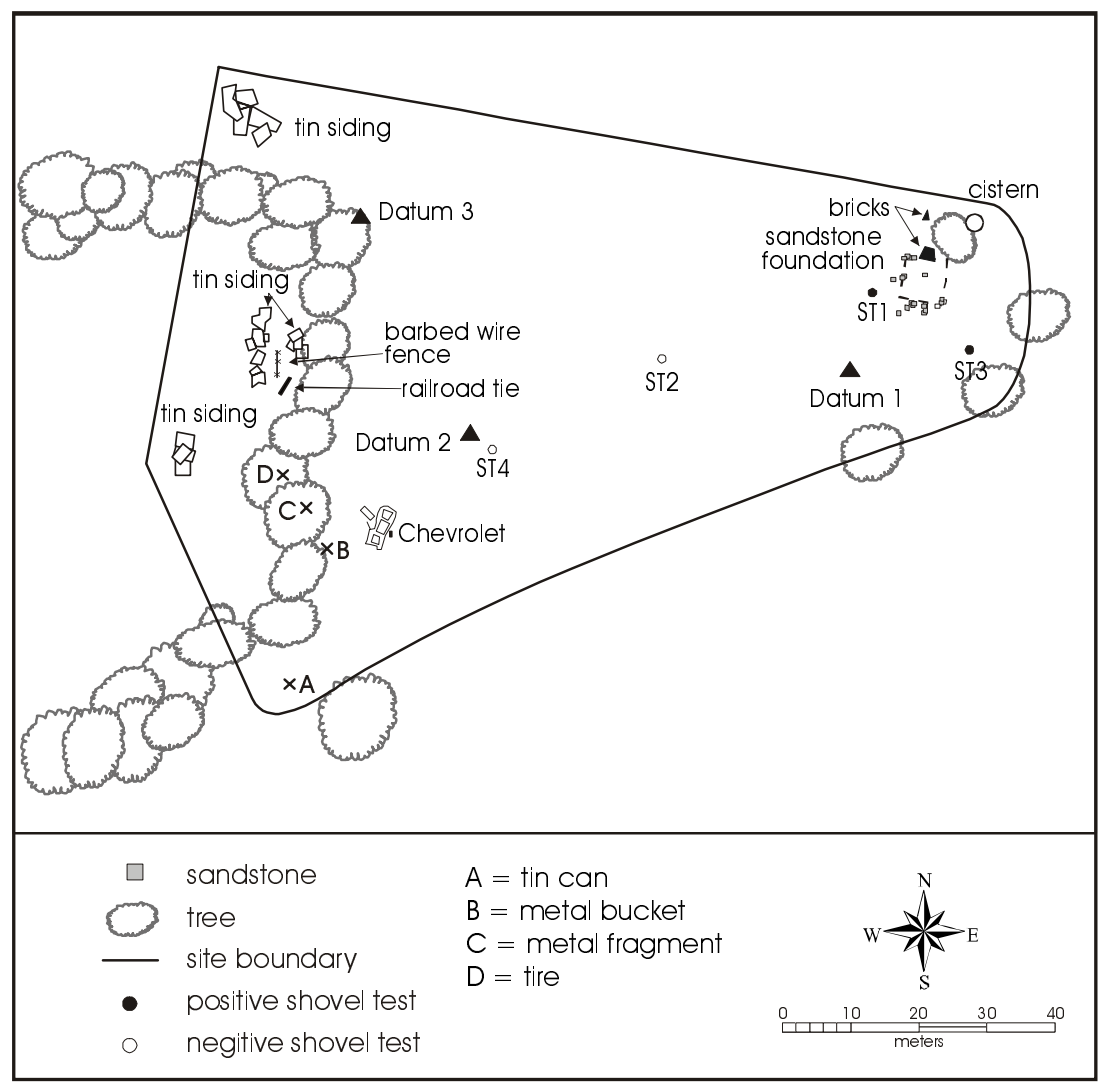

Figure 46. Map of $41 B P 479$.

Table 22. Artifacts from 41BP479

\begin{tabular}{|c|c|c|}
\hline Unit & $\operatorname{Depth}(\mathrm{cm})$ & Observations \\
\hline Surface & -- & $\begin{array}{l}\text { bricks, metal siding, tires, metal } \\
\text { buckets, license plate, sandstone slabs, } \\
\text { metal sheets, wire, body of a } 1950 \mathrm{~s} \\
\text { Chevrolet sedan }\end{array}$ \\
\hline \multirow[t]{3}{*}{ ST-1 } & $0-20$ & $\begin{array}{l}3 \text { colorless glass fragments, } \\
1 \text { piece man-made fiber }\end{array}$ \\
\hline & $20-40$ & $\begin{array}{l}1 \text { piece man-made fiber, } \\
6 \text { fragments colorless glass, } \\
1 \text { wire nail }\end{array}$ \\
\hline & $40-60$ & -- \\
\hline ST-2 & $0-60$ & -- \\
\hline \multirow[t]{3}{*}{ ST-3 } & $0-20$ & 1 metal wire \\
\hline & $20-40$ & 1 whiteware fragment \\
\hline & $40-60$ & -- \\
\hline $\begin{array}{l}\text { ST-4 } \\
\end{array}$ & $0-20$ & -- \\
\hline
\end{tabular}




\section{BP481}

Site Type:

Historic bridge

Site Size:

$750 \mathrm{~m}^{2}$, determined by shovel tests and surface inspection (Figure 47)

Topographic Setting:

Floodplain of an upland creek

Description:

Site 41BP481 is an historic bridge site on the stream banks crossing Big Sandy Creek. Oak, elm, hackberry, and riparian undergrowth are the dominant ground cover on the stream banks, with less than $5 \%$ surface visibility. The soil at the site is Sayers fine sandy loam.

\section{Investigation:}

The crew excavated two shovel tests, both of which were sterile. This was sufficient to determine that the site consists of earthen bridge approach ramps and two parallel lines of rotten wood pilings in the creek in an area $50 \mathrm{~m}$ east/west by $15 \mathrm{~m}$ north/south, or $750 \mathrm{~m}^{2}$.

\section{Results:}

The field crew observed no artifacts, surface or subsurface. The bridge approach ramps and pilings were the only evidence of the site, but the bridge they supported is gone. Examination of historic maps failed to show any roads or bridge crossings in the immediate vicinity. There are a few large, old hackberry trees growing out of the approach ramps, however, hackberry trees are a fast-growing species. It cannot be ruled out that this bridge was built since the establishment of Camp Swift. The shovel tests, dug in each of the approach ramps largely to determine the fill stratification, revealed only uniform sands. Features identified at the site include two earthen approach ramps (one on either side of Big Sandy Creek). The ramps are overgrown with vegetation, but still intact, while the wood pilings are severely rotted with only the tops of each piling projecting above the water. 


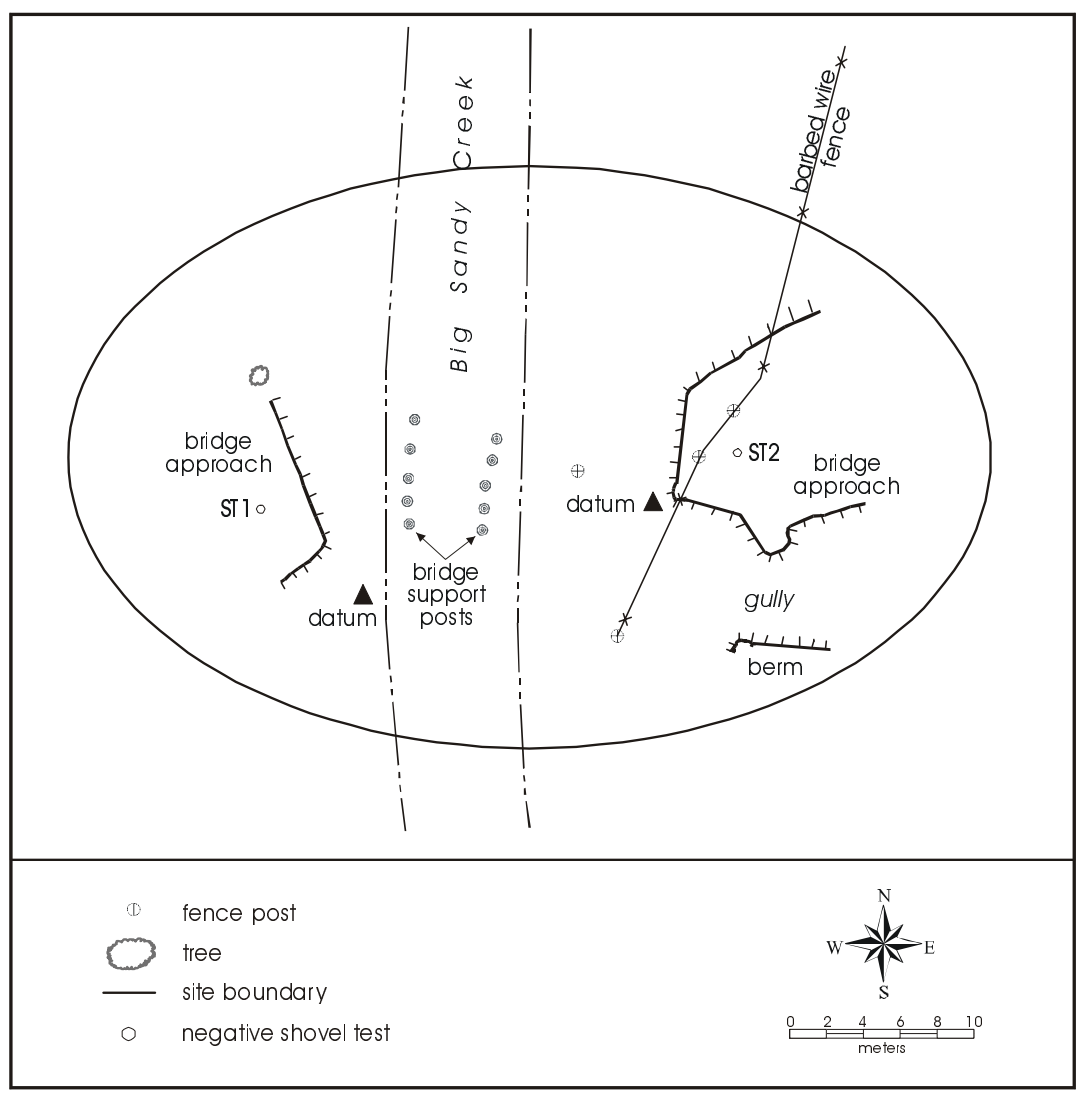

Figure 47. Map of $41 \mathrm{BP} 481$. 


\section{$41 B P 482$}

\section{Site Type:}

Historic bridge

Site Size:

$630 \mathrm{~m}^{2}$, determined by shovel tests and surface inspection (Figure 48)

\section{Topographic Setting:}

Floodplain of an upland creek

\section{Description:}

Site 41BP482 is a historic bridge on the stream banks of Big Sandy Creek. Oak, elm, and cedar are the dominant vegetation on the stream banks, with $10 \%$ surface visibility. The soil at the site is Sayers fine sandy loam.

\section{Investigation:}

The field crew excavated two shovel tests, one on the bridge approach north and one on the bridge approach south of Big Sandy Creek. One shovel test was positive. The crew also inspected the site's surface. This was sufficient to determine that the site consists of bridge remains in an area $42 \mathrm{~m}$ north/south by $15 \mathrm{~m}$ east/west, or $630 \mathrm{~m}^{2}$.

\section{Results:}

A total of four flakes and one burned rock were recovered in one of the shovel tests from a depth of $60-120 \mathrm{~cm}$, from the north ramp approach (Table 23). However, these artifacts were found only within the ramp fill and are in a disturbed context. The artifacts may have been from the area that surrounded the bridge site, but the transect survey was unable to relocate the site. Surface artifacts include a pile of cream-colored bricks protruding from the base of the northern approach ramp. Some of the bricks were labeled "Butler Velvatex" and "Butler". These are from the Elgin-Butler Brick and Tile Company, which was in business from 1921 to 1942 (Guercke 1987:212). The earthen ramps appear to be at least partially intact, although both have suffered damage by erosion and flooding activity. The remainder of the bridge has been destroyed. Examination of historic maps failed to show any roads or bridge crossings in the immediate vicinity. This site is similar to 41BP481 except for the lack of pilings in the stream. As at 41BP481, hackberry trees a minimum of six inches in diameter grow out of the approach ramps. However, as hackberry is a fast-growing, short-lived tree, this does not provide evidence that the bridge was built before the establishment of Camp Swift. The bricks do suggest, however, a pre-Camp Swift date for this site. 


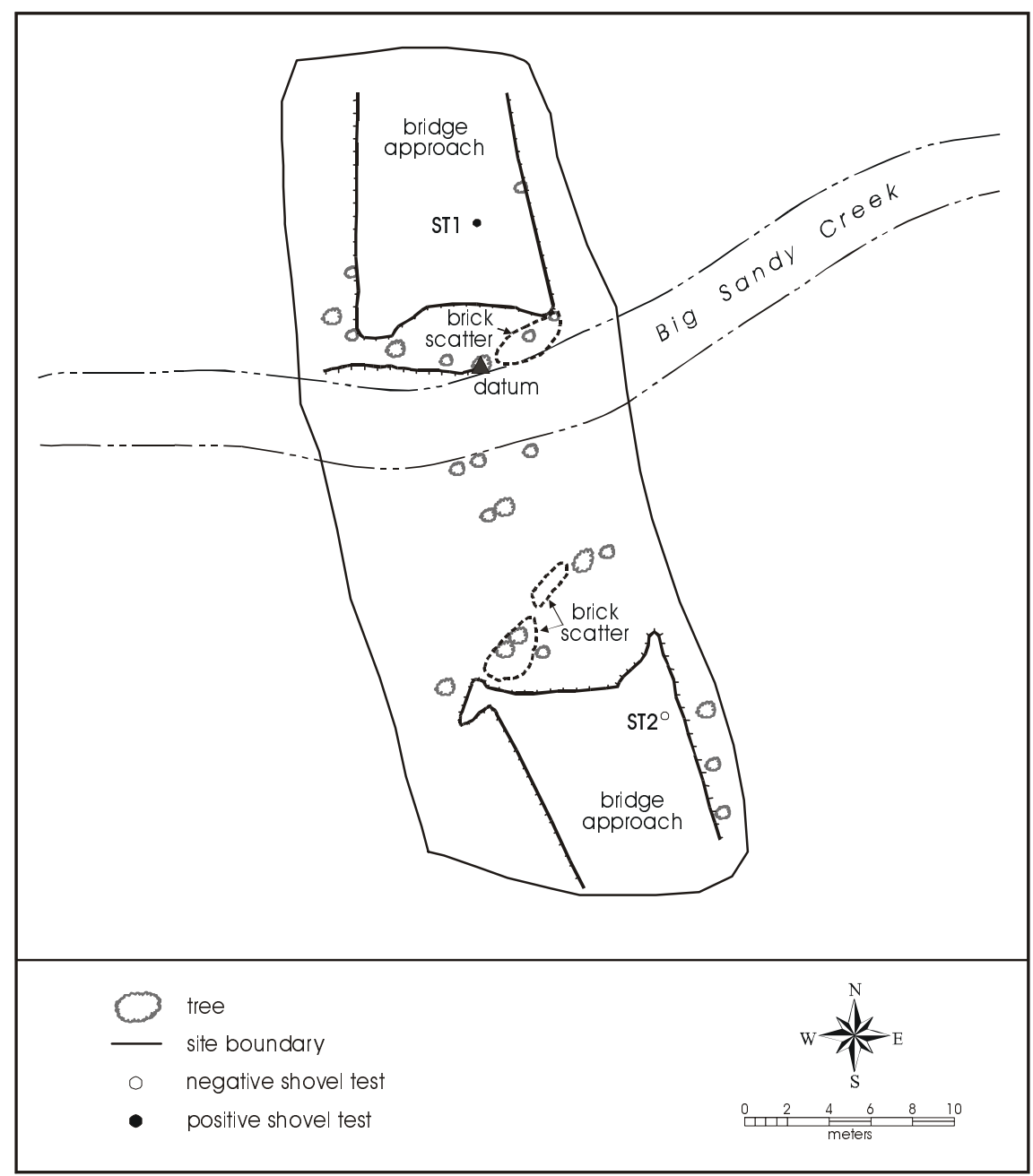

Figure 48. Map of 41BP482.

Table 23. Artifacts from 41BP482

\begin{tabular}{|lll|}
\hline Unit & Depth $(\mathbf{c m})$ & \multicolumn{1}{c|}{ Observation } \\
\hline Surface & -- & $\begin{array}{l}\text { bricks, some inscribed with } \\
\text { "BUTLER VELVATEX" } \\
\end{array}$ \\
& & or "BUTLER" \\
\hline ST-1 & $0-60$ & -- \\
& $60-80$ & 1 burned rock \\
& $80-100$ & 2 chert flakes \\
& $100-120$ & 1 chert flake \\
\hline ST-2 & $0-100$ & -- \\
\hline
\end{tabular}




\section{$41 B P 483$}

Site Type:

Historic trash dump

Site Size:

$1,125 \mathrm{~m}^{2}$, determined by surface inspection (Figure 49 )

\section{Topographic Setting:}

Minor floodplain of an upland tributary

\section{Description:}

Site 41BP483 is a historic trash scatter on the eastern bank of an unnamed tributary of Big Sandy Creek. Scattered oak, cedar, and hackberry are the floral dominants, with $60 \%$ ground surface visibility. The soil at the site is Axtell fine sandy loam.

\section{Investigation:}

The crew inspected the site's surface. This was sufficient to determine that the site consists of a light scatter of historic domestic artifacts in an area $75 \mathrm{~m}$ north/south by 15 east/west, or $1,125 \mathrm{~m}^{2}$.

\section{Results:}

Surface artifacts found included shards of a salt-glazed stoneware jug and whiteware, two tin can fragments, three snuff bottles, two tin buckets, and two bullet casings. No site features were observed; the site appears to be a light trash dump, and may represent a secondary deposit.

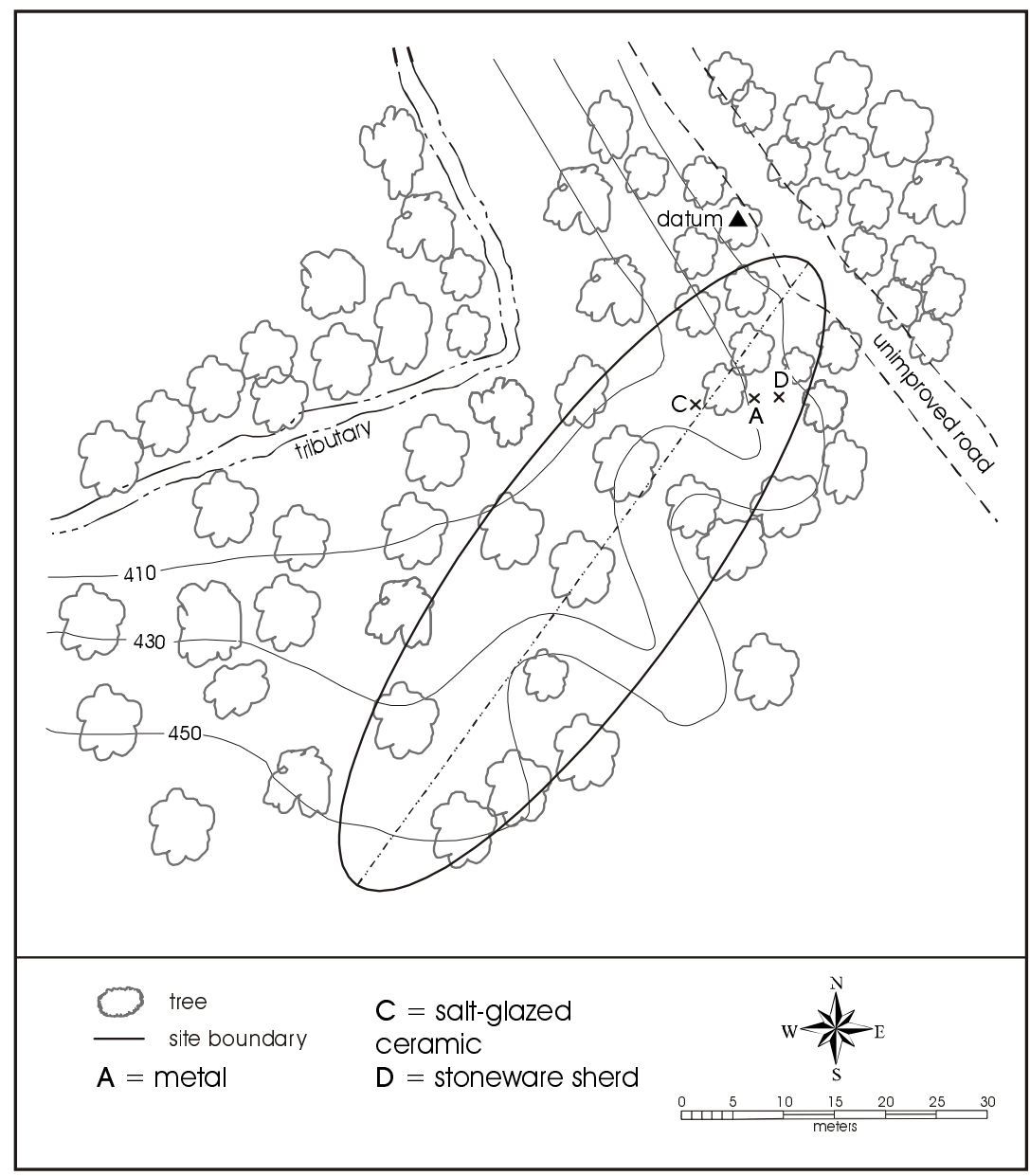

Figure 49. Map of $41 B P 483$. 


\section{BP489}

\section{Site Type:}

Historic installation

Site Size:

$25 \mathrm{~m}^{2}$, determined by shovel probe and surface inspection (Figure 50)

\section{Topographic Setting:}

Upper drainage-divided slopes

Description:

Site 41BP489 is a very small historic installation consisting of a circular arrangement of cut sandstone, located on gently wooded slopes approximately $45 \mathrm{~m}$ southeast of the Camp boundary. Oak and cedar are the dominant ground cover, with $10 \%$ surface visibility. The soil at the site is Patilo complex.

\section{Investigation:}

The field crew inspected the ground surface and excavated one shovel probe, which was sterile. This was sufficient to determine that the site consists of cut sandstone blocks and associated surface artifacts in an area 5 $\mathrm{m}$ north/south by $5 \mathrm{~m}$ east/west, or $25 \mathrm{~m}^{2}$.

\section{Results:}

Artifacts observed included a galvanized metal bucket and a stoneware bowl. The site feature consists of an approximately two-meter-diameter circle of dressed sandstone blocks. All of the cultural materials were found on the surface of the site. Artifacts on the surface included dressed sandstone blocks, one galvanized metal bucket, and one stoneware bowl. One shovel probe was excavated to a depth of $40 \mathrm{~cm}$, but no artifacts were found below the surface. It should be noted that this site is $67 \mathrm{~m}$ from the Wine Cellar site and $85 \mathrm{~m}$ from Scott Falls, roughly in between them. It may be associated with the construction of the dam. The sandstone blocks are cut and shaped in the same fashion that Aussilloux used in his other structures (see Chapter 6).

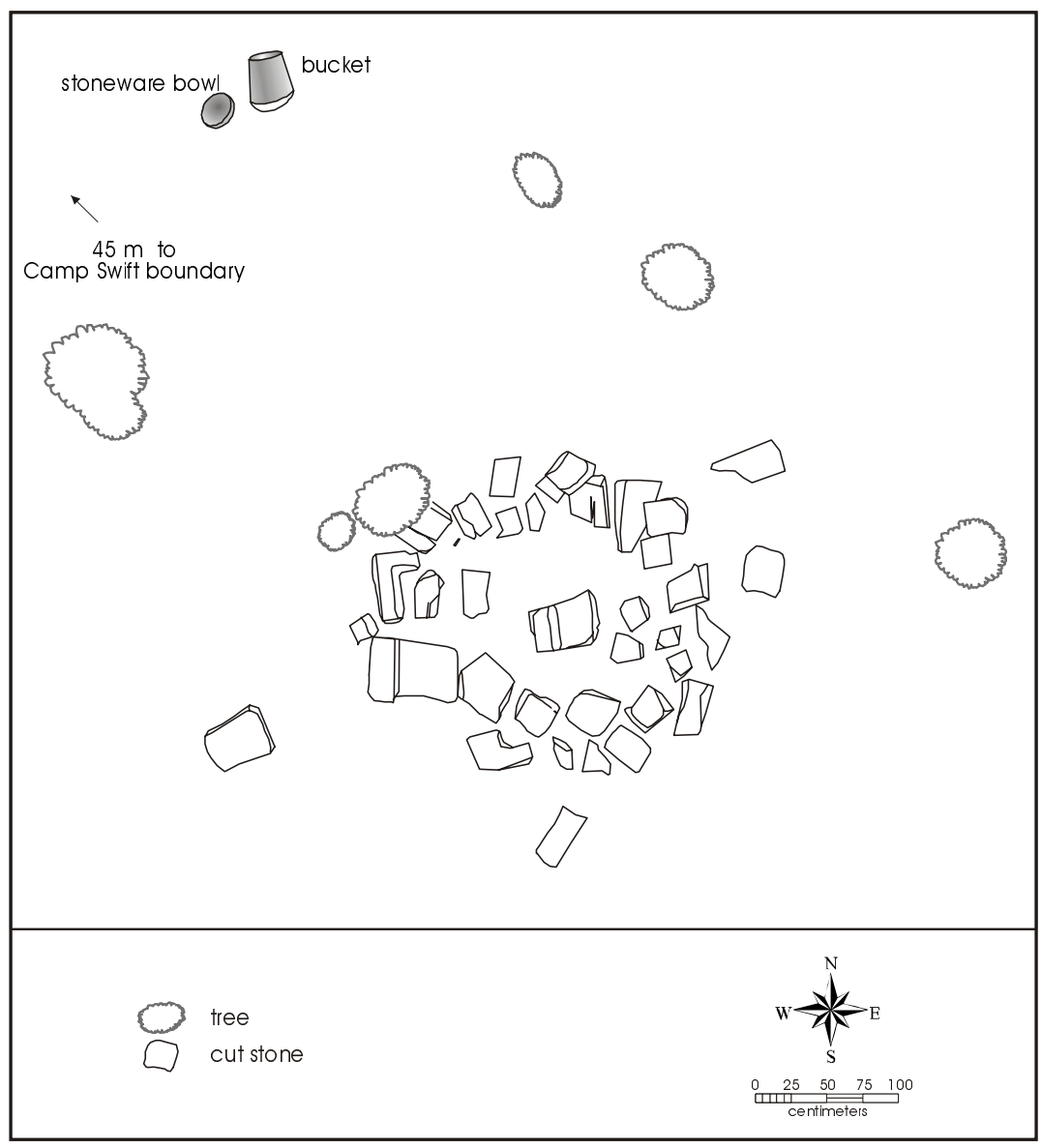

Figure 50. Map of $41 B P 489$. 


\section{BP490}

\section{Site Type:}

Historic habitation

Site Size:

$1,720 \mathrm{~m}^{2}$, determined by surface inspection (Figure 51 )

\section{Topographic Setting:}

Oak-cedar woodland on upper drainage-divided slopes

Description:

Site 41BP490 is a historic habitation site on gentle wooded slopes near the northeast perimeter fence of the camp. The site is in an oak-cedar woodland. Ground surface visibility is $10-20 \%$. The soil at the site is Silstid loamy fine sand.

\section{Investigation:}

The field crew inspected the ground surface. This was sufficient to determine that the site consists of a light to moderate scatter of architectural and domestic artifacts limited to the site surface, a well, and remains of a demolished shed in an area $43 \mathrm{~m}$ north/south by $40 \mathrm{~m}$ east/west, or 1,720 $\mathrm{m}^{2}$.

\section{Results:}

Cultural materials observed on the surface included bricks, sheet metal, wire, and ceramics. Additionally, the site has collapsed sheds, fence lines, pens, and a brick and concrete-lined hand-dug well. The last owners before Camp Swift were F. Gordon and others and B.C. and Hettie Daughtry; it is not known if any of these people were the actual residents of the homestead. Artifacts observed on the surface include bricks, sheet metal, wire, ceramics, barbed wire, a cinder block, and a metal brake drum. Features at the site include one brick-lined well covered by cement and a wood piling foundation of a demolished corrugated tin shed. The well is entirely intact, while the demolished shed is in scattered ruins. 


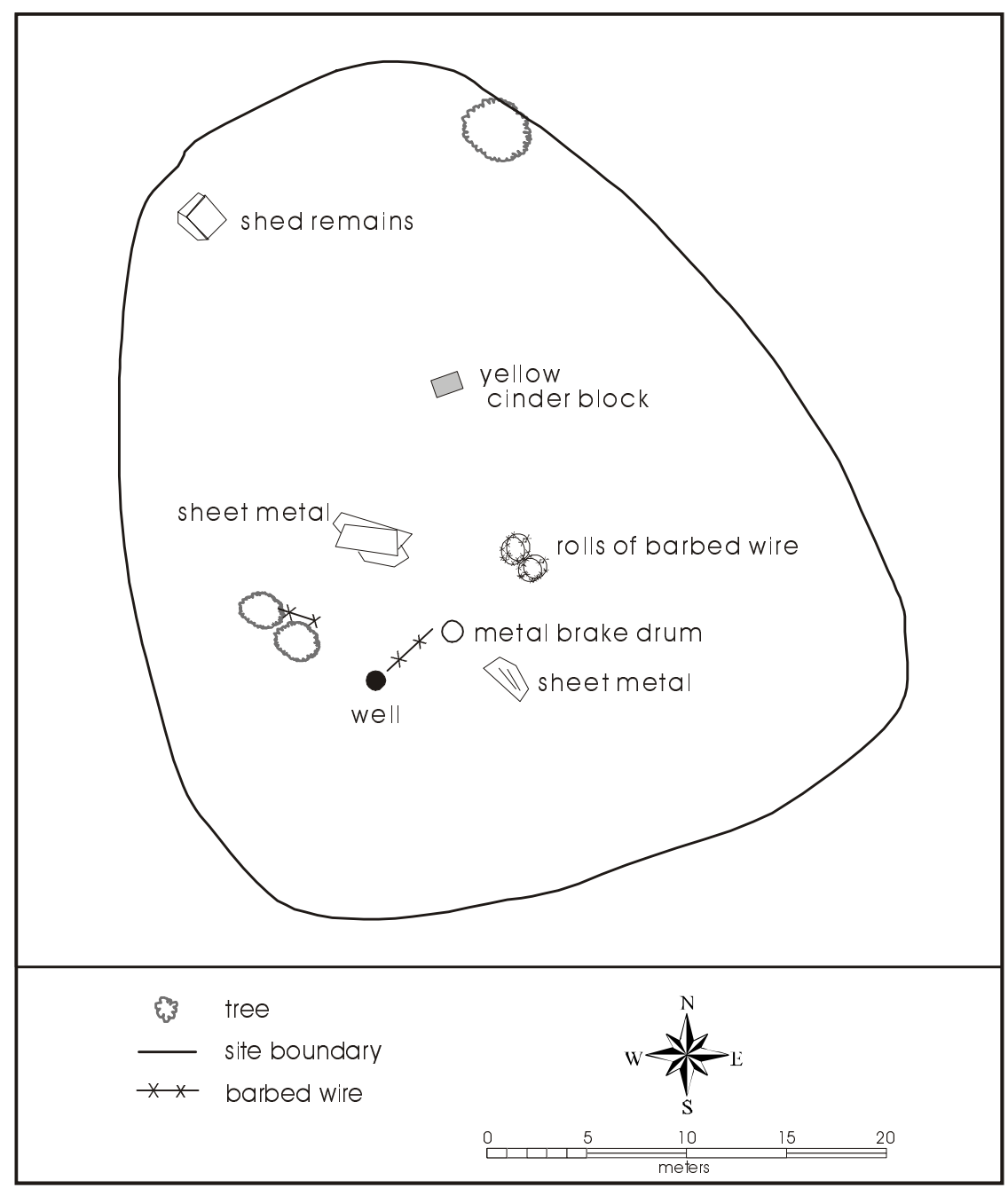

Figure 51. Map of 41BP490. 


\section{$41 \mathrm{BP} 492$}

\section{Site Type}

Historic trash dump

\section{Site Size:}

$450 \mathrm{~m}^{2}$, determined by inspecting the site surface and the gully (Figure 52)

\section{Topographic Setting:}

Upland drainage divides

\section{Description:}

Site 41BP492 is a historic trash dump located at the head of a deeply entrenched gully at the northwest boundary fence of the camp. Oak, cedar, and other deciduous trees are the local dominants, with $40-50 \%$ surface visibility. Site soils are Axtell fine sandy loam. The land that the site is on was formerly Gordon and Daughtry property, but there are no known associated habitation sites and it cannot be associated reliably with any personages.

\section{Investigation:}

The field crew examined the site surface as well as the deeply entrenched gully, which passes through the southern portion of the site. Inspection of the deep cutbank, which is over two $m$ deep, was sufficient to show that the late historic site sits on the ground surface and is not partially contained within it. The site limits were the gully banks and the gully channel containing items from the midden gradually eroding down it. The site dimensions are $30 \mathrm{~m}$ north/south by $15 \mathrm{~m}$ east/west, or $450 \mathrm{~m}^{2}$.

\section{Results:}

Artifacts observed on the surface included glass and metal bottles, cans, various ceramic items and two shell buttons. The site has no constructed features. It is probably a community dump. Recent trash has been thrown over the camp boundary fence onto the dump, giving evidence of the site's continuing use as an informal midden. Artifacts observed on the surface and counted in the field include numerous cans and glass bottles, and numerous other glass and ceramic fragments. One colorless glass bottle bottom (not collected) had embossing, "Design pat'd Mar. 3, 1925."

\section{Artifacts:}

Potentially diagnostic items collected from the surface were one glass jar lid, one whiteware plate fragment, and two shell buttons.

- Specimen 492-83 is an undecorated whiteware plate fragment that has a partial maker's mark on the bottom that can be dated to 1913 and afterwards (Godden 1964:356).

- Specimen 492-85 is the two buttons, each $2.7 \mathrm{~cm}$ in diameter, made of freshwater shell, that were found on the surface. They are two-hole cat's-eye buttons of a variety commonly seen on coats until about World War I, when such shell buttons were replaced with bakelite and hard rubber buttons on moderate to cheap clothing (Meissner 1997:167; Pool 1987:283).

- Specimen 492-84 is the glass jar lid embossed with the following text "TO OPEN INSERT KNIFE AT NOTCH [arrow symbol] PAT. RE. 17562" on the outer ring and "PRESTO" and " 3 " on the inner ring (Figure 53). The dating of this item is not known at this time, but it appears to be fairly recent, almost certainly post- 1900 . 


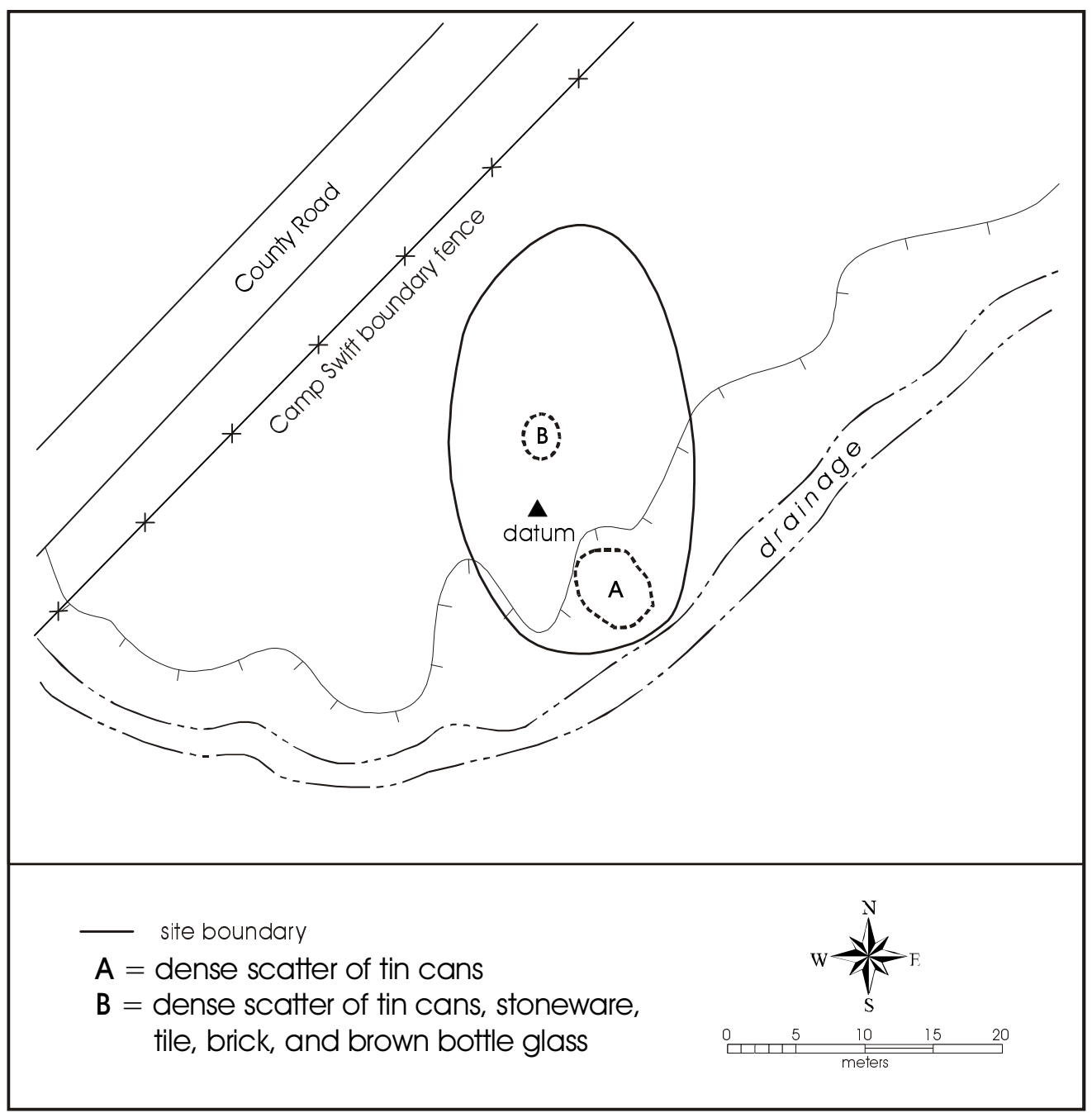

Figure 52. Map of $41 B P 492$.
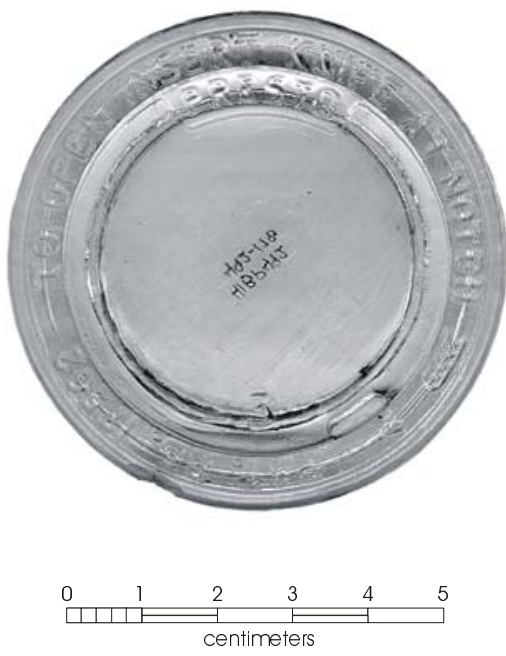

Figure 53. Clear glass jar lid from 41 BP 492. 


\section{BP500}

\section{Site Type:}

Historic trash dump

Site Size:

$1,400 \mathrm{~m}^{2}$, determined by a shovel test and surface inspection (Figure 54)

\section{Topographic Setting:}

Upper stream drainage slopes

Description:

Site 41BP500 is a historic trash dump located on wooded slopes north of Big Sandy Creek. Oak and cedar are the dominant ground cover, with $10-20 \%$ surface visibility. The site is on Patilo complex soils. The property was previously owned by T. H. and Ada Lockett before becoming part of Camp Swift.

Investigation:

The field crew excavated one shovel test, which was positive, and inspected the site surface. This was sufficient to determine that the site consists of a scatter of historic trash in an area $40 \mathrm{~m}$ north/south by $35 \mathrm{~m}$ east/west, or $1400 \mathrm{~m}^{2}$.

\section{Results:}

Within the site, metal cans, glass bottles, whiteware ceramics, and a galvanized metal bucket were observed on the surface. One colorless glass fragment was collected subsurface at a depth of 40-60 cm (Table 24). There was a low density of surface artifacts and subsurface artifacts. The site has no observed features.

\section{Artifacts:}

Two potentially datable artifacts were collected.

- Specimen 500-110 is a semi-porcelain plate in two pieces, decorated with red and green stripes along the rim. This plate was made by the Wellsville Company in Wellsville, Ohio, sometime after 1900 (Barber 1976:127-128).

- Specimen 500-111 is a small colorless glass condiment jar. This jar is machine-made, with the maker's mark of the Ball Glass Co. on the bottom. It can be dated only as post-1903 (Toulouse 1971:67). 


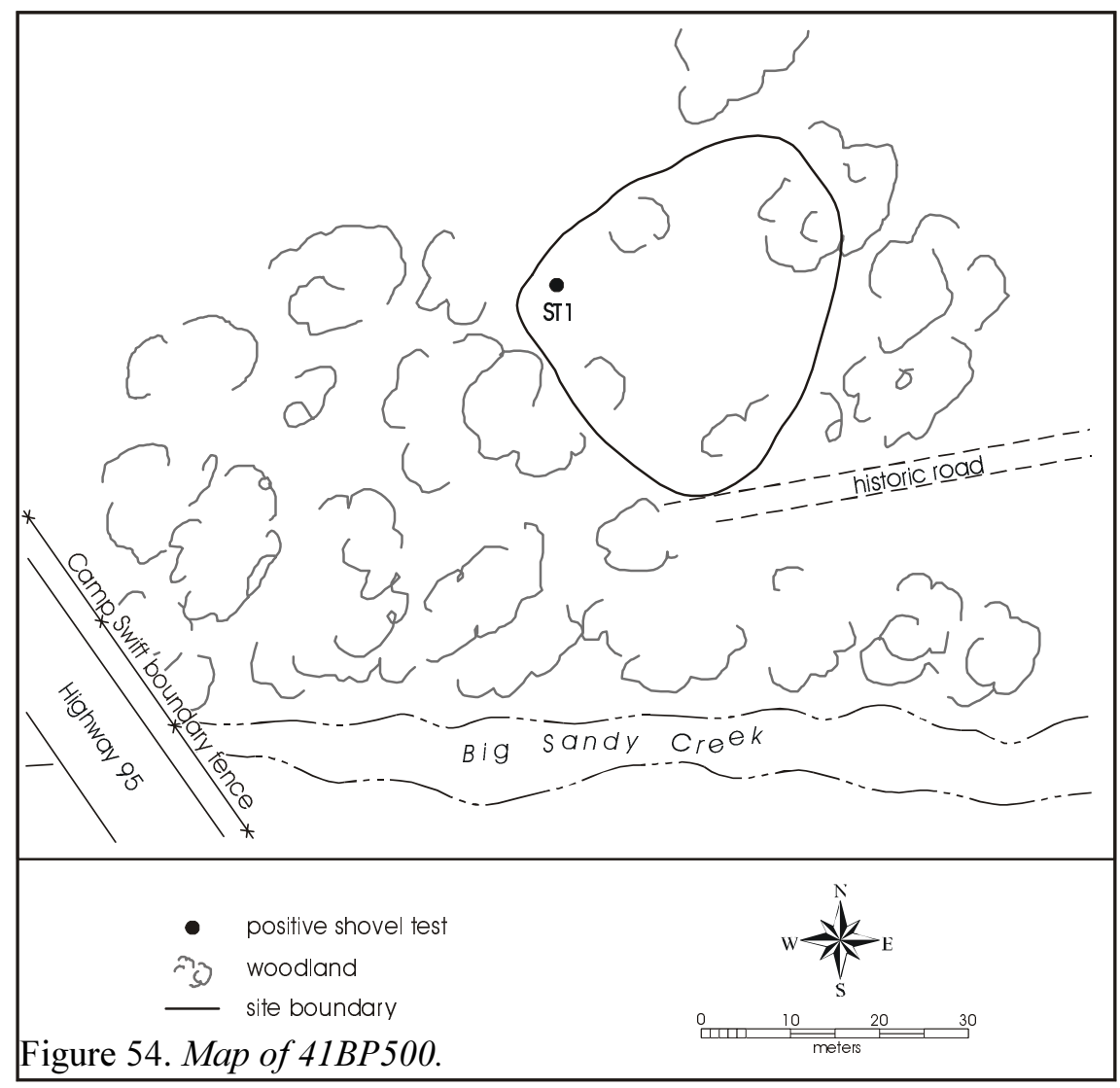

Table 24. Artifacts from 41BP500

\begin{tabular}{|cclc|}
\hline Unit & Depth(cm) & \multicolumn{3}{c|}{ Observations } \\
\hline Surface & -- & metal cans, glass bottles, \\
& & whiteware, 1 galvanized metal \\
& & bucket, 2 & semi-porcelain plate \\
& & fragments with green and red \\
& & striped edges, 1 glass condiment \\
& machine-made bottle base (post \\
& & 1903), 1 glass Pepsi bottle (late \\
& & 1960s). & \\
\hline ST-1 & $0-40$ & -- & \\
& $40-60$ & 1 colorless glass fragment \\
& $60-75$ & -- & \\
\hline
\end{tabular}




\section{BP501}

Site Type:

Historic trash dump

Site Size:

$450 \mathrm{~m}^{2}$, determined by a shovel test and surface inspection (Figure 55)

Topographic Setting:

Wooded stream-divided uplands

Description:

Site 41BP501 is a historic trash dump located on wooded upper slopes approximately $200 \mathrm{~m}$ west of Dogwood Creek. Oak and cedar are the dominant vegetation, with 20\% surface visibility. The site is on Patilo complex soils. The owners of record before the creation of Camp Swift were Amanda Owens and others.

Investigation:

The crew excavated one shovel test, which was sterile, and inspected the ground surface. This was sufficient to determine that the site consists of a surface scatter of historic trash over an area $30 \mathrm{~m}$ northwest/southeast by 15 $\mathrm{m}$ northeast/southwest, or $450 \mathrm{~m}^{2}$.

\section{Results:}

Artifacts observed on the site surface included a low density of whiteware, salt-glazed stoneware ceramics, various types of glass, sheet metal fragments, a glass electrical insulator, and a steak bone. One shovel test was excavated, with no artifacts recovered. No cultural features were observed.

Artifacts:

- Specimen 501-114 is a dark aqua glass insulator, a variety called a pintype, which is designed to screw down onto a wooden pen which sticks up above the cross bar of a telephone or telegraph pole (Figure 56). This particular variety is a Hemingrey No. 40 (Insulator Collectors on the Net 2001a), in common use between 1910 and 1921 (Insulator Collectors on the Net 2001b). 


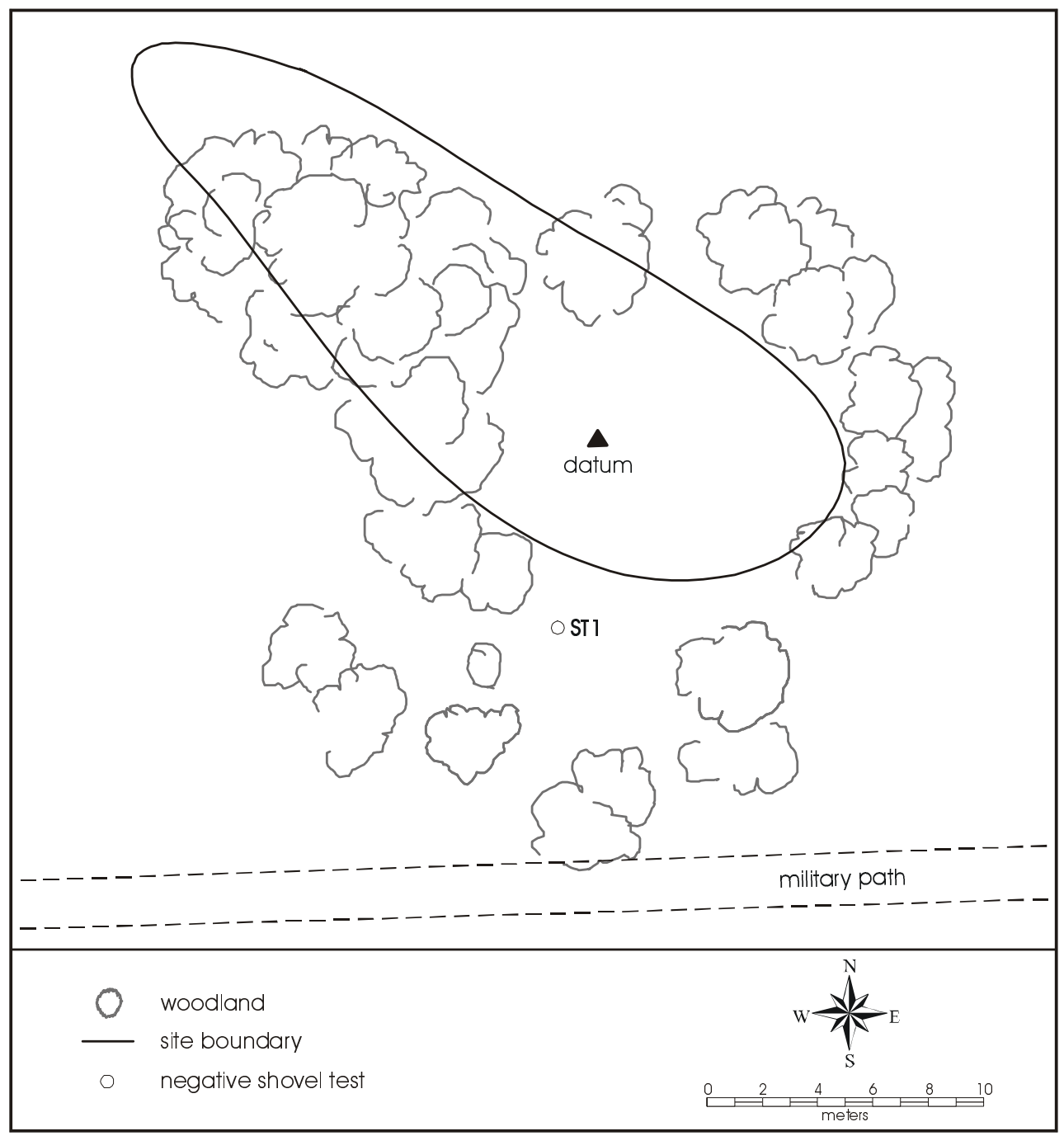

Figure 55. Map of 41BP501.

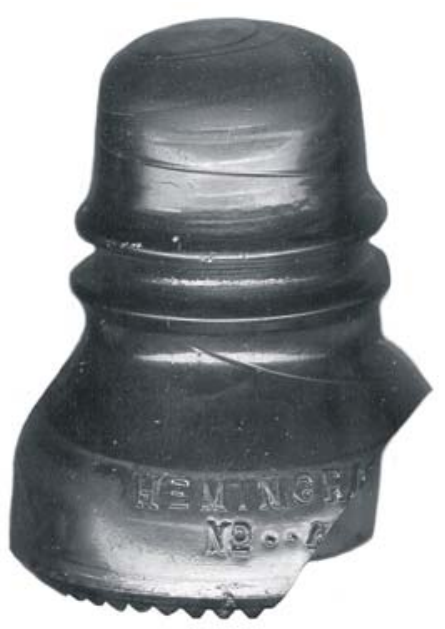

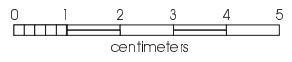

Figure 56. Glass insulator from $41 B P 501$. 


\section{BP502}

\section{Site Type:}

Historic trash dump

Site Size:

$150 \mathrm{~m}^{2}$, determined by surface inspection (Figure 57)

\section{Topographic Setting:}

Upland drainage divides

Description:

Site 41BP502 is a historic trash dump located in woodlands about 250 m east of Highway 95 near the northwest corner of the camp. Oak and cedar are the dominant ground cover, with $20 \%$ surface visibility. The site is on Patilo complex sandy loam. The site is a late historic low density trash scatter on property owned by Florence Woods and others before the establishment of Camp Swift.

\section{Investigation:}

The field crew inspected the site's surface, which was sufficient to determine that the site consists of a scatter of historic trash in an area $15 \mathrm{~m}$ by $10 \mathrm{~m}$, or $150 \mathrm{~m}^{2}$.

\section{Results:}

Artifacts observed on the surface included metal cans, various types of ceramics, and glass bottles, including a Sun Tex soft drink bottle, a Pop Kola bottle, and a 7-up bottle. Maker's marks showed production since 1956, since 1966, and between 1912 and 1929. The material classes and the production dates suggest the dump may have originated in military operations after World War II and not with civilian owners before Camp Swift. No features were observed.

\section{Artifacts:}

The only artifact collected was the 7-up bottle (Specimen 502-115). This bottle has maker's marks on the bottom that indicate it was made in 1946 (Figure 58). 


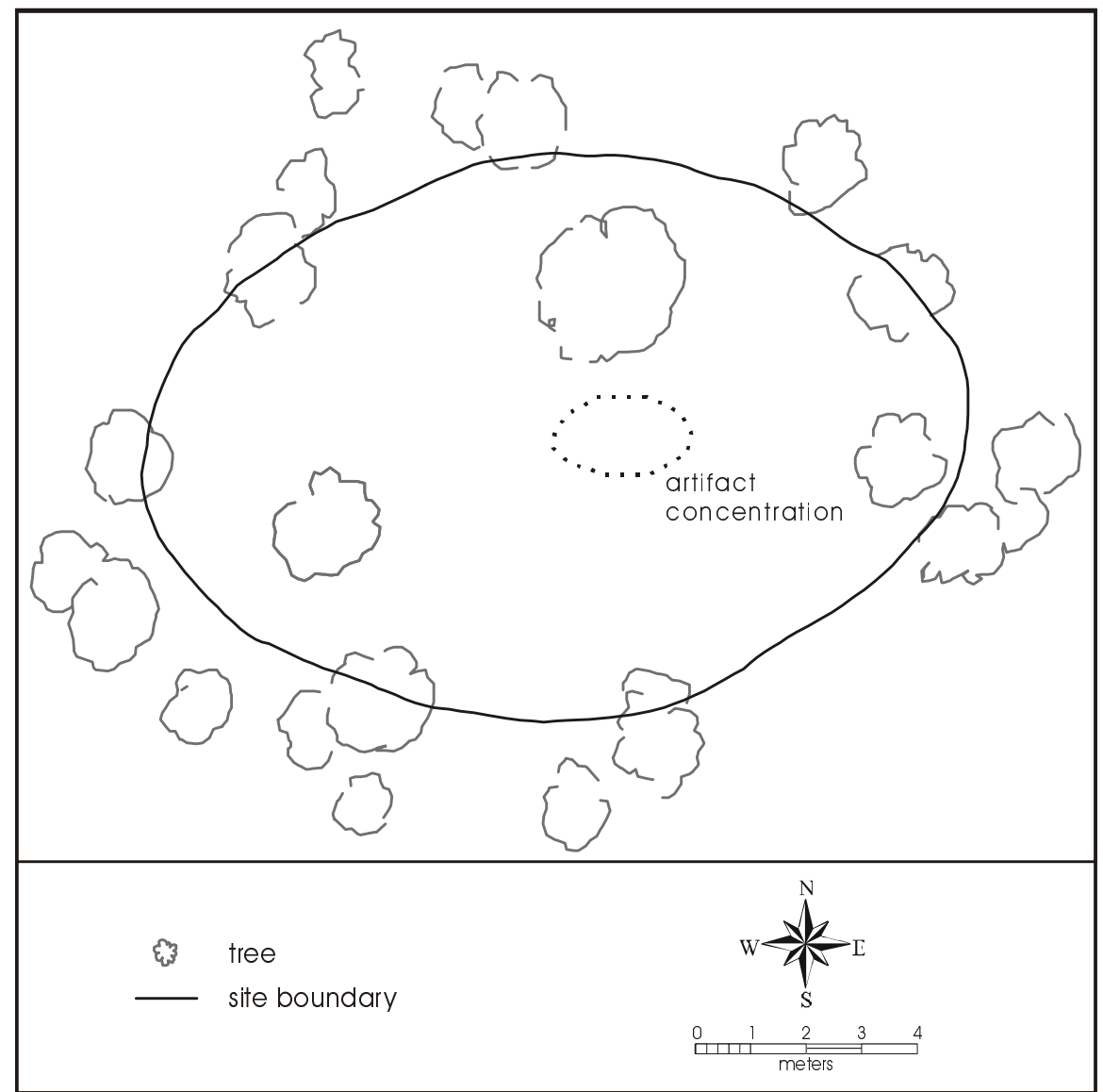

Figure 57. Map of 41 BP502.

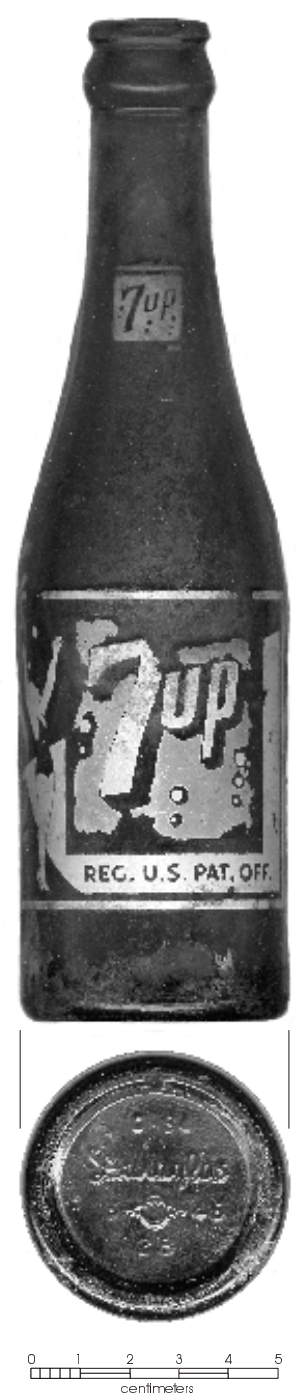

Figure 58. 7-up bottle from 41BP502.

Shown $1 / 2$ actual size. 


\section{$41 B P 503$}

\section{Site Type:}

Historic trash dump

\section{Site Size:}

$50 \mathrm{~m}^{2}$, determined by surface inspection (Figure 59)

\section{Topographic Setting:}

Upper drainage-divided slopes

\section{Description:}

Site 41BP503 is a historic trash scatter located in woodlands about $200 \mathrm{~m}$ east of Highway 95 and $400 \mathrm{~m}$ north of the Pipeline Road. Oak and cedar are the floral dominants, with $20 \%$ surface visibility. The site is on Demona loamy fine sand.

\section{Investigation:}

The field crew inspected the site surface, which was sufficient to determine that the site consists of a low-density scatter of historic trash in an area $5 \mathrm{~m}$ north/south by $10 \mathrm{~m}$ east/west, or $50 \mathrm{~m}^{2}$.

\section{Results:}

Artifacts observed on the surface include eight metal cans and nine glass bottles. Maker's marks date between 1905 and 1956. The property owners immediately before the creation of Camp Swift were Florence Woods and others, but most of the trash assemblage suggests deposition by the military since World War II. No features were observed.

\section{Artifacts:}

One artifact was collected: (Specimen 503-118), a rectangular, colorless glass, machine-made bottle with "Castoria/ Cha. H. Fletcher" embossed on the side panels. The embossing on the bottom is typical of bottles produced by the Pierce Glass Company from about 1905 to 1917 (Toulouse 1971:412).

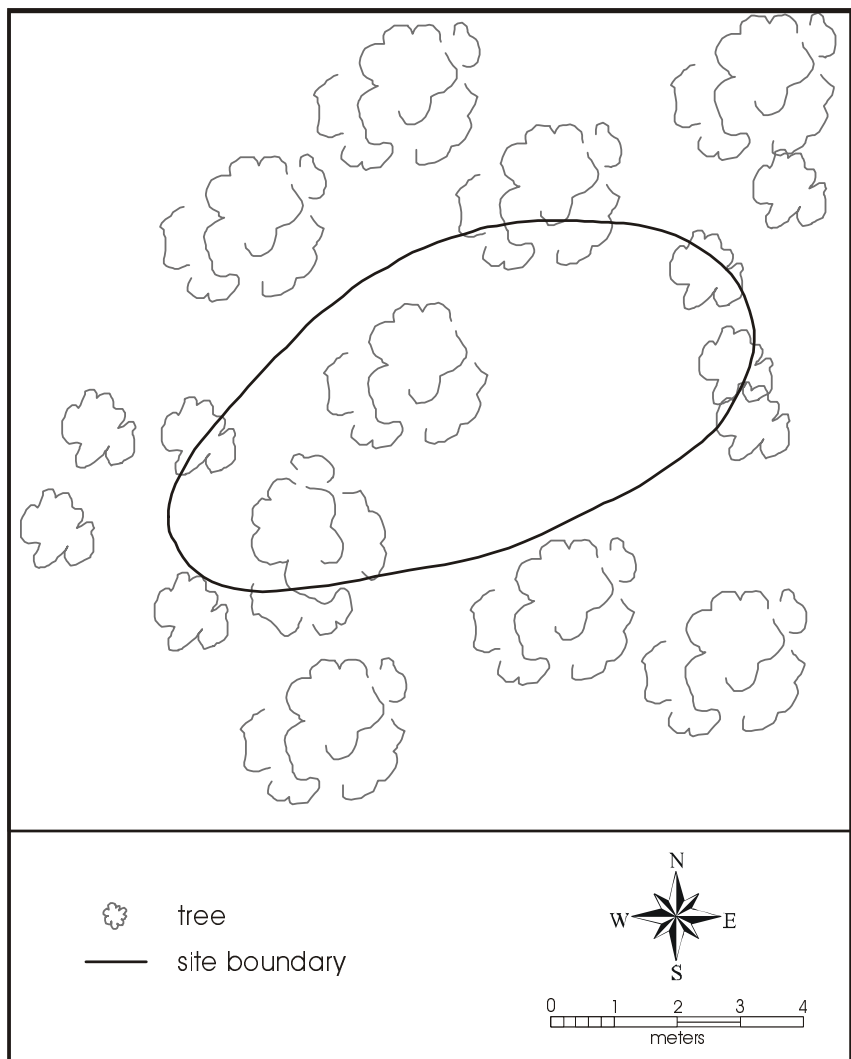

Figure 59. Map of 41BP503. 


\section{BP504}

\section{Site Type:}

Historic trash dump

Site Size:

$500 \mathrm{~m}^{2}$, determined by inspection of site's surface and gully (Figure 60)

\section{Topographic Setting:}

Upper drainage-divided slopes

\section{Description:}

Site 41BP504 is a historic trash dump located at the head of a gully near mixed woodlands and open fields approximately $150 \mathrm{~m}$ south of a pipeline road. Oak, cedar, domesticated grasses, and invader herbaceous species comprise the floral assemblage, with $75 \%$ surface visibility. The site is on Crockett soils. Many items of the dump are eroding down the gully.

\section{Investigation:}

The field crew inspected the site surface and the gully. This was sufficient to determine that the site consists of historic trash scattered over an area $10 \mathrm{~m}$ northeast/southwest by $50 \mathrm{~m}$ northwest/southeast, or $500 \mathrm{~m}^{2}$.

\section{Results:}

Cultural materials at the site consist of a wide variety of medium density domestic trash. These include one kerosene lamp, one metal skillet, one bed spring, about 15 pieces of colorless, green, blue, and brown bottle and jar glass, about ten pieces of transfer print ceramics, about five pieces of Bakelite, about five auto license plates, ceramic bottles and jars, and a rubber shoe sole. There is also a $12 \mathrm{~m}$ diameter mechanically formed mound of dirt and brush. Maker's marks date since 1925, since 1927, between 1920 and 1964, and between 1929 and 1954. License plate dates are 1931, 1932, 1934, 1936, and 1939. The property owners before Camp Swift are not currently known. This dump may be associated with a pre-Camp Swift habitation site, although no evidence of any such habitation was found. No features were observed.

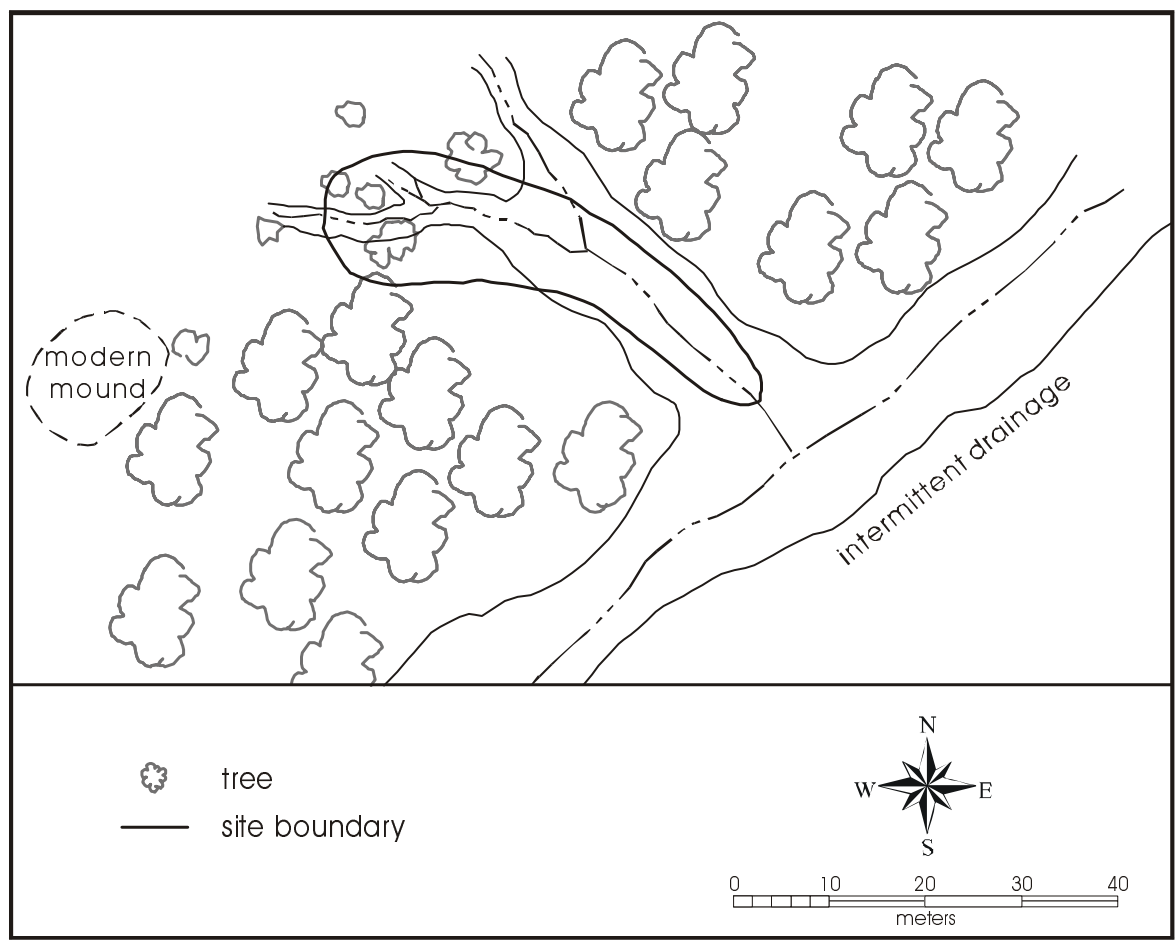

Figure 60. Map of $41 B P 504$. 


\section{Artifacts:}

A sample of four artifacts was collected.

- Specimen 504-135 is a fragment of a whiteware bowl with a decal decoration. Decal-decorated ceramics began in the 1850s and continued through the early twentieth century (Durrenburger 1965:21).

- Specimen 504-134 is a whiteware cup fragment, transfer-decorated in the tradition of Chinese porcelain. This is a late, very cheap version of an old pattern (A. Fox, personal communication 2001).

- Specimen 504-133 is a fragment of the oval base of a small whiteware dish, possibly a gravy boat (Figure 61a). The Homer Laughlin maker's mark lists the pattern name "Genesee." This pattern dates to about 1915 (Gates and Ormerod 1982:134).

- Specimen 504-132 is a whiteware plate fragment with a Homer Laughlin maker's mark (Figure 61b). The maker's mark indicates the plate was made in 1934 (Gates and Ormerod 1982:138).
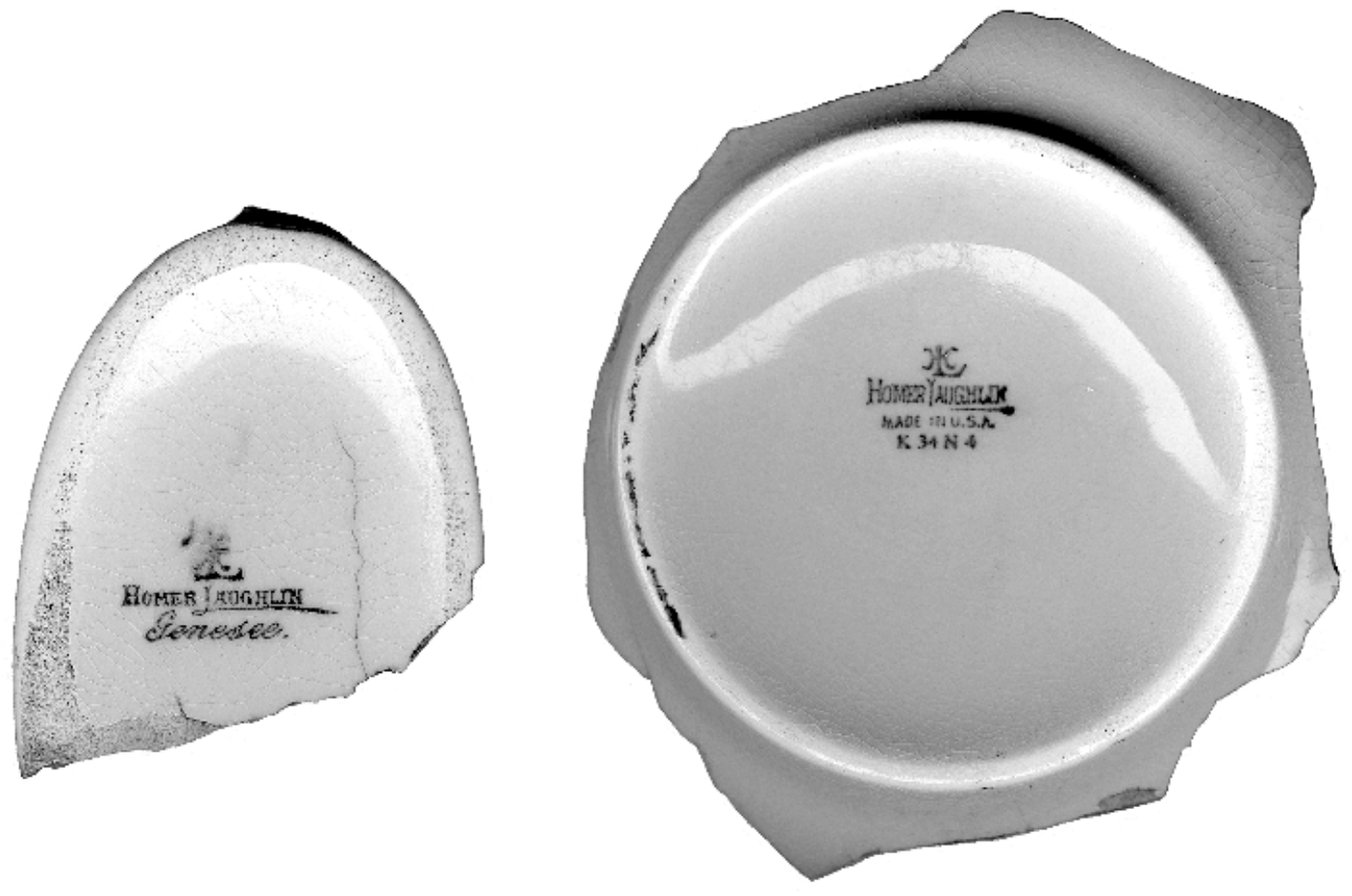

a

b

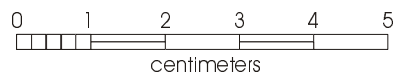

Figure 61. Maker's marks from two whiteware ceramic fragments: a) dated 1915; b) dated 1934. Shown $3 / 4$ actual size. 


\section{BP507}

\section{Site Type:}

Historic trash dump

Site Size:

$200 \mathrm{~m}^{2}$, determined by a shovel test and surface inspection (Figure 62)

\section{Topographic Setting:}

Drainage-divided upland

\section{Description:}

Site 41BP507 is a historic trash dump located in woodlands approximately $200 \mathrm{~m}$ east of a powerline road. Oak, cedar, and prickly pear cactus are the dominant ground cover, with $10-20 \%$ surface visibility. The site is on Axtell fine sandy loam.

\section{Investigation:}

The crew excavated one shovel test, which was sterile, and inspected the site's surface. This was sufficient to determine that the site consists of a low-density surface scatter of historic artifacts in an area 20 m northwest/ southeast by $10 \mathrm{~m}$ northeast/southwest, or $200 \mathrm{~m}^{2}$.

\section{Results:}

Artifacts found include a brown glass bottle, a Pepsi-Cola bottle, cans opened with puncture-type openers, sheet metal, cream colored brick, tar paper roofing fragments, and asbestos siding. The one shovel test excavated was sterile. One maker's mark shows manufacture in 1946; otherwise, the materials and character of the dump suggest origin before the creation of Camp Swift. Property ownership before Camp Swift is not currently known. The site has no identifiable features or remains of structures nearby.

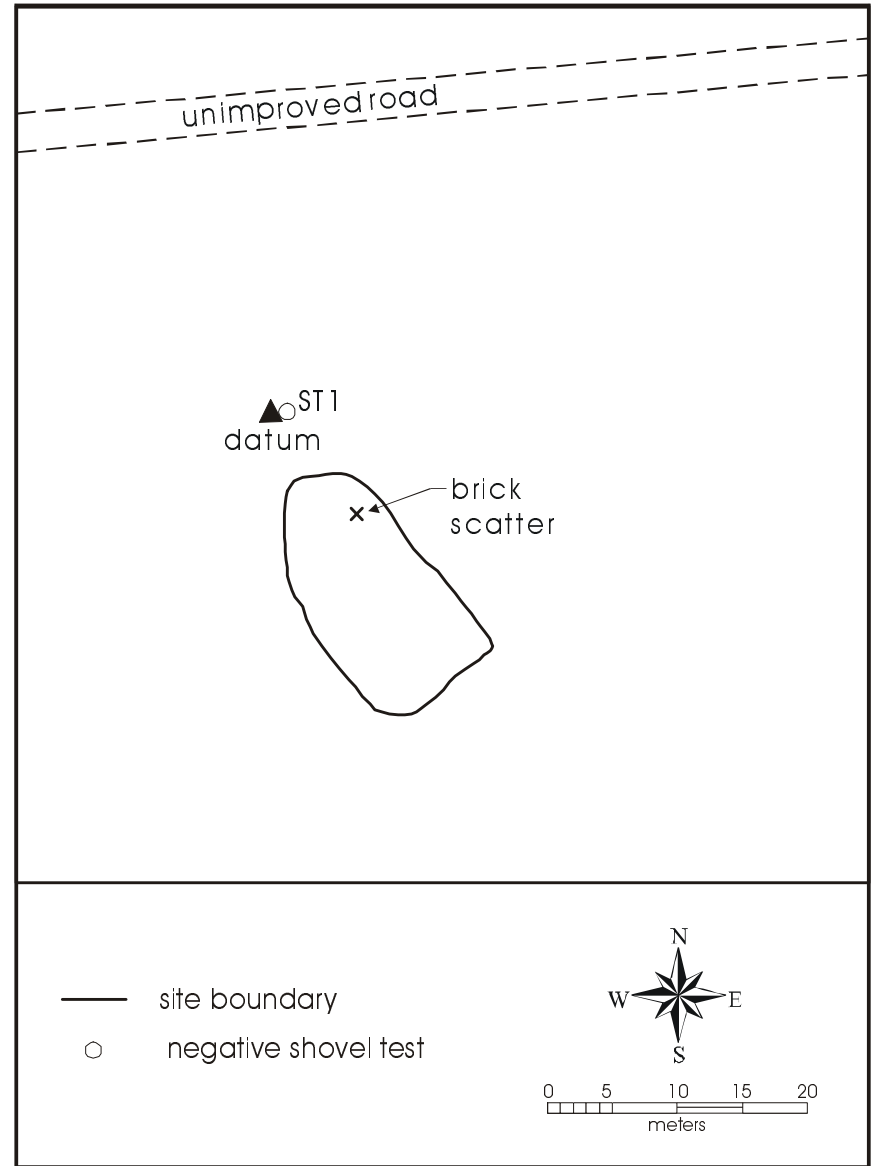

Figure 62. Map of $41 B P 507$. 


\section{BP508}

\section{Site Type:}

Historic agricultural installation

\section{Site Size:}

$800 \mathrm{~m}^{2}$ (Figure 63)

\section{Topographic Setting:}

Wooded drainage divides

\section{Description:}

Site 41BP508 is a historic trash dump and pen located on wooded upper slopes ca. $150 \mathrm{~m}$ east of the powerline road. The setting is a wooded upper drainage-divided slope, with oak, cedar, and prickly pear cactus the dominant vegetation on-site. Surface visibility at the time of survey was $10-20 \%$. The soil is Axtell fine sandy loam. The site is a late historic agricultural installation, primarily an animal holding pen and associated trash. The pen retains some integrity in that its structure and functioning remain identifiable, but debris from the midden is eroding downslope and the fencing is beaten-down and unusable.

\section{Investigation:}

The eligibility of the site was based on ground surface inspection. This was sufficient to characterize the site because the site consists of a surface scatter of historic artifacts and the animal holding pen. The site boundary determined by distribution of cultural material was $40 \mathrm{~m}$ north/south by $20 \mathrm{~m}$ east/west, or $800 \mathrm{~m}^{2}$. Up-slope of the midden is a post-and-hogwire pen. Wedged under the fencing and wired to it is a curved slab of sheet metal, which probably functioned as a feeding trough, likely for penned hogs.

\section{Results:}

Within the site, two patent medicine bottles, one Ball mason jar, one green glass bottle, one whiskey bottle, tin cans, sheet metal, wire, and various miscellaneous bottle fragments were observed on the site surface. Maker's marks date since 1925, between 1911 and 1929, between 1924 and 1968, between 1929 and 1954, between 1933 and 1964, 1947, and 1957. No artifacts were retrieved subsurface. There was a medium density of surface artifacts based on observations and counts in the downslope dump. The site has been disturbed by erosion and military training activity and retains no integrity. The survey and recording, however, have established the site as a single-component late historic agricultural installation. The character of the site suggests formation before Camp Swift, but some of the makers' marks indicate contributions to the midden after the establishment of the camp. Property ownership prior to Camp Swift is currently unknown.

\section{Artifacts:}

A two bottles were collected as a sample.

- Specimen 508-153 is a colorless glass, one-pint whiskey bottle, intended for a screw cap. The bottle was made by the Obear-Nester Glass Co. (Toulouse 1971:373-374). Embossed on the shoulder is "FULL PINT." On the other side is "FEDERAL LAW FORBIDS SALE/OR RE-USE OF THIS BOTTLE." This dates the bottle between the end of Prohibition in 1934 and the late 1960s (Munsey 970:124).

- Specimen 508-154 is a round, colorless glass bottle, intended for a cork closure, with “MRS. STEWART'S BLUEING" embossed on the shoulder. The bottle was made by Owens Illinois sometime after 1929 (Toulouse 1971:403). 


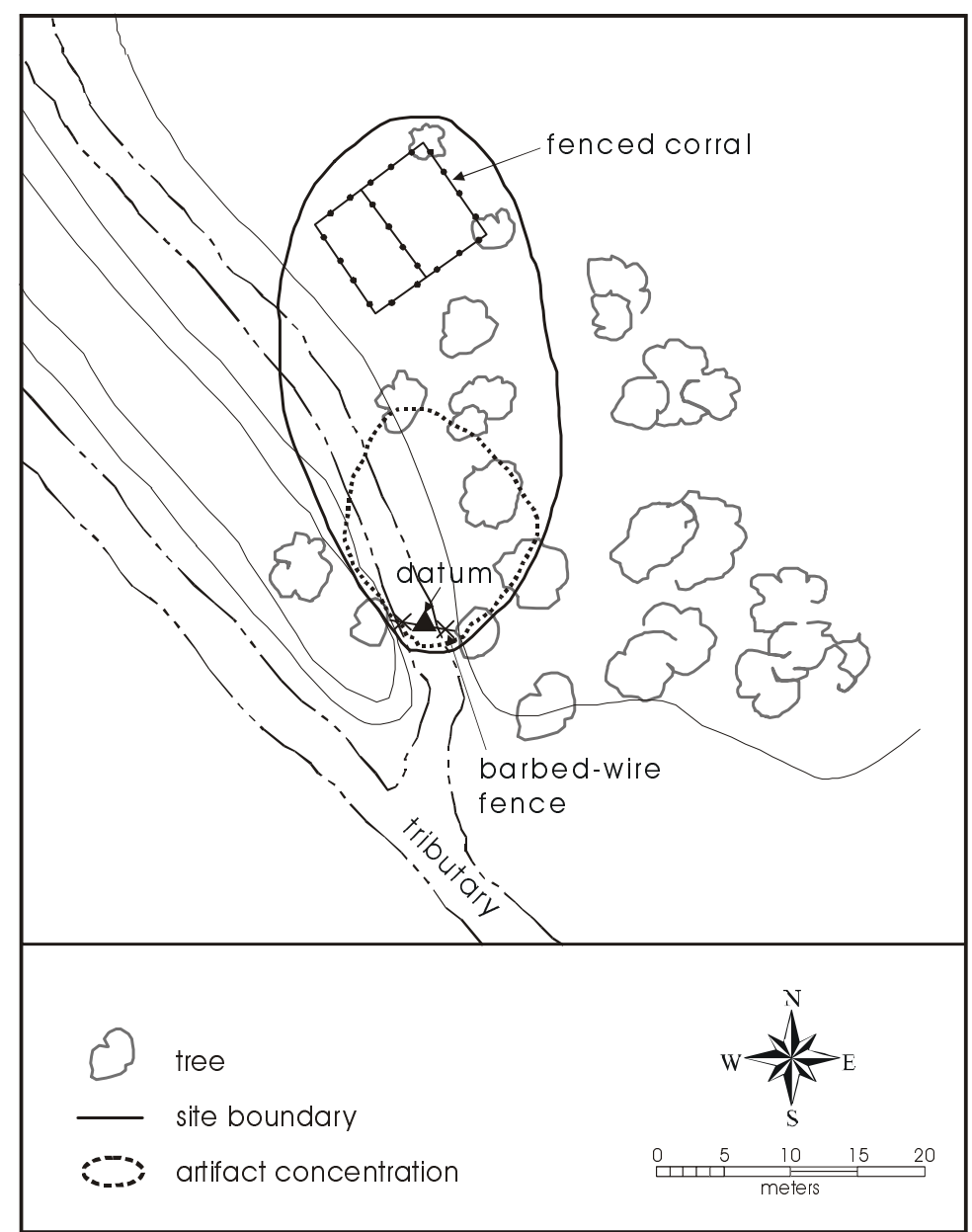

Figure 63. Map of 41BP508. 


\section{BP511}

\section{Site Type:}

Historic habitation site

Site Size:

$800 \mathrm{~m}^{2}$, determined by a shovel test and surface inspection (Figure 64)

\section{Topographic Setting:}

Upper drainage divides

\section{Description:}

Site 41BP511 is a historic habitation site on wooded upland slopes approximately $50 \mathrm{~m}$ east of a powerline road. Oak, cedar, and domesticated grasses are the dominant ground cover, with $60-70 \%$ surface visibility. The soil is Demona loamy fine sand. The site has been extensively disturbed by military activities.

\section{Investigation:}

The field crew excavated one positive shovel test and two sterile shovel probes and also inspected the site's surface. This was sufficient to determine that the site consists of a moderate density of historic debris scattered over an area $40 \mathrm{~m}$ east/west by $20 \mathrm{~m}$ north/south, or $800 \mathrm{~m}^{2}$.

\section{Results:}

Artifacts found include whiteware and stoneware ceramics, window glass, metal cans, wire, cut nails, and an enamel washbasin. Also observed were colorless glass fragments that had a distinct amethyst tint. Clear glass made with manganese will turn an amethyst color if left in the sun for an extended period. Manganese was used to make clear glass largely between about 1880 to 1915 (Munsey 1970:55-56). The amethyst glass and window glass were retrieved from $0-60 \mathrm{~cm}$ below ground surface (Table 25). The site also has an alignment of undressed sandstone blocks that may mark the site of a pre-Camp Swift structure, since removed or destroyed by the advanced military disturbance on the site. No other features were observed. The ownership of the site before Camp Swift is currently unknown. 


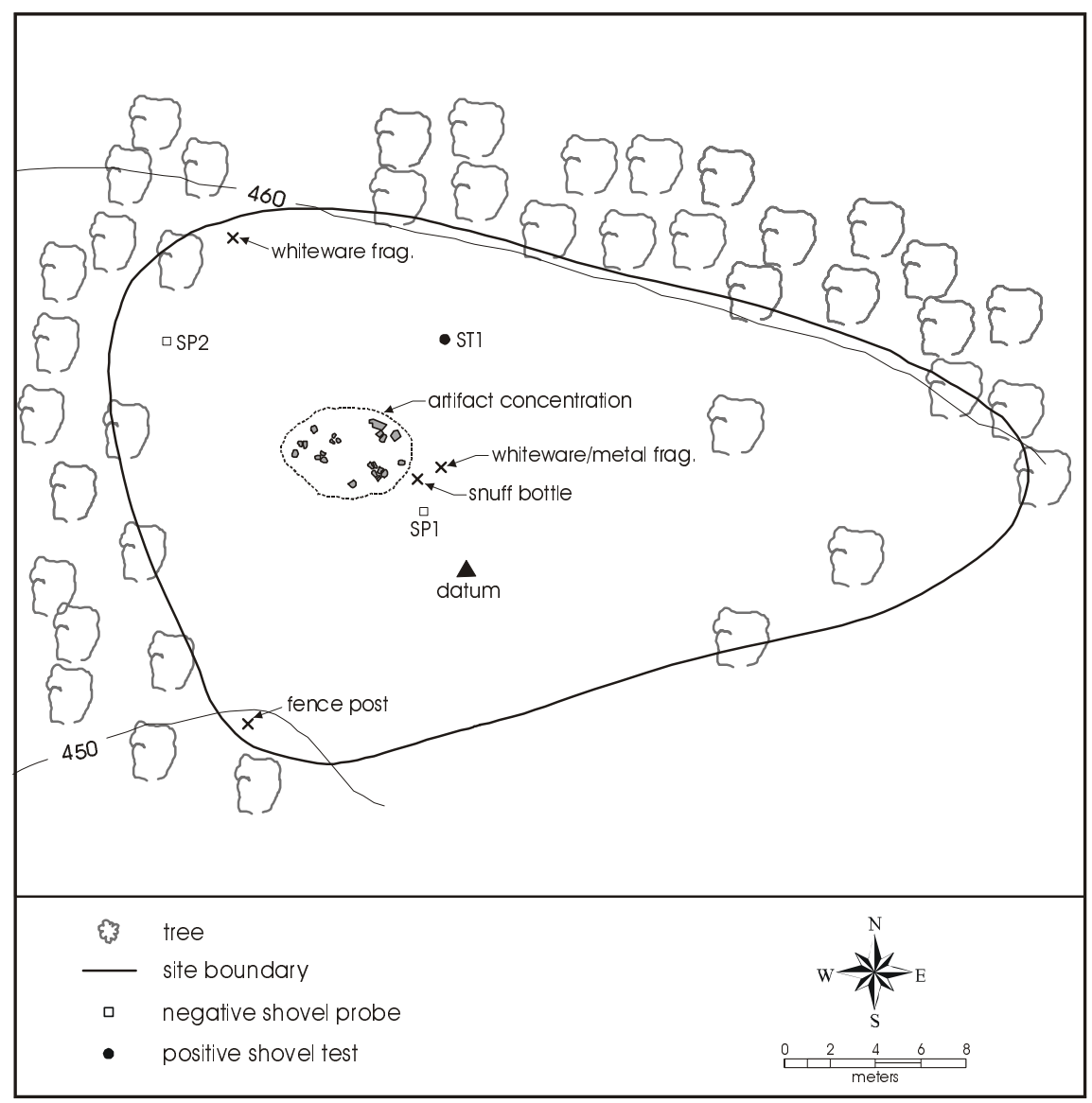

Figure 64. Map of 41 BP511.

Table 25. Artifacts from 41BP511

\begin{tabular}{|c|c|c|}
\hline Unit & Depth (cm) & Observations \\
\hline Surface & -- & $\begin{array}{l}\text { whiteware and stoneware, } \\
\text { ceramics, window glass, } \\
\text { amethyst glass, metal cans, } \\
\text { wire, cut nails, enamel } \\
\text { washbasin }\end{array}$ \\
\hline \multirow[t]{4}{*}{ ST-1 } & $0-20$ & $\begin{array}{l}3 \text { amethyst bottle fragments, } \\
1 \text { colorless window glass } \\
\text { fragment }\end{array}$ \\
\hline & $20-40$ & -- \\
\hline & $40-60$ & $\begin{array}{l}1 \text { whiteware fragment } \\
2 \text { clear glass fragments }\end{array}$ \\
\hline & $60-85$ & -- \\
\hline
\end{tabular}




\section{$41 B P 513$}

\section{Site Type:}

Historic habitation site

Site Size:

2,400 $\mathrm{m}^{2}$, determined by a shovel test, surface inspection, and natural landforms (Figure 63)

\section{Topographic Setting:}

Nearly flat drainage divide

\section{Description:}

Site 41BP513 is a historic habitation site located on a cleared hilltop approximately one kilometer east of Gate 10. Domesticated grasses and herbaceous invader species of shrubs are the dominant ground cover, with 5-10\% surface visibility. The site is on Demona loamy fine sand.

\section{Investigation:}

The field crew excavated one shovel test, which contained cultural material to $20 \mathrm{~cm}$ below surface. One sterile shovel probe was also excavated, and the crew inspected the ground surface. This was sufficient to determine that the site consists of low-density scatter of historic artifacts in an area $60 \mathrm{~m}$ east/west by $40 \mathrm{~m}$ north/south, or $2,400 \mathrm{~m}^{2}$.

\section{Results:}

Artifacts found on the surface include bricks, limestone footing stones, two glass bottles, and one snuff bottle base. The shovel test contained a brown snuff bottle base, and two bottle necks at a depth of $20 \mathrm{~cm}$ below surface (Table 26). The site has a possible house depression, but one unmarked by foundation stones. The owners might have been among those who demolished and removed their domiciles after sale to the War Department (see discussion in Chapter 2); this interpretation cannot be confirmed, but it accounts for the relative lack of domestic and architectural debris on the site. Lonnie Lane and others owned the property prior to the creation of Camp Swift.

\section{Artifacts:}

Three artifacts were recovered from the shovel test.

- Specimen 513-171-3 is a colorless glass bottle neck, sun-stained amethyst (Figure 66a). The bottle was blown in a mold, with an applied lip, finished with a finishing tool. The bottle was either a large medicine bottle or a liquor bottle, intended for a cork closure. It was most likely made sometime between about 1880 and 1903 (Munsey 1970:55-56).

- Specimen 513-171-2 is an aqua bottle neck with an applied lip, finished with a finishing tool (Figure 66b). The bottle was made sometime between about 1840 and 1903, probably used as a liquor bottle, and was intended for a cork closure.

- Specimen 513-171-1 brown snuff bottle base, $5.3 \mathrm{~cm}$ square. The bottle was blown in a mold, but was probably not machine-made. There are no maker's marks on the bottom.

Table 26. Artifacts from 41BP513

\begin{tabular}{|ccl|}
\hline Unit & Depth (cm) & \multicolumn{1}{c|}{ Observations } \\
& & \\
\hline Surface & -- & whiteware, metal \\
& & frags., bricks, \\
& & limestone footings, \\
& snuff bottle, 2 glass \\
& & bottles \\
& & 1 brown snuff bottle \\
ST-1 & $0-20$ & base \\
& & 1 green glass bottle \\
& & neck \\
& & 1 amethyst bottle \\
& & neck \\
& & -- \\
& &
\end{tabular}




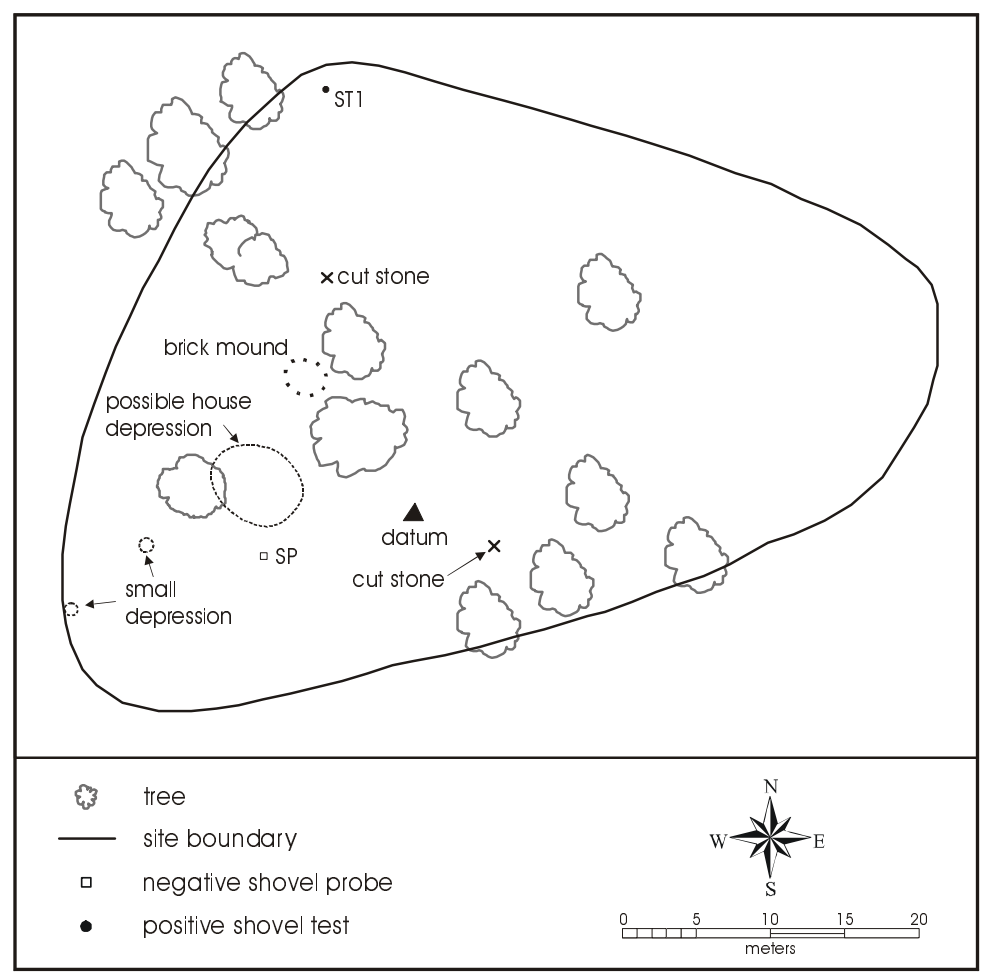

Figure 65. Map of 41BP513.
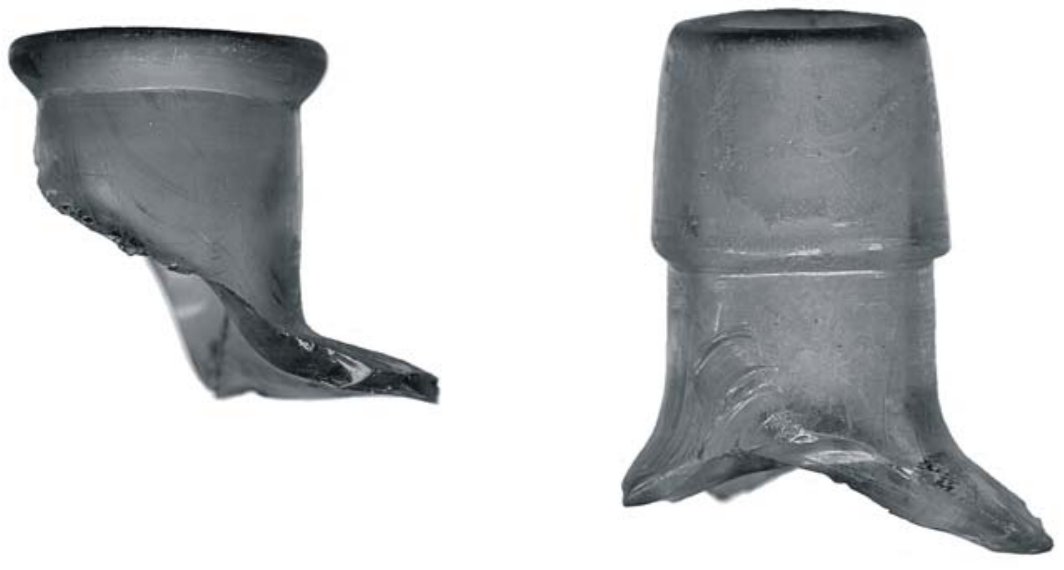

a

b

$\begin{array}{lllll}0 & 1 & 2 & 3 & 4\end{array}$

Figure 66. Glass bottle necks from 41BP513: a) clear-amethyst bottle neck with medicine type finish; b) aqua bottle neck with liquor type finish. 


\section{$41 B P 514$}

\section{Site Type:}

Historic agricultural installation

Site Size:

$119 \mathrm{~m}^{2}$, determined by the extent of artifacts and features observed at the site (Figure 67)

\section{Topographic Setting:}

Upper stream slopes

\section{Description:}

Site 41BP514 is a historic well site located in an open field with tree regrowth approximately $300 \mathrm{~m}$ west of FM 2336. The setting is upper stream slopes, with oak, hackberry, domesticated and native grasses, greenbriar, and herbaceous invader species comprising the local plant community. Ground surface visibility at the time of survey was $10 \%$. The site is on Demona loamy fine sand.

\section{Investigation:}

The crew conducted ground surface inspection at the site. This was sufficient to characterize the site as a well and possible trough site associated with a light scatter of surface artifacts scattered over an area $7 \mathrm{~m}$ northwest/ southeast by $17 \mathrm{~m}$ northeast/southwest, or $119 \mathrm{~m}^{2}$. No subsurface testing was conducted.

\section{Results:}

Artifacts observed on the site surface included bricks, metal cans, sawed lumber fragments, barbed wire, a tin bucket, and a brick watering trough. The hand-dug, brick-lined well is inscribed with the date "9-10-34" in the exterior mortar. The possible date and style of the well suggest that it may have been built by the WPA as a ranch improvement. Such wells could be located anywhere on a property, at the request of the rancher. There are no other remnants or indications of other buildings nearby to suggest a habitation. The overall density of surface artifacts was low. Site functional information strongly suggested the absence of any subsurface deposits, apart from the bricklined well.

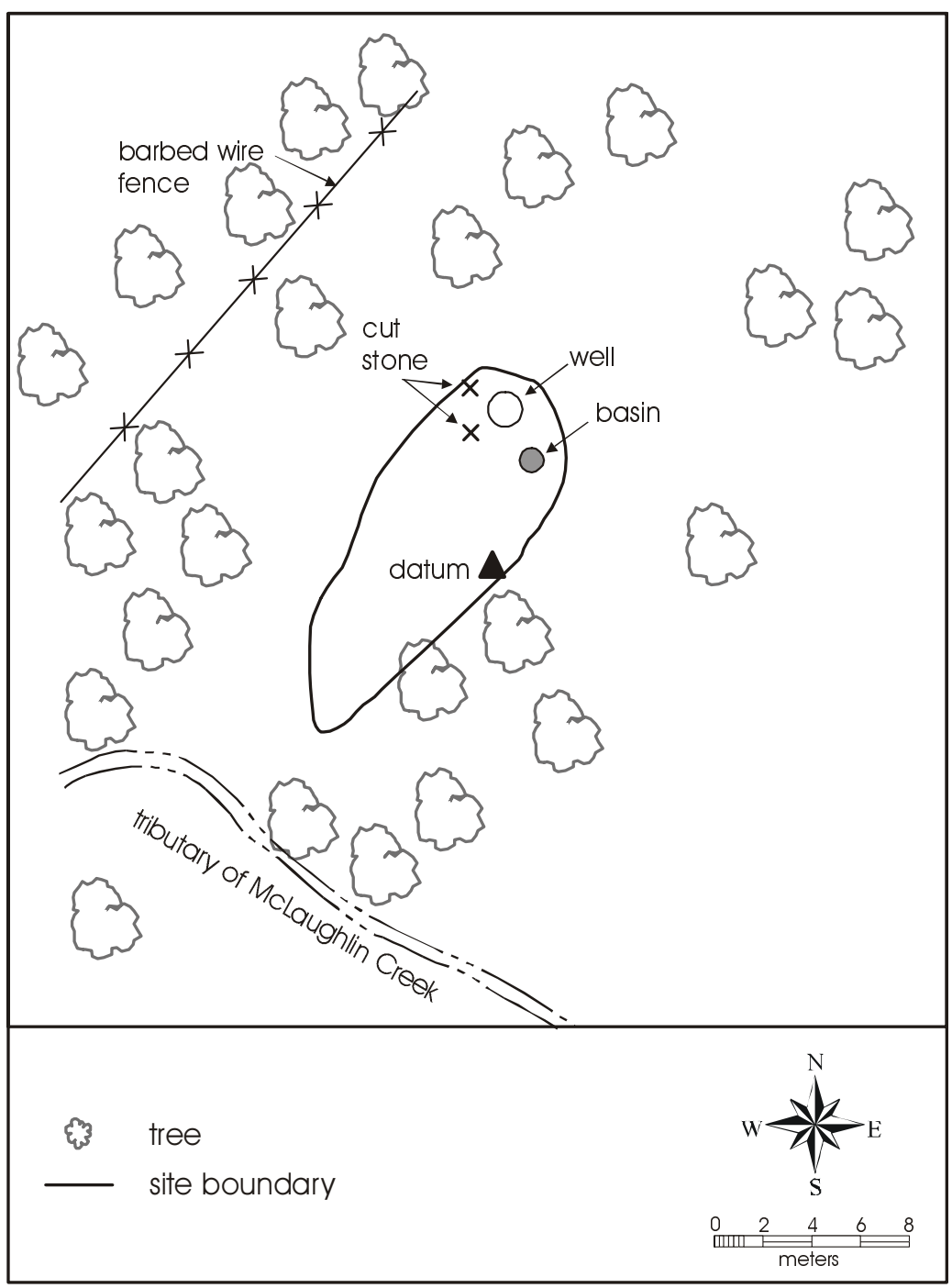

Figure 67. Map of 41BP514. 


\section{$41 B P 515$}

\section{Site Type:}

Historic trash dump

Site Size:

$6,050 \mathrm{~m}^{2}$, determined by the extent of the surface scatter of artifacts (Figure 68)

\section{Topographic Setting:}

Drainage-divided upland

Description:

Site 41BP515 is a multi-incident historic trash dump located in woodlands a few meters from the northern tip of the camp. The setting is a drainage divide upland, with oak and cedar the dominant ground cover. Ground surface visibility is $30-40 \%$. The soil type on the site is Tabor fine sandy loam.

\section{Investigation:}

The crew conducted ground surface inspection, which included the examination of rills and gullies. Based on these inspections the boundaries of the site were determined by the surface distribution of four historic trash concentrations. The overall site was determined to be $110 \mathrm{~m}$ northwest/southeast by $55 \mathrm{~m} \mathrm{north} / \mathrm{south}$, or $6,050 \mathrm{~m}^{2}$.

\section{Results:}

The artifacts observed at the site are patterned in four widely dispersed concentrations and appear to date to the mid twentieth century. Artifacts included more than 150 tin cans, eight bottles and fragments, ten glass canning jars and fragments, two shoe soles, two bricks, two paint cans, and a cement fragment. Maker's marks dated between 1929 and 1954. No artifacts were collected from the site. There was a high density of surface artifacts in the primary dumping spots, based on observations and counts. Local natural processes are dispersing the dump materials across the surface downhill. No associated structures or other constructions were observed at the site. Property ownership just prior to Camp Swift is unknown at present. Examination of nearby rills and gully cutbanks showed no subsurface burial of the recent artifacts.

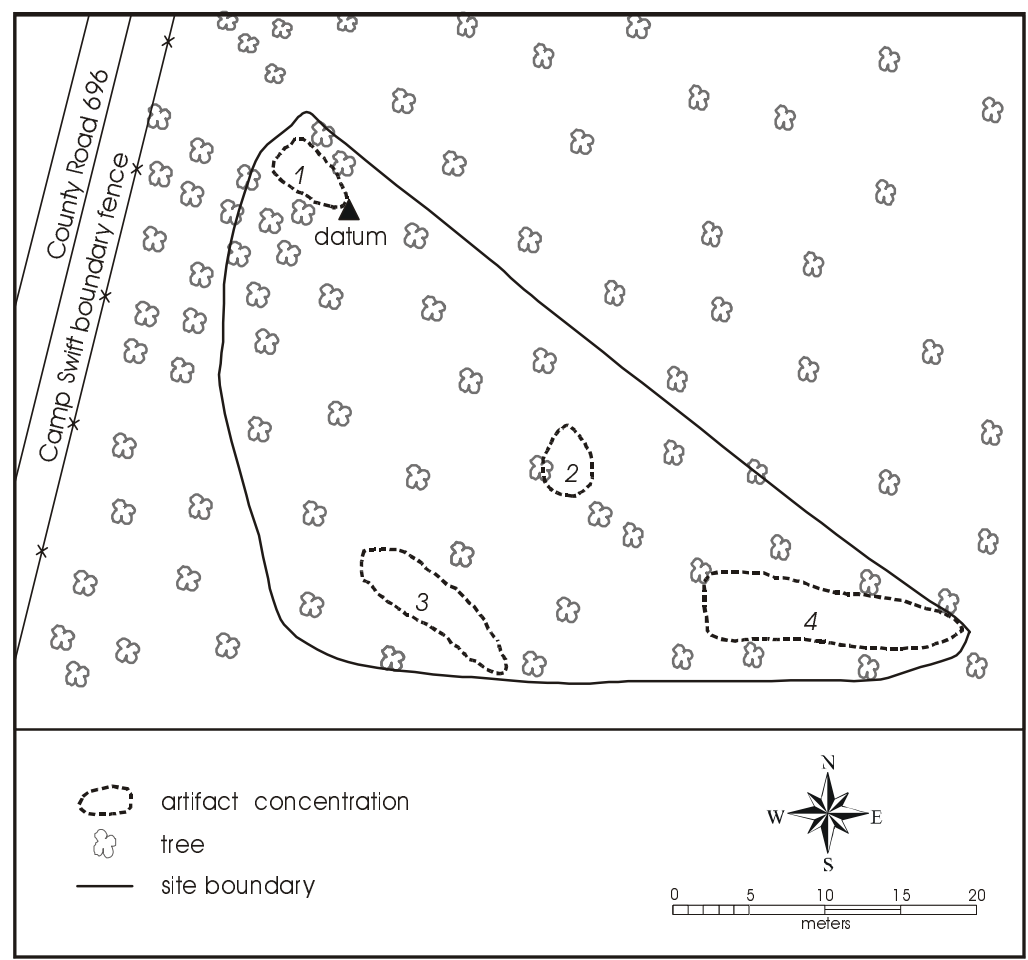

Figure 68. Map of 41BP515. 


\section{$41 B P 516$}

\section{Site Type:}

Historic agricultural installation

Site Size:

$12 \mathrm{~m}^{2}$, determined by site surface inspection (Figure 69)

\section{Topographic Setting:}

Stream floodplain

\section{Description:}

Site 41BP516 is a historic well and possible trough site located in wooded stream lowlands approximately 200 $\mathrm{m}$ west of FM 2336. The setting is a stream floodplain between two unnamed tributaries of McLaughlin Creek, with oak, cedar, and greenbriar the dominant ground cover. The soil type on the site is Sayers fine sandy loam.

Investigation:

The field crew inspected the surface of the site. The site has a hand-dug, brick-lined well and a possible brick watering trough. The site boundary is roughly circular, encompassing an area of approximately $4 \mathrm{~m}$ by $3 \mathrm{~m}$, or $12 \mathrm{~m}^{2}$. Within the site, no artifacts were observed in association with the well and trough. The site's property ownership when purchased for Camp Swift is not known at present. Site surface observations suggested no subsurface cultural material other than the wood and wire remains of the well superstructure.

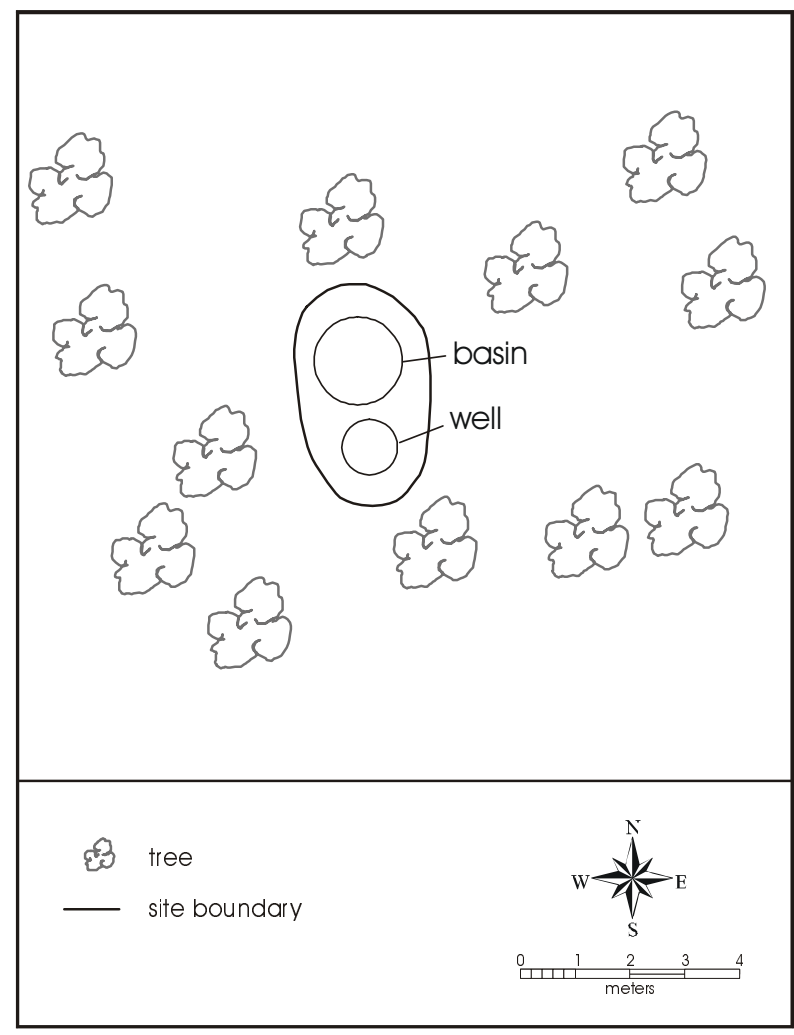

Figure 69. Map of $41 B P 516$. 


\section{BP517}

\section{Site Type:}

Historic trash scatter

Site Size:

$5,400 \mathrm{~m}^{2}$, determined by the extent of surface artifact scatter (Figure 70)

\section{Topographic Setting:}

Stream-divided uplands

\section{Description:}

Site 41BP517 is a historic trash scatter located in a cleared field approximately $50 \mathrm{~m}$ west of the eastern boundary fence of the camp. The setting is stream-divided uplands, with oak and cedar the dominant ground cover. Ground surface visibility is $30-40 \%$. The soil at the site is Axtell fine sandy loam.

\section{Investigation:}

The field crew conducted a site surface inspection. This surface inspection was sufficient to determine that the site consisted of a surface scatter of artifacts over an area of $120 \mathrm{~m}$ northwest/southeast by $45 \mathrm{~m}$ northeast/ southwest, or $5,400 \mathrm{~m}^{2}$.

\section{Results:}

The artifacts identified at the site appear to date to the early twentieth century. Within the site, colorless glass bottles, metal cans, and barbed-wire were observed on the site surface. No artifacts were retrieved from the subsurface. There was a low density of surface deposits, based on observations. The property ownership prior to the establishment of Camp Swift is currently unknown. No evidence of buried deposits was observed at the site.

\section{Artifacts:}

A single small colorless glass bottle was collected. Specimen 517-191 is three inches tall, rectangular, and machine-made. The letters "R\&G" are embossed on the front panel and a starburst design is molded on the bottom. It was intended for cork closure, and was probably some sort of cosmetics bottle.

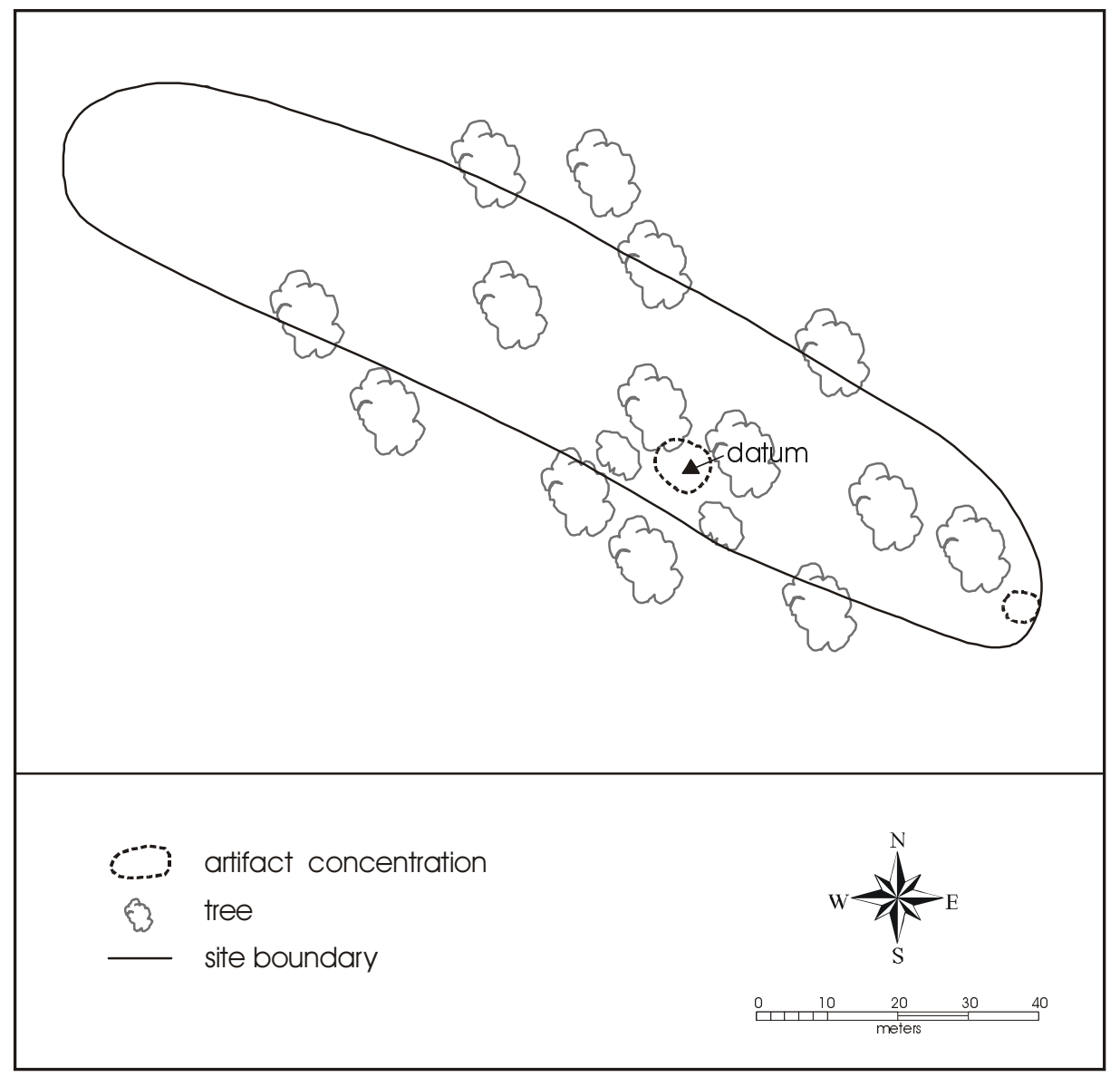

Figure 70. Map of $41 B P 517$. 


\section{$41 B P 519$}

\section{Site Type:}

Historic trash scatter

Site Size:

$100 \mathrm{~m}^{2}$, determined by the extent of the surface artifacts (Figure 71)

\section{Topographic Setting:}

Drainage divide

\section{Description:}

Site 41BP519 is a historic trash scatter located in a mixed open/wooded field near the eastern boundary fence and FM 2336. The setting is a drainage-divided slope, with oak and various domesticated and native grasses comprising the floral community. Ground surface visibility is $50 \%$. The soil type on the site is Axtell fine sandy loam.

\section{Investigation:}

The field crew conducted a ground surface inspection of the site. This inspection was sufficient to characterize the site as a single component late historic trash scatter. The site boundaries were determined by the extent of the artifact scatter to be $10 \mathrm{~m}$ by $10 \mathrm{~m}$, or $100 \mathrm{~m}^{2}$.

\section{Results:}

Artifacts identified at the site suggest an early to mid twentieth-century date for the site. These artifacts include glass bottles, whiteware, and terra cotta (flower pot) ceramics. A glass jar lid, identical to that shown in Figure 53, was collected. All artifacts observed at the site were on the site surface. There was a low density of surface artifacts based on observations and counts. The site has no associated cultural features. Property ownership before Camp Swift is unknown at present. Military training activity, severe erosion, and bioturbation have disturbed the site.

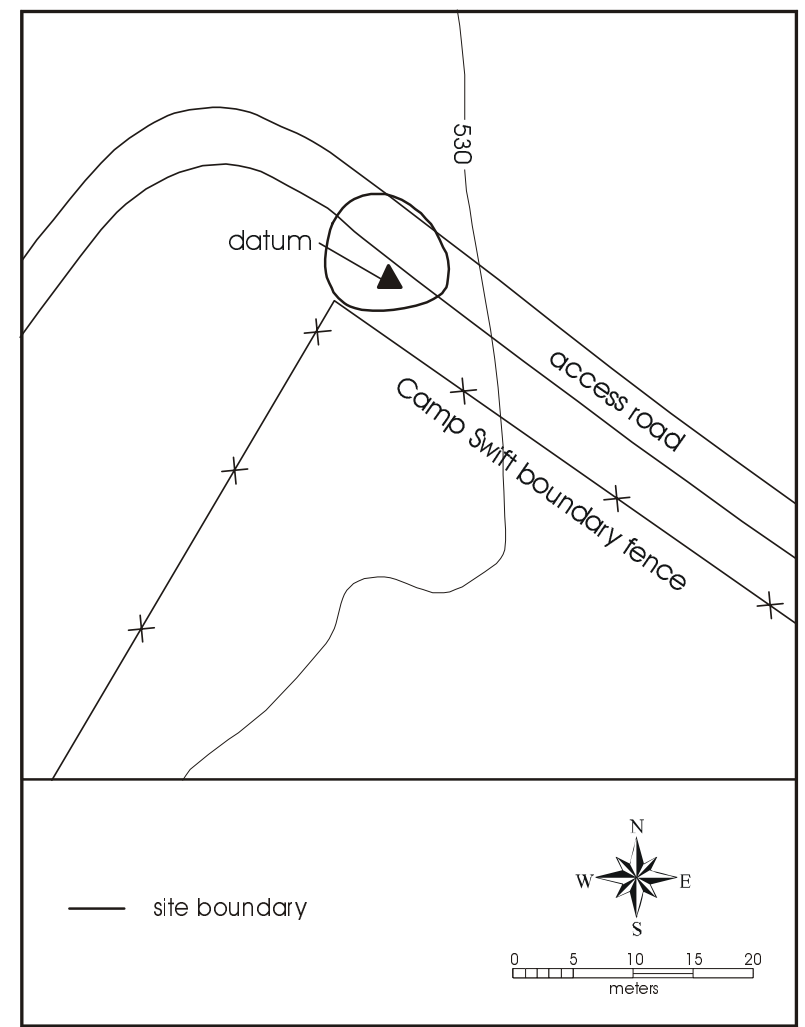

Figure 71. Map of 41BP519. 


\section{$41 B P 525$}

\section{Site Type:}

Historic habitation site

Site Size:

$7,800 \mathrm{~m}^{2}$, determined by the extent of the surface artifact scatter (Figure 72)

\section{Topographic Setting:}

Upper drainage divide

Description:

Site 41BP525 is a historic habitation site, located in oak woodlands along East Loop Road near an unnamed tributary of McLaughlin Creek. The setting is an upper drainage divide with oak, understory cactus, domesticated grasses, and herbaceous shrubs as the dominants of the plant community. Ground surface visibility is $5 \%$. The soil type on the site is Axtell fine sandy loam.

\section{Investigation:}

The field crew conducted a site surface inspection and excavated two shovel probes. Neither shovel probe contained cultural material. These investigations were sufficient to characterize 41BP525 as a single-component historic habitation site. The distribution of surface artifacts and excavation of shovel probes determined the site boundaries at $120 \mathrm{~m}$ northwest/southeast by $65 \mathrm{~m}$ east/west, or $7,800 \mathrm{~m}^{2}$.

\section{Results:}

Artifacts observed at the site appear to date to the twentieth century. In addition, one hand-dug, brick-lined well and a man-made pond were observed on the site surface. No cultural remains were retrieved from the subsurface. Observations of rills and gopher spoil suggested no subsurface accumulations. There was a medium density of surface artifacts based on these observations. Property ownership at the time of the establishment of Camp Swift is currently unknown. Artifacts observed at the surface included over ten Elgin-Butler brick fragments, one glass jar, two bottle bases (one embossed "Owens, Illinois"), window glass, shards of whiteware, and a 55-gallon drum. No artifacts were collected. Military training and bioturbation have disturbed the site.

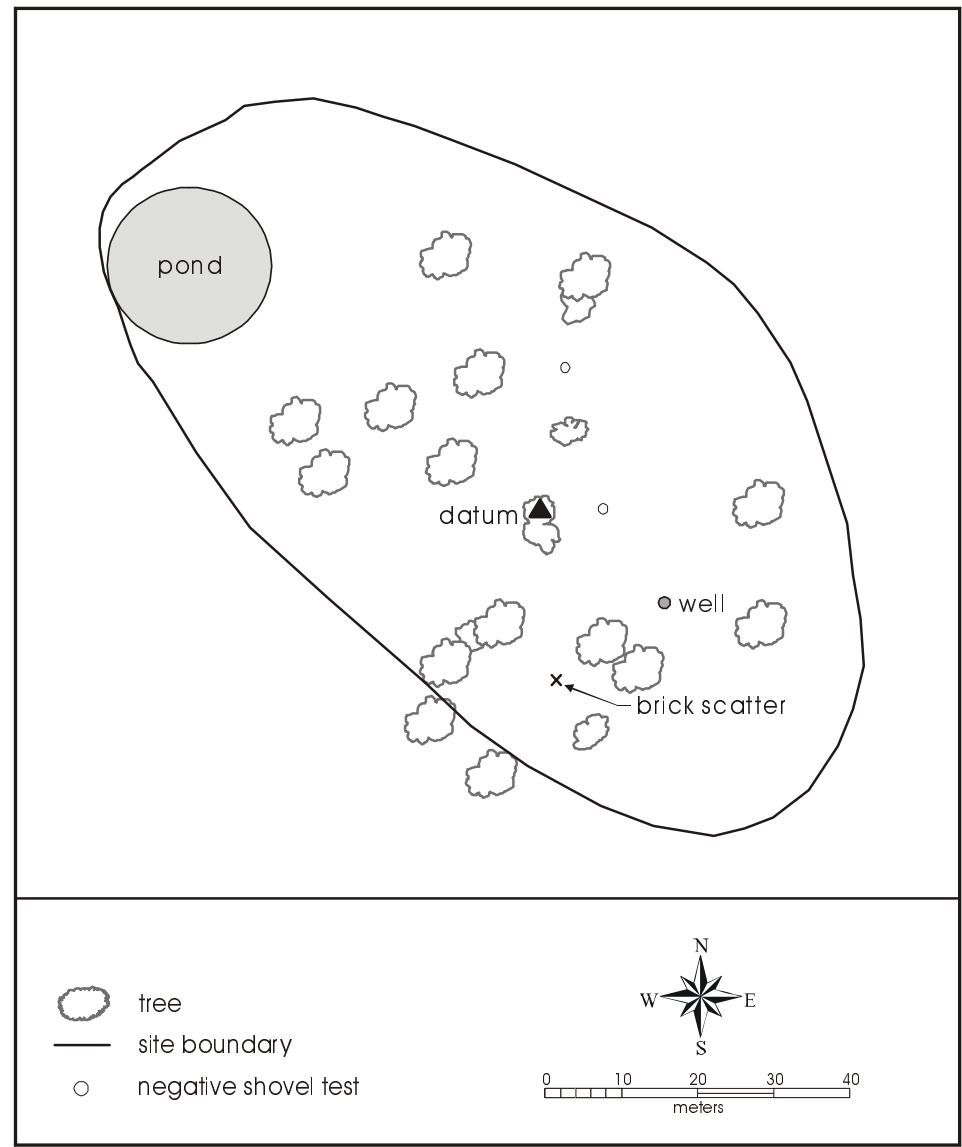

Figure 72. Map of 41BP525. 


\section{BP531}

\section{Site Type:}

Historic trash scatter

Site Size:

$3,600 \mathrm{~m}^{2}$, determined by the extent of the surface artifact scatter (Figure 73)

\section{Topographic Setting:}

Cleared upland slope

\section{Description:}

Site 41BP531 is a late historic artifact scatter located in a clearing on an upland slope. The setting is upper stream slopes, with cedar and domesticated grasses the dominants of the plant community. The soil at the site is part of the Patilo complex.

\section{Investigation:}

The field crew conducted inspection of the site surface and excavated one shovel test to a depth of $65 \mathrm{~cm}$. No cultural material was found in the shovel test. This work has established the site as a single-component historic artifact scatter on the basis of the distribution of surface artifacts. The site boundaries were determined by the distribution of artifacts and subsurface excavation, with an approximate size of $45 \mathrm{~m}$ northwest/southeast by 80 $\mathrm{m}$ northeast/southwest, or $3,600 \mathrm{~m}^{2}$.

\section{Results:}

Artifacts identified at the site are limited to the surface and appear to be from the twentieth century. Cultural materials identified included over 20 cut sandstone blocks, more than ten fragments of various colored glass, three portions of sheet metal, whiteware, three fragments of earthenware ceramics with salt glazed interiors, and five porcelain fragments. No artifacts were retrieved from the subsurface and no cultural features were observed at the site. There was a medium density of surface artifacts based on these observations and counts. Property ownership before the establishment of Camp Swift is currently unknown. The site appears to be disturbed by military training, erosion, and bioturbation.

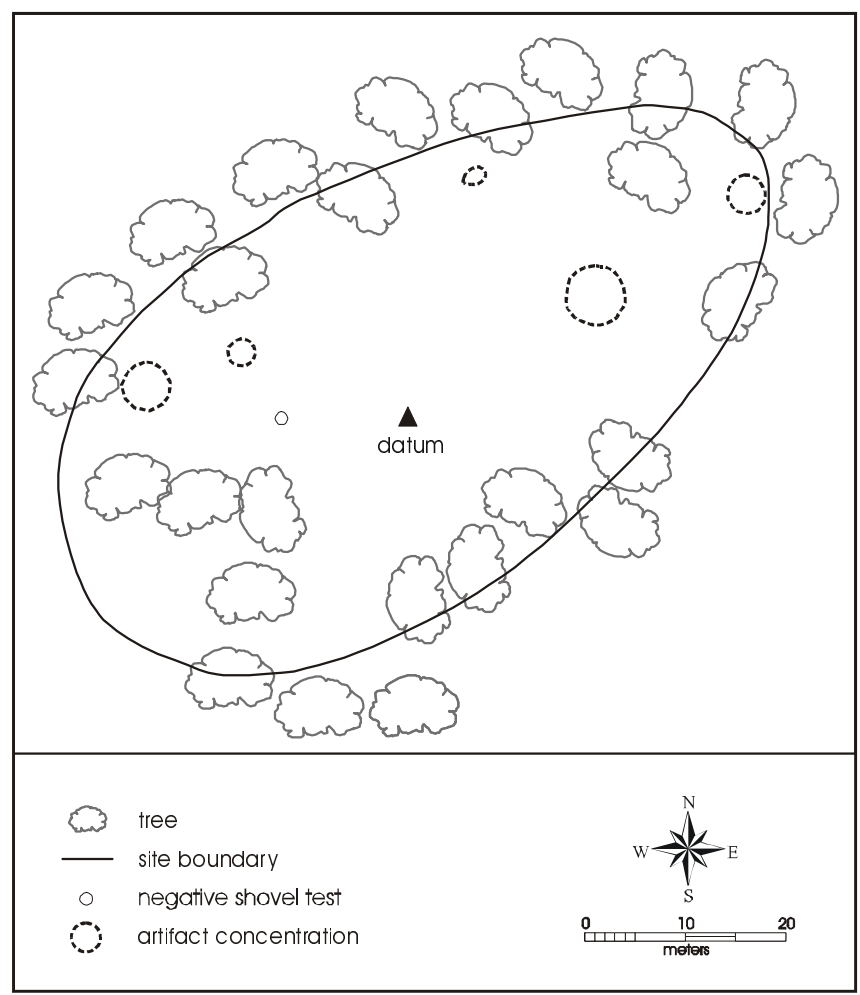

Figure 73. Map of 41BP531. 


\section{BP534}

\section{Site Type:}

Historic domestic trash dump

Site Size:

$3,990 \mathrm{~m}^{2}$, determined by the extent of the surface artifact scatter (Figure 74)

\section{Topographic Setting:}

Lower stream slopes

\section{Description:}

Site 41BP534 is a late historic domestic trash scatter located in a mixed open field and woodlands. The setting is lower stream slopes, with mixed oak-cedar woodland and understory herbaceous shrubs and grasses the principal components of the plant community. Ground surface visibility is $10-50 \%$. The site is on Patilo complex sandy loams.

\section{Investigation:}

The field crew conducted ground surface inspection of the site and the excavation of one shovel probe. This work established the site as a single-component late historic domestic trash scatter, which included possible cutstones. Inspection of the site surface established the site boundaries to be $95 \mathrm{~m}$ northeast/southwest by $42 \mathrm{~m}$ northwest/southeast, or $3,990 \mathrm{~m}^{2}$.

\section{Results:}

Artifacts observed at the site were found in a light scattering on the site surface. These artifacts include six possible cut foundation stones, one brown glass snuff bottle base, one bottle lip, six bottle and window glass fragments, one whiteware fragment, one porcelain fragment, and one amethyst plate base. No artifacts were retrieved from the subsurface. No artifacts were collected. There was a low density of surface artifacts based on these observations and counts. The site has no intact features, but the possible sandstone foundation stones and window glass suggest a former structure, destroyed or perhaps removed. Property ownership prior to the establishment of Camp Swift is currently unknown. The site appears mostly destroyed due to military training and erosion.

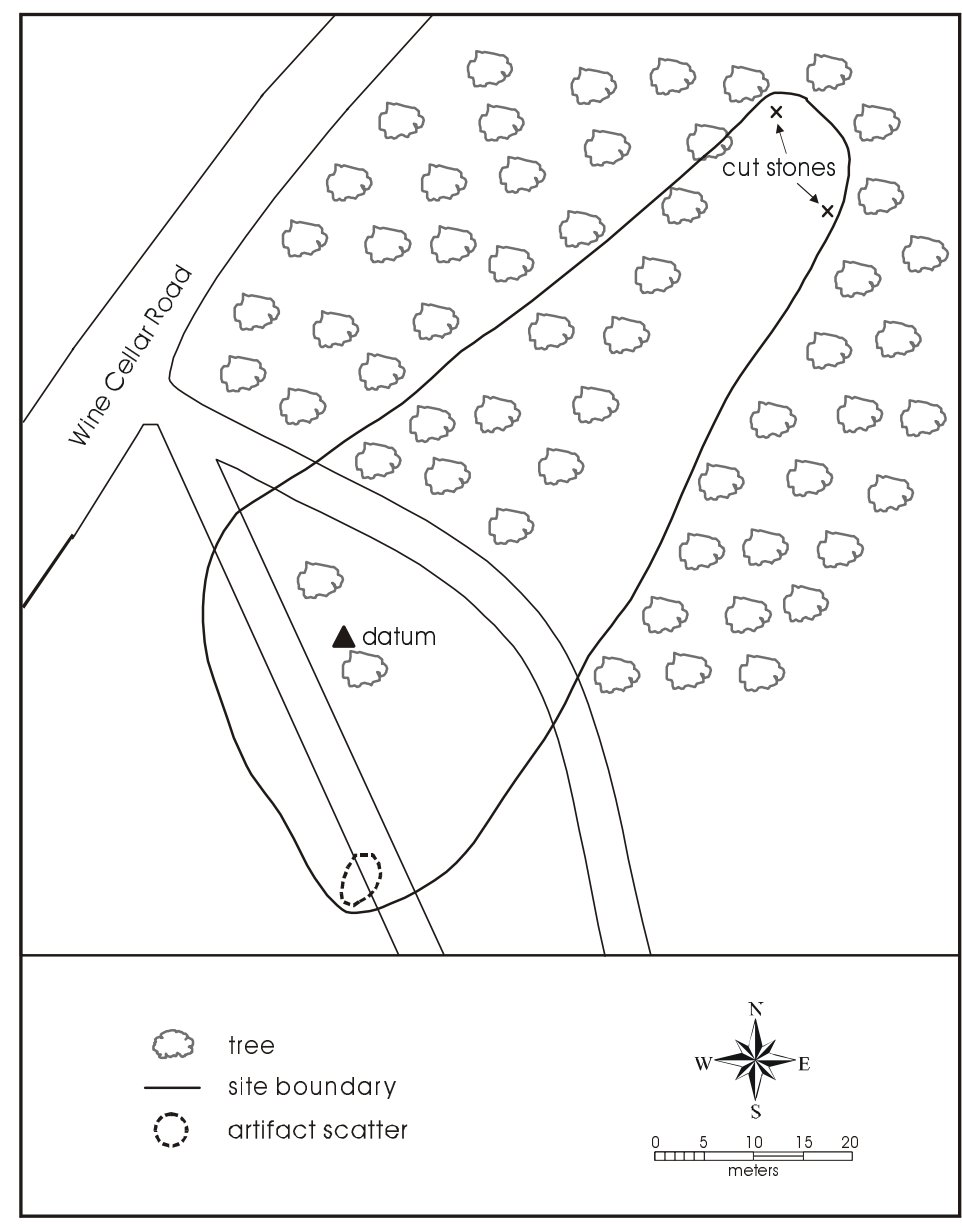

Figure 74. Map of 41 BP534. 


\section{Chapter 5 c: Results - Mullti-Component}

\section{Multi-component sites}

Eight multi-component sites were recorded during this survey. They are: 41BP480, 41BP484, 41BP485, 41BP487, 41BP518, 41BP520, 41BP523, and 41BP532. Site descriptions for each follow. 


\section{$41 B P 480$}

Site Type:

Historic trash scatter/Prehistoric open camp

Site Size:

$182 \mathrm{~m}^{2}$, determined by shovel tests, probes, and examination of the surface (Figure 75)

\section{Topographic Setting:}

Upper slopes above Big Sandy Creek

\section{Description:}

Site 41BP480 is a very small prehistoric open campsite, with a historic component, in an open field on upper slopes above Big Sandy Creek. Little blue stem, buffalo grass, and woody shrubs are the dominant ground cover, with less than $5 \%$ surface visibility. The soil type on the site is Sayers fine sandy loam. Military training activities have severely disturbed the site. Across 41BP480, the surface is deeply rutted and undulating. Tank trenches 5 feet across and 20 feet long have been excavated and refilled repeatedly.

\section{Investigation:}

The crew excavated seven shovel tests, four of which did not contain cultural material. The field crew also excavated shovel probes and inspected the site's surface. This was sufficient to determine that the site consists of a very light scatter of lithic debris from a depth of 0-80 cm deep scattered over an area $13 \mathrm{~m}$ north/south by $14 \mathrm{~m}$ east/west, or $182 \mathrm{~m}^{2}$.

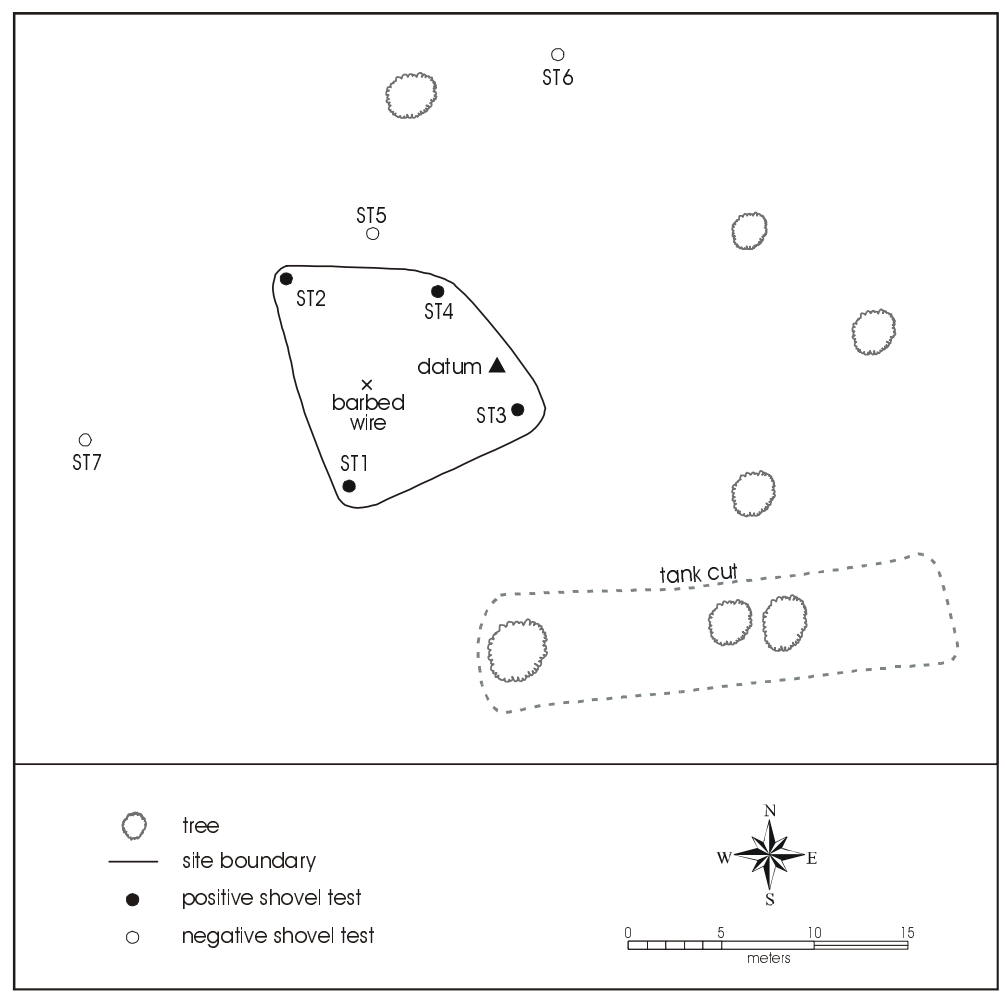

Figure 75. Map of 41BP480.
Table 27. Results of shovel tests at 41BP480

\begin{tabular}{|lrl|}
\hline Shovel Test & Depth $(\mathbf{c m})$ & \multicolumn{1}{c|}{ Observations } \\
\hline ST-1 & $0-60$ & -- \\
& $60-80$ & 1 flake \\
& $80-100$ & -- \\
\hline ST-2 & $0-20$ & 1 flake, \\
& & 1 shrapnel, \\
& & 1 bullet casing (1940s) \\
& $20-40$ & 1 burned rock \\
& $40-60$ & 1 burned rock \\
& $60-100$ & -- \\
\hline ST-3 & $0-20$ & -- \\
& $20-40$ & -- \\
\hline ST-4 & $0-20$ & 1 flake \\
& $20-40$ & -- \\
\hline ST-5 & $0-40$ & -- \\
\hline ST-6 & $0-40$ & -- \\
\hline ST-7 & $0-100$ & -- \\
\hline
\end{tabular}

\section{Results:}

Seven artifacts, including of three chert flakes, two burned rocks, a piece of metal (probably shrapnel), and a bullet casing were found in three shovel tests (Table 27). The probes and other four shovel tests were sterile and no artifacts were observed on the surface. 


\section{$41 \mathrm{BP484}$}

\section{Site Type:}

Historic trash scatter/Prehistoric open camp

\section{Site Size:}

$700 \mathrm{~m}^{2}$, determined by a shovel test and surface inspection (Figure 76)

\section{Topographic Setting:}

Nearly flat upland slope

\section{Description:}

Site 41BP484 is a historic artifact scatter and prehistoric open camp located in an open field immediately east of Wine Cellar Road. Domesticated and native grasses are the dominant plant community, with surface visibility of $10-20 \%$. The soil at the site is Patilo complex soils. Ground surface disturbance from military training on the site is severe.

\section{Investigation:}

The crew inspected the site surface and excavated one shovel test, which was positive. This was sufficient to determine that the site consists of a scatter of prehistoric and historic artifacts in an area $20 \mathrm{~m}$ north/south by 35 $\mathrm{m}$ east/west or $700 \mathrm{~m}^{2}$.

\section{Results:}

Historic artifacts found on the site include salt glazed stoneware, whiteware, colorless, brown, and amethyst glass fragments, and a clay pipe fragment (Table 28). The shovel test demonstrated that the historic artifacts

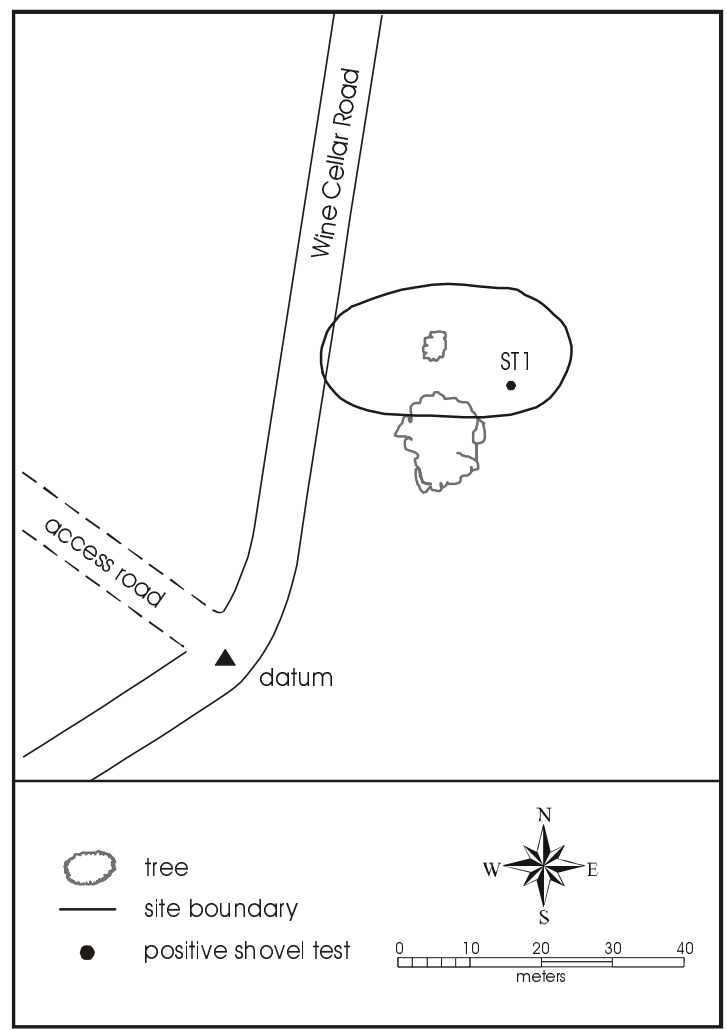

Figure 76. Map of $41 B P 484$.
Table 28. Artifacts from 41BP484

\begin{tabular}{|cll|}
\hline Unit & Depth $(\mathbf{c m})$ & \multicolumn{1}{c|}{ Observations } \\
\hline Surface & & Historic: \\
& & Pipe bowl (glazed ceramic) \\
& Prehistoric: \\
& & 8 flakes \\
& & 3 burned rocks (chert) \\
& & 1 utilized chert flake \\
\hline ST-1 & $0-20$ & 1 brown glass bottle frag. \\
& & 1 whiteware fragment \\
& & 1 salt-glazed stoneware frag. \\
& & 3 glass frags. \\
& & (amethyst, brown, colorless) \\
& & -- \\
\hline
\end{tabular}
extended $40 \mathrm{~cm}$ below surface, and that these deposits were severely disturbed by military activity. No prehistoric artifacts were found in the shovel test. The prehistoric artifacts found on the site's surface include three pieces of burned chert, eight flakes, and one utilized flake. F. Gordon and others, and B. C. and Hettie Daughtry owned the property prior to the establishment of Camp Swift. No site features were observed. Heavy military disturbance may have destroyed any features. Artifacts:

- Specimen 484-63 was found on the surface and is a modified flake made of a gray translucent chert. The principal area of edge-working is an 18.2 millimeter length of microflaking and step-fracturing along one edge. This portion of the edge has a more obtuse angle than the other, feathered edges of the artifact. The wear appears to be from use rather than deliberate preparation. It is $40.5 \mathrm{~mm}$ wide, $50.6 \mathrm{~mm}$ long, and $10.3 \mathrm{~mm}$ maximum thickness.

- Specimen 484-122 is a ceramic pipe bowl fragment. This small fragment is stoneware, glazed on the outside, but only partially glazed on the inside. It does not appear to have ever been used. 


\section{$41 B P 485$}

\section{Site Type:}

Historic trash scatter/Prehistoric open camp

Site Size:

2,200 $\mathrm{m}^{2}$, determined by examination of surface and gully (Figure 77)

\section{Topographic Setting:}

Upland stream-divided slopes

Description:

Site 41BP485 is a multiple component site in an open field dissected by a gully west of Scott Falls Road, on the T1 terrace. Domesticated and native grasses are the dominant ground cover, with $20-30 \%$ surface visibility. The site was on Demona loamy fine sand.

\section{Investigation:}

The crew inspected the ground surface and the gully. The distribution of artifacts was sufficient to determine the horizontal site boundaries, while examination of the drainage cut bank allowed for examination of site stratification. The site is $40 \mathrm{~m}$ north/south by $55 \mathrm{~m}$ east/west, or $2,200 \mathrm{~m}^{2}$.

\section{Results:}

Approximately 21 artifacts were observed on the surface, which include two dart point fragments, approximately eight chert flakes, approximately seven pieces of burned rock, and two red glazed bricks (Table 29). The artifact inventory suggests Paleoindian and Late Archaic components and an early to mid twentieth-century historic dump component, however, all are located on the surface.

\section{Artifacts:}

- The proximal fragment of an Angostura point (Specimen 485-65-2) was found on the surface (Figure 78a). Angosturas are lanceolate points diagnostic of the late Paleoindian period (Turner and Hester 1993:73-74). The specimen consists of the base and about one-third of the blade (see Appendix B for measurements). The blade terminates at a transverse fracture. The stem is contracting, and is heavily and equally ground about $24.4 \mathrm{~mm}$ from the base on both edges. The base lacks grinding, and it has a convex outline with rounded corners. The basal width is $11.2 \mathrm{~mm}$, and the concavity depth is $1.9 \mathrm{~mm}$. The blade is right-beveled and serrated. The material is medium to fine-grained opaque brown chert with light-brown opaque patches within it. Other Angostura points have been found within Bastrop County. For example, at 41BP19 (Kennedy Bluffs site), Angostura points are associated with a radiocarbon assay of $9600 \pm 850$ B.P. (Bement 1989:95), however, this point was recovered from the surface.

- Specimen 485-65-1 was found on the surface and is the distal section of a dart point (Figure 78b). The material is opaque white chert (see Appendix B for measurements). The surface has minute crazed fracture lines and small heat spalls, indicating it has been heavily burned. The section terminates proximally at a

\section{Revisits:} snap fracture. The blade is strongly left-beveled, but is otherwise not diagnostic.

This site was revisited by the crew from CAR in September 2000. Two shovel tests were excavated. A single piece of burned rock was found in the upper $20 \mathrm{~cm}$ of ST-1. The other shovel test was sterile.

Table 29. Surface artifacts from 41BP485

\begin{tabular}{|l|}
1 point base (Angostura) \\
1 beveled dart point tip \\
8 chert flakes \\
7 burned rocks \\
1 piece of chert shatter \\
1 piece of burned chert shatter \\
2 red glazed bricks \\
\hline
\end{tabular}




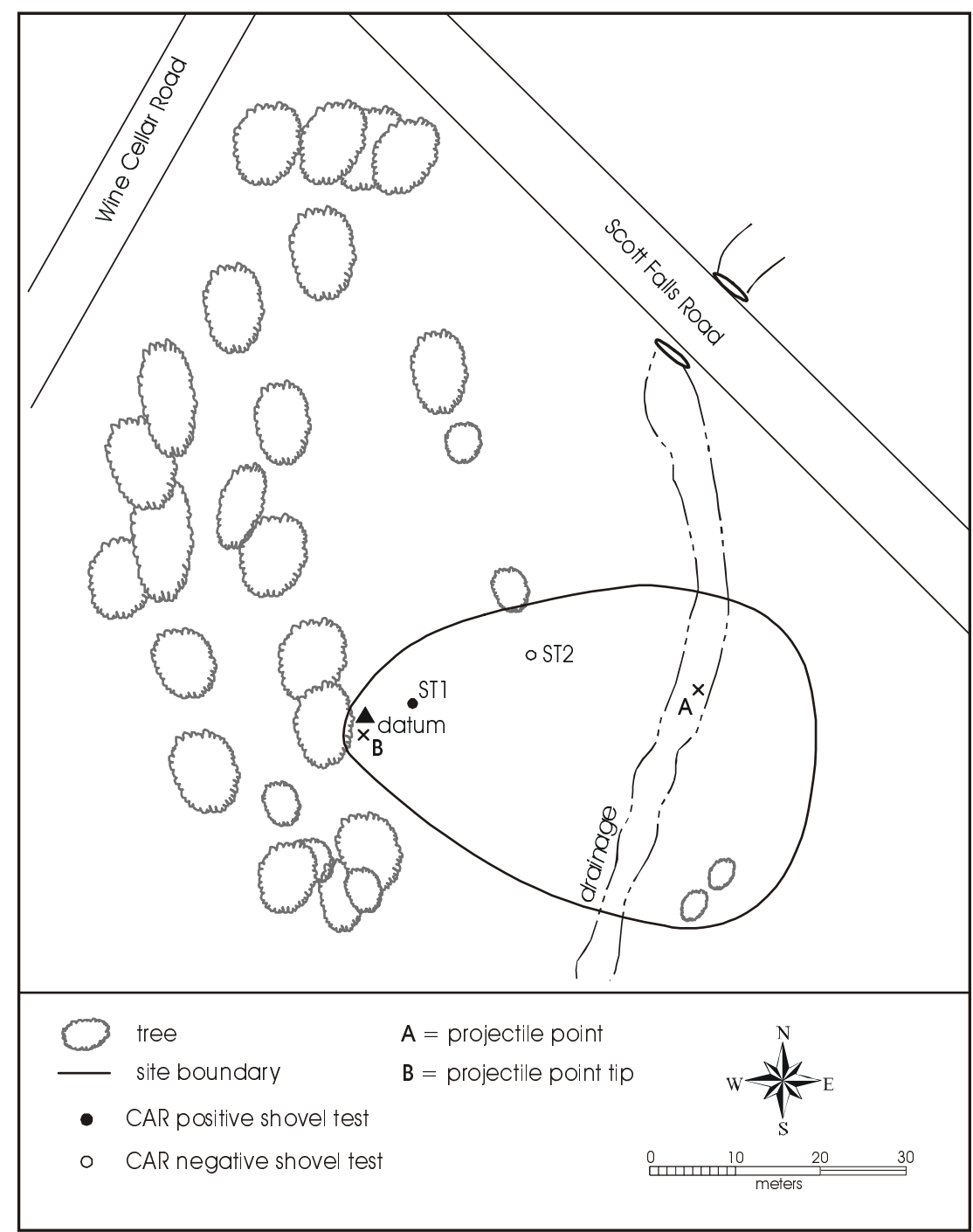

Figure 77. Map of 41 BP 485.

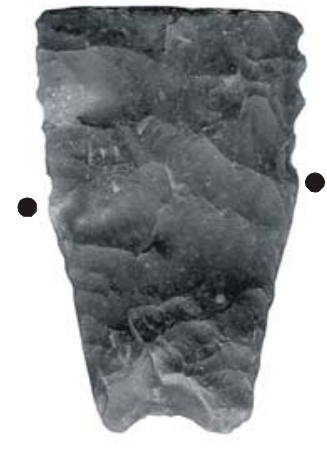

a

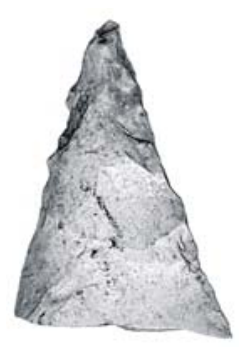

b

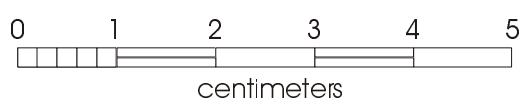

Figure 78. Bifaces from 41BP485: a) a broken Angostura point; b) a distal end of a dart point. 


\section{BP487}

Site Type:

Historic trash scatter/Prehistoric open camp

Site Size:

$3,600 \mathrm{~m}^{2}$, determined by shovel tests, surface inspection, and natural landforms (Figure 79)

\section{Topographic Setting:}

Lower slopes above Big Sandy Creek

\section{Description:}

Site 41BP487 is a prehistoric open camp, with additional historic trash, in a field alongside Big Sandy Creek northeast of Scott Falls Road. It lies on lower slopes above Big Sandy Creek, on the T0 terrace. Domesticated and native grasses are the dominant vegetation, with $0-5 \%$ surface visibility. The soils at the site are Sayers fine sandy loam

\section{Investigation:}

The crew excavated three shovel tests; one was sterile, the other had a historic artifact at $20-40 \mathrm{~cm}$. The field crew also inspected the site surface. The boundary determination was based on the positive shovel test, surface material, and natural landforms to be $45 \mathrm{~m}$ north/south by $80 \mathrm{~m}$ east/west, or $3600 \mathrm{~m}^{2}$.

\section{Results:}

A total of 13 artifacts was found (Table 30). Eight flakes and three burned rocks were found in one shovel test to a depth of $120 \mathrm{~cm}$ and one flake was found on the surface. One historic artifact, a fragment of a cast iron stove, was found at $20-40 \mathrm{~cm}$ in another shovel test. One shovel test contained no artifacts of any kind. No features were identified at the site.

\section{Revisits:}

The site was revisited in September 2000 by the CAR crew, and three shovel tests were excavated (Table 30). Two of the tests were sterile, while the third had debitage and burned rock to a depth of $60 \mathrm{~cm}$.
Table 30. Results of shovel tests at 41BP487

\begin{tabular}{|lcl|}
\hline Unit & Depth (cm) & Observations \\
\hline Surface & & 1 flake \\
\hline ST-1 & $0-20$ & 1 flake \\
& $20-40$ & -- \\
& $40-60$ & 6 flakes, 1 burned rock, \\
& $60-80$ & 1 burned rock \\
& $80-100$ & 1 burned rock \\
& $100-120$ & 1 flake \\
\hline ST-2 & & -- \\
\hline ST-3 & $0-20$ & -- \\
& $20-40$ & 1 cast iron stove fragment \\
\hline ST-4 (CAR \#1) & $0-100$ & -- \\
\hline ST-5 (CAR \#2) & $0-100$ & -- \\
\hline St-6 (CAR \#3) & $0-20$ & 1 flake, 1 burned rock \\
& $20-40$ & 2 flakes, 1 burned rock \\
& $40-60$ & 1 flake, 2 burned rocks \\
& $60-100$ & -- \\
\hline
\end{tabular}

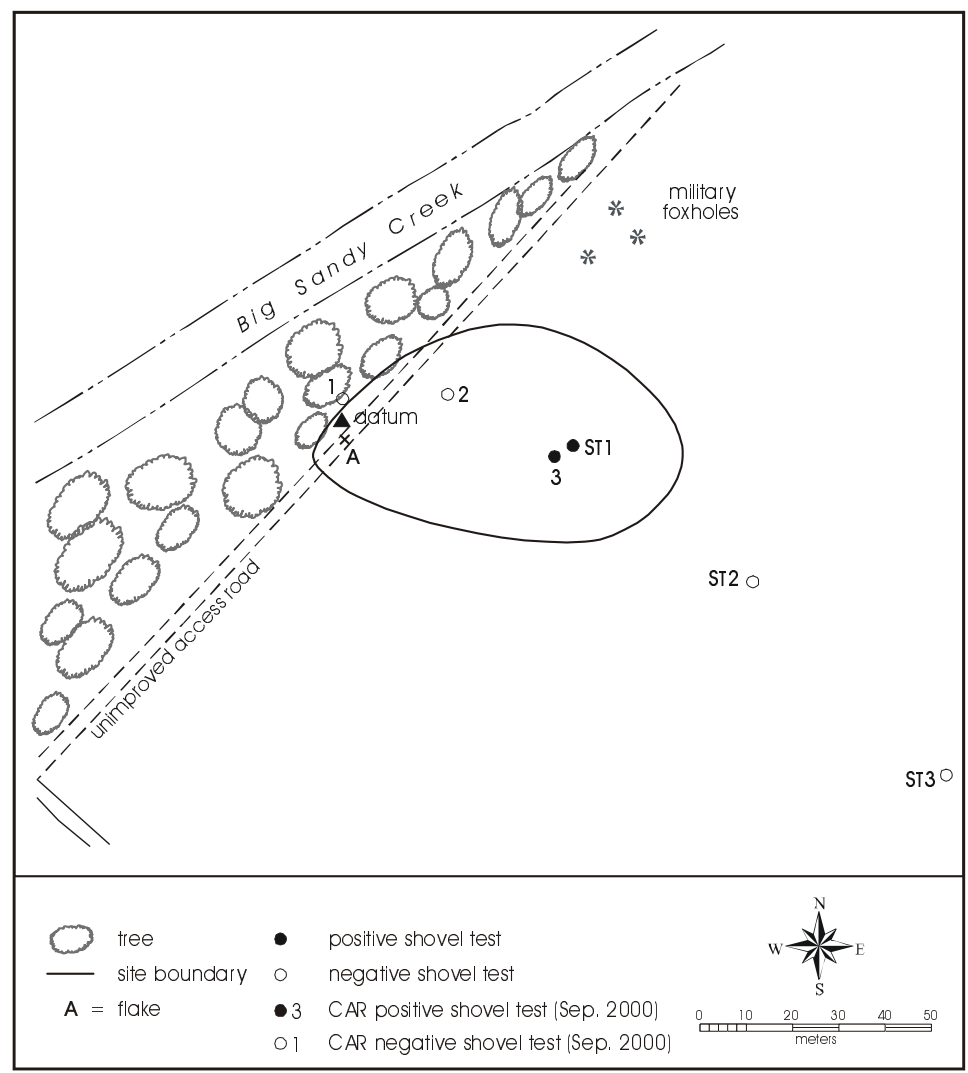

Figure 79. Map of $41 B P 487$. 


\section{$41 \mathrm{BP518}$}

\section{Site Type:}

Historic trash scatter/Prehistoric lithic scatter

Site Size:

$300 \mathrm{~m}^{2}$, based on the extent of surface artifact scatter (Figure 80)

\section{Topographic Setting:}

Drainage upland divide near the head of an unnamed tributary

Description:

Site 41BP518 is a historic trash scatter and prehistoric lithic scatter located in an open field near the head of an unnamed tributary. The setting is a drainage upland divide, with oak and cedar the on-site dominants. The site was on Crockett soils. The site is primarily a late historic trash scatter; only one flake of prehistoric manufacture was observed on the surface to give the site a minimal prehistoric component.

\section{Investigation:}

The field crew conducted ground surface inspection and excavated a negative shovel test to $60 \mathrm{~cm}$ below ground surface. The site boundary, determined by the surface distribution of artifacts, was $25 \mathrm{~m}$ east/west by $12 \mathrm{~m}$ north/ south, or $300 \mathrm{~m}^{2}$.

\section{Results:}

Artifacts at the site were observed on the surface. No subsurface cultural material was recovered. Artifacts observed include glass bottles, one Mason jar, metal cans, whiteware ceramics, a tin washbasin, and one chert flake. There was a low density of surface materials, based on these observations and counts. Property ownership prior to the establishment of Camp Swift is unknown at present. Military training activity, former agricultural activity, erosion, and bioturbation have disturbed the site.

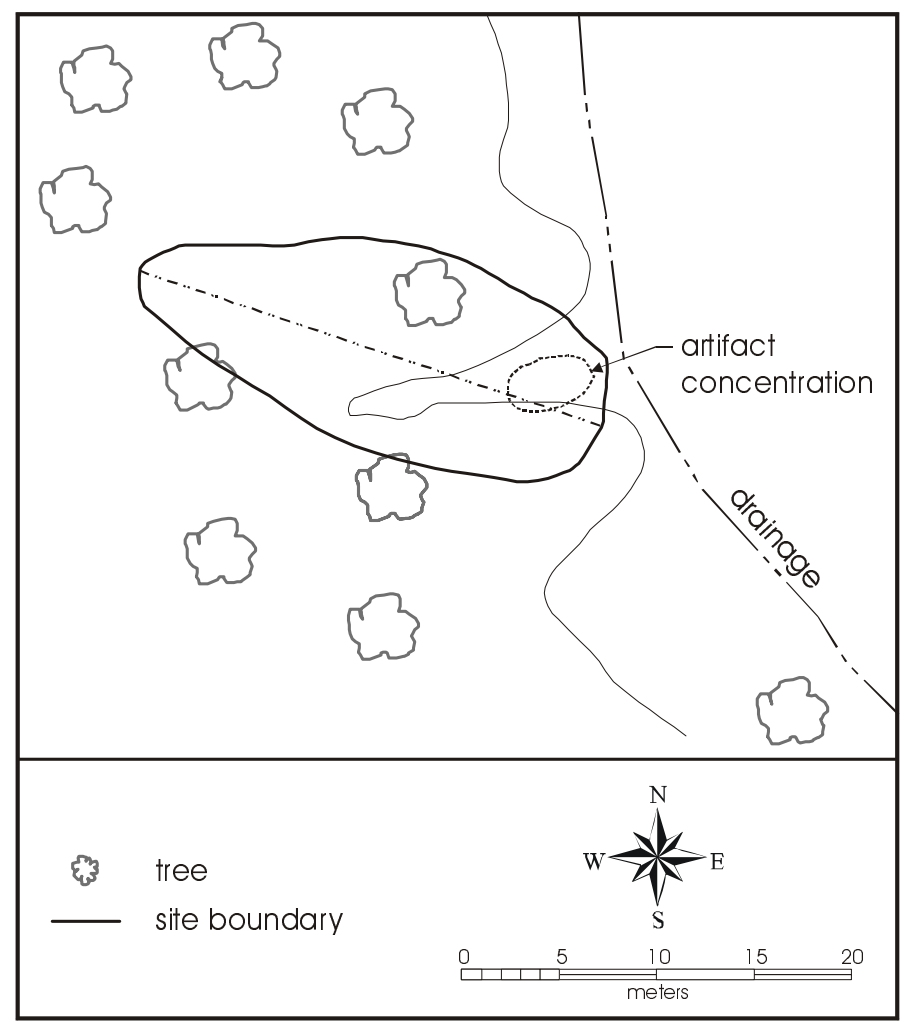

Figure 80. Map of 41BP518. 


\section{BP520}

Site Type:

Historic habitation/Prehistoric open camp

Site Size:

$4,550 \mathrm{~m}^{2}$, boundaries determined by the extent of the surface artifact scatter (Figure 81)

\section{Topographic Setting:}

Lower stream slopes above Big Sandy Creek

\section{Description:}

Site 41BP520 is a historic habitation and prehistoric campsite located on gentle slopes about 100 m northeast of an unnamed tributary of Big Sandy Creek and approximately $400 \mathrm{~m}$ from the confluence of the two streams. The setting is lower stream slopes above Big Sandy Creek, on the T0 terrace, with domesticated and native grasses the dominant ground cover. The soils on the site belong to the Patilo complex.

\section{Investigation:}

The field crew conducted ground surface inspection and excavated one shovel test at the site. The shovel test contained both historic and prehistoric material to $80 \mathrm{~cm}$ below ground surface. The site boundary as determined by the distribution of surface artifacts was $70 \mathrm{~m}$ east/west by $65 \mathrm{~m}$ north/south, $4,550 \mathrm{~m}^{2}$.

\section{Results:}

Both historic and prehistoric artifacts were observed on the site surface (Table 31). These surface artifacts include aqua and amethyst tinted bottle glass, tin cans, tin siding, wire nails, screws, whiteware ceramics, lithic debitage, fire cracked rock, and a distal section of a projectile point. Artifacts from the subsurface include one piece of window glass $(40 \mathrm{~cm})$ and one piece of debitage $(80 \mathrm{~cm})$. There was a low density of surface and subsurface deposits based on observations. The site has a hand-dug, brick-lined well and a probable house structure depression. Property ownership before Camp Swift is unknown at this time, but the historic material culture suggests that the site dates from the nineteenth century. The site has been disturbed by military training activity and bioturbation.

\section{Artifacts:}

- Specimen 520-182 is the distal tip of a dart point (Figure 82a). The material is translucent gray chert with white specks and patches throughout the stone (see Appendix B for measurement). The distal section terminates at a lipped snap fracture. The original artifact was well-finished. The edges in outline are slightly convex, and the cross section is lenticular. The specimen is not diagnostic.

- Specimen 520-181 is a colorless glass bottle neck, sun-colored amethyst (Figure 82b). The bottle was mold-blown, with an applied lip finished with a lipping tool. The finish is a type commonly seen on medicine or extract bottles of the late nineteenth century.

- Specimen 520-180 is an aqua glass bottle neck (Figure 82c). The bottle was mold-blown, with an applied lip finished with a lipping tool. The finish is also a type commonly seen on medicine bottles. 


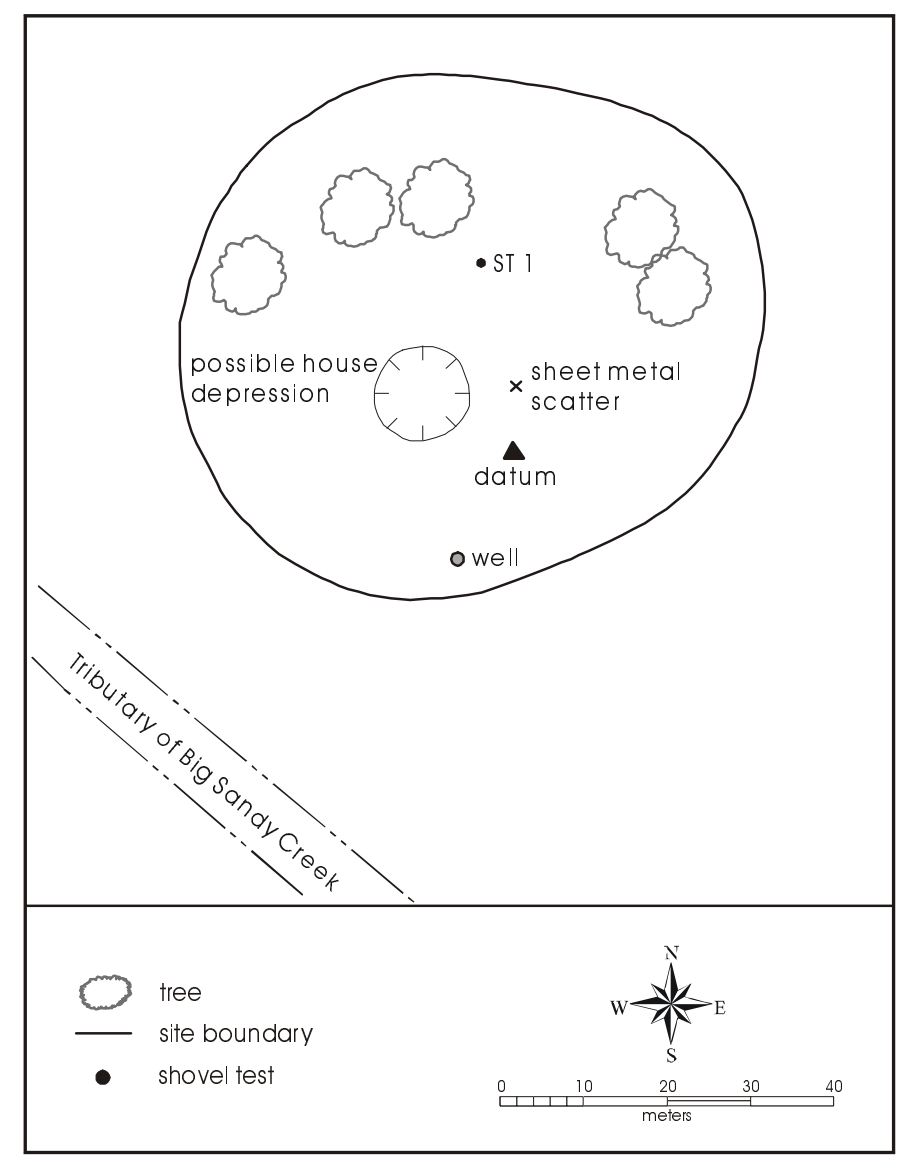

Figure 81. Map of 41 BP520.

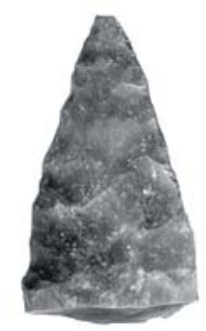

a

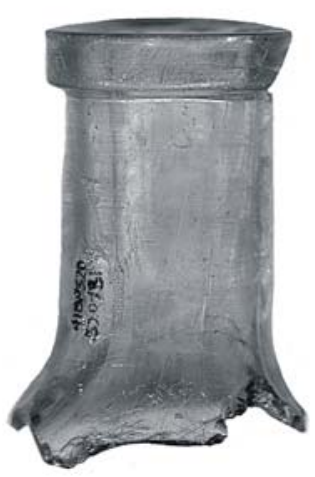

b

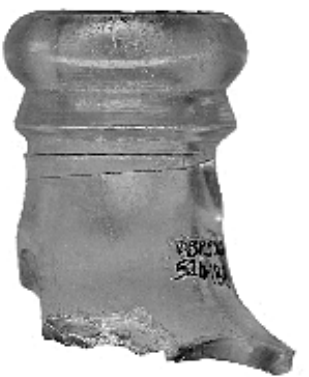

C

\begin{tabular}{|c|c|c|c|}
\hline $\begin{array}{ll}0 & 1\end{array}$ & 2 & 3 & 4 \\
\hline$\square|l| l \mid P$ & - & F & $\theta$ \\
\hline
\end{tabular}

Figure 82. Artifacts recovered from 41BP520: a) distal tip of a dart point; b) clear-amethyst bottle neck; c) aqua bottle neck. 


\section{BP523}

\section{Site Type:}

Historic trash dump/Prehistoric lithic scatter

Site Size:

$18,975 \mathrm{~m}^{2}$, based on artifact distributions, the examination of ground surface exposures, and the excavation of one shovel test (Figure 83)

\section{Topographic Setting:}

Upper drainage divides

\section{Description:}

The site is a historic trash scatter and prehistoric lithic scatter located in mixed grassy fields and woods about $200 \mathrm{~m}$ north of East Loop Road. Its setting is upper drainage divides, with oak, cedar, and mesquite the floral dominants. The site is on Crockett loams.

\section{Investigation:}

The site boundaries were determined by the distribution of historic and prehistoric artifacts, which extended thinly over an area 165 meter northwest/southeast by $115 \mathrm{~m}$ north/south, or about $18,975 \mathrm{~m}^{2}$. The single shovel test excavated to examine subsurface contexts was negative.

\section{Results:}

The surface has a medium density of historic artifacts and a low density of prehistoric artifacts. Artifacts observed at the surface included over 25 bricks, as well as shards of porcelain, whiteware, stoneware, amethysttinted glass, patinated colorless glass, bottle lips, the head of an iron hoe, metal fragments, and five chert flakes. No artifacts were collected. The site has no remnant intact features. The historic artifact classes suggest formation of the historic component in the early twentieth-century, although property ownership at the time of the founding of Camp Swift is not known currently. The prehistoric assemblage did not contain diagnostic artifacts.

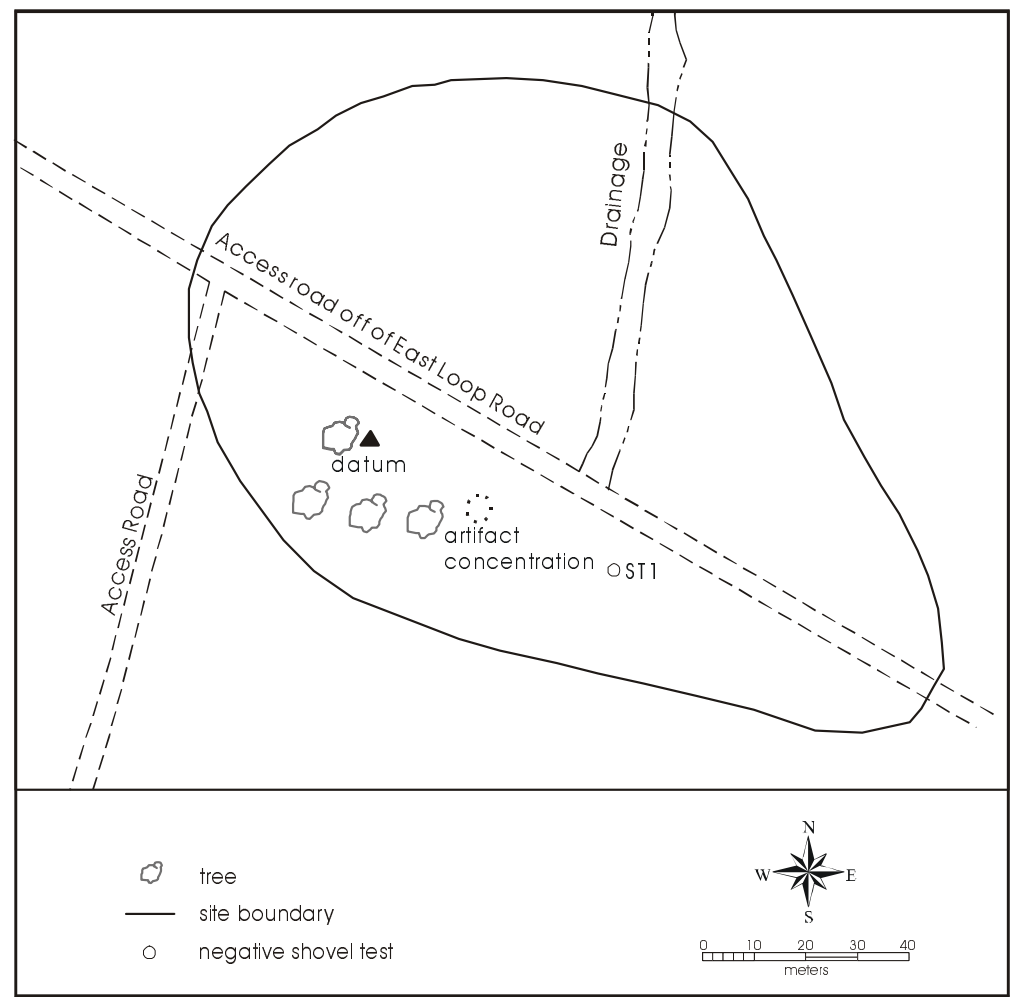

Figure 83. Map of 41BP523. 


\section{$41 B P 532$}

\section{Site Type:}

Historic trash dump/Prehistoric lithic scatter

Site Size:

$25,000 \mathrm{~m}^{2}$, based on the extent of the surface scatter of artifacts (Figure 84)

\section{Topographic Setting:}

Upper stream slopes

\section{Description:}

Site 41BP532 is a historic habitation and prehistoric open camp site located in a clearing in mixed woodlands. The setting is upper stream slopes, with cedar and understory grasses dominating the plant community. Ground surface visibility is $50-60 \%$. The site is on Crockett loams.

\section{Investigation:}

The crew conducted site ground surface inspection and excavated two shovel tests and one shovel probe. This work established the site as a multiple-component historic habitation and prehistoric open camp site with an approximate size of $125 \mathrm{~m}$ northeast/southwest by $200 \mathrm{~m}$ northwest/southeast, or $25,000 \mathrm{~m}^{2}$.

\section{Results:}

The historic artifacts observed on the site date from the early to mid twentieth-century, while the prehistoric component consists of a light scatter of nondiagnostic chert flakes. Cultural materials identified on the site surface included over 30 bricks, over 20 iron hardware objects, more than 15 tin cans, eight enamel buckets, two enamel bowls, one piece of milled lumber, over 20 glass bottles and jars, one cut stone, one boot sole, two stoneware fragments, and ten flakes. No artifacts were retrieved from the subsurface. The site has an old roadway running through it, a dry manmade pond near its eastern periphery, and a small depression near its southern periphery. These are remnants of features associated with the historic component or later Camp Swift constructions. Property ownership at the time Camp Swift was established is currently unknown. Military training, erosion, and bioturbation have disturbed the site.

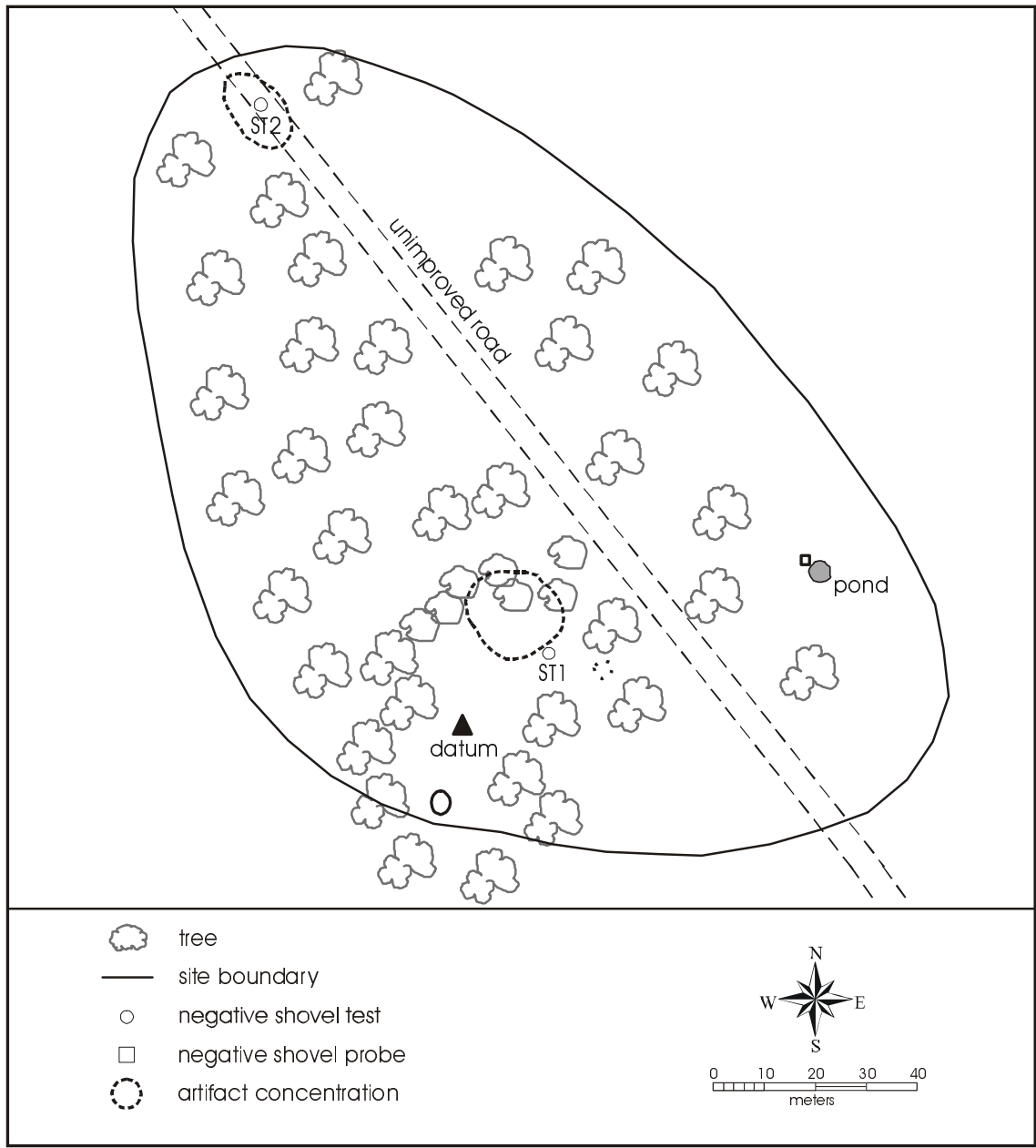

Figure 84. Map of 41BP532. 


\section{Relocation and Assessment of Previously Identified Sites}

The 1997 survey crew attempted to relocate a targeted 80 sites that had been discovered on previous Camp Swift surveys in order to observe the condition of the sites with reference to natural and human impacts in the time between their initial recordings and 1997. A total of 42 sites were relocated and they are listed in the following. Descriptions of the cemetery sites on Camp Swift are given in more detail in the following section.

\section{Revisited Sites}

A total of 80 sites were selected for revisitation, applying these priorities, based on the following prioritization:

1. The Sayers Mine (41BP148);

2. Cemeteries;

3. Sites that Skelton and Freeman (1979) recommended for testing;

4. Sites where there were discrepancies in the locational information; and

5. Any other sites deemed potentially to hold more information than recorded.

Once located, site recording tasks were systematized. The following tasks were completed for each:

1. A "revisit" site form was filled out;

2. Observations were added to field notes; and

3. A new site sketch map was drawn.

As reported above, 42 of the sites on the revisitation list were successfully relocated and recorded anew, but 38 of the selected sites could not be found even after repeated visits and shovel probing in suspected locales.

\section{Relocated Sites}

Forty-two sites were relocated during the survey. They are listed in Table 32.

\begin{tabular}{|l|l|}
\hline \multicolumn{1}{|c|}{ Site \# } & \multicolumn{1}{c|}{ Site Type } \\
\hline 41BP91 & Prehistoric \\
\hline 41BP94 & Prehistoric \\
\hline 41BP95/184 & Multi-component \\
\hline 41BP100 & Prehistoric \\
\hline 41BP112 & Prehistoric \\
\hline 41BP113 & Prehistoric \\
\hline 41BP114 & Prehistoric \\
\hline 41BP115 & Prehistoric \\
\hline 41BP116 & Prehistoric \\
\hline 41BP117 & Prehistoric \\
\hline 41BP119 & Multi-component \\
\hline 41BP121 & Prehistoric \\
\hline 41BP122/143 & Multi-component \\
\hline 41BP125 & Prehistoric \\
\hline
\end{tabular}

$\dagger \quad$ Cemetery - protected by state law.
Table 32. Relocated sites

\begin{tabular}{|l|l|}
\hline \multicolumn{1}{|c|}{ Site \# } & \multicolumn{1}{c|}{ Site Type } \\
\hline 41BP127 & Prehistoric \\
\hline 41BP128 & Prehistoric \\
\hline 41BP129 & Prehistoric \\
\hline 41BP134 & Historic \\
\hline 41BP138 & Multi-component \\
\hline 41BP140 & Historic \\
\hline 41BP141 & Historic \\
\hline $41 \mathrm{BP} 144$ & Historic \\
\hline $41 \mathrm{BP} 145$ & Cemetery \\
\hline 41BP148 & Historic \\
\hline $41 \mathrm{BP} 153$ & Historic \\
\hline $41 \mathrm{BP} 154$ & Historic \\
\hline $41 \mathrm{BP} 156$ & Historic \\
\hline 41BP157 & Historic \\
\hline
\end{tabular}

* Leshley $1994 \quad$ ** Nash et al. 1995

\begin{tabular}{|l|l|}
\hline \multicolumn{1}{|c|}{ Site \# } & \multicolumn{1}{c|}{ Site Type } \\
\hline 41BP158 & Historic \\
\hline 41BP159 & Historic \\
\hline 41BP160 & Historic \\
\hline 41BP162 & Historic \\
\hline 41BP163 & Historic \\
\hline 41BP165 & Multi-component \\
\hline 41BP166 & Historic \\
\hline 41BP170 & Cemetery $~$ \\
\hline 41BP378 & Prehistoric $*$ \\
\hline 41BP381 & Prehistoric \\
\hline 41BP382 & Cemetery \\
\hline 41BP391 & Prehistoric $* *$ \\
\hline 41BP399 & Prehistoric $* * *$ \\
\hline 41BP400 & Historic \\
\hline
\end{tabular}

*** Wormser and Leshley 1995 


\section{BP91}

Site Type:

Prehistoric open camp

Original Investigation:

Skelton and Freeman 1979

1997 Evaluation:

The site is a very light scatter of flakes and burned rock with no distinct concentrations. It is heavily eroded and has been disturbed by military activities.

\section{$41 B P 94$}

\section{Site Type:}

Prehistoric open camp

Original Investigation:

Skelton and Freeman 1979

\section{Evaluation:}

The site was relocated and three shovel tests and a shovel probe were excavated. All were positive (Table 33). Artifacts were recovered as deep as $75 \mathrm{~cm}$. An Ensor point was recovered from ST-3 at 20 to $40 \mathrm{~cm}$ below the surface.

\section{Artifacts:}

Specimen 94-246 is an Ensor point base (Figure 85). This is a Late Archaic point type (Turner and Hester 1993:114), made of medium gray chert. There is a possible impact fracture on the distal end.

Table 33. Results of shovel tests at 41BP94

\begin{tabular}{|crl|}
\hline Unit & Depth(cm) & \multicolumn{1}{c|}{ Artifacts Collected } \\
\hline Probe 1 & $0-20$ & 2 flakes \\
\hline ST-1 & $0-20$ & 1 burned rock \\
\hline ST-2 & $0-20$ & 1 flake \\
\hline ST-3 & $0-20$ & 1 burned rock \\
& $20-40$ & 1 Ensor point, \\
& & 1 burned rock \\
& $40-60$ & 5 burned rocks \\
& $60-75$ & 1 burned rock \\
\hline
\end{tabular}

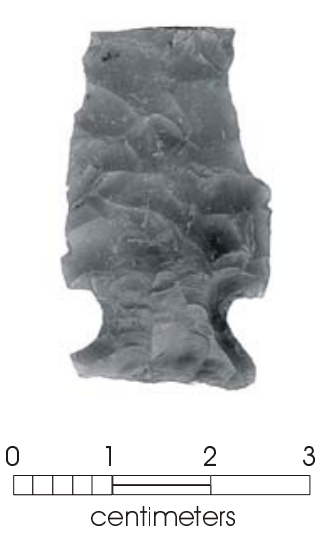

Figure 85. Ensor dart point from 41 BP94.

\section{BP95/184}

\section{Site Type:}

Historic habitation/Prehistoric open camp

Original Investigation:

Skelton and Freeman 1979

1997 Evaluation:

Skelton and Freedman (1979) gave the prehistoric (BP95) and the historic (BP184) components of this site separate site numbers. At that time, a few flakes and burned rocks were seen in gopher backdirt, but nothing was seen in shovel tests. The site was revisited in 1997. A shovel probe and two shovel tests were dug, but only one shovel test was positive. A very small chert core was recovered from 20 to $40 \mathrm{~cm}$ below surface, however the site is on the T1 terrace, which geomorphologic research indicates was probably deposited since 600 B.P. (see Chapter 3). There are no indications of intact buried features. 


\section{$41 B P 100$}

Site Type:

Prehistoric open camp

Original Investigation:

Skelton and Freeman 1979

1997 Evaluation:

The site is on the T1 terrace, which geomorphologic research indicates was probably deposited since 600 B.P. (see Chapter 3), however, there is an apparent intact burned rock feature. Skelton and Freeman (1979) described the site as the location of two hearth remnants eroding out of the cut bank of the creek. One hearth was located $90 \mathrm{~cm}$ below the edge of the bank. The other was $1.75 \mathrm{~m}$ below the bank. The overburden above these hearths was removed and they were recorded in situ. They appeared to be intact except for the creek erosion. In 1997, the site was relocated and six shovel probes were excavated. Burned rock was located in three of them. In addition, burned rock was seen in the cut bank of the creek.

\section{BP112}

\section{Site Type:}

Prehistoric lithic scatter

\section{Original Investigation:}

Skelton and Freeman 1979

1997 Evaluation:

Skelton and Freeman (1979) described the site as a sparse surface lithic scatter. The site was revisited and three shovels tests were dug. Only one test was positive, with flakes to $30 \mathrm{~cm}$ below the surface (Table 34).

Table 34. Results of shovel tests at 41BP112

\begin{tabular}{|rrl|}
\hline Unit & Depth $(\mathbf{c m})$ & \multicolumn{1}{c|}{ Artifacts Collected } \\
\hline ST-1 & $0-20$ & 1 flake \\
& $20-30$ & 2 flakes \\
\hline ST-2 & $0-30$ & -- \\
\hline ST-3 & $0-30$ & -- \\
\hline
\end{tabular}

\section{$41 B P 113$}

\section{Site Type:}

Prehistoric open camp

\section{Original Investigation:}

Skelton and Freeman 1979; revisited 1995 by Wormser and Leshley

1997 Evaluation:

Skelton and Freeman (1979) described a terrace site with artifacts eroded from the terrace edge and flakes to 70 $\mathrm{cm}$. In 1995, a 1 by $2 \mathrm{~m}$ test pit showed extensive bioturbation and sparse cultural debris to approximately $50 \mathrm{~cm}$. During the 1997 revisit, a shovel test found flakes to $80 \mathrm{~cm}$ (Table 35). The site is subject to some erosion, but may have intact buried deposits.

Table 35. Results of shovel tests at 41BP113

\begin{tabular}{|ccl|}
\hline Unit & Depth $(\mathbf{c m})$ & \multicolumn{1}{c|}{ Artifacts Collected } \\
\hline ST-1 & $0-20$ & -- \\
& $20-40$ & 1 flake \\
& $40-60$ & 1 flake \\
& $60-80$ & 2 flakes \\
\hline
\end{tabular}




\section{BP114}

Site Type:

Prehistoric open camp

Original Investigation:

Skelton and Freeman 1979

1997 Evaluation:

Skelton and Freeman (1979) observed considerable quantities of flakes and FCR on the surface and to $50 \mathrm{~cm}$ bs. The site was revisited in 1997. A total of ten shovel probes were excavated, only two of which were positive (Table 36), with flakes and burned rock to $50 \mathrm{~cm}$ below surface. The site is subject to moderate erosion. The site is on the T0 terrace, which geomorphologic research indicates was probably deposited since 600 B.P. (see Chapter 3).

Table 36. Results of shovel probes from 41BP114

\begin{tabular}{|crl|}
\hline Unit & Depth $(\mathbf{c m})$ & \multicolumn{1}{c|}{ Artifacts Collected } \\
\hline Probe 4 & $0-30$ & -- \\
& $30-50$ & 1 flake, 3 burned rocks \\
\hline Probe 5 & $0-30$ & 1 flake \\
\hline
\end{tabular}

\section{BP115}

\section{Site Type:}

Prehistoric open camp

Original Investigation:

Skelton and Freeman 1979

1997 Evaluation:

Skelton and Freeman (1979) found cores, flakes, and burned rock at the site. The site was relocated in 1997 , however, the area is seriously damaged by military activity and is heavily eroded and deflated.

\section{BP116}

Site Type:

Prehistoric open camp

Original Investigation:

Skelton and Freeman 1979

1997 Evaluation:

Skelton and Freeman (1979) observed cores, flakes, and burned rock at the site. The site was relocated in 1997, however, the area is seriously damaged by military activity and is heavily eroded and deflated.

\section{BP117}

\section{Site Type:}

Prehistoric open camp

Original Investigation:

Skelton and Freeman 1979

1997 Evaluation:

This site was described by Skelton and Freeman (1979) as superficial. The site was relocated, but was found to be seriously eroded. 


\section{BP119}

\section{Site Type:}

Historic trash scatter/Prehistoric open camp

\section{Original Investigation:}

Skelton and Freeman 1979

\section{Evaluation:}

Skelton and Freeman (1979) observed cores, flakes, and burned rock eroding on the edge of a terrace and possible intact deposits on the terrace. The site was relocated. Twelve shovel probes were placed in the area, but all were negative. A chert core was found on the surface. A pile of bricks, metal, and glass was observed at the top of the hill, though these may be part of 41BP153. The surface of the site is severely eroded.

\section{BP121}

\section{Site Type:}

Prehistoric open camp

\section{Original Investigation:}

Skelton and Freeman 1979

1997 Evaluation:

Numerous cores, flakes, and burned rock were observed on the surface. Flakes and burned rock were found to at least a depth of $1 \mathrm{~m}$ by Skelton and Freeman (1979), as well as a Montell point in association with a hearth between 50 and $75 \mathrm{~cm}$ bs. However, the site surface was somewhat disturbed by plowing and military activity. Revisit in 1997 found flakes and burned rock in one shovel test of three that were excavated.

\section{BP122/143}

\section{Site Type:}

Historic habitation site/Prehistoric open camp

\section{Original Investigation:}

Skelton and Freeman 1979

\section{Evaluation:}

The prehistoric (BP122) and historic (BP143) components of this site were given different site numbers. Skelton and Freedman (1979) described at least three collapsed buildings and a light scatter of lithics and burned rock. The site is on the T1 terrace, which geomorphologic research indicates was probably deposited since 600 B.P. (see Chapter 3). The site was relocated and six shovel probes were dug, of which two were positive (Table 37). The site has been severely impacted by military training activities.

\section{Artifacts:}

Specimen 122/143-275 is the top of a brown glass snuff bottle. The bottle was blown in a mold, and has an applied lip. It dates sometime before 1903.

Table 37. Results of Shovel Probes from 41BP122/143

\begin{tabular}{|ccl|}
\hline Unit & Depth $(\mathbf{c m})$ & Artifacts Collected \\
\hline Probe 1 & $0-30$ & $\begin{array}{l}\text { brown glass snuff } \\
\text { bottle top. }\end{array}$ \\
\hline Probe 5 & $0-40$ & $\begin{array}{l}\text { aqua bottle glass, } \\
\text { brown bottle glass } \\
\text { 2 cut nails }\end{array}$ \\
\hline
\end{tabular}




\section{BP125}

Site Type:

Prehistoric open camp

Original Investigation:

Skelton and Freeman 1979

1997 Evaluation:

The site is a superficial scatter of flakes and burned rock, at revisit no evidence of buried deposits was observed.

\section{BP127}

Site Type:

Prehistoric open camp

Original Investigation:

Skelton and Freeman 1979

1997 Evaluation:

Skelton and Freeman (1979) described the site's surface as deflated. The site was probably relocated, although there was only a single flake found near the surface in a shovel test. The area is heavily eroded and deflated.

\section{BP128}

\section{Site Type:}

Prehistoric open camp

Original Investigation:

Skelton and Freeman 1979

1997 Evaluation:

Skelton and Freeman (1979) found a sparse, superficial scatter of flakes and burned rock at this site. The site was probably relocated, although there was only a single flake found on the surface. The area is heavily eroded.

\section{BP129}

\section{Site Type:}

Prehistoric open camp

Original Investigation:

Skelton and Freeman 1979

1997 Evaluation:

Skelton and Freeman (1979) described this site as a sparse, superficial scatter of flakes and burned rock. Upon relocation a single flake was found in one of 13 shovel probes at a depth of 20-30 cm. The area is more heavily wooded than previously described with moderate to heavy disturbance by military activity and some erosion.

\section{BP134}

Site Type:

Historic habitation site

Original Investigation:

Skelton and Freeman 1979

1997 Evaluation:

This is the site of the Scott family homestead. The house was built in the late 1860s. At the time it was recorded the house was no longer standing, but the location was still ready visible. The site was relocated. The only remains are an early twentieth-century root cellar and a thin scatter of historic artifacts. 


\section{$41 B P 138$}

\section{Site Type:}

Historic habitation and winery/Prehistoric lithic scatter

\section{Original Investigation:}

Skelton and Freeman 1979

\section{Evaluation:}

This is the site of the Aussilloux House and Winery. The survey in 1979 described the site as the remains of a two-story house, including the stone cellar (which served as the wine cellar for Aussilloux's wine business), stone steps into the cellar, some of the joists for the first floor, a partial fireplace, and a cistern (Figures 86 and 87). Air ducts are still evident in the upper cellar walls. The site was revisited, at which time a prehistoric open camp was identified within the site boundaries. The house site is in excellent condition, considering the fact that the house was burned down (see Chapter 2). A dirt road runs through the site, near the building. The site is currently fenced and designated off-limits.

\section{Artifacts:}

Specimen 138-60 is a chert biface that was broken in the early stages of manufacture, found on the surface (Figure 88). The biface was made from a nodule with two distinct types of chert in layers; one is coarse-grained gray, while the other is fine-grained translucent brown.

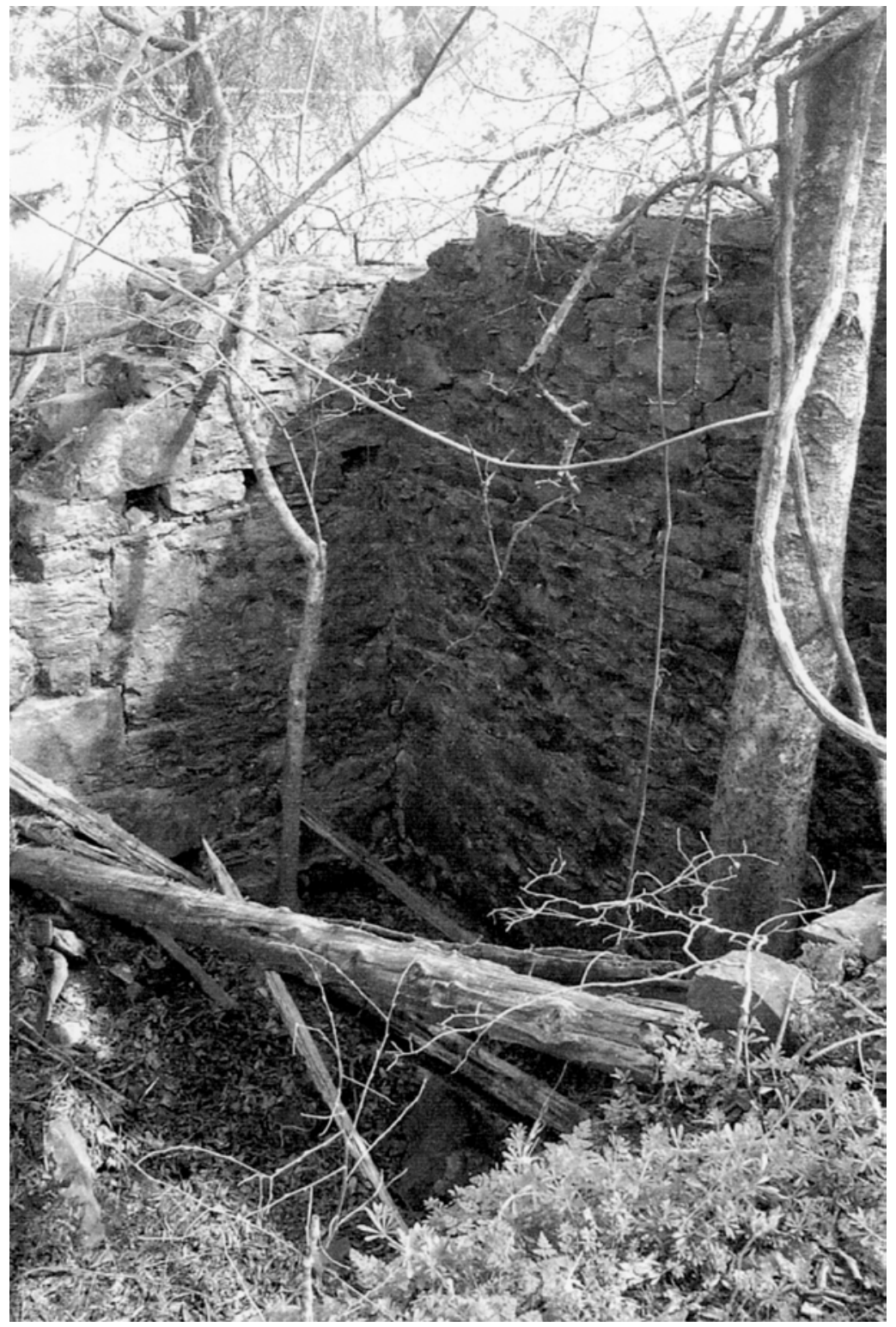

Figure 86. The remains of the Aussilloux House. 


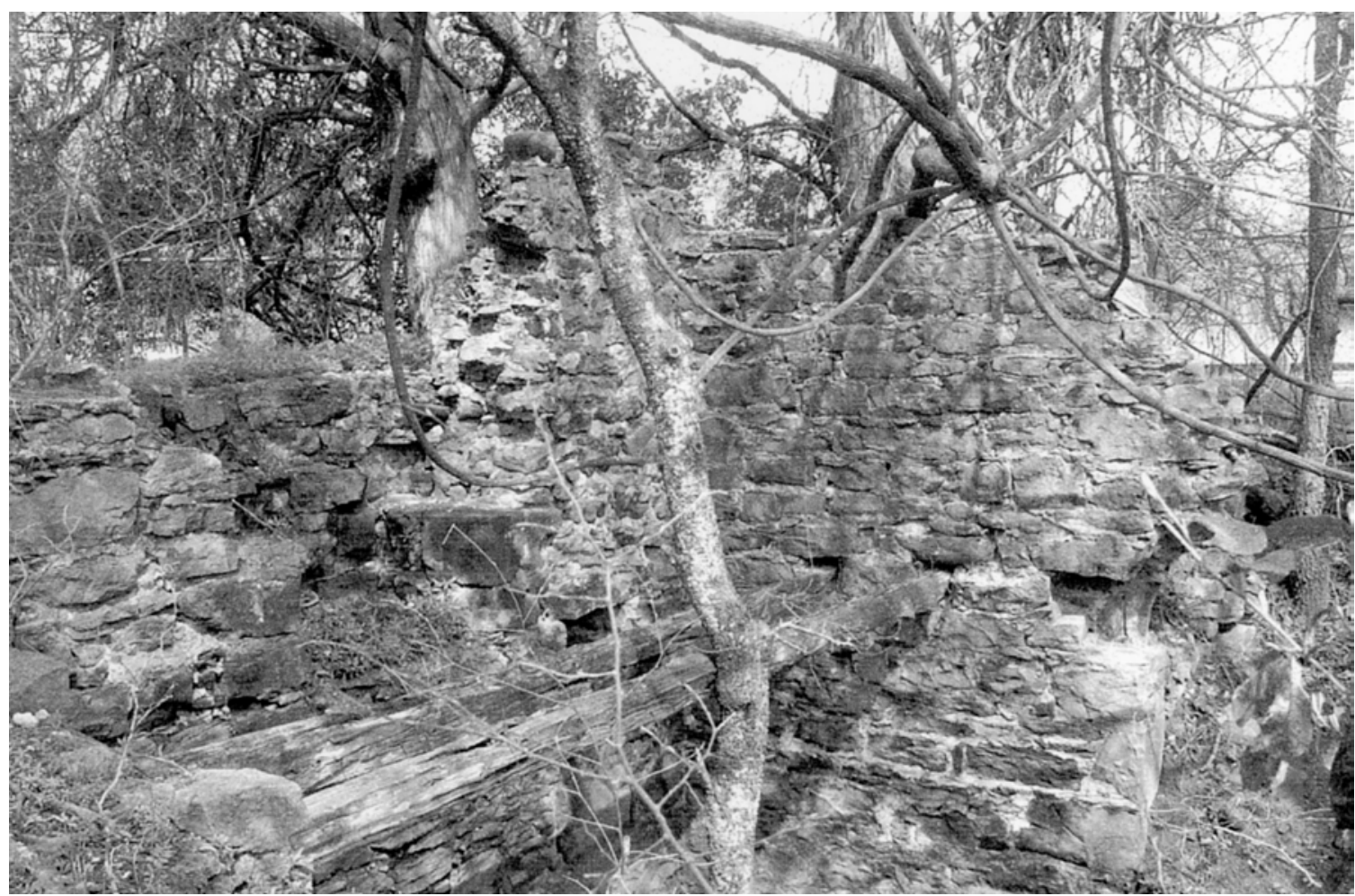

Figure 87. Aussilloux House showing remains of floor joists.
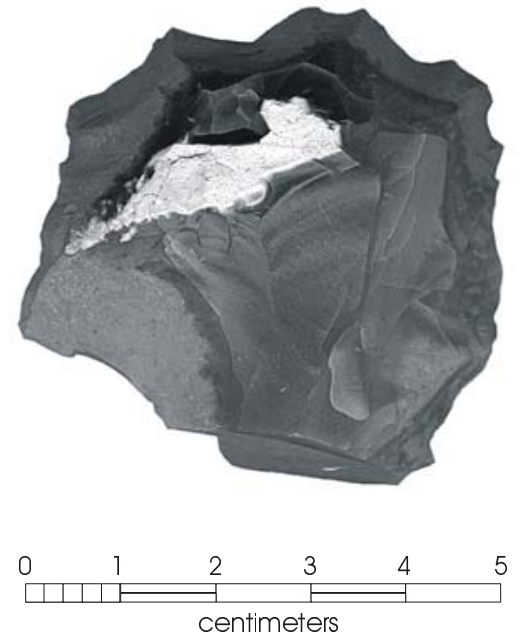

Figure 88. Biface from $41 B P 138$.

41BP140

Site Type:

Historic habitation site

Original Investigation:

Skelton and Freeman 1979

1997 Evaluation:

This site appears to be a nineteenth-century historic house and ranching site. The site is heavily overgrown with grapevine, making evaluation difficult. A pile of cut sandstone blocks may have been part of a chimney. No domestic artifacts were observed on the site surface. Ten shovel probes excavated all proved to be negative. 


\section{BP141}

Site Type:

Historic habitation site

Original Investigation:

Skelton and Freeman 1979

1997 Evaluation:

This appears to be a nineteenth- and twentieth-century historic house and ranching site. At the time the site was first recorded, it was comprised of the footings of a cut stone house and a scatter of domestic debris. The revisit found conditions roughly the same.

\section{BP144}

Site Type:

Historic habitation site

Original Investigation:

Skelton and Freeman 1979

1997 Evaluation:

At the time the site was first recorded, it was comprised of a well or cistern and a scatter of historic trash probably associated with a twentieth-century historic house site. The revisit found conditions roughly the same.

\section{BP148}

Site Type:

Sayersville Mine, historic lignite mine site

Original Investigation:

Skelton and Freeman 1979

1997 Evaluation:

Attempts to revisit the site in 1997 were hampered by dense vegetation. Little sign of the remains recorded by Skelton and Freeman (1979) existed.

\section{BP153}

Site Type:

Historic habitation site

Original Investigation:

Skelton and Freeman 1979

1997 Evaluation:

At the time the site was first recorded, it was comprised of the remains of at least two discrete buildings, consisting of Elgin and handmade brick scattered profusely over an area of about one-half acre. A set of large cut ironstone footings indicates the location of one structure. Mounds of disturbed earth occur at different points around the site. A thin scatter of historic artifacts was noted. At the time the site was relocated, it was in much the same condition. 


\section{$41 B P 154$}

Site Type:

Historic school site

Original Investigation:

Skelton and Freeman 1979

1997 Evaluation:

This is the site of the Wayside school. This one-room school served the community of Wayside, which was begun in 1860 by German immigrants (Smyrl 2001). The school had 55 students in 1905. The original school burned in 1924 and was re-built. At the time the site was first recorded, it was composed of ironstone footings, a brick well, and scattered ceramics, glass, and metal. The revisit found the site in roughly the same condition.

\section{$41 B P 156$}

Site Type:

Historic habitation site

Original Investigation:

Skelton and Freeman 1979

1997 Evaluation:

At the time the site was first recorded, it was comprised of two cisterns, a house depression, and a scatter of historic trash. The site was revisited by Wormser and Leshley (1995). The 1997 revisit found similar conditions.

\section{BP157}

\section{Site Type:}

Historic habitation site

Original Investigation:

Skelton and Freeman 1979

1997 Evaluation:

At the time the site was first recorded, it was comprised of a well or cistern and a scatter of historic trash. The revisit found conditions roughly the same.

\section{$41 B P 158$}

\section{Site Type:}

Historic habitation site

\section{Original Investigation:}

Skelton and Freeman 1979

\section{Evaluation:}

At the time the site was first recorded, it had remains of two separate stone house footings, one of which has a collapsed brick chimney, two brick cisterns, and scattered brick and metal, but little domestic debris. A small fence corral and two tall poles representing the ranch entrance were also observed. At the time of the revisit, the site was in roughly the same condition.

\section{BP159}

\section{Site Type:}

Historic habitation site

Original Investigation:

Skelton and Freeman 1979 


\section{Evaluation:}

At the time it was recorded, the site consisted of a standing sandstone chimney, lined with firebrick and pointed with cement (possibly laid up with older mortar). The house was aligned southeast/northwest with the chimney on the southeast end and historic artifacts were scattered around the area. When revisited, the chimney had fallen and the other remains of the house were not readily visible.

\section{BP160}

\section{Site Type:}

Historic agricultural installation

Original Investigation:

Skelton and Freeman 1979

1997 Evaluation:

The site consisted of the remains of a number of outbuildings, including corrugated metal roofing, stacked ironstone, assorted pieces of lumber, and brick. The revisit showed the site was damaged by military activity.

\section{BP162}

\section{Site Type:}

Historic habitation site

Original Investigation:

Skelton and Freeman 1979

1997 Evaluation:

The site is heavily overgrown with vegetation, but scattered bricks and sandstone house footings were observed. The site appears to have been heavily damaged by military activity, as there are large piles of dirt. In addition, a series of recently drilled monitor wells are located on the site.

\section{BP163}

\section{Site Type:}

Historic well site

Original Investigation:

Skelton and Freeman 1979

1997 Evaluation:

The site was relocated, but due to the dense vegetation, little of the remains of the well could be seen. A modern metal structure used to raise a warning flag when the nearby firing range is in use has been built on the site.

\section{BP165}

\section{Site Type:}

Historic habitation site/Prehistoric lithic scatter

\section{Original Investigation:}

Skelton and Freeman 1979

1997 Evaluation:

Footings for house with chimney and outbuildings, as well as scattered trash, were observed (Skelton and Freeman 1979). A prehistoric component was noted during the revisit, consisting of a scatter of flakes in disturbed context. 


\section{BP166}

\section{Site Type:}

Historic agricultural installation

Original Investigation:

Skelton and Freeman 1979

\section{Evaluation:}

The site was heavily overgrown with vegetation when originally observed. Skelton and Freeman (1979) thought it was probably a house site, though only a corral was visible at the time. The 1997 revisit found only the corral.

\section{$41 B P 378$}

\section{Site Type:}

Prehistoric open camp

\section{Original Investigation:}

Leshley 1994

\section{Evaluation:}

The site was revisited during the survey. The site is a superficial scatter of lithics and burned rock undergoing severe erosion.

\section{Artifacts:}

Two artifacts were recovered from the surface.

- Specimen 378-189 is a uniface (Figure 89), both side and endscraper, made on a secondary flake of light brown chert with darker and lighter brown speckles (see Appendix B for measurements).

- Specimen 378-2 is a utilized flake. The chert is dark to medium tan and appears to have been heat-treated.

\section{BP381}
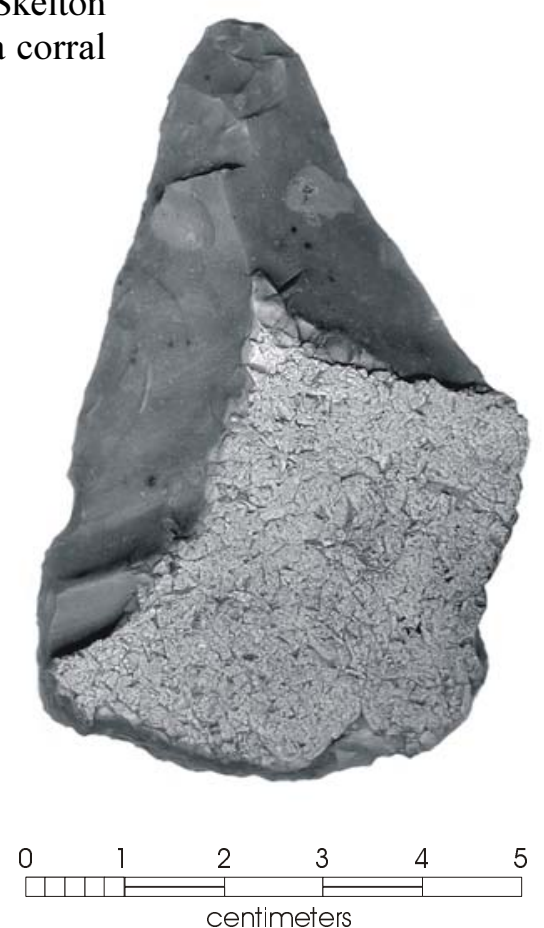

Figure 89. Uniface from $41 B P 378$.

\section{Site Type:}

Prehistoric open camp

\section{Original Investigation:}

Wormser 1994

\section{Evaluation:}

Wormser (1994) originally noted that the site was disturbed, but that the western edge appeared more or less intact. However, the 1997 revisited showed the entire site was severely disturbed. Numerous flakes and burned rock were noted on the surface. Two shovel tests were excavated (Table 38), and debitage was recovered to a depth of $30 \mathrm{~cm}$.

\section{Artifacts:}

The only artifacts of interest were recovered from the surface (see Appendix B for measurements).

- Specimen 381-0-2 is the base of a Bulverde dart point (Figure 90a).

- Specimen 381-0-1 is a ground stone cobble (Figure 90b),

Table 38. Results of shovel tests at 41BP381

\begin{tabular}{|lrl|}
\hline \multicolumn{1}{|c|}{ Unit } & Depth $(\mathbf{c m})$ & \multicolumn{1}{c|}{ Artifacts Collected } \\
\hline Surface & -- & $\begin{array}{l}\text { 1 Bulverde point } \\
\end{array}$ \\
& & 1 Ground stone \\
\hline ST-1 & $0-40$ & -- \\
\hline ST-2 & $0-10$ & -- \\
& $20-$ Oct & 1 flake \\
& $20-30$ & 2 flakes \\
\hline Probe-2 & $0-10$ & -- \\
& $30-$-Oct & 1 flake \\
\hline
\end{tabular}
possibly used as a mano or a nutting stone. 

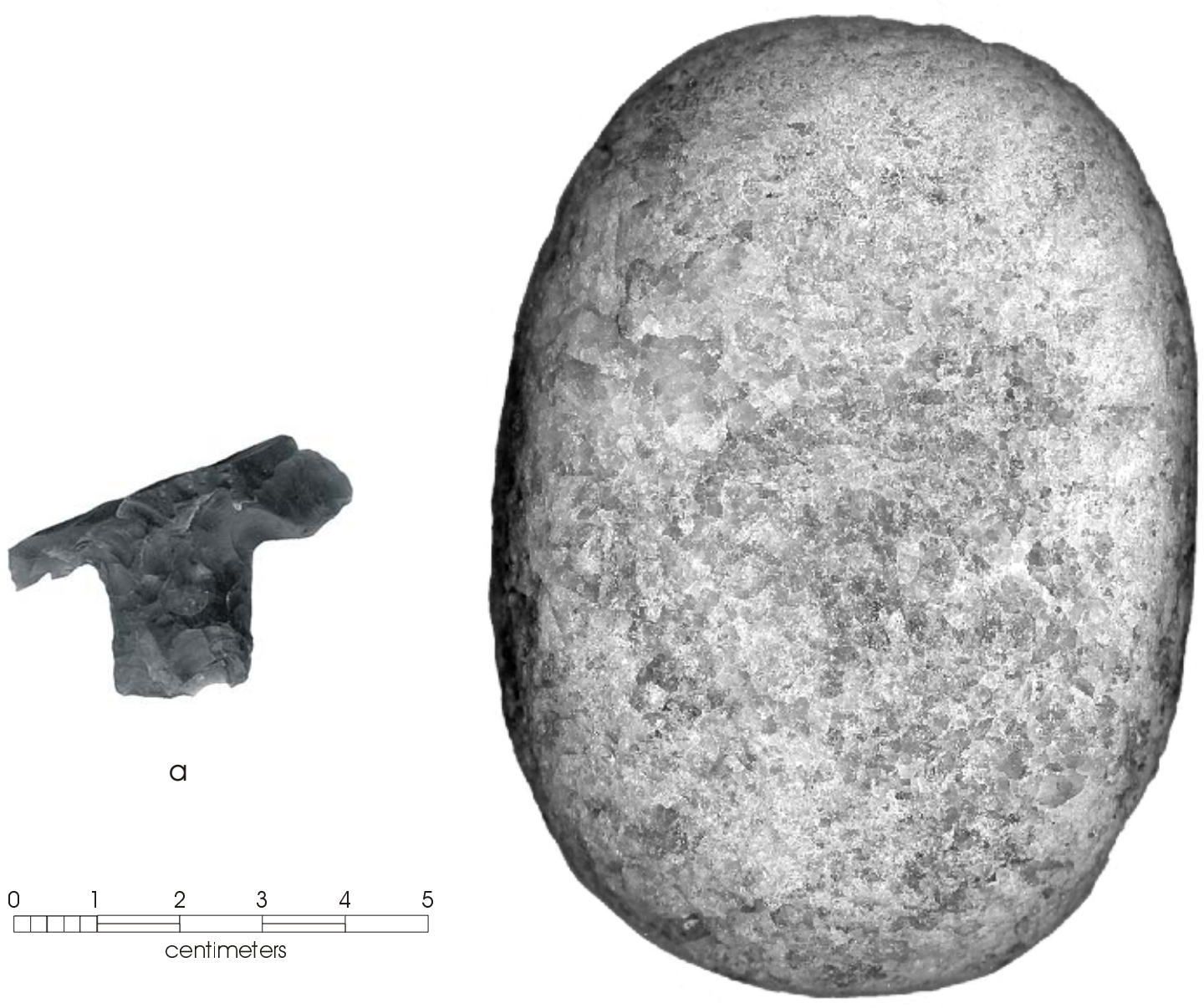

b

Figure 90. Artifacts from 41BP381: a) Bulverde dart point base; b) ground stone.

\section{BP391}

Site Type:

Prehistoric open camp

Original Investigation:

Nash et al. 1995

1997 Evaluation:

This site was originally designated with Field Site No. 97-27 when encountered during the 1997 survey. It was later realized that this was a previously discovered site 41BP391. The original site record indicated that the site was a lithic scatter on a disturbed surface with no depth, however, only the part of the site in the right-of-way of the power transmission line was investigated by Nash et al. (1995:52). At that time, the site was considered not eligible for nomination to the NRHP. At the time of the 1997 survey two more shovel tests were excavated. One test had a flake at $20-40 \mathrm{~cm}$, the other was sterile. In addition, a Scallorn point base and a biface were recovered from the surface.

\section{Artifacts:}

Two artifacts were recovered from the surface (see Appendix B for measurements).

- Specimen 391-119 is the base of a Scallorn point made with white chert (Figure 91a).

- Specimen 391-0 is a biface in medium gray-brown chert. The biface is a blank made on a large flake (Figure 91b). 


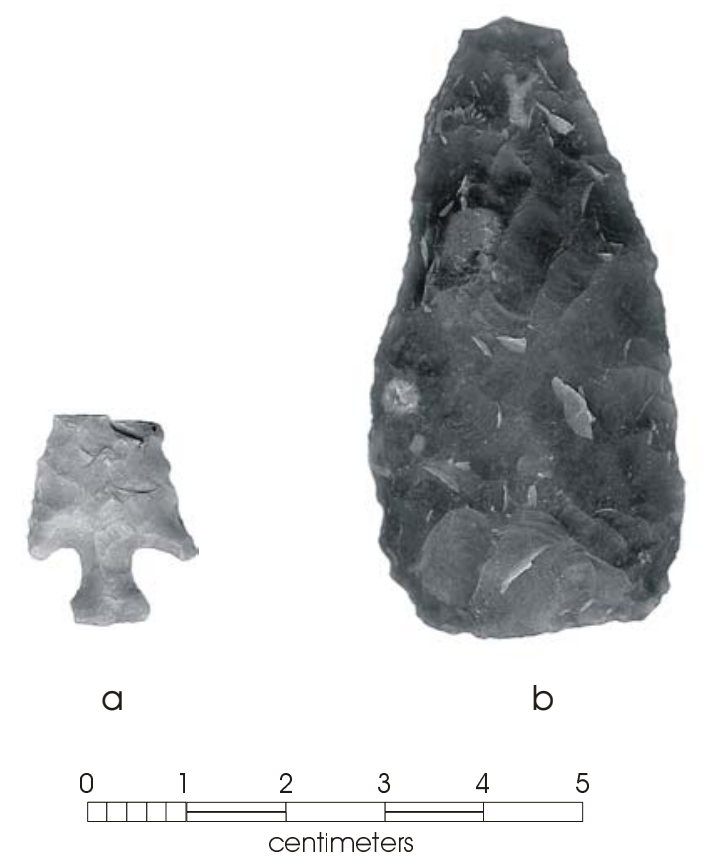

Figure 91. Artifacts from 41BP391: a) Scallorn dart point base; b) biface.

\section{BP399}

Table 39. Results of shovel tests at 41BP399

Site Type:

Prehistoric open camp

Original Investigation:

Wormser and Leshley 1995

1997 Evaluation:

The site was relocated during the survey. Eight shovel tests were excavated. Only the final three were positive (Table 39). The site is on the T0 terrace, which geomorphologic research indicates was probably deposited since 600 B.P. (see Chapter 3).

\begin{tabular}{|rrl|}
\hline Unit & Depth $(\mathbf{c m})$ & \multicolumn{1}{c|}{ Artifacts Collected } \\
\hline ST-1 & $0-90$ & -- \\
\hline ST-2 & $0-90$ & -- \\
\hline ST-3 & $0-90$ & -- \\
\hline ST-4 & $0-90$ & -- \\
\hline ST-5 & $0-90$ & -- \\
\hline ST-6 & $0-20$ & -- \\
& $20-30$ & 1 flake \\
& $30-60$ & -- \\
& $60-70$ & 1 flake \\
& $70-90$ & -- \\
& $80-90$ & 1 flake \\
& $0-10$ & -- \\
& $20-0 c t$ & 1 flake \\
ST-7 & $20-30$ & 2 flakes \\
& $30-60$ & -- \\
& $60-70$ & 1 flake \\
& $70-80$ & -- \\
& $80-90$ & 3 flakes \\
& $0-25$ & 1 flake \\
\hline ST-8 & & \\
\hline
\end{tabular}




\section{$41 B P 400$}

\section{Site Type:}

Historic trash scatter, possible habitation site

\section{Original Investigation:}

Davis 1995

\section{Evaluation:}

The site is a scatter of early twentieth-century trash, including amethyst-colored clear glass that dates to before 1915 (Munsey 1971:55). The site was relocated and a few artifacts collected. The site is now used as a parachute drop zone and is regularly plowed. No evidence of a structure now exists, but the nature of the trash deposit suggests it is largely domestic debris.

\section{Artifacts:}

The following artifacts were collected:

- Specimen 400-165 is the neck of a brown bottle. The bottle is molded, with an applied lip, intended for a cork closure.

- Specimen 400-168 is colorless glass ink bottle. The bottle is machine made and may be exhibiting the early stages of amber staining seen when colorless glass made with selenium is left in the sun. Selenium was in use from about 1915 to about 1930 (Munsey 1971:55).

- Specimen 400-169 is a milk glass container, probably intended for some sort of cosmetic cream. The maker's mark indicates that it was made by the Hazel-Atlas Glass Co. between 1920 and 1964 (Toulouse 1971:239).

- Specimen 400-166 is a fragment of ironstone with a partial maker's mark on it. The mark could not be identified.

- Specimen 400-167 is a fragment of ironstone with a partial maker's mark on it. The mark could not be identified.

\section{Cemeteries at Camp Swift}

\section{Timothy Meade}

Three marked cemeteries exist within the boundaries of Camp Swift: the Chandler Cemetery, the Mexican Cemetery, and the New Hope Cemetery. These cemeteries represent cultural resources that will require special management planning and protection. All cemeteries were revisited to assess their current condition. A detailed site sketch map locating the cemetery boundaries and all possible grave locations was created. This information was used to formulate a cultural resource management plan to preserve the cemeteries.

In addition to the three known cemeteries, Skelton and Freeman (1979) identified a possible individual burial. An attempt was made to re-locate this possible burial, but this effort was unsuccessful.

\section{Chandler Cemetery}

The Chandler family cemetery (41BP145) is approximately 0.23 miles southwest of Oak Hill Road in the southwestern portion of Camp Swift (see Figure 13). The cemetery is approximately 0.48 miles southwest of the reported probable location of the S. B. Chandler house site (41BP169). The cemetery is in a grassy open field on gently rolling uplands, which overlooks a valley to the southwest (Figure 92).

The Chandler cemetery is a small family cemetery that contains three graves (Figure 92a). These graves include those of S. B. Chandler (Figure 92b), an early pioneer of Bastrop County, and his sons Robert and William B. Chandler (Figure 92c). The dates of these interments and general comments on each grave are presented in Table 40. The cemetery is enclosed by a wrought iron fence which measures approximately 12 feet by 12 -feet. 


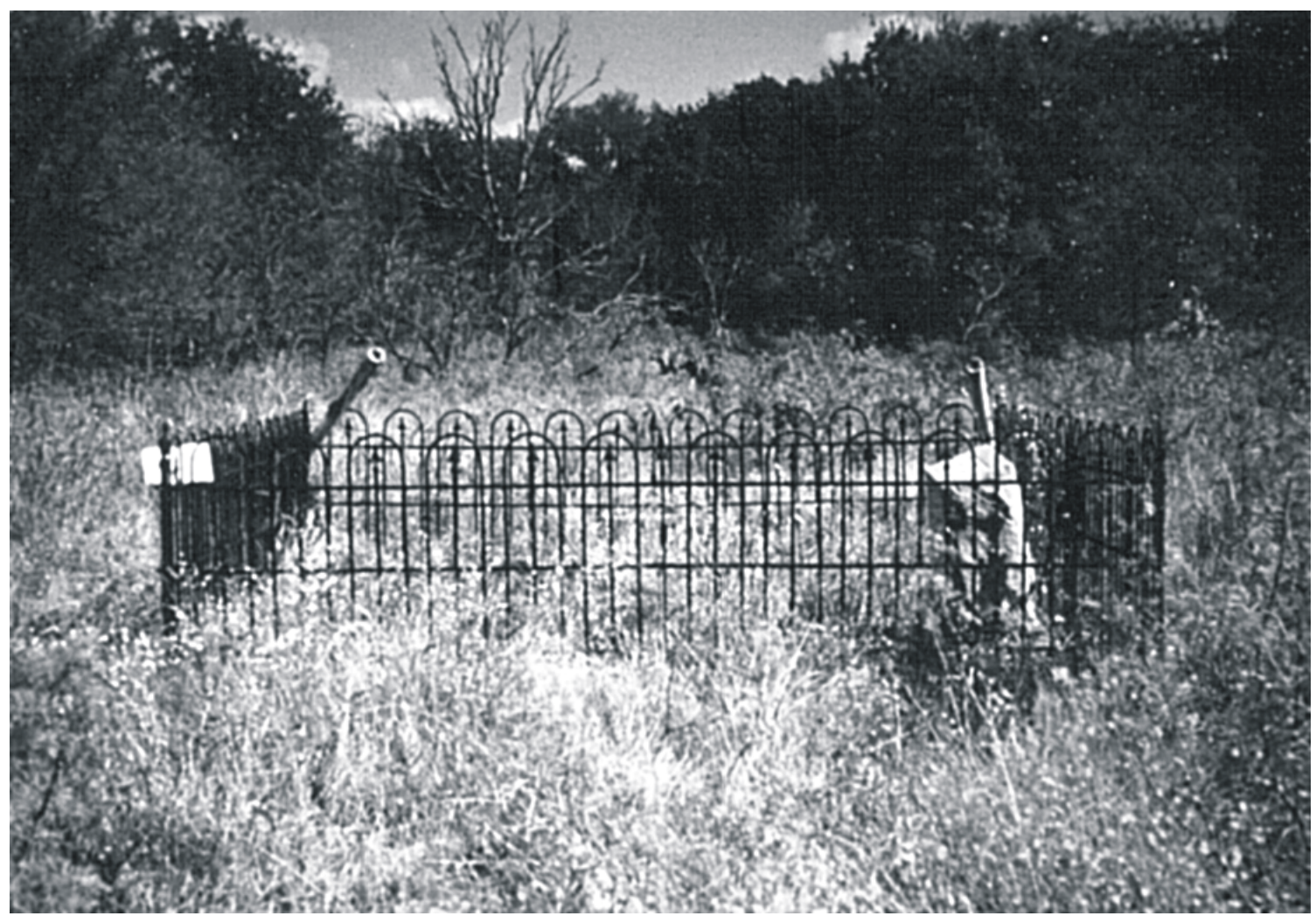

a

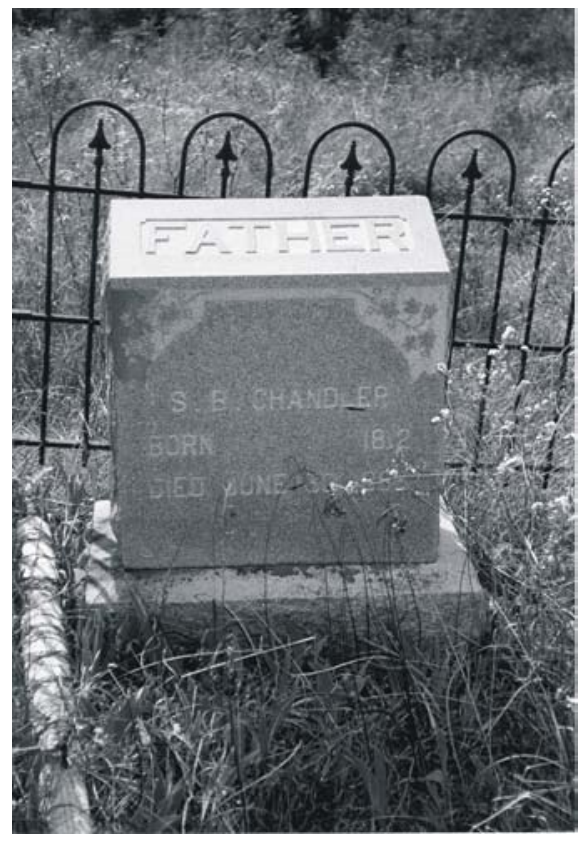

b

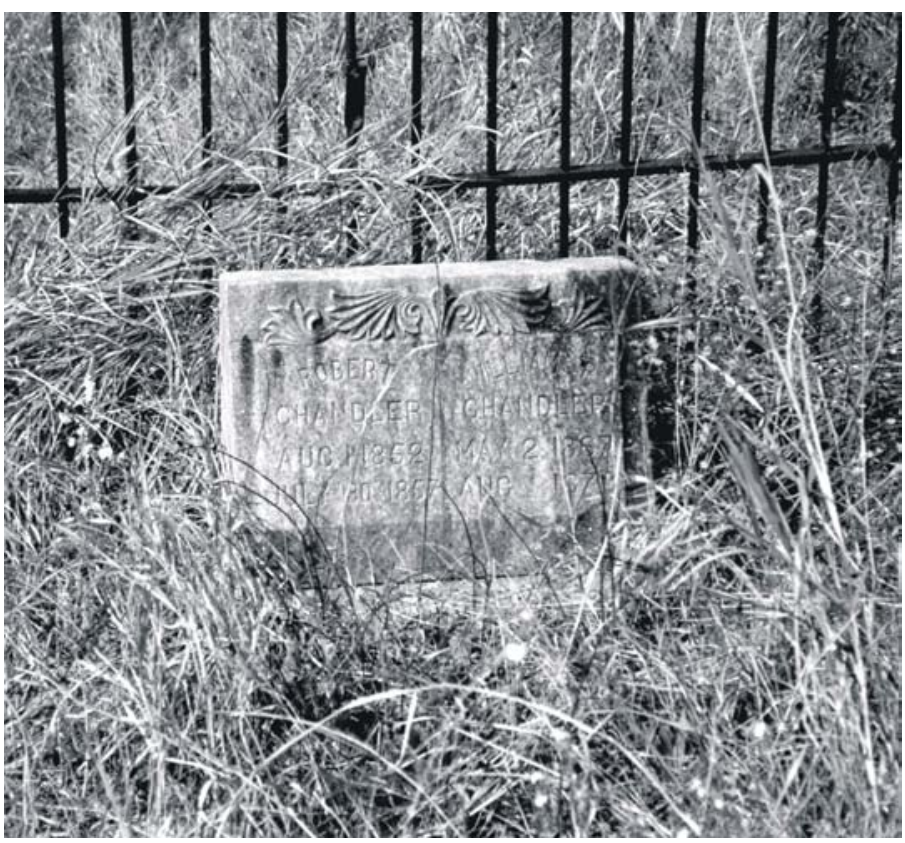

C

Figure 92. The Chandler Cemetery: a) overview of the cemetery; b) headstone of S. B. Chandler; c) headstone of Robert and William Chandler. 
Table 40. Information on graves in the Chandler Cemetery

\begin{tabular}{|l|l|l|}
\hline \multicolumn{1}{|c|}{ Name } & \multicolumn{1}{|c|}{ Dates } & \multicolumn{1}{c|}{ Comments } \\
\hline S.B. Chandler & $1812-1883$ & $\begin{array}{l}\text { Marble headstone and footstone, } \\
\text { grave has collapsed }\end{array}$ \\
\hline Robert Chandler & $1852-1857$ & $\begin{array}{l}\text { Marble headstone and footstone, } \\
\text { excellent condition }\end{array}$ \\
\hline $\begin{array}{l}\text { William B. } \\
\text { Chandler }\end{array}$ & $1867-1870$ & $\begin{array}{l}\text { Marble headstone and footstone, } \\
\text { excellent condition }\end{array}$ \\
\hline
\end{tabular}

The Chandler cemetery has previously been researched by Skelton and Freeman (1979) and Rother (1991). Both studies located the three graves, noted headstones and footstones, documented the grave stone inscriptions, and determined the size of the cemetery. Rother's study also produced a rough sketch map, not drawn to scale. Skelton and Freeman noted that the S. B. Chandler grave had collapsed, leaving a slight depression. The S. B. Chandler headstone has been replaced at some point in the past.
The 1997 revisit of the Chandler cemetery found the condition of the cemetery similar to that described by Skelton and Freeman and Rother (Figure 93). The graves and surrounding wrought iron fence are in reasonably good condition. The cemetery is overgrown with grasses, weeds, and cacti, which nearly cover the graves and fence. To make the cemetery more visible, four large white wooden posts were placed in the corners. At the time of the 1997 survey, these posts were in a state of disrepair, with one post no longer standing and the other three leaning and weather-beaten. However, new fences were installed in 1998.

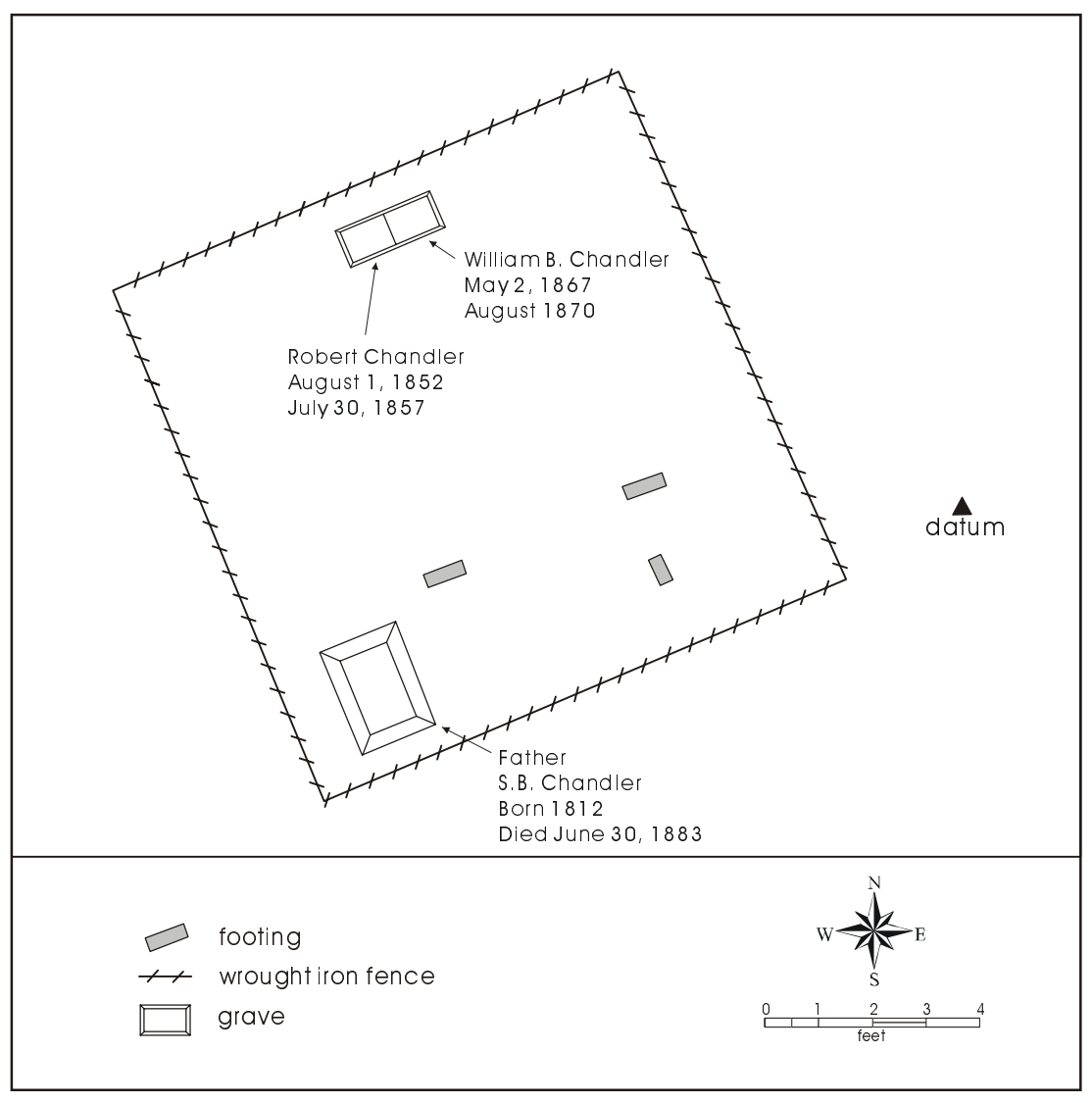

Figure 93. Plan map of the Chandler Cemetery (41BP145). 


\section{"Mexican" Cemetery}

The "Mexican" Cemetery (41BP170) is 0.11 miles southeast of Impact Road (the old Sayersville-McDade road) and 0.58 miles northeast of U.S. Highway 95 (see Figure 13). The site is on a gently sloping upland shoulder slope in a moderately dense wooded area interspersed with patches of grassy clearings (Figure 94).
The "Mexican" cemetery is so termed because the burials are reported to be those of Mexican miners from Frank Dennison Sayers' lignite mine (Skelton and Freeman 1979), which is approximately 0.35 miles northnorthwest of the cemetery. According to an informant of Skelton and Freeman, these burials occurred during the 1910s to 1920s The number of interments in the Mexican cemetery is not known, however, Skelton
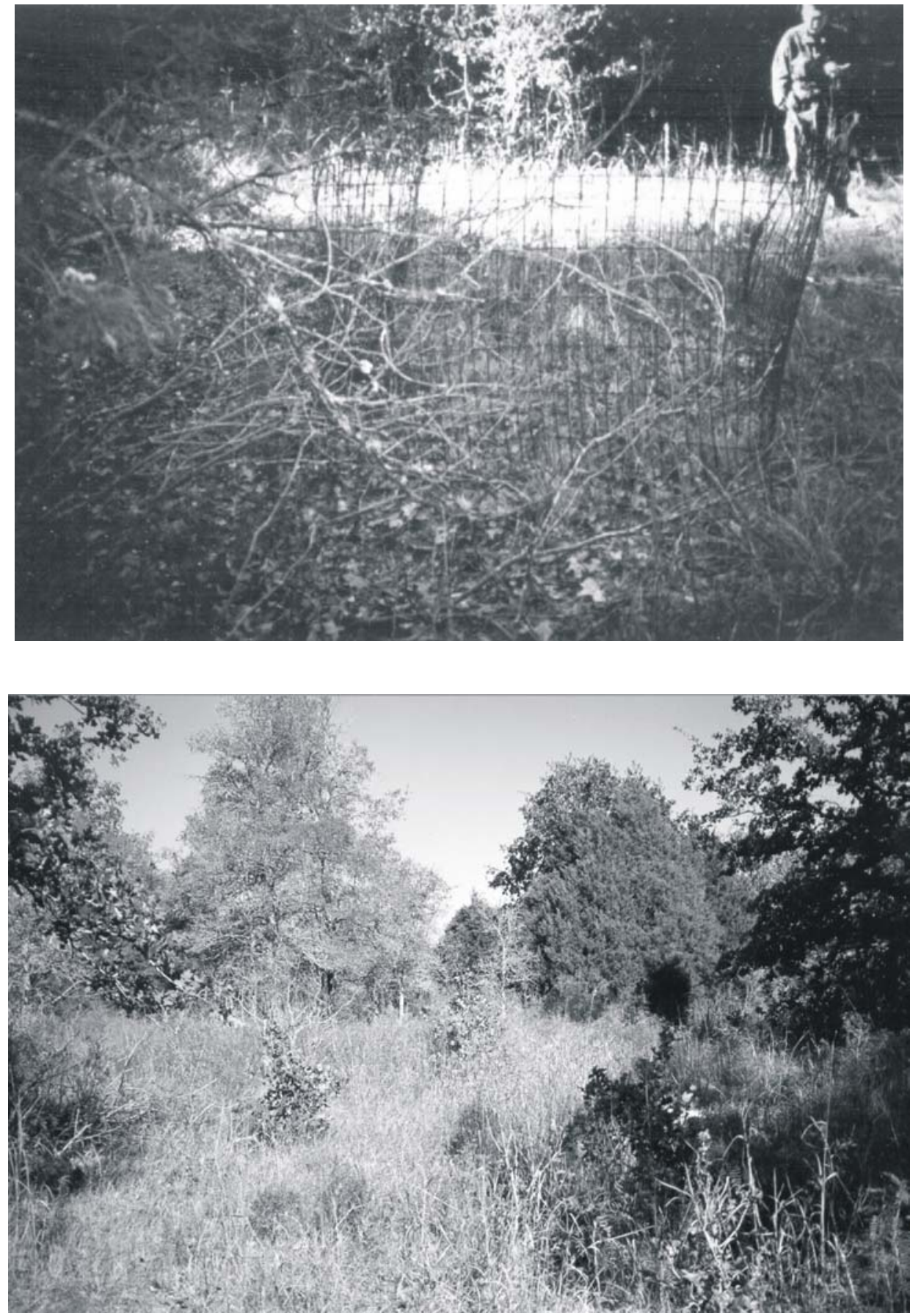

Figure 94. Two views of the "Mexican" Cemetery (41BP170). 
and Freeman (1979) were informed that at least 13 burials were present at the cemetery. None of the burials in the cemetery has been identified by name and no grave markers are present. There is little documented information available on this cemetery. Research on other cemeteries in Bastrop County revealed no recorded cemetery on or near the location of the Mexican cemetery.

The Mexican cemetery was previously investigated by Skelton and Freeman (1979). This investigation located and mapped two graves and one apparent grave (Figure 95). The graves are in a clearing approximately $20 \mathrm{~m}$ east of a former trail or road, which may have connected to the Sayersville-McDade Road at one time. One grave was enclosed by a ferrous metal wire fence, which measures 9.5 feet by 5.5 feet. The second grave location is not enclosed and is marked by earth mounding. The second grave is also covered by various artifacts that date to the early twentieth century. These artifacts include: one shell, Vaseline bottles, amethyst-tinted bottle glass, blue edge-decorated whiteware plate fragments, undecorated whiteware, and milk glass. A third apparent grave is between the two identified graves and is marked by a depression. It was noted that some graves were apparent only because of their proximity to iris patches.

The major goals of the 1997 visit to the Mexican cemetery were to:

a) Identify additional grave locations; and

b) Establish definite cemetery boundaries for future cultural resource management planning.

The iris patches associated with the graves and possible graves described by Skelton and Freeman were not observed during the revisit. The absence of these irises during the present survey cannot be explained. In addition, fragments of chicken wire-like fencing, which may represent the remains of a former cemetery enclosure, were found near the former road.

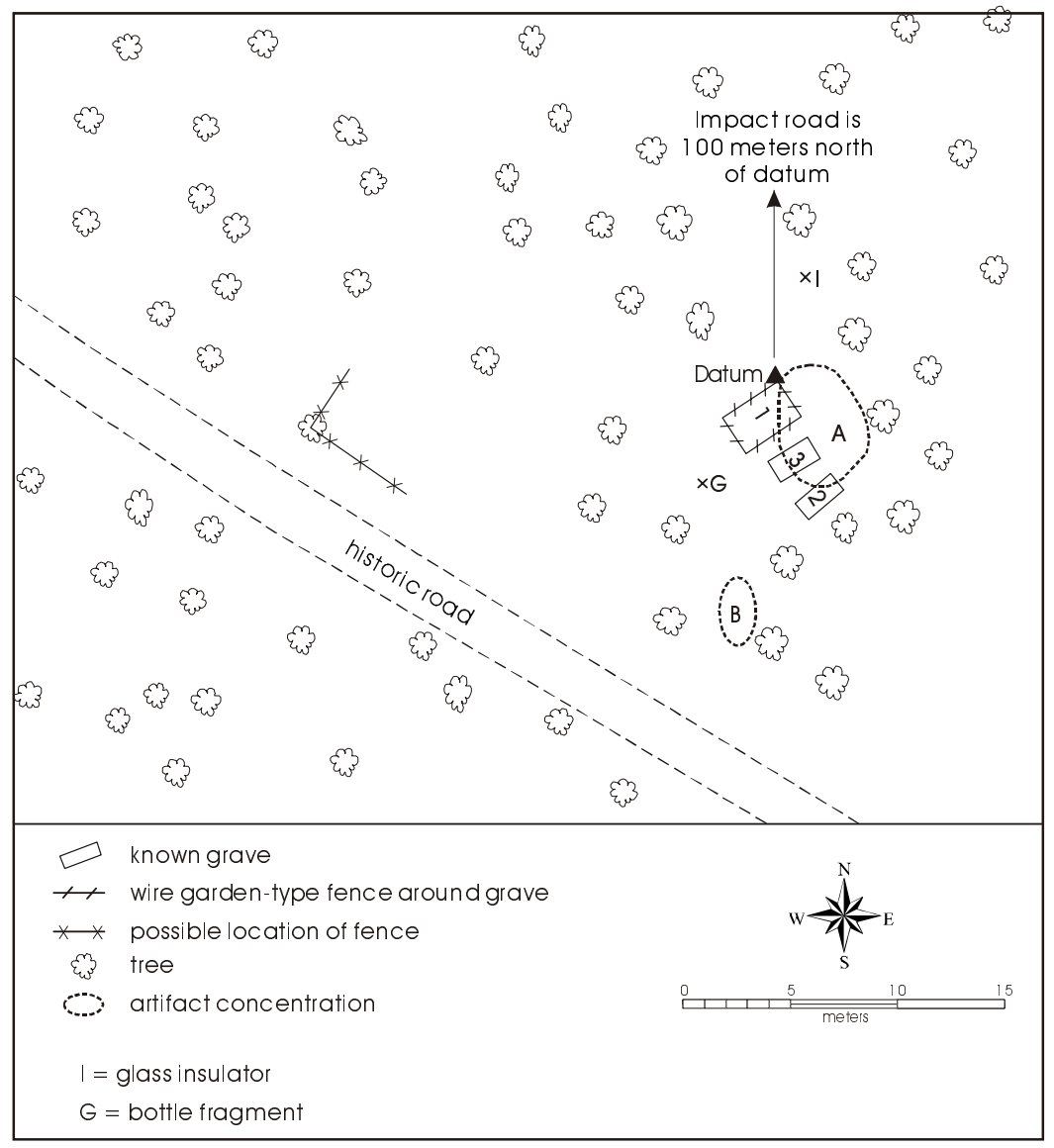

Figure 95. Plan map of the "Mexican" Cemetery. 


\section{New Hope Cemetery}

New Hope Cemetery (41BP382) is in west-central Camp Swift approximately 0.7 miles southwest of Scott Falls Road (see Figure 13). The cemetery is in a lightly to moderately wooded area on the northwestern edge of an upland summit that overlooks Big Sandy Creek, which flows about $100 \mathrm{~m}$ to the north (Figure 96a). A small unimproved road extends southeast from the cemetery and connects with Upper Cut Road approximately 0.4 miles to the southeast of the cemetery.

New Hope cemetery is an African-American cemetery that dates from the late nineteenth-century to its incorporation in Camp Swift at the start of World War II. It is believed that New Hope Cemetery is on one acre of land given, without deed, to the local AfricanAmerican population by landowners John and Johanna Gest (Rother 1991). The date the land for the cemetery was granted is not known. A local informant estimated to Rother (1991) that approximately 35-40 interments lie within New Hope cemetery.

Individuals known to be buried at New Hope cemetery, their life dates, and comments regarding their gravestones and inscriptions are presented in Table 41. The earliest burial marker observed at the cemetery is that of Josephine Davis interred in 1882 (Figure 96b), the latest is an unknown individual reported to have died November 6, 1941 (Rother 1991), though this headstone was not observed during the 1997 fieldwork. It is possible that earlier burials exist at the cemetery, as only ten of the graves are presently marked.
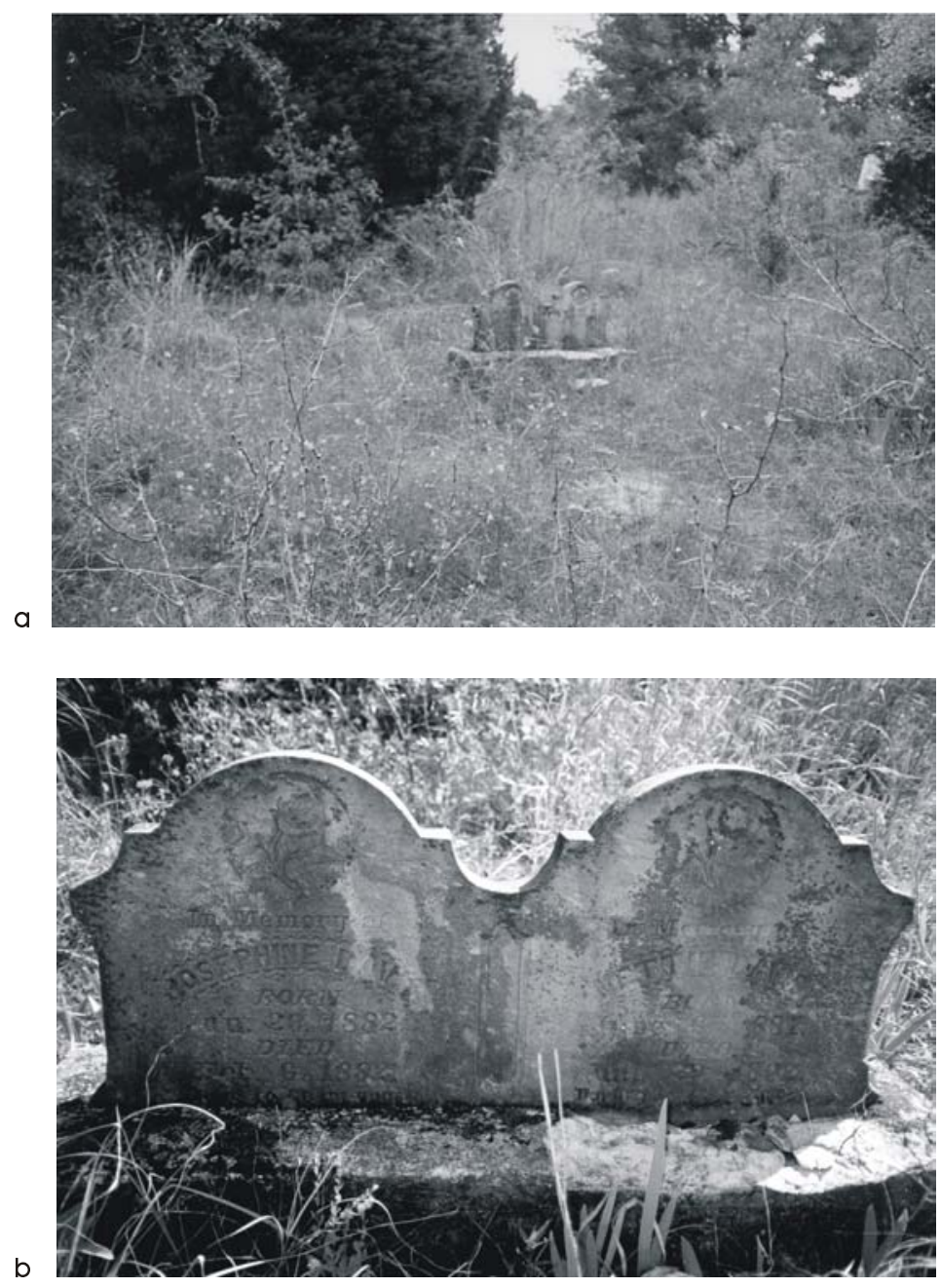

Figure 96. New Hope Cemetery: a) overview of cemetery; b) close-up of double headstone, Josephine and Nettie Davis. 
Table 41. Information on graves in the New Hope Cemetery

\begin{tabular}{|c|l|c|l|}
\hline GRAVE \# & PERSON INTERRED & DATES & \multicolumn{1}{c|}{ COMMENTS } \\
\hline 1 & Josh A. Chambers & $1856-1940$ & Head stone is hand-labeled slab of concrete (see Figure 97a) \\
\hline 2 & Josephine Davis & $1 / 1882-2 / 1882$ & Double marble head stone with Nettie Davis, motto "gone to be an angel" \\
\hline 3 & Nettie Davis & $1887-1892$ & Double marble head stone with Josephine Davis, motto is illegible \\
\hline 4 & (Lou)? Jackson & $?-1940$ & Plain marble head stone \\
\hline 5 & K. Hatch & $?-1918$ & Plain marble stone, lightly engraved \\
\hline 6 & C. Brown & $1853 / 54-1917$ & Grave marker is a galvanized steel pipe \\
\hline 7 & Lucy Anderson & $1832-1897$ & Marble marker with foot stone, quote from Timothy on the stone \\
\hline 8 & Julia Ann Price & $1866-1899$ & Marble head stone, marker broken \\
\hline$* 9$ & Mrs. M.A. McShann & $?$ & Carved in sandstone rock \\
\hline 10 & Julia Houston & $?-1918$ & Marble head stone is currently leaning against a tree in cemetery \\
\hline- & Ben Palmer & $?$ & Unmarked grave \\
\hline- & Joe Palmer & $?$ & Unmarked grave \\
\hline
\end{tabular}

* Not relocated in 1997 revisit

New Hope cemetery was first researched by Rother (1991) as part of a county wide inventory of cemeteries in Bastrop County. The fieldwork for this study consisted of documenting the inscriptions on headstones and constructing a general location map, and a rough sketch map for the cemetery. Rother recorded ten grave markers with script, three metal markers without information, 15 rocks, five iron rods-possibly marking grave sites, five bricks, four cement blocks, fragments of a porcelain urn and vase (Figure 97b), and fragments of a kerosene lamp. Rother (1991) noted at the time of survey that the cemetery was in poor condition, with the barbed-wire fence surrounding the cemetery broken and missing in places and the cemetery itself unattended and overgrown.

The cemetery was revisited in 1993 by Alan Wormser (1993c) of the Adjutant General's Department of Texas (AGTX) and recorded as an archaeological site. The AGTX visit confirmed Rother's findings and further documented the cemetery by the photographing of headstones. No mapping was undertaken during this 1993 revisit.

The present revisit of New Hope Cemetery was undertaken with a number of objectives. The first was to assess the current condition of the cemetery to formulate cultural resource management recommendations for its preservation. The second was to locate possible additional unmarked graves. The third was to generate an improved sketch map of the cemetery. The cemetery revisit relocated nine of the ten inscribed grave markers found by Rother (1991) and Wormser (1993c). The headstone not relocated was from Grave 9, which was previously described as a sandstone slab inscribed "Mrs. M. A. McShann" (Table 41). This stone may have been removed or not observed because of dense vegetation. The marker for Grave 10 has been taken away from the grave and is currently leaning against an oak tree near Grave 8 . The exact location of the grave site is not known.

Possible unmarked graves were noted on the basis of one or several attributes, which include the presence of possible gravestones, depressions in the earth, concentrations of irises, and posts or stakes. Fifty-six possible unmarked grave sites were identified during the cemetery revisit (Figure 98), although the actual number is as yet unknown. The number of gravestones originally in the cemetery was likely greater previously than at present. Informant Captain Michael Diltz of Camp Swift reported hearing of instances of gravestone theft from New Hope cemetery within the last 15 to 20 years. 

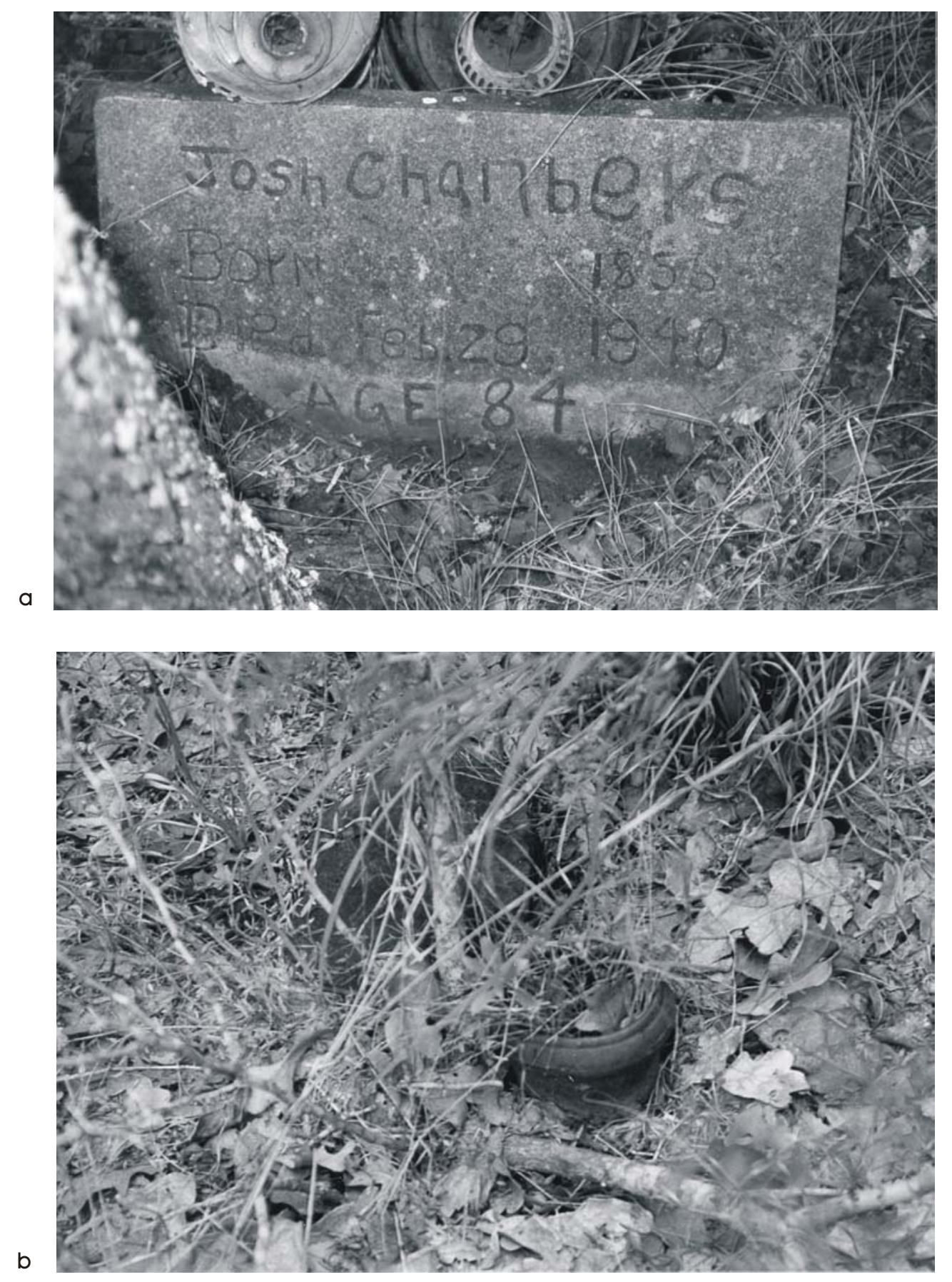

Figure 97. Two more views of New Hope Cemetery: a) headstone of Josh Chambers; b) vase placed between two possible graves (see Figure 98). 


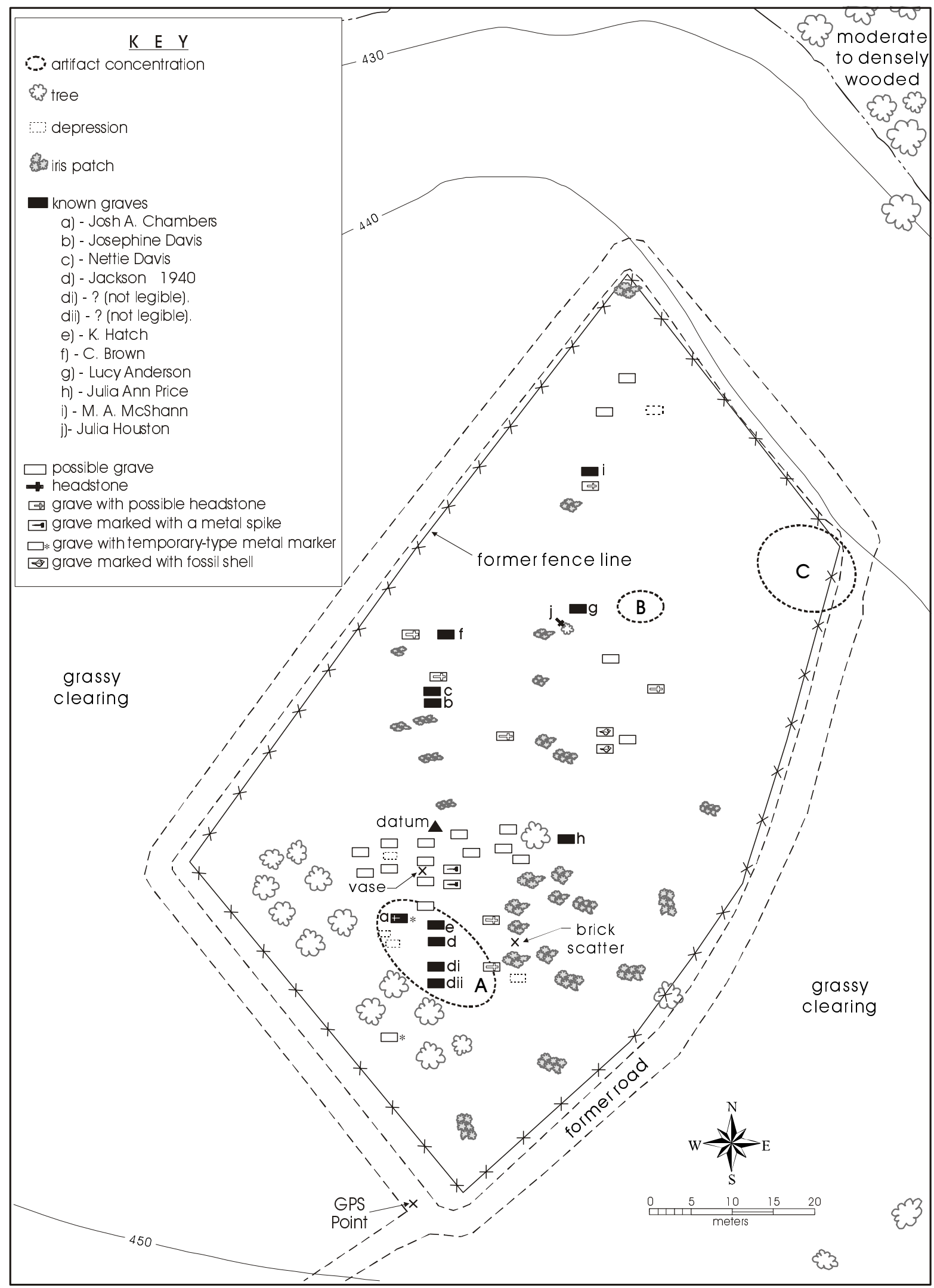

Figure 98. Adaptation of a map of New Hope Cemetery.

(Based on former and current investigations.) 


\section{Possible Isolated Grave Site}

Skelton and Freeman (1979) reported a possible grave site as site 41BP146. It is reportedly about $150 \mathrm{~m}$ northeast of Scott Falls Road on the east side of a tributary of Big Sandy Creek. They observed five cut hematite slabs enclosing an area approximately 2.5 by 4.2 feet. The possible grave was reported to Skelton and Freeman by Ina Fay Scott, the wife of Abner Scott's grandson. Mrs. Scott reported that the grave dated from her husband's grandparents occupation of the area (Skelton and Freeman 1979). However, there is another possible story of who is buried in the grave. According to an employee at Camp Swift, and a former Facility Manager, a young woman visited the camp and inquired about the grave. She believed it was that of her great, great grandfather, who while en route from San Antonio to Camp Swift by stagecoach had died. Unfortunately, no one was available at the time to take her to the site (S. Prewitt, personal communication 2001).

An attempt was made to relocate the possible grave site during the site revisitation portion of the Camp Swift survey, but it was not found. The reasons the site was not relocated may be related to dense vegetation or that the site was plotted in the wrong location on the topographic map.

\section{Discussion}

The 1997 cemetery revisits located the three known cemeteries in Camp Swift. The Chandler and New Hope cemeteries were as plotted by previous investigations. The Mexican Cemetery was found approximately $100 \mathrm{~m}$ to the southeast of the location plotted by Skelton and Freeman.

The cemetery revisits identified additional possible burial locations within New Hope cemetery. These additional grave sites were identified on the basis of ground surface features, such as depressions, earth mounds, and iris clumps.

The present condition of New Hope Cemetery has changed somewhat from that reported in the two previous research investigations. One gravestone has been displaced from its grave and another was not relocated during the revisit. In addition, brush-clearing activities to the east and south of the site may have displaced some artifacts associated with the cemetery. However, the brush clearing activity appears to have been undertaken outside of the cemetery boundaries and does not seem to have had a direct impact on the graves. Artifact collecting has likely occurred at New Hope Cemetery in the form of headstone theft. The condition of the Chandler and Mexican cemeteries is as described in previous research. Fences around all three cemeteries were erected in 1998. 


\title{
Chapter 6: Historic Contexts
}

\section{Developing Historic Contexts for Camp Swift}

\author{
David G. Robinson
}

\section{Research Domains}

Research domains are overarching research questions that are largely derived from anthropological theory and the results of generations of research. They are best thought of as descriptions of the perspective of researchers on any particular research problem. The most useful list of research domains for the region remains that of Black (1989:37-38), who wrote that research domains are most appropriately addressed on a specific, regional level. The 5,000-acre survey area of the Camp Swift Phase I inventory is an appropriate scale for addressing these issues. Phrased intentionally as generalized questions, however, Black's research domains include:

- Paleoindian adaptations

- Environmental relationships

- Social organization

- Burned rock middens

- Subsistence

- Technology

Paleoindian adaptations requires the presence of Paleoindian components but certainly comprise an important topic for research once found.

Environmental relationships focusing on cultural adaptations to the environment may be pursued on the level of Phase I survey by correlating discovered sites with geographical and locational data. Samples for micro-scale analysis (pollen, macrofossil, sediment) may be collected and analyzed as opportunity arises; results apply to the subsistence domain as well.

Social organization has received research attention by the testing of models of social organization derived from ethnohistoric studies within the Texas area. Propositions about social organization and community layout and patterning may also be assessed by comparison with general ethnographic and ethnoarchaeological models (Brooks and Yellen 1987; O’Connell 1987).

Burned rock middens do not occur near Camp Swift, and therefore is not an applicable domain there. However, it is possible that the domain could be addressed indirectly. For example, since burned rock middens are seasonal communal cooking events, it is likely that at least for some time periods, the prehistoric inhabitants of Bastrop County were the same nomads who in the fall of each year moved onto the Balcones Escarpment to harvest acorns or partake in other activities associated with the burned rock middens. Thus, we may be able to improve our understanding of the burned rock midden phenomenon by studying the same people in a different context.

Subsistence, as has already been mentioned, is closely related to environmental relationships. The environment would be the primary constraint to any subsistence model. However, it is also true that broad cultural behaviors, related to social organization and technology, modify the effects of these constraints. Consequently, the subsistence domain is really the fusion of the environmental relationships, social organization, and the technology domains.

Technology may be addressed by numerous studies of lithic tools and debitage, commonly unearthed from regional sites. Artifacts from well-stratified sites may gain heightened research priority, as they permit seriation studies, hence greater understanding of growth and change in technological systems. 


\section{Camp Swift's Historic Contexts}

Whereas research domains frame issues from theory and larger anthropological and historical questions, historic contexts are developed from previous work directly in a region, from its particular history (including prehistory), and from the available data. As a result, historic contexts comprise the most specific level of organized research inquiry and succeed at ordering the data and their interpretations. They are mentioned specifically in the Secretary of the Interior's Guidelines for their value in the eligibility assessment process. The uses of historic contexts are described succinctly in the Guidelines: "Evaluation uses the historic context as the framework within which to apply the criteria for evaluation to specific properties or property types. Decisions about treatment of properties are made with the goal of treating the range of properties in the context (III-59)." From prior research and initial findings of the Phase I inventory, a range of historic contexts were identified. They are introduced briefly here, and those not discussed in Chapter 2 are developed fully later in this chapter.

Prehistoric Settlement Patterns. Relying in part on the above context, the study of settlement patterns will examine the larger patterns of prehistoric use of the land from the perspective of hunter-gatherer community patterns, mobility, and seasonality. This context may tie together findings in social organization, environmental relationships, and subsistence.

Prehistoric Lithic Technology. Lithic debitage and stone tools are the most common material culture classes retrieved from Camp Swift prehistoric sites. Analyses of these classes and comparison with other regional technologies will give important clues to site function and community patterns and help address the overarching research domains of social organization and technology.

Historic Settlement and Ownership (see Chapter 2). Potentially the broadest historic context, this topic traced historical land use from Spanish land grants to the purchase of property for Camp Swift.
The Early Texas Wine Industry (see Chapter 2). This context unites historical personage, architectural remains, and the historical theme of the wine industry in the late nineteenth-century. This context synthesized data from archaeological and archival sources, specifically historical architectural site 41BP138, the winery and habitation of Antoine Aussilloux, a Texas vintner, stonemason, and entrepreneur.

Lignite Mining Period, 1910-1940 (see Chapter 2). This context interprets lignite mining-related sites on Camp Swift: the Sayers Mine and the Mexican cemetery. The lignite mining period brought about significant demographic and economic changes, notably the advent of a recognizable Hispanic population in the region (who immigrated as miners) and the establishment of company towns operated by the mine companies.

Effects of World War II Training on Historic and Prehistoric Sites on Camp Swift. This is an important context as it relates to site integrity. This land use resulted in changes in site formation processes of the cultural resources of the camp. 


\section{Historic Contexts for Camp Swift}

\section{Prehistoric Settlement Patterns-Camp Swift}

\section{David G. Robinson}

The study of settlement patterns, defined simply as the patterning of sites across the landscape, effectively began at Camp Swift with Skelton and Freeman (1979), who stratified their study zone by landforms and classified their sites with a mixture of functional and descriptive categories. The majority of their sites are on valley margins (Skelton and Freeman 1979: 2829). Robinson (1982, 1983b) collected locational data across all the physiographic zones in neighboring Fayette County and described settlement patterns, applying a descriptive, non-functional site classification. Patterning was identified by cross-tabulation. The typology and patterning were tested against followup survey data (Nightengale and Jackson 1983: 8996) and found to have general descriptive value. Robinson (1987) followed up this approach by classifying the Bastrop County inventory (then 184 sites) in the same fashion and using factor analysis for data reduction and pattern searching to test the validity of the physiographic zoning for prehistoric settlement. He then applied cross-tabulation to gain a clearer picture of the nature of the patterning. The outcome of this first wave of research was that variability in prehistoric use of the land across the various physiographic zones of the region could be perceived in site locational data and archaeological materials.

A second wave of research overlapped the first and applied its findings to issues of culture, system, and adaptation. This second wave, implicitly or explicitly, applied a more complex definition of settlement patterns, one more akin to settlement system. This change of perspective sees settlement patterns as manifestations of a cultural system; in hunter-gatherer societies subsistence needs and seasonality are the components most responsible for site locations on the landscape. Study of patterns necessarily relies heavily on inferences of function, both of sites and the artifact assemblages within them. Intersite comparisons of site features and artifacts comprise a common method for identifying functional differences among sites. These identified differences in turn allow the inference of the components of the settlement system. Results may then address questions of general cultural adaptations to the environment (Black 1989:36-37).

Bement's (1984) study of sites 41BP191 and 41BP192 included intersite comparisons of lithic debitage, stone tools, and burned rock features. He concluded that initial stone tool making was carried out at upland sites with tool finishing completed elsewhere, and that large upland sites with features are likely full-range habitation encampments occupied seasonally (Bement 1984:17, 96). Keller and Campbell (1984:217-220) applied a functional site classification in their site distributional study of the Colorado lowlands. They looked at spatial distributions of quarry sites, special activity sites, habitation sites, quarry/habitation sites, and quarry/special activity sites. Their classification was constructed from lithic technology, site size, and ecological features. Their special activity site category (encompassing all the diverse activities that defined them) formed the majority of sites they discovered, and they could be found in all the physiographic zones included within the reservoir flood pool. Continuity more than change was inferred between Late Archaic and Late Prehistoric settlement patterns (Keller and Campbell 1984:222-224). They thought their findings supported the concept of the region as a transition zone, a "no-man's land," between coastal cultures and those of central Texas, where hunting and raiding may have been the dominant land uses (Keller and Campbell 1984:225).

Ensor and Mueller-Wille (1988) synthesized many of the previous findings of the second wave of settlement pattern work and incorporated them into their own analyses. They performed various tests on stone artifact and debitage categories to assess the position and functioning within the settlement system of their large lowland site, the Bull Pen site (41BP280). The features, diversity of implied artifact functions, and their quantities established the site as a full domestic campsite occupied repeatedly, probably seasonally. The site's location at the conjunction of multiple resource zones was advantageous for camping activities, a quality shared with other camps in riverine and upland creek terrace zones (Ensor and Mueller-Wille 1988:193, 196, 199-200). Also applying their 
findings to a thoughtful test of the transition zone hypothesis, Ensor and Mueller-Wille observed differences and similarities between Bastrop and central Texas and proposed a distinction between a shared regional pattern, seen in stylistic issues, and a separate local adaptive pattern, necessitated by differences in the environment (Ensor and MuellerWille 1988:200).

The most recent statement on settlement patterns in the Post Oak Savannah (Fields 1995) curiously excludes the Colorado River basin of the study area, on the basis of its closer similarities with central Texas than with eastern Texas and the erroneous claim that archaeological projects there have been relatively limited in scope (Fields 1995:303). Fields (1995:320-323) described a pattern of trends (based largely on intersite comparisons of artifact assemblages) corresponding to the northeast-southwest sweep of the Post Oak Savannah and its paralleling belts of Blackland Prairie. Generally, settlement patterns in northeastern drainages reflected longer-term residence sites, while southwestern drainages showed patterns of shorter-term site occupations and more commitment to foraging strategies and high mobility. This difference was accentuated in the Woodland and Late Prehistoric periods, when the northeastern regions became heavily influenced by the Caddoan cultural area; these include horticulture as a significant contributor to the subsistence economy and quasi- or full-sedentism as a favored residence option. Southwestern drainages lay outside this zone of interaction and influence apart from trading relations. There, hunting and gathering economies and patterns persisted to the end of the prehistoric period (Fields 1995:320-323, 325-327).

Johnson (1994) has provided a thorough and highly synthesized study of the latest prehistoric periods, one only partly concerned with settlement patterns but nevertheless offering provocative results. His interests focused on the Toyah culture populations, whose easternmost ranges lay in the Post Oak Savannah and the Bastrop region. Again applying intersite comparisons of artifact sets and community structure, Johnson (1994:258-265) described the Toyah people as living in very small one- and two- family encampments. Implicitly, population density and total numbers across the large area were low. Toyah people adopted bison hunting in response to an expansion of bison migratory range ca. A.D. $1250-1300$ and procured the bison in small hunting parties that garnered one or two animals at any one time. Toyah people also engaged in maize horticulture and collecting of wild plant foods and small game such as reptiles, amphibians, fish, and mussels (Johnson 1994:258-265). Despite the Toyah pursuit of far-migrating game animals, the people themselves moved through very small regional territories, probably preferring to allow migrating animals to move into their vicinity rather than persistently tracking the animals throughout their annual range (Johnson 1994:265-268, 285-286). This inference was gained from observations of minor stylistic differences in tool inventories and local variations in Toyah pottery clays and vessel forms. This reconstruction is a point of correspondence with Ensor and Mueller-Wille (1988) who posited a shared regional (i.e., areal) cultural pattern and a variant local (i.e., regional) adaptive pattern for the Late Archaic and earlier Late Prehistoric periods.

\section{Methods of Analysis}

The goal of this settlement pattern study is to make the best possible statement about prehistoric site functions and distributions across the landscape of Camp Swift. This goal is conditioned by two limitations: 1) the incomplete cross section of relevant prehistoric environments represented by the camp (creek terraces through upland divides), and 2) the paucity of chronological information which would allow an assessment of change through time. At best, the findings can speak to specific functions of the Colorado uplands over broad spans of prehistory and are best stated as comparisons to the previously identified or posited patterns, described above.

Site types defined:

- Open camps - sites with any category or class of cultural material (commonly lithic debitage) and burned rock (FCR). Burned rock is the defining criterion, as it implies domestic activities during site stays long enough to leave the distinctive residue of firemaking.

- Limited activity sites - locales with lithic debris and stone tools or other debris (food bone, mussel shell, etc.), but no FCR. 
- Lithic scatters - sites identified by lithic debitage and no other class of artifacts or cultural residues of any kind.

The site classification is functional, in the effort to join the second generation of settlement pattern research. Function is identified broadly, inferred from the cultural materials and features found on and in the sites. In-depth site study, based on excavation, can identify more specific cultural and technical activities conducted at the sites. The potential and need for more specific functional analysis is explained below.

\section{Results}

Table 42 identifies the site types of the Phase I prehistoric sites and the predominance of open camps (21 components) over lithic scatters (10) and limited activity sites (3).

Table 42. Summary of prehistoric components represented among the surveyed sites

\begin{tabular}{|c|c|c|c|c|c|c|c|c|}
\hline Site \# & Type & $\begin{array}{c}\text { Size } \\
\text { (sq. m) }\end{array}$ & Physio. Zone & $\begin{array}{c}\text { Lithic } \\
\text { Debitage }\end{array}$ & FCR & $\begin{array}{c}\text { Flaked } \\
\text { Tools }\end{array}$ & Features & Other \\
\hline BP476 & lithic scatter & 600 & upland divide & $\mathrm{X}$ & & & & \\
\hline BP477 & open camp & 4,104 & upland divide & $\mathrm{X}$ & $\mathrm{X}$ & $\begin{array}{ll}\text { arrow } & \text { pt., } \\
\text { biface }\end{array}$ & & bone \\
\hline BP480 & lithic scatter* & 182 & valley margin & $\mathrm{X}$ & & & & \\
\hline BP484 & open camp * & 700 & upland divide & $\mathrm{X}$ & $\mathrm{X}$ & utilized flake & & \\
\hline BP485 & open camp* & 2,200 & upland divide & $\mathrm{X}$ & $\mathrm{X}$ & $\begin{array}{l}\text { Paleo pt. dart } \\
\text { pt. }\end{array}$ & & \\
\hline BP486 & open camp & 18,813 & valley margin & $\mathrm{X}$ & $\mathrm{X}$ & $\begin{array}{ll}\text { M. } & \text { Archaic } \\
\text { pt. } & \\
\end{array}$ & hearth & \\
\hline BP487 & open camp* & 3,600 & terrace & $\mathrm{X}$ & $\mathrm{X}$ & & & \\
\hline BP488 & open camp & 2,275 & terrace & $\mathrm{X}$ & $\mathrm{X}$ & & & \\
\hline BP491 & open camp & 600 & upland divide & $\mathrm{X}$ & $\mathrm{X}$ & & & \\
\hline BP493 & lithic scatter & 25 & upland divide & $\mathrm{X}$ & & & & \\
\hline BP494 & lithic scatter & 400 & valley margin & $\mathrm{X}$ & & & & \\
\hline BP495 & open camp & 700 & valley margin & $\mathrm{X}$ & $\mathrm{X}$ & & & \\
\hline BP496 & open camp & 1,400 & upland divide & $\mathrm{X}$ & $\mathrm{X}$ & bifaces & & \\
\hline BP497 & open camp & 24 & upland divide & $\mathrm{X}$ & $\mathrm{X}$ & & & \\
\hline BP498 & lithic scatter & 6,780 & terrace & $\mathrm{X}$ & & & & \\
\hline BP499 & lithic scatter & 16 & terrace & $\mathrm{X}$ & & & & \\
\hline BP505 & open camp & 120 & upland divide & $\mathrm{X}$ & $\mathrm{X}$ & & & \\
\hline BP506 & open camp & 6,150 & terrace & $\mathrm{X}$ & $\mathrm{X}$ & & hearth & \\
\hline BP509 & lithic scatter & 420 & upland divide & $\mathrm{X}$ & & & & \\
\hline BP510 & open camp & 1,200 & upland divide & $\mathrm{X}$ & $\mathrm{X}$ & util. flake & & \\
\hline BP512 & open camp & 2,400 & terrace & $\mathrm{X}$ & $\mathrm{X}$ & & & \\
\hline BP518 & lithic scatter* & 300 & upland divide & $\mathrm{X}$ & & & & \\
\hline BP520 & open camp & 5,400 & terrace & $\mathrm{X}$ & $\mathrm{X}$ & proj. pt. & & \\
\hline BP521 & open camp & 1,344 & terrace & $\mathrm{X}$ & $\mathrm{X}$ & biface frag. & & \\
\hline BP522 & open camp & 1,650 & valley margin & $\mathrm{X}$ & $\mathrm{X}$ & & & \\
\hline BP523 & lithic scatter & 18,975 & upland divide & $\mathrm{X}$ & & & & \\
\hline BP524 & open camp & 770 & valley margin & $\mathrm{X}$ & $\mathrm{X}$ & & & \\
\hline BP526 & open camp & 5,200 & terrace & $\mathrm{X}$ & $\mathrm{X}$ & & & \\
\hline BP527 & limited activity & 540 & upland divide & $\mathrm{X}$ & & biface & & \\
\hline BP528 & open camp & 225 & terrace & $\mathrm{X}$ & $\mathrm{X}$ & $\begin{array}{ll}\begin{array}{l}\text { E.Arch } \\
\text { pt. }\end{array} \\
\end{array}$ & & \\
\hline BP529 & open camp & 400 & valley margin & $\mathrm{X}$ & $\mathrm{X}$ & & & \\
\hline BP530 & open camp & 2,100 & upland divide & $\mathrm{X}$ & $\mathrm{X}$ & arrow pt. & & \\
\hline BP532 & lithic scatter* & 25,00 & valley margin & $\mathrm{X}$ & & & & \\
\hline BP533 & lithic scatter & 4,900 & valley margin & $\mathrm{X}$ & & & & \\
\hline
\end{tabular}

*Site also contains historic component. 
Breakdown of all sites by landforms shows site locations slightly favoring the higher landforms (21 components on shoulder slopes, backslopes, and summits) over locally lower landforms (13 components on terraces, footslopes, and toeslopes).

\section{Comparisons}

The most immediate and valuable comparisons of the Phase I site findings are with the Skelton and Freeman survey of 1979. Table 43 presents a comparison of their site locations by physiographic zones with those of the Phase I survey.

Table 43 shows only general similarities and significant disparities in site locations. The general agreement among these findings is in the majority of sites located on the creek terraces and valley margins combined. The two surveys also agree on the lack or nearlack of sites on creek floodplains, probably due for the most part to scouring and removal by flooding (see Chapter 3).

Table 43. Comparison of sites by physiographic zone

\begin{tabular}{|r|r|c|r|r|}
\hline \multirow{2}{*}{ Zone } & \multicolumn{2}{|c|}{ Phase I survey } & \multicolumn{2}{c|}{ Skelton and Freeman } \\
\cline { 2 - 5 } & \multicolumn{1}{|c|}{$\#$} & \multicolumn{1}{c|}{$\%$} & $\#$ & \multicolumn{1}{c|}{$\%$} \\
\hline floodplains & 0 & 0 & 2 & 4.8 \\
\hline creek terraces & 10 & 29.4 & 12 & 28.6 \\
\hline valley margins & 9 & 26.5 & 24 & 57.1 \\
\hline upland divides & 15 & 44.1 & & 9.5 \\
\hline
\end{tabular}

Regarding site typologies, Skelton and Freeman (1979:28) established a descriptive typology rather than a functional typology as implemented by this study. The two are presented here side-by-side for a rough comparison (Table 44).

Table 44. Types of sites found in the 1996-1997 survey compared with the 1979 survey

\begin{tabular}{|l|r|r|l|r|r|}
\hline \multicolumn{2}{|c|}{ 1996-97 Survey } & \multicolumn{3}{c|}{ Skelton and Freeman (1979:28) } \\
\hline \multicolumn{1}{|c|}{ Site Type } & $\#$ & \multicolumn{1}{c|}{ \% } & \multicolumn{1}{c|}{ Site Type } & $\#$ & $\mathbf{\%}$ \\
\hline Procurement Camps & 0 & 0 & Cobble procurement camps & 11 & 26 \\
\hline Lithic scatters & 11 & 32.4 & Chipped stone scatters & 4 & 9.5 \\
\hline Limited activity sites & 1 & 2.9 & Chipped stone/FCR scatters & 25 & 59 \\
\hline Open camps & 22 & 64.7 & Buried hearths & 2 & 4.7 \\
\hline
\end{tabular}

\section{Regional comparisons}

Comparisons with Robinson's (1987) county-wide tabulation of site data help fit the Camp Swift information into the larger regional picture. A total of 175 sites was tabulated across all the physiographic zones of the county, stratified in a fashion similar to the Phase I survey (Robinson 1987:172). One-hundred twenty four components were tabulated in the uplands (creek terrace, lower slopes, upper slopes) and these are broken down in Table 45.

Table 45. Regional upland site breakdown

\begin{tabular}{|c|r|r|}
\hline Upland Physiographic Zone & \multicolumn{1}{|c|}{$\#$} & \multicolumn{1}{c|}{$\%$} \\
\hline creek terrace & 12 & 9.7 \\
\hline lower slopes & 41 & 33 \\
\hline upper slopes & 71 & 57.2 \\
\hline
\end{tabular}

The percentages are of all components in the upland area only, not the total landscape, as reported on the table in Robinson (1987:172). These data show a region-wide emphasis on formation of many sites on the lower slopes (valley margins) and upper slopes (upland divides). The Camp Swift sites are consonant with this overall pattern, although proportionally more sites were found on creek terraces at Camp Swift than region-wide (Phase I - 29.4\%, Skelton and Freeman $28.5 \%$, region-wide $-9.7 \%$ ). A further observation is that the majority of upland sites are quite small (no larger than $5,000 \mathrm{~m}^{2}$ ), the remainder rarely exceeding $10,000 \mathrm{~m}^{2}$. The Camp Swift sites accentuate this aspect of the regional pattern.

Altogether, the regional settlement pattern, without considerations of time stratification, shows redundantly the formation of numerous small sites in its highest topographic reaches. This finding is most likely the result of a long temporal process founded ultimately in the Paleoindian period. Time stratification of the pattern would show fluctuations, interruptions, and innovations in the subsistence exploitation of the hinterland; such chronological refinement remains a long-term goal of research in the region.

The upland pattern culturally is one of small sites created in the performance of limited activity sets, or functions, at any one locale. Quite different activity sets may be performed at other 
sites in the same zone. Individual site functions may range from lithic resource procurement through plant and animal resource acquisition and processing. Other specific functions may be determined by analysis of artifact assemblages from excavated sites.

Base-satellite settlement models account for these broad patterns in hunter-gatherer societies. In these models, base camps housing the full domestic spectrum of the society (extended families) are in convenient settings on the river or creek terraces. Work parties venture from these camps outward to locales targeted for resource procurement or other necessary duties. Typically, work parties are a segment of the total society (adult men, adult women with infants and young children, teenage girls or boys, older men and women, etc.) removed from the full family setting for work purposes. These work parties would form and occupy satellite camps as long as necessary to accomplish the task and then return to the base camp.

Broader comparisons with the previous research, summarized above, are in order. Pertinently, Ensor and Mueller-Wille (1988) have posited a regional cultural pattern versus a local adaptive pattern. The emerging redundant patterning of site locations in the uplands gives emphasis to their distinction. Further, the support of base-satellite site location models applies to interpretive statements by Fields (1995). Base-satellite model settlement dynamics are akin to longer-term residence and logistical mobility, as opposed to shortterm occupations and foraging mobility strategies. Although he explicitly excluded the Colorado river basin from his study area, Fields (1995:303, 320-323, 325327) observed that the southwestern regions of the Post-Oak Savannah/Blackland Prairie province, bordering the Colorado river basin, were landscapes dominated by short-term residence and foraging economic strategies for most, if not all, of prehistory. The findings of the Phase I survey and previous research in Bastrop County fail to support Fields' interpretation. It should be cautioned, however, that a pattern reflective of short-term residence and foraging strategies (small sites with uniform artifact assemblages) might be obscured in the archaeological record by an overlying site pattern formed by strategies of logistical mobility. In this situation, foraging pattern sites would appear as one category of limited activity sites in the logistical pattern. Superior chronological control could sort out these varying site patterns.

\section{Implications for Cultural Resource Management}

The overall value of this study is its demonstration that the small upland sites encompassed by Camp Swift have research value collectively in current settlement pattern studies. Although most of the sites fail individually to meet eligibility criteria for nomination to the National Register of Historic Places, their collective locational information, as well as any artifact assemblages they may contain, can inform current and future research designs. For this reason, prudent management of the ineligible prehistoric sites should include avoidance and preservation whenever possible.

The questions raised by the settlement pattern study contribute to research and excavation designs for the sites recommended for test excavations:

1. Diagnostic artifacts must be collected and studied for their chronological information, and samples for chronological assays by any appropriate method must also be collected and run. Although organic preservation is poor, radiocarbon samples (e.g., charcoal, bone) are the most likely to be available in the sites. Accelerator mass-spectrometry (AMS) dating of small charcoal flecks may readily repay the additional budgeting necessary to run the samples.

2. Paleoindian components should receive exceptional attention in excavation plans, as they figure prominently in overarching research designs (see "Research Design" above).

3. Artifact assemblages should be collected carefully, especially from intact behavioral contexts such as near-hearth zones or activity areas. Contextual analysis of in-situ finds may specify site activities. Overall analysis of sites and all their cultural residues, including floral and faunal specimens, should be oriented toward determining site function as specifically as possible and comparing the findings to the other excavated sites. The results can advance understanding of the range of site functions in the physiographic zones of the uplands. 


\section{Prehistoric Lithic Technology}

Leeann Haslouer Kay and Steve Tomka

\section{Introduction}

The following is an analysis of $1 / 4$-inch and larger lithics including debitage, cores, and tools recovered from the present archaeological inventory of Camp Swift. Thirty-three new lithic sites were recorded and seven previously recorded lithic sites were re-examined.

For the purposes of the analysis, the sites are grouped into three units of analysis consisting of three physiographic zones. These include the terrace, valley margin, and upland divide. The terrace zone consists of the relatively flat area just above the floodplain. However, sometimes there is no floodplain and the terrace directly borders the stream. This zone is represented by 15 sites. The valley margin zone consists of the area between the terrace and the higher upland divide, most prominently the small knolls. Nine sites are found in this zone. The upland divide zone is the high area that is separated by the major tributaries. Vegetation in the upland divides is almost entirely dense woodlands. Fifteen sites are in this zone.

\section{Analysis Methods}

All debitage greater than $1 / 4$-inch was collected from shovel tests. In addition, all diagnostic artifacts were collected from shovel tests as well as from the ground surface.

Lithic artifacts collected include debitage, cores/tested cobbles, and flaked stone tools. Flaked artifacts and debitage were analyzed for heat treatment and burning. The maximum lengths and widths were measured for all complete or mostly complete flakes. Flaked stone tools were sorted into categories of projectile points, bifaces, and use-modified and retouched flakes.

Both the spine-plane angle and the edge angle were measured. The spine-plane angle, or the production angle, is the projection of the angle of the flake before the edge was damaged, and thus is related to the design of the tool. The edge angle, or damage angle, measures the working edge and the damage to that edge. It is the angle of the edge after the load was applied, damaging the tool, and thus is an indicator of how susceptible the edge is to a bending fracture. The edge angle is most important in accounting for cone fractures that are produced by point initiations (Hayden 1979).

Low power examination is useful for identifying small flake scars and edge damage characteristics (i.e., rounding and polish) that are diagnostic of the material worked. The flake scars are best observed with low power magnification; abrasion is best observed with higher powers. Another type of alteration to the working edge of the tool is the formation of a polish. This can only be observed with high powers and can be used to identify the material being worked. However, for this analysis only low power micro-wear examination was performed using a Leica Stereo Zoom 7 microscope with $10 x$ and 20x oculars (magnification ranged from 10x to 140x).

Projectile points were classified using Turner and Hester (1993). In addition, all artifacts were examined for evidence of heat treatment or burning. Edge angles were measured using clay impressions that were examined with comparator and reticle. The mean angle was calculated from three measurements taken on the tool at locations evenly spaced along the working edge (i.e., one at the middle of the edge and two between the middle point and the end).

Volumes excavated were calculated using only positive levels (i.e., levels containing lithic material). In cases where a surface artifact was collected but no shovel test excavated, the recovery context was counted as one positive level. The reason for this is that if a shovel test was to be excavated where the surface find was it would be a positive level. This procedure gives equivalent treatment to surface and subsurface finds. The average diameter of the shovel tests was 35 centimeters $(\mathrm{cm})$.

\section{Results}

\section{Depth of Lithic Material Recovered}

The depth of the lithic material recovered varies greatly. The deepest intact deposits come from the upland divide zones, but even there it ranges from a surface scatter to deep deposit of $120 \mathrm{~cm}$ below 
surface ( $\mathrm{cm} \mathrm{bs).} \mathrm{Figure} 99$ presents the minimum and maximum depths of debitage, flaked stone, and tools from 43 sites containing these artifacts. The majority of the lithic artifacts were found on the surface. Of the buried flaked stone artifacts, the majority was found between 1-60 $\mathrm{cm}$ bs, across all three physiographic zones. More sites have artifacts buried below $60 \mathrm{~cm}$ in the terrace and valley margin zones than the upland divide. This may simply indicate the more favorable depositional context in the first two zones.

\section{Debitage Density}

Debitage density for each site was generally low ranging from 12.99 pieces $/ \mathrm{m}^{3}$ to 363.79 pieces $/ \mathrm{m}^{3}$ (Figure 100). Sites present on the previous figure but not present on Figure 100 had no debitage collected during the field visit. Judging from standard deviation figures, the greatest variability in debitage densities occurs among the terrace sites (s.d. $=83.1)$ followed by upland divide sites (s.d. $=65.5$ ). Valley margin sites have the lowest variability (s.d.=33.0).
In general, mean debitage density among sites with positive shovel tests was lowest in the valley margin and highest in terrace sites (Table 46). On the other hand, mean debitage density among all sites in the zone, including sites with negative shovel tests, indicates that the lowest densities occur in the upland divide sites. These differences suggest that terrace sites have relatively high densities of debitage on a siteby-site level as well as a group. On the other hand, while some upland divide sites have high densities of debitage, as a group debitage densities are relatively low among sites in this zone.

\section{Flake Size and Stage of Production}

The ratio of flake thickness to length was calculated in order to identify general stages of production. For example, a biface thinning flake yields a value ranging from approximately 0.15 and lower, while a primary flake yields a value approximately of 0.3 or greater.

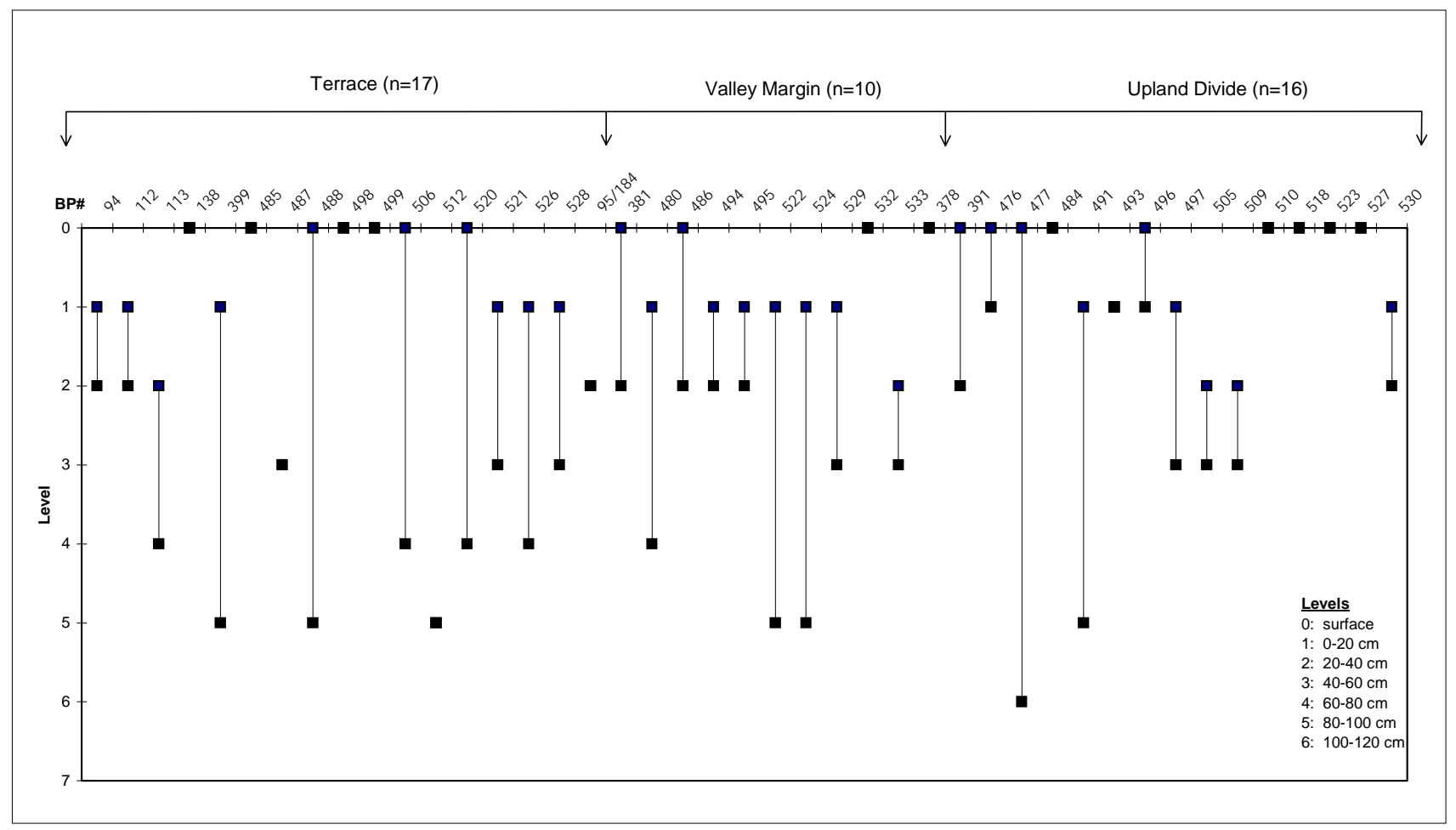

Figure 99. Depth of lithic material by site and physiographic zone. 


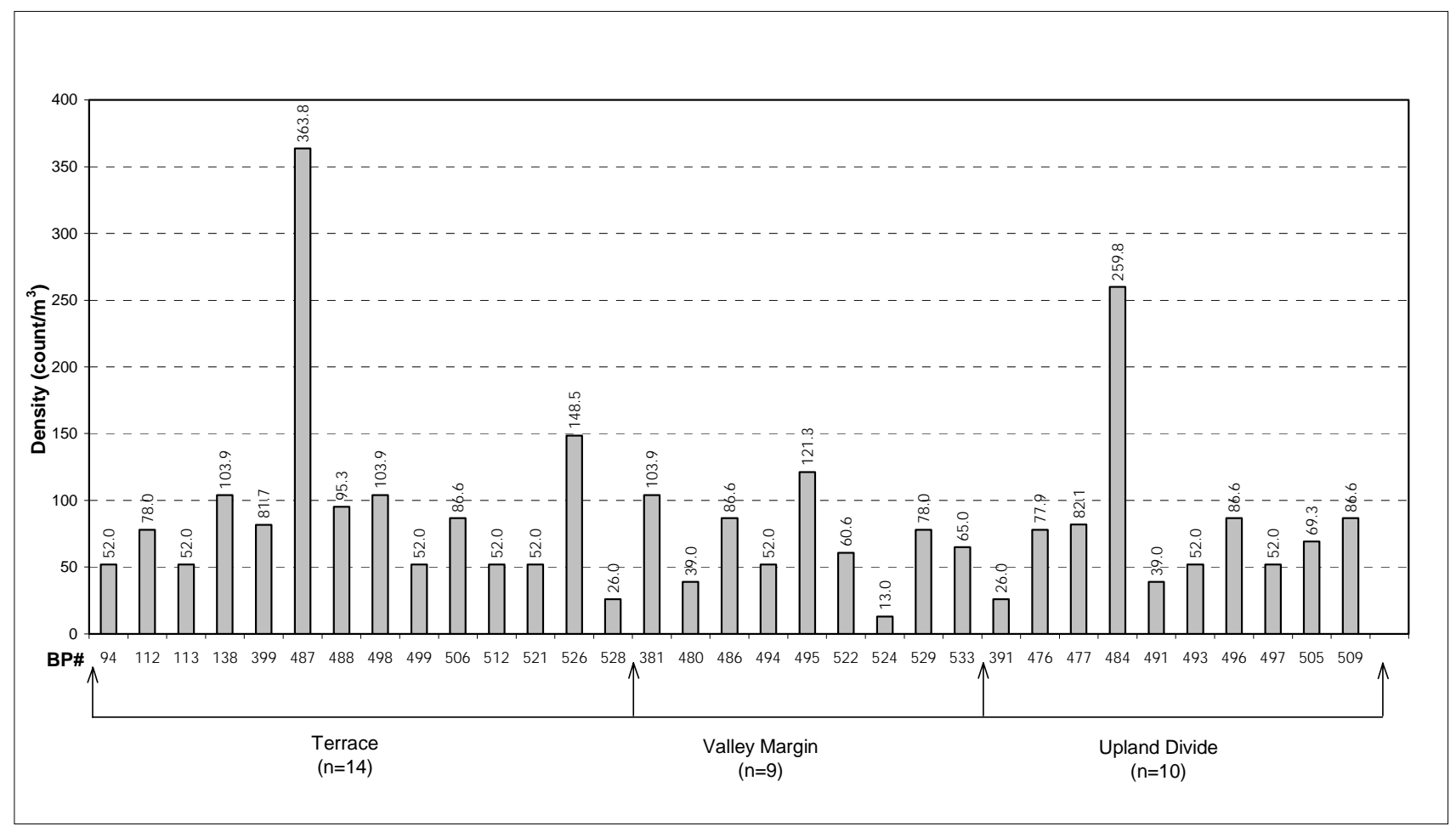

Figure 100. Debitage density (count $\left./ \mathrm{m}^{3}\right)$ distribution by site and physiographic zone.

Table 46. Debitage density by physiographic zone

\begin{tabular}{|ccc|}
\hline $\begin{array}{c}\text { Physiographic } \\
\text { Zone }\end{array}$ & $\begin{array}{c}\text { Debitage density } \\
\left(\text { count } / \mathbf{m}^{\mathbf{3}}\right) \text { among } \\
\text { sites with positive } \\
\text { shovel tests }\end{array}$ & $\begin{array}{c}\text { Debitage density } \\
\left(\text { count } / \mathbf{m}^{\mathbf{3}}\right) \text { among } \\
\text { all sites in zone }\end{array}$ \\
\hline Terrace & $95.3(\mathrm{n}=15)$ & $84.1(\mathrm{n}=17)$ \\
\hline Valley Margin & $68.8(\mathrm{n}=9)$ & $61.9(\mathrm{n}=10)$ \\
\hline Upland Divide & $83.2(\mathrm{n}=9)$ & $46.8(\mathrm{n}=16)$ \\
\hline
\end{tabular}

The average flake size ratio for each site by physiographic zone is indicated in Figure 101. The most common flake ratio for all sites on Camp Swift ranges between 0.15 and 0.2 , indicating that the primary activity on many sites was the manufacture of tools. Of the 33 sites with data, 20 have flake thickness/length ratios between .15-.25. Flake size ratios characteristic of biface thinning and resharpening are present at nine sites, and those characteristic of early reduction procurement sites are present in four sites. All four of these sites are found in the terrace zone. Eight of the ten sites $(80 \%)$ in the upland divide zone have flake size ratios characteristic of tool production. These patterns suggest that lithic raw material procurement may have focused on gravel bars or terrace gravel deposits.

The greatest variability in tool production and reduction activities appears to have occurred in the terrace sites, where - in some instances - limited tool production was occurring (Figure 102). Figure 102 shows the range of flake ratios found in each site by physiographic zone. Clearly, a range of production stages was occurring in the terraces, while limited late stages of production were the most common occurrence in every other physiographic zone. 


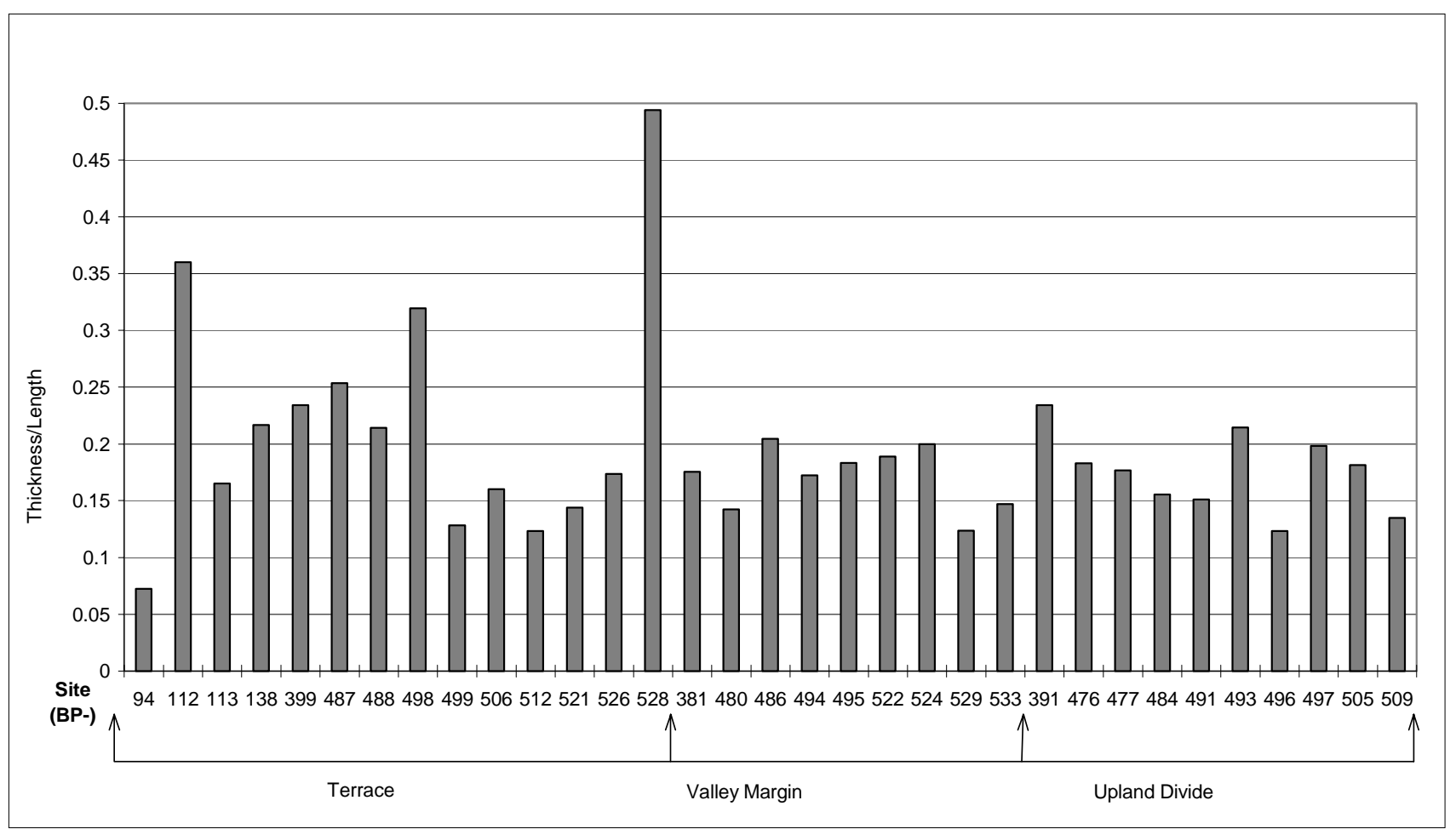

Figure 101. Distribution of average flake thickness/length ratios by site and physiographic zone.

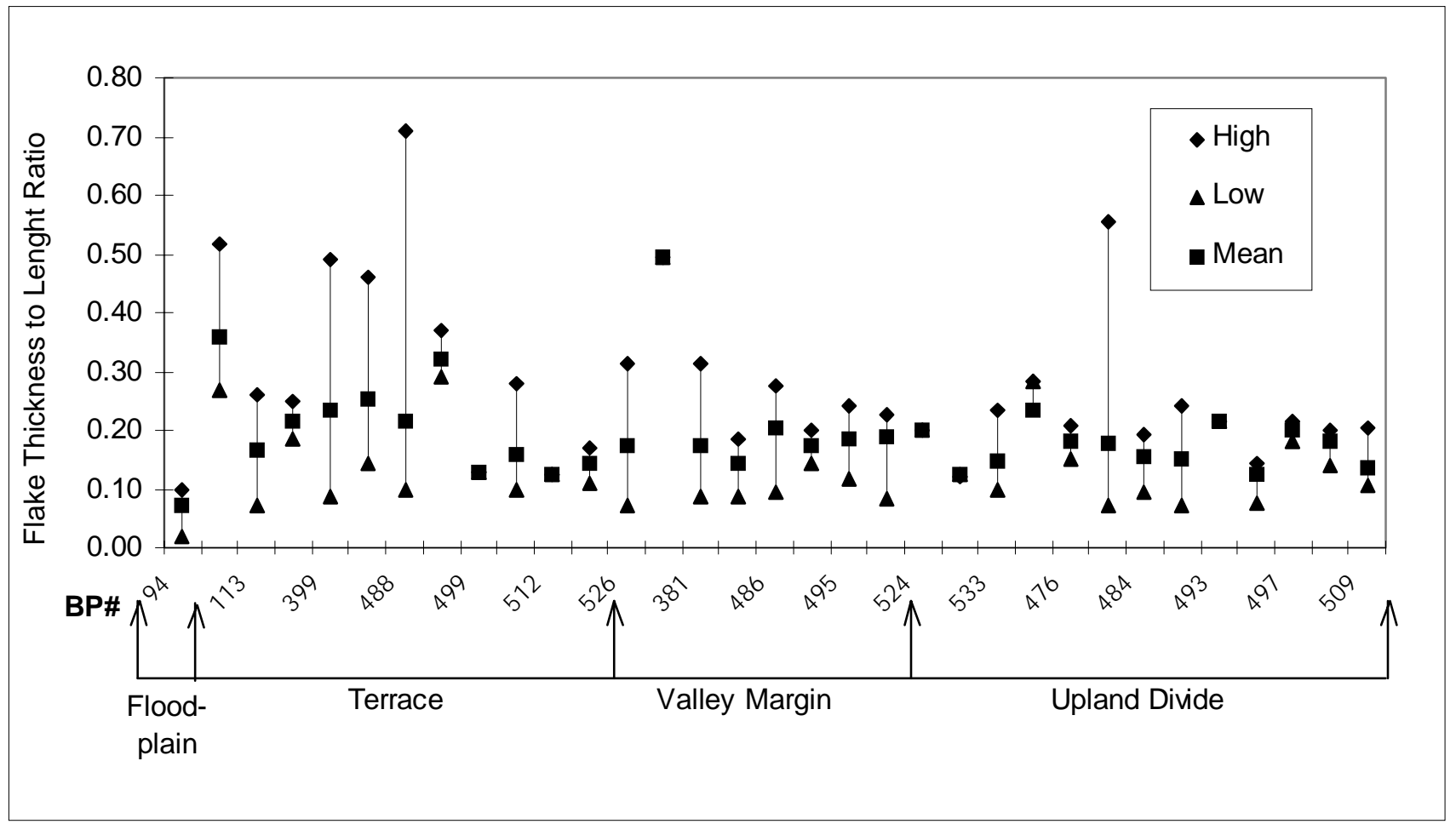

Figure 102. Distribution of ranges in flake thickness/length ratios by site and physiographic zone. 


\section{Sources of Lithic Raw Material}

"Chert within the lower Cretaceous Edwards Group constitutes one of the largest and most variable lithic sources on the High Plains of the United States and northern Mexico" (Frederick and Ringstaff 1994). However, size and variability of the outcrop has been poorly documented and has led to confusion (Frederick and Ringstaff 1994). Frederick and Ringstaff (1994) incorporate the work of others to provide a detailed description of the variability and workability of Edwards chert, and an examination of the bedrock outcrops as a comprehensive discussion of its distribution.

The locally available lithic material at Camp Swift consists of the Uvalde gravel deposits. These are upland gravel deposits of central and south Texas. In many instances, the Uvalde Gravels occur on the highest hills in the area south of the Edwards Plateau (Sellards et al. 1981). The gravels are believed to be derived from the Edwards Plateau and spread south by the streams (Sellards et al. 1981).

The Uvalde gravel deposits present at Camp Swift consist primarily of chert cobbles with pieces of limestone and quartz and chert pebbles set in a matrix of chalky marl and caliche (Sellards et al. 1981). The size of the cobbles ranges from less than an inch in diameter to six inches in diameter (Sellards et al. 1981).

These deposits were a major local source of lithic raw material. Although the quality of the material is relatively poor, its natural abundance occurring in thin isolated patches made for easy procurement. This ease of availability of lithic material no doubt contributed to the attractiveness of this area to indigenous people (Skelton and Freeman 1979).

No attempt was made in this analysis to type the cherts because Uvalde gravels are a combination of numerous sources.

\section{Heat Treatment and Burning}

Heat treatment was identified based on raw material luster and color. The color change is more pronounced when the chert was placed closer to the heat source. Burning was identified by crazing and the presence of heat spalls.
Frederick and Ringstaff (1994) conducted experiments on Edwards chert and found that in addition to the red colors and the increased luster, that gray cherts can change to light blue, and dark grays or browns can change to lighter grays and browns. Experiments have shown that significant beneficial changes can be made to the material simply by slowly heating the material in a household oven to $550^{\circ} \mathrm{F}$ or in a controlled campfire (Frederick and Ringstaff 1994).

The results of the heat treatment experiments on Edwards chert from Frederick and Ringstaff (1994) indicate that nearly every type of Edwards chert benefits by heat treatment. Most of the cherts they tested fared well in high temperatures, however, a few showed evidence of heat spalling at around $550^{\circ} \mathrm{F}$, while only one type of Edwards chert exhibited severe heat spalling at relatively low temperatures. Although the properties vary, most Edwards chert responds well to heat treatment.

The highest frequency of heat treatment occurred in the terrace zones (Figure 103). However, as the sites move to the valley margins and to the uplands, the amount of heat treating decreases and burnt lithic material becomes the most frequent. Therefore, the treatment of chert to improve workability was conducted mostly in the terrace zones while incidental burning by wild fires or hearths was common in the valley margins and especially in the uplands.

\section{Flaked Stone Tools and Other Flaked Lithics}

A total of 23 flaked stone tools and flaked lithics were recovered from the present inventory of Camp Swift. In addition, an oval one-handed mano made of quartzite was also recovered from the surface of 41BP381. The specimen showed wear on both faces. The flaked stone tools include two cores and/or tested cobbles, three utilized flakes, one retouched flake tool, seven bifaces, three arrow points, and seven dart points (Table 47).

The highest density of tools among sites with stone tools occurs in the terrace zone, while the lowest density occurs in the valley margins (Table 48 ). The density of tools in the upland divide sites is lower than among the terrace sites with tools. However, the density of stone tools is highest in the upland divide than in the terrace zone, and the density of tools in the 


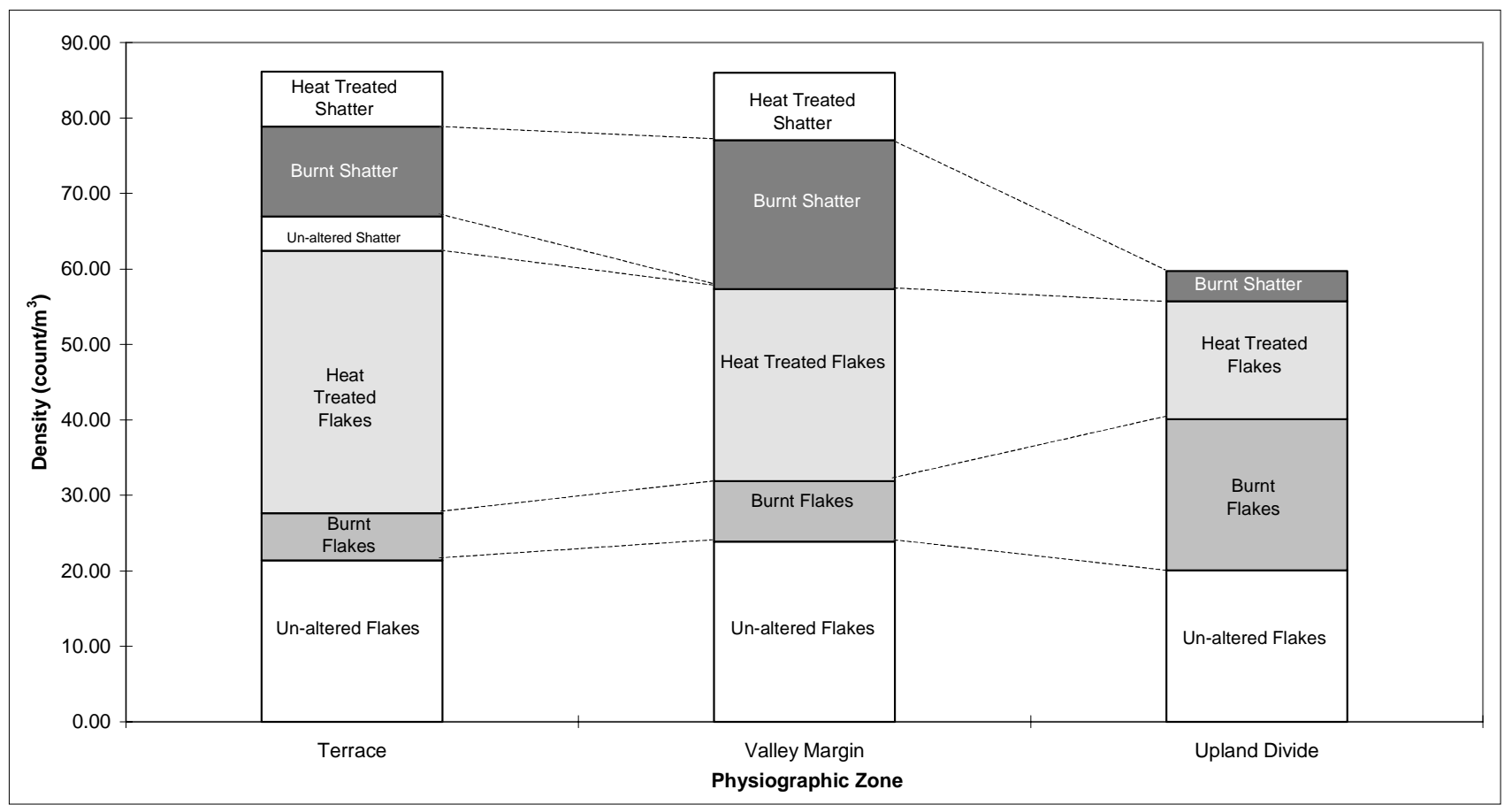

Figure 103. Density of unaltered, burnt, and heat-treated flakes and shatter by physiographic zone.

valley margin is significantly lower than in either of the other two zones (Figure 104).

The largest number and variety of tools were found on the upland divide, including three arrow points, three utilized flakes, a retouched flake, five bifaces, and a core. The temporally diagnostic tools from the uplands yield tools which date from the Late Prehistoric and Historic periods. However, one of the two isolated finds encountered in the upland divide zone (Isolate-50-256) is a single Early Triangular dart point proximal fragment. The terrace zone produced the second highest number and variety of tools with temporal diagnostics dating from the late Paleoindian, Middle Archaic, and Transitional Archaic periods. Only two flaked artifacts were recovered from the valley margin zone and both are Middle Archaic dart points.

\section{Edge Angles}

Because the strength of a tool's edge is directly proportional to the edge angle, basic statements can be made about how the tool was used. Also, basic statements can be made about the material the tool was used to work. On average, the softer the worked material, the more acute the edge angle; the harder the material being worked, the more obtuse the edge angle.

The analysis of the mean spine and edge angles on the four tools indicates that the flakes chosen for use and/ or retouch have a variety of spine angles (Table 49). That is, spine angle was not a critical aspect in selecting flake blanks for use as expedient tools and/or as blanks for retouched tools (i.e., unifacial scrapers). Four of the five working edges identified on the flake tools range between 73-90 degrees. This clustering of working edge angles suggests some preference for relatively strong and durable edges and suggests that the tools were employed in working hard materials. The extremely acute working edge noted on one expedient scraper may indicate that it may have been used in relatively light tasks or on soft materials.

\section{Low-Power Microscopic Examination of Flaked Stone Tools}

All flake tools were examined under low magnification for evidence of use. The two cores and the bifacial mano were not included in this sample. Twelve of 


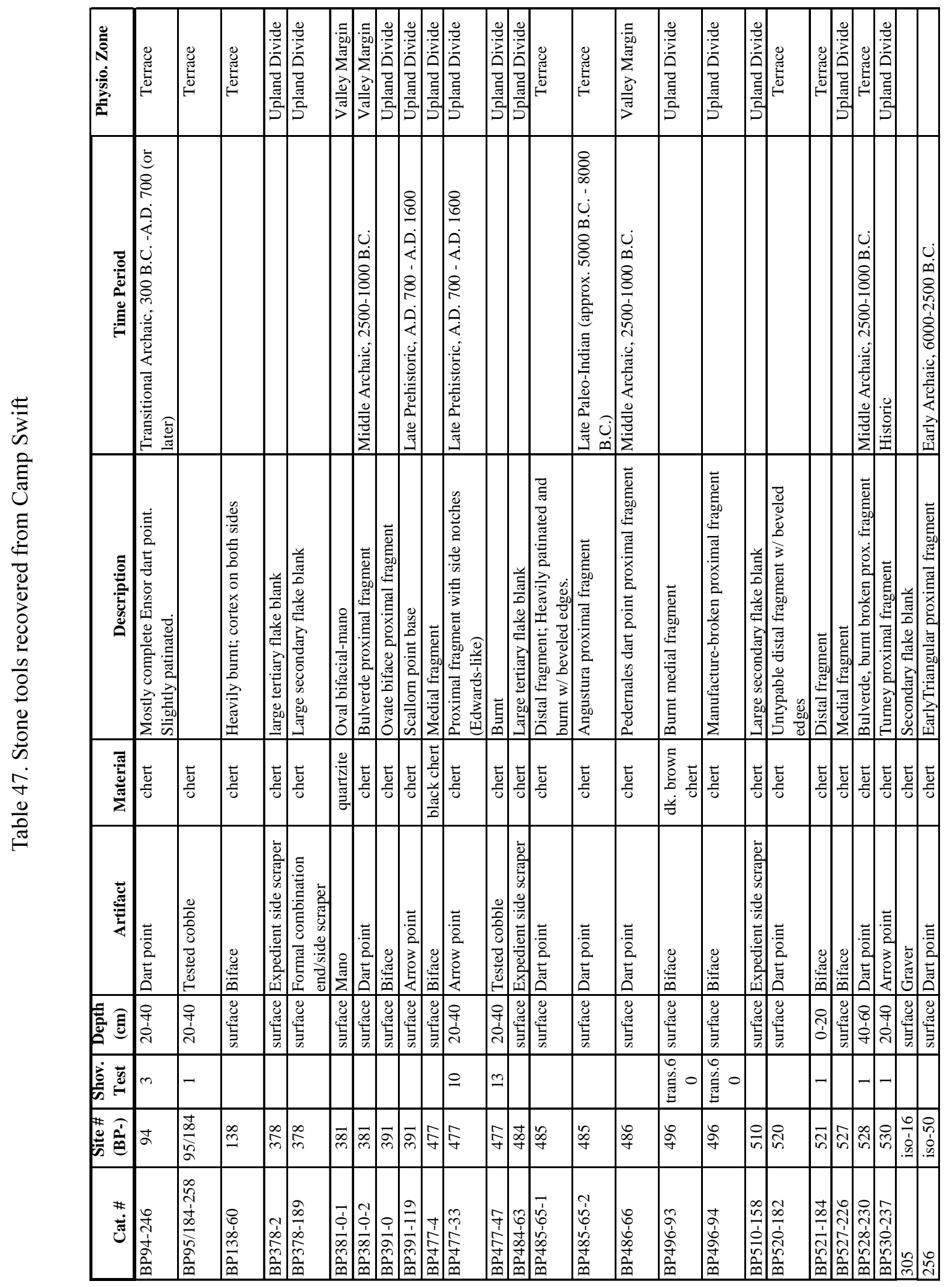


Table 48. Stone tool density by physiographic zone

\begin{tabular}{|ccc|}
\hline $\begin{array}{c}\text { Physiographic } \\
\text { Zone }\end{array}$ & $\begin{array}{c}\text { Stone tool density }\left(\text { count } / \mathbf{m}^{\mathbf{3}}\right) \text { among sites } \\
\text { with stone tools in zone }\end{array}$ & $\begin{array}{c}\text { Stone tool density }\left(\mathbf{c o u n t} / \mathbf{m}^{\mathbf{3}}\right) \\
\text { among all sites in zone }\end{array}$ \\
\hline Terrace & $40.8(\mathrm{n}=7)$ & $16.8(\mathrm{n}=17)$ \\
\hline Valley Margin & $21.7(\mathrm{n}=2)$ & $4.3(\mathrm{n}=10)$ \\
\hline Upland Divide & $35.5(\mathrm{n}=8)$ & $17.8(\mathrm{n}=16)$ \\
\hline
\end{tabular}

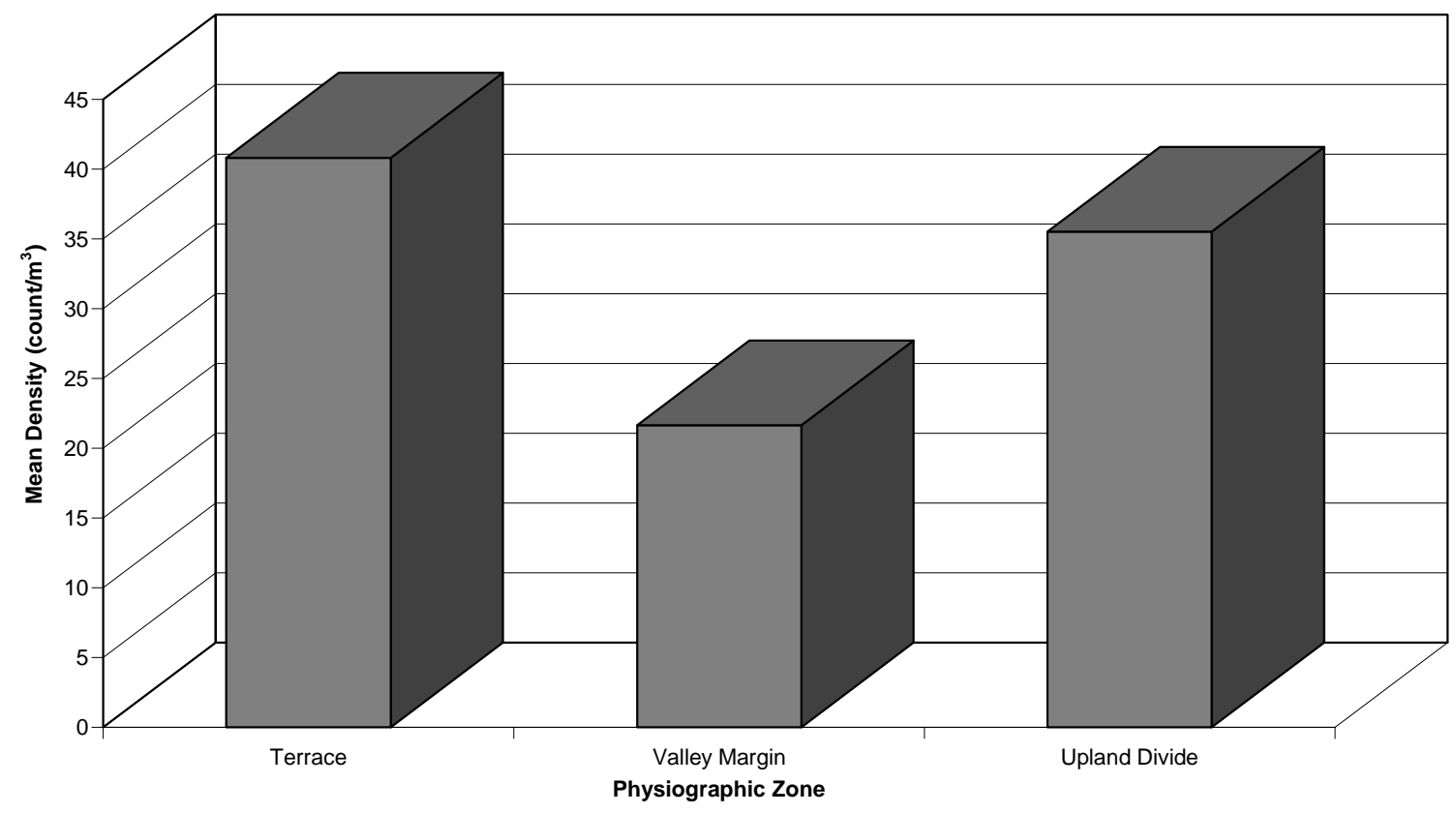

Figure 104. Tool density (count $\left./ m^{3}\right)$ by physiographic zone. 
Table 49. Edge angles of flake tools

\begin{tabular}{|lcccc|}
\hline $\begin{array}{c}\text { Artifact Catalog } \\
\text { No. }\end{array}$ & $\begin{array}{c}\text { Mean Spine } \\
\text { Angle }\end{array}$ & $\begin{array}{c}\text { Spine Angle } \\
\text { Variation }\end{array}$ & $\begin{array}{c}\text { Mean Edge } \\
\text { Angle }\end{array}$ & $\begin{array}{c}\text { Edge Angle } \\
\text { Variation }\end{array}$ \\
\hline $\begin{array}{l}\text { BP378-189 (edge A) } \\
\text { Formal combination } \\
\text { end/side scraper }\end{array}$ & $75^{\circ}$ & $0^{\circ}$ & $87^{\circ}$ & $5^{\circ}$ \\
\hline $\begin{array}{l}\text { BP378-189 (edge B) } \\
\text { Formal combination } \\
\text { end/side scraper }\end{array}$ & $50^{\circ}$ & $0^{\circ}$ & $73^{\circ}$ & $25^{\circ}$ \\
\hline $\begin{array}{l}\text { BP378-2 } \\
\text { Expedient side scraper }\end{array}$ & $28^{\circ}$ & $0^{\circ}$ & $5^{\circ}$ & $60^{\circ}$ \\
\hline $\begin{array}{l}\text { BP484-63 } \\
\text { Expedient side scraper }\end{array}$ & $47^{\circ}$ & $5^{\circ}$ & $90^{\circ}$ & $20^{\circ}$ \\
\hline $\begin{array}{l}\text { BP510-158 } \\
\text { Expedient side scraper }\end{array}$ & $60^{\circ}$ & $5^{\circ}$ & $82^{\circ}$ & $15^{\circ}$ \\
\hline
\end{tabular}

the 23 specimens showed evidence of use, including possible hafting traces. The others were not necessarily unused, but may have been used too expediently for use-wear to form or any evidence of use was destroyed post-depositionally. The results of the micro-wear analysis are provided in Table 50.

Two tools (BP378-2 and BP477-4) showed evidence of possible polish, even though only low-power examination was performed. Five tools (BP477-4, BP486-66, BP476-2, BP484-63, BP485-65) showed promise for high-power microwear analysis.

Four projectile points (BP94-246, Isolate-50-256, BP391-119, and BP530-237) exhibit some blunting on the basal edge, but no other microwear is apparent. It is possible that this type of wear is caused by hafting because it is "thought to result from pressure contact with worked material hard enough to produce fracturing of the stone tool but not necessarily of greater hardness than the stone tool" (Hayden 1979). Another tool, an arrow point (BP477-33), had crushing on the base which may indicate hafting. On the other hand, it is also possible that some of the crushing is the product of manufacture and/or intentional base grinding.

\section{Summary and Analysis of Flaked Stone Tools by Physiographic Zone}

\section{Terrace}

All but one tool (BP521-184) recovered in the terrace zone was associated with open camp sites. 41BP94 produced an Ensor dart point (BP94-246), dating from the Transitional Archaic Period. Based on low power microwear analysis, the Ensor dart point does not exhibit any use-wear, however, there is evidence that it may have been hafted. 41BP95/184 produced a tested cobble or core (BP95/184-258). 41BP138 is a historic wine cellar and domestic site along with a lithic scatter containing a biface (BP138-60). The biface has no evidence of microwear and is probably unused. $41 \mathrm{BP} 485$ is an open camp site containing a heavily patinated beveled dart point (BP485-65) and an Angostura dart point (also designated BP485-65) dating from the Late Paleoindian Period. The Angostura point has grinding and blunting on the edges; high power microwear analysis may yield more specific information. The other dart point is severely damaged by fire and patination, and hence any evidence of microwear would have been eliminated. 41BP520 produced a patinated dart point distal fragment (BP520-182). This dart point was severely damaged by burning, hence 


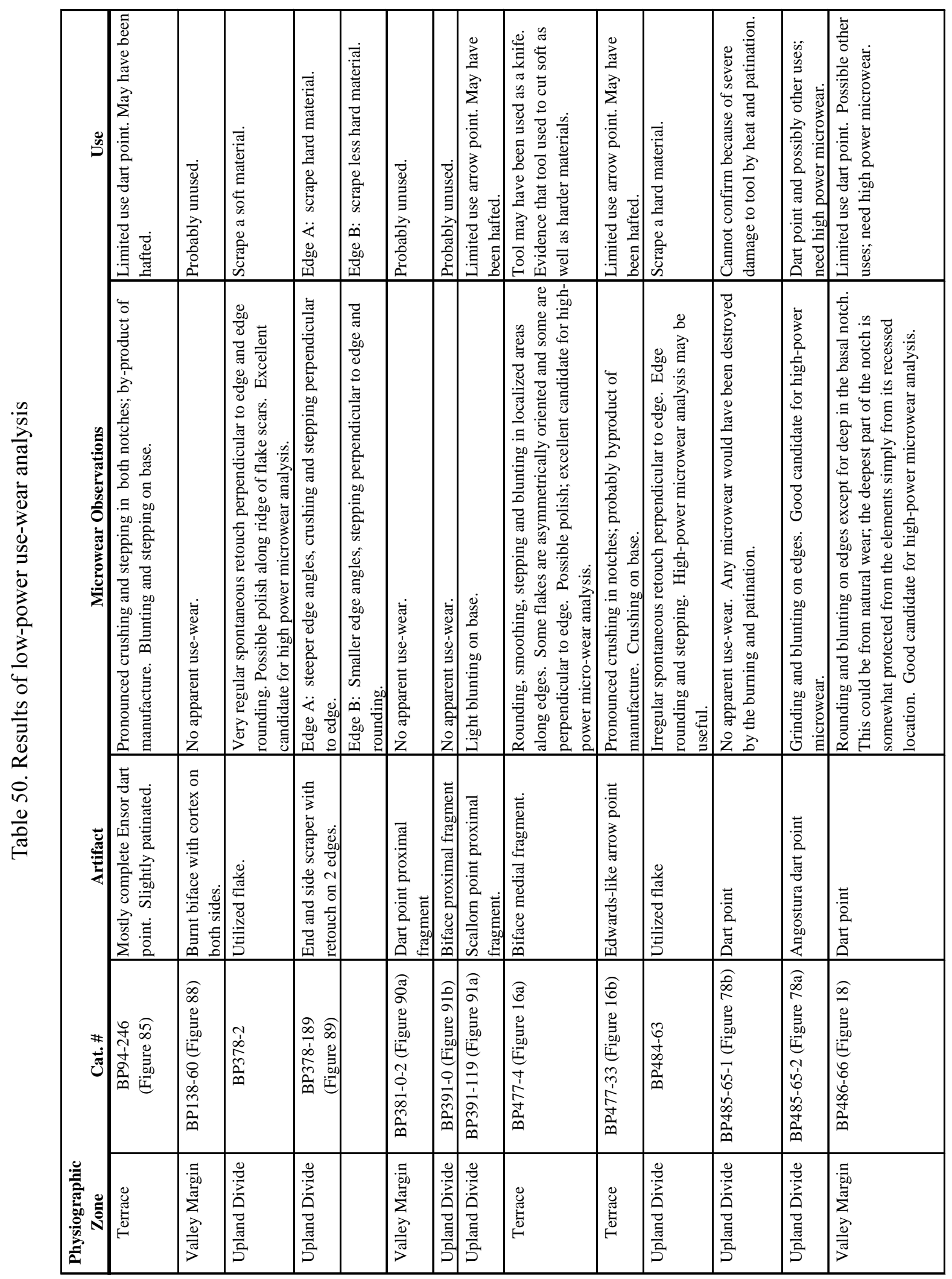




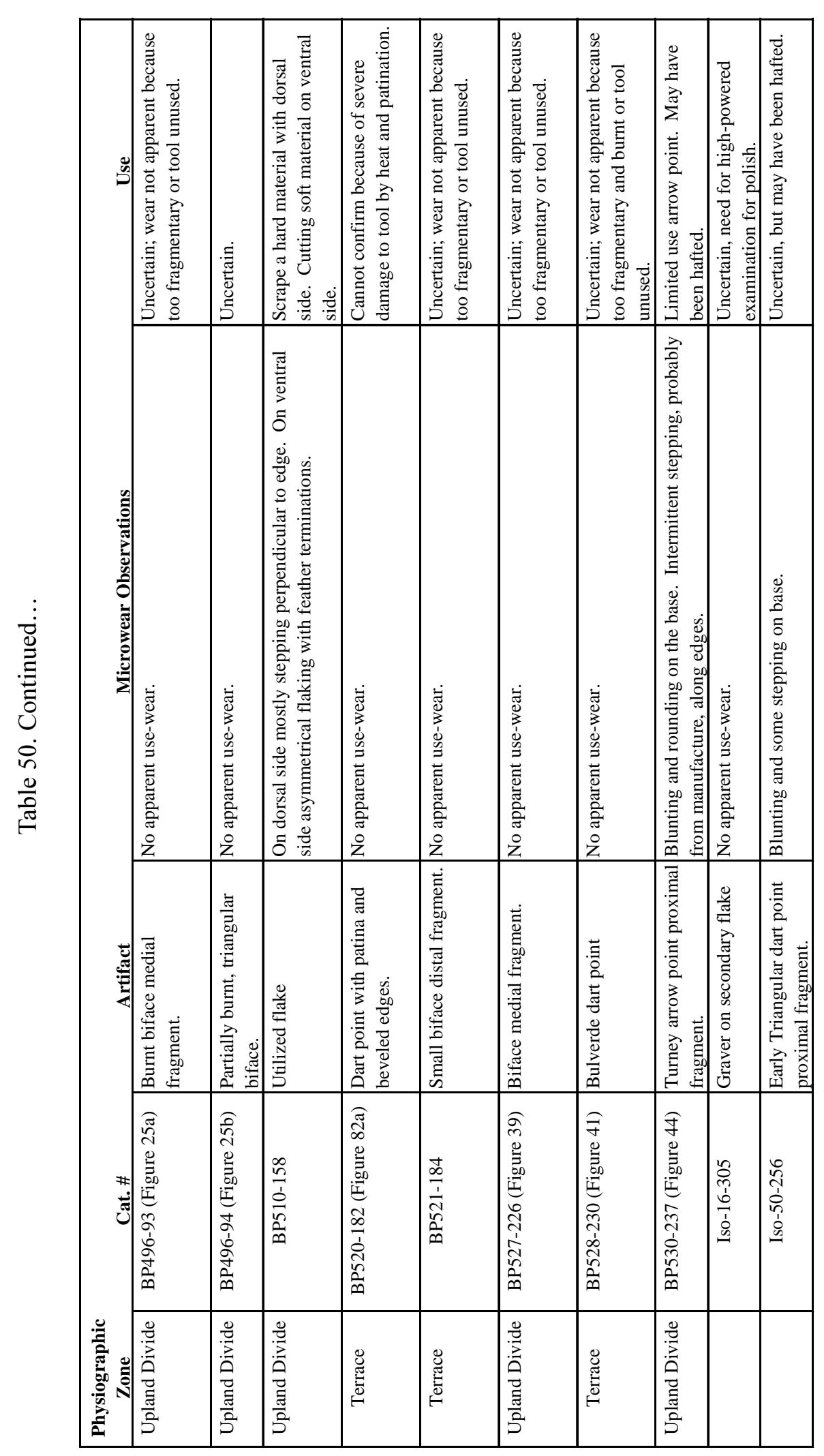


any evidence of microwear would have been eliminated. BP521 produced a very small biface tip (BP521184) with no evidence of microwear. $41 \mathrm{BP} 528$ produced a possible Bulverde dart point (BP528-230) dating from the Middle Archaic. This dart point did not exhibit any use-wear, however it was burnt and fragmentary, thus any use-wear may have been destroyed.

\section{Valley Margin}

Site 41BP381 yielded two surface artifacts, an oval bifacial mano (BP381-0-1) and a Bulverde proximal fragment (BP381-0-2). While the mano is well-used and has been refurbished through pecking, the point exhibits no traces of use-wear. 41BP486 is a limited activity site containing a dart point (BP486-66) that exhibited wear from an unknown source. This point is an excellent candidate for high power microwear analysis.

\section{Upland Divide}

$41 \mathrm{BP} 378$ is an open camp with an expedient side scraper (BP378-2) and a retouched combination end/ side scraper (BP378-189) recovered from the surface. The expedient side scraper appears to have been used on relatively soft materials. The combination end/side scraper has two working edges; the shorter, steeper edge is A and the longer, less steep edge is B. Edge A has a mean spine plane angle of $75^{\circ}$, with negligible variation, and a mean edge angle of $87^{\circ}$, with a variation of $5^{\circ}$. Edge $\mathrm{B}$ has a mean spine angle of $50^{\circ}$, also with negligible variation, and a mean edge angle of $73^{\circ}$, with a variation of $25^{\circ}$. Along with the angle measurements, microwear analysis indicates that edge A was used to scrape a hard material, while edge B was used to scrape a less hard material. 41BP391 is a lithic scatter containing a Scallorn arrow point base (BP391119) dating from the Late Prehistoric period. This point does not exhibit any use-wear, however there is evidence that it may have been hafted. A biface proximal fragment without wear was also recovered from the site. 41BP477 produced an Edwards-like arrow point (BP477-33) dating from the Late Prehistoric, a biface medial fragment (BP477-4), and a tested cobble or core (BP477-47). The Edwards-like arrow point does not exhibit use-wear, however, there is evidence that it may have been hafted. The biface medial fragment exhibits microwear and appears to have been used as a knife; evidence indicates that the tool was used to cut both soft and harder materials. This biface is an excellent candidate for high power microwear analysis. 41BP484 is a limited activity site containing an expedient side scraper (BP484-63) with fine use-retouch on one edge. The mean spine plane angle is $47^{\circ}$ with a variation of $5^{\circ}$, while the mean edge angle is $90^{\circ}$ with a variation of $20^{\circ}$. Along with the angles, microwear analysis indicates it was used to scrape a hard material; high power microwear analysis may be useful for identifying a more specific material worked. $41 \mathrm{BP} 496$ is an open camp containing a biface medial fragment (BP496-93) and triangular biface (BP49693) proximal fragment. Neither biface had evidence of microwear. 41BP510 is an open camp containing a utilized flake (BP510-158) with fine retouching on one edge. The mean spine plane angle is $60^{\circ}$ with a variation of $5^{\circ}$, while the mean edge angle is $82^{\circ}$ with a variation of $15^{\circ}$. Although the edge angles and microwear analysis indicate this tool was primarily used to scrape a hard material on the dorsal side, it was also used to cut a soft material on the ventral side; high power microwear analysis may be useful for identifying a more specific material worked. 41BP527 is a limited activity site containing a biface (BP527-226). The biface does not exhibit any microwear. 41BP530 is a limited activity site containing a Turney arrow point base (BP530-237) dating from the Historic Period. This point does not exhibit any use-wear, however, there is evidence that it may have been hafted.

\section{Conclusion}

Although the sample size is very small, distinctive patterns emerge. Camp Swift contains sites ranging from Paleoindian to Historic and nearly everything in between. These data produce a logical picture of settlement and site function. The floodplain is under represented by sites due to high deposition and scouring that occurs there, thus, leaving a gap in the data set. However, the terrace zone appears to be an area where a variety of tool manufacturing stages was occurring, including heat treating to improve workability. Present here are cores, bifaces, and a few finished projectile points. The density of debitage and tools among sites with positive shovel tests is highest among the terrace sites, and the terrace zone, in general has the highest density of debitage among all sites in the 
zone. However, the zone lacks the sheer number and variety of tools found in the upland divide zone. This pattern may simply be due to the larger sample size in the upland zone or the different depositional contexts and their influence on tool recovery. In contrast, the upland divide zone contains the most limited stages of tool production, consisting of middle and late reduction stages and tool resharpening. In addition, the upland divide zone, in general, contained the highest density of stone tools among all sites in the zone. The combination of microwear and debitage analysis suggest that populations were performing a variety of tool manufacturing and rejuvenation on the terraces while they would travel to the upland divides for the majority of their hunting and butchering activities.

\section{Effects of World War II on Existing Cultural Resources}

\section{David G. Robinson}

The creation of Camp Swift caused changes in site formation processes of the cultural resources of the camp. Five categories of processes have been identified as operating or potentially operating on the different classes of cultural resources.

1. Prehistoric sites suffered disruptive impacts. These had several sources and were meted out on a random basis. The sources included artillery bursts, firearm impacts, tracked and other vehicle maneuvers, and the construction of temporary features such as berms, foxholes, trenches, and revetments. Vehicular impacts continue to the present; the others may also have effects, but with vastly lower frequency than they had in World War II.

2. Pre-Camp Swift historic sites suffered selective demolition and removal of structures. Under the terms of land acquisition and removal, landowners had 30 days to remove any structures on their property. No record exists of the homesteaders who removed structures (many of which were built in the nineteenth century) and those who abandoned them intact, only that some removed and some did not (Pannell, personal communication 1997). Clearly, structure demolition and removal seriously detracted from the integrity of the historic habitation sites, and demolition and removal can only be determined, with difficulty, on a case-by-case basis.

3. Pre-Camp Swift historic sites were used as targets. It is not known how many historic sites were so impacted, but the use of the Harvey Smith house (built in the nineteenth century) as a bombing target has been documented (Pannell, personal communication 1997). With the exceptions of their cisterns and cellars, historic sites at Camp Swift are surface phenomena, and their uses as bombing targets would result in a near-total loss of site integrity.

4. Pre-Camp Swift historic sites suffered neglect. Without upkeep, the environment perpetuates the process of deterioration. Also, casual materialssalvaging for temporary construction is included in this site-formation process. Altogether, neglect of the historic sites has eroded their integrity further.

5. Military constructions in World War II at Camp Swift were temporary and functional. A 1945 map of the camp shows the northern end of the territory, later transferred to the State of Texas and the zone of the Phase I survey, as nearly exclusively a zone of firing and combat ranges and overlapping impact fans. The map lists 35 of these installations arrayed around the perimeter of the camp, their impact fans directed toward the interior. Item 33 on the map is described as a mock village, presumably an area of buildings for training in urban maneuvers. The mock village is about a half mile east of what is now Gate 10 in the Big Sandy Creek drainage. Intensive survey there failed to discover any trace of a multiple-structure historic site. The mock village was the only installation reported on the 1945 map in the Phase I survey zone having structures. The master plan of Camp Swift, dated 26 June 1946, fails to show or label in any way the mock village reported on the 1945 map nor does it delimit an impact fan in the area. Furthermore, the other impact fan arrays around the northern training area are relocated and labeled differently from the 1945 map. The 1946 master plan, does, however, designate a Japanese village (Item 27) and impact fan along the northern segment of Big 
Sandy Creek, near Gate $15 \mathrm{~b}$. The map designator is west of the creek and north of a large concrete construction that exists on-ground and may be marked on the master plan by an unlabeled ink-dot. East of Big Sandy Creek, a dashed line is labeled "tank lane." The zones of the Japanese village and tank lane were surveyed thoroughly by the Phase I survey and prior AGTX fieldwork, but no structural remains, berms, or road and trail alignments were found which may correlate with the mapped features. The correspondence of the concrete construction to a mock Japanese village, if mismapped, is problematic at best, the concrete remains appearing more to amount to a training fortification with an irregular, maze-like plan and firing ports.

The reliable inference from study of the camp maps is that there was functional change and variation in land use on the camp during World War II. The lack of any remains may be due to the mutability of material construction as well, attested to by the auction and removal of the buildings in the cantonment up until 1947 (Tomka and Crouch 1996:22). The 1945 map and the 1946 master plan are curated at Camp Mabry, Austin, Texas. The master plan, in particular, is in a deteriorated condition. 



\title{
Chapter 7: Assessments and Recommendations
}

\section{Cultural Resource Management at Camp Swift}

\author{
Raymond P. Mauldin
}

\section{Considerations in Assessing Eligibility at Camp Swift}

The Phase I cultural resources inventory of Camp Swift surveyed a total of 5,671 acres of the camp, and recorded 58 new sites. Twenty-six of the sites are prehistoric, 24 are historic, and eight have both prehistoric and historic components. These sites are added to the 111 previously known and recorded sites.

In addition to the recording of these 58 new sites, a sample of the previously discovered sites was selected for field revisits to update information and prior eligibility assessments. Thirty-six sites were successfully revisited and reassessed by AGTX archaeologists. Archaeologists from CAR relocated an additional seven previously recorded sites. Using the information presented in Chapter 3, as well as the site descriptions in Chapter 5, descriptions of sites presented in Skelton and Freeman (1979), and information available on the Texas Site Atlas, this chapter develops eligibility recommendations for all 169 recorded sites within the Camp Swift boundaries.

The task of determining site eligibility for the 169 sites is complicated by a number of project-specific elements. For example, the level of reporting on the 81 sites recorded by Skelton and Freeman (1979), though consistent with the reporting standards of the 1970s, frequently omits important details such as the number and location of shovel tests. The 58 sites recorded by the 1997 survey by AGTX archaeologists have this information, but additional problems are present. In spite of the discussion by Robinson in Chapter 4 regarding the determination of site boundaries by a combination of factors, including surface and subsurface artifact distribution and landforms, the application of these criteria on a site-by-site basis is unclear. While in some cases the number of shovel tests is adequate to assess both the distribution and character of deposits, in many instances adequate shovel testing simply was not done. For example, of the 26 sites that have only prehistoric material present, the average number of shovel tests is just under 4.5 , and $50 \%$ $(n=13)$ of the sites have three or fewer shovel tests. If these sites with less than four shovel tests were consistently small, or were restricted to a small, isolated landform, then this level of testing may be adequate. However, the site maps usually lack sufficient detail to determine the nature of the landform, and in some cases, large sites (greater than 10,000 square meters) were tested with a single shovel test or probe. We are faced, then, with developing and implementing eligibility criteria with inadequate data on at least some aspects of many of the sites discussed in this report.

Nevertheless, determinations of eligibility for inclusion in the National Register of Historic Places (NHRP) was made for 166 of the 169 archaeological sites that were present on Camp Swift in accordance with the four criteria listed in 36 CFR 60.4. The remaining three sites are all cemeteries, and-as such - are protected by statutes detailed in the State of Texas Health and Safety code, chapter 711, subchapter A, section 0311 . The primary criterion used in our evaluation is $\mathrm{D}$, the degree to which a site has, or is likely to, yield information important in prehistory or history. A critical aspect of criterion $\mathrm{D}$ is related to the integrity of a site and the current state of regional knowledge regarding history and prehistory. That is, to what degree is the site intact and does it contain information relevant to advancing our current understanding of history or prehistory?

In practice, assessing the integrity of a site usually relies on two elements. The first of these is the level of disturbance to the site. This includes natural erosion, turbation, and damage related to subsequent use of the area. The second element is related to the presence and character of subsurface deposits. While the presence of subsurface material does not assure that a site has integrity, it is the case that subsurface deposits have a higher probability of being intact. 
Assuming that a site has some level of integrity, it is then necessary to evaluate the quantity and nature of the information that the site contains. That is, to what degree is the information present likely to contribute to our overall understanding of history or prehistory? The answer to this question depends on our current understanding, and Chapter 6 has summarized some aspects of that understanding by outlining a series of research domains and historic contexts. A review of that chapter suggests that data from two broad contexts are relevant to prehistoric assessments. The first of these can be grouped under subsistence and settlement issues. Specific data needs include macrobotanical, pollen, and related information from deposits of known ages. In practice, these data can best be acquired by focusing on features in which both chronometric and associated samples may be present. The second class of prehistoric data needs fall under the issues of settlement and technology. Data needs include lithic tools and debitage from contexts that are, or have the potential to be, chronologically secure. These data sets can best be acquired from buried contexts with associated diagnostic artifacts or associated charcoal.

The contexts for the historic period are better developed than their prehistoric counterparts. Chapters 2 and 6 clearly identify three contexts, two of which are specific to material at Camp Swift. The first and broadest context involves historic settlement patterns and ownership. Data needs here involve the nature and location of settlement, and archival or informant research on the uses of these locations. The second and third contexts involve information on the early-Texas wine industry and lignite mining during the period between 1910 and 1940. Because of the specific nature of these contexts, the data needs are specific and can be satisfied by only a limited number of sites.

Using these contexts, associated data needs, and assessments of integrity, all sites found at Camp Swift can be categorized in one of three ways. Sites suggested as eligible for the NRHP meet one or more eligibility criteria in 36 CFR 60.4 by containing necessary data and having good integrity. Sites are not eligible to the NRHP if they either fail to meet any criteria or do contain the required data but lack good integrity. Finally, sites are considered potentially eligible if evidence exists that one or more criteria may be present, the site may have integrity, but further investigations are necessary to establish that potential. This class of determination would include all cases where we lack sufficient information about a site to make reasonable estimates regarding data potential and integrity, either as a result of inadequate testing or inadequate reporting.

Table 51 lists all 169 sites, along with the detailed information used to make the NRHP recommendations. A complete list of the identified sites on Camp Swift, with brief descriptions and our eligibility assessments, are also listed in Appendix D.

\section{Eligible or Protected Sites}

Given available information, only a single site at Camp Swift, 41BP138 (the Aussilloux House site), is clearly eligible for inclusion on the National Register of Historic Places. Three criteria, B, C, and D, of 36 CFR 60.4 are relevant to this determination. Criterion $\mathrm{B}$, which discusses the association of a property with the lives of significant persons, applies, as the life of Aussilloux was regionally significant. Criterion C, dealing with distinctive character, construction methods, or artistic value of a property, is also relevant as Aussilloux's vernacular construction style was unique for the region. Although a large part of the house is gone, the wine cellar at 41BP138 remains as the bestpreserved mid-nineteenth century structure in the area. It represents an example of the way in which individuals brought notions of house construction and industry management from their European cultures and adapted them to the realities of central Texas. Finally, criterion D, also is relevant as Aussilloux's case provides a glimpse into the early-Texas wine industry from the mid-nineteenth to the early-twentieth century. Therefore, the Aussilloux House/wine cellar site should be preserved and protected in the event that it may shed light on a poorly documented industry.

In summary, we suggest that the Aussilloux House site (41BP138) is eligible for inclusion in the NHRP by criteria $\mathrm{B}, \mathrm{C}$ and $\mathrm{D}$. The site should be nominated as soon as possible. It should also be protected. The house is currently fenced and labeled off-limits. This should continue indefinitely. If possible, Wine Cellar Road should be re-routed away from the building, as the vibrations of heavy traffic on this road could damage the remaining portions of the building. 
Table 51. Eligibility assessments for known sites at Camp Swift

\begin{tabular}{|c|c|c|c|c|c|c|}
\hline \multicolumn{7}{|c|}{ Cemeteries and Eligible Sites: Group 0} \\
\hline Site \# & Description & Relocated 97 & Erosion/ Disturbance & $\begin{array}{c}\text { Shovel } \\
\text { Tests/Probes }\end{array}$ & Excavation & $\begin{array}{c}\text { T1/T0 } \\
\text { Location }\end{array}$ \\
\hline 138 & $\begin{array}{l}\text { 19th and 20th century historic } \\
\text { house site/Lithic scatter }\end{array}$ & Yes & 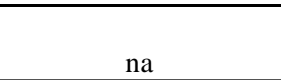 & & & yes \\
\hline 145 & Historic Cemetery & Yes & na & & & \\
\hline 170 & 20th century historic cemetery & Yes & na & & & \\
\hline 382 & Historic Cemetery & Yes & - & & & yes \\
\hline \multicolumn{7}{|c|}{ Ineligible Sites:Group 1} \\
\hline Site \# & Description & Relocated 97 & Erosion/ Disturbance & $\begin{array}{c}\text { Shovel } \\
\text { Tests/Probes }\end{array}$ & Excavation & $\begin{array}{c}\text { T1/T0 } \\
\text { Location }\end{array}$ \\
\hline 90 & Prehistoric open camp & No & eroded & & & \\
\hline 92 & Lithic procurement site & No & eroded & & & \\
\hline 96 & Lithic procurement site & No & eroded & & & \\
\hline 97 & Lithic procurement site & No & eroded & & & \\
\hline 98 & Lithic procurement site & No & eroded & & & \\
\hline 99 & Lithic procurement site & No & eroded & & & yes \\
\hline 101 & Lithic procurement site & No & eroded & & & \\
\hline 102 & Lithic procurement site & No & heavy & & & \\
\hline 103 & Prehistoric open camp & No & eroded & & & \\
\hline 106 & Prehistoric open camp & No & eroded & & & yes \\
\hline 109 & Prehistoric open camp & No & eroded & & & \\
\hline 110 & Lithic procurement site & No & eroded & & & \\
\hline 120 & Prehistoric open camp & No & eroded & & yes & \\
\hline 124 & Prehistoric open camp & No & eroded & & & \\
\hline 126 & Lithic procurement site & No & eroded & & & \\
\hline 130 & Lithic scatter & No & eroded & & & \\
\hline 131 & Prehistoric open camp & No & eroded & & & yes \\
\hline 390 & Lithic scatter & No & heavy & & & \\
\hline \multicolumn{7}{|c|}{ Ineligible Sites:Group 2} \\
\hline Site \# & Description & Relocated 97 & Erosion/ Disturbance & $\begin{array}{c}\text { Shovel } \\
\text { Tests/Probes }\end{array}$ & Excavation & $\begin{array}{c}\text { T1/T0 } \\
\text { Location }\end{array}$ \\
\hline 132 & $\begin{array}{l}\text { 19th and 20th century historic } \\
\text { house site }\end{array}$ & No & na & & & yes \\
\hline 133 & $\begin{array}{l}\text { 19th and 20th century historic } \\
\text { house and ranching site }\end{array}$ & No & na & & & \\
\hline 134 & $\begin{array}{l}\text { 19th and 20th century historic } \\
\text { house site }\end{array}$ & Yes & na & & & \\
\hline 135 & $\begin{array}{l}\text { 19th and 20th century historic } \\
\text { house site }\end{array}$ & No & na & & & yes \\
\hline 136 & 20th century historic ranching site & No & na & & & yes \\
\hline 137 & $\begin{array}{l}\text { 19th and 20th century historic } \\
\text { house site }\end{array}$ & No & na & & & \\
\hline 139 & 20th century historic house site & No & na & & & yes \\
\hline 140 & $\begin{array}{l}\text { 19th century historic house and } \\
\text { ranching site }\end{array}$ & Yes & na & & & \\
\hline 141 & $\begin{array}{l}\text { 19th and 20th century house and } \\
\text { ranching site }\end{array}$ & Yes & na & & & \\
\hline 142 & 20th century historic house site & No & na & & & \\
\hline 144 & 20th century historic house site & Yes & na & & & yes \\
\hline 147 & $\begin{array}{l}\text { 19th and 20th century house and } \\
\text { ranching site }\end{array}$ & No & na & & & \\
\hline
\end{tabular}


Table 51. Continued...

\begin{tabular}{|c|c|c|c|c|c|c|}
\hline \multicolumn{7}{|c|}{ Ineligible Sites:Group 2 (cont.) } \\
\hline Site \# & Description & Relocated 97 & Erosion/ Disturbance & $\begin{array}{c}\text { Shovel } \\
\text { Tests/Probes }\end{array}$ & Excavation & $\begin{array}{c}\text { T1/T0 } \\
\text { Location }\end{array}$ \\
\hline 149 & $\begin{array}{l}\text { 19th and 20th century historic } \\
\text { house site }\end{array}$ & No & 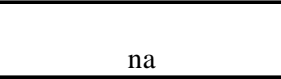 & & & \\
\hline 150 & 19th century house site & No & na & & & \\
\hline 151 & 19th century house site & No & na & & & \\
\hline 152 & $\begin{array}{l}\text { 20th century historic house and } \\
\text { ranch site }\end{array}$ & No & na & & & \\
\hline 153 & $\begin{array}{l}19 \text { th and 20th century historic } \\
\text { house site }\end{array}$ & Yes & na & & & \\
\hline 154 & \begin{tabular}{|l|}
19 th and 20th century school \\
\end{tabular} & Yes & na & & & \\
\hline 155 & $\begin{array}{l}\text { 19th 20th century historic ranching } \\
\text { and house site }\end{array}$ & No & na & & & \\
\hline 156 & $\begin{array}{l}\text { 19th and 20th century house and } \\
\text { ranching site }\end{array}$ & Yes & na & & & \\
\hline 157 & 20th century house site & Yes & na & & & \\
\hline 158 & $\begin{array}{l}\text { 19th and 20th century house and } \\
\text { ranching site }\end{array}$ & Yes & na & & & \\
\hline 159 & $\begin{array}{l}\text { 19th and 20th century historic } \\
\text { house site }\end{array}$ & Yes & na & & & \\
\hline 160 & $\begin{array}{l}\text { Probably 20th century historic } \\
\text { ranching site }\end{array}$ & Yes & na & & & \\
\hline 161 & $\begin{array}{l}\text { Late 19th?, Early 20th century } \\
\text { historic house site }\end{array}$ & No & na & & & \\
\hline 162 & $\begin{array}{l}\text { Late 19th?, Early 20th century } \\
\text { historic house site }\end{array}$ & Yes & na & & & \\
\hline 163 & 20th century historic well & Yes & na & & & \\
\hline 164 & $\begin{array}{l}\text { 19th and 20th century historic } \\
\text { house site }\end{array}$ & No & na & & & \\
\hline 166 & Historic agricultural installation & Yes & na & & & \\
\hline 167 & Historic house site & No & na & & & \\
\hline 168 & 20th century historic well & No & na & & & \\
\hline 169 & $\begin{array}{l}\text { 19th and 20th century historic } \\
\text { house site }\end{array}$ & No & na & & & \\
\hline 171 & $\begin{array}{l}\text { 19th and 20th century historic } \\
\text { house site }\end{array}$ & No & na & & & \\
\hline 172 & Historic trash scattere & No & na & & & \\
\hline 183 & 19th and 20th century historic site & No & na & & & \\
\hline 400 & Historic habitation site & Yes & - & & & \\
\hline 433 & Historic trash scatter & No & heavy & & & \\
\hline 434 & Historic occupation site & No & heavy & & & yes \\
\hline 473 & Historic cistern and trash scatter & No & - & & & \\
\hline 479 & Historic habitation site & -- & heavy & 4 & & \\
\hline 481 & Historic bridge site & -- & heavy & 2 & & yes \\
\hline 482 & Historic bridge site & -- & heavy & 2 & & yes \\
\hline 483 & Historic trash scatter & -- & - & 0 & & \\
\hline 489 & Historic installation & -- & - & 0 & & \\
\hline 490 & Historic habitation & -- & heavy & 0 & & \\
\hline 492 & Historic trash dump & -- & eroded & 0 & & \\
\hline 500 & Historic trash dump & -- & heavy & 1 & & yes \\
\hline 501 & Historic trash dump & -- & - & 1 & & \\
\hline
\end{tabular}


Table 51. Continued...

\begin{tabular}{|c|c|c|c|c|c|c|}
\hline \multicolumn{7}{|c|}{ Ineligible Sites:Group 2 (cont.) } \\
\hline Site \# & Description & Relocated 97 & Erosion/ Disturbance & $\begin{array}{c}\text { Shovel } \\
\text { Tests/Probes }\end{array}$ & Excavation & $\begin{array}{c}\text { T1/T0 } \\
\text { Location }\end{array}$ \\
\hline 502 & Historic trash dump & -- & - & 0 & & \\
\hline 503 & Historic trash dump & -- & - & 0 & & \\
\hline 504 & Historic trash dump & -- & - & 0 & & \\
\hline 507 & Historic trash dump & -- & heavy & 1 & & \\
\hline 508 & Historic agricultural installation & -- & heavy & 0 & & \\
\hline 511 & Historic habitation site & -- & heavy & 3 & & \\
\hline 513 & Historic habitation site & -- & eroded & 2 & & \\
\hline 514 & Historic agricultural installation & -- & eroded & 0 & & \\
\hline 515 & Historic trash dump & -- & eroded & 0 & & \\
\hline 516 & Historic agricultural installation & -- & eroded & 0 & & \\
\hline 517 & Historic trash scatter & -- & heavy & 0 & & \\
\hline 519 & Historic trash scatter & -- & heavy & 0 & & \\
\hline 525 & Historic habitation site & -- & - & 2 & & \\
\hline 531 & Historic trash dump & -- & - & 1 & & \\
\hline 534 & Historic trash dump & -- & heavy & 1 & & \\
\hline \multicolumn{7}{|c|}{ Ineligible Sites:Group 3} \\
\hline Site \# & Description & Relocated 97 & Erosion/ Disturbance & $\begin{array}{c}\text { Shovel } \\
\text { Tests/Probes } \\
\end{array}$ & Excavation & $\begin{array}{c}\text { T1/T0 } \\
\text { Location }\end{array}$ \\
\hline 114 & Prehistoric open camp & Yes & heavy & 10 & yes & yes \\
\hline 119 & $\begin{array}{l}\text { Historic trash scatter/Prehistoric } \\
\text { open camp }\end{array}$ & Yes & eroded & 12 & & yes \\
\hline 129 & Prehistoric open camp & Yes & eroded & $13 ?$ & & yes \\
\hline 391 & Prehistoric open camp & Yes & heavy & 3 & & \\
\hline 398 & Prehistoric open camp & No & none & 9 & & \\
\hline 399 & Prehistoric open camp & Yes & - & 5 & & yes \\
\hline 470 & Lithic scatter & No & - & 11 & & \\
\hline 472 & Lithic scatter & No & - & 7 & & yes \\
\hline 476 & Prehistoric lithic scatter & -- & heavy & 8 & & \\
\hline 480 & Historic trash scatter, Lithic scatter & -- & heavy & 7 & & yes \\
\hline 487 & $\begin{array}{l}\text { Historic trash scatter/ Prehistoric } \\
\text { open camp }\end{array}$ & -- & - & 6 & & yes \\
\hline 493 & Prehistoric limited activity area & -- & - & 3 & & yes \\
\hline 494 & Prehistoric lithic scatter & -- & - & 4 & & \\
\hline 499 & Prehistoric lithic scatter & -- & - & 3 & & yes \\
\hline 509 & Prehistoric lithic scatter & -- & - & 5 & & \\
\hline 522 & Prehistoric open camp & -- & eroded & 5 & & \\
\hline 524 & Prehistoric open camp & -- & & 4 & & \\
\hline 526 & Prehistoric open camp & -- & eroded & 13 & & yes \\
\hline 530 & $\begin{array}{l}\text { Prehistoric/protohistoric open } \\
\text { camp }\end{array}$ & -- & - & 6 & & \\
\hline 533 & Prehistoric limited activity area & -- & - & 10 & & \\
\hline $122 / 143$ & Prehistoric open camp & Yes & heavy & 6 & & yes \\
\hline $95 / 184$ & $\begin{array}{l}\text { Historic habitation site/Lithic } \\
\text { scatter }\end{array}$ & Yes & - & 3 & & yes \\
\hline
\end{tabular}


Table 51. Continued...

\begin{tabular}{|c|c|c|c|c|c|c|}
\hline \multicolumn{7}{|c|}{ Ineligible Sites: Group 4} \\
\hline Site \# & \begin{tabular}{|c|} 
Description \\
\end{tabular} & Relocated 97 & Erosion/ Disturbance & Shovel Tests/Probes & Excavation & T1/T0 Location \\
\hline 379 & Lithic scatter/ Historic trash scatter & No & destroyed & & & \\
\hline 380 & Lithic scatter/ Historic trash scatter & No & destroyed & & & \\
\hline 381 & Prehistoric open camp & Yes & destroyed & 3 & & \\
\hline \multicolumn{7}{|c|}{ Potentially Eligible Sites: Group 5} \\
\hline Site \# & \begin{tabular}{|l} 
Description \\
\end{tabular} & Relocated 97 & Erosion/ Disturbance & Shovel Tests/Probes & Excavation & T1/T0 Location \\
\hline 91 & Lithic scatter & Yes & heavy & 0 & & \\
\hline 104 & Prehistoric open camp & No & eroded & & & yes \\
\hline 107 & Prehistoric open camp & No & minimal & & & \\
\hline 108 & Prehistoric open camp & No & minimal & & & yes \\
\hline 112 & Lithic scatter & Yes & minimal & 3 & & \\
\hline 115 & Lithic procurement site & Yes & heavy & 0 & & \\
\hline 116 & Lithic procurement site & Yes & heavy & 0 & & \\
\hline 117 & Prehistoric open camp & Yes & heavy & & & \\
\hline 125 & Prehistoric open camp & Yes & eroded & & & \\
\hline 127 & Lithic scatter & Yes & eroded & & & \\
\hline 128 & Prehistoric open camp & Yes & eroded & & & \\
\hline 165 & $\begin{array}{l}\text { 19th/20th century historic ranch } \\
\text { house /Lithic scatter }\end{array}$ & Yes & na & & & \\
\hline 378 & Prehistoric open camp & Yes & heavy & & & \\
\hline 383 & Lithic scatter & No & - & & & \\
\hline 384 & Hearth & No & - & & & \\
\hline 385 & Lithic scatter & No & - & & & \\
\hline 389 & Prehistoric open camp & No & heavy & & & \\
\hline 392 & Lithic procurement & No & eroded & & & yes \\
\hline 397 & $\begin{array}{l}\text { Preshistoric open camp/Historic } \\
\text { trash scatter }\end{array}$ & No & - & & & \\
\hline 432 & Prehistoric open camp & No & none & 4 & & \\
\hline 474 & Lithic scatter & No & heavy & 1 & & \\
\hline 484 & Historic trash scatter, Lithic scatter & -- & heavy & 1 & & yes \\
\hline 485 & $\begin{array}{l}\text { Historic trash scatter/ Prehistoric } \\
\text { open camp }\end{array}$ & -- & eroded & 2 & & yes \\
\hline 486 & Prehistoric open camp & -- & eroded & 1 & & yes \\
\hline 488 & Prehistoric open camp & -- & heavy & 2 & & yes \\
\hline 495 & Prehistoric open camp & -- & - & 2 & & \\
\hline 496 & Prehistoric open camp & -- & - & 2 & & \\
\hline 497 & Prehistoric open camp & -- & eroded & 2 & & \\
\hline 498 & Prehistoric lithic scatter & -- & heavy & 1 & & \\
\hline 505 & Prehistoric open camp & -- & eroded & 3 & & \\
\hline 506 & Prehistoric open camp & -- & - & 5 & & yes \\
\hline 510 & Prehistoric open camp & -- & heavy & 2 & & yes \\
\hline 512 & Prehistoric open camp & -- & eroded & 4 & & yes \\
\hline 518 & Historic trash scatter, Lithic scatter & -- & heavy & 1 & & \\
\hline 520 & $\begin{array}{l}\text { Historic habitation site, Prehistoric } \\
\text { open camp }\end{array}$ & - & heavy & 1 & & yes \\
\hline
\end{tabular}


Table 51. Continued...

\begin{tabular}{|c|c|c|c|c|c|c|}
\hline \multicolumn{7}{|c|}{ Potentially Eligible Sites: Group 5 (cont.) } \\
\hline Site \# & Description & Relocated 97 & Erosion/ Disturbance & $\begin{array}{c}\text { Shovel } \\
\text { Tests/Probes }\end{array}$ & Excavation & $\begin{array}{c}\text { T1/T0 } \\
\text { Location }\end{array}$ \\
\hline 521 & Prehistoric open camp & -- & eroded & 1 & & yes \\
\hline 523 & Historic trash dump, Lithic scatter & -- & - & 1 & & \\
\hline 527 & Prehistoric limited activity area & -- & heavy & 0 & & \\
\hline 529 & Prehistoric open camp & -- & - & 5 & & \\
\hline 532 & Historic trash dump, Lithic scatter & -- & - & 3 & & \\
\hline \multicolumn{7}{|c|}{ Potentially Eligible Sites: Group 6} \\
\hline Site \# & Description & Relocated 97 & Erosion/ Disturbance & $\begin{array}{c}\text { Shovel } \\
\text { Tests/Probes } \\
\end{array}$ & Excavation & $\begin{array}{c}\text { T1/T0 } \\
\text { Location }\end{array}$ \\
\hline 93 & $\begin{array}{l}\text { Prehistoric open camp, possible } \\
\text { lithic proc. }\end{array}$ & No & minimal & & & yes \\
\hline 94 & Lithic scatter & Yes & minimal & 4 & & yes \\
\hline 100 & Prehistoric open camp & Yes & minimal & 6 & yes & yes \\
\hline 105 & Prehistoric open camp & No & minimal & & & yes \\
\hline 111 & Prehistoric open camp & No & minimal & & yes & \\
\hline 113 & Prehistoric open camp & Yes & heavy & 1 & yes & \\
\hline 118 & Prehistoric open camp & No & minimal & & yes & yes \\
\hline 121 & Prehistoric open camp & Yes & minimal & 3 & yes & \\
\hline 123 & Prehistoric open camp & No & eroded & & yes & \\
\hline 146 & 19th century historic grave? & No & na & & & \\
\hline 148 & 19th \& 20th century mine site & Yes & na & & & \\
\hline 430 & Historic trash scatter/ Lithic scatter & No & none & 7 & & \\
\hline 431 & Prehistoric open camp & No & none & 5 & & \\
\hline 435 & Prehistoric open camp & No & none & 5 & & \\
\hline 436 & Prehistoric open camp & No & none & 10 & & \\
\hline 471 & Prehistoric open camp & No & - & 13 & & \\
\hline 477 & Prehistoric open camp & -- & heavy & 14 & & yes \\
\hline 491 & Prehistoric open camp & -- & - & 3 & & \\
\hline 528 & Prehistoric open camp & -- & - & 8 & & \\
\hline
\end{tabular}

In addition to $41 \mathrm{BP} 138$, there are three additional sites, 41BP145, 41BP170, and 41BP382 which are known cemeteries at Camp Swift. As such, these sites are protected by state statutes. Currently, these properties are fenced. We suggest that regular maintenance of these fences should be scheduled. Signs should be put up announcing the cemeteries, and off-limit signs and other markings, such as the tall white poles at Chandler Cemetery, should be installed and maintained. These four cemetery sites are listed as Group 0 in Table 51. 


\section{Sites Recommended as not Eligible}

A total of 106 sites are recommended as not eligible for NRHP status. They can be classed into four groups (Groups 1-4 in Table 51).

The first group is made up of 18 sites. These are identified in Table 51 as Group 1 sites. All of these sites are prehistoric in age, and all were recorded prior to the 1997 AGTX survey project. Cultural material on these 18 sites is described as being either on the surface or confined to the upper $10 \mathrm{~cm}$ of the deposit. On 15 of the 18 sites, shovel tests and/or shovel probes have been excavated, though the exact number and location of these tests are not known. All 18 sites are described as being either eroded or heavily eroded, and in three cases, the sites were recorded as being on either the $\mathrm{T} 0$ or $\mathrm{T} 1$ terraces, locations that geomorphic work presented in Chapter 3 suggests are disturbed and redeposited at about 600 B.P. In addition, none of the 18 sites have surface or subsurface features noted in the original descriptions. None of these sites could be relocated by either the AGTX effort or by CAR. Given the excellent probability that in all 18 cases these are surface sites, the fact that they lack critical data in terms of either buried deposits or features, and the fact that they could not be relocated, we suggest that their information potential has been exhausted. As such, we recommend that these sites are not eligible for inclusion on the National Register of Historic Places.

The second group, designated as Group 2 in Table 51, is composed of 63 sites. All 63 are historic in age, and all lack any prehistoric component. These sites represent a variety of types, but are dominated by historic habitation sites and trash dumps. Twenty-four of these sites were recorded on the current survey, and are discussed in Chapter 5, while the remaining 39 were recorded by Skelton and Freeman (1979), Schmidt and Cruse (1995), Davis (1995), and Sullo and Wormser (1996). Fifteen of these 39 previously recorded sites were revisited by AGTX as part of the current survey, and these recent observations are also presented in Chapter 5.

Of the 24 sites recorded on the current survey, shovel tests and/or probes were placed on eleven sites. It is unclear if any of the previously recorded sites were shovel tested. In all cases where detailed descriptions exist, the sites are described as eroded or heavily eroded, and many of these locations, especially those that had standing architecture, appear to have been severely damaged by military activity, reducing their overall integrity. The revisits of the earlier recorded sites by the current survey demonstrate that the integrity of these sites has continued to decline. For example, the historic summary by Skelton and Freeman (1979:Table 5) describe site 41BP159 as the "location of the only recorded standing rock fireplace in the survey area" and a site that had house remains aligned southeast/northwest. When the site was revisited in 1979, the chimney had fallen and the other remains of the house were not visible. Given that these 63 sites have questionable integrity, and as archival and informant research has been conducted on all possible sites (see Skelton and Freeman 1979; Chapters 2,5 , and 6 of the current report), CAR recommends that the research value of these 63 historic sites has been exhausted. As such, we suggested that they are not eligible for inclusion in the National Register of Historic Places.

On 22 sites, identified as Group 3 in Table 51, we have adequate levels of testing to determine eligibility status. These sites represent a variety of types, and while several multicomponent sites are in this group, all have prehistoric material present. In all cases, the historic material is analogous to the 63 sites discussed above, in that it has been severely damaged and lacks critical data. The primary consideration here, then, is with the prehistoric material on these 22 sites.

Reference to Table 51 will demonstrate that 12 of the 22 sites were identified and tested on the current survey, with the remaining ten consisting of five sites identified by Skelton and Freeman (1979) and five identified by more recent surveys. Of these ten sites, AGTX archaeologists relocated seven, and conducted additional work. The five sites identified by Skelton and Freeman (1979) had some level of shovel testing, although the actual numbers for a given site are not reported, and in at least one case (41BP114), a $1 \times 1$ meter unit was excavated into the site. All four of these sites were relocated by AGTX, and additional shovel tests were excavated. In total, then, at least 153 shovel 
tests and/or probes were placed on these 22 sites, an average of 6.95 shovel tests per site, and 20 of the 22 sites have four or more shovel tests. The two sites with less than four shovel tests are both extremely small, being 25 and $16 \mathrm{~m}^{2}$ in total area. These 22 sites, then, have adequate levels of effort for evaluation. In addition, 12 of the 22 are located on the T1 and T0 terraces, locations that geomorphic investigations suggest have been scoured and redeposited at about 600 в.P., further reducing the integrity of the cultural material.

We suggest that the components on these 22 sites have adequate testing to demonstrate that they lack intact features and lack stratified, buried deposits. In addition, many of these sites are described as eroded or heavily eroded, and 55\% are in locations that have recent scouring and redeposition of sediments. These sites lack data needed to address the prehistoric contexts and are of questionable integrity. CAR suggests that the research value of these 22 sites has been exhausted. As such, we suggest that they are not eligible for inclusion on the National Register of Historic Places.

The final group of sites in the not-eligible class consists of three sites, identified as Group 4 in Table 51, that have been destroyed or severely damaged. Two of these (41BP379 and 41BP380) were recorded by Leshley (1994) and the remaining site (41BP381) was recorded by Wormser (1994). Reference to these sites in the Texas Site Atlas suggest that in two cases the sites are primarily historic trash scatters, with a small amount of prehistoric material, while in the case of 41BP381, the site has a single mano, a core, and three flakes present. On 41BP379 and 41BP380, the Texas site forms note that the site integrity has been "completely destroyed by machine scraping of the area" and that both sites were "surface" manifestations. On 41BP381, the site forms note that "most of the site has been destroyed by berms and trenching" and that the core and the mano were collected. Site 41BP381 was revisited by AGTX archaeologists on the current project. They noted that the entire site was severely disturbed. Two shovel tests and one shovel probe were excavated on this revisit, and while debitage was recovered to a depth of $30 \mathrm{~cm}$ in two of these three tests, the overall level of disturbance effectively reduces the integrity of this site. Given that these three sites lack data needed to address the prehistoric contexts and lack any integrity, we suggest that their research value has been exhausted. As such, we suggested that they are not eligible for inclusion on the National Register of Historic Places.

\section{Sites Recommended as Potentially Eligible}

The remaining 59 sites are considered potentially eligible to the National Register of Historic Places. These sites, identified in Table 51 as Groups 5 and 6, have a mixture of historic $(n=2)$, prehistoric $(n=47)$, multicomponent $(\mathrm{n}=9)$, and unknown $(\mathrm{n}=1)$ temporal assignments. Twenty-two of these sites were recorded on the present survey, 23 sites were recorded by Skelton and Freeman (1979), and the remaining 14 sites were recorded on smaller surveys conducted in the 1990s. Of the 23 sites recorded by Skelton and Freeman (1979), AGTX archaeologists revisited 14 as part of the current project.

These 59 sites can be divided into two large classes. The first class consists of 40 sites, identified in Table 51 as Group 5, that will require additional shovel tests to both define the sites and clarify the nature of the subsurface deposits, as well as the production of new site maps. Nineteen of these 40 were recorded on the present survey, and while some shovel tests have been conducted on most of these sites, we simply lack sufficient information for evaluation. For example, a total of 39 shovel tests were excavated on these 19 sites, an average of just under two shovel tests per site, and in nine cases less than two shovel tests were excavated. We suggest that this level of coverage is not adequate to assess either the site boundaries or the nature of the deposits. Of the 40 sites in this group, Skelton and Freeman (1979) recorded 12, and some level of shovel testing and/or shovel probes were excavated on ten of these, though the number and location is not known. In ten of the 12 cases, these locations were revisited as part of the current project, and in two cases, at least a few additional shovel tests and/or probes were excavated, though the exact number is unclear. Finally, the nine remaining sites in this group 
recorded in the early 1990s have minimal information. Five of these nine sites have shovel tests, but it appears that the overall level of information available is minimal.

We cannot make recommendations on these 40 Group 5 sites. This is a direct result of both the overall low density of shovel tests combined with a lack of information on site-specific results. It is probable that many of these sites will ultimately be determined to be not eligible, but additional shovel tests will be required to clarify the site boundaries and assess the potential for buried deposits at these sites. Until that additional work is done, we recommend that these 40 sites be considered potentially eligible, and that these locations be avoided.

The second class of potentially eligible sites, identified as Group 6 in Table 50, has indications of either buried deposits with some integrity, buried features, or charcoal from buried contexts. Additional work will be required to assess their eligibility. In most cases, additional work on these sites will require shovel testing, the excavation of $1 \times 1 \mathrm{~m}$ units, and the production of new site maps. Skelton and Freeman (1979) recorded 11 of these 19 sites, three were recorded on the present survey, and five were recorded on small surveys conducted in the early 1990s. Archaeologists from the AGTX relocated and visited five of these sites, and CAR archaeologists visited nine of these 19 sites.

Two sites recorded by Skelton and Freeman (1979), 41BP146 and 41BP148, are historic in age. Site $41 \mathrm{BP} 146$ consists of a probable grave. The site is described as consisting of five slabs of cut ironstone that an informant identified as a grave. The site was not relocated by AGTX or by CAR. If the site can be located and the nature of the observations confirmed, then the site would be protected by State statutes. Site $41 \mathrm{BP} 148$ is described as a series of coal mines within a 40-acre area. Skelton and Freeman (1979) observed pits and scattered chunks of lignite at the site. The site was relocated in 1997. If the location can be confirmed, then the site may contain information related to the third historic context dealing with lignite mining during the period between 1910 and 1940 .
Additional information on site content, combined with additional archival research, should be conducted at this location.

Skelton and Freeman (1979) recorded nine additional Group 6 sites, all of which were prehistoric in age. Site 41BP93, a lithic scatter, was investigated by an unknown number of shovel tests. The site is described as being minimally eroded, and shovel testing recovered debitage to a depth of $40 \mathrm{~cm}$. Small fragments of burned limestone were also present. This site was not relocated in 1997. Given the low level of erosion and the presence of material from buried contexts, additional investigations, including both shovel tests and $1 \times 1 \mathrm{~m}$ test units, are recommended to assess the potential of both buried features and associated debitage.

Skelton and Freeman (1979) note that site 41BP94 had a variety of lithic debitage and fire-cracked rock down to $50 \mathrm{~cm}$ in shovel tests. The site was described as minimally eroded. The site was revisited in 1997 and three shovel tests and a shovel probe were excavated. All were positive, with artifacts present as deep as $75 \mathrm{~cm}$. An Ensor point was recovered from ST-3 at a depth of 20 to $40 \mathrm{~cm}$ below the surface. Given this recovery, the low incidence of erosion, and the possibility that buried features and associated artifacts are present, additional investigations, including both shovel tests and several $1 \times 1 \mathrm{~m}$ test units, are recommended to assess the potential for buried features and associated artifacts.

On 41BP100, Skelton and Freeman (1979) observed two buried hearths, exposed in a cutbank, approximately 1.0 and $1.75 \mathrm{~m}$ below the present surface. They removed a portion of the cutbank to expose the features, and their description suggests that lithics may be associated with one of these hearths. The site was revisited in 1997, and six shovel tests were excavated. Burned rock was noted in three of the six shovel tests. Although the site is located on the T1 terrace, the presence of the hearths and the results of the shovel tests clearly indicate that an undisturbed component may be present. Additional investigations, including both shovel tests and at least one $1 \times 1 \mathrm{~m}$ test unit, are recommended to assess the potential for other buried features and associated artifacts. 
Site 41BP105 was described by Skelton and Freeman (1979) as containing a hearth exposed in a cutbank. They report that the feature is approximately $50 \mathrm{~cm}$ below the surface, and that the site has minimal erosion. No shovel tests or excavations were conducted by Skelton and Freeman (1979), and the site was not revisited. The presence of a buried feature on a site that apparently has little erosion indicates that the site may contain macrobotanical and chronometric data relevant to a variety of prehistoric contexts. We recommend that the site should be relocated and tested with both shovel tests and at least one $1 \times 1 \mathrm{~m}$ excavation unit in order to assess the potential of this feature, as well as define any additional features or associated artifacts, on 41BP105.

Site 41BP111 was described by Skelton and Freeman (1979) as containing both surface lithic material and at least two buried features. The hearths were within the upper $25 \mathrm{~cm}$ of the deposit and exposed in a cutbank. A 1 x $1 \mathrm{~m}$ test unit was excavated, recovering both fire-cracked rock and debitage. This material was concentrated within the upper $50 \mathrm{~cm}$ though material was present down to $75 \mathrm{~cm}$ below surface. The site was described as having minimal erosion. The site was not relocated by the 1997 field effort, and CAR did not attempt to revisit this site. We recommend that the site be relocated and tested with additional $1 \times 1$ $m$ excavation units in order to assess the potential of the buried feature, as well as define any additional features or associated artifacts.

Site 41BP113 was described by Skelton and Freeman (1979) as a scatter of chert debitage with a few small fragments of fire-cracked rock. Shovel probes were excavated, indicating that material was confined to the upper $50 \mathrm{~cm}$ of the site. A $1 \times 2 \mathrm{~m}$ test unit was also excavated, confirming the shovel probe findings. During the revisit to the site in 1997, a single shovel test found flakes to $80 \mathrm{~cm}$. While no intact features were observed, and while the site is described as heavily disturbed, the presence of buried material, including fire-cracked rock, suggests that the site may contain intact buried deposits. As the overall level of the testing effort at this site is not known, we recommend that additional investigations, including both shovel tests and at least one $1 \times 1 \mathrm{~m}$ test unit, be conducted to assess the potential for other buried features and associated artifacts.
Skelton and Freeman (1979) describe 41BP118 as a minimally eroded, open campsite. Surface lithic debris and fire-fractured rock were observed, and buried material was noted in an eroded terrace. The excavation of a $1 \times 2 \mathrm{~m}$ test unit demonstrated that chipped stone and fire-cracked rock were present to over $120 \mathrm{~cm}$ below surface. A "Marshall type" dart point was recovered from the initial $20 \mathrm{~cm}$ of the excavation. The site was not relocated or revisited. The presence of both buried lithic debitage and burned rock down to $120 \mathrm{~cm}$ suggests that intact deposits may be present. We recommend that additional investigations, including both shovel tests and at least one additional $1 \mathrm{x} 1 \mathrm{~m}$ test unit, be conducted to assess the potential for buried features and associated artifacts.

On site 41BP121, Skelton and Freeman (1979) observed cores, flakes, and burned rock on the surface. Shovel tests and the excavation of a $1 \times 2 \mathrm{~m}$ test unit recovered a high density of material down to $1 \mathrm{~m}$ below surface, including chipped stone, fire-fractured rock, and a "Montell type" dart point. The site was described as being minimally eroded. 41BP121 was revisited in 1997, and flakes and burned rock were recovered from one of three shovel tests excavated. The presence of both buried lithic debitage and burned rock down to $100 \mathrm{~cm}$ suggest that intact deposits may be present. We recommend that additional investigations, including the excavation of at least one additional $1 \times 1 \mathrm{~m}$ test unit, be conducted to assess the potential for buried features and associated artifacts.

Skelton and Freeman (1979) describe 41BP123 as a scatter of chert flakes, cores, and burned rock. Shovel tests and excavation of a single $1 \times 1 \mathrm{~m}$ test unit confirmed the presence of buried material, including burned rock, down to $75 \mathrm{~cm}$ below the surface. The site was not revisited in 1997. The presence of both buried lithic debitage and burned rock down to $75 \mathrm{~cm}$ suggest that intact deposits may be present. We recommend that additional investigations, including the excavation of additional $1 \times 1 \mathrm{~m}$ test units, be conducted to assess the potential for buried features and associated artifacts at 41BP123.

Site 41BP430 was recorded by Espey, Huston, and Associates in 1995 (Schmidt and Cruse 1995). The Texas site form identifies the site as a historic and prehistoric scatter of material. Only the prehistoric 
material is of interest here, as the historic component is not significant. A total of seven shovel tests were excavated, revealing deposits 10-30 $\mathrm{cm}$ below surface. However, the nature and extent of the prehistoric material is not known. CAR located the site in 2000 , and placed a datum at the location, but did not conduct any additional work. Given that prehistoric material is present in a buried context, we recommend that both shovel tests and the excavation of a single $1 \times 1 \mathrm{~m}$ unit be conducted to identify the nature and extent of the prehistoric material.

Site 41BP431 was recorded by Espey, Huston, and Associates in 1995 (Schmidt and Cruse 1995). The Texas site form identifies the site as a prehistoric campsite. Five shovel tests were excavated, at least two of which were positive. Charcoal was noted in several of these shovel tests. CAR located and placed a datum at this site, but did not conduct any additional work. Given that prehistoric material, including charcoal, is present in a buried context, we recommend that both additional shovel tests and the excavation of at least one $1 \times 1 \mathrm{~m}$ unit be conducted to clarify the nature and extent of the prehistoric material.

Site 41BP435 was recorded by Espey, Huston, and Associates in 1995 (Schmidt and Cruse 1995). The Texas site form identifies the site as a prehistoric campsite. Five shovel tests were excavated, with a variety of material recovered, including chert flakes and firecracked rock, down to depths of $50 \mathrm{~cm}$. CAR located and placed a datum at this site, but did not conduct any additional work. Given that prehistoric material is present in a buried context, we recommend that both additional shovel tests and the excavation of at least one $1 \times 1 \mathrm{~m}$ unit be conducted to identify the nature and extent of the prehistoric material.

Site 41BP436 was recorded by Espey, Huston, and Associates in 1995 (Schmidt and Cruse 1995). The Texas site form identifies the site as a prehistoric campsite. A total of ten shovel tests were excavated. Deposits, including debitage, fire-cracked rock, charcoal, and burned nut hulls, were present down to $80 \mathrm{~cm}$. The site appears to have intact deposits, as well as a high density of material. CAR located and placed a datum at this site, but did not conduct any additional work. Given that prehistoric material is present in a buried context, we recommend the excavation of several $1 \times 1 \mathrm{~m}$ units in order to identify the nature and extent of the prehistoric material.

Site 41BP471 was recorded by AGTX archaeologists in 1996. The Texas site form identifies the site as a prehistoric campsite/lithic scatter. A total of 13 shovel tests were excavated, revealing cultural material within the upper $20 \mathrm{~cm}$ of the deposits. The site was not relocated. Given that prehistoric material is present in a buried context, we recommend the excavation of at least one $1 \times 1 \mathrm{~m}$ unit be conducted to identify the nature and extent of the prehistoric material.

Site 41BP477 is large prehistoric open camp recorded on the current survey. A total of 14 shovel tests were excavated, 11 of which were positive. A total of 87 artifacts were found, including chert flakes, burned rock, a possible bison tooth, and a Scallorn arrow point. Artifacts were recovered to a depth of $120 \mathrm{~cm}$. Although no features were identified at the site, the larger quantities of burned rock may be the remnants of burned-rock hearths, or indicate that such features are nearby. Given that prehistoric material is present in a buried context, we recommend that the excavation of several $1 \times 1 \mathrm{~m}$ units will be necessary to clarify the nature and extent of the prehistoric material.

Site 41BP491 is a small prehistoric open camp recorded on the current survey. A total of three shovel tests were excavated. A total of seven artifacts were found, including chert flakes and burned rock, to a depth of $100 \mathrm{~cm}$. Although no features were identified, the presence of burned rock may indicate that features are present. Given that prehistoric material is present in a buried context, we recommend the excavation of several $1 \times 1 \mathrm{~m}$ units to clarify the nature and extent of the prehistoric material.

Site 41BP528 is a prehistoric open camp identified on the current survey. A total of eight shovel tests were excavated on this small site. Several flakes, an untypeable dart point fragment, and a burned rock were retrieved from the subsurface down to $60 \mathrm{~cm}$. The site appears to be relatively undisturbed, with slight evidence of military training and possible erosion from a nearby drainage. The site may have intact buried deposits. Given that prehistoric material is present in a buried context, we recommend the excavation of several $1 \times 1 \mathrm{~m}$ units to clarify the nature and extent of the prehistoric material. 


\section{References Cited}

Aten, L. E.

1983 Indians of the Upper Texas Coast. Academic Press, New York.

Austin American (AA) [Austin, Texas]

1944 Swiftex Village Will Have Christmas Program. Austin American 14 December.

1945 Camp Swift Separation Point Closes. Austin American 19 December.

1947a State May Utilize Surplus Camp Swift Hospital. Austin American 1 April.

1947b WAA Offers 1,500 Camp Buildings for Sale. Austin American 1 December.

1951a State Purchase of Swift Area Debated. Austin American 19 January.

1951b Bastrop County Striving for Re-Activation of Camp Swift to Push War Effort, Aid Business. Austin American 9 January.

Austin Statesman (AS) [Austin, Texas]

1946 Keep Camp Swift, Hardy Hollers Asks. Austin Statesman 1946.

Avakian, A. J., and E. G. Wermund

1993 Physical Environment of Camp Swift Military Reservation, Bastrop County, Texas: Baseline Information for National Guard Land Condition-Trend Analysis Program. Prepared for the Texas National Guard. Bureau of Economic Geology, University of Texas, Austin.

Baker, F. E.

1979 Soil Survey of Bastrop County, Texas. U.S. Department of Agriculture, Soil Conservation Service, Washington, D.C.

Barber, E. A.

1976 Marks of American Potters. In The Pottery and Porcelain of the United States: An Historical Review of Our Ceramic Art from the Earliest Times to the Present Day, by E. A. Barber. Feingold and Louis, New York.

Barnes, V. E.

1974 Austin Sheet. In Geological Atlas of Texas. Bureau of Economic Geology, University of Texas, Austin.

Bastrop Advisor (BA) [Bastrop, Texas]

1978 Lignite Mining in Bastrop County. Bastrop Advisor 25 May:1-2.

Bement, L. C.

1984 Intensive Investigation of 41 BP191 and 41BP192, the Powell Bend Prospect, Bastrop County, Texas. Research Report No. 87. Texas Archeological Survey, University of Texas, Austin.

1989 Excavations at 41BP19, the Kennedy Bluffs Site, Bastrop County, Texas. Contract Reports in Archaeology Report No. 5. Texas State Department of Highways and Public Transportation, Highway Design Division, Austin. 
Black, S. L.

1989 Central Texas Plateau Prairie. In From the Gulf to the Rio Grande: Human Adaptation in Central, South, and Lower Pecos Texas, edited by T. R. Hester, S. L. Black, D. G. Steele, B. W. Olive, A. A. Fox, K. J. Reinhard, and L. C. Bement. Research Series No. 33. Arkansas Archeological Survey, Fayetteville.

Blair, W. F.

1950 The Biotic Provinces of Texas. Texas Journal of Science 2:93-117

Blum, M. D., and S. Valastro

1994 Late Quaternary Sedimentation, Lower Colorado River, Gulf Coastal Plain of Texas. Geological Society of America Bulletin 106:1002-1016.

Brooks, A., and J. Yellen

1987 The Preservation of Activity Areas in the Archaeological Record: Ethnoarchaeological and Archaeological Work in Northwest Ngamiland, Botswana, in Method and Theory for Activity Area Research. In An Ethnoarchaeological Approach, edited by Susan Kent, pp. 63-106. Columbia University Press, New York.

Brooks, S. R.

1945 2,000 Help Camp Swift Celebrate Third Birthday. Austin Statesman 6 May. Austin, Texas

Brown, D. O.

1984 A Cultural Resource Survey and Assessment of the Proposed Wolf Lane Substation and Transmission Corridor, Bastrop County, Texas. Technical Bulletin No. 75. Texas Archeological Survey, University of Texas, Austin.

Brown, V. D. P., and Mrs. G. Smedley

1944 Letter to Citizen of Austin. Dated April 8, 1944. In Camp Swift vertical file in the Center for American History, University of Texas, Austin.

Bryant, V. M., Jr.

1977 A 16,000 Year Pollen Record of Vegetational Change in Central Texas. Palynology 1:143-156.

Bryant, V. M., Jr., and R. G. Holloway

1985 A Late-Quaternary Paleoenvironmental Record of Texas: An Overview of the Pollen Evidence. In Pollen Records of Late-Quaternary North American Sediments, edited by V. M. Bryant, Jr., and R. G. Holloway, pp. 39-70. American Association of Stratigraphic Palynologists Foundation, Dallas, Texas.

Buder, J. D.

1996 Sayersville, Texas. In The New Handbook of Texas, vol. V, edited by R. Tyler, p. 907. Texas State Historical Association, Austin.

Byrd, C. L.

1971 Origin and History of Uvalde Gravel of Central Texas. Baylor Geological Studies Bulletin No. 20. Baylor University Press, Waco, Texas. 
Carpenter, L.

1947 Camp Swift Area Slated for Pasture. Austin American 5 August. Austin, Texas.

Carr, J. T.

1967 The Climate and Physiography of Texas. Report No. 53. Texas Water Development Board, Austin.

Center for American History

1943 Austin Children See Camp Swift. Unidentified clipping dated 1943 in Camp Swift vertical file, Center for American History, University of Texas, Austin.

1946a Johnson Says Fate of Swift in Draft. Unidentified clipping dated April 27, 1946 in Camp Swift vertical file, Center for American History, University of Texas, Austin.

1946b Camp Swift's Closing Date Set for June 15. Unidentified clipping dated April 1946 in Camp Swift vertical file, Center for American History, University of Texas, Austin.

1946c Camp Swift to be Reactivated Temporarily by Lone Battalion. Unidentified clipping dated June 29, 1946 in Camp Swift vertical file, Center for American History, University of Texas, Austin.

1947 Camp Swift Due to Go on Army Surplus List. Unidentified clipping dated January 4, 1947 in Camp Swift vertical file, Center for American History, University of Texas, Austin.

Collins, M. B.

1995 Forty Years of Archeology in Central Texas. Bulletin of the Texas Archeological Society 66:361-400.

Cutrer, T. W.

1996a Pike, Zebulon Montgomery. In The New Handbook of Texas, vol. V, edited by R. Tyler, p. 201. Texas State Historical Association, Austin.

1996b Cunningham, Leander Calvin. In The New Handbook of Texas, vol. II, edited by R. Tyler, p. 449. Texas State Historical Association, Austin.

Davis, G. P.

1994a Archeological Survey for Range Road Extension at Camp Swift, Bastrop County, Texas. Archeological Report. Adjutant General's Department of Texas, Austin.

1994b Archeological Survey for Development of a Mock Village for Military Operations on Urban Training at Camp Swift, Bastrop County, Texas. Archeological Report. Adjutant General's Department of Texas, Austin.

1995 Archeological Survey for the Bastrop County Firefighters Association Training Area at Camp Swift, Bastrop County, Texas. Archeological Survey Report. Adjutant General's Department of Texas, Austin.

Dibble, D. S.

1976 Results of an Archeological Survey of Areas to be Affected by a Proposed Sanitary Landfill, Camp Swift, Texas. Technical Bulletin 11. Texas Archeological Survey, University of Texas, Austin.

Duke, P. L.

1978 Lake Thunderbird Site (41BP78), Bastrop, Texas. La Tierra: The Journal of the South Texas Archaeological Association 4(3):15-26.

Durrenburger, E. P.

1965 Anderson's Mill (41TV130): A Historical Site in Travis County, Texas. Bulletin of the Texas Archeological Society 36:1-70. 
Ensor, H. B., and C. S. Mueller-Wille

1988 Excavations at the Bull Pen Site 41BP280, Colorado River Drainage, Bastrop County, Texas. Contract Reports in Archaeology Report No. 3. Texas State Department of Highways and Public Transportation, Highway Design Division, Austin.

Fawcett, W. B., Jr.

1975 An Archeological Survey of the Proposed Federal Youth Center, Bastrop County, Texas. Technical Bulletin No. 10. Texas Archeological Survey, University of Texas, Austin.

Fields, R. C.

1995 The Archeology of the Post Oak Savannah of East Central Texas. Bulletin of the Texas Archeological Society 66:301-330.

Frazee, J. D.

1991 The Legacy of Antoine Aussilloux. Sayersville Historical Association Bulletin 9:11-13.

Frederick, C. D., and C. Ringstaff

1994 Lithic Resources at Fort Hood: Further Investigations. In Archeological Investigations on 71 Prehistoric Sites at Fort Hood, Bell and Coryell Counties, Texas, edited by W. N. Trierweiler, pp. 125-181. Research Report No. 31. United States Army, Fort Hood Archeological Resource Management Series, Austin, Texas.

Freeman, M. D.

1979 Archaeological site form for 41BP138. Texas Archeological Research Laboratory, University of Texas, Austin.

Gassaway, L.

1997 Landowners and Deed Research. Unpublished draft report on file in Camp Swift historical files, AGTXEV, Camp Mabry, Texas.

Gates, W. D., and D. A. Ormerod

1982 The East Liverpool Pottery District: Identification of Manufacturers and Marks. Historical Archaeology 16(1-2):pp.

Godden, G. A.

1964 Encyclopaedia of British Pottery and Porcelain Marks. Bonanza, New York.

Goode, G. T.

1989 Archaeological Testing and Recommendations for the Kennedy Bluffs Site, 41BP19, in Bastrop County, Texas. In Excavations at 41BP19, the Kennedy Bluffs Site, Bastrop County, Texas, by L. C. Bement, Appendix II. Contract Reports in Archaeology Report No. 5. Texas State Department of Highways and Public Transportation, Highway Design Division, Austin.

Greenwood, J.

1947 Bastrop County Wonders as Camp Swift Passes Out. Austin American 6 January. Austin, Texas.

Guerke, K.

1987 Bricks and Brickmaking: A Handbook for Historical Archaeology. University of Idaho Press, Moscow, Idaho. 
Hayden, B.

1979 Lithic Use-Wear Analysis. Academic Press, New York.

Henderson, N.

1956 The Silent Cadence. Austin American 6 June. Austin, Texas.

Houston, O. P.

1958 History of Camp Swift, Texas. Unpublished manuscript in the Austin History Center, Austin Public Library, Austin, Texas.

Insulator Collectors on the Net

2001a CD 152 Hemingray. Electronic document, http://www.insulators.com/photos/photos/152-ogrn.htm, accessed January 16.

2001b Insluator Profile Hemingray No. 42. Electronic document, http:/www.insulators.com/general/profiles/ 154hemi.htm, accessed January 16.

Johnson, L.

1986 A Plague of Phases. Bulletin of the Texas Archeological Society 57:1-25.

1994 The Life and Times of Toyah-Culture Folk: The Buckhollow Encampment Site, 41KM16, Kimble County, Texas. Office of the State Archeologist Report No. 38. Texas Department of Transportation and Texas Historical Commission, Austin.

Johnson, L., and G. T. Goode

1994 A New Try at Dating and Characterizing Holocene Climates, as well as Archeological Periods, on the Eastern Edwards Plateau. Bulletin of the Texas Archeological Society 65:1-51.

Kay, L. H.

1997 Antoine Aussilloux: Early Texas Wine Industry. Unpublished draft report on file in Camp Swift historical files, AGTX-EV, Camp Mabry, Texas.

Keller, J. E., and L. J. Campbell

1984 Patterns in Prehistoric Settlement: Examining the Distributions of Sites in a Portion of the Colorado River Valley, the Colorado Coastal Plains Project, Fayette and Colorado Counties, Texas. Report of Investigations. New World Research, Pollock, Louisiana.

Kelly, T. C., and E. Roemer, Jr.

1981 Archeological and Historical Investigations in Bastrop and Lee Counties, Texas. Archaeological Survey Report No. 101. Center for Archaeological Research, The University of Texas, San Antonio.

Kenmotsu, R. D.

1982 Cultural Resource Investigation at the Powell Bend Prospect, Bastrop County, Texas. Research Report No. 84. Texas Archeological Survey, University of Texas, Austin.

Kesselus, K.

1986 Bastrop County before Statehood. Stationers Press, Bastrop, Texas.

1987 Bastrop County 1846-1865. Stationers Press, Bastrop, Texas. 
Laurens, J. C., J. A. Guy, and E. R. Prewitt

1979 Archeological Survey and Assessment along Portions of Fayette Electric Cooperative Power Lines, Fayette, Bastrop, and Lavaca Counties, Texas. Reports of Investigations No. 1. Prewitt and Associates, Austin, Texas.

Leffler, J. J.

2001 The History of Camp Maxey and the Surrounding Area. In Camp Maxey II: A 5,000-Acre Survey of Camp Maxey, Lamar County, Texas, by A. S. Lyle, T. K. Perttula, and S. A. Tomka. Archaeological Survey Report No. 312. Center for Archaeological Research, The University of Texas, San Antonio.

Leonard, C. R.

1981 Camp Swift. Bastrop County Advisor and County News 18 June. Bastrop, Texas.

Leshley, C. M.

1994 Archeological Survey for Ammunition Storage Facilities at Camp Swift, Bastrop County, Texas. Archeological Survey Report. Adjutant General's Department of Texas, Austin.

1996 Archeological Survey for the Proposed Army Aviation Support Facility at the Camp Swift Military Reservation, Bastrop County, Texas. Archeological Survey Report. Adjutant General's Department of Texas, Austin.

Lim, B. G., F. B. Pearl, and S. W. Moss.

2000 Cultural Resources Survey of US 290: SH 95 to One Mile East of FM 696, Bastrop County, Texas. Report of Investigations No. 1. Quadrant Consultants, Houston, Texas.

Marks, P. M.

1996a Bastrop, Texas. In The New Handbook of Texas, vol. I, edited by R. Tyler, p. 410-411. Texas State Historical Association, Austin.

1996b Bastrop County. In The New Handbook of Texas, vol. I, edited by R. Tyler, p. 412. Texas State Historical Association, Austin.

1996c McDade, Texas. In The New Handbook of Texas, vol. IV, edited by R. Tyler, p. 389-390. Texas State Historical Association, Austin.

Medlar, C.

1995 Archeological Survey and Testing in Bastrop State Park, Bastrop County, Texas. Cultural Resource Program Report No. 95-3. Texas Parks and Wildlife Department, Austin.

Meissner, B. A.

1997 Matters Public and Private: Items of Personal Use from the Alamodome Project. In Archaeology at the Alamodome: Investigations of a San Antonio Neighborhood in Transition: 3. Artifacts and Special Studies, edited by A. A. Fox, M. Renner, and R. J. Hard, pp. 165-208. Archaeological Survey Report No.238. Center for Archaeological Research, The University of Texas, San Antonio.

Munsey, C.

1970 The Illustrated Guide to Collecting Bottles. Hawthorn, New York.

Murphy, M. C.

1995 Narrative History for Camp Swift, Texas. Manuscript included in application for Historical Event Designation, Texas State Historical Commission, Austin. 
Nash, M. A., R. F. Taylor, and E. A. Skokan

1995 A Cultural Resources Survey of the McNeil-Bastrop 138KV Transmission Line Rebuild Project, Bastrop and Travis Counties, Texas. Document 950195. Espey, Huston and Associates, Austin, Texas.

Nightengale, B. A.

1980 An Archeological Survey of a Transmission Line, Bastrop County, Texas. Technical Bulletin No. 39. Texas Archeological Survey, University of Texas, Austin.

Nightengale, B. A., and J. M. Jackson

1983 Intensive Survey of the Cultural Resources in the Cummins Creek Prospect, Fayette County, Texas. Research Report No. 86. Texas Archeological Survey, University of Texas, Austin.

Nightengale, B. A., and H. B. Moncure

1996 Intensive Cultural Resource Survey and Monitoring at the LCRA Camp Swift Regional Wastewater Project, Bastrop County, Texas. Cultural Resources Report No. 3. Lower Colorado River Authority, Environmental Protection Division, Austin, Texas.

Nordt, L. C., and C. T. Hallmark

1998 Soils-Geomorphology Tour Guidebook for Cowhouse Creek, Fort Hood, Texas. Soil Science Institute, Texas A\&M University, College Station.

North American Commission on Stratigraphic Nomenclature

1983 AGS Manuscript Collection 1. Electronic document; http://www.uwm.edu/Library/arch/findaids/ ags001.htm, accessed September 12, 2001.

O'Connell, J. F.

1987 Alyawara Site Structure and its Archaeological Implications. American Antiquity 52(1):74-108.

Pannell, F.

1998 Bombarded by Explosives, Random House Destroyed. Sayersville Historical Association Bulletin 10:5.

Patterson, L. W.

1995 The Archeology of Southeast Texas. Bulletin of the Texas Archeological Society 66:239-264.

Perttula, T. K.

1995 The Archeology of the Pineywoods and Post Oak Savanna of Northeast Texas. Bulletin of the Texas Archeological Society 66:331-360.

Pool, J. C.

1987 Fanthorp Inn: A Study of Nineteenth and Twentieth Century Buttons. In Archeological Excavations at Fanthorp Inn State Historic Site (41GM79), Grimes County, Texas, Spring and Fall 1982, by J. D. Ing and J. Hart, pp. 277-290. Texas Parks and Wildlife Department, Historic Sites and Restoration Branch, Austin, Texas.

Prewitt, E. R.

1981 Cultural Chronology in Central Texas. Bulletin of the Texas Archeological Society 52:65-89.

1985 From Circleville to Toyah: Comments on Central Texas Chronology. Bulletin of the Texas Archeological Society 54:201-238. 
Proctor, C. V., T. E. Brown, J. H. McGowen, and N. B. Waechter

1974 Austin Sheet. In Geologic Atlas of Texas, Bureau of Economic Geology. University of Texas, Austin.

Robinson, D. G.

1982 A Cultural Resource Survey of the Fayette to Salem Transmission Corridor, Fayette, Austin and Washington Counties, Texas. Technical Bulletin No. 60. Texas Archeological Survey, University of Texas, Austin.

1983a Additional Cultural Resource Investigations on the Powell Bend Prospect, Bastrop County, Texas. Technical Bulletin No. 61. Texas Archeological Survey, University of Texas, Austin.

1983b Research Design. In An Intensive Survey of the Cultural Resources of the Cummins Creek Prospect, Fayette County, Texas, by B. A. Nightengale and J. M. Jackson. Research Report No. 86. Texas Archeological Survey, University of Texas, Austin.

1987 Bastrop County Historical Commission Sesquicentennial Project: Cultural Resource Investigations Along the Colorado River, Bastrop County, Texas. Archeology Series No. 2. Texas Archeological Survey, University of Texas, Austin.

1989 Historical Research at the George Washington Jones Homestead, 41BP86, Bastrop County, Texas. Technical Series No. 11. Texas Archeological Research Laboratory, University of Texas, Austin.

1998 War Camp Creates Oak Hill Refugees. Sayersville Historical Association Bulletin 10:3-4.

2001 Revisiting the Old Sayers Mine. Sayersville Historical Association Bulletin 11:7-11.

Robinson, D. G., and D. K. Utley

1990 Under the Jail: Historical Archeology at the Bastrop County Courthouse and Old Jail, Bastrop County, Texas. Technical Bulletin No. 14. Texas Archeological Research Laboratory, University of Texas, Austin.

Rother, A. M.

1991 Bastrop County, Texas Cemeteries, vol. I. A. Rother, McDade, Texas.

Schmidt, J. C., and M. E. Cruse

1995 Cultural Resources Survey, Camp Swift, Bastrop County, Texas. Draft Report. Espey, Huston, \& Associates, Austin, Texas.

Sellards, E. H., W. S. Adkins, and F. B. Plummer

1932 The Geology of Texas: 1. Stratigraphy. Bulletin No. 3232. Bureau of Economic Geology, University of Texas, Austin.

Shafer, H. J.

1977 Early Lithic Assemblages in Eastern Texas. In Paleoindian Lifeways, edited by Eileen Johnson. The Museum Journal 17:187-197. Texas Tech University, Lubbock.

Skelton, D. W.

1977 Archeological Investigations at the Fayette Power Project, Fayette County, Texas. Research Report No. 60, Texas Archeological Survey. University of Texas, Austin.

Skelton, D. W., and M. D. Freeman

1979 A Cultural Resource Inventory and Assessment at Camp Swift, Texas. Report No. 72. Texas Archeological Survey, University of Texas, Austin. 
Smyrl, V. E.

2001 Wayside, Texas. The Handbook of Texas Online. Electronic document, http://www.tsha.utexas.edu/ handbook/online/articles/view/WW/hrwnx.html, accessed February 6.

Soil Conservation Service

1979 Soil Survey, Bastrop County, Texas. Series 1942, No. 17. United States Department of Agriculture, Washington, D.C.

Soil Survey Division Staff

1993 Soil Survey Manual. Handbook No. 18. United States Department of Agriculture, Washington, D.C.

Story, D. A.

1981 An Overview of the Archaeology of East Texas. Plains Anthropologist 26(192):139-156.

Stringer, S. S., and A. J. Wormser

1996 Archeological Survey for Proposed Pond Improvements, Camp Swift Military Reservation, Bastrop County, Texas. Archeological Report. Adjutant General's Department of Texas, Austin.

Suhm, D. A., A. D. Krieger, and E. B. Jelks

1954 An Introductory Handbook of Texas Archeology. Bulletin of the Texas Archeological Society No. 25.

Sullo, D. M., and A. J. Wormser

1996 Archaeological Survey for Proposed Bradley Fighting Vehicle Training “Area A” At Camp Swift Military Reservation, Bastrop County, Texas. The Adjutant General's Department of Texas, Austin.

Todd, M.

1996 Camp Swift Gets Historical Marker. Austin American-Statesman 30 October. Austin, Texas.

Tomka, M. S. F., and D. J. Crouch

1996 Stone Projectile Points to World War II Tank Destroyers and Land Mines: Intensive Archeological Survey at Lake Bastrop State Park Bastrop County, Texas. Report Submitted to the Department of Antiquities Protection, Texas Antiquities Committee, Permit No. 919. Texas Parks and Wildlife Department, Public Lands Division, Cultural Resources Program, Austin.

Toomey, R. S.

1993 Late Pleistocene and Holocene Faunal Changes at Hall's Cave, Kerr County, Texas. Unpublished Ph.D. dissertation, Department of Geology, University of Texas, Austin.

Toulouse, J. H.

1971 Bottle Makers and Their Marks. Thomas Nelson, New York.

Turner, E. S., and T. R. Hester

1993 A Field Guide to Stone Artifacts of Texas Indians. 2nd edition. Texas Monthly Field Guide Series. Gulf Publishing Company, Houston, Texas.

Tyler, R. (editor)

1996. The New Handbook of Texas. 6 vols. Texas State Historical Association, Austin. 
Vest, D. L.

1996 Wolfberger, Samuel. In The New Handbook of Texas, vol. VI, edited by R. Tyler, p. 1034. Texas State Historical Association, Austin.

Waters, M. R., and Nordt, L. C.

1995 Late Quaternary Floodplain History of the Brazos River in East-Central Texas. Quaternary Research 43:311-319.

Weir, F. A.

1976 The Central Texas Archaic. Unpublished Ph.D. dissertation, Department of Anthropology, Washington State University, Pullman.

Wilson, A. M.

1930 Observations of Indian Life on the Colorado River. Unpublished manuscript on file at the Texas Archeological Research Laboratory, University of Texas, Austin.

Wilson, J. B.

1979 A Preliminary Report on the Little Pin Oak Creek Site (41FY53): A Campsite with Clovis, Plainview, and Subsequent Artifacts in Fayette County, Texas. Bulletin of the Texas Archeological Society 50:135-140.

Wormser, A. J.

1993a Archeological Survey of Proposed Tank Ditches at the Northwest Side of Scott Hill at Camp Swift, Bastrop County, Texas. Archeological Report. Adjutant General's Department of Texas, Austin.

1993b Archeological Survey of a Proposed Septic Field East of the Blackwell Drop Zone at Camp Swift, Bastrop County, Texas. Archeological Report. Adjutant General's Department of Texas, Austin.

1993c Archeological site form for 41BP382. On file at Camp Mabry. Texas Archeological Research Laboratory, University of Texas, Austin.

1994 Archeological Survey for Rechannelization of a Stream at the M60 Range Firing Line at Camp Swift, Bastrop County, Texas. Archeological Report. Adjutant General's Department of Texas, Austin.

Wormser, A. J., and C. M. Leshley

1995 Archeological Survey for the Proposed 386th Engineer Battalion Annual Squad and Platoon Training at Camp Swift, Bastrop County, Texas. Archeological Survey Report. Adjutant General's Department of Texas, Austin.

Wormser, A. J., and D. M. Sullo

1996 Archaeological Survey for Proposed Driver Training “Area B” at Camp Swift Military Reservation, Bastrop County, Texas. Archeological Survey Report. Adjutant General's Department of Texas, Austin. 
Appendix A

\section{Artifact Catalog}


Appendix A: Artifact Catalog

\begin{tabular}{|c|c|c|c|c|c|c|}
\hline Site \# & CAT \# & Prov/ Unit & Depth & Class & Count & Comment \\
\hline 41BP94 & $94-244$ & ST -2 & $0-20$ & Debitage & 1 & \\
\hline 41BP94 & $94-250$ & Probe 1 & $0-20$ & Debitage & 2 & \\
\hline 41BP94 & $94-243$ & ST -1 & $0-20$ & Burned Rock & 1 & \\
\hline 41BP94 & $94-245$ & ST-3 & $0-20$ & Burned Rock & 1 & \\
\hline 41BP94 & $94-247$ & ST-3 & $20-40$ & Burned Rock & 1 & \\
\hline 41BР94 & $94-248$ & ST-3 & $40-60$ & Burned Rock & 5 & \\
\hline 41BP94 & $94-249$ & ST -3 & $60-75$ & Burned Rock & 1 & \\
\hline 41BP94 & $94-246$ & ST-3 & $20-40$ & Point & 1 & Ensor base \\
\hline 41BP95/184 & $95 / 184-258$ & ST-1 & $20-40$ & Core & 1 & \\
\hline 41BP112 & $112-260$ & ST-1 & $0-20$ & Debitage & 1 & \\
\hline 41BP112 & $112-261$ & ST-1 & $20-30$ & Debitage & 2 & \\
\hline 41BP113 & $113-262$ & ST-1 & $20-40$ & Debitage & 1 & \\
\hline 41BP113 & $113-263$ & ST-1 & $40-60$ & Debitage & 1 & \\
\hline 41BP113 & $113-264$ & ST -1 & $60-80$ & Debitage & 1 & \\
\hline 41BP114 & 114-259 & Probe 4 & $30-50$ & Burned Rock & 1 & \\
\hline 41BP114 & $114-270$ & Probe 5 & $0-30$ & Debitage & 1 & \\
\hline 41BP114 & $114-273$ & Probe 4 & $30-50$ & Burned Rock & 2 & \\
\hline 41BP114 & $114-274$ & Probe 4 & $30-50$ & Debitage & 1 & \\
\hline 41BP122/143 & 122/143-265 & Probe 5 & $0-40$ & Nails & 2 & \\
\hline 41BP122/143 & 122/143-266 & Probe 5 & $0-40$ & Bottle Glass & 1 & \\
\hline 41BP122/143 & 122/143-267 & Probe 5 & $0-40$ & Bottle Glass & 1 & \\
\hline 41BP122/143 & 122/143-268 & Probe 1 & $0-20$ & Bottle Glass & 1 & Snuff bottle lip \\
\hline 41BP129 & $129-268$ & Probe 1 & $0-30$ & Debitage & 1 & \\
\hline 41BP138 & $138-60$ & & Surface & Tool & 1 & \\
\hline 41BP138 & $138-61$ & & Surface & Debitage & 1 & \\
\hline 41BP138 & $138-100$ & & Surface & Debitage & 1 & \\
\hline 41BP138 & $138-292$ & & Surface & M etal & 1 & \\
\hline 41BP378 & $378-2$ & & Surface & Tool & 1 & Expedient scraper \\
\hline 41BP378 & $378-189$ & & Surface & Tool & 1 & \\
\hline 41BP381 & $381-0-1$ & & Surface & M ano & 1 & \\
\hline 41BP381 & $381-0-2$ & & Surface & Point & 1 & Bulverde base \\
\hline 41BP381 & $381-276$ & ST-2 & $10-20$ & Debitage & 1 & \\
\hline 41BP381 & $381-277$ & ST-2 & $20-30$ & Debitage & 2 & \\
\hline 41BP381 & $381-278$ & Probe 2 & $10-30$ & Debitage & 1 & \\
\hline 41BP391 & 391-0 & & Surface & Point & 1 & Base \\
\hline 41BP391 & 391-119 & & Surface & Point & 1 & Base \\
\hline 41BP391 & $391-120$ & ST-1 & $20-40$ & Burned Rock & 1 & \\
\hline 41BP391 & $391-121$ & ST-1 & $20-40$ & Debitage & 1 & \\
\hline 41BP399 & $399-278$ & ST-6 & $20-30$ & Debitage & 2 & \\
\hline 41BP399 & $399-279$ & ST-6 & $60-70$ & Debitage & 1 & \\
\hline 41BP399 & $399-280$ & ST-7 & $10-20$ & Debitage & 1 & \\
\hline 41BP399 & $399-281$ & ST-7 & $20-30$ & Debitage & 2 & \\
\hline 41BP399 & $399-282$ & ST-7 & $60-70$ & Debitage & 1 & \\
\hline 41BP399 & $399-283$ & ST-7 & $80-90$ & Debitage & 2 & \\
\hline 41BP399 & $399-284$ & ST-6 & $80-90$ & Debitage & 1 & \\
\hline 41BP399 & $399-286$ & ST -8 & $0-25$ & Debitage & 1 & \\
\hline $41 \mathrm{BP} 400$ & $400-165$ & & Surface & Bottle Glass & 1 & Brown neck \\
\hline 41BP400 & $400-166$ & & Surface & Ceramic & 1 & Whitew are \\
\hline 41BP400 & $400-167$ & & Surface & Ceramic & 1 & Ironstone \\
\hline
\end{tabular}


Appendix A: Artifact Catalog, continued...

\begin{tabular}{|c|c|c|c|c|c|c|}
\hline Site \# & CAT \# & Prov/ Unit & Depth & Class & Count & Comment \\
\hline $41 \mathrm{BP} 400$ & $400-168$ & & Surface & Bottle Glass & 1 & Ink \\
\hline 41BP400 & $400-169$ & & & & & \\
\hline 41BP400 & $400-170$ & & & & & \\
\hline 41BP476 & 476-1 & & Surface & Debitage & 1 & \\
\hline 41BP476 & $476-2$ & & Surface & Debitage & 1 & \\
\hline $41 \mathrm{BP} 476$ & $476-3$ & ST-7 & $0-20$ & Debitage & 1 & \\
\hline 41BP477 & $477-4$ & & Surface & Tool & 1 & Biface \\
\hline 41BP477 & $477-5$ & ST-3 & $20-40$ & Burned Rock & 2 & \\
\hline 41BP477 & $477-6$ & ST-3 & $40-60$ & Burned Rock & 1 & \\
\hline 41BP477 & $477-7$ & ST-3 & $60-80$ & Burned Rock & 6 & \\
\hline 41BP477 & $477-8$ & ST-3 & $80-100$ & Burned Rock & 3 & \\
\hline 41BP477 & $477-9$ & ST-3 & $100-120$ & Burned Rock & 1 & \\
\hline 41BP477 & $477-10$ & ST-3 & $100-120$ & Debitage & 1 & \\
\hline 41BP477 & $477-11$ & ST-4 & $0-20$ & Burned Rock & 3 & \\
\hline 41BP477 & $477-12$ & ST-4 & $20-40$ & Burned Rock & 4 & \\
\hline 41BP477 & $477-13$ & ST-4 & $20-40$ & Debitage & 1 & \\
\hline 41BP477 & $477-14$ & ST-4 & $60-75$ & Debitage & 1 & \\
\hline 41BP477 & $477-15$ & ST-5 & $0-20$ & Debitage & 2 & \\
\hline 41BP477 & $477-16$ & ST-5 & $0-20$ & Debitage & 1 & \\
\hline 41BP477 & $477-17$ & ST-5 & $20-40$ & Burned Rock & 2 & \\
\hline 41BP477 & $477-18$ & ST-5 & $80-100$ & Debitage & 1 & \\
\hline 41BP477 & $477-19$ & ST-6 & $20-40$ & Debitage & 1 & \\
\hline 41BP477 & $477-20$ & ST-6 & $60-80$ & Debitage & 1 & \\
\hline 41BP477 & $477-21$ & ST-6 & $60-80$ & Burned Rock & 1 & \\
\hline 41BP477 & $477-22$ & ST-6 & $80-100$ & Debitage & 1 & \\
\hline 41BP477 & $477-23$ & ST-6 & $100-120$ & Burned Rock & 1 & \\
\hline 41BP477 & $477-24$ & ST-7 & $20-40$ & Burned Rock & 1 & \\
\hline 41BP477 & $477-25$ & ST-7 & $60-80$ & Burned Rock & 3 & \\
\hline 41BP477 & $477-26$ & ST-8 & $20-40$ & Debitage & 2 & \\
\hline 41BP477 & $477-27$ & ST-8 & $20-40$ & Burned Rock & 1 & \\
\hline 41BP477 & $477-28$ & ST-8 & $40-60$ & Burned Rock & 2 & \\
\hline 41BP477 & $477-29$ & ST-8 & $40-60$ & Cow/Bison Tooth & & \\
\hline 41BP477 & $477-30$ & ST-9 & $40-60$ & Debitage & 1 & \\
\hline 41BP477 & $477-31$ & ST-9 & $40-60$ & Burned Rock & 7 & \\
\hline 41BP477 & $477-32$ & ST-10 & $20-40$ & Burned Rock & 3 & \\
\hline 41BP477 & $477-33$ & ST-10 & $20-40$ & Point & 1 & Base \\
\hline 41BP477 & $477-34$ & ST-10 & $40-60$ & Burned Rock & 1 & \\
\hline 41BP477 & $477-35$ & ST-10 & $40-60$ & Debitage & 2 & \\
\hline 41BP477 & $477-36$ & ST-10 & $60-80$ & Debitage & 1 & \\
\hline 41BP477 & $477-37$ & ST-10 & $60-80$ & Burned Rock & 2 & \\
\hline 41BP477 & $477-38$ & ST-10 & $80-100$ & Debitage & 1 & \\
\hline 41BP477 & $477-39$ & ST-11 & $40-60$ & Debitage & 1 & \\
\hline 41BP477 & $477-40$ & ST-11 & $40-60$ & Burned Rock & 1 & \\
\hline 41BP477 & $477-41$ & ST-11 & $60-80$ & Debitage & 5 & \\
\hline 41BP477 & $477-42$ & ST-11 & $60-80$ & Burned Rock & 1 & \\
\hline 41BP477 & $477-43$ & ST-11 & $80-100$ & Debitage & 6 & \\
\hline 41BP477 & $477-44$ & ST-11 & $80-100$ & Burned Rock & 6 & \\
\hline 41BP477 & $477-45$ & ST-11 & $100-117$ & Charcoal & & \\
\hline 41BP477 & $477-46$ & ST-11 & 100-117 & Burned Rock & 2 & \\
\hline 41BP477 & $477-47$ & ST-13 & $20-40$ & Core & 1 & \\
\hline 41BP479 & $479-48$ & ST-1 & $0-20$ & Glass & 3 & \\
\hline 41BP479 & 479-(49) & ST-1 & $0-20$ & DISCARDED & & \\
\hline 41BP479 & $479-50-1$ & ST-1 & $20-40$ & Nail-wire & 1 & \\
\hline
\end{tabular}


Appendix A: Artifact Catalog, continued...

\begin{tabular}{|c|c|c|c|c|c|c|}
\hline Site \# & CAT \# & Prov/ Unit & Depth & Class & Count & Comment \\
\hline 41BP479 & $479-50-2$ & ST-1 & $20-40$ & Window Glass & 3 & \\
\hline 41BP479 & $479-50-3$ & ST-1 & $20-40$ & Bottle Glass & 1 & \\
\hline 41BP479 & $479-50-4$ & ST-1 & $20-40$ & Glass & 1 & \\
\hline 41BP479 & $479-51$ & ST-3 & $0-20$ & Wire & 1 & \\
\hline 41BP479 & $479-52$ & ST-3 & $20-40$ & Ceramic & 1 & Whiteware \\
\hline 41BP480 & $480-53$ & ST-4 & $0-20$ & Debitage & 1 & \\
\hline 41BP480 & $480-54$ & ST-2 & $0-20$ & Debitage & 1 & \\
\hline 41BP480 & $480-55-1$ & ST-2 & $0-20$ & Casing & 1 & \\
\hline 41BP480 & $480-55-2$ & ST-2 & $0-20$ & Metal & 1 & \\
\hline 41BP480 & $480-56$ & ST-2 & $40-60$ & Burned Rock & 1 & \\
\hline 41BP480 & $480-57$ & ST-1 & $60-75$ & Debitage & 1 & \\
\hline 41BP480 & $480-58$ & ST-2 & $20-40$ & Burned Rock & 1 & \\
\hline 41BP482 & $482-79$ & ST-1 & $60-80$ & Burned Rock & 1 & \\
\hline 41BP482 & $482-80$ & ST-1 & $80-100$ & Debitage & 2 & \\
\hline 41BP482 & $482-81$ & ST-1 & $100-120$ & Debitage & 1 & \\
\hline 41BP482 & $482-82$ & ST-4 & $0-20$ & Debitage & 1 & \\
\hline 41BP484 & $484-62$ & & Surface & Burned Rock & 3 & \\
\hline 41BP484 & $484-62$ & & Surface & Debitage & 1 & \\
\hline 41BP484 & $484-63$ & & Surface & Debitage & 5 & \\
\hline 41BP484 & $484-122$ & & Surface & Pipe Bowl Frag & 1 & \\
\hline 41BP484 & $484-172$ & ST-1 & $0-20$ & Ceramic & 2 & Stoneware \\
\hline 41BP484 & $484-172$ & ST-1 & $0-20$ & Glass & 1 & Amber \\
\hline 41BP484 & $484-173$ & ST-1 & $0-20$ & Glass & 3 & Clear, purple, amber \\
\hline $41 \mathrm{BP} 485$ & $485-65-1$ & & Surface & Point & 1 & Tip \\
\hline 41BP485 & $485-65-2$ & & Surface & Point & 1 & Base \\
\hline 41BP485 & $485-65-3$ & & Surface & Burned Rock & 1 & \\
\hline 41BP486 & $486-66$ & & & Point & 1 & Base \\
\hline 41BP486 & $486-174$ & ST-1 & $0-20$ & Debitage & 3 & \\
\hline 41BP486 & $486-175$ & ST-1 & $0-20$ & Burned Rock & 1 & \\
\hline 41BP486 & $486-176$ & ST-1 & $20-40$ & Debitage & 2 & \\
\hline 41BP486 & $486-177$ & ST-1 & $20-40$ & Burned Rock & 1 & \\
\hline 41BP487 & 487-69 & ST-1 & $40-60$ & Debitage & 6 & \\
\hline 41BP487 & $487-69$ & ST-1 & $40-60$ & Burned Rock & 1 & \\
\hline 41BP487 & $487-70$ & ST-1 & $60-80$ & Burned Rock & 1 & \\
\hline 41BP487 & $487-71$ & ST-1 & $80-100$ & Burned Rock & 1 & \\
\hline 41BP487 & $487-72$ & ST-1 & $100-120$ & Debitage & 1 & \\
\hline 41BP487 & $487-73$ & ST-3 & 23 & Metal & 1 & cast-iron oven frag \\
\hline 41BP488 & $488-74$ & & Surface & Debitage & 3 & \\
\hline 41BP488 & $488-123$ & ST-1 & $0-20$ & Debitage & 1 & \\
\hline 41BP488 & $488-124$ & ST-1 & $20-40$ & Debitage & 3 & \\
\hline 41BP488 & $488-125$ & ST-1 & $20-40$ & Debitage & 1 & \\
\hline 41BP488 & $488-126$ & ST-1 & $60-80$ & Burned Rock & 1 & \\
\hline 41BP488 & $488-127$ & ST-1 & $60-80$ & Debitage & 1 & \\
\hline 41BP488 & $488-128$ & ST-2 & $80-100$ & Debitage & 2 & \\
\hline 41BP488 & $488-129$ & ST-2 & $80-100$ & Burned Rock & 1 & \\
\hline 41BP488 & $488-130$ & ST-2 & $40-60$ & Burned Rock & 6 & \\
\hline 41BP488 & $488-131$ & ST-2 & $40-60$ & Debitage & 2 & \\
\hline 41BP491 & $491-75$ & ST-1 & $60-80$ & Burned Rock & 3 & \\
\hline 41BP491 & $491-76$ & ST-2 & $40-60$ & Debitage & 1 & \\
\hline 41BP491 & $491-77$ & ST-2 & $80-100$ & Debitage & 2 & \\
\hline 41BP491 & $491-78$ & ST-1(area55) & $0-20$ & Burned Rock & 2 & 1 possible debitage \\
\hline 41BP492 & $492-83$ & & Surface & Ceramic & 1 & Whiteware \\
\hline 41BP492 & $492-84$ & & Surface & Bottle Glass & 1 & Base \\
\hline
\end{tabular}


Appendix A: Artifact Catalog, continued...

\begin{tabular}{|c|c|c|c|c|c|c|}
\hline Site \# & CAT \# & Prov/ Unit & Depth & Class & Count & Comment \\
\hline 41BP492 & $492-85$ & & Surface & Button & 2 & \\
\hline 41BP492 & 492-178 & & Surface & Glass & 1 & Jar lid \\
\hline 41BP493 & 493-86 & ST -1 & $0-20$ & Burned Rock & 1 & \\
\hline 41BP493 & $493-87$ & ST-1 & $0-20$ & Shell & 1 & \\
\hline 41BP494 & 494-89 & ST -2 & $0-20$ & Debitage & 1 & \\
\hline 41BР494 & $494-90$ & ST -3 & $20-40$ & Debitage & 1 & \\
\hline $41 \mathrm{BP} 495$ & $495-91$ & ST-1 & $0-20$ & Burned Rock & 1 & \\
\hline 41BP495 & $495-92$ & ST-1 & $0-20$ & Debitage & 1 & \\
\hline 41BP495 & $495-101$ & ST-2 & $0-20$ & Debitage & 3 & \\
\hline 41BP495 & 495-102 & ST -2 & $0-20$ & Burned Rock & 1 & \\
\hline $41 \mathrm{BP} 495$ & 495-103 & ST -2 & $20-40$ & Debitage & 3 & \\
\hline 41BP496 & 496-93 & Tran 60 & Surface & Tool & 1 & Biface \\
\hline $41 \mathrm{BP} 496$ & 496-94 & Tran 60 & Surface & Tool & 1 & Biface \\
\hline 41BP496 & $496-95$ & Tran 60 & Surface & Debitage & 4 & \\
\hline 41BP496 & $496-96$ & Tran 60 & Surface & Burned Rock & 1 & \\
\hline $41 \mathrm{BP} 496$ & 496-97 & ST-1 & $0-20$ & Debitage & 1 & \\
\hline 41BP497 & 497-104 & ST-1 & $0-20$ & Debitage & 1 & \\
\hline 41BP497 & 497-105 & ST-1 & $40-60$ & Debitage & 1 & \\
\hline 41BP497 & 497-106 & ST-1 & $40-60$ & Burned Rock & 3 & \\
\hline 41BP497 & $497-107$ & ST-3 & $20-40$ & Burned Rock & 1 & \\
\hline 41BP498 & $498-223$ & & Surface & Burned Rock & 1 & \\
\hline $41 \mathrm{BP} 498$ & $498-224$ & & Surface & Debitage & 1 & \\
\hline 41BP498 & $498-225$ & & Surface & Debitage & 1 & \\
\hline 41BP499 & 499-109 & & Surface & Debitage & 1 & \\
\hline 41BP500 & $500-110$ & & Surface & Ceramic & 2 & \\
\hline 41BP500 & $500-111$ & & & Glass & 1 & Bottle \\
\hline 41BP500 & $500-113$ & & & Glass & 1 & \\
\hline 41BP501 & 501-114 & & Surface & Glass & 1 & Insulator \\
\hline 41BP502 & $502-115$ & & Surface & Glass & 1 & 7 up bottle \\
\hline 41BP503 & $503-118$ & Tran 68 & Surface & Glass & 1 & Fletcher Castoria bottle \\
\hline 41BP504 & $504-132$ & & Surface & Ceramic & 1 & with mark \\
\hline 41BP504 & 504-133 & & Surface & Ceramic & 1 & with mark \\
\hline 41BP504 & 504-134 & & Surface & Ceramic & 1 & design \\
\hline 41BP504 & $504-135$ & & Surface & Ceramic & 1 & decal \\
\hline 41BP505 & $505-136$ & ST-3 & $20-40$ & Debitage & 2 & \\
\hline 41BP505 & 505-137 & ST-1 & $40-60$ & Burned Rock & 3 & \\
\hline 41BP505 & 505-138 & ST-1 & $40-60$ & Debitage & 1 & \\
\hline 41BP505 & $505-314$ & ST-1 & $20-40$ & Debitage & 1 & \\
\hline 41BP506 & 506-139 & & Surface & Debitage & 1 & \\
\hline 41BP506 & 506-140 & ST-1 & $0-20$ & Debitage & 2 & \\
\hline 41BP506 & 506-141 & ST-1 & $0-20$ & Burned Rock & 1 & \\
\hline 41BP506 & 506-143 & ST -2 & $40-60$ & Burned Rock & 1 & \\
\hline 41BP506 & 506-144 & ST-2 & $60-80$ & Debitage & 1 & \\
\hline 41BP506 & 506-145 & ST-3 & $20-40$ & Burned Rock & 1 & \\
\hline 41BP506 & 506-146 & ST -3 & $20-40$ & Debitage & 2 & \\
\hline 41BP506 & 506-147 & ST-3 & $40-60$ & Burned Rock & 3 & \\
\hline 41BP506 & 506-148 & ST-3 & $40-60$ & Debitage & 2 & \\
\hline 41BP506 & 506-150 & ST-3 & $60-80$ & Debitage & 1 & \\
\hline 41BР506 & 506-151 & ST-3 & $60-80$ & Debitage & 1 & \\
\hline 41BP506 & 506-152 & ST -3 & 80 & Burned Rock & 6 & \\
\hline 41BP508 & $508-153$ & & Surface & Bottle Glass & 1 & Flask \\
\hline 41BP508 & $508-154$ & & Surface & Bottle Glass & 1 & Stew art's Blueing bottle \\
\hline 41BP509 & $509-155$ & ST-1 & $20-40$ & Debitage & 3 & \\
\hline
\end{tabular}


Appendix A: Artifact Catalog, continued...

\begin{tabular}{|c|c|c|c|c|c|c|}
\hline Site \# & CAT \# & Prov/ Unit & Depth & Class & Count & Comment \\
\hline 41BP509 & $509-156$ & ST-1 & $40-60$ & Debitage & 1 & \\
\hline 41BP509 & $509-272$ & ST -2 & $40-60$ & Debitage & 1 & \\
\hline 41BP510 & $510-158$ & & Surface & Tool & 1 & \\
\hline 41BP511 & 511-159 & ST -1 & $0-20$ & Glass & 3 & Amethyst \\
\hline 41BP511 & 511-160 & ST -1 & $0-20$ & Glass & 1 & window \\
\hline 41BP511 & 511-161 & ST -1 & $40-60$ & Ceramic & 1 & Whitew are \\
\hline 41BP511 & $511-162$ & ST-1 & $40-60$ & Glass & 2 & Clear \\
\hline 41BP512 & $512-163$ & ST -1 & $80-100$ & Debitage & 1 & \\
\hline 41BP512 & $512-164$ & ST -2 & $40-60$ & Burned Rock & 1 & \\
\hline 41BP513 & 513-171-1 & ST-1 & $0-20$ & Bottle Glass & 1 & Brown base \\
\hline 41BP513 & $513-171-2$ & ST-1 & $0-20$ & Bottle Glass & 1 & Aqua neck \\
\hline 41BP513 & $513-171-3$ & ST -1 & $0-20$ & Bottle Glass & 1 & Amethyst neck \\
\hline 41BP517 & $517-191$ & & Surface & Bottle Glass & 1 & Clear \\
\hline 41BP519 & 519-179 & & Surface & Glass & 1 & Jar Lid \\
\hline 41BP520 & $520-180$ & & Surface & Glass & 3 & Neck \\
\hline 41BP520 & $520-181$ & & Surface & Bottle Glass & 1 & \\
\hline 41BP520 & $520-182$ & & Surface & Point & 1 & \\
\hline 41BP520 & $520-183$ & ST - 1 & $20-40$ & Glass & 1 & \\
\hline 41BP521 & 521-184 & ST -1 & $0-20$ & Tool & 1 & Biface frag \\
\hline 41BP521 & $521-185$ & ST-1 & $20-40$ & Burned Rock & 1 & \\
\hline 41BP521 & $521-186$ & ST-1 & $20-40$ & Debitage & 1 & \\
\hline 41BP521 & $521-187$ & ST -1 & $40-60$ & Burned Rock & 4 & \\
\hline 41BP521 & 521-188 & ST - 1 & $40-60$ & Debitage & 2 & \\
\hline 41BP522 & $522-192$ & ST-1 & $20-40$ & Burned Rock & 2 & \\
\hline 41BP522 & $522-193$ & ST -1 & $20-40$ & Debitage & 2 & \\
\hline 41BP522 & $522-194$ & ST-1 & $20-40$ & Debitage & 1 & \\
\hline 41BP522 & $522-195$ & ST-1 & $40-60$ & Burned Rock & 2 & \\
\hline 41BP522 & $522-196$ & ST -1 & $80-100$ & Debitage & 1 & \\
\hline 41BP522 & $522-197$ & ST-1 & $60-80$ & Debitage & 1 & \\
\hline 41BP522 & $522-198$ & ST-1 & $60-80$ & Burned Rock & 1 & \\
\hline 41BP522 & $522-199$ & ST -2 & $20-40$ & Debitage & 1 & \\
\hline 41BP522 & $522-200$ & ST -3 & $0-20$ & Debitage & 1 & \\
\hline 41BP522 & $522-201$ & ST -3 & $55-60$ & Burned Rock & 3 & \\
\hline 41BP524 & $524-202$ & ST-1 & $0-20$ & Debitage & 1 & \\
\hline 41BP524 & 524-203 & ST -1 & $0-20$ & Burned Rock & 1 & \\
\hline 41BP524 & 524-204 & ST -1 & $20-40$ & Burned Rock & 2 & \\
\hline 41BP524 & $524-205$ & ST-1 & $40-60$ & Burned Rock & 1 & \\
\hline 41BP524 & 524-206 & ST-1 & $60-80$ & Burned Rock & 1 & \\
\hline 41BР524 & 524-207 & ST-1 & $60-80$ & Burned Rock & 2 & \\
\hline 41BP524 & 524-208 & ST -1 & $80-100$ & Burned Rock & 4 & \\
\hline 41BP524 & 524-209 & ST -1 & $80-100$ & Burned Rock & 2 & \\
\hline 41BP526 & $526-211$ & ST -1 & $40-60$ & Burned Rock & 1 & \\
\hline 41BP526 & $526-218$ & ST-1 & $80-100$ & Burned Rock & 2 & \\
\hline 41BP526 & $526-265$ & ST -1 & $20-40$ & Debitage & 2 & \\
\hline 41BP526 & $526-266$ & ST -1 & $40-60$ & Debitage & 3 & \\
\hline 41BP526 & $526-267$ & ST-1 & $60-80$ & Debitage & 8 & \\
\hline 41BP526 & $526-268$ & ST-2 & $0-20$ & Debitage & 1 & \\
\hline 41BP526 & $526-269$ & ST -2 & $40-60$ & Debitage & 4 & \\
\hline 41BР526 & $526-270$ & ST-3 & $0-20$ & Debitage & 1 & \\
\hline 41BP526 & $526-271$ & ST -3 & $20-40$ & Debitage & 1 & \\
\hline 41BP527 & $527-226$ & & Surface & Tool & 1 & Biface frag \\
\hline 41BP528 & $528-227$ & ST -1 & $0-20$ & Debitage & 1 & \\
\hline 41BP528 & $528-228$ & ST -1 & $0-20$ & Burned Rock & 1 & \\
\hline
\end{tabular}


Appendix A: Artifact Catalog, continued...

\begin{tabular}{|c|c|c|c|c|c|c|}
\hline Site \# & CAT \# & Prov/ Unit & Depth & Class & Count & Comment \\
\hline 41BP528 & $528-230$ & ST-1 & $40-60$ & Point & 6 & with fragments \\
\hline 41BP528 & $528-231$ & ST-1 & $40-60$ & Burned Rock & 1 & \\
\hline 41BP529 & $529-232$ & ST-1 & $0-20$ & Debitage & 1 & \\
\hline 41BP529 & $529-234$ & ST-1 & $40-60$ & Debitage & 2 & \\
\hline 41BP529 & $529-235$ & ST-1 & $40-60$ & Burned Rock & 1 & \\
\hline 41BP529 & $529-236$ & ST-1 & $40-60$ & Burned Rock & 3 & \\
\hline 41BP530 & $530-237$ & ST-1 & $20-40$ & Point & 1 & Turney \\
\hline 41BP530 & $530-238$ & ST-2 & $0-20$ & Burned Rock & 1 & \\
\hline 41BP533 & $533-239$ & ST -1 & $40-60$ & Debitage & 2 & \\
\hline 41BP533 & $533-240$ & Probe 1 & $20-40$ & Debitage & 1 & \\
\hline 41BP533 & $533-241$ & Probe 2 & $20-40$ & Debitage & 1 & \\
\hline 41BP533 & $533-242$ & Probe 3 & $20-40$ & Debitage & 1 & \\
\hline Isolated Find & ISO-10-308 & ST -3 & $20-40$ & Debitage & 1 & \\
\hline Isolated Find & ISO-12-298 & ST -1 & $0-20$ & Debitage & 1 & \\
\hline Isolated Find & ISO-13-307 & ST -1 & $20-40$ & Debitage & 2 & \\
\hline Isolated Find & ISO-14-251 & & Surface & Debitage & 1 & \\
\hline Isolated Find & ISO-16-305 & & Surface & Tool & 1 & Graver \\
\hline Isolated Find & ISO-22-303 & ST -1 & $20-30$ & Debitage & 1 & \\
\hline Isolated Find & ISO-23-309 & ST-1 & Surface & Debitage & 1 & \\
\hline Isolated Find & ISO-28-299 & ST -1 & $20-40$ & Debitage & 1 & \\
\hline Isolated Find & ISO-34-252 & Probe & $0-20$ & Debitage & 1 & \\
\hline Isolated Find & ISO-38-304 & ST-1 & $60-80$ & Debitage & 3 & \\
\hline Isolated Find & ISO-39-259 & ST -1 & $0-20$ & Debitage & 1 & \\
\hline Isolated Find & ISO-40-302 & ST-1 & $0-20$ & Debitage & 1 & \\
\hline Isolated Find & ISO-41-300 & ST-2 & $20-40$ & Debitage & 1 & \\
\hline Isolated Find & ISO-43-253 & ST-1 & $0-20$ & Debitage & 1 & \\
\hline Isolated Find & ISO-46-254 & ST - 1 & $0-20$ & Burned Rock & 2 & \\
\hline Isolated Find & ISO-50-256 & & Surface & Point & 1 & Possible Early Triangular base \\
\hline Isolated Find & ISO-51-257 & ST -2 & $0-20$ & Debitage & 1 & \\
\hline Isolated Find & ISO-58-108 & ST-1 & $20-40$ & Debitage & 1 & \\
\hline
\end{tabular}





\section{Appendix $\mathbb{B}$}

\section{Formal Tool Measurements}

\begin{tabular}{|c|c|c|c|c|c|c|}
\hline Site & Provenience & Specimen \# & Description & Width (mm) & Length (mm) & Thickness (mm) \\
\hline $41 \mathrm{BP} 94$ & ST-3, 20-40 cm & $94-246$ & Ensor Point & 21.1 & $36.4 *$ & 5.6 \\
\hline 41BP378 & Surface & $378-189$ & Uniface & 46.2 & 76.7 & 12.1 \\
\hline 41BP381 & Surface & $381-0-2$ & Bulverde point & 42.9 & $30.0 *$ & 6.5 \\
\hline 41BP381 & Surface & $381-0-1$ & Ground stone & 84.3 & 125.1 & 53.0 \\
\hline 41BP391 & Surface & 391-119 & Scallorn point & 17.1 & $21.2 *$ & 5.0 \\
\hline 41BP391 & Surface & $391-0-1$ & Biface & 32.4 & 62.4 & 8.2 \\
\hline $41 \mathrm{BP} 477$ & Surface & $477-4$ & Biface & 31.7 & $30.8 *$ & 6.4 \\
\hline $41 \mathrm{BP} 477$ & ST $10,20-40 \mathrm{~cm}$ & $477-33$ & Point & 19.2 & $15.1 *$ & 5.9 \\
\hline $41 \mathrm{BP} 485$ & Surface & $485-65-2$ & Angostura point & 27.4 & $43.0 *$ & 7.1 \\
\hline $41 \mathrm{BP} 485$ & Surface & $485-65-1$ & Point & 22.6 & $31.3 *$ & 6.1 \\
\hline 41BP496 & Surface & $496-93$ & Biface & $27.4 *$ & $23.5 *$ & 10.6 \\
\hline $41 \mathrm{BP} 496$ & Surface & 496-94 & Biface & 33.7 & $33.6 *$ & 6.5 \\
\hline 41BP520 & Surface & $520-182$ & Point & 17.8 & $31.5 *$ & 6.2 \\
\hline 41BP521 & ST-1, 0-20 cm & $521-184$ & Biface & $6.1 *$ & $10.1 *$ & $2.3 *$ \\
\hline 41BP527 & Surface & $527-226$ & Biface & $22.7 *$ & $20.2 *$ & $5.7 *$ \\
\hline 41BP528 & ST-1, 40-60 cm & $528-230$ & Point & $37.0 *$ & $34.3 *$ & $8.3^{*}$ \\
\hline 41BP530 & $20-40 \mathrm{~cm}$ & $530-237$ & Turney point & 15.6 & $32.5 *$ & 4.0 \\
\hline
\end{tabular}





\section{Backhoe Trench Profile Descriptions}

BHT-1

Big Sandy Creek Alluvium

T0 Floodplain

\begin{tabular}{|c|c|l|}
\hline Horizon & Depth (cm) & \multicolumn{1}{|c|}{ Description } \\
\hline Ap1 & $0-10$ & $\begin{array}{l}\text { Brownish Yellow (10YR 6/7); Sandy Loam; Massive; Slightly Hard; Non- Sticky; } \\
\text { Non-Plastic; Strong Reaction; Common Roots; 5\% Limestone Pebbles from Road } \\
\text { Construction; Abrupt, Smooth Boundary }\end{array}$ \\
\hline Ap2 & $10-18$ & $\begin{array}{l}\text { Yellow (10YR 7/8); Sandy Loam; Massive; Hard; Non- Sticky; Non-Plastic; Strong } \\
\text { Reaction; Few Roots; 10\% Limestone Pebbles from Road Construction; Abrupt, } \\
\text { Smooth Boundary. }\end{array}$ \\
\hline Ab & $18-50$ & $\begin{array}{l}\text { Brownish Yellow (10YR 6/6); Sandy Loam; Massive; Slightly Hard; Non-Sticky; } \\
\text { Non-Plastic; No Reaction; Few Roots; Few, Medium, Faint Mottles (10YR 5/3); } \\
\text { Gradual, Smooth Boundary. }\end{array}$ \\
\hline C1b & $50-66$ & $\begin{array}{l}\text { Yellow (10YR 7/6); Loamy Sand; Massive; Slightly Hard; Non-Sticky; Non-Plastic; } \\
\text { No Reaction; Few Roots; Few, Medium, Faint Mottles (10YR 5/3); Very Few, } \\
\text { Prominent, Pore Linings (2.5YR 4/6); Two Very Thin Beds of C2b Included; } \\
\text { Abrupt, Smooth Boundary. }\end{array}$ \\
\hline C2b & $66-80$ & $\begin{array}{l}\text { Very Dark Grayish Brown (10YR 3/3); Sandy Clay; Massive; Very Hard; Sticky; } \\
\text { Plastic; No Reaction; No Roots; Very Few, Prominent, Pore Linings (2.5YR 4/6); } \\
1 \% \text { charcoal fragments, >1 cm Diameter, within Upper 2 cm of Horizon; Abrupt, } \\
\text { Smooth Boundary. }\end{array}$ \\
\hline C3b & $80-101$ & $\begin{array}{l}\text { Yellow (10YR 7/6); Loamy Sand; Single-Grained; Slightly Hard; Non-Sticky; Non- } \\
\text { Plastic; No Reaction; No Roots; Many, Medium, Faint Mottles (10YR 5/3); Few, } \\
\text { Prominent, Pore Linings (2.5YR 4/6); Abrupt, Smooth Boundary. }\end{array}$ \\
\hline
\end{tabular}


Appendix C: Backhoe Trench Profile Descriptions, continued...

BHT-2

Big Sandy Creek Alluvium

Upland

\begin{tabular}{|c|r|l|}
\hline Horizon & Depth (cm) & \multicolumn{1}{c|}{ Description } \\
\hline $\mathrm{A}$ & $0-25$ & $\begin{array}{l}\text { Yellowish Brown (10YR 5/4); Loamy Sand; Single-Grained; Loose; Non-Sticky; } \\
\text { Non-Plastic; No Reaction; Few Roots; Abrupt, Smooth Boundary. }\end{array}$ \\
\hline $\mathrm{C}$ & $25-37$ & $\begin{array}{l}\text { Very Pale Brown (10YR 7/3); Sand; Single-Grained; Slightly Hard; not Sticky; Non- } \\
\text { Plastic; No Reaction; Few Roots; Abrupt, Smooth Boundary. }\end{array}$ \\
\hline $\mathrm{Eb}$ & $37-80$ & $\begin{array}{l}\text { Very Pale Brown (10YR 8/2); Sand; Single-Grained; Loose; Non-Sticky; Non- } \\
\text { Plastic; No Reaction; No Roots; Clear, Smooth Boundary. }\end{array}$ \\
\hline Bwb & $80-114$ & $\begin{array}{l}\text { Pale Brown (10YR 6/3); Loamy Sand; Weak, Coarse, Subangular Blocky; Hard; } \\
\text { Non-Sticky; Non-Plastic; No Reaction; Few Roots; Few, Fine, Prominent, Pore } \\
\text { Linings (2.5YR 4/6); Few Hematite and Manganese Concretions (.5-1 cm); Abrupt, } \\
\text { Smooth Boundary. }\end{array}$ \\
\hline Btgb & $114-150$ & $\begin{array}{l}\text { Very Dark Grayish Brown (10YR 3/3); Sandy Clay; Massive; Very Hard; Sticky; } \\
\text { Plastic; No Reaction; No Roots; Very Few, Prominent, Pore Linings (2.5YR 4/6); } \\
1 \% \text { charcoal fragments, >1 cm Diameter, within Upper 2 cm of Horizon; Abrupt, } \\
\text { Smooth Boundary. }\end{array}$ \\
\hline
\end{tabular}

\section{BHT-3}

Big Sandy Creek Alluvium

T0 Flood plain

Horizon Depth (cm)

Description

\begin{tabular}{|c|r|l|}
\hline A & $0-10$ & $\begin{array}{l}\text { Pale Brown (10YR 6/3); Loamy Fine Sand; Single-Grained; Loose; Non-Sticky; } \\
\text { Non-Plastic; No Reaction; Abundant Roots; Gradual, Smooth Boundary }\end{array}$ \\
\hline C & $10-250$ & $\begin{array}{l}\text { Yellow (10YR 7/6); Loamy Sand to Fine Sand; Single-Grained; Loose; Non-Sticky; } \\
\text { Non-Plastic; No Reaction; Few Roots; 14 Thin, Wavy Beds of Brown (10YR 4/3) } \\
\text { Sandy Clay Included. The Beds thicken and become more frequent lower in the } \\
\text { exposure. }\end{array}$ \\
\hline
\end{tabular}

\section{BHT-4}

Big Sandy Creek Alluvium

T1 Flood Terrace

\begin{tabular}{|c|c|l|}
\hline Horizon & Depth (cm) & \multicolumn{1}{|c|}{ Description } \\
\hline Ap & $0-15$ & $\begin{array}{l}\text { Yellowish Brown (10YR 5/4); Sandy Loam; Single-Grained; Loose; Non-Sticky; } \\
\text { Non-Plastic; Weak Reaction; Abundant Roots; 5\% Limestone Pebbles from Road; } \\
\text { Abrupt, Smooth Boundary. }\end{array}$ \\
\hline A & $15-60$ & $\begin{array}{l}\text { Pale Brown (10YR 7/3); Sandy Loam; Single-Grained; Loose; Non-Sticky; Non- } \\
\text { Plastic; No Reaction; Few Roots; Clear, Smooth Boundary. }\end{array}$ \\
\hline C1 & $60-90$ & $\begin{array}{l}\text { Very Pale Brown (10YR 7/3); Loamy Sand; Single-Grained; Loose; Non-Sticky; } \\
\text { Non-Plastic; No Reaction; Few Roots; Clear, Smooth Boundary. }\end{array}$ \\
\hline Btgb & $90-180$ & $\begin{array}{l}\text { Very Pale Brown (10YR 6/3); Loamy Sand; Single-Grained; Loose; Non-Sticky; } \\
\text { Non-Plastic; No Reaction; Few Roots; Common, Prominent, Pore Linings (2.5YR } \\
\text { 4/6); Few Ironstone and Manganese Concretions (.5-1 cm); Abrupt, Smooth } \\
\text { Boundary. }\end{array}$ \\
\hline $\begin{array}{l}\text { Reddish Yellow (5YR 6/8) 45\%, Very Pale Brown (10YR 7/3) 40\%, Red (2.5YR } \\
\text { 4/6) 15\%; Sandy Clay; Moderate, Coarse, Prismatic; Hard; Semi-Sticky; Semi- } \\
\text { Plastic; No Reaction; No Roots; Many, Distinct Mottles (10YR 7/3); Common, } \\
\text { Prominent, Pore Linings (2.5YR 4/6); Very Few Ironstone and Manganese } \\
\text { Concretions (.5-1 cm). }\end{array}$ \\
\hline
\end{tabular}




\section{Appendix C: Backhoe Trench Profile Descriptions, continued...}

\section{BHT-5}

McLaughlin Creek

Up0lands

\begin{tabular}{|c|r|l|}
\hline Horizon & Depth (cm) & \multicolumn{1}{|c|}{ Description } \\
\hline Ap & $0-11$ & $\begin{array}{l}\text { Light Yellowish Brown (10YR 6/4); Sandy Clay Loam; Medium, Moderate, } \\
\text { Subangular Blocky; Very Hard; Non-Sticky; Non-Plastic; Strong Reaction; } \\
\text { Common Roots; 40\% Limestone Pebbles and Cobbles from Road; Abrupt, Smooth } \\
\text { Boundary. }\end{array}$ \\
\hline Ap2 & $11-30$ & $\begin{array}{l}\text { Light Yellowish Brown (10YR 6/4); Sandy Clay Loam; Medium, Moderate; } \\
\text { Subangular Blocky; Hard; Non-Sticky; Non-Plastic; Strong Reaction; Common } \\
\text { Roots; 10\% Limestone Pebbles from Road; Abrupt, Smooth Boundary. }\end{array}$ \\
\hline BC & $30-40$ & $\begin{array}{l}\text { Yellowish Brown (10YR 5/6); Sandy Loam; Weak, Medium, Subangular Blocky; } \\
\text { Hard; Non-Sticky; Non-Plastic; No Reaction; Few Roots; Few, Medium, Faint } \\
\text { Mottles (10YR 7/3) Clear, Smooth Boundary }\end{array}$ \\
\hline Btgb & $40-50$ & $\begin{array}{l}\text { Yellowish Brown (10YR 5/6); Sandy Loam; Massive; Slightly Hard; Non-Sticky; } \\
\text { Non-Plastic; No Reaction; Few Roots; Few, Medium, Faint Mottles (10YR 7/3); } \\
\text { Clear, Smooth Boundary. }\end{array}$ \\
\hline Crb & $90-90$ & $\begin{array}{l}\text { Yellow (10YR 7/6); Loamy Sand; Massive; Very Hard; Semi-Sticky; Semi-Plastic; } \\
\text { Weak Reaction; Few Roots; Common, Prominent, Pore Lining (2.5YR 4/6); Few, } \\
\text { Medium, Faint Mottles (10YR 7/3); Very Few Ironstone and Manganese } \\
\text { Concretions (.5-1 cm); Abrupt, Smooth Boundary. }\end{array}$ \\
\hline
\end{tabular}

\section{BHT-6}

Big Sandy Creek Alluvium T0 Flood plain

\begin{tabular}{|c|c|l|}
\hline Horizon & Depth (cm) & \multicolumn{1}{|c|}{ Description } \\
\hline A & $0-10$ & $\begin{array}{l}\text { Brownish Yellow (10YR 6/6); Fine Sand; Single-Grained; Loose; Non-Sticky; Non- } \\
\text { Plastic; No Reaction; Common Roots; Gradual; Smooth Boundary. }\end{array}$ \\
\hline C & $10-250$ & $\begin{array}{l}\text { Yellow (10YR 7/6); Fine Sand; Single-Grained; Loose; Non-Sticky; Non-Plastic; } \\
\text { No Reaction; Few Roots in upper 20 centimeters. Numerous, Wavy, Thin Beds of } \\
\text { Brown Clay (10YR 4/3) throughout Horizon. }\end{array}$ \\
\hline
\end{tabular}


Appendix C: Backhoe Trench Profile Descriptions, continued...

\section{BHT-7}

Big Sandy Creek Alluvium

T1 Flood Terrace

\begin{tabular}{|c|r|l|}
\hline Horizon & Depth (cm) & \multicolumn{1}{|c|}{ Description } \\
\hline A & $0-20$ & $\begin{array}{l}\text { Yellowish Brown (10YR 5/6); Loamy Sand; Weak, Medium, Subangular Blocky; } \\
\text { Hard; Non-Sticky; Non-Plastic; No Reaction; Abrupt, Smooth Boundary. }\end{array}$ \\
\hline C & $20-40$ & $\begin{array}{l}\text { Yellow (10YR 7/5); Loamy Sand; Single-Grained; Loose; Non-Sticky; Non-Plastic; } \\
\text { No Reaction; Few Roots; Very Few Ironstone and Manganese Concretions (.5-1 } \\
\text { cm); Abrupt, Smooth Boundary. }\end{array}$ \\
\hline Btgb & $40-82$ & $\begin{array}{l}\text { Yellowish Brown (10YR 5/6) 75\%, Light Gray (10YR 7/2) 15\%, Red (2.5YR 4/6) } \\
10 \% ; \text { Sandy Clay; Strong, Coarse, Prismatic; Very Hard; Sticky; Plastic; No } \\
\text { Reaction; Few Roots; Common, Medium, Distinct Mottles (10YR 7/2); Common, } \\
\text { Prominent, Pore Linings (2.5YR 4/6); Distinct Clay Films (5YR 4/6); Few Ironstone } \\
\text { and Manganese Concretions (.5-1 cm); Gradual, Smooth Boundary. }\end{array}$ \\
\hline Btg2b & $80-110$ & $\begin{array}{l}\text { Yellowish Brown (10YR 5/6) 40\%, Light Gray, (10YR 7/1) 40\%, Red (2.5YR 4/6) } \\
\text { 20\%; Clay; Strong, Coarse, Prismatic; Hard; Sticky; Plastic; No Reaction; No } \\
\text { Roots; Many, Medium, Distinct Mottles (10YR 7/1); Many, Prominent, Pore } \\
\text { Linings (2.5YR 4/6); Distinct Clay Films (5YR 4/6); Common Ironstone and } \\
\text { Manganese Concretions (.5-1 cm); Gradual, Smooth Boundary. }\end{array}$ \\
\hline Btg3b & $110-133$ & $\begin{array}{l}\text { Yellowish Brown (10YR 5/6) 30\%, Light Gray (10YR 7/1) 50\%, Red (2.5YR 4/6) } \\
\text { 40\%; Sandy Clay; Weak, Coarse, Prismatic; Hard; Sticky; Plastic; No Reaction; No } \\
\text { Roots; Many, Distinct Mottles (10YR 7/1); Many, Prominent, Pore Linings (2.5YR } \\
\text { 4/6); Distinct Clay Films (5YR 4/6); Few Ironstone and Manganese Concretions (.5- } \\
\text { 1 cm); Gradual, Smooth Boundary. }\end{array}$ \\
\hline
\end{tabular}

\section{BHT-8}

Big Sandy Creek Alluvium T0 Flood plain

\begin{tabular}{|c|c|c|}
\hline Horizon & Depth (cm) & Description \\
\hline A & $0-26$ & $\begin{array}{l}\text { Yellowish Brown (10YR 5/6); Loamy Sand; Weak, Medium, Subangular Blocky; } \\
\text { Hard; Non-Sticky; Non-Plastic; No Reaction; Abrupt, Smooth Boundary. }\end{array}$ \\
\hline $\mathrm{C}$ & $26-86$ & $\begin{array}{l}\text { Yellow (10YR 7/5); Loamy Fine Sand; Single-Grained; Loose; not Sticky; Non- } \\
\text { Plastic; No Reaction; Few Roots; Very Few Ironstone and Manganese Concretions } \\
(.5-1 \mathrm{~cm}) \text {; Abrupt, Smooth Boundary. }\end{array}$ \\
\hline Btgb & $86-104$ & $\begin{array}{l}\text { Yellowish Brown (10YR 5/6) (55\%), Light Gray (10YR 7/2) 30\%, Red (2.5YR 4/6) } \\
\text { 15\%; Sandy Clay; Moderate, Medium, Prismatic; Hard; Sticky; Plastic; No } \\
\text { Reaction; Few Roots; Common, Medium, Distinct Mottles (10YR 7/2); Common, } \\
\text { Prominent, Pore Linings (2.5YR 4/6); Distinct Clay Films (5YR 4/6); Very Few } \\
\text { Ironstone and Manganese Concretions (.5-1 cm); Gradual, Smooth Boundary. }\end{array}$ \\
\hline Btg2b & 104-133 & $\begin{array}{l}\text { Yellowish Brown (10YR 5/6) 45\%, Light Gray (10YR 7/1) 40\%, Red (2.5YR 4/6) } \\
\text { 15\%; Clay; Strong, Coarse, Prismatic; Hard; Sticky; Plastic; No Reaction; No } \\
\text { Roots; Many, Medium, Distinct Mottles (10YR 7/1); Many, Prominent, Pore } \\
\text { Linings (2.5YR 4/6); Distinct Clay Films (5YR 4/6); Common Ironstone and } \\
\text { Manganese Concretions (.5-1 cm); Gradual, Smooth Boundary. }\end{array}$ \\
\hline Btg3b & $133-260$ & $\begin{array}{l}\text { Yellowish Brown (10YR 5/6) 40\%, Light Gray (10YR 7/1) 50\%, Red (2.5YR 4/6) } \\
\text { 10\%; Sandy Clay; Weak, Medium, Prismatic; Hard; Sticky; Plastic; No Reaction; } \\
\text { No Roots; Many, Medium, Distinct Mottles (10YR 7/1); Many, Prominent, Pore } \\
\text { Linings (2.5YR 4/6); Distinct Clay Films (5YR 4/6); Few Ironstone and Manganese } \\
\text { Concretions (.5-1 cm); Gradual, Smooth Boundary. }\end{array}$ \\
\hline
\end{tabular}




\section{Appendix C: Backhoe Trench Profile Descriptions, continued...}

\section{BHT-9}

Mclaughlin Creek

Uplands

\begin{tabular}{|c|r|l|}
\hline Horizon & Depth (cm) & \multicolumn{1}{|c|}{ Description } \\
\hline A & $0-12$ & $\begin{array}{l}\text { Yellowish Brown (10YR 5/6); Loamy Sand; Weak, Medium, Subangular Blocky; } \\
\text { Hard; Non-Sticky; Non-Plastic; No Reaction; Abrupt, Smooth Boundary. }\end{array}$ \\
\hline C & $12-40$ & $\begin{array}{l}\text { Yellow (10YR 7/5); Loamy Sand; Single-Grained; Loose; Non-Sticky; Non-Plastic; } \\
\text { No Reaction; Few Roots; Very Few Ironstone and Manganese Concretions (.5-1 } \\
\text { cm); Abrupt, Smooth Boundary. }\end{array}$ \\
\hline Eb & $40-44$ & $\begin{array}{l}\text { Very Pale Brown (10YR 8/3); Fine Sand; Single-Grained; Loose; Non-Sticky; Non- } \\
\text { Plastic; No Reaction; Clear, Smooth Boundary. }\end{array}$ \\
\hline Btg1b & $44-92$ & $\begin{array}{l}\text { Reddish Yellow (7.5YR 6/8) 80\%, Light Gray (10YR 7/2) 10\%, Red (2.5YR 4/6) } \\
10 \% ; \text { Sandy Clay; Strong, Medium, Prismatic; Very Hard; Sticky; Plastic; No } \\
\text { Reaction; Few Roots; Common, Medium, Distinct Mottles (10YR 7/2); Common, } \\
\text { Prominent, Pore Linings (2.5YR 4/6); Distinct Clay Films (5YR 4/6); Very Few } \\
\text { Ironstone and Manganese Concretions (.5-1 cm); Gradual, Smooth Boundary }\end{array}$ \\
\hline Btg2b & $92-120$ & $\begin{array}{l}\text { Reddish Yellow (7.5YR 6/8) 5\%, Light Gray, 10YR (7/1) 80\%, Red (2.5YR 4/7) } \\
\text { 15\%; Clay; Strong, Coarse, Prismatic; Hard; Sticky; Plastic; No Reaction; No } \\
\text { Roots; Many, Medium, Distinct Mottles (10YR 7/1); Many, Prominent, Pore } \\
\text { Linings (2.5YR 4/7); Distinct Clay Films (7.5YR 6/8); Common Ironstone and } \\
\text { Manganese Concretions (.5-1 cm); Gradual, Smooth Boundary. }\end{array}$ \\
\hline Btg3b & $120-250$ & $\begin{array}{l}\text { Reddish Yellow (7.5YR 6/8) 53\%, Light Gray (10YR 7/1) 22\%, Red (2.5YR 4/6) } \\
\text { 25\%; Sandy Clay; Weak, Medium, Prismatic; Hard; Sticky; Plastic; No Reaction; } \\
\text { No Roots; Many, Medium, Distinct Mottles (10YR 7/1); Many, Prominent, Pore } \\
\text { Linings (2.5YR 4/6); Distinct Clay Films (5YR 4/6); Few Ironstone and Manganese } \\
\text { Concretions (.5-1 cm); Gradual, Smooth Boundary. }\end{array}$ \\
\hline
\end{tabular}

BHT-10

Dogwood Creek Alluvium

T0 Floodplain

\begin{tabular}{|c|r|l|}
\hline Horizon & Depth (cm) & \multicolumn{1}{|c|}{ Description } \\
\hline A1 & $0-10$ & $\begin{array}{l}\text { Yellowish Brown (10YR 5/4); Sandy Loam; Weak, Medium, Subangular Blocky; } \\
\text { Slightly Hard; Non-Sticky; Non-Plastic; No Reaction; Abundant Roots; Clear, } \\
\text { Smooth Boundary. }\end{array}$ \\
\hline A2 & $10-16$ & $\begin{array}{l}\text { Dark Yellowish Brown (10YR 4/4); Sandy Loam; Massive; Loose; Non-Sticky; } \\
\text { Non-Plastic; No Reaction; Common Roots; Clear, Smooth Boundary. }\end{array}$ \\
\hline C1 & $16-48$ & $\begin{array}{l}\text { Yellowish Brown (10YR 5/4); Sandy Loam; Massive; Loose; Non-Sticky; Non- } \\
\text { Plastic; No Reaction; Abrupt, Smooth Boundary. }\end{array}$ \\
\hline C2 & $48-83$ & $\begin{array}{l}\text { Yellowish Brown (10YR 6/5); Sandy Loam; Massive; Loose; Non-Sticky; Non- } \\
\text { Plastic; No Reaction; Abrupt, Smooth Boundary. }\end{array}$ \\
\hline C3 & $83-98$ & $\begin{array}{l}\text { Light Yellowish Brown (10YR 6/4); Sandy Loam; Massive; Loose; Non-Sticky; } \\
\text { Non-Plastic; No Reaction; Very Few Prominent Pore Linings (2.5YR 4/6) Abrupt, } \\
\text { Smooth Boundary. }\end{array}$ \\
\hline Cg & $98-113$ & $\begin{array}{l}\text { Light Yellowish Brown (10YR 6/4); Sandy Loam; Massive; Slightly Hard; Non- } \\
\text { Sticky; Non-Plastic; No Reaction; Very Few Prominent Pore Linings (2.5YR 4/6); } \\
\text { Few, Medium Distinct Mottles (10YR7/2); Abrupt, Smooth Boundary. }\end{array}$ \\
\hline
\end{tabular}


Appendix C: Backhoe Trench Profile Descriptions, continued...

BHT-10, continued...

Dogwood Creek Alluvium

T0 Floodplain

\begin{tabular}{|c|c|l|}
\hline Btgb & $113-150$ & $\begin{array}{l}\text { Reddish Yellow (7.5YR 6/8) 50\%, Gray N5/0 40\%, Red (2.5YR 4/6) 10\%; Sandy } \\
\text { Clay; Weak, Medium, Prismatic; Hard; Sticky; Plastic; No Reaction; No Roots; } \\
\text { Common, Medium, Prominent Mottles (10YR 7/2); Common, Prominent, Pore } \\
\text { Linings (2.5YR 4/6); Distinct Clay Films (5YR 4/6); Common Ironstone and } \\
\text { Manganese Concretions (.5-1 cm) }\end{array}$ \\
\hline
\end{tabular}

\section{BHT-11}

Dogwood Creek Alluvium

Upland

\begin{tabular}{|c|r|l|}
\hline Horizon & Depth (cm) & \multicolumn{1}{c|}{ Description } \\
\hline A2 & $0-18$ & $\begin{array}{l}\text { Light Yellowish Brown (10YR 6/4); Loamy Sand; Single-Grained; Loose; Non- } \\
\text { Sticky; Non-Plastic; No Reaction; Abundant Roots; Clear, Smooth Boundary. }\end{array}$ \\
\hline C & $18-73$ & $\begin{array}{l}\text { Very Pale Brown (10YR 7/4); Loamy Sand; Single-Grained; Loose; Non-Sticky; } \\
\text { Non-Plastic; No Reaction; Few Roots; A Wavy, Clay Laminae (10YR 4/4) at Mid- } \\
\text { Horizon. Abrupt, Smooth Boundary. }\end{array}$ \\
\hline Bt1b & $73-96$ & $\begin{array}{l}\text { Yellowish Red (5YR 5/8); Sandy Clay Loam; Weak, Medium Blocky; Slightly } \\
\text { Hard; Non-Sticky; Non-Plastic; No Reaction; Few Roots; Gradual, Smooth } \\
\text { Boundary. }\end{array}$ \\
\hline Bt2b & $96-183$ & $\begin{array}{l}\text { Red (2.5YR 4/6); Sandy Clay Loam; Moderate, Medium, Prismatic; Hard; Sub- } \\
\text { Sticky; Sub-Plastic; No Reaction; No Roots; Distinct Clay Films (10YR 3/6); Few } \\
\text { Ironstone and Manganese Concretions (.5-1 cm); Gradual, Smooth Boundary. }\end{array}$ \\
\hline Btgb & $183-210$ & $\begin{array}{l}\text { Red (2.5YR 4/6) 80\%, Light Gray (10YR 7/1) 10\%, Red (2.5YR 4/6) 10\%; Sandy } \\
\text { Clay Loam; Moderate, Medium, Prismatic; Hard; Sub-Sticky; Sub-Plastic; No } \\
\text { Reaction; No Roots; Common Medium Prominent Mottles (10YR 7/1); Common } \\
\text { Distinct Pore Linings (2.5YR 4/6); Prominent Clay Films (10YR 3/6); Few } \\
\text { Ironstone and Manganese Concretions (.5-1 cm). }\end{array}$ \\
\hline
\end{tabular}

\section{BHT-12}

Dogwood Creek Alluvium

T0 Floodplain

\begin{tabular}{|c|c|l|}
\hline Horizon & Depth (cm) & \multicolumn{1}{|c|}{ Description } \\
\hline A & $0-18$ & $\begin{array}{l}\text { Light Brownish Gray (10YR 6/2); Medium Sand; Single-Grained; Loose; Non- } \\
\text { Sticky; Non-Plastic; No Reaction; Abundant Roots; Clear, Smooth Boundary. }\end{array}$ \\
\hline C1 & $18-50$ & $\begin{array}{l}\text { Pale Brown (10YR 6/3); Medium Sand; Single-Grained; Loose; Non-Sticky; Non- } \\
\text { Plastic; No Reaction; Few Roots; Abrupt, Smooth Boundary. }\end{array}$ \\
\hline C2 & $50-77$ & $\begin{array}{l}\text { Very Pale Brown (10YR 8/2); Fine Sand; Single-Grained; Loose; Non-Sticky; Non- } \\
\text { Plastic; No Reaction; Few Roots; Abrupt, Smooth Boundary. }\end{array}$ \\
\hline Btb & $11-97$ & $\begin{array}{l}\text { Reddish Yellow (7.5YR 6/8); Sandy Clay Loam; Moderate, Medium, Prismatic; } \\
\text { Hard; Semi-Sticky; Semi-Plastic; No Reaction; Distinct Clay Films (10YR 7/3); No } \\
\text { Roots; Very Few Ironstone and Manganese Concretions (.5-1 cm). }\end{array}$ \\
\hline Btgb & $97-201$ & $\begin{array}{l}\text { Reddish Yellow (7.5YR 6/8) 80\%, Light Gray (10YR 7/2) 15\%, Red (2.5YR 4/6) } \\
5 \% ; \text { Sandy Clay; Moderate, Medium, Prismatic; Hard; Sticky; Plastic; No Reaction; } \\
\text { No Roots; Common, Medium, Prominent Mottles (10YR 7/2); Common, Prominent } \\
\text { Pore Linings (2.5YR 4/6); Distinct Clay Films (10YR 7/3); Very Few Ironstone and } \\
\text { Manganese Concretions (.5-1 cm). }\end{array}$ \\
\hline
\end{tabular}


Appendix D

\section{Summary of Known Sites on Camp Swift}


Appendix D: Summary of Known Sites at Camp Swift

\begin{tabular}{|c|c|c|c|c|c|c|c|c|c|c|c|c|c|c|c|c|c|c|c|c|}
\hline 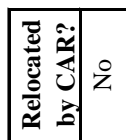 & $\stackrel{2}{z}$ & 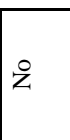 & 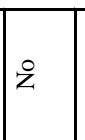 & $z$ & $\not ̊$ & z & $\check{z}$ & 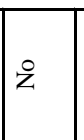 & 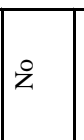 & $\check{c}_{\nu}$ & ż & $z$ & $\not z$ & z & z & z & $\not 2$ & z & ż & z \\
\hline $\begin{array}{l}0 \\
0\end{array}$ & $\overbrace{}^{\infty}$ & z & z & ֻै & $\stackrel{\bullet}{\nu}$ & 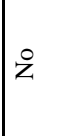 & $\check{z}$ & $\not 2$ & z & 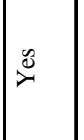 & z & z & ż & z & 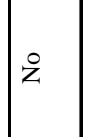 & $\not 2$ & z & z & z & 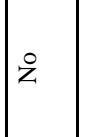 \\
\hline 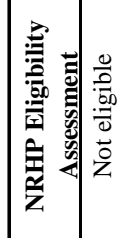 & 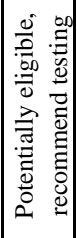 & $\begin{array}{l}0 \\
\frac{0}{0} \\
\frac{.00}{00} \\
\frac{0}{0} \\
0 \\
z \\
z\end{array}$ & 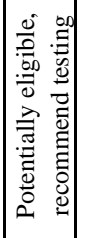 & 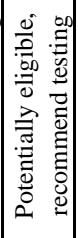 & 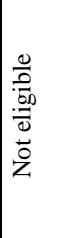 & $\begin{array}{l}\frac{0}{0} \\
\frac{0}{00} \\
\frac{1}{0} \\
0 \\
0 \\
z\end{array}$ & 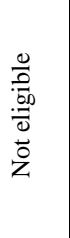 & 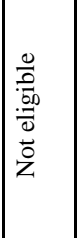 & $\begin{array}{l}0 \\
\frac{0}{0} \\
\frac{0}{60} \\
\frac{0}{0} \\
\stackrel{0}{0} \\
z\end{array}$ & 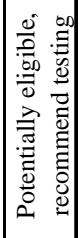 & 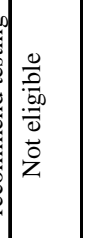 & 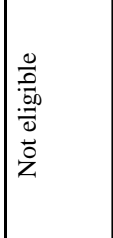 & \begin{tabular}{|l}
0 \\
$\frac{0}{0}$ \\
.00 \\
00 \\
0 \\
0 \\
0 \\
$z$
\end{tabular} & 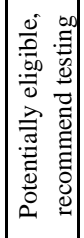 & 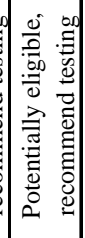 & $\begin{array}{l}\frac{0}{0} \\
\frac{0}{0.00} \\
\frac{.00}{0} \\
\frac{0}{0} \\
z \\
z\end{array}$ & 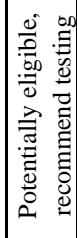 & 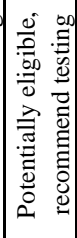 & $\begin{array}{l}\frac{0}{0} \\
\frac{0}{60} \\
\frac{0}{0} \\
\frac{0}{0} \\
z\end{array}$ & $\begin{array}{l}\frac{0}{0} \\
\frac{0}{60} \\
\frac{0}{0} \\
0 \\
0 \\
z\end{array}$ \\
\hline 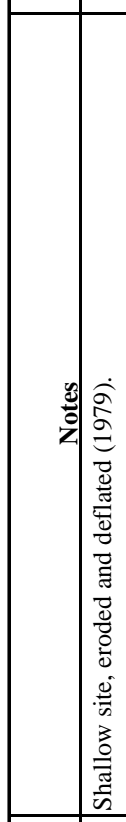 & 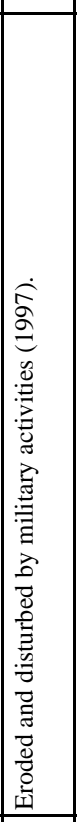 & 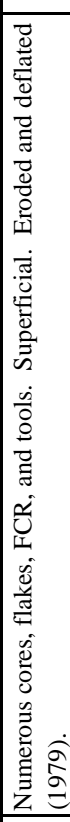 & 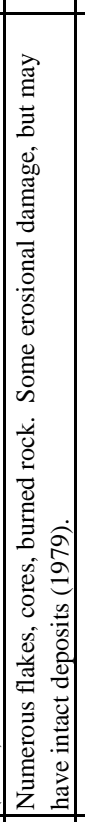 & 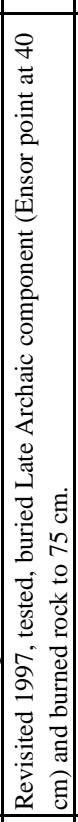 & 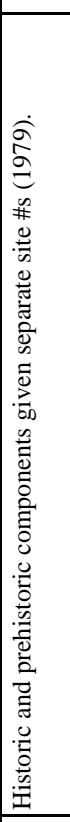 & 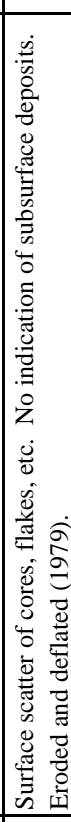 & 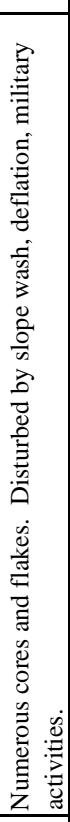 & 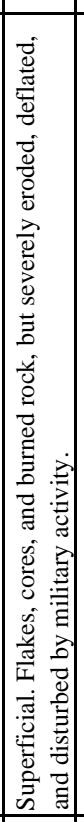 & 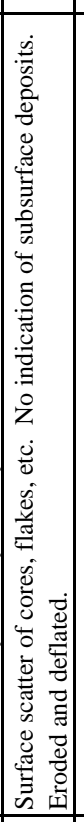 & 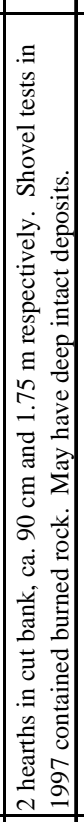 & 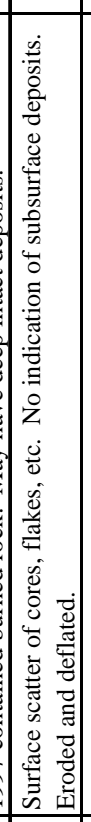 & 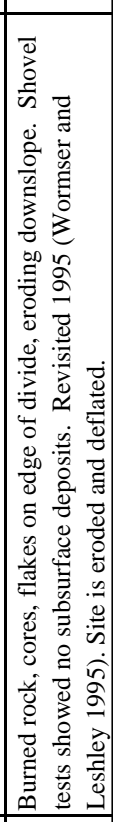 & 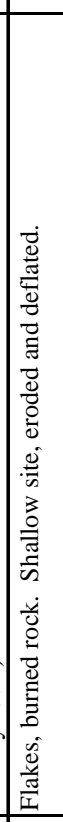 & 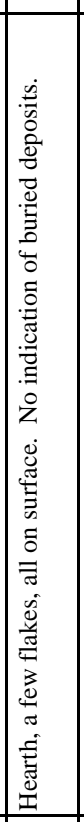 & 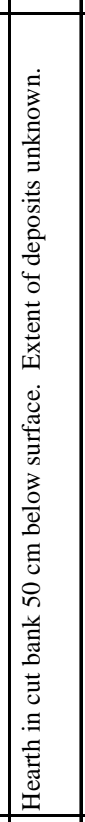 & 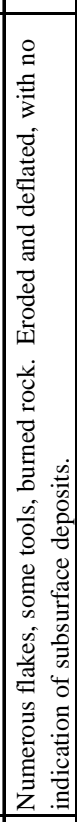 & 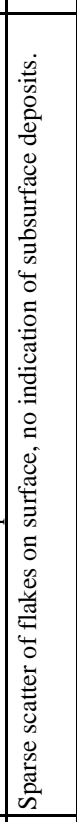 & 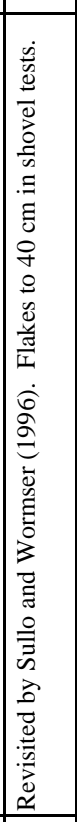 & 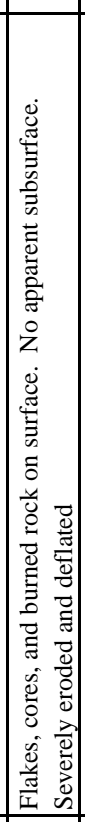 & 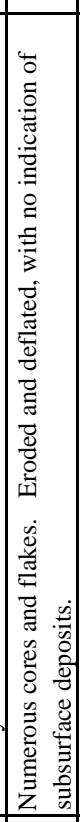 \\
\hline 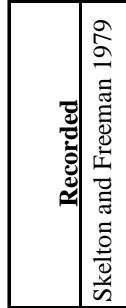 & 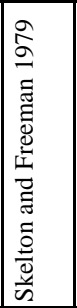 & 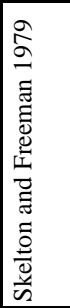 & 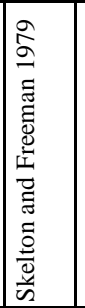 & 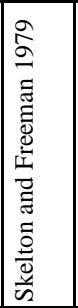 & 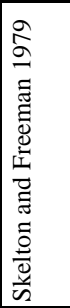 & 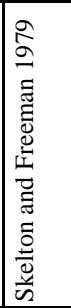 & 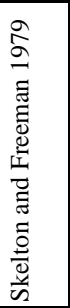 & 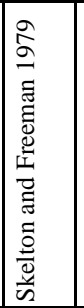 & 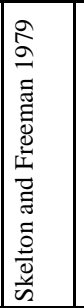 & 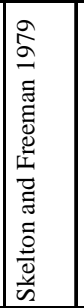 & 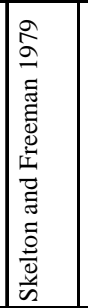 & 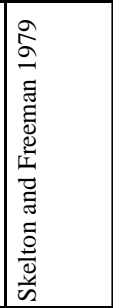 & 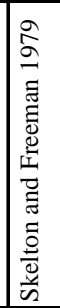 & 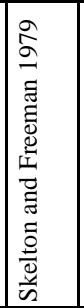 & 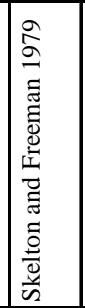 & 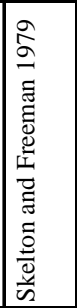 & 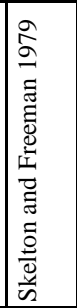 & 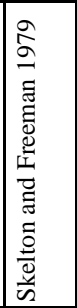 & 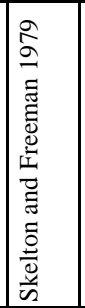 & 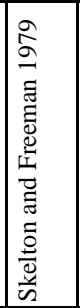 \\
\hline 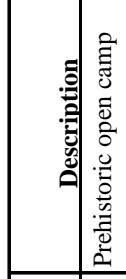 & 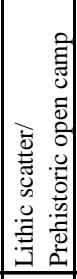 & 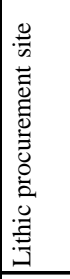 & 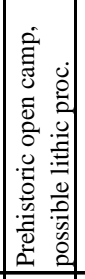 & 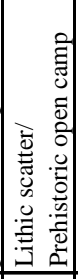 & 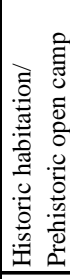 & 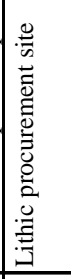 & 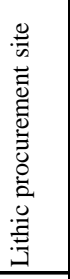 & 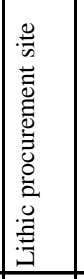 & 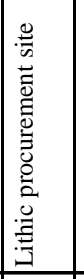 & 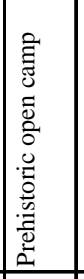 & 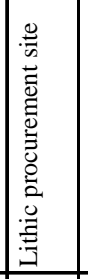 & 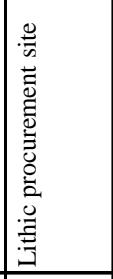 & 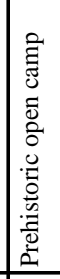 & 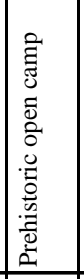 & 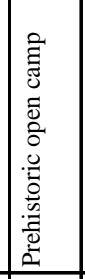 & 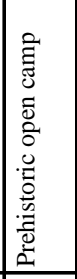 & 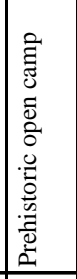 & 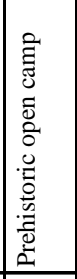 & 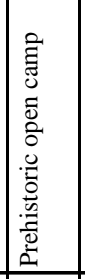 & 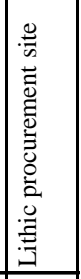 \\
\hline 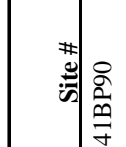 & $\begin{array}{l}\overline{\hat{\partial}} \\
\stackrel{\rho}{\sigma}\end{array}$ & $\mid \begin{array}{l}\tilde{\partial} \\
\frac{\partial}{\sigma} \\
\frac{\partial}{\sigma}\end{array}$ & $\mid \begin{array}{l}\hat{\varrho} \\
\frac{\hat{\rho}}{\sigma}\end{array}$ & 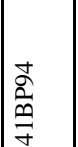 & $\begin{array}{l}\stackrel{+}{\infty} \\
\stackrel{\infty}{\infty} \\
\frac{\infty}{\sigma}\end{array}$ & 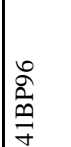 & $\begin{array}{l}\hat{\hat{\alpha}} \\
\stackrel{\underline{m}}{\sigma}\end{array}$ & $\begin{array}{l}\infty \\
\stackrel{0}{0} \\
\stackrel{m}{\forall}\end{array}$ & $\begin{array}{l}\partial \hat{े} \\
\text { के } \\
\vec{\sigma}\end{array}$ & $\frac{8}{\frac{8}{m}}$ & $\frac{\overrightarrow{0}}{\frac{0}{\partial}}$ & $\begin{array}{l}\frac{\sigma}{\sigma} \\
\frac{\partial}{2} \\
\frac{\partial}{\gamma}\end{array}$ & 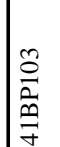 & $\begin{array}{l}\frac{1}{0} \\
\frac{\partial}{9} \\
\frac{\partial}{\sigma}\end{array}$ & $\begin{array}{l}\frac{n}{0} \\
\frac{1}{2} \\
\frac{0}{7}\end{array}$ & $\frac{8}{\frac{8}{2}}$ & $\begin{array}{l}\frac{5}{0} \\
\frac{0}{0} \\
\frac{0}{7}\end{array}$ & $\begin{array}{l}\frac{\infty}{0} \\
\frac{0}{0} \\
\frac{\partial}{\sigma}\end{array}$ & $\frac{\partial}{\frac{\partial}{a}}$ & 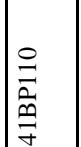 \\
\hline
\end{tabular}


Appendix D: Summary of Known Sites at Camp Swift, continued...

\begin{tabular}{|c|c|c|c|c|c|c|c|c|c|c|c|c|c|c|c|c|c|c|c|c|}
\hline 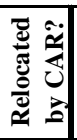 & 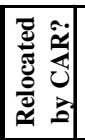 & & 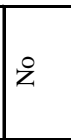 & 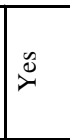 & z & $\check{z}$ & z & 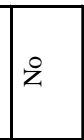 & 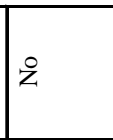 & $\check{z}$ & ¿ & z & z & $\check{z}$ & $\not i$ & $\not z$ & z & z & z & z \\
\hline 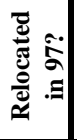 & 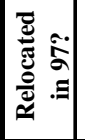 & & $\overbrace{0}^{\infty}$ & $\underset{\nearrow}{\triangle}$ & $\check{\nu}^{\infty}$ & ¿્ટ & $\ddot{x}$ & $\stackrel{\otimes}{\infty}$ & $\check{z}$ & $\overbrace{\nu}^{0}$ & z & $\underset{\sim}{0}$ & 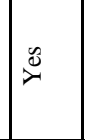 & z & 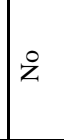 & $\check{\nu}^{\infty}$ & 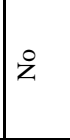 & 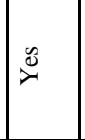 & $\ddot{\sim}$ & ${ }^{3}$ \\
\hline 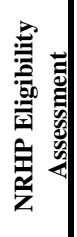 & 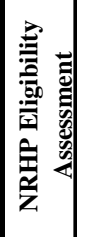 & 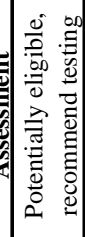 & 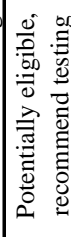 & 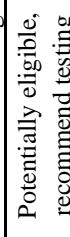 & $\begin{array}{l}0 \\
\frac{0}{0} \\
\frac{0}{50} \\
\overline{0} \\
0 \\
z \\
z\end{array}$ & 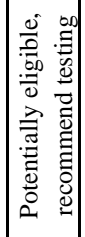 & 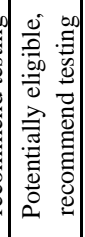 & 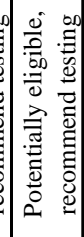 & 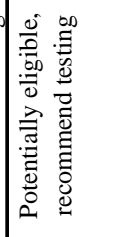 & 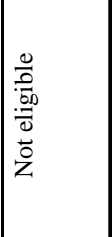 & 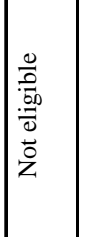 & 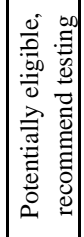 & $\frac{2}{3}$ & 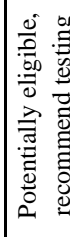 & 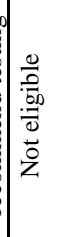 & 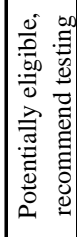 & 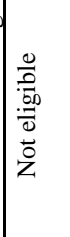 & 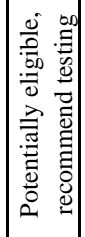 & 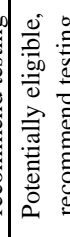 & $\begin{array}{l}\frac{0}{0} \\
\frac{0}{50} \\
\frac{50}{0} \\
\frac{0}{0} \\
2\end{array}$ \\
\hline$\frac{\mathscr{2}}{3}$ & & 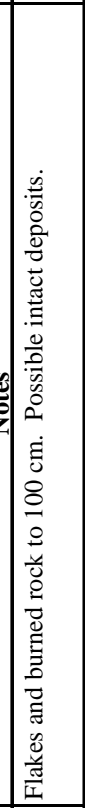 & 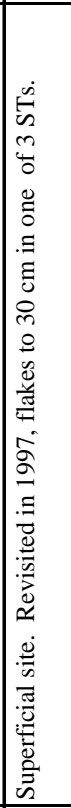 & 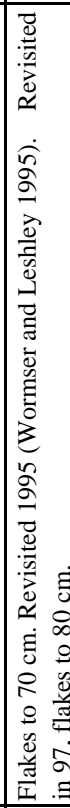 & 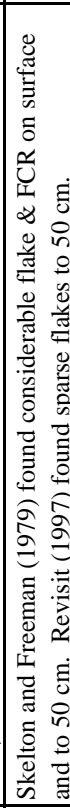 & 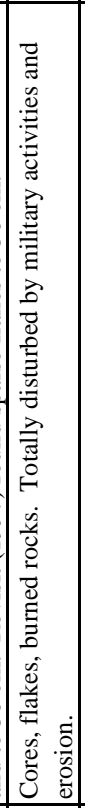 & 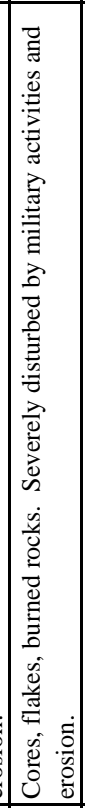 & 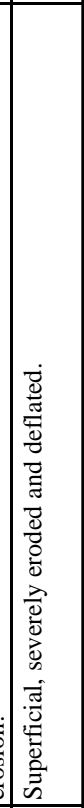 & 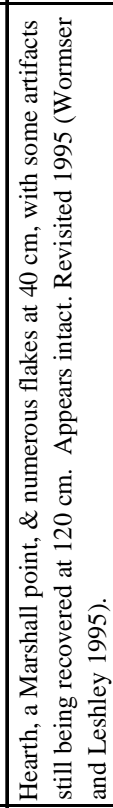 & 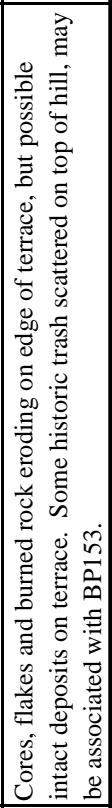 & 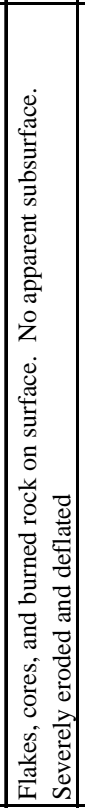 & 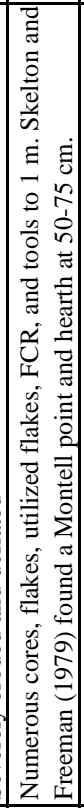 & 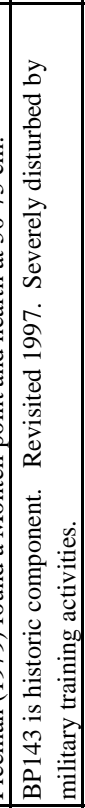 & 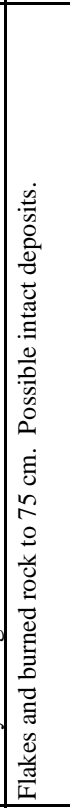 & 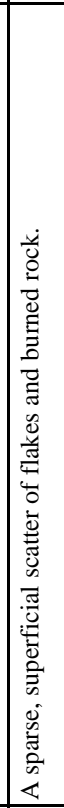 & 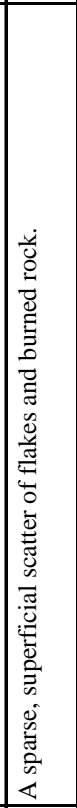 & 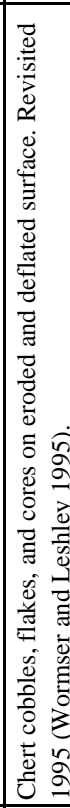 & 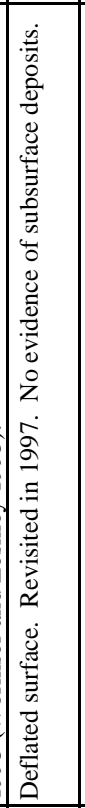 & 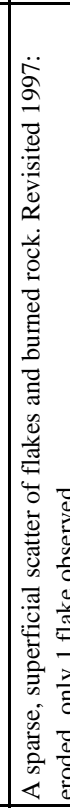 & 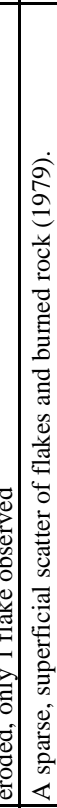 \\
\hline 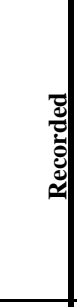 & & 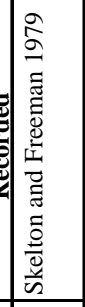 & 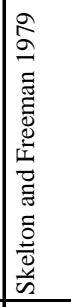 & 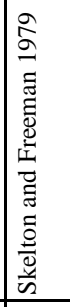 & 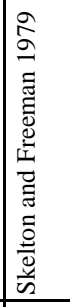 & 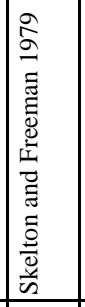 & 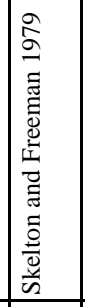 & 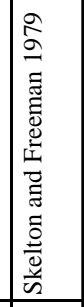 & 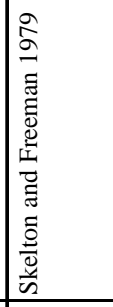 & 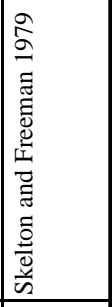 & 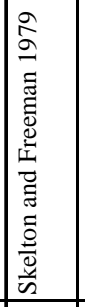 & 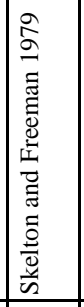 & 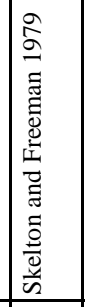 & 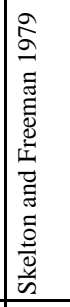 & 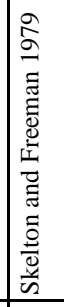 & 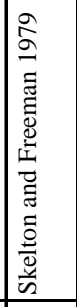 & 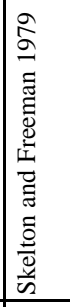 & 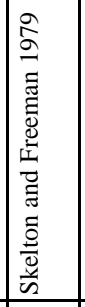 & 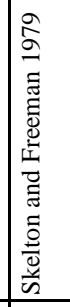 & 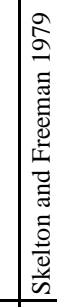 \\
\hline 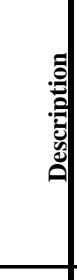 & & 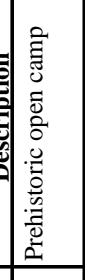 & 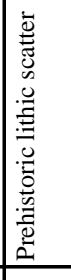 & 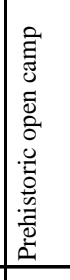 & 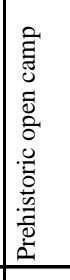 & 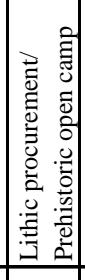 & 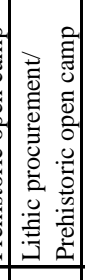 & 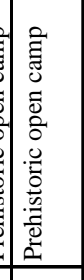 & 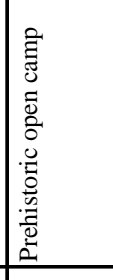 & 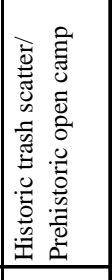 & 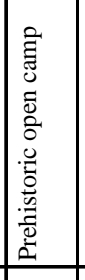 & 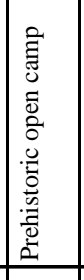 & 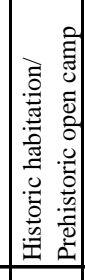 & 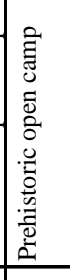 & 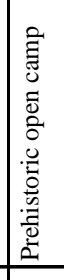 & 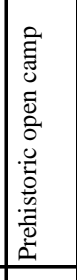 & 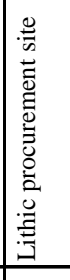 & 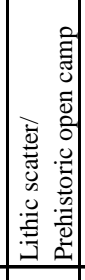 & 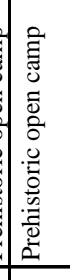 & 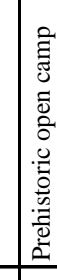 \\
\hline 陆 & & 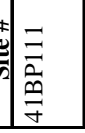 & 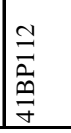 & 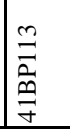 & 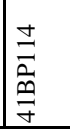 & 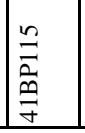 & 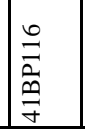 & 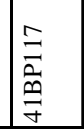 & \begin{tabular}{|l}
$\infty$ \\
$\stackrel{\infty}{\vec{\theta}}$ \\
$\vec{\sigma}$ \\
\end{tabular} & $\frac{\partial}{\vec{m}}$ & 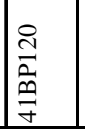 & 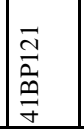 & 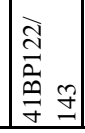 & 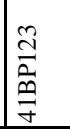 & 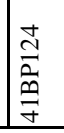 & 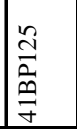 & 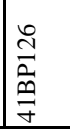 & 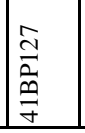 & $\frac{\infty}{\stackrel{\infty}{\sim}}$ & \\
\hline
\end{tabular}


Appendix D: Summary of Known Sites at Camp Swift, continued...

\begin{tabular}{|c|c|c|c|c|c|c|c|c|c|c|c|c|c|c|c|c|c|c|c|}
\hline 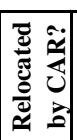 & z & ż & z & $\stackrel{z}{z}$ & ż & Z & $z$ & z & $\check{c}_{0}^{\circ}$ & z & z & ż & z & z̊ & z̊ & z & z & $\nu_{\nu}^{\infty}$ & z̊ \\
\hline 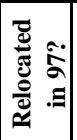 & z & z̊ & z & z & $\check{c}^{\mathscr{C}}$ & ż & z̊ & ż & $\underbrace{\mathscr{C}}_{\nu}$ & z̊ & $\check{c}^{\mathscr{b}}$ & $\nu_{\nu}^{\infty}$ & z & $\stackrel{\infty}{\infty}$ & $\check{\nu}_{\nu}^{0}$ & z & z & $\check{D}^{\infty}$ & ż \\
\hline 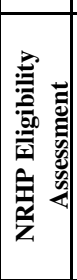 & $\frac{0}{\frac{0}{0}}$ & 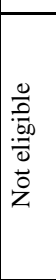 & 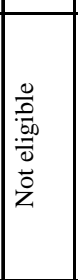 & \begin{tabular}{|l}
$\frac{0}{0}$ \\
$\frac{0}{00}$ \\
$\frac{.0}{0}$ \\
$\stackrel{0}{0}$ \\
$z$
\end{tabular} & $\begin{array}{l}\frac{0}{0} \\
\frac{0}{0} \\
\frac{0}{0} \\
0 \\
0 \\
z\end{array}$ & \begin{tabular}{|l|}
$\frac{0}{0}$ \\
$\frac{0}{00}$ \\
$\frac{\overrightarrow{0}}{0}$ \\
$\stackrel{0}{0}$ \\
$z$
\end{tabular} & 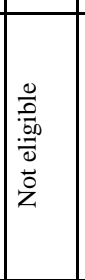 & \begin{tabular}{|l}
$\frac{0}{0}$ \\
$\frac{0}{60}$ \\
$\frac{\overrightarrow{0}}{0}$ \\
$\overrightarrow{0}$ \\
$z$
\end{tabular} & $\mid \frac{0}{\frac{0}{0}}$ & \begin{tabular}{|l}
$\frac{0}{0}$ \\
$\frac{0}{00}$ \\
$\frac{0}{0}$ \\
0 \\
0 \\
$z$
\end{tabular} & \begin{tabular}{|l}
$\frac{0}{0}$ \\
$\frac{0}{60}$ \\
$\frac{0}{0}$ \\
$\stackrel{0}{0}$ \\
$z$
\end{tabular} & \begin{tabular}{|l}
$\frac{0}{0}$ \\
$\frac{0}{50}$ \\
$\frac{.0}{0}$ \\
$\frac{0}{0}$ \\
$z$
\end{tabular} & 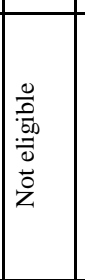 & 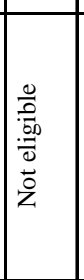 & 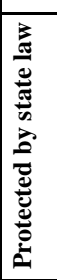 & 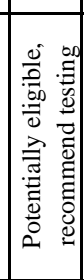 & 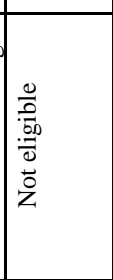 & 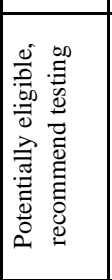 & \begin{tabular}{|l|}
$\frac{0}{0}$ \\
$\frac{0}{60}$ \\
$\frac{0}{0}$ \\
0 \\
0 \\
$z$
\end{tabular} \\
\hline & 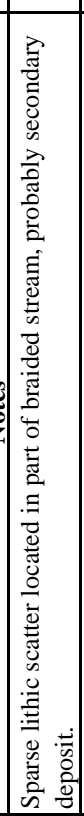 & 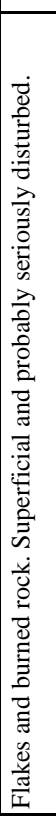 & 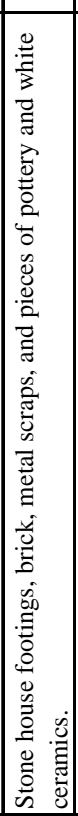 & 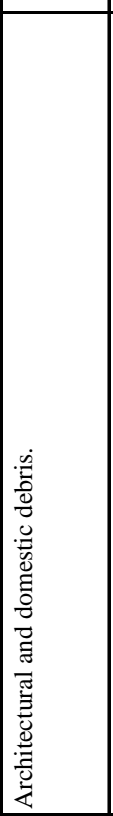 & 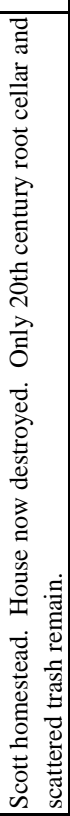 & 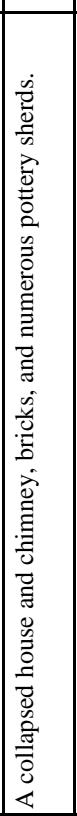 & 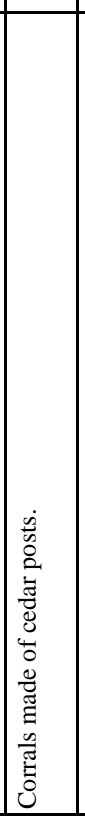 & 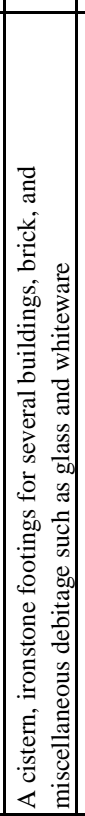 & 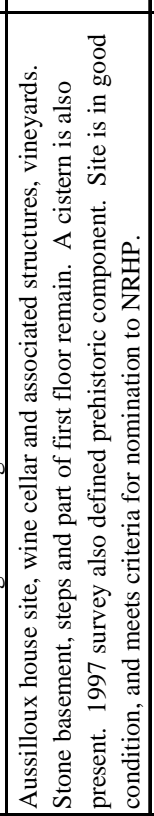 & 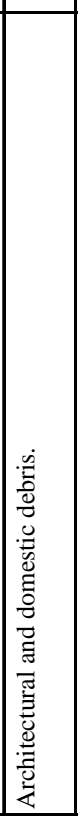 & 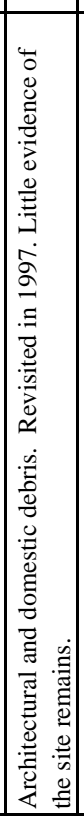 & 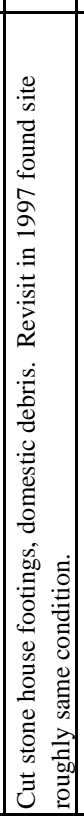 & 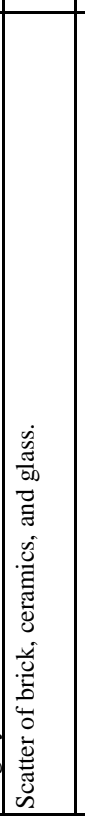 & 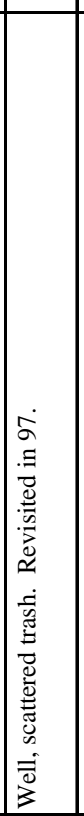 & 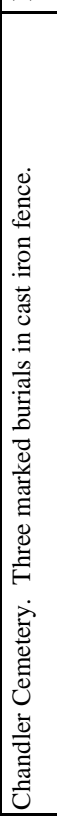 & 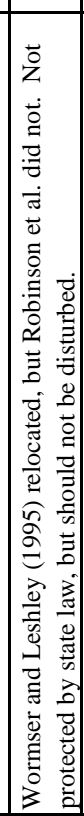 & 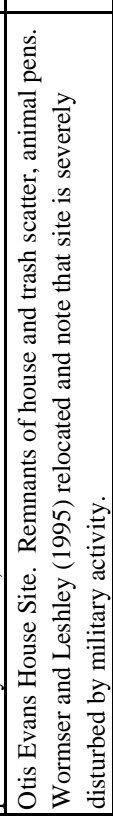 & 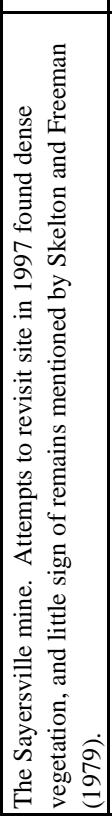 & 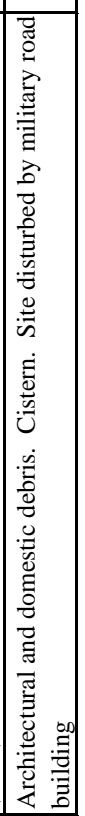 \\
\hline : & 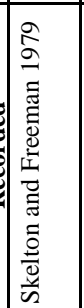 & 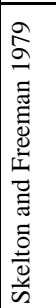 & 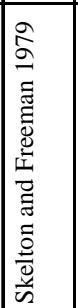 & 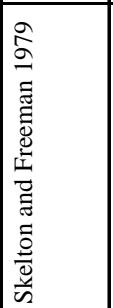 & 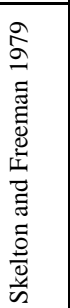 & 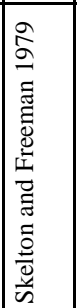 & 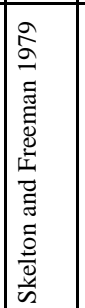 & 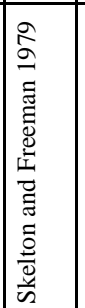 & 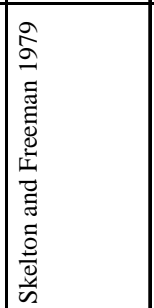 & 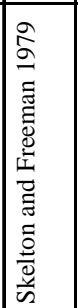 & 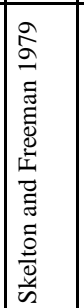 & 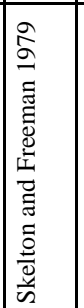 & 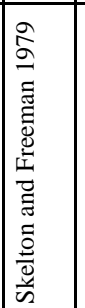 & 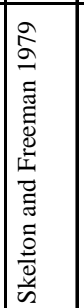 & 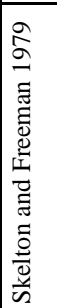 & 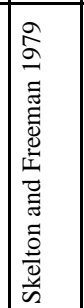 & 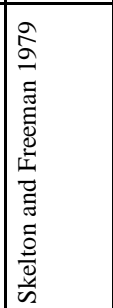 & 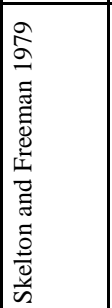 & 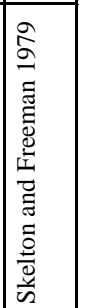 \\
\hline & 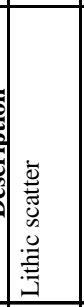 & 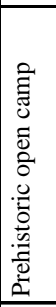 & 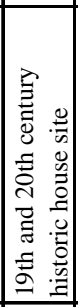 & 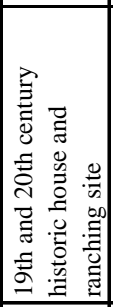 & 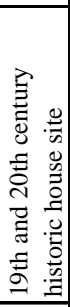 & 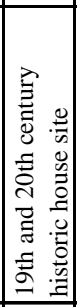 & 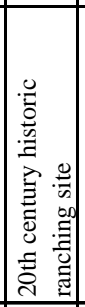 & 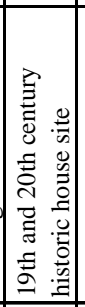 & 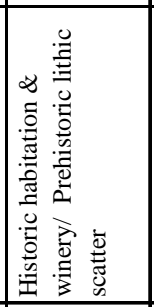 & 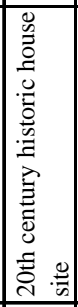 & 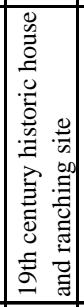 & 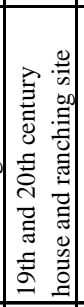 & 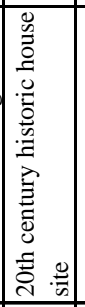 & 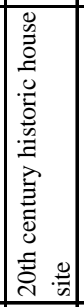 & 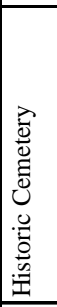 & 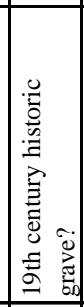 & 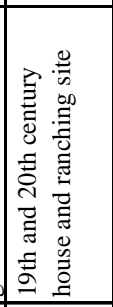 & 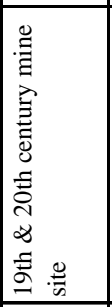 & 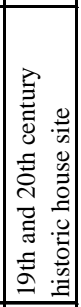 \\
\hline & 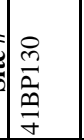 & $\mid \vec{m}$ & $\begin{array}{l}\frac{N}{m} \\
\stackrel{m}{\frac{m}{\sigma}} \\
\frac{a}{\gamma}\end{array}$ & 孞 & $\begin{array}{l}\frac{d}{2} \\
\stackrel{2}{2} \\
\frac{0}{7}\end{array}$ & $\frac{\varkappa}{\stackrel{n}{m}}$ & $\begin{array}{l}\frac{m}{2} \\
\frac{m}{\rho} \\
\frac{m}{\gamma}\end{array}$ & $\mid \begin{array}{l}\hat{m} \\
\overrightarrow{\tilde{p}} \\
\vec{q} \\
\vec{\gamma}\end{array}$ & $\begin{array}{l}\infty \\
\frac{\infty}{\partial} \\
\frac{\rho}{\sigma}\end{array}$ & ले & $\frac{q}{\frac{q}{2}}$ & $\frac{\vec{f}}{\stackrel{\vec{\partial}}{\vec{q}}}$ & 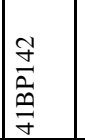 & $\frac{\frac{J}{2}}{\frac{9}{\sigma}}$ & 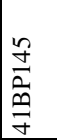 & $\mid \begin{array}{l}\frac{f}{f} \\
\frac{\hat{q}}{\sigma} \\
\frac{\sigma}{q}\end{array}$ & $\frac{f}{\tilde{g}}$ & $\frac{\infty}{\frac{\infty}{\rho 0}}$ & 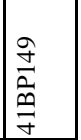 \\
\hline
\end{tabular}


Appendix D: Summary of Known Sites at Camp Swift, continued...

\begin{tabular}{|c|c|c|c|c|c|c|c|c|c|c|c|c|c|c|c|c|c|c|}
\hline 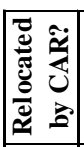 & ż & $\dot{z}$ & z & $\not ̊ z$ & $\dot{z}$ & ż & $\dot{z}$ & $\not z$ & $\not ̊ z$ & ż & $\check{z}$ & $\not z$ & $\not ̊ z$ & iz & $\not z$ & ż & ż & z \\
\hline 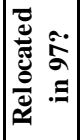 & 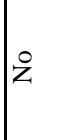 & ż & z & 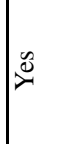 & $\underset{\nu}{\circlearrowright}$ & ż & 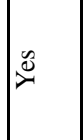 & 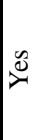 & 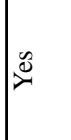 & $\stackrel{\varnothing}{\circlearrowright}$ & $\stackrel{\circlearrowright}{\nu}$ & z & $\triangleq$ & $\stackrel{\circlearrowright}{\nearrow}$ & ż & $\stackrel{\circlearrowright}{\partial}$ & 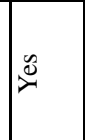 & $\not 2$ \\
\hline 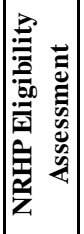 & $\begin{array}{l}\frac{0}{0} \\
\frac{0}{0.0} \\
\frac{.0}{0} \\
\overrightarrow{0} \\
z\end{array}$ & $\mid \begin{array}{l}\frac{0}{0} \\
\frac{0}{0.0} \\
\frac{.00}{0} \\
\stackrel{0}{0} \\
z\end{array}$ & 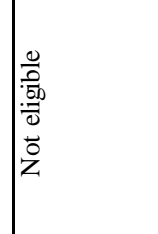 & 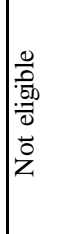 & 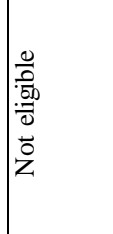 & 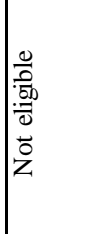 & 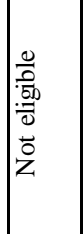 & 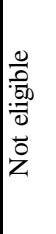 & $\begin{array}{l}\frac{0}{0} \\
\frac{0}{00} \\
\frac{0}{0} \\
\overrightarrow{0} \\
z \\
z\end{array}$ & 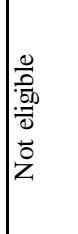 & $\begin{array}{l}\frac{0}{0} \\
\frac{0}{000} \\
\frac{00}{0} \\
\stackrel{0}{0} \\
z\end{array}$ & 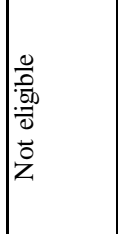 & 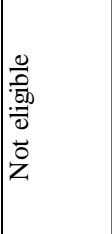 & $\mid \begin{array}{l}\frac{0}{0} \\
\frac{0}{0.00} \\
\frac{.00}{0} \\
\stackrel{0}{0} \\
z\end{array}$ & $\begin{array}{l}\frac{0}{0} \\
\frac{0}{50} \\
\frac{5}{0} \\
\overrightarrow{0} \\
z \\
z\end{array}$ & 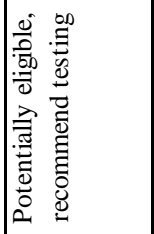 & 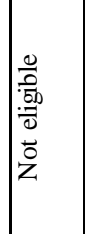 & 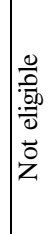 \\
\hline 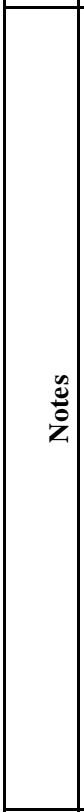 & 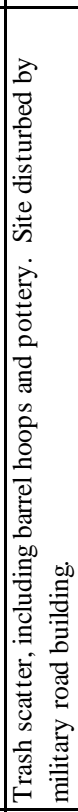 & 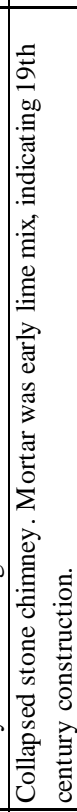 & 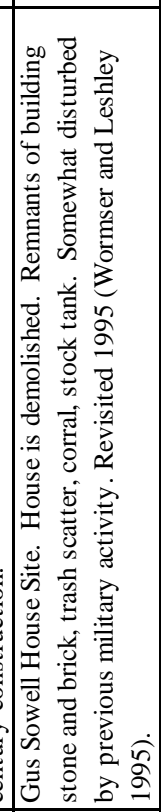 & 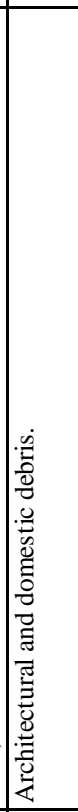 & 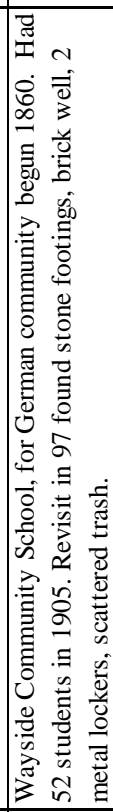 & 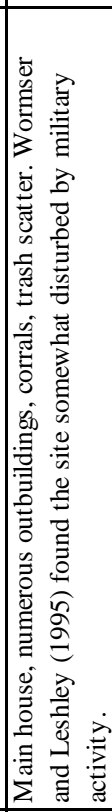 & 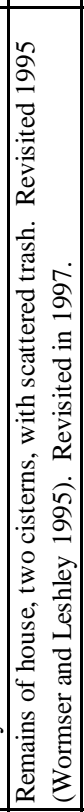 & 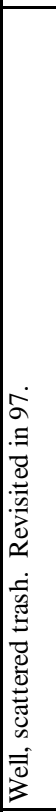 & 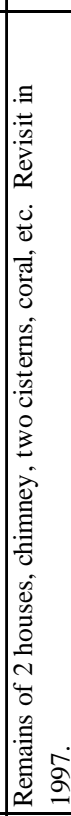 & 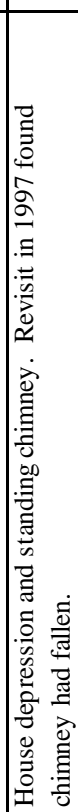 & 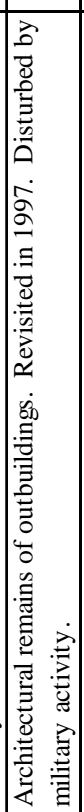 & 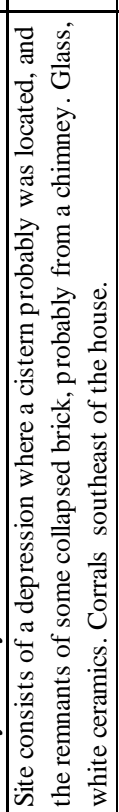 & 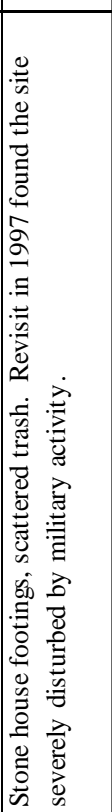 & 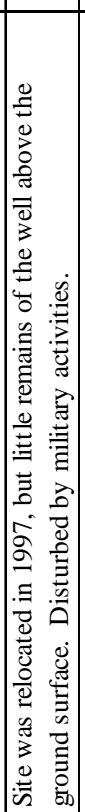 & 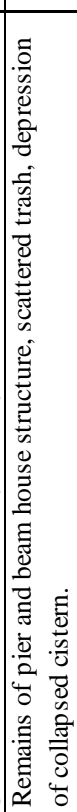 & 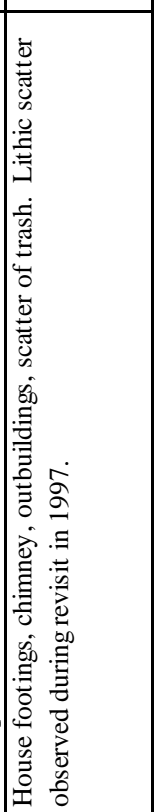 & 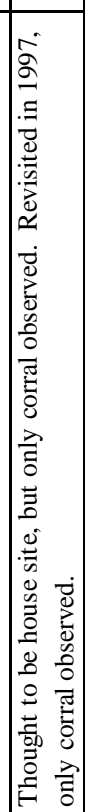 & 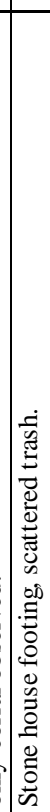 \\
\hline 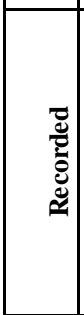 & 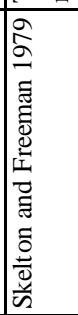 & 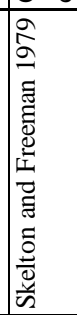 & 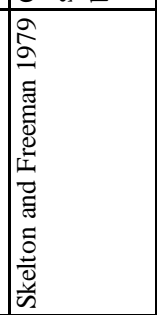 & 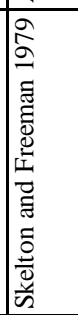 & 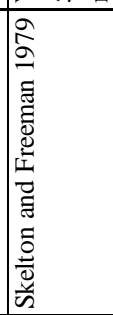 & 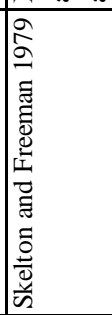 & 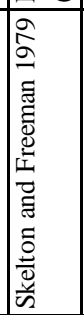 & 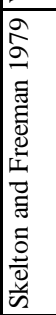 & 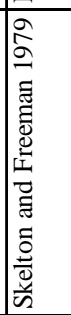 & 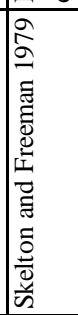 & 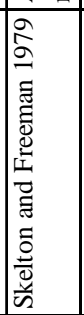 & 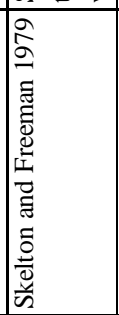 & 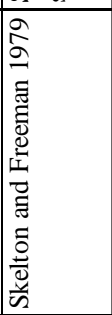 & 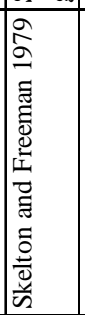 & 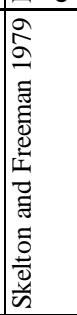 & 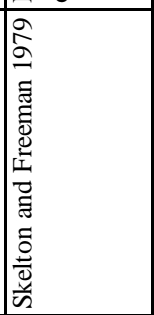 & 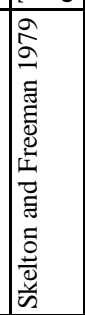 & 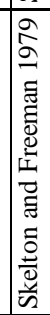 \\
\hline 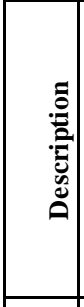 & 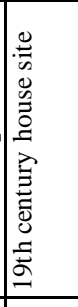 & 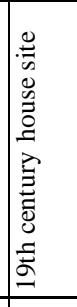 & 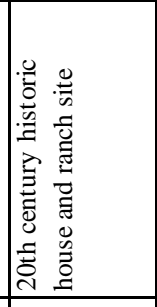 & 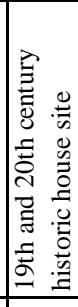 & 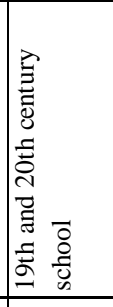 & 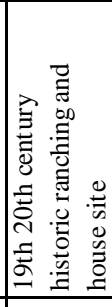 & 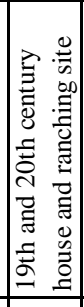 & 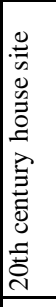 & 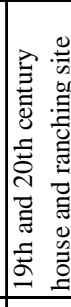 & 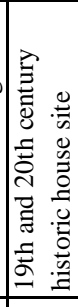 & 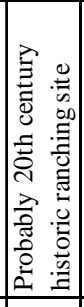 & 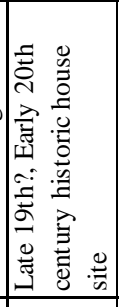 & 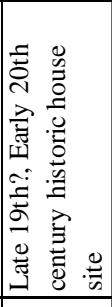 & 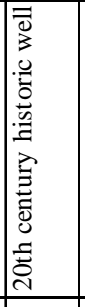 & 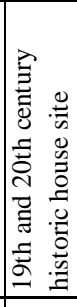 & 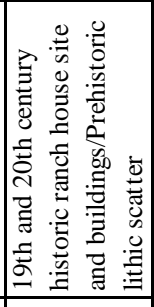 & 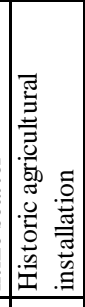 & 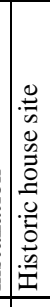 \\
\hline 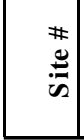 & $\begin{array}{l}\frac{h}{n} \\
\frac{a}{2} \\
\frac{a}{\gamma}\end{array}$ & 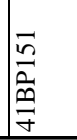 & $\mid \begin{array}{l}\frac{n}{n} \\
\frac{m}{2} \\
\frac{9}{y}\end{array}$ & 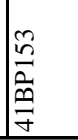 & 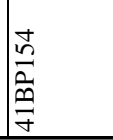 & 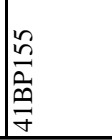 & 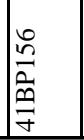 & $\begin{array}{l}\frac{n}{n} \\
\frac{\hat{m}}{\sigma} \\
\frac{9}{\gamma}\end{array}$ & $\frac{\infty}{n}$ & $\begin{array}{l}\frac{\Omega}{n} \\
\frac{\hat{n}}{9} \\
\frac{9}{7}\end{array}$ & 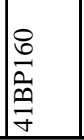 & $\begin{array}{l}\overrightarrow{0} \\
\frac{0}{2} \\
\frac{0}{7}\end{array}$ & 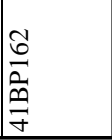 & $\frac{\hat{0}}{\stackrel{0}{a}}$ & 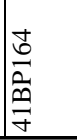 & $\frac{n}{0}$ & 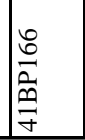 & 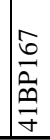 \\
\hline
\end{tabular}


Appendix D: Summary of Known Sites at Camp Swift, continued...

\begin{tabular}{|c|c|c|c|c|c|c|c|c|c|c|c|c|c|c|c|c|c|c|c|c|}
\hline 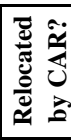 & 8 & $\check{z}$ & z & z & 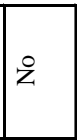 & 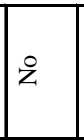 & $\check{z}$ & $\ddot{z}$ & 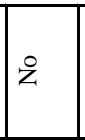 & z & z & z & $\check{z}$ & $\overbrace{\nu}^{\infty}$ & $\stackrel{0}{0}$ & 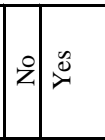 & z & z & $\stackrel{8}{z}$ & ż \\
\hline 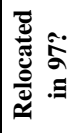 & $\stackrel{8}{z}$ & $\ddot{z}$ & $\underbrace{\infty}_{0}$ & z & 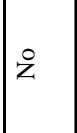 & $\grave{z}$ & $\overbrace{}^{\infty}$ & z & 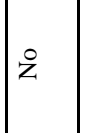 & 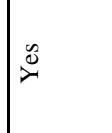 & $\ddot{0}$ & z & $\ddot{z}$ & z & z & 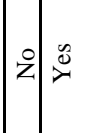 & z & z & $\stackrel{8}{z}$ & $\nu^{\mathscr{0}}$ \\
\hline 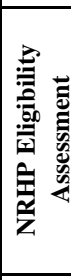 & 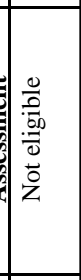 & \begin{tabular}{|l|}
$\frac{0}{0}$ \\
$\frac{0}{50}$ \\
$\frac{.00}{0}$ \\
0 \\
0 \\
$z$
\end{tabular} & 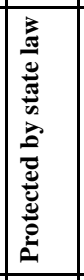 & $\begin{array}{l}\frac{0}{0} \\
\frac{0}{00} \\
\frac{.0}{0} \\
0 \\
0 \\
z\end{array}$ & 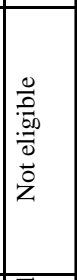 & 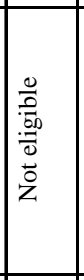 & 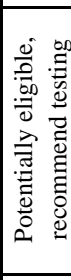 & 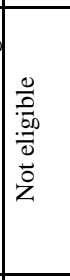 & 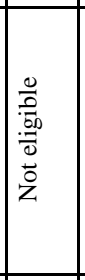 & 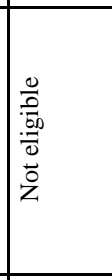 & 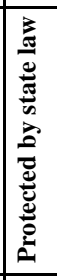 & 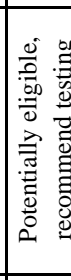 & 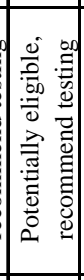 & 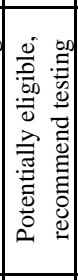 & 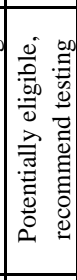 & 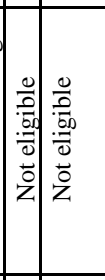 & 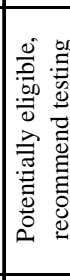 & 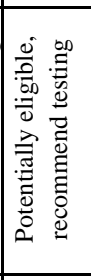 & 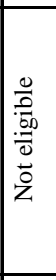 & $\begin{array}{l}\frac{0}{0} \\
\frac{0}{50} \\
\frac{0}{0} \\
0 \\
z\end{array}$ \\
\hline & 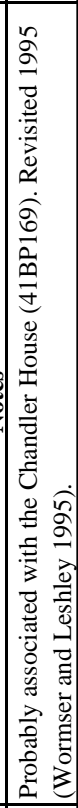 & 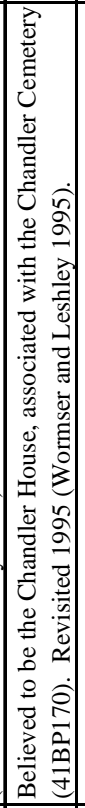 & 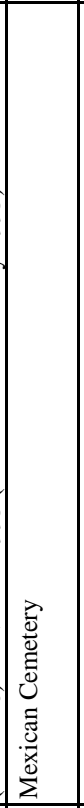 & 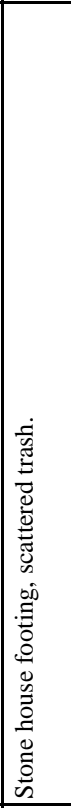 & 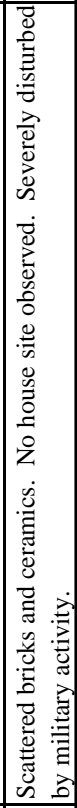 & 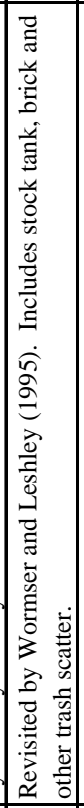 & 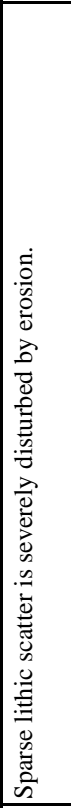 & 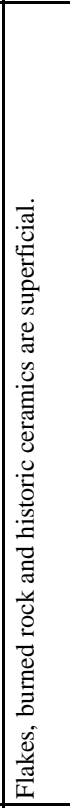 & 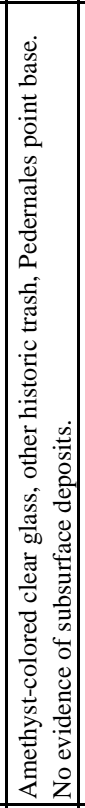 & 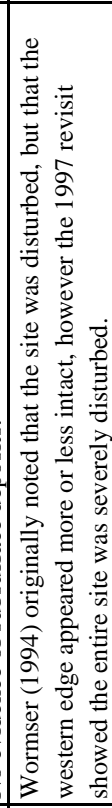 & 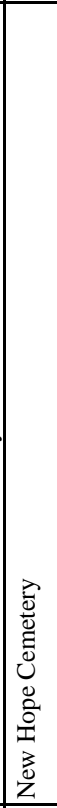 & 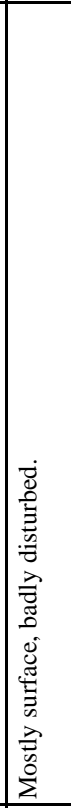 & 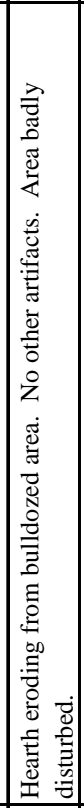 & 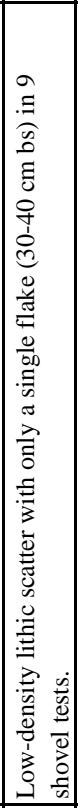 & 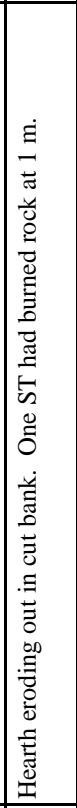 & 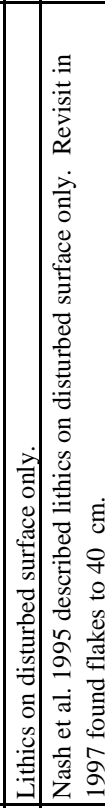 & 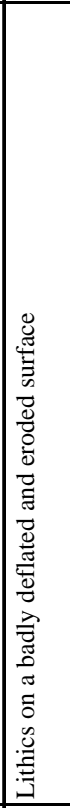 & 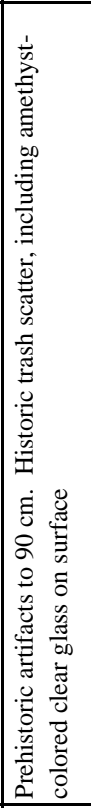 & 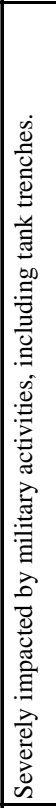 & 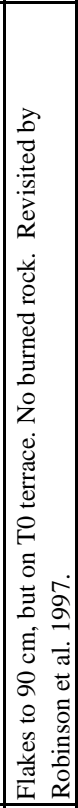 \\
\hline & 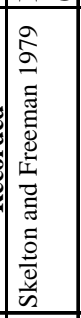 & 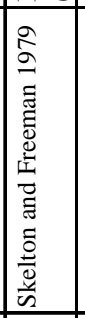 & 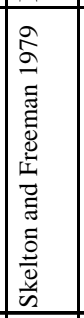 & 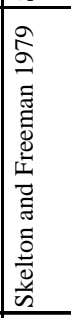 & 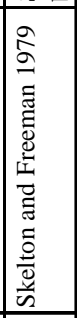 & 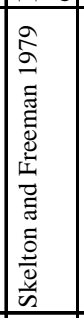 & 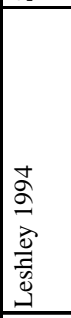 & 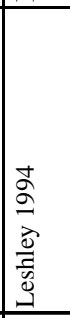 & 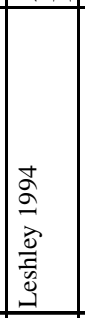 & 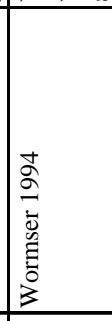 & 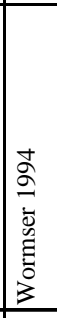 & 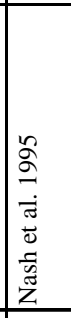 & 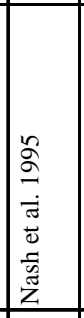 & 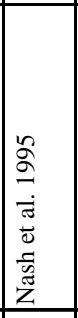 & 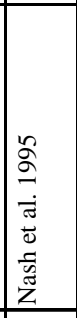 & 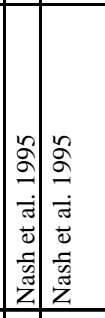 & 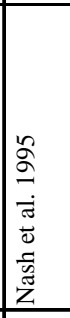 & 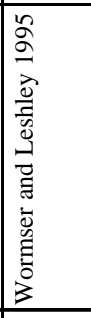 & 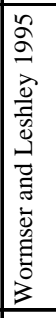 & 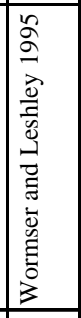 \\
\hline & 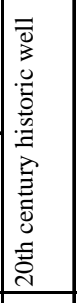 & 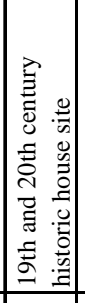 & 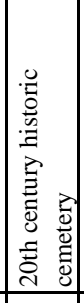 & 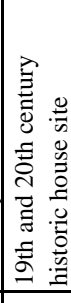 & 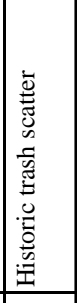 & 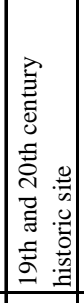 & 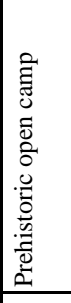 & 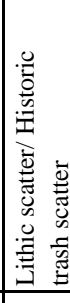 & 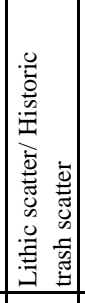 & 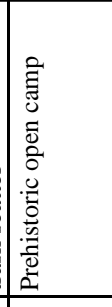 & 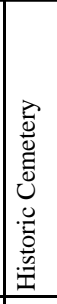 & 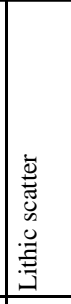 & 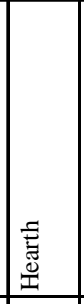 & 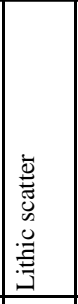 & 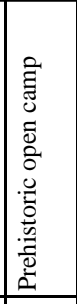 & 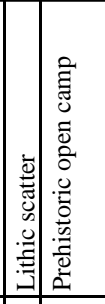 & 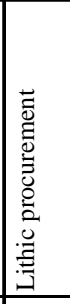 & 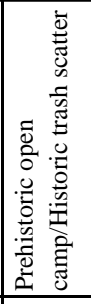 & 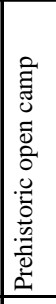 & 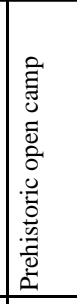 \\
\hline & $\frac{\infty}{\frac{\infty}{2}}$ & \begin{tabular}{|l}
$\frac{a}{2}$ \\
$\frac{0}{a}$ \\
$\frac{0}{\gamma}$
\end{tabular} & \begin{tabular}{|l}
$\frac{9}{9}$ \\
$\frac{9}{9}$ \\
$\frac{9}{q}$
\end{tabular} & 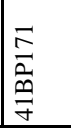 & 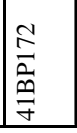 & \begin{tabular}{|l}
$\frac{\infty}{\infty}$ \\
$\frac{\infty}{\infty}$ \\
$\frac{\rho}{\sigma}$
\end{tabular} & 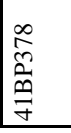 & 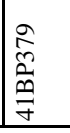 & \begin{tabular}{|l}
$\infty$ \\
$\infty$ \\
$\stackrel{\infty}{\infty}$ \\
$\stackrel{\rho}{\sigma}$ \\
\end{tabular} & \begin{tabular}{|l}
$\bar{\infty}$ \\
$\tilde{\infty}$ \\
$\hat{\infty}$ \\
$\sigma$ \\
\end{tabular} & 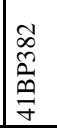 & \begin{tabular}{|l|}
$\infty$ \\
$\infty$ \\
$\stackrel{\infty}{\infty}$ \\
$\sigma$ \\
$\sigma$
\end{tabular} & 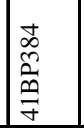 & 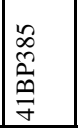 & 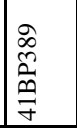 & 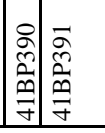 & \begin{tabular}{|l}
\multicolumn{2}{c}{} \\
$\hat{\tilde{\omega}}$ \\
$\stackrel{\rho}{\sigma}$ \\
\end{tabular} & 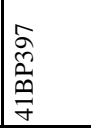 & & 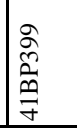 \\
\hline
\end{tabular}


Appendix D: Summary of Known Sites at Camp Swift, continued...

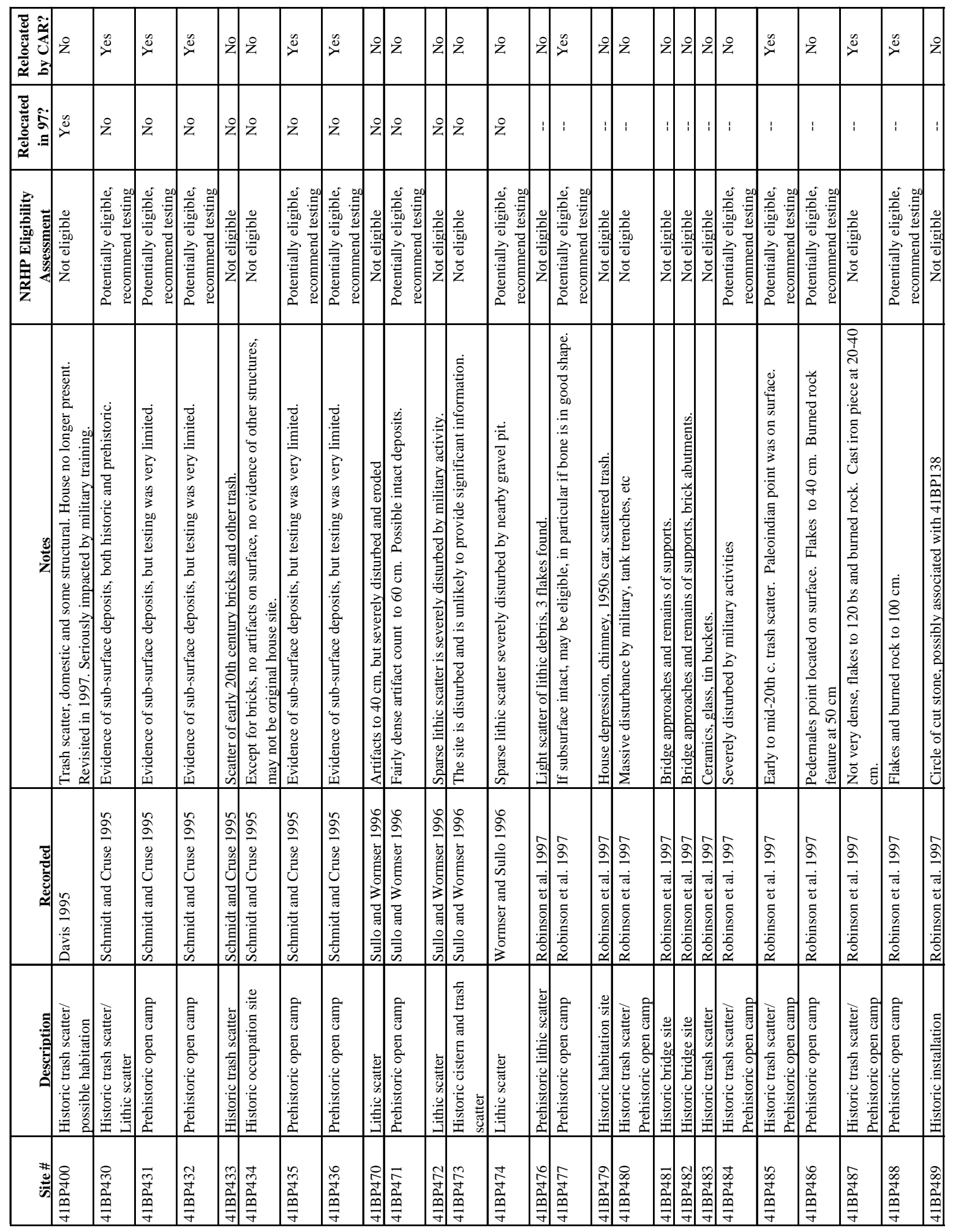


Appendix D: Summary of Known Sites at Camp Swift, continued...

\begin{tabular}{|c|c|c|c|c|c|c|c|c|c|c|c|c|c|c|c|c|c|c|c|c|c|c|}
\hline 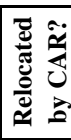 & 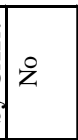 & $\underset{x}{\check{z}}$ & $z \mid \frac{8}{z}$ & ż & $2=$ & z & $\stackrel{8}{z}$ & z & $\dot{z}: \dot{z}$ & $\dot{z} \mid \dot{z}$ & z) & z) & $\stackrel{\partial}{\not}$ & $\stackrel{\mathscr{s}}{\nearrow}$ & żz & ż|z & ż & 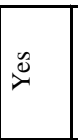 & ż & $\stackrel{8}{z}$ & & z \\
\hline 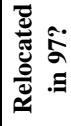 & 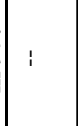 & i & : : & : & : & : & : & : & : : & $\begin{array}{lll}1 & 1\end{array}$ & $1:$ & $\begin{array}{llll} & 1 & 1\end{array}$ & 1 & : & : & : & : & : & : & : & & : \\
\hline 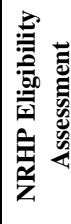 & 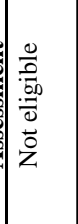 & 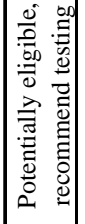 & 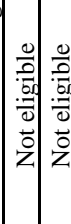 & $\begin{array}{l}\frac{0}{0} \\
\frac{0}{0} \\
\frac{0}{0} \\
\frac{0}{0} \\
\frac{0}{z}\end{array}$ & 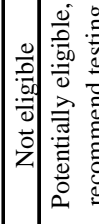 & 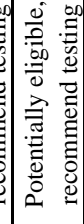 & 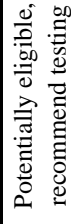 & 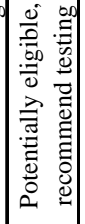 & 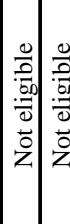 & 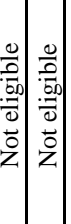 & 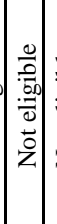 & 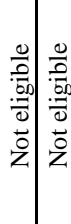 & 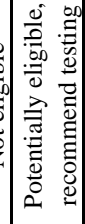 & 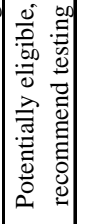 & 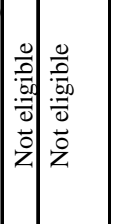 & 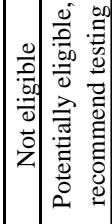 & 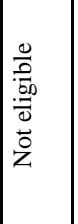 & 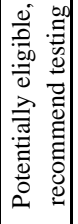 & 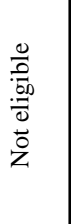 & $\begin{array}{l}\frac{0}{0} \\
\frac{0}{00} \\
\frac{0}{0} \\
\frac{0}{0} \\
z\end{array}$ & & $\begin{array}{l}\frac{0}{0} \\
\frac{0}{50} \\
\frac{0}{0} \\
\overrightarrow{0} \\
z\end{array}$ \\
\hline & 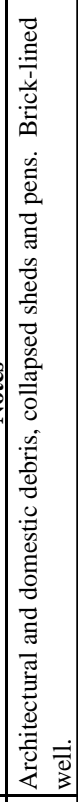 & 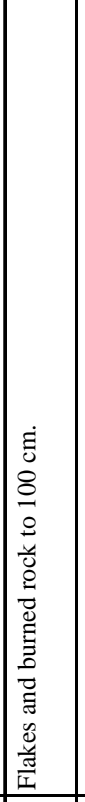 & 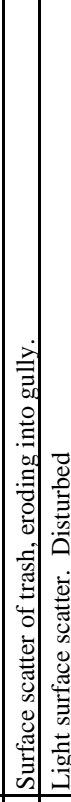 & 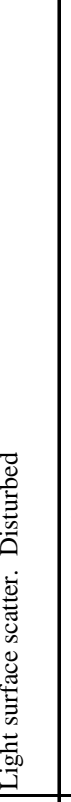 & 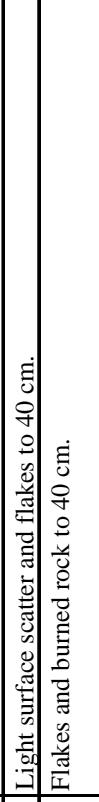 & 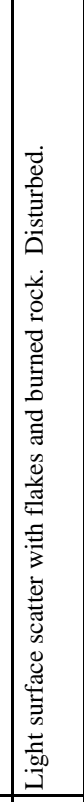 & 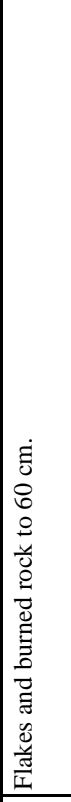 & 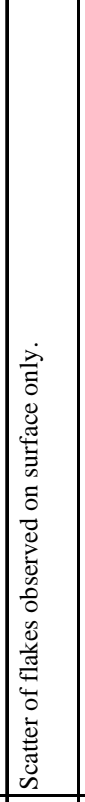 & 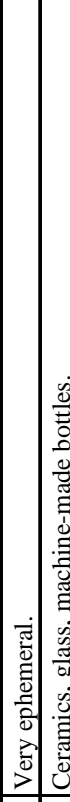 & 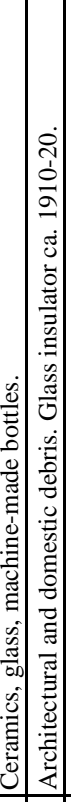 & 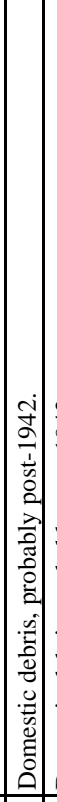 & 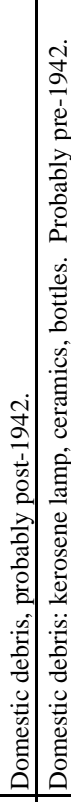 & 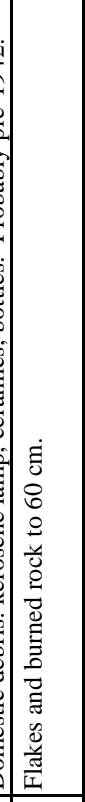 & 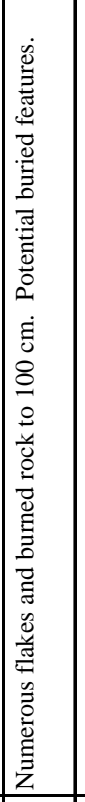 & 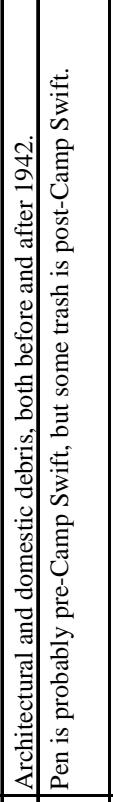 & 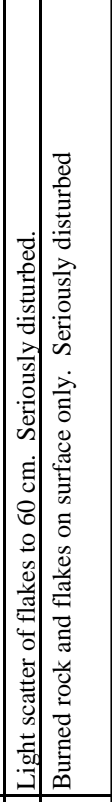 & 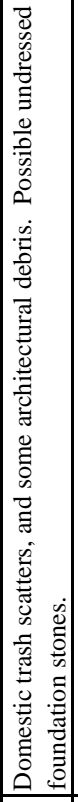 & 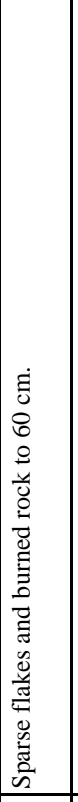 & 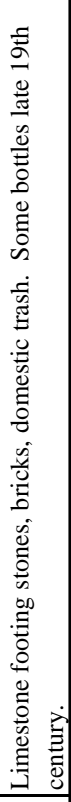 & 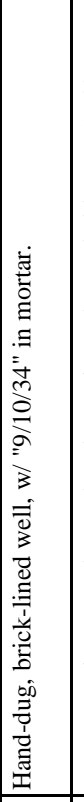 & 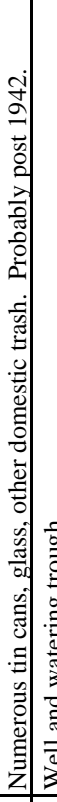 & 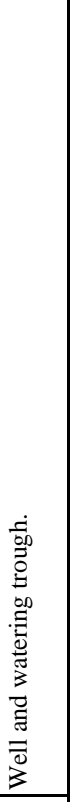 \\
\hline & 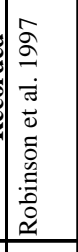 & 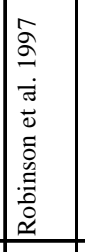 & 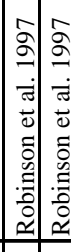 & 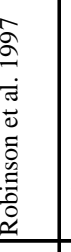 & 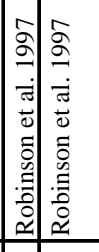 & 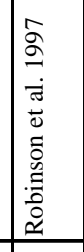 & 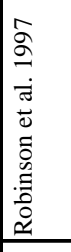 & 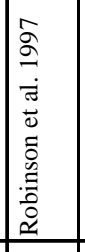 & 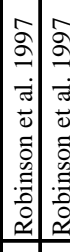 & 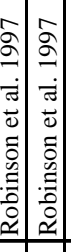 & 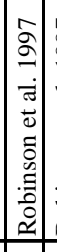 & 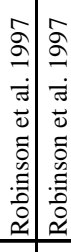 & 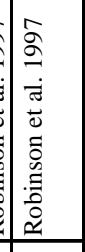 & 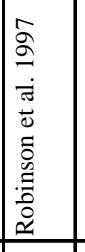 & 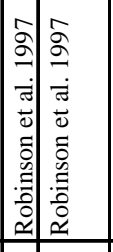 & 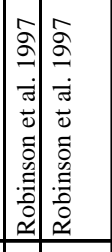 & 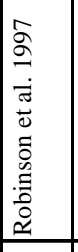 & 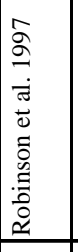 & 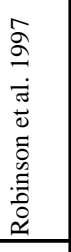 & 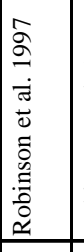 & 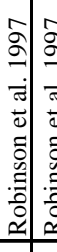 & 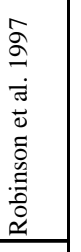 \\
\hline & 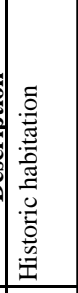 & 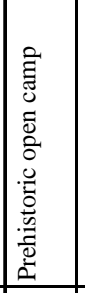 & 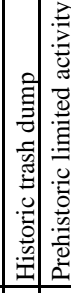 & 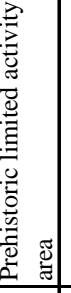 & 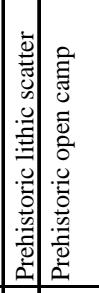 & 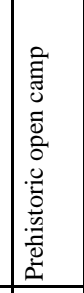 & 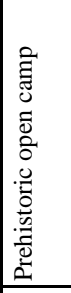 & 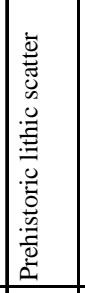 & 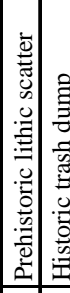 & 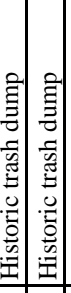 & 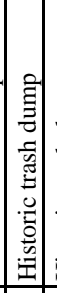 & 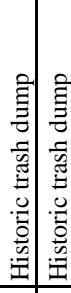 & 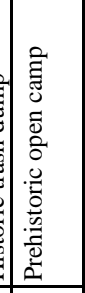 & 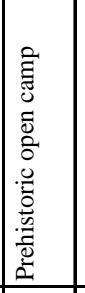 & 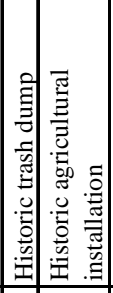 & 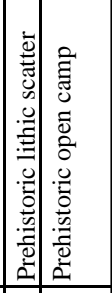 & 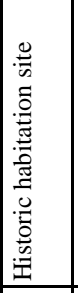 & 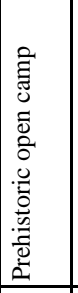 & 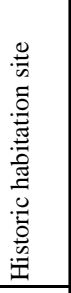 & 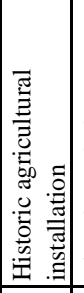 & & 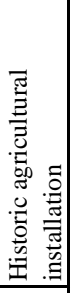 \\
\hline & 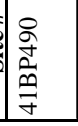 & 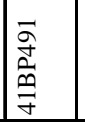 & 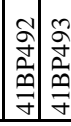 & $\frac{a}{\frac{d}{a}}$ & 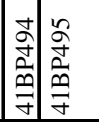 & 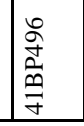 & $\frac{\hat{q}}{\frac{\hat{q}}{y}}$ & 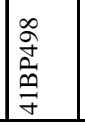 & 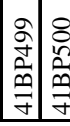 & 吾 & 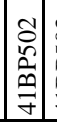 & 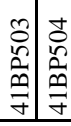 & 竞 & 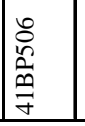 & 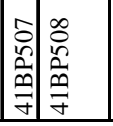 & 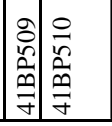 & 言 & 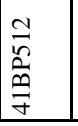 & $\begin{array}{l}\frac{m}{2} \\
\stackrel{n}{a} \\
\frac{a}{\sigma}\end{array}$ & 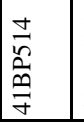 & 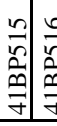 & 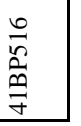 \\
\hline
\end{tabular}


Appendix D: Summary of Known Sites at Camp Swift, continued...

\begin{tabular}{|c|c|c|c|c|c|c|c|c|c|c|c|c|c|c|c|c|c|}
\hline 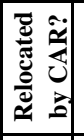 & & \& & 2 & $\stackrel{0}{0}$ & z̊ & $\underbrace{0}$ & ż & 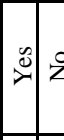 & 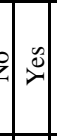 & $\ddot{z}$ & $\overbrace{\nu}^{0}$ & $\dot{z}$ & z & z & 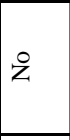 & $\dot{z}$ & \\
\hline 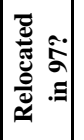 & & : & & i & : & $:$ & : & : & & i & : & : & : & & : & : & \\
\hline 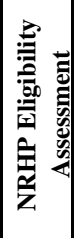 & 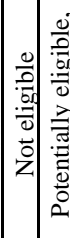 & 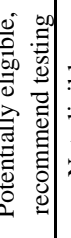 & 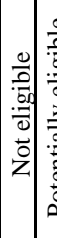 & 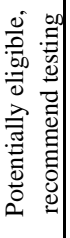 & 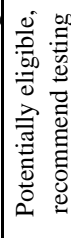 & 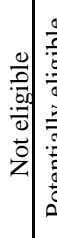 & 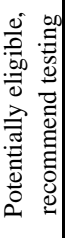 & 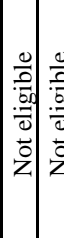 & 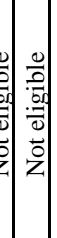 & 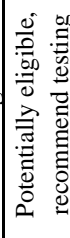 & 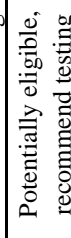 & 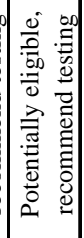 & $\begin{array}{l}0 \\
\frac{0}{0} \\
\frac{0}{60} \\
\frac{0}{0} \\
0 \\
z \\
z\end{array}$ & & 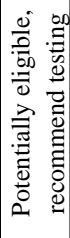 & 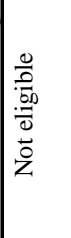 & \\
\hline . & 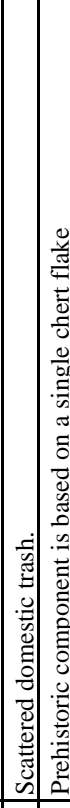 & 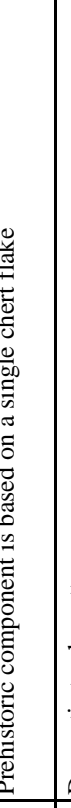 & 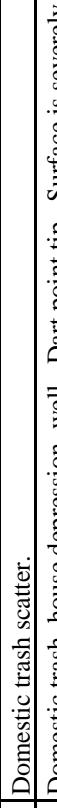 & 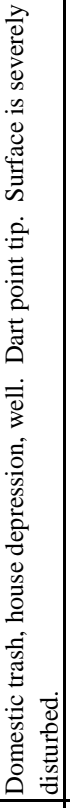 & 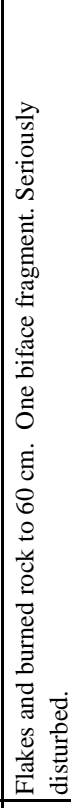 & 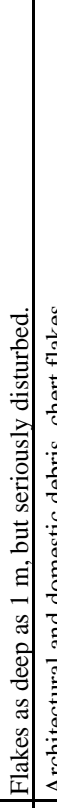 & 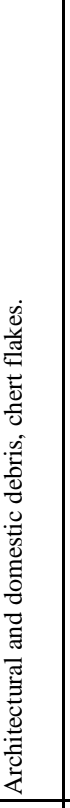 & 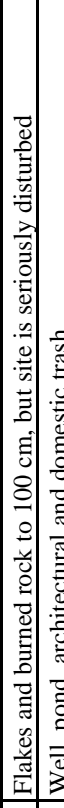 & : & 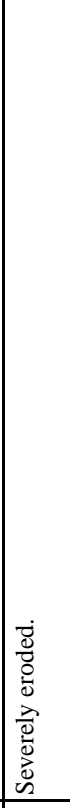 & 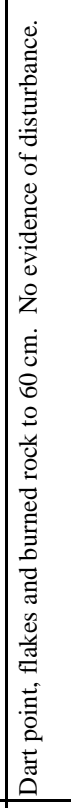 & 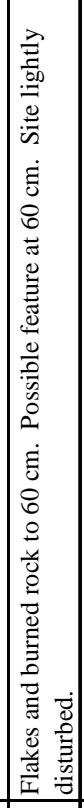 & 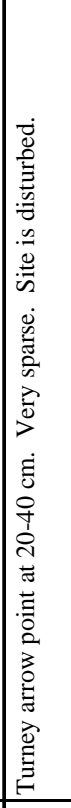 & & 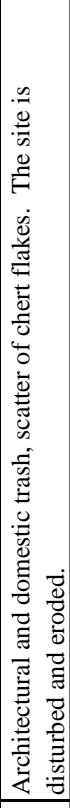 & 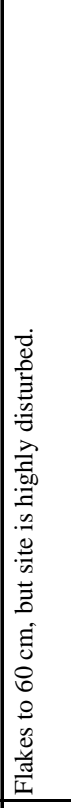 & \\
\hline 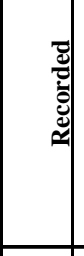 & 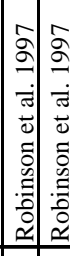 & & 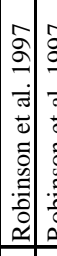 & 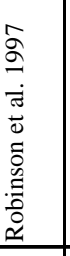 & 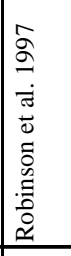 & 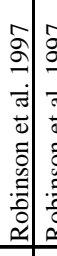 & 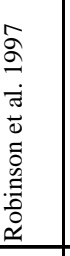 & 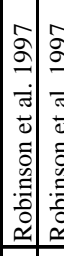 & & 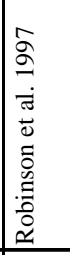 & 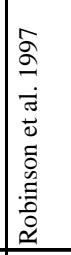 & 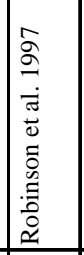 & 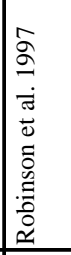 & & 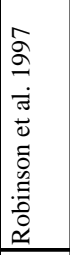 & 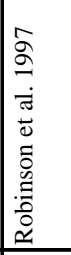 & \\
\hline 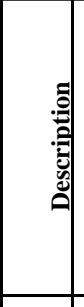 & 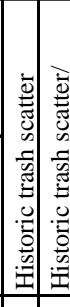 & 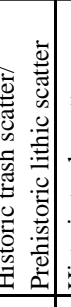 & 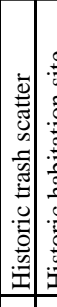 & 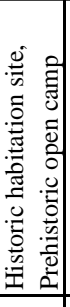 & 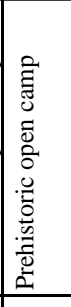 & & 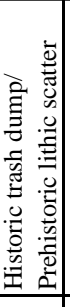 & 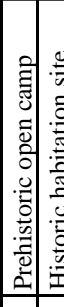 & : & 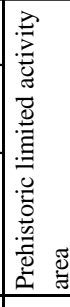 & 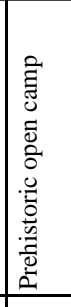 & 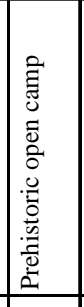 & 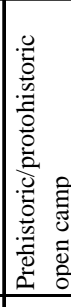 & & 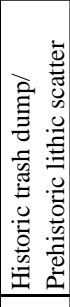 & 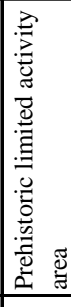 & \\
\hline & 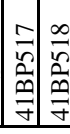 & $\frac{f}{\partial}$ & 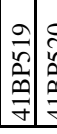 & $\frac{\sqrt{6}}{m}$ & $\frac{\tilde{n}}{\tilde{n}}$ & 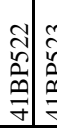 & 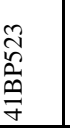 & 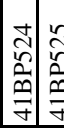 & a & 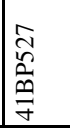 & 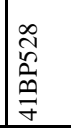 & 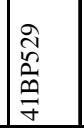 & 离 & & & $\begin{array}{l}\hat{\tilde{n}} \\
\hat{\tilde{n}} \\
\frac{\tilde{\sigma}}{\sigma}\end{array}$ & \\
\hline
\end{tabular}

